\title{
RICKETTS ON MINES
}


Wader Wh Radiey Eop. Complemiento of

Astrecketo 


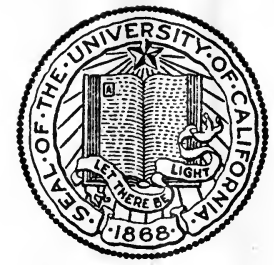

BANCROFT LIBRARY

$\diamond$

\section{THE LIBRARY \\ $\mathrm{OF}$ \\ THE UNIVERSITY \\ OF CALIFORNIA}

WALTER WADSWORTH BRADIEY $1878-1950$

Walter W. Bradley was born in San José and received the degrees of B.S. and E.M. from the University of California. From 1912 to 1946 he was associated with the California Division of Mines, serving as State Mineralogist for the last eighteen years of that period. His published works relate to mining, processing, and geology. This book is from his private collection, presented to the Bancroft Library by Mrs. Alice Roberts Bradley. 




\section{A MANUAL}

OF

AMERICAN MINING LAW

BY

A. H. RICKETTS

OF THE

SAN FRANCISCO BAR

SAN FRANCISCO

- SCIENTIFIC BOOK PUBLISHING CO.

$\mathrm{MCM} \times$ I 


$$
\begin{aligned}
& F 591 \\
& .24 \\
& R 54
\end{aligned}
$$

COPYRIGHT IOII BY A. H, RICKETTS 


\section{2}

\section{BANCROFT}

LIBRARY

TO MY FRIEND

JOHN HAYS HAMMMOND 


\section{PREFACE.}

My schoolmate and friend, Mr. A. H. Ricketts, considers it proper that the eldest son of the author of the first work on American mining law should write the preface to the latest book on that subject. But for the sentiment involved, I should hesitate, as a mere layman, to identify myself even in this small way, with a work of the technical character of this book. My father, the late Gregory Yale, as far back as 1867 wrote his book on "Mining Claims and Water Rights," before which there was no original contribution on mining law in American legal literature. Based largely on the now obsolete mining law of Congress of July, 1866, that work is now mainly of interest for the historical features connected with the subject, and has been long out of print.

This latest work on American mining law, by $\mathrm{Mr}$. Ricketts, brings 'everything on the subject up to date, as to State and Federal legislation, the decisions of the courts, and the rulings of the Departments. On reading the advance sheets one is at once struck by the conciseness in which the facts are presented. There has been no attempt whatever toward elaboration or argument. The author gives what he considers the proper construction of the law and in each case cites the authorities. There is therefore nothing to confuse the layman, while at the same time the book is of great value for reference to those of the legal profession. Under each general heading are num- 
bered and titled paragraphs, exceedingly brief but expressive, and containing reference to the footnote showing the authority and its source. No arrangement could well be handier for reference to the prospector, miner, mine manager or lawyer.

It is to be noted that both the first book on American mining law and the latest one on the same subject are by Californian authors, practicing attorneys in the city of San Francisco, where both books were published.

Charles Gregory Yale.

San Francisco, October 2, 1911. 



\section{TABLE OF CONTEN'TS}

CHAPTER I.

\section{MINING LAW IN THE UNITED STATES.}

$\S 1$. Local rules, regulations and customs-cause of establishment-common law of mining-statutory limitations-Californian provision-absence of rules and customs-when void-presumptions-construction-evidence-effect of non-observance.

§2. Statutory law - lack of uniformity - salutary provisions.

§. 3. Alaska-additional provisions-explorations on Behring Sea - dredging - beach claims - roadway aliens-adverse claims-adverse suits - adverse possession.

§4. Hawaii-land department.

§ 5. Philippine Islands-dissimilar provisions-tunnel sites § 6. Porto Rico. -land department.

CHAPTER II. COURTS.

$\S 10$. In general-jurisdiction - state courts-federal courts -remand-land department-stay.

$\$ 11$. Federal question-pleadings.

$\S 12$. Union of remedies-joinder-exception.

$\S 13$. Dismissal of cause.

$\S 14$. Appeal-federal courts.

$\S 15$. Appeal-state courts-writ of error.

$\$ 16$. Conflicting decisions.

$\S 17$. Recent legislation.

CHAPTER III.

\section{ACTIONS.}

$\S 19$. Possessory actions - possessory right - pleading citizenship-judgment-receivers.

$\S 20$. Adverse suit - jurisdiction-pleading-trial-dismissal-non-suit-judgment-final judgment. 


\section{CHAPTER IV. \\ DISPOSAL OF THE PUBLIC LANDS.}

§ 23. Land department-powers-judgment unassailablejuagment not conclusive-Board of Equitable Adjudication-character of entries to be submittedprocedure-appeal-termination of jurisdiction.

$\S 24$. Contests-grounds for action-procedure-notice required-purpose of notice-effect of notice-default - notice after appearance-compromise-specific performance.

\$25. Hearings-character of land-presumption.

\$26. Testimony-rules-evidence-insufficient evidenceburden of proof.

$\$ 27$. Result of hearing-segregation survey-judgment not equivalent to patent-subsequent legal proceedings.

$\S 28$. State lands-when title passes-when closed to the prospector-rights on state patented lands-land department-register of state land office-contests - pleading - protestant - effect of judgment-payment for land-statute of limitations-recent Californian legislation-school lands withdrawn from sale.

$\S 28$ a. Conservation.

$\S 29$. Railroad lands-classification of land-inconclusiveness of classification - subsequent discovery of mineral-rejection of application for patent-land department.

CHAPTER V.

\section{SURVEYS.}

\$35. Public land surveys-province of land department -questions of fact-duty of surveyor-division and numbering of the public lands-meander lineshigh-water mark-recent Californian legislation.

$\S 36$. Official surveys-lode claims-placer claims-connecting line-reference to connecting line-mapsmap must be supported by evidence-testimony, of surveyor-fabricated survey-map not proof of lode.

$\S 37$. Segregation survey - when ordered - township records.

$\S 38$. Adverse claim survey - what plat of must show when survey not necessary - not made by surveyorgeneral.

8 39. Appeal.

§ 40. Surveys under state laws-surface survey-recordevidence-underground survey-service of order. 
CHAPTER VI.

\section{LAND DISTRICTS.}

§41. Land district-additional land districts and changes therein.

$\S 42$. Mineral district.

$\S 43$. Mining district-extent-changing boundaries-persons - corporation - regularity of proceedings officers of district-duties of recorder.

\section{CHAPTER VII.}

\section{MINERAL LANDS.}

$\S 45$. Land subject to location-land valuable for its mineral deposits - classification of land - who may question character of land.

§46. Land not subject to location - Indian lands-allotments-patents.

§ 47. Mineral deposits.

\section{CHAPTER VIII.}

\section{VEIN, LODE AND LEDGE.}

$\S 50$. In general-interchangeable terms-miners' use of terms-common use-the miner's vein or lodeminers' distinction between vein and lode-vein within lode-synonymous terms-statutory meaning-judicial definitions-general rule-no conflict - various definitions - no arbitrary definition approved definition - gravel deposits - characteristics of a vein or lode-elements of a vein or lode-fissure veins-broad lodes-walls of broad lode-indivisibility of a broad lode-separate veins within zone-blind vein-blanket vein-secondary or incidental vein-extra-lateral right to secondary vein-single vein-intersecting veins-apex of intersecting veins-cross veins-space of intersection-contact vein-known vein-ledge matter-in place-rock in place-other rock in place-vein or lode in place-vein or lode not in place-country rock - horse - dykes - outcroppings - identity of vein and outcrop-outcroppings not essential-top or apex--highest point-legal top or apex-discovery of top or apex-location must include top or apex-course or strike-determining course or 
strike-practical rule-following course or strikedip or downward course-measuring dip-easement or servitude-following the dip-walls of vein or lode-boundaries of vein or lode-indications-impregnations.

CHAPTER IX.

\section{GRUB-STAKE CONTRACTS-MINING PARTNERSHIPS CO-TENANTS.}

\$57. Grub-stake-in general-nature of contract-trustees -essential requisites-consideration-termination -accrued rights-duty of outfitter-duty of prospector-what is not a grub-stake.

§58. Mining partnerships-peculiar rules applicable-essential difference between mining and general partnerships - how created - general partners trustees - control- debts-liens - accounting - dissolution-sale.

§59. Co-tenants-not mining partners-trustees-termination of trust-corporation not co-tenant-inchoate rights-divestiture of title-exclusion from patent -when rights barred-actions-questioning titleworking the claim-accounting-contribution-liability for loss and debts-adverse possession.

CHAPTER X.

\section{MINING LEASES AND LICENSES.}

$\S 61$. Mining leases-in general-covenants-provision as to stoping-royalty.

$\S 62$. Licenses in general-intent controls-test-when revocable-when irrevocable-injunction.

CHAPTER XI.

\section{OPTIONS-DEEDS-EXAMINATION OF TITLE.}

$\S 66$. Options-distinction between option and contractconsideration - sufficient consideration - duty of owner-damages-default.

$\S 67$. Deeds-what passes by deed-unnecessary recitalcreation of independent estates-effect of quitclaim deed-title of corporation-title of association - attack by grantor - agreement for deed description-statute of limitations-taxation. 
$\S 68$. Examination of title-unappropriated land-character of location - form of location - cross vein known vein - discovery - boundaries - annual expenditure - receiver's receipt - conclusiveness of patent-inconclusiveness of patent.

\section{CHAPTER XII.}

\section{POSSESSION-ABANDONMENT-FORFEITURE.}

§ 71. Possession-actual possession-actual possession not required-actual possession without boundariesconstructive possession-boundaries without discovery-presumption as to ownership-evidence of ownership-adverse possession-general principle - continuity of possession - insufficient adverse possession-effect of patent.

\$ 72. Abandonment - intent controls - how effected - cotenant-not abandonment - deed - proof - test pleading.

§ 73. Forfeiture-proof-burden of proof-reasonable doubt -pleading-absence of right.

\section{CHAPTER XIII.}

\section{REMEDIES.}

$\S 76$. Condemnation proceedings-constitutional provision -limitation of power-public use.

\$ 76a. Recent Californian legislation.

$\$ 77$. Easements - vested rights - right of way-damages.

$\S 78$. Laches-unlike limitations-equitable defense-delay -measure of diligence-pleading laches-plaintiff's allegations.

§ 79. Liens-not impaired by patent-loss of lien-mechanic's liens-purpose-contract essential-protection of owner-statutory requirement-indemnification-subordinate to mortgage.

$\S 80$. Master and servant-fellow servants-assumption of risk - legislative safeguards - limiting hours of labor-constitutionality of act.

$\S 80$ a. Recent Californian legislation.

\$ 81. Partition - agreed partition - arbitration - mining right.

$\S 82$. Patent-bona fide purchaser-burden of proof-fraudulent patentee-not attack upon patent-status of trustor-fraud-application to sue-false testimony insufficient. 
$\S 83$. Rescission-condition precedent-application of rule - grounds for rescission - salting - unintentional salting-remedies-insufficient grounds for rescission-marketable title.

\$ 84. Statute of limitations-establishes right to patentcontrolling factor-Californian provisions.

$\$ 85$. Trespass -ignorance of boundary - test of trespassinjunctional proceedings - denial of injunction right of inspection-grounds for order-substance of order - damages - good faith of trespasser pleading-model.

\section{CHAPTER XIV.}

\section{DEFINITIONS.}

(For other definitions, see appropriate titles.)

$\S$ 87. Assays-assay value-value of assay-car and mill samples.

$\S 88$. Blanket sluices-concentrates.

$\S$ 89. Claim-application of term-perfected claim-contiguous claims.

$\S 90$. Conspicuous place-penalty.

$\S$ 91. Corporation-location rights.

$\S$ 92. Desert lands.

$\S 93$. Entry-preferential right-certificate of entry-issuance-effect of issuance-cancellation-repayment.

$\S$ 94. Exemptions-Californian provision.

$\S 95$. Fixtures - examples - Californian provision-character of title immaterial.

§ 96. Location-location and mining claim-consolidated locations-technical locations-illustrations-location as property-incidents of ownership-not community property-taxation.

$\S$ 97. Markings.

$\S 98$. Mine-existence determined-synonyms-descriptive name-want of identity.

$\S 99$. Mineral-mineral substances-within purview of mining laws-float-ore-ore in sight-ore personal property-placers-placer workings-zone.

$\$ 100$. Miner's inch-Californian provision.

$\S 101$. Mining-prospecting and mining-process of mining -process of milling-business of mining-instrumentalities-superintendent-shift boss-miner. 
$\S 102$. Mining claim-statutory meaning-distinction between mining claim and location-distinction between mining claim and mining ground-navigable river-Mexican grant-agricultural patent-oil claim-ditch-unworked placer.

$\S 103$. Mining right-species of trade - legal relationsmining title.

$\S 104$. Public land-distinction between public land and public use-unoccupied and unappropriated landvacant land-occupancy and improvements-public mineral land-homesteads-possession.

$\S 105$. Salt lick.

$\S 106$. Scrip-written authorization-selection-sale-guarantee.

$\S 107$. Tunnel right-implied rights.

\section{CHAPTER XV.}

\section{COAL LANDS.}

$\S 108$. In general - entry - preferential right - consolidation.

\section{CHAPTER XVI.}

\section{LODE CLAIMS.}

§110. In general-top or apex-surface rights-subsurface rights-presumption-departure from surface lines.

$\S 111$. Limitation of subsurface rights - form of locationexceptions - priority of location - priority immaterial.

$\S 112$. Dip right-basis of right-identity of vein-want of identity.

§ 113. Unlawful intrusion-exception.

\section{CHAPTER XVII.}

\section{MILL-SITES.}

$\S 116$. In general-limitations-character of land-mining and milling purposes-who may locate-locationannual expenditure-patent.

\section{CHAPTER XVIII. \\ PLACER CLAIMS.}

$\S 119$. In general - location rights - known vein - subsequent discovery-conflicting locations-area of placer locations-discovery, marking and annual expenditure-patent-joint entry-effect of ex. cluding known vein-limitation. 
§120. Petroleum oil claims-rights preserved-withdrawals-withdrawals in California-the power of the President-act of June 25, 1910-construction of statute-protection under saving clause-opinion of the writer-peculiar conditions-questions arising from conditions-conflict of authority-established law-forcible entry and detainer-possessio pedis -conveyance before discovery-departmental ruling-confusion in land titles-rule of propertyremedial legislation-ambiguity in statute-construction of statute - validity of withdrawalsdiscovery-insufficient discovery-possession while making discovery-good faith-single discoveryscripping.

$\S 120$ a. Natural gas-definition of.

$\S 121$. Mining for oil-no limit-unlawful drainage-possession of land not possession of oil-nuisanceCalifornian provision - commencing operations diligence-test well-partnership-limitation-partition-damages.

$\S$ 121a. Recent Californian legislation.

$\S 122$. Oil land leases-implied covenants-forfeiturevested right-paying quantity-taxation.

$\S 123$. Hydraulic claims-restriction-constitutionality of act-mining without restriction.

$\S 124$. Dredge claims-in general-location.

$\S 124$ a. Recent Californian legislation-uplands.

$\S 125$. Stone claims-in general-character of locationtimber and stone act-agricultural entry-sale by entryman-return of fees.

§ 126. Salt claims - character of deposit - limitation - nitrate and borate land.

$\S 127$. Tailings-deposition of tailings.

\section{CHAPTER XIX.}

\section{TIMBER LANDS.}

§ 129. In general-mineral lands-mineral location-subsisting location-subsequent discovery.

$\S 130$. Timber cutting on mineral lands-purposes-restriction-exceptional right.

$\S 131$. Timber cutting in forest reserves.

$\S 132$. Timber cutting on Indian lands-criminal offense.

$\S 133$. Timber cutting on abandoned military reservations.

$\S 134$. Damages-bona fide purchaser. 


\section{CHAPTER XX.}

\section{TOWN SITES.}

$\S 135$. In general-corporate authorities-county judgetrust - mineral reservation - insufficient mineral rights.

$\S 136$. Adverse suits.

CHAPTER XXI.

\section{TUNNEL-SITES.}

§ 138. In general-beyond boundaries-assessment worklocation of tunnel-location of blind veins-prior location-adverse location-line of tunnel-no annual expenditure-abandonment-patent.

$\S 139$. Dump.

\section{CHAPTER XXII.}

\section{WATER RIGHTS.}

§141. Real property-what may be appropriated-volume and extent-public grants-private grants.

$\S 142$. Rights of way.

§ 143. Appropriation-different systems-compliance with local statute-no constructive appropriation-measure of right-non-user-adverse user-interruption of right-prescriptive right.

§144. Diversion of water-adjacent water-pollution of water.

§ 145. Nuisance.

$\S 146$. Tide lands-not subject to location-temporary possession.

CHAPTER XXIII.

NATURAL OBJECT-PÉRMANENT MONUMENT.

$\S 149$. Natural objects-reference.

$\S 150$. Permanent monuments.

$\S 151$. Purpose-record-presumptions-burden of proo'r.

\section{CHAPTER XXIV.}

\section{DISCOVERY.}

§ 154. In general-location not complete without discovery - requisites of discovery-discovery may be insufficient - bisected discovery - single discovery in 
$\S 155$. Character of lode discovery.

$\S 156$. Development of discovery-local provisions-essential act of location-discovery shaft.

\$157. Proof of discovery-rule between rival claimantsreason for rule-test-contests between mineral claimants-mineralogical and geological conditions - supplementary. evidence-testimony-discovery point-expert testimony-conclusive testimonynegative testimony.

$\S 158$. Loss of discovery - sale before discovery-sale after discovery.

\section{CHAPTER XXV.}

\section{LOCATORS.}

$\S 162$. Rights of locators-basis of possession-forfeitureabandonment.

$\S 163$. Citizens and aliens-location by alien-rights of alien-patent proceedings-presumption.

$\S 164$. Agents-no divestiture of title.

$\S 165$. Who can not be locators.

\section{CHAPTER XXVI.}

\section{ORIGINAL LOCATIONS.}

$\S 168$. In general-possessory title-priority of title-independent locations-invalid locations-form of lode location-form of placer location-must conform to law-time of location-qualification of locator.

$\S 169$. Equivalent of location-right to patent.

$\S 170$. Fraudulent placer location-innocent participants.

$\S 171$. Voidable locations.

$\S 172$. Void locations-absence of discovery-boundariesillustrations-timber-trespass.

$\S 173$. Size of lode claims-measurement-presumptionexcessive size - segregation - reasonable time to cast off.

$\S 174$. Size of placer claims-excessive size.

$\S 175$. Size of tunnel sites-excessive location.

$\$ 176$. Size of mill-sites-form.

$\$ 177$. Acts of location-acts incumbent on locator-order of performance-original discoverer-re-locator not discoverer-limitation-boundaries-time and man. 
ner of marking boundaries-essential acts of location-possible insufficiency of acts-question of fact-what controls-monuments as boundariesposition of lode claim monuments - consent of owner - limitation - monuments as boundaries position of placer claim monuments-possible discrepancy-changing position of marks-obliteration of marks - no presumption - by whom the marks may be placed-end lines-effect of establishing end lines-question of fact-constructive end lines - side lines-irregularity of side linesagreed lines.

\section{CHAPTER XXVII. \\ SUBSEQUENT LOCATIONS.}

§ 178. Amended or additional location - basis - office of amendment-contents of notice-one instrument.

$\S 179$. Re-location-when void-assumption of risk-statutory bar to re-location-fraudulent re-location-exception-improvements.

§180. Overlapping locations - basis - boundary marks consent of owner-re-location-application for patent-laches and limitation.

$\S 181$. Lode location within placer claim-presumptiontrespass-not trespass-limitation of area.

$\S 182$. Location of cross lodes.

\section{CHAPTER XXVIII.}

\section{NOTICE OF LOCATION.}

$\S 185$. In general-supplementary legislation-contents of record-additional recitals-not necessarily part of location-substantial. compliance-oral testimonyimportance of boundaries-construction of noticesufficiency of notice-purpose fulfilled.

$\S 186$. The posted notice-evidence of discovery and appropriation-recitals-question of fact-descriptionname of lode-errors in description-surplusagewhere posted-miner's devices-presumption.

\$ 187. The amended notice-intervening rights-evidence.

$\S 188$. The re-location notice-void notice-effect of statement-proof.

$\S 189$. Ante-dated notice-felony.

$\$ 190$. Where recorded-county recorder-district recorder -failure to make record-description-what rec- 
ord need not show-question of fact-record as notice-record not notice-record as title-effect of record-record as evidence-does not preclude parol evidence-when prima facie evidence-color of title.

\section{CHAPTER XXIX.}

\section{ANNUAL EXPENDITURE.}

$\S 193$. Provisions of the mining act-district rule.

$\S 194$. Place of performance-character of labor and improvements-personal services-group of locations -labor upon group-burden of proof.

$\S 195$. Sufficiency of performance-compliance with local statute or district rule-payment not conclusivepayment bears upon value-payment not essential.

$\S 196$. Proof of performance-not mandatory laws-effect of filing-neglect to file not fatal.

$\S 197$. Non-performance-when claim forfeited - claim of forfeiture-adverse possession-what is not excuse for non-performance.

$\S 198$. Resumption of labor-time for resumption-effect of resumption-what is not resumption-trespass.

$\S 199$. Who may make expenditure-presumption.

$\S 200$. Failure to contribute-effect of demand-character of title-basis of notice-right to give noticecontents of notice-personal service-publication.

\section{CHAPTER XXX. \\ PATENTS.}

$\S 206$. In general-mining rights-agricultural patent-lode patent-placer patent-equivalent to patent-void patents-voidable patents.

$\S 207$. Legal title-equitable title - superiority of title priority of title-evidence-facts settled by patent -presumptions.

$\S 208$. State legislation.

CHAPTER XXXI.

\section{PATENT PROCEEDINGS.}

§ 211. In general-manner of obtaining patent-limitations - survey of claims-all placer-mixed lode and placer-waiver-adverse claimant-time to apply for a patent-place of filing-time to complete ap- 
plication-completion-payment-divers patentserroneous description.

$\S 212$. The survey-accompanying papers-deputy surveyor -duties of deputy-errors of deputy-expenditure upon the claim - conclusiveness of certificate equivalent of certificate-basis of deputy's reportsufficient expenditure - insufficient expenditureplat and field notes.

$\S 213$. Posting plat and notice-proof of posting-time for filing.

§214. Proceedings in the local land office-application for patent-citizenship-appointment of attorney-abstract of title-subsequent transfers-the noticecontents of notice-insufficient notice-publication of notice-charges for publication-proof of publication-proof of continuous posting-statement of fees and charges-application to purchase-receiver's receipt - transmission of record - protest grounds of protest-waiver of protest-delayed patent-cancellation of entry.

\$215. Adverse claim - distinction - contents of adverse claim-time for filing adverse-computation of time - no extension of time-effect of filing adverseevidence of waiver-appeal.

$\S 216$. The adverse suit-subsequent proceedings-duty of register-proceedings in general land office.

\section{CHAPTER XXXII.}

\section{TAXATION OF MINING CORPORATIONS.}

$\S 220$. Federal taxation-returns-filing return-principal place of business-penalty.

\$221. Commissioners' decisions-oil wells-dry wellstimber cutting-depreciation of minerals-exhaustion of deposits-unearned increment-market value of minerals - determination of valueunit value-record of estimates-compilation of values-immaterial question-excess in development-memorandum of exclusion-deduction for depreciation - royalties - leasehold investment limited deduction-no deduction.

$\S 222$. Undetermined questions.

$\S 223$. State taxation-graduated tax-time of paymentforfeiture-revival - penalty-trustees-settlement of affairs-popular fallacy-consent not necessary.

\$224. Recent legislation. 



\section{CHAPTER I.}

\section{MINING LAW IN THE UNITED STATES.}

$\S 1$. Local rules, regulations and customs-cause of establishment - common law of mining - statutory limitations-Californian provision-absence of rules and customs - when void-presumptions-construction-evidence-effect of non-observance.

\$2. Statutory law-lack of uniformity-salutary provisions. $\$ 3$. Alaska-additional provisions-explorations on Behring Sea-dredging-beach claims - roadway - aliens - adverse claims-adverse suits-adverse possession.

$\S$ 4. Hawaii-land department.

$\S 5$. Philippine Islands-dissimilar provisions-tunnel sites§ 6. Porto Rico.
land department.

$\S 1$. Local Rules, Regulations and Customs. The basic principle of the rules, regulations and customs of miners are discovery, appropriation and development. $^{1}$ They were introduced into California by the early miners, who obtained them from various foreign sources. ${ }^{2}$

2. Cause of Establishment. The absence of statutory law regulating mining and the use of water on the public domain was the cause of their establishment. ${ }^{3}$

3. Common Law of Mining. They were, in their general features, adopted throughout all the mining regions of the United States and are deemed the common law of mining in the United States. ${ }^{4}$

4. Statutory Limitations. Local rules and regulations are now practically superseded by legislative enactment in the mining states and territories, although miners are still permitted in their respective districts, ${ }^{5}$. particularly in Alaska, ${ }^{6}$ to make rules and regulations and adopt customs not in conflict with the paramount law. ${ }^{7}$

5. Californian Provision. Under the express provisions of the "mining act" of California, (in effect July 1, 1909), the mining districts or the rules 
and regulations thereof in that State, are not, in any manner to be construed as thereby affected or abolished. ${ }^{8}$

6. Absence of Rules and Customs. Where there are no local statutes nor district rules, regulations or customs affecting the manner of acquiring and maintaining possession of a mining claim, the observance of the provisions of the federal mining act is sufficient. ${ }^{9}$

7. WHEN VoID. When the district rules or customs are unreasonable, in conflict with higher law, ${ }^{10}$ fall into disuse or are generally disregarded, they are void. ${ }^{11}$

8. Presumptions. Where they are shown to have been established their existence is presumed to continue ${ }^{12}$ unless abrogated by federal or local legislation. In the absence of proof of their existence it is presumed that none exist. ${ }^{13}$

It will be presumed that a party in possession of a mining claim holds it in accordance with the district rules and customs. ${ }^{14}$

9. Construction. In a legal sense there is no distinction between a written rule or regulation and a custom or usage. ${ }^{15}$ The validity of each depends upon the customary obedience and acquiescence of the miners of the district. ${ }^{16} \mathrm{~A}$ custom reasonable in itself will prevail over a written rule which has fallen into disuse and is generally disregarded.17 A miner's rule is subject to the same rule of construction as a statute, ${ }^{18}$ although it does not, like a statute, acquire. validity by its mere enactment. ${ }^{19}$

10. Evidence. Courts do not take judicial notice of miner's rules and customs. ${ }^{20}$ The proof of their existence is governed by the ordinary rules of evidence. ${ }^{21}$

11. Effect of Non-Observance. While a valid rule, regulation or custom is in force it must be complied with. ${ }^{22}$ It has been held that no forfeiture fol- 
lows non-compliance unless the rules so expressly provide. ${ }^{23}$

1. Jennison v. Kirk, 98 U. S. 453.

2. Yale on Min. Claims, 58; DeFoos on Mines, 5, 7; see, generally, Lindley on Mines, ( $2 \mathrm{~d}$ ed.) $\$ 1$, et seq. For a collection of District rules see Browne's Report, H. R. Ex. Doc. No. 29, 39th Cong. 2d Sess.

3. Jennison v. Kirk, ante.

4. Morton v. Solambo Co., 26 Cal. 527; King v. Edwards, 1 Mont. 235.

5. Erhardt v. Boaro, 113 U. S. 527; see Northmore v. Simmons, 97 Fed. 386; Sisson v. Sommers, 24 Nev. 379. As to Alaska, see 31 Stats. 321; Butler v. Good Enough Co., 1 Alaska 246; Price v. M'Intosh, 1 Alaska 286; see Pierce's Wash. Code, \&6452; Wyo. Rev. Stats. § 2533 ; see Wyo. Stats. 1901 , p. 39.

6. 31 Stats. 321 .

7. Erhardt v. Boaro, ante.

8. C. C. $\S 1426 \mathrm{r}$.

9. Anderson v. Caughey, 3 Cal. A. 22; McKay v. McDougall, 25 Mont. 258; Golden Fleece Co. v. Cable Con. Co., 12 Nev. 312; see Sears v. Taylor, 4 Colo. 38 .

10. Rev. Stats. \& 2324 .

11. Haws v. Victoria Copper Co., 160 U. S. 303 . As to rules and customs invalid because inconsistent with paramount law or because unjust or unreasonable see Woodruff v. N. Bloomfield Co., 18 Fed. 763; Butler v. Good Enough Co., ante; Price v. M'Intosh, ante; Woody v. Bernard, 69 Ark. 579; Prosser v. Parks, 18 Cal. 47; Table Mt. Co. v. Stranahan, 21 Cal. 548; Strang v. Ryan, 46 Cal. 33; Original Co. v. Winthrop, 60 Cal. 678; Cleary v. Skiffich, 28 Colo. 362 ; Penn v. Oldhauber, 24 Mont. 287.

12. Riborado v. Quang Pang Co., 2 Ida. (Hasb.) 144.

13. McCleary v. Broaddus, 14 Cal. A. 60.

14. Robertson v. Smith, 1 Mont. 410; see Anderson v. Caughey, ante.

15. Harvey v. Ryan, 42 Cal. 626.

16. Id.; see Haws v. Victoria Copper Co., ante.

17. Harvey v. Ryan, ante.

18. Rush v. French, 1 Ariz. 99.

19. Harvey v. Ryan, ante; see Haws v. Victoria Copper Co., ante.

20. Butte City Co. v. Baker, 196 U. S. 119; Sullivan v. Hense, 2 Colo. 424 ; see $\$ 19$, note 2 , post.

21. Orr v. Haskell, 2 Mont. 225; see Campbell v. Rankin, 99 U. S. 261; Doe v. Waterloo Co., 70 Fed. 455; English v. Johnson, 17 Cal. 107; Pralus' v. Pacific Co., 35 Cal. 31; Harvey v. Ryan, ante; Sears v. Taylor, ante; Roberts v. Wilson, 1 Utah, 292.

22. Northmore v. Simmons, ante; Hughes v. Ochsner, 27 L. D. 396; Riborado v. Quang Pang Co., ante; King v. Edwards, ante; Mallett v. Uncle Sam Co., 1 Nev. 188.

23. Jupiter Co. v. Bodie Con. Co., 11 Fed. 666; Sturtevant v. Vogel, 167 Fed. 448; Johnson v. McLaughlin, 1 Ariz. 493; Emerson v. McWhirter, 133 Cal. 510; Flaherty v. Gwinn, 1 Dak. 509; but see King v. Edwards, ante. 
§2. Statutory Law. Except within the State of Texas, which has its independent code of mining law ${ }^{1}$ the statutory mining law consists of the acts of Congress and the laws of the various mining states and territories supplemental thereto. ${ }^{2}$ This subsidiary legislation is invited by the mining act of Congress, with the proviso that it shall not conflict with the laws of the United States. ${ }^{3}$ If repugnant thereto it is void. ${ }^{4}$

2. LACK of UNIFormity. The application and operation of the mining law are not uniform. Certain Congressional enactments apply only to Alaska. ${ }^{5}$ The mining acts of the several mining states are dissimilar in detail, have no extra-territorial force, and often needlessly add to the burden of the locator. ${ }^{6}$

3. Salutary Provisions. Salutary provisions found in the local statutes are such as provide for the recording of an affidavit of annual expenditure, the. legal effect to be given thereto, ${ }^{7}$ and for a means for establishing record evidence of a demand for contribution for assessment work from a delinquent co-owner. ${ }^{8}$

1. Sayles Ann. Civ. St. Texas 1897, arts. 3481-3498t; Sayles Ann. Civ. St. Supp. 1897-1904, 355; Tex. St. 1907, p. 331.

2. Rev. Stats. $\$ 2324$, Saxton v. Perry, 47 Colo. 263 . The history of mining has proved that the law of 1872 , and amendments thereto do not offer clear, adequate and simple solution for some of the practical conditions that arise in the development of the mining industry. King v. Amy Co., 9 Mont. 543.

3. Rev. Stats. $\S 2319$.

4. Butte City Co. v. Baker, 196 U. S. 119; Northmore v. Simmons, 97 Fed. 386 ; Original Co. v. Winthrop, 60 Cal. 678; Sharkey v. Candiani, 48 Or. 112; Copper Globe Co. v. Allman, 23 Utah 410 .

5. 31 Stats. 321 .

6. See Anderson v. Caughey, 3 Cal. A. 22; McKay v. McDougall, 25 Mont. 258; Golden Fleece Co. v. Cable Con. Co., 12 Nev. 312.

7. Book v. Justice Co., 58 Fed. 106; Ariz. Rev. Stats. 1901, $\S \S 3245-3249$; Cal. Stats. 1891, p. 219 ; Ida. C. C. $\S 3211$; Nev. Com. Laws, § 217 ; Mills Ann. Stats. Colo., § 3161; Utah Com. Iaws, § 1500; Pierce's Wash. Code, § 6445; Riste v. Morton, 20 Mont. 139.

8. Cal. Stats. 1891 , p. 155 ; C. C. $\$ 14260$; Nev. Com. Laws, $\$ 217$. 
§ 3. Alaska. The laws of the United States relating to mining claims, mineral locations, and rights incident thereto have been extended to the district of Alaska.

2. Additional Provisions. Provision is also made for the appointment of mining recorders, the recording of location notices, affidavits of annual expenditure and the place where such instruments shall be recorded.

3. Explorations on Behring Sea. Mining may be conducted on the Behring Sea subject to regulations prescribed by the Secretary of War.

4. Dredging. Dredging may be conducted in said sea subject to such regulations.

5. Beach Clatms. Miners on the beach of said sea have the right to dump tailings into or pump from the sea opposite their claims except where such dumping would actually obstruct navigation.

6. Roadway. The reservation of a roadway 60 feet wide under an act extending the homestead laws, etc., to Alaska does not apply to mineral lands and townsites. ${ }^{1}$

7. Aliens. Mining rights are accorded to native born citizens of the Dominion of Canada under certain restrictions. ${ }^{2}$

8. Adverse Claims. Adverse claims may be filed within the 60 days period of newspaper publication or within 8 months thereafter. ${ }^{3}$

9. Adverse SuIts. Adverse suits may be commenced within 60 days after the filing of the adverse claim. ${ }^{4}$

10. Adverse Possession. Adverse possession of a mining claim as against the locator thereof or his successors in interest cannot be instituted before the issuance of patent. ${ }^{5}$ 
1. 23 Stats. 24; 31 Stats. 321; McFadden v. Mt. View Co., 97 Fed. 670; as to "Beach claims" in Utah see Jeremy Co. v. Thompson, 20 L. D. 299 . For regulations concerning the manner of acquiring title to townsites in Alaska, see Circular 33 L. D. 163.

2. 30 Stats. 415 ; see Instructions 32 L. D. 424 .

3. 39 L. D. 49 .

4. Id.

5. Tyee Con. Co. v. Jennings, 137 Fed. 863.

§4. Hawaii. Title to public land in Hawaii is obtained under local statutes. ${ }^{1}$

2. Land Department. The land department of the United States has no jurisdiction over the public lands within Hawaii. ${ }^{2}$

1. 31 Stats. 154; see Opinion, 30 L. D. 295; McFadden v. Mt. View Co., 97 Fed. 670.

2. Michael Pszyk, 37 L. D. 18.

$\S 5$. Philippine Islands. A special act regulates the manner of acquiring and holding mining claims. in the Philippine Islands. ${ }^{1}$

2. Dissimilar Provisions. This act provides for lode locations of equal length and breadth without extra-lateral right, and restricts the "holder" to one location on the same vein or lode. It further provides how a claim shall be marked, and that the location notice shall be verified. That such notice shall be recorded within a certain time and have on its back a sketch plan showing as near as may be the position of the adjoining mineral claims and the size or shape of the claim to be recorded. Unless recorded within the statutory period the claim is deemed to be abandoned. Abandonment is also effected by filing written notice thereof with the mining recorder.

3. Tunnel Sites. There is no provision as to tunnel sites.

4. Land Departinent. The land department has no jurisdiction in these Islands.

1. 32 Stats. 697; 33 Stats. 691; see Reavis v. Fianza, 215 U. S. 16 . 
§ 6. Porto Rico. Public land in Porto Rico is under the control of the government established, and the legislative assembly, created by Congress. ${ }^{1}$

1. 31 Stats. $80 ; 32$ Stats. 731 ; see McFadden v. Mt. View Co., 97 Fed. 670.

\section{CHAPTER II.}

\section{COURTS.}

\$10. In general-jurisdiction-state courts-federal courtsjurisdiction-remand-land department-stay.

\$11. Federal question-pleadings.

$\$ 12$. Union of remedies-joinder-exception.

$\S 13$. Dismissal of cause.

$\$ 14$. Appeal-federal courts.

$\$ 15$. Appeal-state courts-writ of error.

$\S 16$. Conflicting decisions.

$\S 17$. Recent legislation.

$\S 10$. In General. "A court of competent jurisdiction," as that term is used in the mining act, undoubtedly means a court of general jurisdiction, whether it be a state court or a federal court. ${ }^{1}$

2. State Court. The jurisdiction of a state court is only such as is conferred upon it by the laws of the state in which it exists. ${ }^{2}$

3. Federal Court. The jurisdiction of the federal court depends upon either diversity of citizenship $^{3}$ or a federal question being involved in the controversy. ${ }^{4}$ The matter in dispute must exceed in value the sum of $\$ 2,000$, exclusive of interest and costs. ${ }^{5}$

4. JuRisdiction. Where the jurisdictional facts exist and appear upon the record a cause may be commenced in the latter court ${ }^{6}$ or, within the statutory period may be removed thereto from the state court in which it may have been brought ${ }^{7}$ upon a petition affirmatively showing such facts. ${ }^{8}$

5. REMAND. Upon the presentation of such a petition accompanied by a proper bond, the order of removal is made $;^{9}$ the case being subject to remand 
if the jurisdictional facts do not clearly appear of record. ${ }^{10}$

6. Land Department. Questions affecting the character of land ${ }^{11}$ or as to the party entitled to purchase it from the government 12 are wholly within the jurisdiction of the land department.

7. Stay. While a contest is pending therein a court should not interfere with nor proceed to the determination of a cause involving the property, but should dismiss the case or stay proceedings therein until the matter is concluded in the department; ${ }^{\mathbf{1 3}}$ unless there exists the necessity of preserving the peace or of determining controversies arising out of temporary rights in public land ${ }^{14}$ or to prevent waste which will result in a serious and permanent injury to the land.15

1. Blackburn v. Portland Co., 175 U. S. 571.

2. Nome \& Sinook Co. v. Simpson, 1 Alaska, 578; Bernard v. Parmelee, 6 Cal. A. 537; but see Warnekros v. Cowan, (Ariz.) 108 Pac. 238; Lightner v. Court, 14 Cal. A. 642.

3. Shoshone Co. v. Rutter, 177 U. S. 505.

4. Id. An attempt to raise a federal question in an assignment of errors in the Supreme Court of the United States is too late. Chapin v. Fye, 179 U. S. 127.

Elaboration of an assignment of errors after appeal is taken to a federal circuit court of appeals is futile. Doe v. Watexloo Co., 70 Fed. 455.

5. U. S. Comp. Stats., p. 508; see $\S 17$, post.

6. Blackburn v. Portland Co., ante; Florida Cent. Co. v. Bell, 176 U. S. 321 . It is possible that the requisite diversity of citizenship may be shown by amendment to the complaint. Newcomb v. Burbank, 181 Fed. 334.

7. Phoenix Co. v. Pèchner, 95 U. S. 183; De Lamars Co. v.

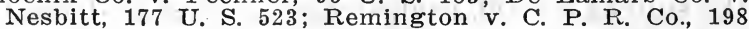
U. S. 95. For practice on removals in general, see Foster's Fed. Prac. (4th ed.), \$385.

8. U. P. R. Co. v. Myers, 115 U. S. 1; Powers v. C. \& O. R. Co., 169 U. S. 92 . See Foster's Fed. Prac. (4th ed.), \$385b.

9. Crehore v. O. \& M. R. Co., 131 U. S. 240.

10. Cameron v. Hodges, 127 Ü. S. 322 ; Crehore v. O. \& M. R. Co., ante. For amendment of record, see Foster's Fed. Prac., ante.

11. Standard Co. v. Habishaw, 132 Cal. 115.

12. Marquez v. Frisbie, 101 U. S. 473; Steel v. St. Louis Co., 106 U. S. 447 ; Lee v. Johnson, 116 U. S. 48; Sanford v. Sanford, 139 U. S. 642 . As to decisions of the land department upon matters of law see Hastings Co. v. Whitney, 132 U. S. 357 ; Menotti v. Dillon, 167 U. S. 703; see $\S 23,4$ post. 
13. Cosmos Co. v. Gray Eagle Co., 190 U. S. 301; Humbird v. Avery, 110 Fed. 465; Ripinsky v. Hinchman, 181 Fed. 786; see Lightner Co. v. Court, ante.

14. Warnekros v. Cowan, ante.

15. Humbird v. Avery, ante; Lightner v. Court, ante.

$\S 11$. Federal Question. A federal question does not necessarily arise under the mining act, as the case made may not involve any question as to the construction or effect of the Constitution or laws of the United States but may simply present a question of facts as to the time of the discovery of mineral, the location of the claim on the ground or a determination of the meaning and effect of the local rules and customs prescribed by the miners of the district or the effect of state statutes. ${ }^{1}$

2. Pleading. The jurisdictional facts must be shown in the plaintiff's pleadings or in the petition for removal. ${ }^{2}$

1. Blackburn v. Portland Co., 175 U. S. 571; Shoshone Co. v. Rutter, 177 U. S. 505.

2. Metcalf v. Watertown, 128 U. S. 586; Argonaut Co. V. Kennedy Co., 84 Fed. 1; Kan. City Co. v. Quigley, 181 Fed. 190.

\$12. Union of Remedies. Legal and equitable causes of action cannot be united in a federal court. ${ }^{1}$

2. JoINDER. Where such joinder exists prior to removal appropriate pleadings must thereafter be filed in both the law and equity side of the court within the time provided by the rules. ${ }^{2}$

3. Excerrion. A pleading which has been filed in a state court prior to removal and setting forth an equitable cause of action need not be recast, though lacking the formal fashion of a bill in equity. ${ }^{3}$

1. Whitehead v. Shattuck, 138 U. S. 146; So. Penn. Co. v. Miller, 175 Fed. 729; Clark v. Rosario Co., 176 Fed. 180. The equity jurisdiction conferred on the federal courts is the same as that the High Court of Chancery in England possesses; it is subject to neither limitation nor restraint by state legislation and is uniform 
throughout the different states of the union. U. P. R. Co. v. Flynn, 180 Fed. 565.

A suit for an accounting may be joined with an action for trespass in a federal court. Con. Wyo. Co. v. Champion Co., 63 Fed. 540.

2. McDonnell v. Eaton, 18 Fed. 710.

3. Durgan v. Redding, 103 Fed. 914.

$\S 13$. Dismissal of Cause. A cause may be dismissed upon motion or by the trial or appellate court, upon its own motion, at any time before its final disposition when it appears that it is not within the jurisdiction of the court ${ }^{1}$ or has been improperly or collusively brought for the purpose of creating a case cognizable or removable thereto. ${ }^{2}$

1. Morris v. Gilmer, 129 U. S. 315; Newcomb v. Burbank, 181 Fed. 334 ; Hare v. Birkenfield, 181 Fed. 825.

2. Hawes v. Contra Costa Co., 104 U. S. 450 ; Shreveport v. Cole, 129 U. S. 36.

\section{$\S 14$. Appeal - Federal Courts. An appeal lies} from the judgment of a circuit court to a circuit court of appeals ${ }^{1}$ and from thence may be taken to the Supreme Court of the United States by appeal or writ of error when it appears that the jurisdiction of the court is in issue or that the case involves the construction or application of the Constitution of the United States or when the constitution or law of a state is claimed to be in contravention of the Constitution of the United States. ${ }^{2}$

1. 26 Stats. 826; Alaskan appeals and writs of error go to the Circuit Court of Appeals for the 9 th judicial cirsuit, 35 Stats. 585; Shields v. Mongollon Co., 137 Fed. 539; see Alexander McKenzie, 180 U. S. 536; Judiciary Act of 1911,36 Stats. p. 1087.

2. U. S. Comp. Stats., p. 546. The same case may be taken up both by appeal and writ of error. McFadden v. Mt. View Co., 97 Fed. 670 . For form of supersedeas, see Alexander McKenzie, ante.

§15. Appeal - State Courts. Appeals in state courts are governed by the laws of the several states.

2. WrIT of ERror. A writ of error lies from a final decision of a state supreme court to the Supreme 
Court of the United States when it affirmatively or by fair implication appears that some federal question was involved which was necessary to the determination of the case. ${ }^{1}$ The mere fact that the action is brought in support of an "adverse claim" is not sufficient. ${ }^{2}$

1. Broughton v. Exchange Bank, 104 U. S. 427.

2. Beals v. Cone, 188 U. S. 184 .

$\S 16$. Conflicting Decisions. When a conflict exists between a decision of the Supreme Court of the United States and that of another appellate court regarding federal questions, the former prevails. ${ }^{1}$ It is the special prerogative of the former court to construe federal statutes. ${ }^{2}$

1. Quigley v. Gillett, 101 Cal. 462; Foss v. Johnstone, (Cal. A.) 110 Pac. 294; Duncan v. Fulton, 15 Colo. A. 140 ; Nash v. McNamara, 30 Nev. 114; Small v. Lutz, 41 Or. 570.

2. Street v. Delta Co., 42 Mont. 371.

§ 17. Recent Legislation. An Act entitled "An" Act to codify, revise, and amend the laws relating to the judiciary," approved March 3, 1911, and taking effect on January 1, 1912, among other things, merges the Circuit and District Courts into the "District Court," with both civil and criminal jurisdiction. In civil cases, thereunder, the amount in controversy must exceed $\$ 3,000$, exclusive of interest and costs. ${ }^{1}$

1. 36 Stats., p. 1087 :

\section{CHAPTER III.}

\section{A CTIONS.}

\$19. Possessory actions-possessory right-pleading-citizenship-judgment-receivers.

\$20. Adverse suit-jurisdiction-pleading-trial-dismissalnon-suit-judgment-final judgment.

$\S 19$. Possessory Actions. A possessory action for the recovery of any mining title or for damages to any 
such title is adjudged by the law of possession between the parties, although the paramount title to the land is in the United States. ${ }^{1}$

2. Possessony Right. The "possessory right" is the right to explore and work the property under the existing laws and regulations on the subject. ${ }^{2}$

3. Plending. The complaint need not be different from that required in possessory actions generally. It is sufficient to allege ownership and right of possession and that the defendant wrongfully entered therein. The means by which the possessor is entitled to the possession are matters of evidence. ${ }^{3}$

4. Citizenship. It is not necessary to either plead or prove the citizenship of either party to the action. ${ }^{4}$

5. Judgment. Pending litigation is ineffective and the effect of a judgment previously or subsequently obtained by an adverse claimant is nugatory as against an applicant for patent, unless made the subject of an "adverse claim" and suit thereunder. ${ }^{5}$

6. ReCEIVERS. A court will appoint a receiver to take possession of an unpatented location pending litigation to the end that the annual work may be performed for the benefit of the party who may ultimately prevail in the suit, in order to conserve the property for the benefit of the party entitled thereto, and prevent the extraction and disposition of the mineral therein. ${ }^{6}$

1. Rev. Stats. $\$ 910$; see Belk v. Meagher, 104 U. S. 279; RicoAspen Co. v. Enterprise Co., 53 Fed. 321; Gillis v. Downey, 85 Fed. 483; Fulkerson v. Chisna Co., 122 Fed. 782 ; Duggan v. Davey, 4 Dak. 110; see Loney v. Scott, (Or.) 112 Pac. 172. The law of possession is that the prior location and occupation carry with them the prior and better right. Meydenbauer v. Stevens, 78 Fed. 787.

2. Forbes v. Gracey, 94 U. S. 762. Possessory rights in mining claims may be divested by sale or gift, by forfeiture or by abandonment. Harkrader v. Carroll, 74 Fed. 474. In actions respecting mining claims, proof must be admitted of the customs, usages, or regulations established and in force at the bar or diggings embracing such claim; and such customs, usages, or 
regulations, when not in conflict with the laws of this state, must govern the decision of the action. C. C. P. $\S 748$; see Rev. Stats., $\$ 2324$; Woodruff v. N. Bloomfield Co., 18 Fed. 753.

3. Fulkerson v. Chisna Co., ante; Harris v. Kellogg, $117 \mathrm{Cal}$. 484; National Co. v. Piccolo, 54 Wash. 617. In a suit to recover possession of land, a separate cause of action may be added to restrain a threatened trespass and commission of waste. See Waskey v. M'Naught, 163 Fed. 927.

4. Harris v. Kellogg, ante; Contreras v. Merck, 131 Cal. 211.

5. Selma Oil Claim, 33 L. D. 187; Capital No. 5 Claim, 34 L. D. 462 ; see Jones v. Pac. Co., 9 Ida. 186.

6. Nev. Sierra Oil Co. v. Home Oil Co., 98 Fed. 673; Kjellman v. Rogers, 106 Fed. 775; see Cosmos Co. v. Gray Eagle Co., 104 Fed. 20; Midland Oil Co. v. Turner, 179 Fed. 74; Childers v. Neely, 47 W. Va. 70; see, generally, Loaiza v. Court, 85 Cal. 11. For form of appointment of receiver, see Alexander McKenzie, 180 U. S. 536.

§20. Adverse Suit. An "adverse suit" is one in the form of an action in ejectment or one to quiet title ${ }^{1}$ brought in a court of competent jurisdiction ${ }^{2}$ in opposition to an application for a patent. ${ }^{3}$ It arises only from claims to independent and conflicting locations. ${ }^{4}$ The suit or intervention must be based upon an adverse claim. ${ }^{5}$

This suit must be commenced within 30 days after the filing of the adverse claim ${ }^{6}$ and be prosecuted with reasonable diligence. ${ }^{7}$

2. JuRIsDiction. The jurisdiction of the court is limited to the area in conflict ${ }^{8}$ and the burden is upon the plaintiff to show the conflict of surface area. ${ }^{9}$

3. Plending. The extent of the allegations in the pleadings as well as the extent of the proof required varies in the different states. ${ }^{10}$ Each party is plaintiff and actor and both may fail.11 Each must set forth the facts upon which he relies to show that his is the better right. ${ }^{12}$

It is essential that each party allege and prove, if not admitted, that he is a citizen of the United States, or has declared his intention to become such. ${ }^{13}$ It is too late, however, to raise the question for the first time in the appellate court. ${ }^{14}$ 
4. TRIAL. Each party must prove his right against his adversary as well as against the United States. ${ }^{15}$ Neither can depend upon the weakness of the title of the other, ${ }^{16}$ as the question is, Has the plaintiff the title or does the defendant have it, or do neither have it ?17

5. Dismissal. The suit may on motion be dismissed upon withdrawal of the application for patent ${ }^{18}$ or because the suit is not prosecuted with reasọnable diligence to final judgment. ${ }^{19}$

6. Non-SUIT. A non-suit may be granted. ${ }^{20}$

7. JudGMent. The judgment only determines the right of possession as between the parties; ${ }^{21}$ that they are entitled to separate and different portions of the claim involved ${ }^{22}$ or that they are neither one entitled to judgment 23 or to proceed with the application for patent. ${ }^{24}$ All other questions affecting the right to patent are decided by the land department. ${ }^{25}$

8. Final Judgment. The judgment is not final if an appeal has been taken or a motion for a new trial be pending. ${ }^{26}$

See $\S 216$, post.

1. Perego v. Dodge, 163 U. S. 160. As an "adverse suit" in the form of an action to quiet title is in effect a suit in equity a jury trial is not a matter of right. Butte Con. Co. v. Barker, 35 Mont. 327. The term "suit" applies to any proceeding in a court of justice by which an individual pursues that remedy which the law affords. Kohl v. U. S., 91 U. S. 367 .

2. Shoshone Co. v. Rutter, 177 U. S. 505.

3. Bunker Hill Co. v. Empire State Co., 109 Fed. 538; Upton v. Sta. Rita Co., 14 N. M. 96.

4. Turner v. Sawyer, 150 U. S. 578; Creede Co. v. Uinta Co., 196 U. S. 337; Stevens v. Grand Cent. Co., 133 Fed. 28; Thomas v. Elling, 25 L. D. 495; Grand Canyon Co. v. Cameron, 35 L. D. 495; Providence Co. v. Burke, 6 Ariz. 323; Champion Co. v. Con. Wyo. Co., 75 Cal. 78; Doherty v. Morris, 11 Colo. 12; Davidson v. Fraser, 36 Colo. 1.

5. Perego v. Dodge, ante; Madison Placer Claim, 35 L. D. 551; Mt. Blanc Co. v. Debour, 61 Cal. 364; Jefferson v. Anchoria Co., 32 Colo. 176; Healey v. Rupp, 37 Colo. 25; Murray v. Polglase, 23 Mont. 401; Rose v. Richmond, 17 Nev. 25; Nesbitt v. Delamar Co., 24 Nev. 273; Lockhart v. Farrell, 31 Utah 155. 
6. Rev. Stats. §2326; see Steves v. Carson, 42 Fed. 821; Madison Placer Claim, ante; Deniss v. Sinnott, $35 \mathrm{~L}$. D. 304; see also Selma Oil Claim, 33 L. D. 187.

7. Rev. Stats. $\$ 2326$. The question of diligence is one for the court, not the land department. Rose v. Richmond, ante.

8. Mares v. Dillon, 30 Mont. 117; see Shoshone Co. v. Rutter, ante.

9. Porter v. Tonopah Co., 133 Fed. 756; see Hoban v. Boyer, 37 Colo. 185.

10. See Bennett v. Harkrader, 158 U. S. 441; Lavagnino v. Uhlig, 198 U. S. 443; Brown v. Gurney, 201 U. S. 184; Tonopah Co. v. Douglass, 123 Fed. 936; Providence Co. v. Marks, 7 Ariz. 74; Phillips v. Smith, 11 Ariz. 309; Rough v. Simmons, 65 Cal. 227; Holmes v. Salamanca Co., 5 Cal. A. 659; Contreras v. Merck, 131 Cal. 211; Jackson v. McFall, 36 Colo. 119; Penn. Co. v. Bales, 18 Colo. A. 108; Rawlings v. Casey, 19 Colo. A. 152; Hoban v. Boyer, ante; Cronin v. Bear Creek Co., 3 Ida. (Hasb.) 614; Hahn v. James, 29 Mont. 1; Hopkins v. Butte Co., 29 Mont. 390 ; Woody v. Hines, 30 Mont. 189; Thornton v. Kaufman, 35 Mont. 181; Deeny v. Min. Creek Co., 11 N. M. 279; Perego v. Dodge, 9 Utah 3; Iba v. Cent. Ass'n, 5 Wyo. 355; Sherlock v. Leighton, 9 Wyo. 297.

11. Bay State Co. v. Brown, 21 Fed. 167; Gird v. Cal. Oil Co., 60 Fed. 531; Anthony v. Jillson, 83 Cal. 296; Cronin v. Bear Creek Co., ante; see Smith v. Imperial Co., 11 Ariz. 193; Mt. Blanc Co. v. Debour, ante; Murray v. Polglase, ante; Lily Co. v. Kellogg, 27 Utah 111 . As to form of bill in equity in a suit removed from a state court to a federal court, see Durgan v. Redding, 103 Fed. 914.

12. See note 11 , ante.

13. Allyn v. Schultz, 5 Ariz. 152; Sherlock v. Leighton, ante; see Altoona Co. v. Integral Co., 114 Cali, 100; Strickley v. Hill, 22 Utah, 257; Stolp v. Treasury Co., 38 Wash. 619.

14. O'Reilly v. Campbell, 116 U. S. 418.

15. Brown v. Gurney, ante.

16. Weed v. Snook, 144 Cal. 439; Thomas v. Chisholm, 13 Colo. 105. The defendant may show that the plaintiff's location was made upon ground embraced within a prior, valid, subsisting location, and if he succeeds in the same it is a bar to plaintiff's recovery. Hoban v. Boyer. ante; but see Farrell v. Lockhart, 210 U. S. 242.

17. Iba v. Cent. Ass'n, ante. It is absolutely necessary that a party claiming the right to possession by virtue of a mining location must establish such right by evidence of compliance with the federal and state statutes relating to the location and holding of mining claims. It therefore devolves upon each of the parties litigant to prove every material fact necessary to sustain the validity of his contention. Becker v. Pugh, 9 Colo. 589; Duncan v. Eagle Rock Co., 48 Colo. 569 ; see note 16 , ante.

18. Beals v. Cone, 27 Colo. 473.

19. Rose v. Richmond, ante; Davis v. McDonald, 33 L. D. 641; see Providence Co. v. Marks, ante. When such a motion is made the court will consider the date of the filing of the adverse and of the complaint. Bernard 
v. Parmelee, 6 Cal. A. 537; but the court cannot pass upon the sufficiency of the adverse claim. Waterhouse v. Scott, 13 L. D. 718; see Kannaugh v. Quartette Co., 16 Colo 341. See Richmond Co. v. Rose, 114 U. S. 576. See, also, Gypsum Placer, 37 I. D. 484; see, generally, $\$ 216$, note 2 , post.

20. McWilliams v. Winslow, 34 Colo. 341 ; Lozar v. Neill, 37 Mont. 287; see Iba v. Cent. Ass'n, ante.

21. Wolverton v. Nichols, 119 U. S. 485; Last Chance Co. v. Tyler Co., 157 U. S. 683; Wheeler v. Smith, 23 L. D. 395; Manning v. Strehlow, 11 Colo. 451; Healey v. Rupp, ante; Upton v. Sta. Rita Co., ante. The judgment may be entered by consent of the parties. Morrison's Mg. Rights (13th ed.) 494; but see Bay State Co. v. Brown, ante; Becker v. Pugh, 17 Colo. 243; see note 17, ante; see Carrie S. Co., 29 L. D. 287.

22. Rev. Stats. $\$ 2326$. The judgment must designate the part, if any, of the area in conflict that may belong to each of the adverse claimants and the complaint must sustain the judgment. Smith v. Imperial Co., ante.

23. 21 Stats. 505; Wilson v. Freeman, 29 Mont. 470; Helena Co. v. Baggaley, 34 Mont. 464; see Perego v. Dodge, ante; Tonopah Co. v. Tonopah Co., 125 Fed. 400; Mares v. Dillon, ante; Kirk v. Meldrum, 28 Colo. 453; Anthony v. Jillson, ante. The claim may still, however, be held under possessory title as long as there may be a compliance with the requirements of the law. McGowan v. Alps Co., 23 L. D. 113; see Brien v. Moffitt, 35 L. D. 32 ; but see Lauman v. Hoofer, 37 Wash. 382 .

24. Bay State Co. v. Brown, ante; Willett v. Baker, 133 Fed. 937; Brien v. Moffitt, ante; see Newman v. Barnes, 23 L. D. 257.

25. Perego v. Dodge ante; Apple Blossom Co. v. Cora Lee, 14 L. D. 641 ; Clipper Co., 33 L. D. 660.

26. Doon v. Tesh, 131 Cal. 406.

\section{CHAPTER IV.}

\section{DISPOSAL OF THE PUBLIC LANDS.}

§23. Land department - powers - judgment unassailable judgment not conclusive-Board of Equitable Adjudication-character of entries to be submitted-procedure -appeal-termination of jurisdiction.

$\$ 24$. Contests-grounds for action-procedure-notice required-purpose of notice-effect of notice-defaultnotice after appearance-compromise-specific performance.

\$25. Hearings-character of land-presumption.

$\$ 26$. Testimony-rules-evidence-insufficient evidence-burden of proof.

$\$ 27$. Result of hearing-segregation survey-judgment not equivalent to patent-subsequent legal proceedings.

§28. State lands-when title passes-when closed to the prospector-rights on state patented land-land departmient-register of state land office-contestspleading-protestant-effect of judgment-payment for 
land-statute of limitations-recent Californian legislation-school lands withdrawn from sale.

$\$ 28$ a. Conservation.

$\$ 29$. Railroad lands-classification of land-inconclusiveness of classification-subsequent discovery of mineral-rejection of application for patent-land department.

§ 23. Land Department. The Land Department of the United States, including in that term the Secretary of the Interior, the Commissioner of the General Land Office and their subordinate officers, constitutes a special tribunal vested with the judicial power to hear and determine the claims of all parties to the public lands and authorized to dispose of and to execute its judgments by conveyance to the parties entitled to them ${ }^{1}$ according to rules and regulations promulgated by it under the provisions of law, ${ }^{2}$ regarding the disposition of the public domain.

2. Powers. Necessarily, therefore, it must consider and pass upon the qualifications of the applicant, the acts he has performed to secure the title, the nature of the land and whether it is open for sale.

3. Judgment Unassailable. Its judgment upon these matters is unassailable except by direct proceedings for its annulment or limitation. ${ }^{3}$ 'The courts have no revisory power over the decisions of the land department upon questions of fact. ${ }^{4}$

4. Judgment NOT Conclusive. Its decisions are open to re-litigation in the courts on the ground of its want of jurisdiction in the case, ${ }^{5}$ or that it misconstrued the law, ${ }^{6}$ or in cases of fraud ${ }^{7}$ (when extrinsic or collateral and do not consist of perjury or "false proofs"), 8 inadvertence, mistake, ${ }^{9}$ etc., which permit any determination to be re-examined. ${ }^{10}$

5. Board of Equitable Adjudication. This board consists of the Secretary of the Interior and the Attorney-General. ${ }^{11}$

6. Character of Entries to be Submitteded. The entries to be submitted to this board are only those where the law has been substantially complied with 
and the error and informality therein arose from ignorance, accident or mistake, which can satisfactorily be explained. ${ }^{12}$

7. Procedure. All proceedings in relation to the disposal of the public lands must be initiated in the proper district land office, and all papers on appeal must be transmitted through that office. ${ }^{13}$

8. Appenu. An appeal lies from the decision of the officers of the local land office to the Commissioner of the General Land Office and from him to the Secretary of the Interior. ${ }^{14}$

9. Termination of Jurisdiction. The jurisdiction of the land department over the land and over the title which it has conveyed ceases upon the actual issuance of the patent $;^{15}$ that is, its due issuance and recordation, not necessarily accompanied by actual delivery. ${ }^{16}$

1. Rev. Stats. $\S \S 441,453,2478$; U. S. v. Winona Co., 67 Fed. 948; see Knight v. U. S. Land Ass'n, 142 U. S. 161; Lawrence v. Potter, 22 Wash. 32. The "subordinate offcers" are the respective U. S. surveyors general-Cragin v. Powell, 128 U. S. 691-and the registers and receivers of the several local land offices-Rev. Stats. $\S \S 2234-2237$.

2. Rev. Stats. $\$ \S 441,453,2478$; Boske v. Comingore, 177 U. S. 459; Cosmos Co. v. Gray Eagle Co., 190 U. S. 301; Leonard v. "Lennox, 181 Fed. 760; Gage v. Gunther, 136 Cal. 338; Clyde v. Cummings, 35 Utah 461; see Garfield v. Goldsby, 211 U. S. 249; Anchor v. Howe, 50 Fed. 366. Courts take judicial notice of the regulations of the land department. Ieonard v. Lennox, ante. When a rule is established in the land department it will not be overthrown or ignored by the courts unless they are clearly convinced that it is wrong or tends to confusion and conflict of claims. Holt v. Murphy, 207 U. S. 407.

3. Steel v. St. Louis Co., 106 U. S. 447; Burfenning v. Chicago Co., 163 U. S. 321 ; Cosmos Co. v. Gray Eagle Co., ante; Grand Canyon Co. v. Cameron, 36 L. D. 66.

4. Jefford v. Hines, 2 Ariz. 162. It would lead to endless litigation and be a fruitful source of evil if a supervisory power vested in the courts over the action of the land department on mere questions of fact presented for their examination. Quinby v. Conlan, 104 U. S. 420; Gage v. Gunther, ante.

5. Burfenning $v$. Chicago Co., ante.

6. Hawley v. Diller, 178 U. S. 476; Hoyt v. Weyerhaueser, 161 Fed. 324; So. Cross Co. v. Sexton, 147 Cal. 758.

7. U. S. v. Iron Co., 128 U. S. 673 ; Whitcomb v. White, 214 
U. S. 15; James v. Germania Co., 107 Fed. 597; LeMarchal v. Tegarden, 175 Fed. 682.

8. U. S. v. Atherton, 102 U. S. 372 ; U. S. v. White, 17 Fed. 561; U. S. v. Minor, 26 Fed. 672; Kennedy v. Dickey, 34 Mont. 205; Cagle v. Dunham, 14 Okla. 610; see Cragie v. Roberts, 6 Cal. A. 309.

9. Germania Iron Co. v. U. S., 165 U. S. 379.

10. U. S. V. Iron Co., ante; McCormick v. Hayes, 159 U. S. 332 ; Germania Iron Co. v. U. S., ante; Hawley v. Diller, ante; James v. Germania Iron Co., ante; Thallman v. Thomas, 111 Fed. 277.

11. Rev. Stats. \$ 2451; Hawley v. Diller, ante.

12. Rev. Stats. $\$ \$ 2450-2457$; Crosby Claims, 35 L. D. 434 ; see Regulations, 39 L. D. 320 .

13. Rules of Practice, 4 L. D. 37 . Id., 39 L. D. 395.

14. Rev. Stats. $\$ \$ 453-2478$; Rules of Practice, ante; see Shepley v. Cowan, 91 U. S. 330; Emblen Co. v. Lincoln Land Co., 102 Fed. 559. An order for hearing is discretionary and interlocutory and is not appealable. American Co., 39 L. D. 299.

15. Moore v. Robbins, 96 U. S. 530; see U. S. v. Rumsey, 22 L. D. 101; Baldwin Co. v. Quinn, 28 L. D. 307.

16. U. S. v. Schurz, 102 U. S. 378; U. S. v. Laam, 149 Fed. 581.

$\S 24$. Contests. The land department may, upon its own motion, or upon the initiation of a contest by any person seeking to acquire title to, or claiming any interest in, the land involved, against a party to any entry, filing, or other claim under laws of Congress relating to the public lands, because of priority of claim, or for any sufficient cause affecting the legality or validity of the claim, not shown by the records of the land department; or upon the filing of a corroborated protest by any other party, or upon the protest or report of a special agent of the government order a hearing for any sufficient cause affecting the validity of the applicant's claim, ${ }^{1}$ and thereupon take such action as may be appropriate and necessary to enforce its jurisdiction and preserve the rights and interests of the public. ${ }^{2}$

2. Grounds For Action. The grounds for such action may be to determine the character of the land embraced in the claim. ${ }^{3}$ That the claim is merely colorable and is used to cloak acts subversive of the law as, a patent that is sought for land under the mining law for purposes or uses foreign to those of mining. ${ }^{4}$ 
That the applicant for patent has failed to comply with the law in any manner essential to a valid entry ${ }^{5}$ or that a private claim is ineonsistent with some public use or purpose to which the land may be devoted pursuant to law. ${ }^{6}$

3. Procedure. An adverse claim is determined only by the courts; proceedings upon either a contest or a protest are subject to the Rules of Practice, confined to the land department, and determined therein. ${ }^{7}$

4. Notice Required. Applicants for patent, whether mineral or agricultural, are required to publish, and in some instances to post, notice of their application. ${ }^{8}$

5. Purpose of Notice. The purpose of the notice is to afford opportunity to any person having a claim against the property to appear in the local land office and contest the applicant's right to a patent. ${ }^{9}$

6. EFfect of Notice. In an application for $a^{*}$ mineral patent, at least, the published notice is deemed to be equivalent to a summons in a judicial proceeding. ${ }^{10}$

7. Default. Failure to appear and contest the application precludes the adverse claimant's rights, ${ }^{\mathbf{1 1}}$ except those which a court of equity might allow to be urged against a judgment at law. ${ }^{12}$

8. Notice after Appearance. The right to personal notice of all proceedings in the land department is dependent upon having made appearance in the particular proceeding. ${ }^{13}$

9. Compromise. Where there is a bona fide contest between a mineral claimant and an agricultural claimant for the same land an amicable adjustment of the difficulty by a division of the land between them may be made. Patent may issue to either claimant according to the classification of the land by the land department and subsequent transfer may then be made by the patentee to the other claimant. ${ }^{\text {is }}$ 
10. Specific Performance. The specific performance of such a contract will be enforced by the courts. $^{15}$

1. Jurisdiction, 35 L. D. 565 ; Rule 3 of Practice; 4 L. D. 37 ; Rule 1 of Practice, 39 L. D. 395 ; see Instructions, 21 L. D. 367 ; H. H. Yard, 38 L. D. 59; Charles F. Whitehead, 38 L. D. 144; Thomas B. Walker, 39 L. D. 426. A protest should set forth all material and issuable facts with sufficient particularity to apprise the applicant of the definite nature of the case and enable him to defend without danger of surprise by any fundamental question. A protest by a mineral claimant based upon the alleged mineral character of the land embraced in an application for agricultural land should set forth the amount and kind of mineral that has been taken from the land; whether any assays thereof have been made, and if so the result thereof, the character and value of the mining improvements, if any, that have been placed upon the property as well as any other material matter upon which the respective rights of the parties may be determined. Yard v. Cook, 37 L. D. 401.

2. U. S. v. Smith, 181 Fed. 545; Jurisdiction, ante. The reports of special agents of the government are confidential and privileged communications and cannot be demanded as a matter of right by the parties in interest and will not be furnished except upon authority of the Secretary of the Interior. Clark, Prentiss \& Clark. 38 L. D. 464 . For an outline of the proceedings upon the report of a special agent, see John C. Miller, 28 L. D. 45 . The question of discovery raises an issue generally to be tried out in an adverse suit but where it is charged in a protest that no discovery within the limits of the claim was made at or prior to the beginning of the period of notice of application for patent the land department will take jurisdiction to determine that question. This upon the ground that the allegation, if true, would disclose the absence of a seasonable and essential basis for a judgment in favor of the applicant op the adverse claimant. Rupp v. Healey, 38 L. D. 387.

3. Barden v. N. P. R. Co., 154 U. S. 288; Coleman v. McKenzie, 28 L. D. 348 ; H. H. Yard, ante; American Co., 39 L. D. 299; Standard Co. v. Habishaw, 132 Cal. 115.

4. Jurisdiction, ante; Grand Canyon Co. v. Cameron, 36 L. D. 66 .

5. Rev. Stats. § 2325.

6. Jurisdiction, ante; see § 213-18, § 215-2.

7. Wight v. Dubois, 21 Fed. 693 ; Fred A. Williams, 17 L. D. 282 ; Lake Superior Co. v. Patterson, 30 L. D. 160.

8. Id.; Rev. Stats. $\$ 2325$. The several laws and regulations providing for and requiring publication of notice in relation to entries of and claims to public lands are collated in 38 L. D. 136.

9. Kerns v. Lee, 142 Fed. 985.

10. Wight v. Dubois, ante; Jefferson v. Anchoria Co., 32 Colo. 176. 
11. Kerns v. Lee, ante; Richards v. Wolfing, 98 Cal. 195.

12. Golden Reward Co. v. Buxton, 79 Fed. 868; see German Ins. Co. v. Hayden, 21 Colo. 127; So. End Co. v. Tinney, 22 Nev. 19. Where due notice is given the parties to a controversy in the land department, and they appear therein with their witnesses, and are given a full and fair hearing, and submit their cause to the department for final decision, courts of equity will not intervene to set aside such decision, upon an allegation in a petition or bill that perjury was committed by the parties or their witnesses in the course of the trial. Cagle v. Dunham, 14 Okla. 610.

13. N. P. R. Co. v. Cannon, 54 Fed. 252; see Rules of Practice, ante; Lake Superior Co. v. Patterson, ante.

14. Murray v. White, 42 Mont. 423 ; see St. Louis Co. v. Mont. - Co., 171 U. S. 650 .

15. Id.

$\S 25$. Hearings. Hearings are governed by the Rules of Practice promulgated by the land department. ${ }^{1}$

2. Character of Land. Hearings to determine the character of lands are practically of two kinds, viz.:

(1) Lands returned as mineral by the SurveyorGeneral.

(2) Lands returned as agricultural and alleged to be mineral in character. ${ }^{2}$

3. Presumption. Public land returned by the Surveyor-General as mineral in character is withheld as agricultural land until the presumption arising from such return is overcome by testimony in the manner prescribed by the land department. ${ }^{3}$

1. Min. Reg. par. 99; Rules of Practice, 4 L. D. 37 . Id., 39 L. D. 395 .

2. Min. Reg. par. 101. That one person in perfect good faith may assert a mineral claim for a particular parcel of public land, and another person, equally in good faith, may assert an agricultural claim to the same ground is beyond question. The same land may be valuable for both mining and agricultural purposes. In such circumstances the controversy is settled by the land. department determining whether the land, in whole or in part, is more valuable for one purpose than another. Murray v. White, 42 Mont. 423.

3. Min. Rcg., par. 100; see Kinkade v. Cal., 39 L. D. 491; see Lindley on Mines ( $2 \mathrm{~d}$ ed.), $\$ \S 94,98,207$. 
$\S 26$. Testimony. At hearings to determine the character of land the testimony is directed to both the mineral and the agricultural character of the land. ${ }^{1}$

2. RULES. The proceedings are conducted under rules prescribed by the land department as to the nature of the testimony required. ${ }^{2}$

3. Evidence. The proof of the mineral claimant must be specific, based upon the production of mineral at a profit. ${ }^{3}$

4. InsUfFicient Evidence. It is insufficient for the mineral claimant to show the existence of a mere location ${ }^{4}$ or a discovery that might be sufficient to sustain a location in the first instance. ${ }^{\mathbf{5}}$

5. Burden of Proof. The burden of proof is upon the person who asserts the mineral character of the ground in dispute ${ }^{6}$ or has the burden of proof cast upon him by order of the land department. ${ }^{7}$

1. Min. Reg. pars. 105, 106, 107. The question of the character of land is always one of fact. Evidence of the actual use to which it has been placed by those who occupy it and make it a means of livelihood is not conclusive evidence but tends to establish its character and is relevant and material for that purpose. Lynch v. U. S., 138 Fed. 535 .

2. Min. Reg. ante.

3. Dughi v. Harkins, 2 L. D. 721 , cited approvingly in U. S. v. C. P. R. Co., 98 Fed. 874 ; see U. S. v. Iron Co., 128 U. S. 673; Davis v. Weibbold, 139 U. S. 507; Royal K. Placer, 13 L. D. 86 ; Brophy v. O'Hare, 34 L. D. 596 ; Alford v. Barnum, 45 Cal. 482 ; Merrill v. Dixon, 15 Nev. 407; Bay v. Oklahoma Co., 13 Okla. 425. Lands are not reserved from entry under the land laws simply because some one is foolish or visionary enough to claim or work some portion of them as mineral ground without reference to whether it would pay to work or not. U. S. v. Reed, 28 Fed. 482; Ferrell v. Hoge, 27 L. D. 129 ; Hunt v. Steese, 75 Cal. 620 ; see also Eting v. Potter, 17 L. D. 424; Purtle v. Steffee, 31 L. D. 400; Steele v. Tanana Co., 148 Fed. 678; see also Chrisman v. Miller, 197 U. S. 313.

4. Sweeney v. N. P. R. Co., 20 L. D. 394.

5. Brophy v. O'Hare, ante.

6. Dughi v. Harkins, ante; Tinkham v. McCaffrey, 13 L. D. 517: Winters v. Bliss, 14 L. D. 59; Aspen Co. v. Williams, 27 L. D. 1.

7. Magruder v. O. \& C. R, Co., 28 L. D. 174. 
$\S 27$. Result of Hearing. The character of the land is conclusively determined by the judgment in either a contest or protest proceeding. ${ }^{1}$ It may be held to be wholly or in part mineral or agricultural land.

2. Segregation Survey. Where it is held to be partly of each class a segregation survey may be had, through the local land office, on application made by the proper party. ${ }^{2}$

3. Judgmént not Equivalent to Patent. A judgment in favor of the mineral elaimant is not equivalent to a patent for the land embraced therein. ${ }^{3}$

4. Subsequent Legal Proceedings. After the land department shall have disposed of the questions within its jurisdiction if any legal right of either party to the proceedings has been invaded, he may seek redress in the courts. ${ }^{4}$

1. Casey v. Vassor, 50 Fed. 258; see Marquez v. Frisbie, 101 U. S. 473 .

2. Min. Reg. par. 108. As to land segregated by the issuance of a mineral patent see 33 Stats. 545 .

3. Min. Reg. par. 111.

4. Litchfield v. Reg. \& Rec., 76 U. S. 575; Kirwan v. Murphy, 189 U. S. 35.

$\S 28$. State Lands. Congress has granted to certain of the states for educational purposes and for internal improvements, certain parts of the public domain not known to be mineral in character at the time of the grant and the right to select other lands in lieu thereof, if mineral in character or if covered by a prior valid subsisting claim. ${ }^{1}$

2. When Titue Passes. Title does not pass to the state under such a grant until the land is surveyed and the survey is approved 2 if the grant is a present one, ${ }^{3}$ or until the land is selected by the state and the selection is approved, certified to or "listed" to the state by the land department of the United States, ${ }^{4}$ 
which is equivalent to patent, when the selection is of lieu or indemnity land. 5

3. When Closed to the Prospector. Land which has passed to the state by grant or certification is no longer open to exploration, occupation or mineral location. ${ }^{6}$

4. Rights on State Patented Land. Where it happens that a subsisting mineral location is covered by a non-mineral patent the mineral claimant, in order to sustain his rights, must prove the greater mineral value than agricultural value of the land at the time the patent issued. ${ }^{7}$

Discovery of mineral subsequent to the issuance of a non-mineral patent inures to the benefit of the patentee. ${ }^{8}$

5. Land Department. The land-grant-aided states maintain land departments of their own which are not a part of the land department of the United States. This because a state may administer its public lands in any way that it sees fit, so long as it does not conflict with the rights guaranteed by the Constitution of the United States. ${ }^{9}$

6. Register of Stite Land Office. In California the state surveyor-general is ex-officio register and the assistant deputy surveyor-general is ex-officio deputy register of the state land office. ${ }^{10}$

7. Contests. If the question involved in a contest is as to the survey of state lands, or one purely of fact, etc., the register may proceed to hear and determine the same; but when, in his judgment a question of law is involved, or when either party demands a trial in the state courts he must make an order referring the contest to the superior court of the county in which the land is situated. ${ }^{11}$

8. Plending. When the proceeding is referred to a court for determination each party thereto becomes an actor therein ${ }^{\mathbf{1 2}}$ and whether plaintiff, defendant 
or intervenor, ${ }^{13}$ he must state in his pleadings all the facts upon which he relies as showing his right to become the purchaser and the steps he has taken to avail himself of and secure his right to make the purchase. ${ }^{14}$ The facts must be set out so that the court can discern that the application is in due form of law, or rather that it complies with the requirements of the law. ${ }^{15}$

9. Protestant. Where a party merely protests against the application of another party, he must state the facts constituting the grounds therefor, as, for instance, that he has acquired the title from the United States, or that he has the right of pre-emption, stating the facts upon which his right is based. ${ }^{16}$

10. EFFect of Judgment. Upon filing with the surveyor-general or register, as the case may be, a copy of the final judgment of the court, that officer must approve the survey or location, or issue the certificate of purchase or other evidence of title in accordance with such judgment. ${ }^{17}$

11. Payment For Land. When the full amount of the purchase price has been paid the purchaser becomes vested with the ownership of the land described in the certificate of purchase, and can make the same disposition of the land as could any other owner. The patent is but evidence of his title. ${ }^{18}$

12. Statute of Limitations. Contests relating to applications to purchase state school lands can only be brought within five years from and after the date on which the certificate of purchase may have been issued. ${ }^{19}$ No suit can be brought upon a patent or grant from the state of California after ten years from its date 20 unless the same is judicially declared to be void, in which case the suit must be brought within five years thereafter. ${ }^{21}$

13. Recent Californian Legislation. Under the provisions of a recent act of the legislature of the state 
of California any person claiming or deraigning title under an unrecorded deed or patent from that state is authorized to bring suit to quiet title against the state to the land embraced therein, or any part thereof, within one year from the twenty-fourth day of March, $1911 . .^{22}$

14. School Lands Withdrawn From Sale. School lands (16th and 36th sections) situated within a military, Indian, national or state forest reservation, national park or national monument are withdrawn from sale by the state. ${ }^{23}$

1. Ivanhoe Co. v. Keystone Co., 102 U. S. 167; see Bond v. California, 31 L. D. 34 .

2. Heydenfeldt v. Daney Co., 93 U. S. 634 ; F. A. Hyde \& Co., 37 L. D. 164; Medley v. Robertson, 55 Cal. 396; Clemmons v. Gillette, 33 Mont. 321 ; see State v. Wright, 24 L. D. 54 .

3. Johanson v. Washington, 190 U. S. 179.

4. McCreery v. Haskell, 119 U. S. 327.

5. Hendy v. Compton, 9 L. D. 106.

6. Buena Vista Co. v. Tulare Co., 67 Fed. 226 ; Rice v. State, 24 L. D. 14. But see Cal. Stats. 1897, p. 438, which provides for the exploration and sale of mineral lands within the grant of school lands to the state in conformity with the provisions of the mining act. See also Cuttings Com. Laws Nev., \$§ 281-282; Or. Stats. 1907 , p. 214.

7. Bonner v. Meikle, 82 Fed. 697; McCormick v. Sutton, 97 Cal. 373 .

8. Deffebach v. Hawke, 115 U. S. 392: Davis v. Weibbold, 139 U. S. 507; Ferry v. Street, 4 Utah 521.

9. Frellsen \& Co. v. Crandell, 217 U. S. 71; see Thomas B. Walker, 39 L. D. 426 ; Kinkade v. Cal., 39 L. D. 491.

10. Pol. C. $\S \S 350-485$.

11. Pol. C. \$ 3414; Danielwitz v. Temple, 55 Cal. 42; see Polk v. Sleeper, (Cal.) 112 Pac. 179.

12. Cadierque v. Duran, ante.

13. Moran v. Bonynge, 157 Cal. 295.

14. Cadierque v. Duran, ante.

15. Reese v. Thorburn, 78 Cal. 117.

16. Cadierque v. Duran, ante.

17. Pol. C. $\$ 3416$.

18. Forestier v. Johnson, 12 Cal. A. Dec. 9.

19. Pol. C. $\S 3499$.

20. C. C. P. $\$ 315$.

21. C. C. $P . \$ 317$.

22. Cal. Stats. 1911, p. 466.

23. Pol. C., \$3494. (Amended March 8, 1911.) For right to sue United States and State of California in condemnation proceedings see C. C. P., \& 1240; Pol. C., § $3498 ; 19$ L. D. 24 ; but, as to United States, see Carr v. U. S., 98 U. S. 433. See \&76a, ante. 
$\S 28$ a. Conservation. By legislative enactment, taking effect April 8, 1911, there was created and established in California, a committee to be known as the Conservation Committee of the State of California the province of which is to gather data and information concerning the subjects of forestry, water, the use of water, water power, electricity, electrical and other power, mines and mining, mineral and other lands, dredging, reclamation and irrigation and for revising, systematizing and reforming the laws of the state upon, concerning, regarding or appertaining to said subjects. ${ }^{1}$

1. Cal. Stats. 1911, p. 822 .

§29. Railroad Lands. Land grants to certain transcontinental railroads have from time to time been made by Congress upon substantially similar terms and conditions as to certain of the states as to the character of the land within the limits of the grant; coal and iron deposits therein, however, being excluded from the operation of the mining laws. ${ }^{1}$

2. Classification of Land. There is no provision in any of these grants for the demarcation of mineral lands therein except that the land within the grant to the N. P. R. Co. within the States of Montana and Idaho is subject to examination and classification by a commission appointed under an act of Congress. ${ }^{2}$

3. Inconclusiveness of Classification. The return of this commission as to the character of land is not conclusive. ${ }^{3}$

4. Subsequent Discovery of Mineral. After title has passed to a railroad company no mineral rights in the land covered thereby can be initiated thereon without its consent. ${ }^{4}$

5. Rejection of Application for Patent. Where it appears that an application for a mineral patent embraces land within a railroad grant the application 
will be rejected by the local land officers. The applicant may appeal from the order of rejection and apply for a hearing to determine the character of the land. ${ }^{5}$

6. LANd Department. Land-grant-aided railroads usually maintain land departments in order to facilitate the disposal of such lands. Such departments are, of course, unconnected with the United States land department.

1. 12 Stats. $489 ; 12$ Stats. $492 ; 13$ Stats. $367 ; 13$ Stats. $567 ; 14$ Stats. 239: see O. \& C. R. R. Co. v. Puckett, 39 L. D. 169.

2. 28 Stats. 683 .

3. Lynch v. U. S., 138 Fed. 535; Beaudette v. N. P. R. Co., 29

L. D. 248 ; see State v. N. P. R. Co., 37 L. D. 95.

4. C. P. R. Co. v. De Rego, 39 L. D. 288 ; Traphagen v. Kirk, 30 Mont. 562; see Weyerhaeuser v. Hoyt, 219 U. S. 380.

5. Min. Reg. par. 44; see Benjamin v. S. \& C. P. R. Cos., 21 L. D. 387 ; see Loney v. Scott, (Or.) 112 Pac. 172.

\section{CHAPTER V.}

\section{SURVEYS.}

§35. Public land surveys-province of land departmentquestions of fact-duty of surveyor-division and numbering of the public lands-meander lines-high water mark-recent Californian legislation.

$\S 36$. Official surveys-lode claims-placer claims-connecting line-reference to connecting line-maps-map must be supported by evidence-testimony of surveyorfabricated survey-map not proof of lode.

$\$ 37$. Segregation survey-when ordered-township records.

$\$ 38$. Adverse claim survey-what plat of must show-when § 39. Appeal.

survey not necessary-not made by surveyor-general.

$\$ 40$. Surveys under state laws-surface survey-recordevidence-underground survey-service of order.

$\S$ 35. Public Land Surveys. There are two classes of surveys, public and official. The first refers to the system of public-land surveys and the second to the survey made in an application for patent for a mining claim. Both classes of surveys are made by or under the direction of the proper surveyor-general.

2. Province of Land Department. It is the peculiar province of the land department to consider 
and determine what lands have been surveyed, what are to be surveyed, what have been disposed of, what remains to be disposed of, and what are reserved. ${ }^{1}$ Its action, when within the scope of its authority, is unassailable in the courts, except in direct proceedings. $^{2}$

3. Questions of FACT. The land department may make and correct surveys of either class, ${ }^{3}$ and while the boundaries of a surveyed tract may not be open to dispute, yet where the lines run by such a survey lie on the ground, and whether any particular tract is on one side or the other of that line are questions of fact which are open to inquiry in the courts. ${ }^{4}$

4. Duty of Surveyor. Every surveyor when making a public survey is required to note in his field book the true situation of all mines, salt licks, salt springs and mill seats which come to his knowledge, all water courses over which the line he runs may pass, and also the quality of the land. ${ }^{5}$ The report of the surveyor in this regard is the basis of the surveyorgeneral's return as to the character of the land. This classification of the land is not conclusive. ${ }^{6}$

5. Division and Numbering of the Public Lands. By the public surveys the public lands are, generally, divided into townships of 6 miles square. The corners of the townships are marked with progressive numbers from the beginning. Each distance of a mile between such corners is distinctly marked with marks different from those of the corners. ${ }^{7}$ No marks are required by law to be placed at the quarter sections. Interior lines of sections are protracted by the United States Surveyor-General. ${ }^{8}$

The sections are 1 mile square, contain 640 acres, and are numbered, respectively, beginning with the number " 1 ," in the north-east section of the township, thence running to the north-west section thereof, which is numbered " 6 ," thence west and east, alter- 
nately through the township, with progressive numbers to the southeast section of the township, which is numbered " 36. ." 9

6. Meander Lines. A meander line is an irregular line having no certain significance. ${ }^{10}$ Such lines are not run as boundaries of a tract, but for the purpose of defining the sinuosities of the banks of a stream or lake upon which the tract may border, and also as a means of ascertaining the quantity of land in the tract subject to sale and which is to be paid for by the purchaser. ${ }^{11}$ A proprietor of lands bordering on a stream, lake or pond, not navigable unless restricted by the terms of his grant, holds to the center of such stream, pond or lake. ${ }^{12}$

7. High WATER MARK. Land below high-water mark of a meandered stream should not be included in the survey of a mining claim. ${ }^{13}$

8. Recent Californian Legislation. Under a recent Act of the legislature of the state of California the public lands of that state which are embraced within the original meander lines of streams and lakes the waters of which contain minerals in commercial quantities are withdrawn from selection and sale. Such lands may, however, be leased from the state at the rate of $\$ 2.50$ an acre and a royalty on the mineral extracted. ${ }^{14}$

1. Kirwan v. Murphy, $189^{\prime}$ U. S. 35 ; see Harvey M. La Follette, 26 L. D. 453.

2. Stoneroad v. Stoneroad, 158 U. S. 240; Murphy v. Tanner, 176 Fed. 537; Brown v. Yarraham Co., 3 Cal. A. 474.

3. Cragin v. Powell, 128 U. S. 691; see Gauthier v. Morrison, (Wash.) 114 Pac. 501.

4. Russell v. Maxwell Land Grant Co., 158 U. S. 253.

5. Rev. Stats. $\S 2395$; see Barden v. N. P. R. Co., 154 U. S. 288; Winscott v. N. P. R. Co., 17 I. D. 274.

6. Barden v. N. P. R. Co., ante; Cole v. Markley, 2 L. D. 847; Winscott v. N. P. R. Co., ante; Kinkade v. Cal., 39 I. D. 491; see Benjamin v. S. \& C. R. Cos., 21 L. D. 387.

7. Rev. Stats. $\S 2395$; Finch v. Ogden, 175 Fed. 20 ; Johnson v. Johnson, 14 Ida. 561.

8. Chapman v. Pollack, 70 Cal. 487. The smallest subdivision except under the placer mining laws is a tract of 40 acres-that is, a tract in square form constituting one quarter of a quarter section-except where, owing to 
certain peculiar local conditions a tract irregular in shape and dimensions is noted upon the plat of survey as a legal subdivision. Wm. F. Roedde, 39 L. D. 365; see $\$ 211$, note 9 , post.

9. Rev. Stats., $\S \S 2395,2396,2397$. For a synopsis of acts of Congress in regard to the surveying of the public lands, see Circular, 38 L. D. 1.

10. Niles v. Cedar Point Club, 175 U. S. 300 ; Kean v. Calumet Co., 190 U. S. 452 .

11. St. Paul R. Co. v. Schurmeier, 74 U. S. 272 ; Restoration of lost corners, etc., 38 L. D. 1; Kirby v. Potter, 138 Cal. 686.

12. St. Paul R. Co. v. Schurmeier, ante; Horne v. Smith, 159 U. S. 40; Hardin v. Jordan, 140 U. S. 371; Kean v. Calumet Co., ante; Amanda Hines, 14 L. D. 156; Kirby v. Potter, ante; Foss v. Johnstone, (Cal. A.) 110 Pac. 294 ; see Lux v. Haggin, 69 Cal. 255. The law of California, with respect to the incidents attaching to land bordering upon waters, is settled by section 830 of the Civil Code as follows:-

Except where the grant under which the land is held indicates a different intent, the owner of the upland, when it borders on tide water takes to ordinary high-water mark; when it borders upon a navigable lake or stream, where there is no tide, the owner takes to the edge of the lake or stream, at low water mark; when it borders upon any other water, the owner takes to the middle of the lake or stream. See Packer v. Bird, 137 U. S. 661.

13. Argillite Co., 29 L. D. 585; see Victor A. Johnson, 33 L. D. 593.

14. Cal. Stats. 1911 , p. 1154 .

$\S 36$. Official Survey. An official survey is one made in the course of patent proceedings. ${ }^{1}$

2. Lode Clatims. The claimant of a lode claim is not compelled at any time to follow the lines of the public surveys. ${ }^{2}$

3. Placer Claims. A placer location is the subject of official survey when laid upon unsurveyed land or is a fractional part of an irregularly-shaped surveyed tract. ${ }^{3}$

4. Connecting Line. Unless good cause is shown therefor the line connecting the location with the public survey should be given in the official survey. ${ }^{4}$

5. Reference to Connecting Line. A failuire to incorporate proper reference to such line in the published notice of application for patent renders the application defective, and proceedings must be commenced anew. ${ }^{5}$ 
6. MaPs. A map in itself proves nothing, unless it is shown by competent evidence to be a correct representation of the relative positions of the objects it purports to delineate. ${ }^{6}$

7. Map Must be Supported by Evidence. In the case of an unpatented mining claim a map purporting to show the lines of the location is of no probative value unless supported by the evidence of some one who knows the position of the monuments which define those lines; for it is by the location monuments alone that their beginning and direction can be determined. ${ }^{7}$

8. Testimony of Surveyor. A surveyor may properly testify as to the correctness of a plat that is made by him, although partly copied from the government survey and partly made from his own observation. 8

9. Fabricated Survey. A map based upon a fabricated public survey may be referred to in aid of the description of a mining claim. ${ }^{9}$

10. MAP Not Proof of Lode. The marking of an ideal lode line across an official survey and diagram thereof does not have the effect of putting a lode into the ground if there is no vein or lode there. The facts may be shown. ${ }^{10}$

1. Holmes Placer, 29 L. D. 368 .

2. Rev. Stats. \$\$ 2327-2331; Del Monte Co. v. Last Chance Co., 171 U. S. 55.

3. Min. Reg. pars. 135-141; Chicago Placer, 34 L. D. 9.

4. Min. Reg. par. 138.

5. Henry Wax, 29 L. D. 592 ; Alice Lode, 30 L. D. 481.

6. Daggett v. Yreka Co., 149 Cal. 357 ; see Blake v. Doherty, 5 Wheat. 359 ; U. S. v. Mont. Co., 196 U. S. 573 ; Duncan v. Eagle Rock Co., 48 Colo. 569.

7. Daggett v. Yreka Co., ante; Duncan v. Eagle Rock Co., ante.

8. Tillotson v. Prichard, 60 Vt. 94.

9. Gird v. Cal. Oil Co., 60 Fed. 531.

10. Con. Wyo. Co. v. Champion Co., 63 Fed. 540.

§37. Segregation Survey. A segregation survey, as the term is used in mining law, means a survey which is expressly made for $^{1}$ or has the effect of, 
separating mineral from agrieultural land. ${ }^{2}$ An official survey has, but not always conclusively, the same effect. $^{3}$

2. When ORdered. A segregation survey is ordered at the expense of the proper party. ${ }^{4}$

Such a survey may be ordered upon the application and at the expense of a non-mineral claimant after the approval of an official survey which is not followed by further patent proceedings thereon. In that event such claimant must establish the mineral character of the land embraced within the lines of the official survey. ${ }^{5}$

3. TownSHIP RECORDS. The segregation of a mining claim from the public domain does not appear upon the official township records until after entry has been made and approved for patent. ${ }^{6}$

1. Min. Reg. par. 108; Wm. F. Roedde. 39 L. D. 365.

2. Rev. Stats. $\S 2331$.

3. Rev. Stats. § 2327; Min. Reg. par. 37 (c).

4. Min. Reg. par. 108.

5. Min. Reg. par. 37 (c).

6. Min. Reg. par. 37 (a).

$\S 38$. Adverse Claim Survey. An adverse claim survey is one made in support of an adverse claim filed in the locad land office in opposition to an application for patent for an overlapping mining claim.

2. What Plat of Must Show. The plat of such a survey must show the adverse claimant's entire location, its relative situation or position with the one against which he claims, and the extent of the conflict.

3. When Survey Not Necessary. Neither survey nor plat is necessary where the respective locations are described by legal subdivisions. ${ }^{1}$

4. Not Made by Surveyor-General. Unlike the other surveys before mentioned this survey is not made by or under the direction of the surveyor-general. ${ }^{2}$

1. Rev. Stats. § 2326; Min. Reg. par. 82 .

2. Min. Reg. par. 82; Anchor v. Howe, 50 Fed. 366. 
§ 39. Appeal. An appeal lies from the ruling of the surveyor-general in relation to a survey or its amendment, in like manner as in other land office matters. $^{1}$

1. Emma Lode, 7 L. D. 169.

§ 40. Surveys under State Law-Surface Survey. The establishment or identification by survey of the exterior limits of a location prior to an official survey of the claim is usually provided for by local statute. ${ }^{1}$

2 . RECORD. The field notes of such a survey accompanied by the certificate of the surveyor making the same should be incorporated into the recorded or the amended notice of location. ${ }^{2}$

3. Evidence. Such survey and certificate become a part of the record of the claim. Such record is prima facie evidence of the facts therein contained. ${ }^{3}$

4. Underground Survey. The court in which an action is pending and in which say the extra-lateral right is involved, may, upon the application of either party to the controversy, good cause being shown therefor, order a survey of the underground workings of the mining property of the other party. ${ }^{4}$

5. Service OF Order. Upon due service of the order the survey may be made. ${ }^{5}$

1. The Californian Mining Act provides that "Where a locator, or his assigns, has the boundaries and corners of his claims established by a United States deputy mineral survey(or), or a licensed surveyor of this state, and his claim connected with the corner of the public or minor surveys of an established initial point, and incorporates into the record of the claim the field notes of such survey, and attaches to and files with such location notice, a certificate of the surveyor, setting forth: first, that said survey was actually made by him, giving the date thereof; second, the name of the claim surveyed and the location thereof; third, that the description incorporated in the declaratory statement is sufficient to identify; such survey and certificate becomes a part of the record, and such record is prima facie evidence of the facts therein contained." C. C. $\$ 14261$; see Cal. Stats. 1907 , p. 310 . 
2. C. C., § $1426 \mathbf{i}$.

3. Id.

4. See $\$ 85$ post.

The provisions of the law of California upon this subject are as follows: "The court in which an action is pending for the recovery of real property, or for damages for an injury thereto, or a judge thereof may, on motion, upon notice by either party for good cause shown, grant an order allowing to such party the right to enter upon the property and make survey and measurement thereof, and of any tunnels, shafts, or drifts therein, for the purpose of the action, even though entry for such purpose has to be made through other lands belonging to parties to the action." C. C. P. $\$ 742$.

"The order must describe the property, and a copy there of must be served on the owner or occupant; and thereupon such party may enter upon the property, with necessary surveyors and assistants, and make such survey and measurement; but if any unnecessary injury be done to the property he is liable therefor." C. C. P. § 743 .

5. C. C. P. $\S 743$.

For survey of land divided by a county line see Pol. C. $\$ 4216$.

\section{CHAPTER VI.}

\section{LAND DISTRICTS.}

§ 41. Land district-additional land districts and changes therein.

§ 42. Mineral district.

§ 43. Mining district-extent-changing boundaries-persons -corporation-regularity of proceedings-officers of district-duties of recorder.

§41. Land District. A land district is a division of a state or territory, as the case may be, created by law, in which is located such a district for the disposition of the public lands therein. ${ }^{1}$

2. Additional Land Districts and Changes Therein. The President is authorized to establish additional land districts, ${ }^{2}$ change or re-establish the boundaries thereof, ${ }^{3}$ and discontinue ${ }^{4}$ or consolidate districts. $^{5}$

1. U. S. V. Smith, 11 Fed. 487. As to Alaska see Columbia Co. v. Hampton, 161 Fed. 60 .

2. Rev. Stats. § 2343 .

3. Rev. Stats. $\$ 2253$.

4. Rev. Stats. \$2 252 ; see Rev. Stats. $\$ 2240$.

5. 27 Stats. 368 . 
§42. Mineral District. The term "mineral district" as used in acts of Congress is said to be neither known in the law or fact as the designation of any well-defined or exact locality, and there being no method of proceeding known to the law by which a district can be prospected, surveyed and established or declared to be a "mineral district," the term is void and incapable of definite signification or local application and is without effect. ${ }^{1}$

1. U. S. v. Smith, 11 Fed. 487; see Rev. Stats. §2334; see U. S. v. Copper Queen Co., 7 Ariz. 80; U. S. v. Edgar, 140 Fed. 655; U. S. v. Benjamin, 21 Fed. 285.

$\S 43$. Mining District. A mining district is a section of country designated by name, having described, or understood, boundaries and subject to the customs, rules and regulations adopted and prescribed by the miners therein. ${ }^{1}$

2. Extent. There is no limit to its territorial extent. ${ }^{2}$

3. Changing Boundaries. The boundaries of a district may be changed if vested rights are not thereby interfered with. ${ }^{3}$

4. Persons. No certain number of persons are necessary to effect its organization. ${ }^{4}$

5. Corporation. A corporation may take part in the formation of a mining district. ${ }^{5}$

6. Regularity of Proceedings. The regularity of the mode in which the district was organized will not be inquired into by the courts unless some fraud be shown. ${ }^{6}$

7. OfFicers of District. The officers of a district are usually limited to a "Mining Recorder," who is elected by the miners thereof and therein, for a specified term.

8. Duties of Recorder. He should keep proper books for recording instruments therein. ${ }^{7}$ Errors of recordation are not necessarily fatal. ${ }^{8}$ 
1. U. S. v. Smith, 11 Fed. 487; see Campbell v. Rankin, 99 U. S. 261 .

2. King v. Edwards, 1 Mont. 235.

3. Id.

4. But see Fuller v. Harris, 29 Fed. 814.

5. McKinley v. Wheeler, 130 U. S. 630 .

6. Gore v. McBrayer, 18 Cal. 583.

7. Fuller v. Harris, ante; see McCann v. McMillan, 129 Cal. 350.

8. Myers v. Spooner, 55 Cal. 257; Weese v. Barker, 7 Colo. 178.

\section{CHAPTER VII.}

\section{MINERAL LANDS.}

§ 45. Land subject to location-land valuable for its mineral deposits-classification of land-who may question character of land.

\$ 46. Land not subject to location-Indian lands-allotments -patents.

$\S 47$. Mineral deposits.

§45. Land Subject to Location. All valuable mineral deposits in land belonging to the United States, both surveyed or unsurveyed, and the lands in which they are found, are free and open to exploration, occupation and purchase. ${ }^{1}$ This includes mineral land within a forest reservation, ${ }^{2}$ the unpatented parts of a Congressional grant to a railroad company ${ }^{3}$ or to a state, ${ }^{4}$ or of an unconfirmed Mexican grant, ${ }^{5}$ or land within the limits of an unpatented town-site, ${ }^{6}$ or when known to be mineral at the date of the application for patent therefor, ${ }^{7}$ or an unlocated or unpatented "known vein" within the exterior limits of a patented or unpatented placer mining claim. ${ }^{8}$

2. Land Valuable for Its Mineral Deposits. Land valuable for its mineral deposits is land which contains minerals in sufficient quantities to justify exploitation and development; that is, land which is "chiefly valuable" for other than agricultural purposes, whether the deposit is metallic or non-metallic, and all such lands as are chiefly valuable for their deposits of a mineral character which are useful in the arts or valuable for purposes of manufactire. ${ }^{9}$ 
3. Classification of Land. There is no certain, well-defined, obvious line of demarcation between mineral and non-mineral land. ${ }^{10}$ No land can be valuable mineral land unless it contains a deposit of mineral in some form, metalliferous or non-metalliferous in quantity sufficient to justify expenditures in the effort to extract it. ${ }^{11}$

4. Who May Question Character of Land. The question of the character of land ean be raised only by the United States or those claiming under them ${ }^{12}$ and is conclusively determined in and by the land department. ${ }^{13}$ The question usually arises at the instance of some party connected with the paramount title, who claims the land to be non-mineral. ${ }^{14}$

1. Rev. Stats. $\$ 2319$. Only mineral lands are subject to disposition under the mining laws. American Co., 39 L. D. 299.

2. 29 Stats. 11; 30 Stats. 36 ; see H. H. Yard, 38 L. D. 59. The land department has full authority, of its own motion or at the instance of others, to inquire into and determine whether mining locations within National Forest Reserves were preceded by the requisite discovery of mineral; whether the lands are of the character subject to occupation and purchase under the mining laws notwithstanding the locator has not applied for patent; and if the location be found to be invalid the lands covered thereby will be administered as part of the public domain, subject to the reservation for forest purposes, without regard to the location. H. H. Yard, ante; see, generally, U. S. v. Rizzinelli, 182 Fed. 675.

For Rules and Regulations governing Forest Reserve see 24 L. D. 589; see, also, Roughton v. Knight, 219 U. S. 537.

3. 13 Stats. 567; N. P. R. Co. v. Soderberg, 188 U. S. 526.

4. Ivanhoe Co. v. Keystone Co., 102 U. S. 167; Utah, 32 L. D. 117; see McQuiddy v. California, 29 L. D. 181; Heydenfeldt v. Daney Co., 93 U. S. 634; Garrard v. S. P. Mines. 94 Fed. 983; Keystone Co. v. Nevada, 15 L. D. 259; Stanley v. Mineral Union, 26 Nev. 55; Wheeler v. Smith, 5 Wash. 704.

5. Lockhart v. Wills, 9 N. M. 344; see s. c. 181 U. S. 516; Lockhart v. Leeds, 10 N. M. 568.

6. Steel v. St. Louis Co., 106 U. S. 447 ; see Davis v. Weibbold, 139 U. S. 507.

7. Lalande v. Saltese, 32 L. D. 211.

8. Reynolds v. Iron Co., 116 U. S. 687; Clary v. Hazlitt, 67 Cal. 286; Mt. Rosa Co. v. Palmer, 26 Colo. 56.

9. N. P. R. Co. v. Sollerberg, ante; Steele v. Tanana Co., 148 Fed. 678; see Pacific Coast Co. v. N. P. R. Co., 25 L. D. 233: Alford v. Barnum, 45 Cal. 482; Merrill v. Dixon, 15 Nev. 401 ; see $\$ 99$, post. 
10. Ah Yew v. Choate, 24 Cal. 562.

11. Deffeback v. Hawke, 115 U. S. 392 ; N. P. R. Co. v. Soderberg, ante; Brophy v. O'Hare, 34 L. D. 596.

12. Ryan v. Granite Hill Co., 29 L. D. 522 ; Lorenz v. Waldron, 96 Cal. 243; Standard Co. v. Habishaw, 132 Cal. 115.

A trespasser making no claim to the land under any of the public land laws could not be heard to urge, against one who had made a discovery upon mineral land and performed the acts of location, that the land was more useful for purposes other than mining. Zeiger v. Dowdy, (Ariz.) 114 Pac. 765.

13. Burfenning v. Chicago R. Co., 163 U. S. 321; Standard Co. v. Habishaw, ante. There must be some point of time when the character of the land must be finally determined; and for the interest of all concerned there can be no better point to determine this question than at the time of issuing the patent. Cowell v. Lammers, 21 Fed. 200.

14. Chrisman v. Miller, 197 U. S. 313 ; Book v. Justice Co., 58 Fed. 106; Olive Land Co. v. Olmstead, 103 Fed. 568; Mutchmor v. McCarty, 149 Cal. 603. When the question of the character of land is raised it must be tried out, and until patent has been issued the question as to the character of land at the date of entry is an open one, subject to investigation and determination by the land department. American Co., ante.

$\S 46$. Land Not Subject to Location. Land is not subject to mineral location when lying within the States of Michigan, Minnesota, ${ }^{1}$ Missouri, Kansas, ${ }^{2}$ Alabama, ${ }^{3}$ or within a subsisting Indian, ${ }^{4}$ military, ${ }^{5}$ naval, ${ }^{6}$ and, possibly, a park, ${ }^{7}$ or a reservoir ${ }^{8}$ reservation; or when withdrawn from sale by authority of Congress or by an executive order, express or implied, ${ }^{9}$ or when situated below high tide, ${ }^{10}$ (except, in a limited way, in Alaska), ${ }^{11}$ or when the bed of a navigable river $;^{12}$ or coal or iron lands within the limits of a Congressional land grant to a railroad company ${ }^{13}$ or within its rights of way ${ }^{14}$ or its indemnity limits, or land within the limits of a Congressional land grant to a state, after approval of survey or certification by the land department $;^{15}$ or any mineral springs ${ }^{16}$ (not salt springs $\left.{ }^{17}\right)$; or land which is occupied, under color of title, (unless it can be done peaceably ${ }^{18}$ ) or land which has passed into private ownership. ${ }^{19}$

2. INDIAN LANDS. Although no mineral location may be laid upon land within an Indian reservation, 
mineral land therein may be leased for a period not to exceed ten years by authority of the council speaking for the Indians, upon such terms and conditions as the agent in charge of such reservation may recommend, subject to the approval of the Secretary of the Interior. ${ }^{20}$

3. Allotments. The character of the land embraced in an allotment in severalty or in a trust or first patent may be examined into, but the party instigating the attack thereon secures no preferential right to the land involved in the event of cancellation. ${ }^{21}$

4. Patents. Patents in fee-simple, without restriction as to incumbrance or taxation, may issue at any time that the Secretary of the Interior is satisfied that the allottee is competent and capable of managing his affairs $;^{22}$ formerly an interval of twenty-five years, possibly longer, might elapse between the issuance of the first and second patents. ${ }^{23}$

1. 17 Stats. 465 .

2. 19 Stats. 52 .

3. 22 Stats. 487 .

4. Buttz v. N. P. R., 119 U. S. 55; McFadden v. Mt. View Co., 97 Fed. 670 ; Gibson v. Anderson, 131 Fed. 39; Acme Co., 31 L. D. 125; Kendall v. San Juan Co., 9 Colo. 349 affd., 144 U. S. 658; Bay v. Oklahoma Co., 13 Okla. 425. Lands within the limits of an Indian reservation are excluded from disposal as the public lands are usually disposed of and are exempt from all Congressional legislation unless there is an express declaration therein to the contrary. Leavenworth Co. v. U. S., 92 U. S. 733. In Oklahoma only mineral land within the houndaries of tracts ceded by various Indian tribes therein to the United States are subject to mineral location. Bay v. Oklahoma Co., ante.

5. Behrends v. Goldstein, 1 Alaska 518. See 31 Stats. 180.

6. Behrends v. Goldstein, ante.

7. Rev. Stats. \& $2474 ; 30$ Stats. 993.

8. 25 Stats. $527 ; 29$ Stats. 484 ; Colomokas Co., 28 L. D. 172. See John U. Gabathuler, 15 L. D. 418; Loney v. Scott, (Or.) 112 Pac. 172.

9. Lockhart v. Johnson, 181 U. S. 516; Gibson v. Anderson, ante; Allen H. Cox, 31 L. D. 193 . See $\$ 120$, note 3, post.

Lands valuable for mineral deposits and embraced within a withdrawal of lands susceptible of irrigation by means of a reclamation project under Act of June 17,1902 , are not thereby taken out of the operation of the mining laws, but continue open to exploration and 
purchase under such laws. 32 Stats. 388; Instructions 35 L. D. 216; Loney v. Scott, ante.

10. Knight v. U. S. Land Ass'n., 142 U. S. 161; Alaska Co. v. Barbridge, 1 Alaska 311.

11. Carter's Anno. Alaska Codes, 139.

12. Argillite Co., 29 L. D. 585; Ball v. Tolman, 119 Cal. 358. As to bed of non-navigable river see Kirby v. Potter, 138 Cal. 686.

13. Wilkinson v. N. P. R. Co., 5 Mont. 538; S. C. R. Co. v. O'Donnell, 3 Cal. A. 382 .

14. 18 Stats. 482; St. Jos. R. Co. v. Baldwin, 103 U. S. 426; Washington Co. v. Osborn, 160 U. S. 103; Spokane Co. v. Zeigler, 167 U. S. 65. See S. C. R. Co. v. O'Donnell, ante; Bonner v. Rio Grande S. R. Co., 31 Colo. 446.

15. See Saunders v. La Purisima Co., 125 Cal. 159 ; see $\$ 28$, ante; U. S. v. Missouri R. Co., 141 U. S. 358 ; U. S. v. Winona R. Co., 67 Fed. 948.

16. Pagosa Springs, 1 L. D. 562 .

17. 31 Stats. 745 .

18. Nev. Sierra Oil Co. v. Home Oil Co., 98 Fed. 673; Olive Land Co. v. Olmstead, 103 Fed. 568; Miller v. Chrisman, 140 Cal. 440 ; see Phillips v. Smith, 11 Ariz. 309.

19. Pac. Coast Co. v. Spargo, 16 Fed. 348 ; Francoeur v. Newhouse, 40 Fed. 618 . See Olive Land Co. v. Olmstead, ante; Janette W. Riley, 33 L. D. 68.

20. 24 Stats. 388 .

21. Indian Lands, 32 L. D. 17.

22. 34 Stats. 182 ; 36 Stats. 855 ; Bond v. U. S. 181 Fed. 613 ; see. Joseph Black Bear, 38 L. D. 422.

23. 24 Stats. 388. As to statutes of limitation see Stats. 284; Ballinger v. Frost, 216 U. S. 240.

\section{$\S 47$. Mineral Deposits. The mineral deposits} declared by Congress as subject to location are gold, silver, cinnabar, lead, tin, copper, ${ }^{1}$ building stone, ${ }^{2}$ petroleum and other mineral oils, ${ }^{3}$ salt springs and other deposits of salt, ${ }^{4}$ and, generally, any mineral in rock in place ${ }^{5}$ or other form of deposit. ${ }^{6}$

The courts and the land department have found the following substances in land to be mineral, viz. : agate, ${ }^{7}$ albertite, ${ }^{8}$ alum, ${ }^{9}$ amber, ${ }^{10}$ amygdaloid bands, ${ }^{11}$ asphalt, ${ }^{12}$ auriferous cement, ${ }^{13}$ auriferous clay or gravel, ${ }^{14}$ black lead, ${ }^{15}$ borax, ${ }^{16}$ brick clay, ${ }^{17}$ building sand, building stone, ${ }^{18}$ calk, calc-spar, ${ }^{19}$ carbonate of soda, ${ }^{20}$ china clay, ${ }^{21}$ chromate of iron, ${ }^{22}$ coal, ${ }^{23}$ cropolites, ${ }^{24}$ diamonds, ${ }^{25}$ fahl band, ${ }^{26}$ fire clay, ${ }^{27}$ galena, ${ }^{23}$ gilsonite, ${ }^{29}$ gold-bearing gravel, ${ }^{30}$ granite, ${ }^{31}$ graphite, ${ }^{32}$ gypsum, ${ }^{33}$ gypsum-cement, ${ }^{34}$ guano, ${ }^{35}$ iron, ${ }^{36}$ kaolin, ${ }^{37}$ lepidolite, ${ }^{38}$ lignite, ${ }^{39}$ limestone, ${ }^{40}$ lustral, ${ }^{41}$ 
magnesia, ${ }^{42}$ magnesite, ${ }^{43}$ marble, ${ }^{44}$ mica, ${ }^{45}$ mineral paint stone, ${ }^{46}$ natural gas, ${ }^{47}$ nitrate of soda, ${ }^{48}$ onyx, ${ }^{49}$ opal, ${ }^{50}$ petroleum, ${ }^{51}$ phosphates, phosphate lands, ${ }^{52}$ potash, ${ }^{53}$ plumbago, ${ }^{54}$ resin, ${ }^{55}$ rock salt, ${ }^{56}$ saline lands, ${ }^{57}$ salt springs, ${ }^{58}$ slate, ${ }^{59}$ soda, ${ }^{60}$ stone, flint stone, sand stone, ${ }^{61}$ stone suitable for making lime, ${ }^{62}$ salt, ${ }^{63}$ stockwerke, ${ }^{64}$ sulphur, ${ }^{65}$ tailings, ${ }^{66}$ umber, ${ }^{67}$ water, ${ }^{68}$ (but not subject to location under the mining laws ${ }^{69}$ ) zinc. $^{70}$

1. Rev. Stats. $\S 2320$.

2. 27 Stats. 348 .

3. 29 Stats. 526 .

4. 31 Stats. 745 .

5. Rev. Stats. $\$ 2320$.

6. Rev. Stats. 2329 . As to coal, iron and lead see 19 Stats. 52. As to gilsonite, asphaltum, elaterite, or other like substances see 30 Stats. 87 . The test which Congress provided by this legislation to be applied to determine how mineral deposits should be secured was the form and character of the deposits. If they are in veins or lodes in rock in place, they may be located and purchased under this legislation by means of lode mining claims.; if they are not in fissures in rock in place but are loose or scattered on or through the land they may be located and bought by the use of placer mining claims. Webb v. American Co., 157 Fed. 203; Utah Onyx Dev. Co., 38 L. D. 504.

7. P. M. Gill, Min. Law Dig. 27.

8. Com'r to Secretary Noble, Min. Law Dig. 27.

9. Min. Lands, Val. Dep. 1. L. D. 561 ; N. P. R. Co. v. Soderberg, 188 U. S. 526 .

10. N. P. R. Co. v. Soderberg, ante.

11. Copps Min. Lands 52.

12. N. P. R. Co. v. Soderberg, ante; Webb v. American Co., ante: Min. Lands Val. Dep., ante.

13. Maxweil v. Brierly, 10 C. L. O. 50.

14. Copps Min. Lands, 121 ; see N. P. R. Co. v. Soderberg, ante.

15. C. F. Conrad, Min. Law Dig. 28.

16. N. P. R. Co. v. Soderberg, ante; Min. Lands Val. Dep., ante.

17. N. P. R. Co. v. Soderberg, ante; Blake Placer Min. Law Dig. 27; Montague v. Dobbs, 9 C. L. O. 165; see King v. Bradford, 31 L. D. 108; Zimmerman v. Brunson, 39 L. D. 310.

18. Loney v. Scott, (Or.) 112 Pac. 172; N. P. R. Co. v. Soderberg, ante; Forsythe v. Weingart, 27 L. D. 680 ; Freezer v. Sweeney, 8 Mont. 508; see note 30, post.

19. Stone v. Arkwright, 77 L. T. Rep. N. S. 400.

20. Min. Lands Val. Dep., ante.

21. N. P. R. Co. v. Soderberg, ante.

22. Gibson v. Tyean, 5 Watts 34 .

23. N. P. R. Co. v. Soderberg, ante; Mullan v. U., S., 118 U. S. 271; Murray v. Allred, 100 Tenn. 100.

24. Atty. Gen. v. Tomline, 5 Ch. Div. 762 .

25. N. P. R. Co. v. Soderberg, ante. 
26. Cir. 1 C. L. O. 11.

27. Maxwell v. Brierly, ante; N. P. R. Co. v. Soderberg, ante.

28. Duggan v. Davey, 4 Dak. 110 :

29. Webb v. American Co., ante.

30: Gregory v. Pershbaker, 73 Cal. 109. Gravel and sand deposits unless they possess a peculiar property or characteristic giving them a special value are not regarded as mineral. So, such deposits are not necessarily subject to mineral location when suitable for mixing with cement for concrete construction. Zimmerman v. Brunson, ante.

31. N. P. R. Co. v. Soderberg, ante.

32. C. F. Conrad, ante.

33. N. P. R. Co. v. Soderberg, ante; McQuiddy v. California, 29 L. D. 181; Madison v. Octave Oil Co., 154 Cal. 768.

34. Phifer v. Heaton, 27 L. D. 57.

35: N. P. R. Co. v. Soderberg, ante; Richter v. Utah, 27 L. D. 95; see U. S. v. Duncan Co., 137 U. S. 647.

36. Stewart, 1 C. I. O. 34 .

37. Maxwell v. Brierly, ante.

38. Stewart v. Douglass, 148 Cal. 511.

39. Min. L. \& M. Res., 35 L. D. 665 .

40. N. P. R. Co. v. Soderberg, ante; Morrill v. N. P. R. Co., 30 L. D. 475.

41. Johnson v. Cal. Lustral Co., 127 Cal. 283.

42. Gibson v. Tyean, ante.

43. Johnson v. Withers, 9 Cal. A. 52.

44. Pac. Coast Co. v. N. P. R. Co., 25 L. D. 233 ; N. P. R. Co. v. Soderberg, ante; Scrimpf v. N. P. R. Co., 29 L. D. 327 ; Henderson v. Fulton, 35 L. D. 652.

45. N. P. R. Co. v. Soderberg, ante; Arnold, 2 C. L. O. 131.

46. Chas. A. Barnes, 7 L. D. 66 ; Hartwell v. Camman, 10 N. J. Eq. 128.

47. Buffalo Co., 73 Fed. 191; Manufacturing Co. v. Indiana Co., 155 Ind. 461.

48. Min. Lands Val. Dep., ante.

49. Utah Onyx Dev. Co., ante.

50. F. T. Palmer Min. Law Dig. 29.

51. N. P. R. Co. v. Soderberg, ante; Gird v. Cal. Oil Co., 60 Fed. 531. The term "oil bearing strata" has been defined as any bed, seam or stratum of rock or sand or other material which contains, includes or yields earthoil, rock oil, or petroleum oil or natural gas or any of them. Cal. Stats. 1909 , p. 586 .

52. Gary v. Todd, 18 L. D. 58; Florida Co., 26 L. D. 600.

53. Maxwell v. Brierly, ante.

54. C. F. Conrad, ante.

55. N. P. R. Co. v. Soderberg, ante.

56. Megarrigle, 9 C. L. O. 113; see Southwestern Co., 14 L. D. 597.

57. Garrard v. S. P. Mines, 94 Fed. 983; Leonard v. Lennox, 181 Fed. 760 ; Elliott v. S. P. R. Co., 35 L. D. 149 ..

58. State v. Parker, 61 Tex. 265.

59. Schrimf v. N. P. R. Co., ante; Murray v. Allred, ante.

60. Cir. ante; E. M. Palmer, 38 L. D. 294.

61. N. P. R. Co. v. Soderberg, ante; Van Doren v. Plested, 16 L. D. 508 ; see E. M. Palmer, ante.

62. Shepherd v. Bird, 17 L. D. 82 .

63. Murray v. Allred, ante.

64. Copps Min. Isands 52 . 
65. Min. Lands Val. Dep., ante.

66. Rogers v. Cooney, 7 Nev. 213.

67. Copps Min. Lands 161.

68. Westmoreland Co. v. DeWitt, 130 Pa. St. 235; Ridgeway Co. v. Elk Co., 191 Pa. St. 465.

69. Snyder v. Colo. Co., 181 Fed. 62 ; but see Schwab v. Beam, 86 Fed. 41.

70. Buffalo Zinc Co. v. Crump, 70 Ark. 525.

\section{CHAPTER VIII.}

\section{VEIN, LODE AND LEDGE.}

$\$ 50$. In general-interchangeable terms--miners' use of terms -common use-the miner's vein or lode-miner's distinction between vein and lode-vein within lodesynonymous terms-statutory meaning-judicial definitions-general rule-no conflict-various definitionsno arbitrary definition-approved definition - gravel deposits-characteristics of a vein or lode-elements of a vein or lode-fissure veins-broad lodes-walls of broad lode-indivisibility of a broad lode-separate veins within zone-blind vein-blanket vein-secondary or incidental vein-extra-lateral right to secondary vein-single vein-intersecting veins-apex of intersecting veins-cross veins-space of intersectioncontact vein-known vein-ledge matter-in placerock in place-other rock in place-vein or lode in place-vein or lode not in place-country rock-horse -dykes-outcroppings-identity of vein and outcrop-. outcroppings not essential-top or apex-highest point-legal top or apex-discovery of top or apexlocation must include top or apex-course or strikedetermining course of strike-practical rule-following course of strike-dip or downward course-measuring dip-easement or servitude-following the dipwalls of vein or lode-boundaries of vein or lodeindications-impregnations.

\section{\$5. In General. No definition of the term} "vein, lode and ledge" is given in the mining act. ${ }^{1}$

2. INTERCHANGEABLE TERMS. In that act those terms are used interchangeably, the object being to give them a more comprehensive meaning than the technical definitions convey. Their meaning as used therein is that which is so called by miners. ${ }^{2}$

3. Miners' Use of 'Terms. Miners used the terms "vein, lode and ledge" before geologists attempted to give them a definition. ${ }^{3}$

4. Common Use. The terms "vein, lode and ledge" are now used synonymously by miners, Congress and the courts. ${ }^{4}$ 
5. The Miner's Vein or Lode. To the miner a vein or lode is any body of ore, quartz or other mineral-bearing substance lying within the crust of the earth, bounded on each side by the country rock, greatly varying in extent across and through the country for greater or less distances. ${ }^{5}$

6. Miners' Distinction Between Vein and Lode. Among practical miners, generally; narrow veins are designated simply as "veins," while veins of great thickness are called "great veins" 6 or "lodes." This distinction, of course, is not scientific.

7. Vein Within Lode. A "lode" may, and often does, contain more than one "vein." 7 It is then popularly called a "broad lode" or zone.

8. Synonymous Terms. The term "lode" is a Cornish word nearly synonymous with the term vein. 8

9. Statutory Meaning. The terms "vein, lode and ledge," within the meaning of the mining act is whatever the miner could follow and find ore. ${ }^{9}$

10. Judicial Definitions. Various courts have at different times given a definition of what constitutes a vein, lode and ledge, within the meaning of that act.

11. General Rule. The definitions that have been given by the courts, as a general rule, apply to the peculiar character of the ore deposits or vein matter and of the country rock in the particular district where the claims are located.

12. No Conflict. There is no conflict in the decisions but the result is that some definitions have been given in some of the states that are not deemed wholly applicable to the conditions and surroundings of mining districts in other states, or other districts in the same state.

13. Various Definitions. So, many definitions of veins have been given, varying according to the facts under consideration. 
14. No Arbitrary Definition. The terms are not susceptible of an arbitrary definition, applicable to every case. In a measure, conditions of locality and deposit control. ${ }^{10}$

15. Approved Definition. An approved definition is as follows: "A zone or belt of mineralized rock lying within boundaries clearly separating it from neighboring rock. It includes all deposits of mineral matter found through a mineralized zone or belt coming from the same source, impressed with the same forms and appearing to have been created by the same processes." 11

This definition, expressed in other words, is that a "lode" designates any zone or belt of mineralized rock lying within boundaries clearly separating it from the neighboring rock. It further implies a oneness, genetically, of the ore deposits included within its boundaries.

16. Gravel Deposits. The above definition does not apply to gravel deposits inclosed within defined boundaries. ${ }^{12}$

17. Characteristics of a Vein or Lode. In the books and among miners, veins and lodes are invested with many characteristics, as that they lie in fissures or other openings in the country rock; that they contain materials differing or in some respects corresponding with the country rock; that they are of a tabular form and a banded structure; that some one or several things are generally associated with the valuable ores; that they have selvages and slickensides in the fissures and openings, and the like. Some of these characteristics are said to be common to all lodes and veins, and others are of rare occurrence. ${ }^{13}$

18. Elements of a Vein or Lode. The elements of a vein or lode are mineral or mineral-bearing rock and boundaries in place in the general mass of the mountain. When one of these is well established 
very slight evidence may be accepted as to the existence of the other. ${ }^{14}$ But every seam or crevice in the rock does not constitute a vein or lode nor every ridge of stained rock its croppings. ${ }^{15}$ The vein or lode need be continuous only in the sense that it may be traced through the surrounding rocks. ${ }^{16}$

It need not have well-defined walls. ${ }^{17}$ It may vary in direction, width, dip and value, split or divide into branches, both in length and in depth. These branches may or may not again unite. ${ }^{18}$

That it is occasionally found in the general course of the vein or shoot in pockets deeper down into the earth or higher up, does not affect its character as a vein, lode or ledge. ${ }^{19}$

19. Fissure Veins. A fissure vein, in mining parlance, is a longitudinal opening with a foreign substance in it. ${ }^{20}$

True fissures often exist and are continuous without having any filling in certain points or places of mineral matter. A majority of such lodes have in addition to the clean fissure filling of mineral, a considerable amount of decomposed rock, clay, etc. ${ }^{21}$

Metalliferous rock in place, not in fissure, may be found under such conditions within clearly defined boundaries as to require recognition as a vein or lode. ${ }^{22}$

A broad metalliferous zone, having within its limits true fissure veins, plainly bounded, cannot be regarded as a "vein" or "lode," although such zone may have boundaries of its own which can be traced. ${ }^{23}$

20. BROAD Lodes. The term "lode" has become extensively used in the classification of ore deposits that are not comprehended by the definition of a vein. Such an ore occurrence is called by the courts a "broad lode" or zone. ${ }^{24}$

21. Whlls of Brond Lode. A broad lode may be without distinct walls, in which case its legal width is 
determined by the lines beyond which indications sufficient to encourage its further exploitation, with the hope of profit, do not appear. ${ }^{25}$

22. Indivisibility of a Brosd Lode. The ownership of the apex of a broad lode. or vein confers the right to all mineral extending into adjoining territory, although adversely held, when its formation is such as to present a unity of the whole mass as a vein or lode. It is usually treated as a unit and indivisible in point of width as respects the right to pursue it extra-laterally beneath the surface because, usually, the width of the vein or lode is so irregular and its strike and dip depart so far from right lines that it is altogether impracticable, if not impossible, to continue the longitudinal bisection at the apex throughout the vein or lode, on its dip. Where two or more mining claims longitudinally bisect or divide the apex of a vein or lode, the senior claim takes the entire width of the vein or lode. on its dip, if it is in other respects so located as to give the extra-lateral right. ${ }^{26}$

23. Separate Veins Within Zone. Where mineral deposits are separated into well-defined parts, traceable for a great distance in their length and depth, and having distinct foot and hanging walls, each part is a separate vein within the meaning of the mining laws giving the right to follow the dip of the vein beyond the side lines, although there are many ore-bearing cracks and seams running out from each vein, and sometimes extending over to the other. ${ }^{27}$ Ore bodies formed off from and unconnected with a fissure vein do not form a separate vein, lodge, ledge, or mineral deposit. ${ }^{28}$

24. Blind Vein. A blind vein or lode is one which does not erop upon the surface 29 and has its top or apex below the surface of the ground. ${ }^{30}$. Such veins belong to the surface location. ${ }^{31}$ 
25. Blanket Vein. Blanket vein is a term applicable to a horizontal vein or deposit which may have no distinct apex. ${ }^{32}$

26. Secondary or Incidental Vein. A secondary or incidental vein or lode is a vein or lode within a mining claim or location other than the one located or intended to be located. ${ }^{33}$

27. Extra-Lateral Right to Secondary Vein. The extra-lateral right to secondary veins is not confined to such veins as apex within the same segment of the claim in which the apex of the discovery vein exists. ${ }^{34}$ But no extra-lateral right attaches thereto should the vein or lode happen to extend transversely to the vein or lode located or intended to be located, although it may have its apex within the lines of such location. ${ }^{35}$

28. Single Vein. A "single vein" in the sense in which the term is used by miners is a single ore deposit of identical origin, age and character throughout. ${ }^{36}$ A single small vein is weighed and measured by the same law and entitled to the same consideration as the "mother lode," and very often is far more valuable in the eyes of the miner. ${ }^{37}$

29. Intersecting Veins. Veins or lodes may intersect upon their strike or dip, and below the point of union become one vein or lode, in which case the prior locator takes the same below the point of union, including all the space of intersection. ${ }^{38}$

30. Apex of Intersecting Veins. Where two or more veins or lodes with an apex in different mining claims unite in their dip within the lines of a third claim the owners of the latter claim have no right in either vein or lode beyond the point of union. ${ }^{39}$

31. Cross VeIns. Where two or more veins or lodes cross each other, priority of title governs and the senior locator is entitled to all the mineral within the space of intersection of the veins or lodes, but the 
junior locator has the right of way through the space of intersection for the convenient working of the mine. ${ }^{40}$

32. Space of Intersection. There is some ambiguity in the term "space of intersection," that is, whether it means through the space of intersection of the veins or lodes or through the space of intersection of the locations. ${ }^{41}$

33. Contact Vein. A contact vein is one where each of the inclosing walls is of a different character or formation. One of such walls may be composed of limestone and the other wall be of porphyry. ${ }^{42}$

34. KNOwN VeIN. A "known vein," as the term is used in the mining act, is one that contains mineral in such quantity and quality as to justify expenditure for the purpose of its extraction. ${ }^{43}$ Its existence is not established by indications of outcroppings. ${ }^{44}$ The amount of ore, the facility for reaching and working it, as well as the product per ton, are all to be considered in determining whether the vein or lode is one which justifies exploitation and working. ${ }^{45}$

35. LedGe MATter. Ledge or vein matter is the matrix, or gangue, of all veins or lodes. By its peculiarities the experienced miner easily recognizes the vein, lode or ledge, when discovered.46 Ledge or vein matter, of itself, may not warrant a location. ${ }^{47}$ The filling of the vein or lode must be considered with special reference to the district where the vein or lode is found.

36. IN Place. The term "in place" indicates the body of the country which has not been affected by the action of the elements, which may remain in its original state and condition, as distinguished from the superficial mass which may lie above it. ${ }^{48}$

37. Rock IN Place. The term "rock in place" has always received a liberal construction. It means that which is inclosed and embraced in the fixed and im- 
movable rock forming the general mass of the mountain as distinguished from merely on the surface, or covered only by float, wash, slide, soil, waste, drift, debris, boulders and gravel. ${ }^{49}$

It does not mean merely hard rock, merely quartz rock, but any combination of rock broken up, mixed up with minerals and other things. ${ }^{50}$ It is not material where the rock or mineral was originally formed or deposited ${ }^{51}$; if it is in its original position, although somewhat broken up and shattered by the movement of the country or other causes, it is in place. ${ }^{52}$ It is immaterial, if in its original place, that the vein or lode matter is loose, broken, disintegrated, or solid material. ${ }^{53}$

38. Other Rock in Place. The term "other rock in place," as used in the mining act, means any rocky substance containing mineral matter. ${ }^{54}$

39. Vein or Lode in Place. A vein or lode is in place if the mineral is continuous to the extent that it may maintain that character, whether deposited in that form or removed bodily with its inclosing rocks to the place in which it may be found. ${ }^{55}$

40. Vein or Lode not in Place. A vein or lode cannot be in place unless it is within the general mass of the mountain. It must be inclosed by or held within the general mass of fixed and immovable rock. It is not enough to find the vein or lode lying on the top of fixed or immovable rock, for that which is on top is not within, and that which is without the rock in place cannot be said to be within it, and the mineral must be in place within definite boundaries. ${ }^{56}$ A vein or lode is not in place if not fixed in rock -in a loose state ${ }^{57}$ or if found lying on the top of fixed or immovable rock. ${ }^{58}$

41. Country Rock. Country or neighboring rock designates the mass of rock, whether granite, gneiss, syenite, porphyry, or any other of the many different 
kinds of rock which may surround and inclose a vein or lode. ${ }^{59}$

42. Honse. An intrusion of country, or neighboring rock, into a vein or lode is called a "horse" or "rider." 60

43. Dykes. Dykes are characteristically of igneous rocks and are matter between or through sedimentary beds. ${ }^{61}$

44. OUtcroppings. Outcroppings are the edges of the strata appearing at the surface of the ground or which appear immediately under the soil and surface debris. ${ }^{62}$ They relate to the vein or lode and mean the presentation of the mineral to the naked eye on the surface of the earth. ${ }^{63}$ The term "outcrop" or "outeroppings" is sometimes used synonymously with the terms "top" and "apex." 64

45. Identity OF VeIn AND OUtcrop. The vein or lode which the miner pursues from its outcrop must, of course, be the same which he pursues outside of his side lines. ${ }^{65}$

46. Outcroppings not Essential. While it is on the line of the croppings that lode claims are most generally, but not always accurately, laid without regard to the surface, whether level or inclined, ${ }^{66}$ it is not necessary that the vein or lode shall crop upon the surface that locations may be made upon it. If the vein or lode lies entirely beneath the surface its course may be ascertained by underground work at different points, or if slightly covered by foreign matter the course of the apex may be ascertained by ordinary surface explorations and locations be made substantially following its course. ${ }^{67}$

A location is not invalid because its length is not along the vein or lode. ${ }^{68}$

47. Top or APEx. The term "top or apex," as used synonymously, may mean either a point ${ }^{69}$ or a line of great length, ${ }^{70}$ and designates the summit or 
edge of a vein or lode on, ${ }^{71}$ or at any depth, below the surface, ${ }^{72}$ if it should be a "blind" vein or lode.

48. Highest PoINT. The highest point in a vein or lode is the ascent along the line of its dip or outcroppings and beyond which the vein or lode extends no further, so that it is the end or reversely the beginning of the vein or lode. ${ }^{73}$

49. Legal Top or Apex. For the purpose of discovery and purchase under the mining act, the legal apex or top of a vein or lode dipping out of the ground disposed of under the placer or non-mineral laws is that portion of the vein or lode within the public lands which would constitute its actual apex if the vein or lode had no actual existence in the ground previously disposed of. ${ }^{74}$

50. Discovery of TOP or APEx. Any portion of the apex on the course or strike of the vein or lode within the limits of the claim is sufficient discovery to entitle the locator to obtain title. ${ }^{75}$ The vein or lode beyond the end lines of the claim is subject to further discovery and location. ${ }^{76}$

51. Location Must Include Top or Apex. A location of a lode claim must be upon the top or apex of a vein or lode in order to enable the locator to perfect his location and obtain title. ${ }^{77}$

52. COURSE OR STRIKE. The course or strike of a vein or lode is the direction of the vein or lode across or through the country. ${ }^{78}$

53. Practical Rule. The most practical rule is to regard the course of the vein or lode as that which is indicated by surface outcrop or surface explorations and workings. ${ }^{79}$

54. Following Course or Strike. To follow the course, strike or trend is to work lengthwise of the vein or lode on a level, that is, advancing along the vein or lode, neither rising towards the surface of the ground nor descending, but going on a level with the 
plane of the earth's surface ${ }^{80}$ within the perpendicular planes of the end lines of the location, whether this be more upon the course or strike than the dip of the vein or lode. 81

55. DiP or Downward Course. The term "dip" is a miner's word not found in the mining act. The term there used is "downward course," which is synonymous with the term "dip."

The direction of the vein or lode as it goes downward into the earth is called the dip. It may vary from a perpendicular to the earth's surface to an angle perhaps only a few degrees below the horizon. The same vein or lode may have different dips. ${ }^{82}$

56. MEasuring DiP. It is practically the universal custom to measure the dip by its angular deflection from the horizontal. A dip of 20 degrees means 20 degrees from the horizontal.

57. Easement or Servitude. The right to follow the dip, also termed the "extra-lateral" right, is a sort of easement or servitude laid upon the mining claim adjoining. ${ }^{83}$

58. Following the Dip. The miner follows the dip of the vein or lode when he works downward, leaving the apex further from and above him at each advance. ${ }^{84}$

59. WALLS OF VeIN OR Lode. The term "wall" in mining parlance is a body of rock bounding a vein or lode on either or both sides thereof and serving as a line of demarcation between the vein or lode and the neighboring or country rock. ${ }^{85}$ The wall rock may be barren or be more or less impregnated with mineral. ${ }^{86}$

A wall is called the "hanging wall" or the "foot wall" according to its relative position to the vein or lode with which it is connected. ${ }^{87}$ Both the walls of a vein or lode may be of a similar character as to formation,, 88 yet have different colors; one wall may 
be composed of yellow and the other wall be of purple porphyry ${ }^{89}$ or one wall may be of limestone and the complemental wall be of porphyry ${ }^{90}$ or other dissimilar rocky substances.

60. Boundaries of Vein or Lode. To the practical miner the walls, in connection with the fissure, are only of importance as indicating the boundaries within which he may look for and reasonably expect to find the ore he seeks. ${ }^{91}$ It is not essential that both walls of a vein or lode be disclosed; their existence and continuance may be determined by assay and analysis. ${ }^{92}$ The clay, the selvages, slickensides, striation, and ribbing of the walls are frequently as strong evidence of the indication of permanency and continuity as the existence of the quartz itself. ${ }^{93}$

61. Indications. The mere indication or presence of mineral is not sufficient to establish the existence of a vein or lode. The mineral must exist in such. quantities as to justify the expenditure of money for the development of the mineral and the extraction thereof. ${ }^{94}$

62. Impregnations. An impregnation, to the extent to which it may be traced as a body of ore, is as fully within the broad terms of the act of Congress as any other form of deposit. ${ }^{95}$

1. Eureka Co. v. Richmond Co., 8 Fed. Cas. 4548; Hayes v. Lavagnino, 17 Utah 185.

2. Eureka Co. v. Richmond Co., ante; Harrington v. Chambers, 3 Utah 94.

3. Eureka Co. v. Richmond Co., ante.

4. Synott v. Shaugnessy, 2 Ida. (Hasb.) 122.

5. King v. Amy Co., 9 Mont. 543. The question of what constitutes a vein or lode within the intent of different sections of the mining law arises (1) between miners who have located on the same vein or lode (2) between placer and lode claimants (3) between mineral claimants and townsite patentees (4) between mineral and agricultural claimants; and what is said in one character of cases may or may not be applicable in the other, and must always have a special reference to the formation and particular characteristics of the particular district in which the vein or lode is found. Migeon v. Mont. Cent. Co., 77 Fed. 249; Bonner v. 
Meikle, 82 Fed. 697; Fox v. Myers, 29 Nev. 169; Grand Cent. Co. v. Mammoth Co., 29 Utah 490.

6. See Lawson v. U. S. Co., 207 U. S. 1; Eureka Co. v. Richmond Co., ante.

7. U. S. v. Iron Co., 128 U. S. 673.

8. Bullion Co. v. Croesus Co., 2 Nev. 168.

9. Hyman v. Wheeler, 29 Fed. 347; Burke v. McDonald, 2 Ida. (Hasb.) 679. A lead or lode is not an imaginary line without dimensions. It is not a thing without shape or form; but before it can legally and rightfully be denominated a lead or lode it must have length, width, and depth. It must be capable of measurement. It must occupy defined space and be capable of identification. Foote v. Nat. Co., 2 Mont. 402 . It is by no means always a straight line of uniform dip, or thickness, or richness of mineral matter throughout its course. Iron Co. v. Cheesman, 116 U. S. 529.

10. For a collection of definitions of a vein or lode see Henderson v. Fulton, 35 L. D. 652 ; Book v. Justice Co., 58 Fed. 106; Beals v. Cone, 27 Colo. 473; Fox •v. Myers, ante; Grand Cent. Co. v. Mammoth Co., ante. In some mining districts the veins, lodes and ore deposits are so well and clearly defined as to avoid any questions being raised. In other localities the mineral is found in seams, narrow crevices, cracks or fissures in the earth, the precise extent and character of which cannot be fully ascertained until extensive explorations are made, and the continuity of the ore and the existence of the rock in place, bearing mineral is established. Book v. Justice Co., ante.

11. Eureka Co. v. Richmond Co., ante.

12. Gregory v. Pershbaker, 71 Cal. 109.

13. Hyman v. Wheeler, ante.

14. Id.; Iron Co. v. Cheesman, ante; U. S. v. Iron Co., ante; Eureka Co. v. Richmond Co., ante.

15. Burke v. McDonald, ante. Crevice is a word sometimes applied to a mineral-bearing vein. St. Anthony Co. v. Shaffra, 138 Wis. 507; see Shoshone Co. v. Rutter, 87 Fed. 801; Empire Co. v. Tombstone Co., 131 Fed. 339.

16. Iron Co. v. Cheesman, ante; Cheesman v. Shreve, 40 Fed. 787; Tombstone Co. v. Way Up Co., 1 Ariz. 426.

17. Burke v. McDonald, ante; see Hyman v. Wheeler, ante; Con. Wyoming Co. v. Champion Co., 63 Fed. 540 ; Beals v. Cone, ante.

18. Book v. Justice Co., ante; Cosmopolitan Co. v. Foote, 101 Fed. 518; King v. Amy Co., ante.

19. Synott v. Shaugnessy, ante.

20. Crocker v. Manley, 164 Ill. 282.

21. Con. Wyoming Co. v. Champion Co., ante.

22. Mt. Diablo Co. v. Callison, 17 Fed. Cas. 9886.

23. Id.; see Doe v. Waterloo Co., 54 Fed. 935; Grand Cent. Co. v. Mammoth Co., ante.

24. See Lawson v. U. S. Co., ante; Eureka Co. v. Richmond Co., ante; Hyman v. Wheeler, ante; U. S. Co. v. Lawson, 134 Fed. 769 ; Bullion Beck Co. v. Eureka Co., 5 Utah 3.

25. Bunker Hill Co. v. Empire State Co., 134 Fed. 268; see Grand Central Co. v. Mammoth Co., ante. See, also, Mt. Diablo Co. v. Callison, ante; Waterloo Co. v. Doe, 82 Fed. 45. 
26. Eureka Co. v. Richmond Co., ante; Book v. Justice Co., ante; St. Louis Co. v. Mont. Co., 104 Fed. 664; Last Chance Co. v. Bunker Hill Co., 131 Fed. 579; U. S. Co. v. Lawson, ante, affd. in 207 U. S. 1.

27. Doe v. Waterloo Co., ante.

28. Cheesman v. Shreve, ante; see Justice Co. v. Barclay, 82 Fed. 554 .

29. Calhoun Co. v. Ajax Co., 27 Colo. 1.

30. Larkin v. Upton, 144 U. S. 19.

31. Calhoun Co. v. Ajax Co., ante.

32. Iron Co. v. Mike \& Starr Co., 143 U. S. 394; Harper v. Hill, (Cal.) 113 Pac. 162.

33. Cosmopolitan Co. v. Foote, ante.

34. Ajax Co. v. Hilkey, 31 Colo. 131. Where a secondary or accidental vein crosses a common side line between two mining locations at an angle and the apex of the vein is of such width that it is for a given distance partly within one claim and partly within the other, the entire vein must be considered as apexing upon the senior location until it has wholly passed beyond its side line whether the vein dips towards either claim or does not dip at all. St. Louis Co. v. Mon'. Co., ante.

35. Cosmopolitan Co. v. Foote, ante.

36. Eureka Co. v. Richmond Co., ante.

37. Stinchfield v. Gillis, 96 Cal. 33.

38. Calhoun Co. v. Ajax Co., 182 U. S. 499; Con. Wyoming Co. v. Champion co., ante; Watervale Co. v. Leach, 4 Ariz. 34 ; Champion Co. v. Wyoming Co., 75 Cal. 78; Lee v. Stahl, 13 Colo. 174.

39. Roxana Co. v. Cone, 100 Fed. 168. As to priority see Little Josephine Co. v. Fullerton, 58 Fed. 521.

40. Rev. Stats. $\S 2336$; Wilhelm v. Silvester, 101 Cal. 358; Omar v. Soper, 11 Colo. $380 ; \S 2336$ Rev. Stats. does not conflict with $\S 2322$ but supplements it. Calhoun Co. v. Ajax Co., ante.

41. Calhoun Co. v. Ajax Co., ante. As to mining claim carved out of other land see Stinchfield v. Gillis, ante.

42. Iron Co. v. Cheesman, ante; Grand Cent. Co. v. Mammoth Co., ante.

43. U. S. v. Iron Co., ante; Mutchmor v. McCarty, 149 Cal. 603. A vein is known to exist within the meaning of the statute (1) when it is known to the placer claimant; (2) when its existence is generally known; (3) when any examination of the ground is sufficient to enable the placer claimant to make oath that it is subject to location, as such would necessarily disclose the existence of the vein. Mutchmor v. McCarty, ante. The term "known vein" is not synonymous with "located vein." Iron Co. v. Mike \& Starr Co., ante.

44. Iron Co. v. Mike \& Starr Co., ante.

45. Id.; Migeon v. Mont. Cent. Co., ante; Mutchmor v. McCarty, ante.

46. Burke v. McDonald, ante.

47. Ter. v. Mackey, 8 Mont. 168; see Grand Cent. Co. v. Mammoth Co., ante.

48. Stevens v. Williams, 23 Fed. Cas. 13414.

49. Iron Co. v. Cheesman, ante; Leadville Co. v. Fitzgerald, 15 Fed. Cas. 8158; Stevens v. Gill, 23 Fed. Cas. 13398; Stevens v. Williams, ante; Tabor v. Drexler, 23 Fed. 
Cas. 13723; Iron Co. v. Cheesman, 8 Fed. 297; Meydenbauer v. Stevens, 78 Fed. 787; Jones v. Prospect Co., 21 Nev. 339.

50. See note 49 , ante.

51. Jones v. Prospect Co., ante.

52. Stevens v. Williams, ante.

53. Id.

54. Rev. Stats. § 2320; Stevens v. Williams, 23 Fed. Cas. 13413.

55 . See note 49 , ante.

56. Jupiter Co. v. Bodie Con. Co., 11 Fed. 666.

57. Jones v. Prospect Co., ante.

58. Tabor v. Drexler, ante.

59. Leadville Co. v. Fitzgerald, ante.

60. Book v. Justice Co., ante; Con. Wyoming Co. v. Champion Co., ante.

61. Grand Cent. Co. v. Mammoth Co., ante.

62. Duggan v. Davey, 4 Dak. 110.

63. Id.; see Empire Co. v. Tombstone Co., ante; see note 94, post.

64. Stevens v. Williams, ante.

65. Cheesman v. Shreve, ante.

66. Flagstaff Co. v. Tarbet, 98 U. S. 463; Daggett v. Yreka Co., 149 Cal. 357; Empire Co. v. "Tombstone. Co., ante; Harper v. Hill, ante.

67. Last Chance Co. v. Bunker Hill Co., ante. Lodes or veins frequently do not appear upon the surface except at intervals. Sometimes they do not appear at all. The true apex or middle of the vein may not be accurately determined except by extensive excavations. Veins do not run in straight lines throughout their courses, but with many turns and angles. Detached masses projecting above the surface may be mistaken for the ledge or vein. The ore may occur in a blanket formation having no distinct apex. Harper v. Hill, ante.

68. Flagstaff Co. v. Tarbet, ante; Iron Co. v. Elgin Co., 118 U. S. 196.

69. Duggan v. Davey, ante.

70. Larkin v. Upton, ante; see note 66 , ante.

71. Duggan v. Davey, ante; Iron Co. v. Murphy, 3 Fed. 368; see Illinois Co. v. Raff, 7 N. M. 336.

72. Larkin v. Upton, ante; Iron Co. v. Murphy, ante. A swell in a vein should not be mistaken for its true apex. Stevens v. Williams, ante.

73. Duggan v. Davey, ante.

74. Woods v. Holden, 26 L. D. 198. What is the top or apex of a vein or lode is a question of fact and not of law. Blue Bird Co. v: Largey, 49 Fed. 289.

75. Larkin v. Upton, ante.

76. Id.

77. Id.; see Brewster v. Shoemaker, 28 Colo. 176.

78. King v. Amy Co., ante.

79. Flagstaff Co. v. Tarbet, ante; see Con. Wyo. Co. v. Champion Co., ante.

80. King v. Amy Co., ante.

81. Bunker Hill Co. v. Empire State Co., ante.

82. King v. Amy Co., ante.

83. Mt. Diablo Co. v., Callison, ante.

84. King v. Amy Co., ante; C. C. $\$ 801$, subd. 5 .

85. See Grand Cent. Co. v. Mammoth Co., ante.

86. Golden v. Murphy, (Nev.) 103 Pac. 394. 
87. Cheesman v. Shreve, ante; Grand Cent. Co. v. Mammotlı Co., ante.

88. Illinois Co. v. Raff, ante.

89. Book v. Justice Co., ante; Hyman v. Wheeler, ante.

90. Iron Co. v. Cheesman, ante.

91. Eureka Co. v. Richmond Co., ante.

92. Hyman v. Wheeler, ante; but see Grand Cent. Co. v. Mammoth Co., ante.

93. Con. Wyo. Co. v. Champion Co., ante.

94. Chrisman v. Miller, 197 U. S. 313. See Steele v. Tanana Co., 148 Fed. 648; Madison v. Octave Oil Co., 154 Cal. 768 , in regard to placers. See Shoshone Co. v. Rutter, 87 Fed. 801; McMillen v. Ferrum Co., 32 Colo. 38; Ambergris Co. v. Day, 12 Ida. 108, in relation to lode claims. The mere existence of outcroppings does not constitute a mine. There must be evidence of the

- actual value of the deposit to establish the mineral value of the land to render it mineral land. Colo. Coal Co. v. U. S., 137 U. S. 307; Frees v. State, 22 L. D. 510; see Cascaden v. Bartolis, 162 Fed. 267.

95. Hyman v. Wheeler, ante.

\section{CHAPTER IX.}

\section{GRUB STAKE CONTRACTS - MINING PARTNERSHIPS- CO-TENAN'TS.}

$\S 57$. Grub stake-in general-nature of contract-trusteesessential requisites - consideration - termination-accrued rights - duty of outfitter-duty of prospectorwhat is not a grub stake.

\$58. Mining partnerships-peculiar rules applicable-essential difference between mining and general partnerships - how created-general partners-trustees-control-debts-liens-accounting-dissolution-sale.

\$59. Co-tenants-not mining partners-trustees-termination of trust-corporation not co-tenant-incohate rightsdivestiture of title-exclusion from patent-when rights barred-actions-questioning title-working the claim-accounting - contribution-liability for loss and debts-adverse possession.

§57. Grub Stake-In General. A grub stake or prospecting contract is an agreement, not within the Statute of Frauds and, therefore, not necessarily in writing, ${ }^{*}$ except in Oregon ${ }^{1}$ and Nevada, ${ }^{2}$ by which one of the parties thereto is to furnish to the other supplies, money, or both, to and while the other is prospecting for and obtaining mineral land, by location, for their joint advantage or in such proportions as may be agreed upon. ${ }^{3}$ 
2. Nature of Contract. The contract is in the nature of a qualified partnership. ${ }^{4}$ It does not constitute a "mining partnership" unless the parties thereto actually engage in the joint working of property, ${ }^{5}$ otherwise the parties are tenants in common in the property acquired. ${ }^{6}$

3. Trustees. As the parties are trustees or agents for each other in the prosecution of the joint adventure, ${ }^{7}$ all locations made during the existence of the partnership inure to the benefit of each, whether made in the name of only one of them, or in the name of a third person, at the instigation of either. ${ }^{8}$

4. Essential Requisites. In order to have a right in property under the grub stake it is essential that the property was acquired by means of the grub stake and pursuant to the provisions of the grub-stake contract. ${ }^{9}$

5. Consideration. The contract must be baseil upon an adequate consideration and be clear, definite, just and reasonable. ${ }^{10}$

6. Termination. The contract may expire by limitation of time, be dissolved by mutual consent, ${ }^{11}$ or, if its terms permit, at the option of either party, ${ }^{12}$ be abandoned or become impracticable. ${ }^{13}$

7. AcCrued Rights. Accrued rights are not disturbed by its termination, ${ }^{14}$ and in the absence of fraud either party may locate unappropriated discoveries known to him during the existence of the contract. ${ }^{15}$

8. Duty of Outfitter. The outfitter must furnish the supplies agreed upon or the contract will fail. ${ }^{16}$

9. Duty of Prospector. It is the duty of the prospector to use reasonable diligence and make reasonable exertions in seeking mineral deposits, ${ }^{17}$ and within a reasonable time make proper location covering discovery. ${ }^{18}$ 
10. What is not a Grub Stake. Payment of wages and promising to give the prospector an interest in property obtained is not a grub-stake contract, but one of hiring. ${ }^{19}$ Neither is an exchange of interests in subsisting claims such a contract. ${ }^{20}$

* Hendricks v. Morgan, 167 Fed. 106; Murley v. Ennis, 2 Colo. 300 ; Hardin v. Hardin, (S. Dak.) 129 N. W. 108.

1. Or. Stats. 1898 , p. 18 ; Ball. Codes $\$ 3985$.

2. Nev. Stats. 1907, p. 370 .

3. Berry v. Woodburn, 107 Cal. 504; Meylette v. Brennan, 20 Colo. 242; Costello v. Scott, 30 Nev. 43; Hartney v. Gosling, 10 Wyo. 346 ; see Ida. C. C. $\$ 2784$; see Ida. Stats. 1899 , p. 366.

4. Berry v. Woodburn, ante; Meylette v. Brennan, ante; Hisbour v. Reeding, 3 Mont. 15; see Prince v. Lamb, 128 Cal. 120; Hartney v. Gosling, ante; see Lawrence v. Robinson, 4 Colo. 567.

5. Skillman v, Lachman, 23 Cal. 198; Dorsey v. Newcomer, 121 Cal. 213; Manville v. Parks, 7 Colo. 128; Anaconda Co. v. Butte \& Boston Co., 17 Mont. 519.

6. G. V. B. Mg. Co. v. Bank, 95 Fed. 35; Cascaden v. Dunbar, 2 Alaska 408; Marks v. Gates, 2 Alaska 519; Gore v. McBrayer, 18 Cal. 582; Hartney v. Gosling, ante.

7. Shea v. Nilima, 133 Fed. 209; Hendricks v. Morgan, ante; Settembre v. Putnam, 30 Cal. 490; Moritz v. Lavelle, 77 Cal. 10; Stewart v. Douglass, 148 Cal. 511; Byrne v. Knight, 12 Cal. A. 56; Jennings v. Rickard, 10 Colo. 395; Meagher v. Reed, 14 Colo. 356; Hardin v. Hardin, ante. See Botsford v. Van Riper, (Nev.) 110 Pac. 705.

8. Delmonico v. Roudebush, 5 Fed. 165 ; Shea v. Nilima, ante. It is immaterial to his rights whether the trustor's name is inserted in the location notice or not. Byrne v. Knight, ante; Hardin v. Hardin, ante; see Moore v. Hammerstag, 109 Cal. 122.

9. Prince v. Lamb, ante; see Cascaden v. Dunbar, ante; Marks v. Gates, ante.

10. Cisna v. Mallory, 84 Fed. 851; Marks v. Gates, 154 Fed. 481; Cascaden v. Dunbar, ante; Copper River Co. v. M'Clellan, 2 Alaska 134; Prince v. Lamb, ante; Rice v. Rigley, 7 Ida. 115; Morrow v. Matthew, 10 Ida. 423; see Stewart v. Douglass, ante; Brown v. Bowman, 119 Ga. 153. See Martin's Min. Law, §§ 379-380.

11. Page v. Summers, 70 Cal. 121; McLaughlin v. Thompson, 2 Colo. A. 135; see, also, McKenzie v. Coslett, 28 Nev. 65.

12. Lawrence v. Robinson, ante.

13. Roberts v. Date, 123 Fed. 238; Eubanks v. Petree, 1 Alaska 427; Miller v. Butterfield, 79 Cal. 62; Murley v. Ennis, ante; McLaughlin v. Thompson, ante; see McGahey v. Oregon Co., 165 Fed. 86.

14. Lawrence v. Robinson, ante.

15. Page v. Summers, ante; see also, note 7 , ante.

16. Prince v. Lamb, ante; but see Byrne v. Knight, ante, in which it is held that the fact that the prospector afterwards pays for the supplies does not invalidate the contract; see Murley v. Ennis, ante. 
17. See Skidmore v. Eikenberry, 53 Iowa 621; Ray v. Hodge, 15 Or. 20.

18. Murley v. Ennis, ante.

19. Berry v. Woodburn, ante.

20. Roberts v. Date, ante.

§58. Mining Partnerships. Mining partnerships are distinct associations with different liabilities attaching to members of ordinary partnerships. ${ }^{1}$

2. Peculiar Rules Applicable. Many of the rules of general partnership obtain in mining partnerships, but the latter have some rules peculiar to themselves. ${ }^{2}$

3. Essential Difference Between Mining and General Partnerships. The essential difference is that dissolution does not result from the death or bankruptcy of a partner, ${ }^{3}$ and a partner has no right to decide what new partners shall be admitted to the firm. ${ }^{4}$

4. How Created. A mining partnership is created when the owners of a mining claim or shares therein, or lessees of a mining claim unite in the actual working of such claim for the purpose of extracting mineral therefrom, sharing the losses and profits arising from such working, although no express agreement to form a partnership is entered into between them. ${ }^{5}$

5. General Partners. The parties may become general partners as a result of their own agreement. ${ }^{6}$

6. TRustees. The partners are in the relation of trustees for each other. ${ }^{7}$

7. Control. The property worked and the business of the firm may be controlled by a majority of the members of the partnership acting for the best interests of all concerned. 8

8. Debts. Each partner is jointly liable for the debts of the firm. ${ }^{9}$

9. Liens. The property worked is not necessarily property owned by the partnership $;^{10}$ if it be so, it is subject to the lien of each member of the firm for debt due to himself or to the ereditors of the firm. ${ }^{11}$ 
10. Accounting. One mining partner may sue his co-partner for an accounting. ${ }^{12}$

11. Dissolution. The partnership may be dissolved at the will of one of the partners ${ }^{13}$ or by the abandonment ${ }^{14}$ or sale of the property. ${ }^{15}$

12. SALE. A partner may properly sell his interest at a greater price than that received by the others. ${ }^{16}$

1. Kahn v. Smelt. Co., 102 U. S. 641 ; Congdon v. Olds, 18 Mont. 487.

2. SSkillman v. Lachman, 23 Cal. 198; Congdon v. Olds, ante. The law of California provides that: $\$ 2511$. A mining partnesship exists when two or more persons who own or acquire a mining claim for the purpose of working it and extracting the mineral therefrom actually engage in working the same.

$\$ 2512$. An express agreement to become partners or to share the profits and losses of mining is not necessary to the formation or existence of a mining partnership. The relation arises from the ownership of shares or interests in the mine and working the same for the purpose of extracting the minerals therefrom.

$\$ 2513$. A member of a mining partnership shares in the profits and losses thereof in the proportion which the interest or share he owns in the mine bears to the whole partnership capital or whole number of shares.

$\S 2514$. Each member of a mining partnership has a lien on the partnership property for the debts due the creditors thereof, and for money advanced by him for its use. This lien exists notwithstanding there is an agreement among the partners that it must not.

$\$ 2515$. The mining ground owned and worked by partners in mining, whether purchased with partnership funds or not, is partnership property.

$\$ 2516$. One of the partners in a mining partnership may convey his interest in the mine and business without dissolving the partnership. The purchaser, from the date of his purchase, becomes a member of the partnership.

$\$ 2517$. A purchaser of an interest in the mining ground of a mining partnership takes it subject to the liens existing in favor of the partners for debts due all creditors thereof, or advances made for the benefit of the partnership, unless he purchases in good faith, for a valuable consideration, without notice of such lien.

\$ 2518 . A purchaser of the interest of a partner in a mine when the partnership is engaged in working it, takes with notice of all liens resulting from the relation ef the partners to each other and to the creditors of the partnership.

$\S 2519$. No member of a mining partnership or other agent or manager thereof can, by a contract in writing, bind the partnership, except by express authority derived from the members thereof. 
$\S 2520$. The decision of the members owning a majority of the shares or interests in a mining partnership binds it in the conduct of its business. C. C., $\$ \S 2511-2520$.

3. Jones v. Clark, 42 Cal. 180; Higgins v. Armstrong, 9 Colo. 38; Boeme v. Fitzgerald, (Mont.) 115 Pac. 413; Bently v. Brossard, 33 Utah, 396; Hartney v. Gosling, 10 Wyo. 346.

4. Jones v. Clark, ante; Patrick v. Weston, 22 Colo. 45; see Bissel v. Foss, 114 U. S. 252.

5. Loy v. Alston, 172 Fed. 90; Ferris v. Baker, 127 Cal. 520; Walker v. Bruce, 44 Colo. 109; Anaconda Co. v. Butte \& Boston Co., 17 Mont. 519; Congdon v. Olds, ante; Kirchner v. Smith, 61 W. Va. 434; see Chung Kee v. Davidson, 102 Cal. 188; Vietti v. Nesbitt, 22 Nev. 390.

6. Decker v. Howell, 42 Cal. 636; Congdon v. Olds, ante; Hartney v. Gosling, ante.

7. Gore v. McBrayer, 18 Cal. 582; Con. Divide Co. v. Bliley, 23 Colo. 160 ; see Bissel v. Foss, ante.

8. Dougherty v. Cleary, 30 Cal. 291; Jones v. Clark, ante; Patrick v. Weston, ante; Congdon v. Olds, ante; Hartney v. Gosling, ante; see Edinger v. So. Oil Co., (W. Va.) 71 S. E. 266

9. Hailey v. G. V. B. Co., 89 Fed. 449; Stuart v. Adams, 89 Cal. 367.

10. Settembre v. Putnam, 30 Cal. 490; Hartney v. Gosling, ante.

11. G. V. B. Co. v. Hailey, 95 Fed. 35; Duryea v. Burt, 28 Cal. 569 ; see Brunswick v. Winters, 3 N. M. 386.

12. Howard v. Luce, 171 Fed. 584.

13. Lawrence v. Robinson, 4 Colo. 567.

14. Larsh v. Boyle, 36 Colo. 18.

15. Dellapiazza v. Foley, 112 Cal. 380 ; but see Kahn v. Cent. Smelt. Co., ante; Kimberly v. Arms, 129 U. S. 512.

16. Harris v. Lloyd, 11 Mont. 390.

$\S 59$. Co-tenants. Co-tenancy arises from the joint location of or ownership in a mining claim. ${ }^{1}$

2. Not Mining Partíners. Co-tenants are not "mining partners" unless they unite in working the claim. ${ }^{2}$

3. Trustees. A co-tenant becomes a trustee for his co-tenants when he re-locates the claim ${ }^{3}$ or permits its re-location by a third person with whom he is in collusion, unless there has been due severance of the relations of co-tenancy ${ }^{4}$ or he obtains patent in his own name for the claim held in eo-tenancy ${ }^{5}$ or purchases an outstanding title to such claim. ${ }^{6}$

4. Termination of Trust. The trust may be terminated by agreement or laches ${ }^{7}$ or by the statute of limitations. ${ }^{\mathrm{s}}$ 
5. Corporation not Co-tenant. A stockholder in a corporation is in no sense a co-tenant with the corporation nor with the other shareholders of the corporate property. ${ }^{9}$

6. INCHOATE Rights. The holder of a sheriff's certificate of purchase under an execution sale and as the assignee of judgments which are liens against the claim or interest therein is not a co-tenant. ${ }^{10}$

7. Divestiture of Titue. The title of a co-tenant may be divested by failure of the other co-tenants to make the annual expenditure on the claim, although they may have agreed with him to make the same; ${ }^{11}$ or by his failure, after due notice, to contribute his proportion of such expenditure; ${ }^{12}$ or by the actual adverse possession for the statutory period of the other co-tenants, or some one of them, ${ }^{13}$ evidenced by ouster ${ }^{14}$ or by their obtaining a patent from the government in their own names. ${ }^{15}$

8. Exclusion from Patent. A co-owner excluded by his co-tenants from an application for a United States patent may, ${ }^{16}$ but he is not compelled to, file an adverse claim ${ }^{17}$ or a protest ${ }^{18}$ or institute legal proceedings to enforce the trust during the pendency of patent proceedings; ${ }^{19}$ although he may so do. ${ }^{20}$

9. When Rights Barred. The excluded co-tenant may maintain a suit to enforce the trust after the issuance of the patent to the excluding co-tenants ${ }^{21}$ when not barred by laches, the statute of limitations, or the intervention of the rights of third parties, without notice. ${ }^{22}$

10. Actions. A co-tenant may maintain an action for the recovery of the claim without joining his cotenants. ${ }^{23}$

11. Questioning Title. A co-tenant cannot question the common title upon a contest between him and his co-owners; nor purchase an adverse title and set it up against his co-tenants if they are willing to reim- 
burse him for the amount so expended ${ }^{24}$ within a reasonable time, or offer to contribute their proportion thereof, provided that the purchasing co-tenant wishes to be paid and conducts himself accordingly. ${ }^{25}$

12. Working the Clatm. In the absence of a local statute prohibiting such action 26 or an agreement to the contrary between the co-tenants, a cotenant who does not exclude his co-tenants may work the claim and remove mineral therefrom without being charged with waste or liable to the other co-tenants for damages or subject to an injunction at the instance of his co-tenants. ${ }^{27}$

13. Accounting. The working co-owner is liable to the non-participating or non-assenting co-owners for their pro rata share in the net results. ${ }^{28}$

14. Contribution. In the absence of a ratification the operating co-owner has no claim for contribution from them ${ }^{29}$ except in a partition suit where the court may adjust the equities between them. ${ }^{30}$

15. Liability for Loss and Debts. As a rule the working co-tenant must alone sustain any loss which results from his working of the property, and he is alone responsible for the debts thereby contracted. ${ }^{31}$

16. Adverse Possession. Hostility of possession under claim of title exclusive of any other right will conclude the right of the excluded co-tenants, if continued for sufficient time under the statute of limitations, ${ }^{32}$ and bar an accounting. ${ }^{33}$

1. Lockhart v. Leeds, 195 U. S. 427; Morton v. Solambo Co., 26 Cal. 527; Morenhaut v. Wilson, 52 Cal. 263; Chase v. Savage Co., 2 Nev. 14; Elder v. Horseshoe Co., $9 \mathrm{~S}$. Dak. 636.

2. Madar v. Norman, 13 Ida. 585; Hartney v. Gosling, 10 Wyo. 346.

3. Hunt v. Patchin, 35 Fed. 816; Stevens v. Grand Cent. Co., 133 Fed. 28; Yarwood v. Johnson, 29 Wash. 643. See Turner v. Sawyer, 150 U. S. 578.

4. Strang v. Ryan, 46 Cal. 34 ; Doherty v. Morris, 11 Colo. 12 ; Saunders v. Mackey, 5 Mont. 523.

5. Stevens v. Grand Cent. Co., ante.

6. Franklin Co. v. O'Brien, 22 Colo. 129; Cedar Canyon Co. v. Yarwood, 27 Wash. 271. 
7. Patterson v. Hewitt, 195 U. S. 309; Holt v: Murphy, 207 U. S. 407 .

8. Gregory v. Gregory, 102 Cal. 50.

9. Repeater Claims, 35 L. D. 54 ; see $\$ 223$, post.

10. Turner v. Sawyer, ante.

11. Stuart v. Adams, 89 Cal. 367.

12. Rev. Stats., \$2324; Faubel v. MeFarland, 144 Cal. 717; Elder v. Horseshoe Co., 194 U. S. 248; see Haynes v. Briscoe, 29 Colo. 137; see $\$ 200$, post.

13. Feliz v. Feliz, 105 Cal. 1 .

14. Union Co. v. Taylor, 100 U. S. 37.

15. Stevens v. Grand Central Co., ante; Suessenback v. Bank, 5 Dak. 477; see Wetzstein v. Largey, 27 Mont. 212.

16. Gold Dirt Lode, 10 C. L. O. 19 ; Davidson v. Fraser, 36 Colo. 1; Mattingly v. Lewisohn, 8 Mont. 259.

17. Turner v. Sawyer, ante.

18. Coleman v. Homestake Co., 30 L. D. 364; Thomas v. Elling, 25 L. D. 495; Golden and Cord Claims, 31 L. D. 178.

19. Davidson v. Fraser, ante.

20. Malaby v. Rice, 15 Colo. A. 364.

21. Turner v. Sawyer, ante; Stevens v. Grand Cent. Co., ante; Thomas v. Elling, ante; Suessenback v. Bank, ante.

22. Reed v. Munn, 148 Fed. 737; Davidson v. Fraser, ante.

23. Morenhaut v. Wilson, ante; see Union Co. v. Dangberg, 81 Fed. 73. The judgment in such case will be in subordination to the rights of the other co-tenants. Hardy v. Johnson, 68 U. S. 371 .

24. Cedar Canyon Co. v. Yarwood, ante.

25. Boskowitz v. Davis, 12 Nev. 446.

26. Butte \& Boston Co. v. Mont. Co., 24 Mont. 125.

27. McCord v. Oakland Co., 64 Cal. 134; Downing v. Rademacher, 133 Cal. 220; see Hawkins v. Spokane Co., 3 Ida. (Hasb.) 241; Russell v. Bank, 47 Minn. 288.

28. Paul v. Cragnaz, 25 Nev. 293. An accounting may be compelled by either of the parties holding a majority or minority interest in a mine, of work done and metals extracted. Hawkins v. Spokane Co., ante.

29. Stickley v. Mulrooney, 36 Colo. 242. While the operating co-tenant may, in case he is called upon to account for profits, set off, as against a non-operating co-tenant, the cost of the necessary improvements, he must show that such improvements were necessary and added to and enhanced the value of the common property. Wolfe v. Childs, 42 Colo. 121.

30. Neuman v. Driefurst, 9 Colo. 228; see Goodenow v. Ewer, 16 Cal. 461: McDaniel v. Moore, (Ida.) 112 Pac. 317; Welland v. Williams, 29 Nev. 230.

31. Neuman v. Driefurst, ante; Welland v. Williams, ante.

32. Gregory v. Gregory, ante; Feliz v. Feliz, ante.

33. Howard v. Throckmorton, 59 Cal. 79. 


\section{CHAP'TER X. \\ IINING LEASES AND LICENSES.}

$\$ 61$. Mining leases-in general-covenants-provision as to stoping-royalty.

$\$ 62$. Licenses in general-intent controls-test-when revocable-when irrevocable-injunction.

\$61. Mining Leases-In General. Each mining lease has its own peculiar details. It is sometimes coupled with an option to purchase the property leased, in which case they are separate and independent agreements. ${ }^{1}$ Time is always of the essence of the lease. $^{2}$ It is a contract of labor and not a lease if it provides that the lessor shall have a certain part of the mineral extracted as a return for working the property for a fixed time. ${ }^{3}$

2. Covenants. A covenant to work the property continuously means continuously to the end of the term. ${ }^{4}$ But a mere covenant to work the property is not tantamount to an agreement to work continuously. ${ }^{5}$

3. Provision as to Stoping. A provision that ore may be stoped only from a certain named level includes the right to stope ore between such level and the next level immediately below. ${ }^{6}$

4. Royalty. Where a lease provides for a royalty there is an implied covenant on the part of the lessee for diligent search and operation and the lessee is bound to proceed with his mining operations with reasonable diligence. ${ }^{\top}$ Acts of the lessor that hinder and delay the lessee in his mining operations serve to extend the time for the extraction of mineral beyond that which is fixed in the lease. ${ }^{8}$

See Oil Land Leases, §122, post.

1. Settle v. Winters, 2 Ida. (Hasb.) 215. See Mathews Slate Co. v. New Empire Slate Co., 122 Fed. 972; Kift v. Mason, 42 Mont. 232; Snider v. Yarborough, (Mont.) 115 Pac. 411.

2. Montrozona Co. v. Thatcher, 19 Colo. A. 371; Settle v. Winters, ante; Merk v. Bowery, 31 Mont. 298; see Halla v. Rogers, 176 Fed. 709; see Westerman v. Dinsmore, (W. Va.) 71 S. E. 250 . 
3. Hudephol v. Liberty Hill Co., 80 Cal. 553; Vietti v. Nesbitt, 22 Nev. 390.

4. Zelleken v. Lynch, 80 Kan. 746 .

5. Caley v. Portland Co., 12 Colo. A. 397.

6 . Chambers v. Lowry, 21 Mont. 478.

7. McIntosh v. Robb, 4 Cal. A. 484 ; see $\$$ 122-3.

8. Halla v. Rogers, ante.

§ 62. Licenses-In General. A license, as it affects real property, is a privilege or permit, oral or written, with or without consideration, ${ }^{1}$ to do a particular act or series of acts, upon the estate of another without possessing any estate therein, ${ }^{2}$ and which otherwise would be unlawful. ${ }^{3}$

2. Intent Controls. It is the intention of the parties, as expressed in the instrument, and not its form, that determines whether it is a license or a lease. A quitclaim deed may, in effect, be a license ${ }^{4}$ or a grant, bargain and sale deed may contain covenants to that effect. ${ }^{4 a}$

$2^{\mathrm{a}}$. Test. If the contract gives exclusive possession it is a lease, if it merely confers the privilege of occupation, under the owner, it is a license. ${ }^{5 a}$

3. When Revocable. A mere license is revocable at will and is unassignable, although based upon a consideration. 5 .

4. When IrRevocable. When coupled with an interest a license is irrevocable and assignable. ${ }^{6}$

5. InJUNCTION. Where the license has been revoked, the licensee refuses to surrender possession, is insolvent, and is committing waste and destroying the substance of the licensor's estate the latter is entitled to an injunction. ${ }^{7}$

1. Stoner v. Zucker, 148 Cal. 516; Wessels v. Colebank, 174 III. 618 .

2. Wynn v. Garland, 19 Ark. 23; Emerson v. Bergin, 76 Cal. 197; see Wheeler v. West, 71 Cal. 126.

3. Grubb v. Vayard, 11 Fed. Cas. 5849; Clark v. Wall, 32 Mont. 219.

4. Baker v. Clark, 128 Cal. 181; see, also, Coolbaugh v. Lehigh \& Wilkes-Barre Co., 213 Pa. St. 28.

4a. Shaw v. Caldwell, (Cal. A.) 115 Pac. 941. 
5. East Jersey Co. v. Wright, 32 N. J. Eq. 248; Manning v.

Fraser, 96 Ill. 279; Johnson v. Skillman, 29 Minn. 95;

Huff v. McCauley, 53 Pa. St. 206; see Stoner v. Zucker, ante; Stacy v. Glen Ellyn Co., 223 Ill. 546; Hosford V. Metcalf, 113 Iowa 240.

5a. Shaw v. Caldwell, ante.

6. Grubb v. Bayard, ante; Cary Co. v. McCarty, 10 Colo. A. 200; Clark v. Wall, ante; Hall v. Abraham, 44 Or. 477.

7. Clark v. Wall, ante; see $\S 8 \dot{5}$.

\section{CHAPTER XI.}

\section{OPTIONS-DEEDS-EXAMINATION OF TITLE.}

$\$ 66$. Options-distinction between option and contract-consideration-sufficient consideration-duty of ownerdamages-default.

\$67. Deeds-what passes by deed-unnecessary recital-creation of independent estates-effect of quitclaim deed -title of corporation-title of association-attack by grantor-agreement for deed-description-statute of limitations-taxation.

\$68. Examination of title-unappropriated land-character of location-form of location-cross vein-known veindiscovery-boundaries-annual expenditure-receiver's receipt-conclusiveness of patent-inconclusiveness of patent.

§66. Options. An option is a privilege to purchase a certain property, at an agreed price, within a certain time. ${ }^{1}$ It may be a license or a covenant running with the land. ${ }^{2}$ It may be coupled with a lease. $^{3}$ Time is of the essence of the contract 4 whether so therein expressly stated or not. ${ }^{5}$

2. Distinction Between Option and Contract. The distinction between a contract to purchase or sell real estate and an option to purchase is that the contract to purchase or sell creates a mutual obligation on the one party to sell and on the other to purchase while an option merely gives the right to purchase within a limited time without imposing any obligation to purchase. That is, an option is a right acquired by contract to accept or reject a present offer within a limited or reasonable time in the future. ${ }^{6}$

3. Consideration. Unless based upon a sufficient consideration an option is merely a continuing offer of sale which may be withdrawn at any time before acceptance. ${ }^{7}$ 
4. Sufficient Consideration. A consideration of one dollar, in the absence of fraud or bad faith ${ }^{s}$ or the making of expenditures upon the property," as, for instance, the performance of the annual assessment work thereon is a sufficient consideration. ${ }^{10}$

5. DUTY OF OWNER. It is essential that the owner of the property shall ascertain, in due time, whether the option holder has performed the annual assessment work upon an unpatented claim should he have agreed to do so, and if not so done by the latter to himself cause the same to be done in time sufficient to save the claim from forfeiture. ${ }^{11}$

6. Damages. Where the option holder defaults in such particular the amount of damages is the amount of the annual expenditure. and not the value of the claim that may be forfeited.12

7. DeFAULT. If it is provided that in default of any of the payments the property shall revert back to the grantor of the option it is not necessary in case of such default to rescind the contract nor offer to return the payments made, nor wait until final payment was due and in default before bringing suit in ejectment. ${ }^{13}$

1. Richardson v. Hardwick, 106 U. S. 252; Marthinson v. King, 150 Fed. 48; Ide v. Leiser, 10 Mont. 5; Snider v. Yarborough, (Mont.) 115 Pac. 411; Hanley v. Watterson, 38 W. Va. 214. See, generally, Pollard v. Sayre, 45 Colo. 195; Botsford v. Van Riper, (Nev.) 110 Pac. 705; Anderson v. Phegley, (Or.) 110 Pac. 975.

It is provided in California that:-

$\$ 1577$. Whenever, in any estate now being administered, or that may hereafter be administered, it shall appear to the superior court, or a judge thereof, to be fol the advantage of the estate to raise money upon a note or notes to be secured by a mortgage of the real property of any decedent, or of a minor, or an incompetent person, or any part thereof, or to make a lease of said realty, or any part thereof, or to agree to sell a claim, or mining claims, or real property worked as a mine, the court or judge, as often as occasion therefor shall arise in the administration of any estate, may on a petition, notice, and hearing as provided in this article, authorize, empower and direct the executor or administrator, or guardian of such minor or incompetent person, to mortgage such real estate, 
or any part thereof, and to execute a note or notes to be secured by such mortgage, or to lease such real estate, or any part thereof, or to enter into an agreeinent to sell such real estate, or any part thereof.

$\$ 1580$. To obtain an order to enter into an agreement for the sale of a mining claim, or claims, or real property, worked as a mine, the proceedings to be taken and the effect thereof shall be as follows:

First. The executor, administrator, guardian of a minor, or of an incompetent person, or any person interested in the estate of such decedents, minors, or incompetent persons, may file a verified petition showing:

1. The advantage or advantages that may accrue to the estate from entering into. such an agreement.

2. A general description of the property affected by said agreement.

3. The terms and general conditions of the proposed agreement.

4. The names of the legatees and devisees, if any, and of the heirs of the deceased, or of the minor, or of the incompetent person, so far as known to the petitioner.

Second. Upon filing such petition an order shall be made by the court or judge requiring all persons interested in the estate to appear before the court or judge, at a time and place specified, not less than two or more than four weeks thereafter, then and there to show cause why an agreement for the sale of the realty should not be made, and referring to the petition on file for further particulars.

Third. The order to show cause must be personally served on the persons interested in the estate at least ten days before the time appointed for hearing the petition, or it may be published for four successive weeks in a newspaper of general circulation in the county if there be one, and if there is none then in some newspaper of general circulation in the county.

Fourth. At the time and place appointed to show cause, or at such other time and place to which the hearing may be postponed the power to make all needful postponements being hereby vested in the court or jury, the court or judge having first received satisfactory proof of personal service or publication of the order to show cause, must proceed to hear the petition, and any objections that may have been filed or presented thereto. If, after a full hearing, the court or judge is satisfied that it will be for the advantage of the estate to enter into the proposed agreement for the sale of the mines or real estate, an order must be made authorizing, empowering and directing the executor, administrator or the guardian to make such agreement. The order may prescribe the terms and conditions of such agreement.

Fifth. After the making of the order to enter into said agreement, the executor, administrator or guardian of a minor or of an incompetent person shall execute, acknowledge and deliver an agreement containing the conditions specified in the order, sefting forth in the agreement that it is made by authority of the 
order, and giving the date of such order. A certified copy of the order shall be recorded in the office of the county recorder of every county in which the land affected by the agreement or any portion thereof is situated. C. C. P., \$§ 1577-1580.

The provisions of the probate law of California in relation to the summary sale of mines and mining interests are as follows:-

$\$ 1529$. When it appears from the inventory of the estate of any decedent that his estate consists in whole or in part of mines, or interests in mines, such mines or interests may be sold under the order of the court having jurisdiction of the estate, as hereinafter provided.

$\$ 1530$. The executor or the administrator, or any heir at law, or creditor of the estate, or any partner or member of any mining company, in which interests or shares are held or owned by the estate, may file in the court a petition in writing, setting forth the general facts of the estate being then in due course of administration, and particularly describing the mine, interest, or shares which it is desired to sell, and particularly the condition and situation of the mines or mining interests, or of the mining company in which such interests or shares are held, and the grounds upon which the sale is asked to be made.

$\S 1531$. Upon the presentation of such petition, the court, or a judge thereof, must make an order direct = ing all persons interested to appear before such court, at a time and place specified, not less than four or more than ten weeks from the time of making such order, to show cause why an order should not be granted to the executor or administrator to sell such mine, mining interests, shares, or stocks, as are set forth in the petition and belonging to the estate. A copy of the order to show cause must be personally served on all persons interested in the estate, at least ten days before the time appointed for hearing the petition, or published at least four successive weeks in such newspaper as such court or judge shall specify. If all persons interested in the estate signify in writing their assent to such sale, the notice may be dispensed with.

\$1532. If, upon hearing the petition, it appears to the satisfaction of the court that it is to the interest of the estate that such mining property or interests of the estate should be sold, or that an immediate sale is necessary in order to secure the just rights or interests of the mining partners, or tenants in common, such court must inake an order authorizing the executor or administrator to sell such mining interests, mines, or shares, as hereinafter provided.

$\$ 1533$. After the order of sale is made, all further proceedings for the sale of such mining property, and for the notice, report, and confirmation thereof. must be in conformity with the provisions of article four of this chapter. C. C. P., \$§ 1529-1533.

2. Smith v. Jones, 21 Utah, 270 .

3. Mathews Slate Co. v. New Empire Slate Co., 122 Fed. 972; Settle v. Winters, 2 Ida. (Hasb.) 215; Snider v. Yarborough, ante. 
4. Gaines v. Chew, 167 Fed. 630; Harper v. Independence Co., (Ariz.) 108 Pac. 701; Settle v. Winters, ante; Merk v. Bowery Co., 31 Mont. 298; Snider v. Yarborough, ante.

5. Waterman v. Banks, 144 U. S. 394; Clark v. American Co., 28 Mont. 468.

6. Brickell v. Atlas Co., 10 Cal. A. 17; Clark v. American Co., ante. What is termed an option, although unilateral in form, may, in effect, be an agreement to sell; and when possession is taken and payments made thereunder, such acts are an acceptance of its terms. The "option holder" is then bound as a purchaser, and in case of default, the vendor has the right to re-enter and recover unpaid installments. Reed v. Hickey, 13 Cal. A. 136.

7. Milwaukee Co. v. Shea, 123 Fed. 9; Brown v. S. F. Sav. Union, 134 Cal. 448; Frank v. Stratford-Handcock, 13 Wyo. 37; see Snow v. Nelson, 113 Fed. 353; Gordan v. Darnell, 5 Colo. 302; Penn. Co. v. Smith, 207 Pa. St. 210. An offer which in its terms limits the term of acceptance is withdrawn by the expiration of the time. Waterman v. Banks, ante. After acceptance of the terms by the holder of the option the parties are mutually bound and either one may compel specific performance by the other. Hoogendorn v. Daniel, 178 Fed. 765. See, also, Marthinson v. King, ante. That an accounting may be had, see S. P. Mines v. Court, (Nev.) 110 Pac. 503.

8. Pittsburg v. Bailey, 76 Kan. 42.

9. Ford v. Milk Ass'n., 155 Ill. 166.

10. Ferguson v. McGuire, 17 Ida. 141.

11. Stamey v. Hemple, 173 Fed. 61.

12. Id.

13. Williams v. Long, 129 Cal. 229.

$\S 67$. Deeds. A mining claim being real estate it can be transferred only by operation of law ${ }^{1}$ or by an instrument in writing, ${ }^{2}$ but a discoverer of mineral may transfer his right of location by parol. ${ }^{3}$

2. What Passes by Deed. It is sufficient if it be clear from the language used that the grantor intended to pass the title to the property and whatever is incident and appurtenant thereto. ${ }^{4}$

3. UnNeCESSaRy Recital. It is not necessary to insert in a deed a clause conveying the "dips, spurs and angles" of the lode or vein conveyed. ${ }^{5}$

4. Creation of Independent Estates. Independent estates may be carved out of the same land, as, where the owner of the surface grants only the right to the underlying mineral. ${ }^{6}$ 
The term "surface" has been defined as that part of the land which is capable of being used for agricultural purposes. ${ }^{7}$

A deed for a specific portion of an unpatented claim renders each an independent claim subject to all the incidents of separate ownership as to discovery, ${ }^{8}$ (if not previously made), and as to annual expenditure.

5. Effect of Quitclaim Deed. Ordinarily a quitclaim deed conveys only the present title of the grantor, but if executed during the pendency of patent proceedings in behalf of the grantor the title acquired by the issuance of patent inures to the benefit of the grantee named in the quitclaim deed. ${ }^{9}$

6. Title of Corporation. Title to mining ground will not pass to or from a corporation if the assent of the stockholders is not given, ${ }^{10}$ or, if a foreign corporation, if it has not filed its articles of incorporation. in the foreign state as required by local statute. ${ }^{10 a}$

7. Title of Association. A deed to an unincorporated association of persons as to the firm of "A. B. \& Co." passes the title to "B." alone. ${ }^{11}$ A deed to an unincorporated mining company is not void for want of a grantee therein capable of taking under it. ${ }^{12}$

8. Aтtrack by Grantor. A grantor cannot attack the validity of the location conveyed ${ }^{13}$ nor re-locate the claim upon the failure of the grantee to make the necessary annual expenditure upon the claim. ${ }^{14}$

9. Agreement for Deed. A party may agree to sell one or more mining claims to which he may not then have title, and to convey a good and sufficient title upon the performance of all the conditions assumed by the purchaser. ${ }^{15}$

10. Description. It is sufficient that the property can be identified. ${ }^{16}$ Hence a mining claim which has a known descriptive name may be sufficiently described 
by such name, coupled, when possible, with a proper reference to the record or the patent. ${ }^{17}$

A conveyance of ground "lying east of the grantor's patented mining ground" carries no right to the vein or lode which may dip under the ground conveyed, as it does not purport to grant any part of the patented ground. ${ }^{18}$

11. Statute of Limitations. Where independent estates exist in the same land, possession of the surface does not carry with it possession of the minerals under the statute of limitations. ${ }^{19}$

12. Taxation. Independent estates in the same land are each subject to separate taxation. ${ }^{20}$

1. Lohman v. Helmer, 104 Fed. 178; O'Connell v. Pinnacle Co., 131 Fed. 106; Moore v. Hammerstag, 109: Cal. 122.

2. Id. An oral agreement cannot act as a transfer. Garthe v. Hart, 73 Cal. 541; nor create a trust in a mining claim. Moore v. Hammerstag, ante.

3. Doe v. Waterloo Co., 70 Fed. 455; Miller v. Chrisman, 140 Cal. 440. See H. H. Yard, 38 L. D. 59; see also \$120$19 \mathrm{a}$, post.

4. Meyers v. Farquharson, 46 Cal. 190; Stinchfield v. Gillis, 96 Cal. 33 ; s. c. 107 Cal. 8; Riley v. N. Star Co., 152 Cal. 549 ; see Noland v. Coon, 1 Alaska, 36.

5. Montana Co. v. St. Louis Co., 204 U. S. 204; Mont. Co. v. Mont. \& Boston Co., 27 Mont. 288.

6. Id.; Catron v. So. Butte Co., 181 Fed. 941; Stinchfield v. Gillis, ante; Williams v. So. Penn. Co., 52 W. Va. 181: Smith v. Jones, 21 Utah, 270; Yellow Poplar Co. v. Thompson, 108 Va. 612. See Woodside v. Ciceroni, 93 Fed. 1. When the surface of land is owned by one, and the mineral beneath, with the right to extract the same, is owned by another, it is immaterial whether the two interests have been created by a conveyance of the surface, with a reservation of the mineral, or by a grant of the mineral, with a reservation of the surface. In elther case the obligation to protect the surface is the same. And it is well settled that the grant of the surface, with a reservation of the minerals, and a right to extract the same, does not permit the destruction of the surface, unless the right to do so has been expressed in terms so plain as to admit of no doubt. Catron v. So. Butte Co., ante. For rights of owner of surface as against owner of minerals thereunder, see West Pratt Co. v. Dorman, and monographic note, $135 \mathrm{Am}$. St. Rep. 127. As to statutory provision for the separation of mineral and nonmineral rights in coal lands, see 36 Stats. 583 ; also $\S 108$, post.

7. Murray v. Allred. 100 Tenn. 100. 
8. Merced Oil Co. v. Patterson, 153 Cal. 624; Zeckendorf v. Hutchinson, 1 N. M. 476; see Pittsburg-Nevada Co., 39 L. D. 523 ; see $\S 158$, post.

9. People v. Blake, 84 Cal. 611. See Witcher v. Conklin, 84 Cal. 499; Wholey v. Cavanaugh, 88 Cal. 132; Liddia Claim, 33 L. D. 127. A transfer of title by an applicant for a patent during the pendency of the application has the effect of making him a trustee and as such he holds the title only for the purposes of such application and when patent is issued the title immediately reverts to his grantee. Slothower v. Hunter, 15 Wyo. 189. A deed in escrow prior to entry passes no title. Brady's Mortgagee v. Harris, 29 L. D. 89.

10. McShane v. Carter, 80 Cal. 310; Kennedy v. Pekin Co., 81 Cal. 356 ; Royal Con. Co. v. Royal Con. Mines, 157 Cal. 737. See Granite Co. v. Maginness, 118 Cal. 131. This rule applies to a mortgage. Williams v. Gaylord, 186 U. S. 157; Bennett v. Red Cloud Co., 14 Cal. A. 728; see $\$ 223$, post.

10a. Cal. C. C. $\$ 410$.

11. Winters v. Stock, 29 Cal. 408.

12. Cochran v. O'Keefe, 34 Cal. 554.

13. Blake v. Thorne, 2 Ariz. 347; Drake v. Gilpin, 16 Colo. 231; McCarthy v. Speed, 11 S. Dak. 362 . See Philes v. Hickies, 2 Ariz. 407; Shreve v. Copper Bell Co., 11 Mont. 309.

14. Drake v. Gilpin, ante.

15. Donovan v. Hanauer, 32 Utah, 317.

16. Carter v. Bacigalupi, 83 Cal. 187; see Mont. Co. v. St. Louis Co., 183 Fed. 51.

17. Glacier v. Willis, 127 U. S. 471; Harris v. Equator Co., 3 Fed. 863; Reed v. Munn, 148 Fed. 737; Carter v. Bacigalupi, ante: Murray v. Tulare Co., 120 Cal. 311; Bergquist v. W. Va. Co., (Wyo.) 106 Pac. 673. That a claim is known by several names and only one of them is given in the deed is immaterial. Lebanon Co. v. Con. Republican Co., 6 Colo. 371; Collins v. McKay, 36 Mont. 123; Phillpotts v. Blasdell, 8 Nev. 61 ; Weill v. Lucerne Co., 11 Nev. 200. In a complaint in ejectment a mining claim is sufficiently described by its descriptive name. Veronda v. Dowdy, (Ariz.) 108 Pac. 482.

18. Cent. Eureka Co. v. East Cent. Eureka Co., 146 Cal. 147. The recelver's receipt issued in patent proceedings should describe the claim by the name borne in the location notice and the official survey. Sold Again Fraction, 20 L. D. 58.

19. Tyee Con. Co. v. Langstedt, 136 Fed. 124; Catlin Coal Co. v. Lloyd, 176 Ill. 275.

20. Con. Coal Co. v. Baker, 135 Ill. 545. See Hutchinsonv. Kline, $199 \mathrm{~Pa}$. St. 564. Each of separate layers or strata becomes a subject for taxation, of incumbrance, levy and sale, precisely like the surface. Murray v. Allred, 100 Tenn. 100. See, also, McGraw v. Lakin. 67 W. Va. 385 ; see $\$ 122-7$.

$\S 68$. Examination of Title. An abstract of title of an unpatented mining claim is hardly more than a chain of title. ${ }^{1}$ 
2. UnAPPRopriated LAND. Such an abstract does not show that the land embraced in the location was subject to appropriation ${ }^{2}$ or whether or not there is an adverse claimant or a party in adverse possession. ${ }^{3}$

3. Character of Location. It does not show that the mineral deposit (if any) therein is of such a nature as to warrant the character of location made. ${ }^{4}$

4. FORM of Location. It does not show that the location is laid along instead of across the vein or lode ${ }^{5}$ or that it is upon the strike and not the dip thereof. ${ }^{6}$

5. Cross Vein. It does not show that, if, a lode claim, there is not a cross or united vein or lode therein having priority of title. ${ }^{7}$

6. KNown Vein. It may not show that, if a placer claim, there is not a known vein or lode therein. ${ }^{8}$

7. Discovery. It does not show that "discovery" has been made. ${ }^{9}$

8. Boundaries. It can not show that the claim is so demarked that its boundaries can be readily traced. ${ }^{10}$

9. Annual Expenditure. It does not conclusively show that the proper annual expenditure has been made. ${ }^{11}$

10. RECEIVER's RECEIPT. The receiver's receipt is not conclusive because it is subject to cancellation. ${ }^{\mathbf{1 2}}$

11. Conclusiveness of Patent. The patent is conclusive evidence, if a lode claim, that the end lines are parallel; ${ }^{13}$ and that no adverse claims exist. ${ }^{14}$

12. Inconclusiveness of Patent. Unless because of lapse of time ${ }^{15}$ the patent is not conclusive of sufficient discovery, ${ }^{16}$ that the location is valid, ${ }^{17}$ that the location accords with the mode of occurrence of the mineral therein, ${ }^{18}$ that the title is vested in the patentee, ${ }^{19}$ that the claim is free from subsisting lien, ${ }^{20}$ that the claim on the ground is correctly described, ${ }^{21}$ that a tunnel claimant may not have a better right to blind veins ${ }^{22}$ or a townsite, ${ }^{23}$ or a placer ${ }^{24}$ patentee 
to a known vein therein, or that its issuance was within the jurisdiction of the land department. ${ }^{25}$

1. Patterson v. Hitchcock, 3 Colo. 533.

2. U. S. v. Rossi, 133 Fed. 380 .

3. Reedy. v. Wesson, 1 Alaska, 570; Wetzstein v. Largey, 27 Mont. 212.

4. Henderson v. Fulton, 35 L. D. 652 ; E. M. Palmer, 38 L. D. 294.

5. Flagstaff Co. v. Tarbet, 98 U. S. 463 .

6. Larkin v. Upton, 144 U. S. 19 ; Bunker Hill Co. v. Shoshone Co., 33 L. D. 142; see Van Zandt v. Argentine Co., 8 Fed. 725 .

7. Rev. Stats., $\$ 2336$; Patterson v. Hitchcock, ante; Last Chance Co. v. Tyler Co., 61 Fed. 557.

8. Rev. Stats. $\$ 2333$.

9. Rev. Stats. $\$ 2320$.

10. Rev. Stats. $\& 2324$.

11. Id. See Last Chance Co. v. Tyler, ante.

12. Deffebach v. Hawke, 115 U. S. 392 ; see $\S 214-15$, post.

13. Waterloo Co. v. Doe, 82 Fed. 45 ; affirming Doe v. Waterloo Co., 54 Fed. 935.

14. Rev. Stats., $\$ 2325$.

15. 26 Stats. 1099 ; Patterson v. Hewitt, 195 U. S. 309 ; U. S. v. Chandler-Dunbar Co., 209 U. S. 447; see Holt v. Murphy, 207 U. S. 407.

16. U. S. v. Iron Co., 128 U. S. 673 ; see Creede Co. v. Uinta Co., 196 U. S. 337; see Calhoun Co. v. Ajax Co., 182 U. S, 499.

17. Hickey v. Anaconda Co., 33 Mont. 46.

18. U. S. v. Iron Co., ante.

19. Burfenning v. Chicago Co., 163 U. S. 321 ; Stevens v. Grand Cent. Co., 133 Fed. 28; Cascaden v. Dunbar, 157 Fed. 62; Van Sice v. Ibex Co., 173 Fed. 895; U. 'S. v. Smith, 181 Fed. 545; Mery v. Brodt, 121 Cal. 332; Suessenbach v. Bank. 5 Dak. 477 ; see Patterson v. Hewitt. ante; Wetzstein v. Largey, ante. For collection of cases, see Tonopah Co. v. Fellanbaum, (Nev.) 107 Pac. 882 .

20. Rev. Stats., §§ 2332-2340-2477; Butte H. Co. v. Frank, 25 Mont. 344.

21. Rev. Stats., \$2327.

22. Creede Co. v. Uinta Co., ante.

23. Bonner v. Meikle, 82 Fed. 697 ; Lalande v. Saltese, 32 L. D. 211; Callahan v. James, 141 Cal. 291; see Dower v. Richards, 151 U. S. 658; Larned v. Jenkins, 113 Fed. 634; Brophy v. O'Hare, 34 L. D. 596 ; Board v. Mansfield, 17 S. Dak. 72 .

24. Rev. Stats., $\$ 2333$; see Reynolds v. Iron Co., 116 U. S. 687; Clipper Co. v. Eli Co., 194 U. S. 220; Cranes Gulch Co. v. Scherrer, 134 Cal. 350 ; Mt. Rosa Co. v. Palmer, 26 Colo. 56.

25. Burfenning v. Chicago Co., ante; Francoeur v. Newhouse, 40 Fed. 618; Rose v. Richmond Co., 17 Nev. 25. 


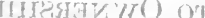 CHAP'TER XII.}

\section{POSSESSION-A BANDONMENT-HORFEITURE.}

§ 71. Possession-actual possession-actual possession not required-actual possession/without boundaries-constructive possession-boundaries without discovery -presumption as to ownership Hevidence of ow hership -adverse possession-general principle - continuity of possession-insufficient adverse possession- - effect of patent.

§ 72. Abandonment-intent controls-how effected-co-tenant -not abandonment-deed-proof + test-pleading

§73. Forfeiture-proof-burden of proof-reasonable doubtpleading-absence of right.

§71. Possession. A valid location of a mining claim carries with it the right of possession. ${ }^{1}$ Location does not follow from possession, ${ }^{2}$ but location will be presumed from possession maintained for a sufficient time under the statute of limitations. ${ }^{3}$

2. Actual Possession. Actual possession means a subjection to the will and dominion of the claimant. ${ }^{4}$

3. Actual Possession Not Required. The "actual possession" which is applied to agricultural lands and which is understood to be a possessio pedis is not required in a completely located mining claim. ${ }^{5}$

4. Actual Possession Without Boundaries. Actual possession without boundaries or discovery protects only that part of the location which is being worked. ${ }^{6}$

5. Constructive Possession. Where a claim lacks none of the essential elements of location and the requisite expenditure is made thereon it may be held by constructive possession. ${ }^{7}$

6. Boundaries Without Discovery. Constructive possession extends to the entire location if its boundaries are clearly defined although there may be an absence of discovery therein, provided, that the discovery is being sought by actual exploitation of the ground. ${ }^{8}$ 
7. Presumption as to Ownership. Every locator is presumed to be the owner of his claim and of the mineral therein until some one else shows a better right thereto. ${ }^{9}$

8. Evidence of OWNersinip. Working the property, ${ }^{10}$ living thereon, ${ }^{11}$ or the presence of a watchman is evidence of possession. ${ }^{12}$

9. Adverse Possession. Adverse possession to ripen into a title by prescription must be in consonance with the laws of the state within which the claim may lie. ${ }^{13}$

10. General Principle. The acts of dominion must be adapted to the particular land, its condition, locality and appropriate use, ${ }^{14}$ for he who asserts an exclusive ownership over land must perform acts in harmony with his claim of title. ${ }^{15}$

11. Continuity of Possession. An interval in the continuity of the possession necessary to constitute adverse possession will not Hecessarily defeat the adverse right. ${ }^{16}$

12. Insufficient Adverse Possession. The occasional use of mining ground without the knowledge of the owner or the repudiation of his rights $;^{17}$ or secret underground working will not establish an adverse right ${ }^{18}$ nor will such right arise from the possession of the dip of a vein or lode without possession of the top or apex thereof. ${ }^{19}$

13. EFfect of Patent. An adverse right will be lost if not made the subject of an adverse claim when patent is adversely applied for. ${ }^{20}$ The adverse right must commence anew from and after the date of the patent. $^{21}$

1. Wolverton v. Nichols, 119 U. S. 485; Malone v. Jackson, 137 Fed. 787; McLemore v. Express Co., 158 Cal. 559.

2. Belk v. Meagher, 104 U. S. 279; Malone v. Jackson, ante.

3. Harris v. Equator Co., 8 Fed. 863; Vogel v. Warsing, 146 Fed. 949; Buffalo Zine Co. v. Crump, 70 Ark. 525; see Rev. Stats., \$2332. 
4. N. J. Co. v. Gardner, 178 Fed. 772 ; Coryell v. Cain, 16 Cal. 567; Attwood v. Fricot, 17 Cal. 37.

5. Attwood v. Fricot, ante; English v. Johnson, 17 Cal. 107.

6. Crossman v. Pendery, 8 Fed. 693; see Cowell v. Lammers, 21 Fed. 200; Hanson v. Craig, 170 Fed. 62 . In the case last cited the court says: "Pedis possessio" means the actual possession, and pending a discovery by anybody the actual possession of the prior arrival will be protected to the extent needed to give him room for work and to prevent probable breaches of the peace. But, while the pedis possessio is thus protected, it must yield to an actual location on a valid discovery made by one who has located peaceably, and neither clandestinely nor with fraudulent purpose. Citing, with approval, Costigan on Min. Law, p. 156.

7. Harris v. Equator Co., ante; Attwood v. Fricot, ante.

8. Nev. Sierra Oil Co. v. Home Oil Co.; 98 Fed. 673; English v. Johnson, ante; Hess v. Winder, 30 Cal. 349; Chrisman v. Miller, $140 \mathrm{Cal}$. 440 . The attempting locator has the right to continue possession undisturbed by any form of hostile or clandestine entry while he is diligently prosecuting his work to a discovery. McLemore v. Express Co., ante; but see Hanson v. Craig, ante.

9. Leadville Co. v. Fitzgerald, 15 Fed. Cas. 8158.

10. Koons v. Bryson, 69 Fed. 297; Cosmos Co. v. Gray Eagle Co., 112 Fed. 4 ; Lange v. Robinson, 148 Fed. 799; see Badger Co. v. Stockton Co., 139 Fed. 838; Costello v. Muheim, 9 Ariz. 422.

11. Lange v. Robinson, ante.

12. Justice Co. v. Barclay, 82 Fed. 554.

13. Glacier Co. v. Willis, 127 U. S. 471; Tyee Con. Co. v. Langstedt, 136 Fed. 124; Standard Co. v. Habishaw, 132 Cal. 115 ; see $\S 84$, post.

14. Webber v. Clarke, 74 Cal. 11; see Scadden Flat Co. v. 15. Id. Scadden, 121 Cai. 33 .

16. Id.; see Stewart v. Rees, 25 L. D. 447.

17. Id.

18. Badger Co. v. Stockton Co., ante; see Last Chance Co. v. Bunker Hill Co., 131 Fed. 579.

19. Davis v. Shepherd, 31 Colo. 141.

20. Rev. Stats., \$2325.

21. Clark v. Barnard, 15 Mont. 176; So. End. Co. v. Tinney, 22 Nev. 221; see Redfield v. Parks, 132 U. S. 239; Hamilton v. So. Nev. Co., 33 Fed. 562 ; see Tyee Con. Co. v. Langstedt, ante.

§ 72. Abandonment. Abandonment is a voluntary act ${ }^{1}$ and operates instantly ${ }^{2}$ to extinguish all rights in the property abandoned. ${ }^{3}$

2. Intent Controlis. Unlike forfeiture, (as that term is used and understood in the mining law ${ }^{4}$ ), it does not depend upon lapse of time ${ }^{5}$ nor the act of another for loss of right in the property, ${ }^{6}$ but on the 
intention of its claimant, to be determined from all the facts and circumstances of the case. ${ }^{7}$

3. How EFFECTED. Abandonment may consist of departure from the claim without intention to repossess it and regardless of who may appropriate it, 8 by verbal permission to another to re-locate it in whole or in part, or by a written relinquishment of all rights to the claim..$^{10}$ The abandonment may be as to the whole or a part of the claim. ${ }^{11}$

4. Co-TENANT. A co-tenant may abandon his individual interest in a claim without prejudice to the rights of his co-owners therein. ${ }^{12}$

5. Not ABANDONMENT. A part of a claim intentionally excluded from an application for patent is not abandoned if the claimant retains possession of such part and makes the annual expenditure thereon 13 nor does error in excluding a part of a claim from such an application operate as an abandonment. thereof. It may be included in an amendment or re-survey ${ }^{14}$

6. DEED. A deed executed after abandonment conveys no interest in the claim abandoned. ${ }^{15}$

7. Proof. In order to sustain an allegation of abandonment it must appear that there was a leaving of the claim without any intention of making any further use of it. ${ }^{16}$ The burden of proof of the intent to abandon rests upon him who asserts it and the proof must be clear and convincing. ${ }^{17}$

8. TEST. The intention to return is the test ${ }^{18}$

9. Pleading. The courts do not agree as to whether abandonment may be proved in the absence of an allegation thereof. ${ }^{19}$

1. Lakin v. Sierra Buttes Co., 25 Fed. 337.

2. Brown v. Gurney, 201 U.'S. 184; Wolfskill v. Smith, 5 Cal. A. 175; Derry v. Ross, 5 Colo. 295; Street v. Delta Co., 42 Mont. 371.

3. Dower v. Richards, 151 U. S. 658; Brown v. Gurney, ante; Cowell v. Lammers, 21 Fed. 200; Badger Co, v. 
Stockton Co., 139 Fed. 838; Utt v. Frey, 106 Cal. 392; Conn v. Oberto, 32 Colo. 313.

4. Morton v. Solambo Co., 26 Cal. 528; see Black v. Elkhorn Co., 163 U. S. 445.

5. Moon v. Rollins, 36 Cal. 333; McCarthy v. Speed, 11 S. Dak. 362. It is immaterial to the question whether the annual expenditure has been made or not. Farrell v. Lockhart, 210 U. S. 142; Street v. Delta Co., ante.

6. Morenhaut v. Wilson, 52 Cal. 263; McCarthy v. Speed, ante.

7. Crary v. Dye, 208 U. S. 515; Lakin vierra Buttes Co., ante; Moon v. Rollins, ante; Myers v. Spooner, 55 Cal. 257; McCann v. McMillan, 129 Cal. 350; McCarthy v. Speed, ante.

8. Harkrader v. Carroll, 76 Fed. 474; Moffat v. Blue River Co., 33 Colo. 142; McKay v. McDougall, 25 Mont. 258.

Where the appearance of a mining claim unimistakably indicates an abandonment of the premises for many years and no stakes or other monuments mark the boundaries such evidence warrants the assumption that all possessory rights thereto have been relinquished and authorizes another location thereon. Strickland v. Com. Co., (Or.) 104 Pac. 965 .

By legislative enactment in California it is provided that:-

\$1. All abandoned mining shafts, pits, or other abandoned excavations dangerous to passers-by or livestock shall be securely covered or fenced, and kept so, by the owners of the land or persons in charge of the same, on which such shafts, pits or other excavations are located. Any person or persons failing to comply with the provisions of this section shall be deemed guilty of a misdemeanor.

§ 2. All abandoned mining shafts, pits or other excavations situated on unoccupied public lands may be securely covered or fenced by order of the board of supervisors of the county wherein the same is situated, and it shall be the duty of the board of supervisors to keep the same. securely fenced or covered, whenever it appears to them, by proof' submitted, that the same is dangerous or unsafe to man or beast. The cost of $^{\circ}$ said covering to be a county charge.

§3. Any person or persons maliciously removing or destroying any covering or fencing placed around or over any shaft, pit or other excavation, as hereinbefore provided, shall be guilty of a misdemeanor. Cal Stats. 1903, p. 283.

9. Oberto v. Smith, 37 Colo. 21; Sharkey v. Candiani, 48 Or. 112.

10. Brown v. Gurney, ante; Miller v. Chrisman, 140 Cal 440. 11. Tyler Co. v. Sweeney, 54 Fed. 284; Last Chance Co. v. Tyler, 61 Fed. 557. The re-location of an invalid location is not an abandonment or forfeiture of the former location, even though attempted in the interest of the original locator. Bergquist v. W. Va: Co., (Wyo.) 106 Pac. 673.

12. Badger Co. v. Stockton Co., ante; Worthen v. Sidway, 72 Ark. 215; see Kinney v. Fleming, 6 Ariz. 263; Sharkey v. Candiani, ante.

13. Miller v. Hamley, 31 Colo. 495. Failure to file an adverse claim because of ignorance of an application for 
patent is not evidence of intent to abandon the remainder of the claim. Bingham v. Ute Co., 181 Fed. 748 .

14. Basin Co. v. White, 22 Mont. 147.

15. Harkrader v. Carroll, ante; Wolfskill v. Smith, ante.

16. Bell v. Bed Rock Co., 36 Cal. 214.

17. Loeser v. Gardiner, 1 Alaska 641; Buffalo Co. v. Crump, 70 Ark. 525.

18. Stone v. Geyser Co., 52 Cal. 315; Davis v. Dennis, 43 Wash. 54.

19. See Willson v. Cleaveland, 30 Cal. 192; Contreras v. Merck, 131 Cal. 211; Renshaw v. Switzer, 6 Mont. 464; Bishop v. Baisley, 28 Or. 119.

$\S 73$. Forfeiture. Forfeiture is the loss of the right to a mining claim by adverse re-location ${ }^{1}$ and rests upon the fact of the non-observance of the requirements of the mining laws and district rules ${ }^{2}$ which is taken advantage of by another. ${ }^{3}$ A mere failure to make the requisite annual expenditure while it may cause a forfeiture does not constitute an abandonment. ${ }^{4}$

2. Proof. The law should be liberally construed to prevent a forfeiture ${ }^{5}$ and the proof must be clear and convincing. ${ }^{6}$

3. Burden OF Proof. The burden of proof of forfeiture is cast upon him who asserts it. ${ }^{7}$

4. Reasonable Doubt. Every reasonable doubt will be resolved in favor of the validity of a mining location, ${ }^{8}$ as the courts are reluctant to enforce forfeiture. ${ }^{9}$

5. Pleading. The burden of pleading forfeiture is upon him who asserts it. ${ }^{10}$

6. ABSENCE of Right. The question of forfeiture cannot be raised by one claiming the ground under a void location. ${ }^{11}$

1. Du Prat v. James, 61 Cal. 361; Snowy Peak Co. v. Tamarack Co., 17 Ida. 630,107 Pac. 60; McCarthy v. Speed, 11 S. Dak. 362 ; Knutson v. Fredlund, 56 Wash, 634. The distinction between the effect of an abandonment and a forfeiture is pointed out in McKay v. McDougall, 25 Mont. 258.

2. Strang v. Ryan, 46 Cal. 34; see Emerson v. MeWhirter, 133 Cal. 510. Ordinarily forfeitures are not favored, and a very strict or severe construction ought not to 
be placed on the statute where the prior locators have proceeded in good faith and apparently done all that is required by a fair construction of the laws relating to mining locations. Murray v. Osborne, (Nev.) 111 Pac. 31.

3. Lockhart v. Johnson, 181 U. S. 516; Street v. Delta Co., 42 Mont. 371.

4. Lakin v. Sierra Buttes Co., 25 Fed. 337.

5. Emerson v. McWhirter, ante.

6. Hammer v. Garfield Co., 130 U. S. 291; Book v. Justice Co., 58 Fed. 106; McKay v. Neussler, 148 Fed. 86; Callahan v. James, 141 Cal. 291; Little Dorrit Co. v. Arapahoe Co., 50 Colo. 431; Power v. Sla, 24 Mont. 243; see Zerres v. Vanina, 134 Fed. 610; Cunningham v. Pirrung, 9 Ariz. 288. For a qualification of the rule, see Big 3 Co. v. Hamilton, 157 Cal. 130.

7. Hammer v. Garfield Co., ante; Whalen Co. v. Whalen, 127 Fed. 611; Quigley v. Gillett, 101 Cal. 462 ; Callahan v. James, ante; Hall v. Kearney, 18 Colo. 505; Coleman v. Curtis, 12 Mont. 301.

8. Thornton v. Kaufman, 40 Mont. 282.

9. Copper Co. v. Butte \& Corbin Co., 39 Mont. 487.

10. Power v. Sla, ante; Bishop v. Baisley, 28 Or. 119; but see Holmes v. Salamanca Co., 5 Cal. A. 659 .

11. Knutson v. Fredlund, ante;

\section{CHAPTER XIII.}

\section{REMEDIES.}

\$76. Condemnation proceedings-constitutional provisionlimitation of power-public use.

$\$ 76 \mathrm{a}$. Recent Californian legislation.

\$ 77. Easements-vested rights-right of way-damages.

\$78. Laches-unlike limitations-equitable defense-delaymeasure of diligence-pleading laches-plaintiff's allegations.

§ 79. Liens-not impaired by patent-loss of lien-mechanic's liens-purpose-contract essential-protection of owner - statutory requirement-indemnification-subordinate to mortgag̀e.

$\S 80$. Master and servant - fellow servants - assumption of risk-legislative safeguards-limiting hours of laborconstitutionality of act.

$\S 80 \mathrm{a}$. Recent Californian legislation.

81. Partition-agreed partition-arbitration-mining right.

\$ 82. Patent-bona fide purchaser-burden of proof-fraudulent patentee-not attack upon patent-status of trustor-fraud-application to sue-false testimony insufficient.

§83. Rescission-condition precedent-application of rulegrounds for rescission-salting-unintentional salting -remedies-insufficient grounds for rescission-marketable title.

\$ 84. Statute of limitations-establishes right to patent-controlling factor-Californian provisions. 
8 85. Trespass-ignorance of boundary-test of trespass-injunctional praceedings-denial of injunction-right of inspection-grounds for order-substance of orderdamages-good faith of trespasser-pleading-model.

§76. Condemnation Proceedings. The Federal government's general sovereignty of eminent domain within a state or territory 1 is not delegated to the mining elaimant.

2. Constitutionál Provision. The power to exercise the right of eminent domain by a mining claimant exists by virtue of a local constitutional provision.

3. Limitation of Power. In the absence of such a provision a local legislature has no power to authorize the taking of private property for mining purposes. ${ }^{2}$ 4. Public Use. When mining is expressly de. clared, by a constitutional provision, to be a public use, as in Colorado, ${ }^{3}$ Nevada, ${ }^{4}$ and Utah 5 a local statute authorizing the taking of land, by a miningcompany for its own purposes, as, for instance, a right of way through another's mining claim for a tunnel in operating its mining claim is a taking for a public use. ${ }^{6}$

1. See Kohl v. U. S., 91 U. S. 367 ; Burley v. U. S., 179 Fed. 1; Postal Tel. Co, v. O. S. L. Ry. Co., 23 Utah, 474; Jones v. U., S. 48 Wis. 385 ; but see Gilmer v. Lime Point, 18 Cal. 229 ; see $\$ 28$, note 23 , ante.?

2.'Con. Chánnel Co. v. C. P. P. Co., 51 Cal. 269, Lorenz v. Jacob, 63 Cal. 73 ; Sutter Co. v. Nichols, 152/Cal. 688; People v. District Court, 11 Colo. 147; see Clark v. Nash, 198 U. S. 361 ; compare Strickley v. Highland Boy Co., 200 U. S. : 527 .

3. Tripp v. Overocker, 7 Colo. 72; Downing v. More, 12 Colo. 318; see People v. District Court, ante; Tanner v, Treasury Co., 35 Colo. 509 :

4. Byrnes v. Douglas, 83 Fed. 45; Dayton Co. v. Seawell, 11 Nev. 394; Overman v. Corcoran, $15 \mathrm{Nev}, 147$.

5. Highland Boy Co. v. Strickley, 28 Utah 215: affd, in $200 \mathrm{U}$. S. 527; Clark v: Nash, 27 Utah 158; affd. in 198 U. S. 361.

6. Byrnes'v. Douglas, ante; see Tanner v. Treasury Co., ante.

\$76a. Recent Californian Legislation. Recent Californian legislation (approved April 5,1911 ) in relation to mining rights is shown in the subjoined note. ${ }^{1}$ 
1. 81238 (C. C. P.) 1. The risht of eminent domain may bo exercised in behalf of the following publle uses.

5. Roads, tunnols, ditches, flumes, pipes and dumping places for worktus mines, also outlets, natural or otherwise, for the flow, doposit, or conduct of tallinss or refuse mattor from mines, also an occupancy In common by the owners or possossors of alferent mines of any place for the flow, deposit, or conduct of tallings or refuse mattor from thelr soveral mines.

10. Oll pipe lines.

12. Conals, reservolrs, darns, ditchos, flumes, acqueducts and pipes and outlots, natural or otherwise, for supplyins, storins, and ilstributing water for the operation of machinery for the purpose of sonoruting and transmitting clectricity for tho supply of minos. (auartes, rallroads, tramways, mllis and factorles with olectrle power; and also for the applying of eloctricity to lisht or heat inines, quarrles, mills, eactorles, in corporated clties and counttes, villafes or towns; and alao for furnishins olectricity for lighting, heating or power purposes to Individuale or corporations, toEother with lands, bulldings and all othor improvesments in or upon which to orect, install, place, use, or operate mabhinery for the purpose of senerating and trnnamltting electriclty for any of the purposes or uses above sot forth.

13. Wlectric power Ilnes, olectrie heat IInes, and olectric llght, heat and power lines. See \$76-2, \&76, noto 2 , ante.

8 1299. The following is a clasalfleation of the entaice and rights in lands subject to be taken for publlc noe,

1. A fee afmple, when taken for publie bullalngs or Erounds, or for permanent billdinge, for reservolrs and dams, and pormanent flooding occasioned thereby. or for an outlet for a flow, or a place for the deposit of dobris or tallings of a mins.

2. An onsement, when taken for any other use. (hore follows proviso as to taklus by a mianlelpal (corporation).

3. The right of entry upon nud occupation of Ianda, and the right to take thorefrom such earth, Eravol, stonea, troes, and timber as may bes necesanry for some publle was.

Soe (C, C, P., $8840,1241,1248$; nee $28-14$, ante.

\$77. Easements. Easements for the working, drainage and complete development of mining claims have been left by Congress to local law. ${ }^{1}$ Rights of way over public lands are granted by Congress. ${ }^{2}$ 112. Vestos Ruars. All patents granted, or precmintion or homesteads allowed are subject to vested arrid aceriod "water "rights, "or ' rights to ditehes and rescrvoirs vised in idonndetion with such water rights, 
as may have been acquired under or recognized by the provisions of the mining act. ${ }^{3}$

3. Right of WaY. No legal proceedings are necessary to establish a right of way over public lands. ${ }^{4}$ An unpatented mining claim being property ${ }^{5}$ no right of way can be acquired therein or thereunder without the acquiescence of the owner thereof except by condemnation proceedings under a valid local statute. ${ }^{6}$

4. Damages. When in the construction of any ditch or canal, the possession of any settler on the public domain is injured or damaged, the party committing such injury or damage is liable therefor to the party injured. ${ }^{7}$

1. Rev. Stats., §§ 2338-2339; Calhoun Co. v. Ajax Co., 182 U. S. 499; Woodruff v. North Bloomfield Co., 18 Fed. 753; Amador Queen Co. v. Dewitt, 73 Cal. 482; Quinlan v. Noble, 75 Cal. 250. By legislative enactment in California, "All mining locations and mining claims shall be subject to a reservation of the right of way through or over any mining claims, ditches, roads, canals, cuts, tunnels, and other easements for the purpose of working other mines; provided, that any damage occasioned thereby shall be assessed and paid for in the manner provided by law for land taken for public use under the right of eminent domain. Cal. Stats. 1891, p. 219.

2. Rev. Stats., \& 2477; 28 Stats. 635; 29 Stats. 120; 30 Stats. 404; Circular 18 L. D. 168; Regulations 27 L. D. 495; Circular 31 L. D. 13; Circular 33 L. D. 451; Big Horn R. Co., 39 L. D. 174 .

3. Rev. Stats. $\S 2340$.

4. Hobart v. Ford, 6 Nev. 77; Yunker v. Nichols, 1 Colo. 551; Tynon v. Despain, 22 Colo. 240; Stoner v. Zucker, 148 Cal. 516.

5. Forbes v. Gracey, 94 U. S. 762 .

6. Miocene Co. v. Jacobson, 146 Fed. 680 .

7. Rev. Stats., $\$ 2339$; Jennison v. Kirk, 98 U. S. 453 ; Titcomb v. Kirk, 51 Cal. 288; Yunker v. Nichols, ante.

$\S 78$. Laches. Laches is the neglect or failure to actively assert a right in or to property within a reasonable time, under the facts of the particular case, after a cause of action, in relation thereto, has arisen.

2. Unlike Limitations. Laches is not like limitation, a mere matter of time, but principally a question of the inequity of permitting the claim to be enforced; 
an inequity founded, for instance, upon some change in the condition or the relation of the party or parties. ${ }^{1}$

3. Equitable Defense. Inexcusable delay for a period short of the time provided by the statute of limitations may constitute laches, and is an equitable defense wholly independent and outside of the statute of limitations, whenever the relief sought is wholly equitable. ${ }^{2}$

4. Delay. Delay cannot be excused except by some actual hindrance or impediment caused by the fraud or concealment of the party in possession. ${ }^{3}$

5. Measure of Diligence. In some cases the diligence required is measured by months rather than years; in others a delay of 2,3 , or 4 years has been held fatal. ${ }^{4}$ The speculative character of a mining claim requires prompt action in asserting an adverse right therein. ${ }^{5}$

6. Pleading Laches. When a suit is brought within the time limited by the statute of limitations the burden is upon the defendant to show, by demurrer or answer, that unusual conditions or extraordinary circumstances exist which require the application of the doctrine of laches. ${ }^{6}$

7. Plaintiff's Allegations. When suit is brought after the statutory time has elapsed the burden is on the plaintiff to show by suitable allegations in the complaint that it would be inequitable to apply it to his case. ${ }^{7}$

1. Galliher v. Cadwell, 145 U. S. 368; Ward v. Sherman, 192 U. S. 168.

2. Scruggs v. Decatur Min. Co., 86 Ala. 173. See Morrow v. Matthew, 10 Ida. 423.

3. Wagner v. Baird, 7 How. 234 ; Lansdale v. Smith, 106 U. S. 391; Westerman v. Dinsmore, (W. Va.) 71 S. E. 250.

4. Patterson v. Hewitt, 195 U. S. 309; Starkweather v. Jenner, 216 U. S. 524.

5. Twin Lick Co. v. Marbury, 91 U. S. 587; Johnston v. Standard Co., 148 U. S. 360 ; Patterson v. Hewitt, ante.

6. Stevens v. Grand Cent. Co., 133 Fed. 28.

7. Id. 
§ 79. Liens. A lien upon a mining claim may be created by contract, as, by mortgage, ${ }^{1}$ by operation of law, as, for taxes, ${ }^{2}$ by a judgment of a court, ${ }^{3}$ or by a proceeding under a mechanic's lien law. ${ }^{4}$

2. Not Impaired By Patent. No lien which has attached to a mining claim is impaired by the issuance of a patent therefor. ${ }^{5}$

3. Loss of Lien. A lien may be waived; ${ }^{6}$ or lost by the effluxion of time. ${ }^{7}$

4. Mechanic's Lien. A mechanic's lien is a creature of a local statute, which should be consulted and substantially followed. ${ }^{8}$

5. Purpose. Its purpose is to secure the unpaid wages of those doing manual labor in or upon a mining claim or mill or reduction works $;^{9}$ also the debt due to the material-man, that is, the person who furnishes materials actually used in the improvement, alteration or repair of such property..$^{10}$

6. Contract Essential. The work must be done or the materials must be furnished under a contract, express or implied, with one in lawful possession of the property as the owner, agent, receiver, lessee, ${ }^{11}$ or one working the claim under an option or working bond. ${ }^{12}$

7. Protection of Owner. When property is being worked by one other than the owner the latter usually protects the property from possible lien by posting notice thereon to the effect that the property is being so worked and that he will not be responsible for any debt or charge created thereby. ${ }^{13}$

8. Statutory Requirement. Sometimes a local statute requires that such a notice, to be effective, must be verified and recorded within a certain number of days after its posting upon the property. ${ }^{13 a}$

9. INDEMNIFICATION. It is not unusual for the owner to exact an indemnity bond from the party working the property or to require that all persons employed in or furnishing materials to the claim shall 
contract in writing to look only to the latter person and not to the property for their pay. ${ }^{14}$

10. Subordinate to Mortgage. Claims for materials, supplies and labor furnished to a mining claim before the appointment of a receiver are subordinate to a prior mortgage. ${ }^{15}$

1. Forbes v. Gracey, 94 U. S. 762 .

2. Graciosa Oil Co. v. Sta. Barbara Co., 155 Cal. 140; see Forbes v. Gracey, ante.

3. Bradford v. Morrison, 212 U. S. 389 ; Butte H. Co. v. Frank, 25 Mont. 344.

4. Cary Co. v. McCarty, 10 Colo. A. 200.

5. Rev. Stats., § 2332 .

6. Bowen v. Aubrey, 22 Cal. 566; Hughes v. Lansing, 34 Or. 118; see Cal. C. C. P., $\$ 1202$.

7. Burns v. White Swan Co., 35 Or. 305.

8. Church v. Smithea, 4 Colo. A. 175; see Davis v. Alford, 94 U. S. 545; Labor expended by a blacksmith, Malone v. Big Flat Co., 76 Cal. 578; boss and time keeper, Capron v. Strout, 11 Nev. 304; cook, Cascaden v. Wímbish, 161 Fed. 241 ; but see McCormick v. Los Angeles Co., 40 Cal.185; foreman, overseer and watchman, Flagstaff Co. v. Collins, 104 U. S. 178; Idaho Co. v. Davis, 123 Fed. 396; but see Barnard v. McKenzie, 4 Colo. 251; superintending work on mill and machinery, Rara Avis Co. v. Bouscher, 9 Colo. 385 ; teamster, Gray v. N. M. Co., (N. M.) 110 Pac. 102; or upon a house contiguous to a mining claim. Keystone Co. v. Gallagher, 5 Colo. 23; in a lime kiln, Gray v. N. M. Co., ante; Thompson v. Wise Boy Co., 9 Ida. 363; Williams v. Mountaineer Co., 102 Cal. 134; or in operating a hoist, Tredinnick v. Red Cloud Co., 72 Cal. 78; milling ore Thompson v. Wise Boy Co., ante; cleaning up and washing gold from a mining claim, Cascaden v. Wimbish, ante, furnish a basis for a claim of lien upon a mining claim.

9. Palmer v. Uncas Co., 70 Cal. 614; Reese v. Bald Mt. Co., 133 Cal. 285; Higgins v. Carlotta Co., 148 Cal. 700; Lindemann v. Belden Con. Co., 16 Colo. A. 342; Cullins v. Flagstaff Co., 2 Utah 219; see Smallhouse v. Kentucky Co., 2 Mont. 443; Boyle v. Mt. Key Co., 9 N. M. 237; Gould v. Wise, 18 Nev. 253 .

10. Sylvester v. Coe Co., 80 Cal. 510.

11. Higgins v. Carlotta Co., ante; Jurgenson v. Diller, $114 \mathrm{Cal}$. 491; Traylor v. Barry, 96 Ill. A. 644; Stinson v. Hardy. 27 Or. 584; see Donohoe v. Trinity Co., 113 Cal. 119; Lewis v. Beeman, 46 Or. 311.

12. Hines v. Miller, 122 Cal. 517. The holder of an option is not a vendee nor an agent of the owner; Harper v. Independence Co., (Ariz.) 108 Pac. 701.

13. Hamilton v. Delhi Co., 118 Cal. 148; Gould v. Wise, ante; see Jno. R. Gentle \& Co. v. Britton, (Cal.) 111 Pac. 9; Williams v. Eldora Co., 35 Colo. 127; Idaho Co. v. Winchell, 6 Ida. 729 .

13a. See Cal. C. C. P. §1192.

14. Settle v. Winters, 2 Idaho (Hasb.) 215.

15. Fidelity Co. v. Shenandoah Co., 42 Fed. 372. 
§ 80. Master and Servant. The master must provide the servant with a reasonably.safe place to work ${ }^{1}$ and reasonably safe appliances to work with. ${ }^{2}$

2. Fellow Servants. The master is not liable for injury to a servant resulting from the negligence of a fellow servant. ${ }^{3}$

3. Assumption of Risk. Where a servant enters upon or continues in a dangerous employment with either knowledge of the danger or full opportunity to observe the conditions making the employment dangerous he assumes the risk of such employment.4

4. Legislative Safeguards. In California and elsewhere it is provided under what circumstances the mine owner shall furnish a second means of escape from quartz mines, ${ }^{\mathbf{5}}$ distinct means of ingress and egress from and ventilation of coal mines, ${ }^{6}$ a uniform system of bell signals to be used in all mines ${ }^{7}$ and the liability to be incurred by acts of omission.

5. Limiting Hours of LaBor. In California, as in other mining states, the hours for persons employed in underground work and in the reduction and refining of ores and metals is limited to 8 hours in every 24 hours for each person so employed, except in cases of emergency, where life or property is in imminent danger. ${ }^{8}$

6. Constitutionality of Act. Such an act is constitutional. ${ }^{9}$

1. Western Coal Co. v. Ingraham, 70 Fed. 219; Utah Con. Co. v. Bateman, 176 Fed. 57.

2. Mt. Copper Co. v. Van Buren, 133 Fed. 1.

3. Id.

4. Bunker Hill Co. v. Kettleson, 121 Fed. 529; Utah Con. Co. v. Bateman, ante.

5. Quartz Mines. $\$ 1$. It shall not be lawful for any corporation, association, owner, or owners of any quartz mining claims within the State of California, where such corporation, association, owner, or owners employ twelve men daily, to sink down into such mine or mines any perpendicular shaft or incline beyond a depth from the surface of three hundred feet without providing a second mode of egress from such mine, by shaft or tunnel, to connect with the main shâft at a depth of not less than one liundred feet from the surface. 
$\S 2$. It shall be the duty of each corporation, association, owner, or owners of any quartz mine or mines in this state, where it becomes necessary to work such mines beyond the depth of three hundred feet, and where the number of men employed therein daily shall be twelve or more, to proceed to sink another shaft or construct a tunnel so as to connect with the main working shaft of such mine as a mode of escape from underground accident, or otherwise.

And all corporations, associations, owner, or owners of mines as aforesaid, working at a greater depth than three hundred feet, not having any other mode of egress than from the main shaft, shall proceed as herein provided.

$\S 3$. When any corporation, association, owner, or owners of any quartz mine in this state shall fail to provide for the proper egress as herein contemplated, and therein shall be hurt or injured, and from such injury might have escaped if the second mode of egress had existed, such corporation, association, owner, or owners of the mine where the injuries shall have occurred shall be liable to the person injured in all damages that may accrue by reason thereof; and an action at law in a court of competent jurisdiction may be maintained against the owner or owners of such mine, which owners shall be jointly or severally liable for such damages. And where death shall ensue from injuries received from any negligence on the part of the owners thereof, by reason of their failure to comply with any of the provisions of this act, the heirs or relatives surviving the deceased may commence an action for the recovery of such damages as provided by an act entitled an act requiring compensation for causing death by wrongful act, neglect, or default, approved April twenty-sixth, eighteen hundred and sixty-two. Cal. Stats. 1871-1872, p. 413.

For the use of safety cages and iron bonnets in vertical shafts in Nevada, see Nev. Stats. 1905, p. 199.

6. Coal Mines. $\S 1$. The owner or agent of every coal mine shall make or cause to be made an accurate map or plan of the workings of such coal mine, on a scale of 100 feet to the inch.

\$ 2. A true copy of which map or plan shall be kept at the office of the owner or owners of the mine, open to the inspection of all persons, and one copy of such map or plan shall be kept at the mines by the agent or other person having charge of the mines, open to the inspection of the workmen.

§3. The owner or agent of every coal mine shall provide at least two shafts, or slopes, or outlets, separated by natural strata of not less than 150 feet in breadth, by which shafts, slopes, or outlets distinct means of ingress and egress are always available to the persons employed in the coal mine; provided, that if a new tunnel, slope, or shaft will be required for the additional opening, work upon the same shall commence immediately after the passage of this act, and continue until its final completion, with reasonable dispatch.

$\S 4$. The owner or agent of every coal mine shall 
provide and establish for every such mine an adequate amount of ventilation, of not less than 55 cubic feet per second of pure air, or 3300 feet per minute, for every 50 men working in such mine, and as much more as circumstances may require, which shall be circulated through to the face of each and every working place throughout the entire mine, to dilute and render harmless and expel therefrom the noxious, poisonous gases, to such an extent that the entire mine shall be in a fit state for men to work therein, and be free from danger to the health and lives of the men by reason of such noxious and poisonous gases, and all workings shall be kept clear of standing gas.

\$5. To secure the ventilation of every coal mine, and provide for the health and safety of the men employed therein, otherwise and in every respect, the owner, or agent, as the case may be, in charge of every coal mine, shall employ a competent and practical inside overseer, who shall keep a.careful watch over the ventilating apparatus, over the air-ways, the travelling-ways, the pumps and sumps, the timbering, to see as the miners advance in their excavations that all loose coal, slate, or rock overhead is carefully secured against falling; over the arrangements for signaling from the bottom to the top, and from the top to the bottom of the shaft or slope, and all things connected with and appertaining to the safety of the men at work in the mine. He, or his assistants, shall. examine carefully the workings of all mines generating explosive gases, every morning before the miners enter, and shall ascertain that the mine is free from danger, and the workmen shall not enter the mine until such examination has been made and reported, and the cause of danger, if any, be removed.

isuif $\$ 6$. The overseer shall see that hoisting machinery is kept constantly in repair and ready for use, to hoist the workmen' in or out of the mine.

8 7. The word "owner" in this act shall apply to lessee as well.

\& 8. For any injury tó person or property occasioned by any violation of this act, or any wilful failure to comply with its provisions, a right of action shall accrue to the party injured for any direct damages he or she may have sustained thereby, before lany court of competent jurisdiction.

\$ 9. For any wilful fallure or negligence on the part of the overseer of any coal mine, he 'shall'be' liable to conviction of misdemeanor, and punished according to law provided, that if such wilful failurelor negligence is the cause of the death of any person, the overseer, upon conviction, "shall be deemed guilty of manslaughter.

\$10. All bollers used for generating 'steam in and about coal mines shall be kept in good order, and the owner or agent thereof shall have them examined and inspected, by a competent boiler-maker, as often as once in three months.

\$11. This act shall not apply to opening new coal mine.

\$12. This act shall take efféct immediately. 
Cal: Stats.'1873-1874, p. 726. See, generally, Deserant v. Cerillos Co., 178 U. S. 409; Carterville Co. v. Abbott, 181 Ill. 495; Pawnee Co. V. Royce, 184 Ill. 402; Athens Co. vi: Carnduff, 221 Ill. 354; Sans Bois Co. v. Janeway, 22 Okla. 154; Czarecki v. Seattle Co., 30 Wash. 288.

7.'Ariz: Stats. 1907 , p. 118; Cal Stats. 1893, p. 82; Mills Ann. Stats. (Colo.) Rev. Sup., \$3220f; B. \& C. Codes (Or.) \$\$ 3987-3988; see Manning v. App. Con. Co. 149 Cal. 35.

Bell Signal Act. \&1. Every person, company, corporation, or individual, operating any mine within the State of California-gold, silver, copper, lead, coal, or any other metal or substance-where it is necessary to use signals by means of bell or otherwise, for shafts, inclines, / drifts, i crosscuts, tunnels, and underground | workings, "shall, after the passage of this bill adopt, use and put in force the following, system or code of mine bell signals, as follows:-

1 bell, to hoist. (See Rule 2.)

1 bell, to stop if in motion.

2 bells, to lower: (See Rule 2.)

3 bells, man to be hoisted, run slow. (See Rule 2.)

4. bells; start pump, if not running, or stop pump if running:

1 - 3 bells, start or stop air compressor.

5 !bells, send down tools. (See Rule 4.)

6 bells; send down timbers. (See Rule, 4.)

7 belis, accident; move, bucket or cage, by verbal orders only.

1 - 4 bells, foreman wanted.

Iu $2-1-1$ bells, done hoisting until called.

Ifi $2-1-2$ bells, done hoisting for the day.

$2+2-2$ bells, change buckets from ore to water, or vice versa.i

$3+2-1$ bells, realy to shoot in the shaft. (See Eule 3.)

longineer's signal, that he is ready to hoist is to raise the: bucket or cage two feet and lower it again. (See Rule 3.)

Levels shall be designated and inserted in notice hereinafter mentioned:I (See, Rule 5.)

\$2. For the purpose of enforcing and properly understanding the above code of signals, the following

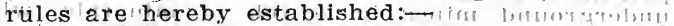

Rule 1-In'giving signals make strokes on bell at regular intervals. The bar (-) must take the same time as for one istroke of the bell, and no more. If timber," tools, the foreman, bucket or cage are wanted to'stop at any level in the mine, signal, by number of strokes on the bell, number of the level, first before giving the signal for timber, tools, etc. Time between signals to be double bars (-) Examples:

6 - 5 would mean stop at sixth, level, with, tools.

$4-1-1-1+-1, ;$ would Imean stop/at fourth

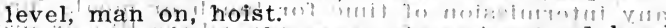

$2-1$ would mean stop at second level with foreman!

'Rule' $2-\mathrm{No}$ person'must get off or on the buaket or cage while the same is in motion. When men are to be hoisted give the signalifor men. Men must then get on bucket or cage," then give the: signal to hoist. 
Bell cord must be in reach of man on the bucket or cage at stations.

Rule 3.-After signal "Ready to shoot in shaft," engineer must give his signal when he is ready to hoist. Miners must then give the signal of "Men to be hoisted," then "spit fuse," get into the bucket, and give the signal to hoist.

Rule 4-All timbers, tools, etc., "longer than the depth of the bucket," to be hoisted or lowered, must be securely lashed at the upper end to the cable. Miners must know they will ride up or down the shaft without catching on rocks or timbers and be thrown out.

Rule 5-The foreman will see that one printed sheet of these signals and rules for each level and one for the engine-room are attached to a board not less than twelve inches wide by thirty-six inches long, and securely fasten the board up where signals can be easily read at the places above stated.

Rule 6-The above signals and rules must be obeyed. Any violation will be sufficient grounds for discharging the party or parties so doing. No person, company, corporation, or individuals operating any mine within the State of California, shall be responsible for accidents that may happen to men disobeying the above rules and signals. Said notice and rules shall be signed by the person or superintendent having charge of the mine, who shall designate the name of the corporation or owner of the mine.

§ 3. Any person or company failing to carry out any of the provisions of this act shall be responsible for all damages arising to or incurred by any person working in said mine during the time of such failure.

§ 4. This act shall take effect immediately. Cal. Stats., 1893, p. 82 .

8. Ariz. Stats. 1907, p. 118; Cal. Stats. 1909, p. 279; Mont. Rev. Codes, \$1731; Nev. Stats. 1903 , p. 33 ; 1909, p. 73 ; Oregon Stats. 1907, p. 311; Utah Stats. 1896, p. 219; Wyo. Stats. 1909 , p. 21.

The law of California limiting the hours of labor is as follows: \&1. That the period of employment for all persons who are employed or engaged in work in underground mines in search of minerals, whether base or precious, or who are engaged in such underground mines for other purposes, or who are employed or engaged in other underground workings whether for the purpose of tunneling, making excavations or to accomplish any other purpose or design, or who are employed in smelters and other institutions for the reduction or refining of ores or metals, shall not exceed eight hours within any twenty-four.hours, and the hours of employment in such employment or work day shall be consecutive, excluding, however, any intermission of time for lunch or meals; provided that, in the case of emergency where life or property is in imminent danger, the period may be a longer time during the continuance of the exigency or emergency.

\$2. Any person who shall violate any provision of this act, and any person who as foreman, manager, 
director or officers of a corporation, or as the employer or superior officer of any person, shall command, persuade or allow any person to violate any provision of this act, shall be guilty of a misdemeanor and upon conviction shall be punished by a fine of not less than fifty dollars $(\$ 50.00)$ nor more than three hundred dollars $(\$ 300.00)$, or by imprisonment of not more than three months. And the court shall have discretion to impose both fine and imprisonment as herein provided.

\$3. All acts and parts of acts inconsistent with this act are hereby repealed. Cal. Stats., 1909 , p. 279.

9. Ex parte Martin, 157 Cal. 51, 59, 60; citing Holden v. Hardy, 169 U. S. 366; Ex parte Boyce, 27 Nev. 299; Ex parte Kair, 28 Nev. 127; but see In re Morgan, 26 Colo. 415.

§80a. Recent Californian Legislation. Recent Californian legislation in relation to the subject of this title is "An Act relating to the liability of employers for injuries or death sustained by their employees, providing for compensation for the accidental injury of employees, establishing an industrial accident board, defining its powers and providing for a review of its awards." Approved April 8, 1911. ${ }^{1}$

1. Cal. Stats. 1911, p. 796.

§ 81. Partition. Mining claims are subject to partition, ${ }^{1}$ although the paramount title thereto may be in the United States. ${ }^{2}$ A suit therefor usually results in a decree for the sale of the property. ${ }^{3}$

2. Agreed Partition. A mining claim may be partitioned by agreement between the parties. ${ }^{4}$

3. Arbitration. The question of title to a mining claim is not a subject for arbitration. ${ }^{5}$

4. Mining Right. A bare "mining right" is usufructuary in its character and is not in its nature capable of partition. ${ }^{6}$

1. Aspen Co. v. Rucker, 28 Fed. 220; Hughes v. Devlin, 23 Cal. 501; Brown v. Challis, 23 Colo. 145; see Manley v. Boone, 159 Fed. 633 ; Smith v. Jones, 21 Útah, 270.

2. Aspen Co. v. Rucker, ante.

3. Royston v. Miller, 76 Fed. 50; Brown v. Challis, ante; see Mitchell v. Cline, 84 Cal. 409; Dall v. Confidence Co., 3 Nev. 531; see Ryan v. Egan, 26 Utah 241 . Mining property from its very nature is not susceptible of partition. The ores are unevenly distributed, while the values are purely conjectural until tested by extended develop- 
ment and careful tests, which can only be obtained as the result of a vast expenditure of money and time; so that it is known in advance of bringing the suit for partition that the only feasible relief that can be awarded is a decree for the sale of the property. Brown v. Challis, ante; see Hall v. Vernon, 47 W. Va. 295.

4. 420 Co. v. Bullion Co., 9 Fed. Cas. 4989 ; see Tonopah Co. v. Tonopah Co., 125 Fed. 400 ; see Empire State Co. v. Bunker Hill Co., 131 Fed. 591; Mullins v. Butte Co., 25 Mont. 525.

5. Spencer v. Winselman, 42 Cal. 479.

6. Smith v. Cooley, 65 Cal. 46 ; see $\$ 103$, post.

§ 82. Patent. A patent may be cancelled by a direct proceeding in equity when issued by the Land Department through an error of law or when the patent is obtained in fraud of the rights of the Government, ${ }^{1}$ provided, that suit is brought within 6 years from the date of its issuance. ${ }^{2}$

2. Bona Fide Purchaser. A sale to a bona fide purchaser, for value, without notice, will bar an action against a patentee or his transferee. ${ }^{3}$

3. Burden of Proof. The burden of proof is on the attacking party. ${ }^{4}$

4. Fraudulent Patentee. A person wrongfully or fraudulently obtaining a patent for land which properly belongs to another, or whether acting in good faith, will be treated in equity as trustee for the equitable owner and be required to transfer the legal title to him. ${ }^{5}$

5. Not Attack Upon Patent. This proceeding is not an annulment or setting aside of the patent wrongfully issued, ${ }^{6}$ but is based upon the theory that the title - evidenced by the patent inured to the benefit of such trustor. ${ }^{7}$

6. Status of Trustor. Where it is sought to have the patentee declared the trustee for another, not named in the patent, the plaintiff, in such a suit, in the absence of any contract between the parties, must allege and clearly prove that he occupies such a status as to entitle him to control the legal title. ${ }^{8}$ 
7. FraUd. If charges of fraud are made they must be specific and show that the fraud must, necessarily, have affected the action of the land department in issuing the patent. ${ }^{9}$

8. Application to Sue. If a party is not entitled to control the legal title yet seeks to annul the patent or limit its operation he must make application to the Government to take the proper steps to that end, as such a suit can be maintained only by and in the name of the United States. ${ }^{10}$

9. False Testimony Insufficient. False testimony or forged documents will not defeat the patent if the disputed matter has actually been presented to or considered by the appropriate tribunal. ${ }^{11}$ To be considered, the perjury must be extrinsic or collateral to the matter determined. ${ }^{12}$

See $\S 206$, post.

1. King v. McAndrews, 111 Fed. 860 ; Hiram M. Hamilton, 38 L. D. 597.

2. 26 Stdts. 1093; see Peabody v. Gold Hill Co., 106 Fed. 241; U. S. v. Chandler-Dunbar Co., 209 U. S. 447 . The object of this statute is to extinguish any right the government may have in the land and vest a perfect title in the adverse holder after 6 years from date of patent regardless of any mistake or error in the land department or the fraud or imposition of the patentee. U. S. v. Smith, 181 Fed. 545.

3. Hawley v. Diller, 178 U. S. 476 ; U. S. v. Scholl, 45 Fed. 758 ; U. S. v. Detroit Co., 131 Fed. 668 ; U. S. v. Clark, 138 Fed. 294; Schultz v. McLean, 93 Cal. 329; see 20 Stats. 89 ; U. S. v. Winona Co., 165 U. S. 463 ; see U. S. v. Smith, ante.

4. Colorado Coal Co. v. U. S., 123 U. S. 307; U. S. v. Iron Co., 128 U. S. 673.

5. Silver v. Ladd, 74 U. S'. 219 ; Johnson v. Towsley, 80 U. S. 72 ; Craig v. Leitendorfer, 123 U. S. 189; Sanford v. Sanford, 139 U. S. 642 ; Monroe Cattle Co. v. Becker, 147 U. S. 47; Emblen Co., 161 U. S. 52; Emblen Co. v. Lincoln Co., 184 U. S. 660; Greenameyer v. Coate, 212 U. S. 434; Lakin v. Sierra Buttes Co., 25 Fed. 337; Hunt v. Patchin, 35 Fed. 816; Suessenback v. Bank, 5 Dak. 477; Rose v. Richmond Co., 17 Nev. 25; see Hartman v. Warren, 76 Fed. 157; Delmoe v. Long, 35 Mont. 139; So. End Co. v. Tinney, 22 Nev. 19; Oregon Co. v. Hertzberg. 26 Or. 216.

6. Silver v. Ladd, ante; So. End Co. v. Tinney, ante. 
7. Silver v. Ladd, ante; Nowell v. McBride, 162 Fed. 432.

8. James v. Germania Co., 107 Fed. 597; Plummer v. Brown, 70 Cal. 544; Dreyfus v. Badger, 108 Cal. 58; Pierce v. Sparks, 4 Dak. 3, affd. in 115 U. S. 408; Neilson v. Champagne Co., 119 Fed. 123; see Lee v. Johnson, 116 U. S. 48; Loney v. Scott. (Or.) 112 Pac. 172.

9. Vance v. Burbank, 101 U. S. 514. Where it is sought to attack a patent upon the ground of fraud or gross mistake which caused a misapprehension by the land department of the facts proved before it and thereby caused the wrongful issuance of the patent, it must be alleged and proved not only that there was a mistalke in the findings but the evidence before the department from which the mistake resulted, the particular mistake that was made, the way in which it occurred and the fraud, if any, which induced it, before any court can enter into the consideration of any issue of fact determined by the officers of the department at the hearing. James v. Germania Co., ante; Semple v. Hagar, 27 Cal. 163.

10. Lee v. Johnson, ante; Carter v. Thompson, 65 Fed. 329; Jameson v. James, 155 Cal. 275; Poire v. Wells, 6 Colo. 406 ; see Doolan v. Carr, 125 U. S. 618; So. End Co. v. Tinney, ante.

11. Greenameyer v. Coate, ante; U. S. v. Reed, 28 Fed. 482; Peabody Co. v. Gold Hill Co., ante; Jameson v. James, ante; Cragie v. Roberts, 6 Cal. A. 309 ; see U. S. v. Smith. ante.

12. U. S. v. White, 17 Fed. 561; U. S. v. Minor, 26 Fed. 672 ; Cragie v. Roberts. ante. A concealment of facts is not sufficient basis for an attack upon a patent. U. S. v. Atherton, 102 U. S. 272; U. S. v. McGraw, 12 Fed. 449; Kerns v. Lee, 142 Fed. 985; Semple v. Hagar, ante. For instances of extrinsic or collateral fraud see Cragie v. Roberts, ante.

§ 83. Rescission. A rescission can be effected only by placing or offering to place the party against whom the rescission is sought in the position in which he stood in relation to the property at the time the contract or option was entered into, unless the property is of no value. ${ }^{1}$

2. Condition Precedent. Restoration is a condition precedent to suit for rescission; it must be promptly made and suit be brought within a reasonable time thereafter. ${ }^{2}$

3. Application of Rule. This rule applies with peculiar force in relation to mining. property because of its fluctuating and speculative character. ${ }^{3}$ 
4. Grounds for Rescission. 'The "salting" of a mining claim which is the subject of a contract or option, or an error as to the amount of "ore in sight" therein, are sufficient grounds for rescission. ${ }^{4}$

5. Salting. "Salting" consists in placing, usually surreptitiously, valuable mineral from a foreign source in such form and place within the claim as the characteristics of the latter may require, or, in like manner, tampering with the samples of ore or mineral taken therefrom or with the assays thereof, or the amalgam or other matter in the mill or other reduction works, with the intent and for the purpose to thereby give increased apparent, but misleading and inflated value to the property which is the subject of the option or contract of sale thereof and, so, induce its sale at a price greater than its mineral value warrants.

6. Unintentional Salting. A faulty method of prospecting or of sampling may result in a party "salting himself." This, for instance, may be by "driving" after drilling in an auriferous free gravel deposit.

7. REMedies. In the event of a sale of a salted property the party who has been thus defrauded may keep the property and sue for damages, or repudiate the contract, restore the property and demand the return of his money, provided, that he acts within a reasonable time after discovery of the fraud. ${ }^{5}$

8. InsuFficient Grounds fOR Rescission. The following are instances of insufficient grounds for rescission, viz: Where the purchaser is to find out for himself whether the claim is valuable or not $;^{6}$ concealment of the mineral value of the land ${ }^{7}$ or the output of adjoining property, provided, there be no wilful misstatement of a material fact intended to mislead the seller as to the value of the land. ${ }^{8}$ 
9. Marketable Titue. The want of a marketable title prior to the expiration of the time to purchase the property $^{9}$ or mere reliance upon rumors of a defect in the title ${ }^{10}$ are insufficient.

1. Harrington v. Paterson, 124 Cal. 542; Kelley v. Owens, 120 Cal. 502

2. So. Nev. Dev. Co. v. Silva, 125 U. S. 247; Bishop v. Thompson, 196 Ill. 206; Pettus v. Roberts, 6 Ala. 811.

3. Twin Lick Co. v. Marbury, 91 U. S. 587; Johnston v. Standard Co., 148 U. S. 360 ; Patterson v. Hewitt, 195 U. S. 309 .

4. See Mudsill Co. v. Watrous, 61 Fed. 163; Johnson v. Withers, 9 Cal. A. 52 .

5. Wheeler v. Dunn, 13 Colo. 428.

6. Winter v. Bostwick, 172 Fed. 285 ; see So. Nev. Dev. Co. v. Silva, ante; Crocker v. Manley, 164 Ill. 282.

7. Caples v. Steel, 7 Or. 491.

8. Harris v. Tyson, 24 Pa. St. 347; Neill v. Shamburg, 158 Pa. St. 263.

9. Winter v. Bostwick. ante; Wiley v. Helen, (Kan.) 112 Pac. 158.

10. Moore v. Pooley, 17 Ida. 57.

$\S 84$. Statute of Limitations. Under the provisions of the mining act in regard to State or Territorial statute of limitations, the latter statute becomes the foundation upon which actively to assert a right, and is not limited as in other cases, to be used as a defense against an adversary's attack.

2. Establishes Right to Patent. Where claims have been held and worked for a period equal to the term prescribed by the statute of limitations for mining claims for the state or territory where the same is situated, evidence of such possession and working is sufficient to establish a right to a patent thereto in the absence of any adverse claim, ${ }^{1}$ provided, the statutory expenditure has been made thereon. ${ }^{2}$

3. Controlling Factor. The statute of limitations thus becomes a controlling factor as the basis of a claimant's right to a mining claim in contradistinction from its ordinary use as a shield for defense against an adverse attack. ${ }^{3}$

4. Californian Provisions. In California the time for commencing an action for the recovery of real 
property is limited to five years after the plaintiff or his ancestor, predecessor or grantor was seized or possessed of the property in question ; ${ }^{4}$ the time for commencing an action for trespass upon real property is limited to three years ${ }^{5}$ and the time for commencing an action for relief on the ground of fraud is limited to three years after the discovery of the facts constituting the fraud or mistake. ${ }^{6}$

See $\$ 82$, note 2 .

1. Rev. Stats., $\$ 2332$; Glacier Co. v. Willis, 127 U. S. 471 ; Harris v. Equator Co., 8 Fed. 8.63 ; Altoona Co. v. Integral Co., 114 Cal. 100; Cleary v. Skiffich, 28 Colo. 362; 420 Co. v. Bullion Co., 9 Nev. 240 ; see $\$ 169$, post.

2. Capital No. 5 Claim, 35 L., D. 551.

3. See Min. Reg., pars. 74-75.

4. C. C. P. $\S 318$.

5. C. C. P. $\$ 338-2$.

6. C. C. P. $\$ 338-4$.

§ 85. Trespass. In cases of trespass upon a mining, timber, or like claim an injunction will be granted to restrain the commission of acts by which the substance of the estate is injured, destroyed or carried away. ${ }^{1}$

2. IGNORANCE OF BOUNDARY. The fact that the trespass is due to ignorance of the dividing line between two claims is no excuse or justification ${ }^{2}$ as one is bound to know the boundaries of his own property and to refrain from injuring the property of others. ${ }^{3}$

3. Test of Trespass. A trespass may be due to mistake $^{4}$ or be intentional. ${ }^{5}$ The test which determines whether one was a wilful or an innocent trespasser is not his violation of or compliance with the law, but his honest belief at the time he committed the injury. ${ }^{6}$

4. Injunctional Proceedings. The courts are more liberal in granting a writ of injunction in mining cases than in those affecting other real estate, ${ }^{\top}$ because of the necessity of preventing injury which can not be accurately estimated and therefore cannot be 
adequately compensated, or in order that neither party may get the advantage of the other during the litigation by force or violence. ${ }^{8}$ 'The doubt should be resolved in favor of granting the writ. ${ }^{9}$

5. Denial of InJunction. In an action of ejectment the defendant cannot be restrained from entering upon or from "working" the property in dispute, provided, he does not commit waste or extract or remove ore therefrom. ${ }^{10}$ Co-tenants in possession will not be enjoined from working a mining claim in the ordinary way. ${ }^{11}$

6. Right of Inspection. Incident to an action in trespass is the right, by one having a real interest therein, to inspect, examine and survey the property involved in the action. ${ }^{11 a}$

7. GRounds FOR ORDER. From the very nature of the case the ignorance of the party invoking the aid of the court and the want of the means to acquire the information necessary to make out his case are of the greatest import; if these facts appear, and the circumstances otherwise appearing to the court in the evidence furnish reasonable ground for the belief that an inspection will aid the court in the investigation of the case the order should be granted. ${ }^{12}$

8. SubSTANCE OF ORDER. The order for the examination, inspection and survey of the defendant's claim should strictly limit the examination to the workings of which it is necessary for the moving party to have knowledge and to the making of surveys and maps thereof. ${ }^{13}$

9. DAMAGES. The ultimate recovery against a trespasser, must be determined largely upon the question of the good or bad faith of the undertaking. ${ }^{14}$ Where the trespass is wilful the measure of damages is the enhanced value of the mineral at the mouth of the shaft, or where it was finally converted to the use of the defendant. ${ }^{15}$. If an innocent trespass the measure 
of damages is the value of the mineral as it was in the ground before its disturbance. ${ }^{16}$

10. Good Faith of Trespasser. Good faith is not necessarily dependent upon ignorance of an adverse claim; ${ }^{17}$ but an intentional or reckless omission to ascertain the rights or the boundaries of land of the victim for the purpose of maintaining ignorance regarding them, or the reckless disregard of them, is as fatal to the claim of a trespasser to limit the recovery of damages against him to the lower measure as is an intentional or wilful trespass or taking. ${ }^{18}$

11. Pleading. Where the damage is irreparable, the insolvency of the defendant need not be pleaded, as it is the nature of the injury and not the incapacity of the party to respond in damages which determines the right to an injunction in cases of trespass or waste. ${ }^{19}$

12. Model. A model of a mine may not be admissible in evidence because not a perfect mechanical fac simile thereof, but it may be admitted in connection with and for the purpose of explaining the testimony of witnesses. ${ }^{20}$

1. Allen v. Dunlap, 24 Or. 229; see Waskey v. M'Naught, 163 Fed. 929; Haggin v. Kelly, 136 Cal. 481.

2. Maye v. Yappen, 23 Cal. 306; see Resurrection Co. v. Fortune Co., 129 Fed. 668.

3. Durant Co. v. Percy Co., 93 Fed. 166; Cent. Coal Co. v. Penny, 173 Fed. 340.

4. Donovan v. St. Louis Co., 187 Ill. 28.

5. Resurrection Co. v. Fortune Co., ante.

6. U. S. v. Homestake Co., 117 Fed. 481.

7. Mabel v. Pearson, 121 Ala. 567; Safford v. Flemming, 13 Ida. 271. As a general rule the writ should contain a concise description of the particular acts or things in respect to which the party is enjoined, so that there may be no misapprehension on the subject. Whipple v. Hutchinson, 29 Fed. Cas. 17,517; see Erhardt v. Boaro, 113 U. S. 527; St. Louis Co. v. Mont. Co., 58 Fed. 129.

8. Safford v. Fleming, ante; Bullion Beck Co. v. Eureka Co., 5 Utah 3.

9. Erhardt v. Boaro, ante; Big 6 Co. v. Mitchell, 138 Fed. 279 ; Hunt v. Steese, 75 Cal. 620.

10. Williams v. Long, 129 Cal. 229 ; see Safford v. Flemming, ante. The writ will be refused to enjoin the defendant from working upon or extracting any ore from any vein having its top or apex in plaintiff's ground. This 
would call upon the defendant to ascertain what veins have their apex in plaintiff's ground and the extent of such apex therein. St. Louis Co. v. Mont. Co., ante.

11. McCord v. Oakland Co., 64 Cal. 134; see Downing v. Pademacher, 133 Cal. 220; Butte \& Boston Co. v. Mont. Ore Co., 25 Mont. 41. See $\$ 39$, ante.

11a. Bacon v. Federal Co. (Ida.), 112 Pac. 1055.

12. State v. District Court, 26 Mont. 412,$416 ; 29$ Mont. 105. It is now the recognized practice to direct the survey on the application of the party out of possession of the excavations. Without this course it is within the power of the party in possession to conceal from the party out of possession the direction of the excavation, to determine whether or not it is beneath the surface survey, and to ascertain the quantity of mineral extracted. Penny v. Cent. Coal Co., 138 Fed. 769.

13. State v. District Court. 30 Mont. 206 ; see Smuggler Co. v. Kent, (Colo.) 112 Pac. 223.

14. Backer v. Penn Lub. Co., 162 Fed. 627. That for every trespass upon real property the law presumes nominal damages: see Empire Co. v. Bonanza Co.. 67 Cal. 406.

15. Cent. Coal Co. v. Penny, ante; see Benson Co. v. Alta Co., 145 U. S. 428 . The presumption is that the defendant has the means to show the actual value of the ore

16. Id. removed. Mont. Co. v. St. Louis Co., 183 Fed. 51.

17. Backer v. Penn Lub. Co., ante.

18. Cent. Coal Co. v. Penny, ante.

19. U. S. v. Guglard, 79 Fed. 21; Waskey v. M'Naught, ante; Halla v. Rogers. 176 Fed. 709; Merced Co. v. Fremont, 7 Cal. 317; Kellogg v. King, 114 Cal. 378; Haggin v. Kelly, ante; Ganse v. Perkins, 3 Jones Eq. (N. Car.) 177; Kerlin v. West. 4 N. J. Eq. 449 ; Sierra Nev. Co. v. Sears, 10 Nev. 346: Sullivan v. Dooley, 31 Tex. Civ. App. 589. A trespass is irreparable when from its nature it is impossible to make full and complete reparation in damages. Justice Co. v. Plank Co., 11 Ga. 246. The unlawful extraction of oil or gas is an act of irrenarable injury. Bettman v. Harness. 42 W. Va. 433 . Inability to correctly estimate the damage after the evidence obtainable has been produced makes a case of irreparable damage but difficulty in collecting evidence as to damage would not. Gray Lumber Co. v. Gaskin, 122 Ga. 342 .

20. Illinois Co. v. Raff, 7 N. M. 336 .

\section{CHAPTER XIV.}

\section{DEFINITIONS.}

(For other definitions see appropriate titles.)

$\S$ 87. Assays-assay value-value of assay-car and mill samples.

88. Blanket sluices-concentrates.

$\S$ \$9. Claim-application of term-perfected claim-contiguous claims.

$\$ 90$. Corspicuous place-penalty.

$\S$ 91. Corporation-location rights. 
92. Desert lands.

93. Entry-preferential right-certificate of entry-issuance-effect of issuance-cancellation-repayment.

94. Exemptions-Californian provision.

95. Fixtures-examples-Californian provision-character of title immaterial.

\$ 96. Location-location and mining claim-consolidated locations - technical locations - illustrations-location as property - incidents of ownership - not community property-taxation.

\$ 97. Markings.

\$ 98. Mine - existence determined - synonyms - descriptive name- want of identity.

\$ 99. Mineral-mineral substances-within purview of mining laws-float-ore-ore in sight-ore personal property-placers-placer workings-zone.

\$100. Miner's inch-Californian provision.

101. Mining-prospecting and mining-process of miningprocess of milling-business of mining-instrumentalities-superintendent-shift boss-miner.

s 102. Mining claim-statutory meaning-distinction between mining claim and location-distinction between mining claim and mining ground-navigable river-Mexican grant - agricultural patent - oil claim - ditch - unworked placer.

103. Mining right-species of trade-legal relations-mining title.

5104. Public land-distinction between public land and public use-unoccupied and unappropriated land-racant land-occupancy and improvements-public mineral land-homesteads-possession.

\$105. Salt iick.

106. Scrip-Written authorization-selection - sale-guarantee.

\$107. Tunnel right-implied rights.

\$ 87. Assays. An assay is a means of ascertaining the commercial value of a mineralized substance, as. for example, ore or black sand, or the product of a mill or smelter, either by a "fire" or a "wet" process., and termed "Ordinary assays," "Commercial assays," "Specimen assays," "Control assays," and "Umpire assays."

2. Assay Value. The term "assay value" means the standard assay value of gold everywhere.

3. VAlue of Assar. An average assay value of several samples cannot be taken as an absolute mathematical demonstration of the value of an ore bodr, ${ }^{3}$ nor is the assay return necessarily conclusive of the value of the thing assayed.t 
4. Car and Mill Samples. As car samples always run above the true value of the ore, mill samples are a better test thereof. 5

1. Puget Co., 96 Fed. 90 .

2. Vietti v. Nesbitt, 22 Nev. 390. A judgment for the conversion of silver bullion, payable in coin, should be based upon the coin or market value of the bullion, and not upon an arbitrary standard of value above its market value. Fox v. Hale \& Norcross Co., 108 Cal. 369.

3. Golden Reward Co. v. Buxton Co., 97 Fed. 413; Pittsburg Co. v. Glick, 7 Colo. A. 43. An assay may tend to prove discovery. Healey v. Rupp, 28 Colo. 102.

4. Phipps v. Hully, 18 Nev. 133; see Mudsill Co. v. Watrous, 61 Fed. 163; Ormund v. Granite Mt. Co., 11 Mont. 303; see also Cheesman v. Shreve, 40 Fed. 787.

5. Fox v. Hale \& Norcross Co., ante; Vietti v. Nesbitt. ante.

§ 88. Blanket Sluices. A blanket sluice consists of a double line of flat, wooden troughs, set at a proper grade or inclination, and lined with blankets over which the mill tailings are to flow, with the result that there is deposited upon the blankets a portion of the quicksilver that is always escaping from the mill, and a portion of the ore, known as "sulphurets" which is heavier and richer than the rest of the tailings, but resists amalgamation.

2. Concentrates. The material so caught in the blanket sluice is called "concentrates."1

1. Fox v. Hale \& Norcross Co., 108 Cal. 369.

§ 89. Claim. The word "claim" in mining parlance when used as a noun has a definite meaning, denoting, when coupled with the name of a miner, a particular piece of ground to which he has a recognized, vested and exclusive right of possession for the purpose of extracting precious metals and minerals therefrom. ${ }^{1}$

2. Application of Term. The term "claim" is applied indifferently to both lode and placer claims."

3. Perfected Claim. As used in the mining act the term means a claim not yet perfected by patent. ${ }^{3}$ 
4. Contiguous Claims. The term "contiguous" means touching sides, adjoining, adjacent. 'Two tracts of land touching only at a point, are not contiguous. ${ }^{4}$

1. N. P. R. Co. v. Sanders, 49 Fed. 129.

2. Sweet v. Webber, 7 Colo. 443.

3. Iron Co. v. Campbell, 135 U. S. 286.

A mining claim, until a patent therefor has been issued, is held by peculiar title, - a title which is never complete and absolute, and which can only be maintained by the annual expenditure thereon by law required. Bay State Co. v. Brown. 21 Fed. 167.

4. Hidden Treasure, 35 L. D. 485 . Cited in Anvil Co. v. Code, 182 Fed. 205 ; see $\$ 194$, note 35 , post.

§90. Conspicuous Place. A "conspicuous place" is a discovery shaft ${ }^{1}$ or shaft house ${ }^{2}$ or the placing of the plat and notice of intention to apply for a patent in a box and fastening the same on a tree, or otherwise placing such matter at an elevation above the level of the ground so it can be seen by those going over the land, or so that it might not be obscured by the snow falling at the season of the year when posted. ${ }^{3}$

2. Penalty. A failure to post such matter in a "conspicuous place" will, in patent proceedings, make a new posting necessary. 4

1. Ferguson v. Hanson, 21 L. D. 336.

2. Gowdy v. Kismet Co., 22 L. D. 624 ; see Louisville Lode Case, 1 L. D. 548.

3. Ferguson v. Hanson, ante.

4. Id.; Tom Moore Co. v. Nesmith, 36 L. D. 199.

§ 91. Corporation. A corporation is a legal entity and can have no greater rights than an individual in acquiring public land. ${ }^{1}$

2. Location Rights. A corporation, regardless of the number of its stockholders, may lawfully locate no greater area than is allowable in the case of an individual. ${ }^{2}$

1. Igo Bridge Ex. Placer, 38 L. D. 281; see Gird v. Cal. Oil Co., 60 Fed. 531; see also U. S. v. Trinidad Co., 137 U. S. 160 .

2. Id.; see also Nome \& Sinook Co. v. Snyder, 187 Fed. 385. 
§92. Desert Lands. Lands valuable for their timber or lands containing deposits of coal or other minerals are not desert in character. ${ }^{1}$

1. See Cary Act, 37 L. D. 489; Jeremy Co. v. Thompson, 20 L. D. 299 .

For statutes and regulations governing entries and proofs under the Desert Land laws, see Circular 39 L. D. 253. For relief of assignees of entries in Imperial Co., Cal., see 39 L. D. 277.

§ 93. Entry. The term "entry" as applied in the appropriation of public land means that act by which an individual acquires an inceptive right to a portion of the unappropriated soil of the country. ${ }^{1}$

The term is also applied to an adverse re-location. ${ }^{2}$

2. Preferential Right. A preferential right of entry is a privilege to make the statutory entry of a particular tract in preference to others. ${ }^{3}$

3. Certificate of Entry. A certificate of entry is equivalent to a patent issued. When in fact the patent does issue it relates back to the inception of the right of the patentee, and cuts off intervening claimants. ${ }^{4}$

4. ISSUANCE. The certificate of entry is issued by the receiver of the proper district land office to the party entitled by law thereto. ${ }^{5}$

5. EFFECT of Issuance. The contract of purchase is complete when the certificate of entry is executed and delivered. The land then ceases to be a part of the public domain. Patent issues in due course.

In the mean time the government holds the naked legal title in trust for the entryman. ${ }^{6}$

6. Cancellation. It is the province of the land department to investigate the legality of an entry prior to patent and cancel the certificate of entry, in whole or in part, so as to conform the entry to the law. ${ }^{7}$. If the cancellation is based upon a misconstruction of the law it can be corrected by the courts. ${ }^{8}$ 
7. Repayment. When an entry is rejected, in whole or in part, and there is no fraud nor attempted fraud in connection with the application, the purchase money and commissions paid to the Government will be refunded by it to the applicant or his legal representatives upon verified demand made through the local or general land office. ${ }^{9}$

See § 104. post.

1. Sturr v. Beck, 133 U. S. 541; see Witherspoon v. Duncan, 71 U. S. 210. Under the Homestead law three things are needed to be done in order to constitute an entry on public land: First, the applicant must make an affidavit setting forth the facts which entitle him to make such entry; second, he must make a formal application; third, he must make payment of the money required. When these three requisites are complied.with, and the certificate of entry is issued to him, the entry is made - the land is entered. Hastings Co. v. Whitney, 132 U. S. 357; see McLemore v. Express Co., 158 Cal. 559; see $\$ 104-7-8$.

2. Bradford v. Morrison, 212 U. S. 389.

3. U. S. v. Forrester, 211 U. S..399. The term "preference" means exclusive. Chas. S. Morrison, 36 L. D. 126.

4. Stark v. Starrs, 73 U. S. 402; Amador Median Co. v. So. Spring Hill Co., 36 Fed. 668 .

5. Witherspoon v. Duncan, ante.

6. Id.

7. Albert R. Pfau, Jr., 39 L. D. 359 ; see, generally, Hiram M. Hamilton, 38 L. D. 597 .

8. Hawley v. Diller, 178 U. S. 476.

9. 35 Stats. 48 ; Repayment, 39 L. D. $141-146$; see $\$ 212$. note 4 ; Frank G. Bell, 39 L. D. 191; Hulda Rosling, 39 L. D. 477; Mary Ward, 39 L. D. 495.

§ 94. Exemptions. Exemption laws are grants of personal privileges to debtors which may be waived by contract or surrender or by neglect to claim before sale. ${ }^{1}$

2. Californian Provision. In California the following property of a miner is exempt from execution or attachment, viz.: The cabin or dwelling of a miner, not exceeding in value the sum of $\$ 500$; also his sluices, pipes, hose, windlass, derrick, ears, pumps, tools, implements, and appliances necessary for carrying on any mining operation, not exceeding in value the aggregate sum of $\$ 500$; and two horses, mules or 
oxen with their harness, and food for such horses, mules or oxen for one month, when necessary to be used on any whim, windlass, derrick, car pump, or hoisting gear; and also his mining claim, actually worked by him, not exceeding in value the sum of $\$ 1,000 .^{2}$

1. Spitley v. Frost, 15 Fed. 299; see Conde v. Sweeney, 12 Cal. A. Dec. 647 .

2. C. C. P., $\S 690$, sub. 5 .

$\S 95$. Fixtures. A fixture is an article affixed to the freehold. ${ }^{1}$

2. Examples. Engines, boilers, hoisting works, mills, pumps, electric hoist firmly bolted to the substructure upon which it rests, the superstructure and engine house sufficiently affixed to the soil for mining purposes, a gallows frame together with the gallows, hoist and transformers forming integral parts of one mechanism are fixtures. ${ }^{2}$

3. Californian Provision. In California, sluice boxes, flumes, hose, pipes, railway tracks, cars, blacksmith shops, mills, and all other machinery or tools used in working or developing a mine, are deemed to be affixed to the mine. ${ }^{3}$

4. Character of Title Immaterial. It is immaterial whether the fixtures be attached to property held by a possessory or a fee-simple title. ${ }^{4}$

1. Merritt v. Judd, 14 Cal. 59; Washburn v. Inter Mt. Co. (Or.), 109 Pac. 382; see Conde v. Sweeney, $12 \mathrm{Cal}$. A. Dec. 647. That a chattel will remain such although attached to the realty when it is the subject of a conditional sale, see Arnold v. Goldfield Co., (Nev.), 109 Pac. 718.

2. Arnold v. Goldfield Co., ante. See Mammoth Co. v. Juab Co., 10 Utah 232.

3. C. C., \$661; Malone v. Big Flat Co., 76 Cal. 578; see Hamilton v. Delhi Co., 118 Cal. 148.

4. Merritt v. Judd, ante; Roseville Alta Co. v. Iowa Gulch Co., 15 Colo. 29.

§96. Location. The term "location" refers to the acts constituting the appropriation of a portion of 
the public domain under the mining law ${ }^{1}$ not necessarily coupled with discovery. ${ }^{2}$ It includes a lode or a placer claim ${ }^{3}$ not yet perfected by patent. ${ }^{4}$

2. Location and Mining Claim. The terms "location" and "mining claim" are used interchangeably, although a "mining claim" may consist of several locations. ${ }^{6}$

3. Consolidated Locations. It is common to consolidate two or more locations into one claim and thereafter to treat and work them as one claim. Thereafter they are in law and in fact only parts of one claim. ${ }^{7}$

4. Technical Locations. What may be termed a technical location is one made under the provisions of the mining act, irrespective of the mode of occurrence of the mineral therein.

5. Illustrations. Cinnabar occurs, generally, in fibrous or amorphous masses imbedded in shales or slate rock. Lead is frequently found between strata in flat cavities, in beds within sand stones and rudimentary limestones-formations which would not answer to veins or lodes when speaking with scientific accuracy, ${ }^{8}$ yet each of these formations, to be included within a valid location, must be located as a "Iode claim." 9 Unmineralized marble, occurring in vein formation, that is rock in place, must be located as a "placer claim," 10 but sand rock, or sedimentary sandstone formation, in the general mass of the mountain, bearing mineral, is rock in place and must be located as a lode claim. ${ }^{10 a}$

6. Location as Property. A location perfected under the law, that is, a valid location, is property in the highest sense of that term, ${ }^{11}$ although until patent issues, the fee remains in the United States. ${ }^{12}$

7. INCIDENTS OF OWNERSHIP. It may be bought, conveyed, ${ }^{13}$ sold under judicial decree, ${ }^{\mathbf{1 4}}$ leased, ${ }^{15}$ made a homestead under a state law, ${ }^{16}$ mortgaged, ${ }^{17}$ 
or pass by descent, ${ }^{18}$ without in any manner infringing the title of the United States. ${ }^{19}$

8. Not Community Property. While unpatented it is not community property, ${ }^{20}$ nor subject to the right of dower. ${ }^{21}$

9. Taxation. While unpatented it is not subject to taxation, ${ }^{22}$ but the possessory right thereto and the product from the location may be taxed and the lien be enforced by a sale of the right of possession. ${ }^{23}$

1. Belk v. Meagher, 104 U. S. 279; St. Louis Co. v. Kemp, 104 U. S. 636; Poire v. Wells, 6 Colo. 406; McKay v. McDougall, 25 Mont. 258.

2. Uinta Co. v. Ajax Co., 141 F'ed. 563.

3. Sweet v. Webber, 7 Colo. 443 .

4. Iron Co. v. Campbell, 135 U. S. 286.

5. Del Monte Co. v. Last Chance Co., 171 U. S. 55; Clipper Co. v. Eli Co., 194 U. S. 220; Castagnetto v. Coppertown Co., 146 Cal. 329.

6. St. Louis Co. v. Kemp, ante; Del Monte Co. v. Last Chance Co., ante; see $\$ 102$.

7. Idaho Co. v. Davis, 123 Fed. 396; Tredinnick v. Red Cloud Co., 72 Cal. 78; Hamilton v. Delhi Co., 118 Cal. 148; Phillips v. Salmon River Co., 9 Ida. 149.

8. Hayes v. Lavagnino, 17 Utah 185.

9. Rev. Stats., § 2320 ; Henderson v. Fulton, 35 L. D. 652; see Webb v. American Co., 157 Fed. 203; McCann v. McMillan, 129 Cal. 350 .

10. Henderson v. Fuiton, ante; compare Webb v. American Co., ante; see E. M. Palmer, 38 L. D. 294.

10a. E. M. Palmer, ante.

11. Belk v. Meagher, ante.

12. Robertson v. Smith, 1 Mont. 410.

13. Forbes v. Gracey, 94 U. S. 762.

14. Hamilton v. So. Nevada Co., 33 Fed. 562 ; see Phœnix v. Scott, 20 Wash. 48; Bradford v. Morrison, 212 U. S. 389.

15. Weed v. Snook, 144 Cal. 439.

16. Gaylord v. Place, 98 Cal. 472.

17. Wemple v. Yosemite Co., 4 Cal. A. 78.

18. Black v. Ellkhorn Co., 163 U. S. 445 ; Sullivan v. Iron Co., 143 U. S. 431.

19. Bradford v. Morrison, ante.

20. Black v. Elkhorn Co., ante; Phœnix Co. v. Scott, ante.

21. Black v. Elkhorn Co., ante; see Headley v. Colonial Oil Co., 67 W. Va. 628.

22. Doyle v. Austin, 47 Cal. 353.

23. Bakersfield Co. v. Kern Co., 144 Cal. 148; Forbes v. Gracey, ante; Elder v. Wood, 208 U. S. 226; Graciosa Oil Co. v. Sta. Barbara Co., 155 Cal. 140. The right of possession means the claim itself, that is the right of possession of the land for mining purposes. The tax deed conveys merely such right without affecting the interest of the United States. Elder v. Wood, ante. See $\$ 67-12 ; \S 122-7$. 
§97. Markings. Stakes or posts, or piles of stone or boulders, blazing trees along the boundaries of the claim, or at the corners thereof, cutting away undergrowth, making a trail through the timber along the sides or ends of the claim, putting up a stake at the point of discovery, blazing stumps, posting a notice at the point of discovery, posting a notice on the ground, placing such notice in a tin can, and attaching it to a stake, fastening such notice to a tree, or placing it in a box, are all markings. ${ }^{1}$

1. Meydenbauer v. Stevens, 78 Fed. 787 ; see Book v. Justice Co., 58 Fed. 106.

§ 98. Mine. A "mine" is a work for the excavation of minerals by means of pits, shafts, levels, tunnels, etc., as opposed to a "quarry," where the whole excavation is open. ${ }^{1}$

2. Existence Determined. In general the existence of a mine is determined by the mode in which the mineral is obtained, and not by its chemical or geological character. ${ }^{2}$

3. Synonyms. The term "mine" as used in the mining act appears to be synonymous with the term "vein or lode." 3 The term "mine" is also defined as including only mines valuable for their minerals or valuable mineral deposits. ${ }^{4}$

4. Descriptive Name. When the term is used as a part of the descriptive name of a mining property it means the "whole claim or body of mining ground." 5

5. WANT OF Identity. A mine or mining ground has no necessary identity with land patented as a placer claim. ${ }^{6}$

1. Murray v. Allred, 100 Tenn. 100; see People v. Bell, 237 IIl. 332 ; Escott v. Crescent Co., (Or.) 106 Pac. 452.

A prospect is a parcel of mineral land from which the miner hopes to obtain mineral or metals of value at a profit by further development work. 
2. Johnson v. California Lustral Co., 127 Cal. 283; see Marvel v. Merritt, 116 U. St 11.

3. Bullion Beck Co. v. Eureka Hill Co., 5 Utah 3.

4. Davis v. Weibbold, 139 U. S. 507; Dower v. Richards, 151 U. S. 658 ; Barden v. N. P. R. Co., 154 U. S. 288; Callahan v. James, 141 Cal. 291.

5. Smith v. Sherman, 12 Mont. 524; see $\S 67-10$, ante.

6. Byrnes Estate, 112 Cal. 176.

§99. Mineral. Mineral is any constituent of the earth's crust, more especially an inorganic body, occurring in nature homogeneous and having a definite chemical composition which can be expressed by a chemical formula, and having certain distinguishing characteristics ${ }^{1}$ and which is capable of being got from the earth for the purpose of profit.

2. Mineral Substances. The term "mineral" includes coal, metal, ores of all kinds, clay, stone, slate, cropolites, salt, paint stone and similar substances. ${ }^{2}$

3. Within Purview of Mining Laws. Whatever is recognized as mineral by the standard authorities on the subject, whether of metallic or other substances when the same is found in the public lands, in quantity and quality sufficient to render the land more valuable on account thereof than for agricultural purposes is within the purview of the mining laws. ${ }^{3}$

4. Float. The term "float" or "float rock" means bunches, blotches, pieces, or boulders of quartz or rock lying detached from, or resting upon the earth's surface without any walls. ${ }^{4}$

5. Ore. Ore is a compound of metal and some other substance. ${ }^{5}$

6. ORE IN Sight. "Ore in sight" means orebearing rock so separated and blocked off by being worked around on two or more sides, that it is subject to examination and measurement. ${ }^{6}$

A contract of purchase of mining property may be rescinded when based upon a mathematical error of an expert as to the amount of "ore in sight." 7 
7. Ore, Personal Property. Ore, or other mineral product, becomes personal property when detached from the soil in which it is imbedded. ${ }^{8}$

8. Placers. The term "placers," as used in the mining act of Congress, means ground within defined boundaries chiefly valuable for its deposits, metallic or non-metallic, in earth, sand or gravel, not in place, that is, in a loose state, upon or near the surface or occupying the bed of ancient rivers or valleys and may, in most cases, be collected by washing or amalgamation, without milling. ${ }^{9}$

"Placers" include all forms of deposit excepting veins of quartz or other rock in place. ${ }^{10}$

9. Placer Workings. Placer workings are surface workings. ${ }^{11}$

10. Zone. A metal zone is equivalent to a mineral zone, ${ }^{12}$ yet the terms "mineral" and "metal" are not synonymous. ${ }^{13}$

1. Marvel v. Merritt, 116 U. S. 11; Jenkins v. Johnson, 13 Fed. Cas. 7271; N. P. R. Co. v. Soderberg, 104 Fed. 425. The term "mineral" should not be confined to metals or metallic ores. All metals are minerals, but all minerals are not metals. N. P. R. Co. v. Soderberg, 188 U. S. 526. See $\S 45$, ante.

2. Murray v. Allred, 100 Tenn. 100; Williams v. South Penn. Co., 52 W. Va. 181; see $\$ 47$, ante.

3. Pac. Coast M. Co. V. N. P. R. Co., 25 L. D. 233 . See Zimmerman v. Brunson, 39 L. D. 310.

4. Book v. Justice Co., 58 Fed. 106; Meydenbauer v. Stevens, 78 Fed. 787. Float found upon unappropriated territory belongs to finder. Burns v. Schoenfield, 1 Cal. A. 121.

5. Marvel v. Merritt, ante.

6. Mudsill Co. v. Watrous, 61 Fed. 163; see Green v. Turner, 86 Fed. 837. As to measurement of ore under water, see Ward v. Eastwood, 3 Cal. A. 437.

7. Johnson v. Withers, 9 Cal. A. 52. Prospective purchasers have a right to rely upon statements as to amount of ore in sight. Green v. Turner, ante. See So. Nev. Dev. Co. v. Silva, 125 U. S. 247.

8. Forbes v. Gracey, 94 U. S. 762 ; see Waskey v. M'Naught. 163 Fed. 929.

9. U. S. v. Iron Co., 128 U. S. 673 ; N. P. R. Co. v. Soderberg, 188 U. S. 526; Clipper Co. v. Eli Co., 194 U. S. 220; Gregory v. Pershbaker, 73 Cal. 109; Moxon v. Wilkinson, 2 Mont. 421; Sullivan v. Schultz, 22 Mont. 541. 
10. Gregory v. Pershbaker, ante; compare Henderson v. Fulton, 35 L. D. 652 ; see Webb v. American Co., 157 Fed. 203 ; see E. M. Palmer, 38 L. D. 294.

11. Clipper Co, v. Eli Co., ante.

12. Mt. Diablo Co. v. Callison, 17 Fed. Cas. 9886.

13. N. P, R. Co. v. Soderberg, 99 Fed. 506.

$\S 100$. Miner's Inch. The term "miner's inch" is not definite without specification of the head or pressure. ${ }^{1}$

2. Californian Provision. In California the standard miner's inch of water is equivalent to one and one half cubic feet of water per minute, measured through any aperture or orifice. ${ }^{2}$

1. Longmire v. Smith, 26 Wash. 439; see also Dougherty v. Haggin, 56 Cal. 522.

2. Cal. Stats. 1901, p. 660 .

$\S 101$. Prospecting and Mining. Prospecting and mining are generic terms which include the whole mode of obtaining metals and minerals. ${ }^{1}$

2. Process of Mining. The process of mining is the prospecting or developing of ground by shaft, tunnel, or other opening, whether mineral is extracted at a profit or at all; by quarrying; or by dredging the bed or banks of a water way for the purpose of obtaining mineral therefrom. ${ }^{2}$

3. Process of Mrluing. Milling and the reduction of ores by smelting, cyaniding, etc., is the separating of the materials found together in the earth, the one from the other, and extracting from the mass the particular natural product desired. ${ }^{3}$

4. Business of Mining. The business of mining for the benefit of the mine owner (unless otherwise provided by law) is as much a private affair as that of the farm or factory and the right of eminent domain cannot be invoked in aid of it. ${ }^{4}$

5. Instrumentalities. The true meaning of such expressions as shafts, tunnels, levels, uprises, cross cuts, inclines, etc., when applied to mines signifies 
instrumentalities whereby and through which such mines are opened, developed, prospected and worked. ${ }^{5}$

6. Superintendent. A superintendent of a mine has no implied general authority to borrow money to carry on mining operations and can only do so by express authority of the owner. But he has implied authority to bind the owner in the employment of labor and materials to run the mine, and incur, if necessary, debts for that purpose; and incidental to such authority he may execute and deliver to employees, or persons furnishing materials necessary to run the mine, written evidences in the form of memoranda, orders or checks for such amounts as may be due thereon. ${ }^{6}$

7. ShIFT Boss. The term "shift boss" means a master workman who directs the work of the set of men engaged upon a particular shift; that is, a set of workmen who work in turns with other sets. ${ }^{7}$

8. Miner. A miner is one who mines, a digger for metals and other minerals. $\mathrm{He}$ is not necessarily a mechanic, handeraftsman or artisan, and the term imports neither learning nor skill. ${ }^{8}$

1. Williams v. Toledo Co., 25 Or. 426 ; see Bishop v. Baisley, 28 Or. 119.

2. Johnson v. Cal. Lustral Co., 127 Cal. 283. For custom prevailing along the Comstock Lode in regard to mining and milling, see Fox v. Hale \& Norcross Co., 108 Cal. 369.

3. Rollins Co., 102 Fed. 982.

4. Sutter Co. v. Nichols, 152 Cal. 688 ; see $\$ 76$, ante.

5. Hines v. Miller, 122 Cal. 517.

6. Alderson v. Crocker, 28 Fed. 745: see Providence Co. v. Nicholson, 178 Fed. 29. In California the issuance as payment for wages of any evidence of indebtedness, unless the same is negotiable and payable without discount, and is payable on demand at some bank or other established place of business within the state, is prohibited, under penalty of both fine and imprisonment. Cal. Stats. 1911 , p. 259; see Id., p. 1268.

7. Johnson v. Butte \& Superior Co., 41 Mont. 158.

8. Watson v. Lederer, 11 Colo. 577.

$\S 102$. Mining Claim. Independent of acts of Congress providing a mode for the acquisition of title 
to the mineral lands of the United States, the term "mining claim" has always been applied to a portion of such lands to which the right of exclusive possession and enjoyment, by a private person or persons, has been asserted by actual occupation, or by compliance with the local mining laws, or district rules. ${ }^{1}$

2. Statutory Meaning. As the term "mining claim" is used in the mining act, a mining claim is that portion of a vein or lode and of the adjoining surface, or of the surface and subjacent material to which a claimant has acquired the right of possession by virtue of a compliance with such statute and the local laws and rules of the district in which the location may be situated. ${ }^{2}$

3. Distinction Between Mining Claim and Location. A mining claim is a parcel of land containing precious metals in its soil or rock. A location is the act of appropriating such parcel, according to certain established rules. ${ }^{3}$

4. Distinction Between Mining Claim and MinING GROUnd. No land can be a "mining claim" unless based upon a location, or its equivalent; otherwise it may be "mining ground" or a "mine." 4

The terms "valuable for minerals" and "valuable for mineral deposits" are not equivalent to the term "mining ground." 5 Hence, land from which a mineral substance is obtained from the earth by the process of mining may with propriety be called mining ground or mining land. ${ }^{6}$

5. NAvigABLE RIVER. The bed of a navigable river is not subject to mining location, but if mining is conducted thereon by dredging, it is "mining ground." 7

6. Mexican Grant. Land within a Mexican grant is not a mining claim within the purview of a state law giving to a miner a lien for his unpaid work upon a "mining claim," although many "mines" may have been opened within its boundaries. 8 
7. Agricultural Patent. Under such a law land covered by an agricultural patent and worked for its mineral deposits is "mining ground" and not a "mining claim." 9

8. Oil Claim. Land worked as an oil claim, ${ }^{10}$ or as a coal mine, ${ }^{11}$ is a mining claim under such a statute.

9. Diтch. A ditch appurtenant to and furnishing water to a mining claim, is mining ground within the meaning of a statute, requiring the consent of a majority of the stockholders of a corporation to a sale of its mining ground. ${ }^{12}$

10. UNWORKed Placer. A patented mining claim, unworked for years, is not a mine in the sense of a statute providing for the summary sale of mines in a probate proceeding. ${ }^{13}$

1. Morse v. De Ardo, 107 Cal. 622.

2. Mt. Diablo Co. v. Callison, 17 Fed. Cas. 9886.

3. St. Louis Co. v. Kemp, 104 U. S. 636; Williams v. Sta. Clara Ass'n, 66 Cal. 193; see $\S 96$, ante.

4. Forbes v. Gracey, 94 U. S. 762 ; Williams v. Sta. Clara Ass'n., ante; Morse v. De Ardo, ante; Ball v. Tolman, 119 Cal. 358; see Bewick v. Muir, 83 Cal. 368.

5. Johnson v. Cal. Lustral Co., 127 Cal. 283.

6. People v. Bell, 237 Ill. 332.

7. Ball v. Tolman, ante.

8. Williams v. Sta. Clara Ass'n, ante.

9. Morse v. De Ardo, ante: see Gray v. N. M. Co., (N. M.) 110 Pac. 102.

10. Berentz v. Belmont Oil Co., 148 Cal. 577.

11. Escott v. Crescent City Co., (Or.) 106 Pac. $45 \%$.

12. McShane v. Carter, 80 Cal. 310.

13. Byrnes Estate, 112 Cal. 176.

§ 103. Mining Right. A "mining right" upon a specific piece of ground is a right to enter upon and occupy the ground for the purpose of working it, either by underground excavation or open workings, to obtain from it the minerals or ores which may be deposited therein. By implication the grant of such right carries with it whatever is incident to it, and necessary to its beneficial enjoyment. ${ }^{1}$ 
2. Species of Trade. The working of a mine under a bare "mining right" has been uniformly considered by courts of equity as a species of trade. ${ }^{2}$

3. Legal Relations. The legal relations existing between two or more persons interested in such a right is that of a qualified partnership and the remedies relating to a mining partnership are available for the assertion or violation of any right arising out of it. ${ }^{3}$

4. Mining Titue. By "mining title" as employed in Rev. Stats., $\S 910$, is meant the title which the miner obtains by his discovery and location, followed up by a compliance with the statutory regulations to preserve his right of possession. ${ }^{4}$

1. Smith v. Cooley. 65 Cal. 46; People v. Bell, 237 Ill. 332. See Armstrong v. Maryland Co., 67 W. Va. 589; see Last Chance Co. v. Bunker Hill Co., 131 Fed. 579; see $\$ 81-4$, ante.

A "mineral right" imports title or right to all that is mineral in the land. McGraw v. Lakin, 67 W. Va. 385 .

2. Smith v. Cooley, ante.

3. Id.; see $\$ 58$, ante.

4. Gillis v. Downey, 85 Fed. 483.

$\S 104$. Public Land. The term "public land" as used in the legislation of Congress means such lands as are subject to appropriation as a mining claim ${ }^{1}$ or subject to sale, or other disposition, under general laws. ${ }^{2}$

2. Distinction Between Public Land and PubLIC UsE. There is a clear distinction between public lands and lands that have been severed from the public domain and reserved for sale, or other disposition under general laws. Such reservation severs the land from the mass of the public domain and appropriates it to a public use. ${ }^{3}$

3. UNOCCUPIED AND UNAPPROPRIATED LAND. The terms "unoccupied" and "unappropriated" refer to land that is not in the possession of one who claims 
the right of possession thereto by virtue of a compliance with the law. ${ }^{4}$

4. Vacant Land. Land is not vacant when occupied as a mining, claim without discovery by one who is diligently prospecting it for the minerals which it may contain. ${ }^{5}$

5. Occupancy AND ImPRovements. Mere occupancy of the public lands and making improvements thereon give no vested right therein as against the United States and consequently not against any purchaser from them. ${ }^{6}$

6. Public Mineral Land. Public mineral land is land belonging to the United States containing a deposit of mineral in some form, metalliferous or nonmetalliferous, in quantity and quality sufficient to justify expenditures in the effort to extract it and subject to occupation and purchase under the mining laws. ${ }^{7}$

7. Homesteads. One who has a valid homestead entry upon lands classed as agricultural, but subject to the mineral laws, may be divested of his right by a showing that the land is more valuable for mineral than agricultural purposes, if made at any time before final proof and payment are made and final receipt issues. ${ }^{8}$

8. Possession. The homestead entryman is entitled to exclusive possession as against all adverse claimants except one having a valid prior, equal or superior right. A person qualified to make a mining location and having a valid prior location has such right of possession as against the homestead entryman. But a contestant for a mining claim or location is not entitled to either joint or adverse possession as against the homestead entryman. ${ }^{\mathbf{9}}$

1. Rev. Stats., § 2319; McFadden v. Mt. View Co., 97 Fed. 670. 2. Newhall v. Sanger, 92 U. S. 761; Barden v. N. P. R. Co., 154 U. S. 288; U. P. R. v. Harris, 215 U. S. 386; McFadden v. Mt. View Co., ante; U. S. v. Blendauer, 122 Fed. 703. 
3. U. S. v. Tygh Valley Co., 76 Fed. 693.

4. Conn v. Oberto, 32 Colo. 313.

5. Cosmos Co. v. Gray Eagle Co., 104 Fed. 20, 112 Fed. 4; McLemore v. Express Co., 158 Cal. 559.

6. Sparks v. Pierce, 115 U. S. 408; Hays v. U. S. 175 U. S. 248 ; S. P. R. Co. v. Purcell, 77 Cal. 69 ; see Bonner v. Meikle, 82 Fed. 697; Chism v. Price, 54 Ark. 251. Every competent locator has the right to initiate a lawful claim to unappropriated public land by a peaceable adverse entry upon it while it is in the possession of those who have no superior right to acquire the title or to hold the possession. Any other rule would make the wrongful occupation of public land by a trespasser superior in right to a lawful entry of it under the acts of Congress by a competent locator. Thallman v. Thomas, 111 Fed. 277; Malone v. Jackson, 137 Fed. 878; see also Nev. Sierra Co. v. Home Oil Co., 98 Fed. 673; Chrisman v. Miller, 140 Cal. 440.

7. Pac. Coast Co. v. N. P. R. Co., 25 L. D. 233; see Deffebach v. Hawke, 115 L. S. 392 ; Alford v. Barnum, 45 Cal. 482.

8. Bay v. Oklahoma Co., 13 Okla. 425.

9. Id.

$\S 105$. Salt Lick. A salt lick is so called in the Western country from the fact that deer and other wild animals resort to it, and lick or drink the brackish water. And in this respect no distinction is perceived between a "lick" as frequently used and a "salt. spring." 1

1. Indiana v. Miller, 13 Fed. Cas. 7022.

§ 106. Scrip. The term "scrip," sometimes called "indemnity certificates" or "land warrants," has not been judicially defined.

2. Written Authorization. It is a written authorization, created by legislative enactment; whereby the holder thereof is entitled to acquire public nonmineral land, in the certain quantity therein named upon the surrender of the scrip to the officers of the land office for the district of lands subject to sale and wherein the selected land may lie, or as otherwise provided by law.

3. Selection. The scrip may be laid upon surveyed or unsurveyed non-mineral land, as the terms of the particular act creating it may permit. 
4. SALE. The scrip is subject to assignment and sale in the open market. Its price, per acre, therein is governed by the law of supply and demand.

5. Guarantee. The seller should, properly, guarantee its acceptance by the government as the doctrine of a bona fide purchaser does not apply to one who purchases from a pre-emptor before patent issues. ${ }^{1}$

1. R. F. Pettigrew, 2 L. D. 598. See James v. Germania Co., 107 Fed. 597; Pol. C., $\$ 3398$ et seq. For cases which involved conflicts between "scrippers" and" oil locators, see McLemore v. Express Co., 158 Cal. 559.

§107. Tunnel Right. A grant of a tunnel right through a specific piece of ground is a right to enter upon and occupy the ground for the purpose of prosecuting work in the tunnel, and to extract therefrom waste rock or earth necessary to complete the running of the tunnel, and making such use thereof, after completion, as may be necessary to work the mining ground or lode owned by the party running the tunnel.

2. Implied Rights. By implication the grant of such a right carries with it every incident and appurtenant thereto, including the right to dump the waste rock at the mouth of the tunnel on the land owned by the grantor at the time of the conveyance of the tunnel right, such right or easement being necessary for the full and free enjoyment of the tunnel right. ${ }^{1}$

1. Scheel v. Alhambra Co., 79 Fed. 821.

\section{CHAPTER XV.}

COAL LANDS.

$\S 108$. In general-entry-preferential right-consolidation.

$\S 108$. In General. Coal lands are mineral lands ${ }^{1}$ and subject to location as such ${ }^{2}$ when not within the limits of a railroad grant. ${ }^{3}$ 
The fee-simple title thereto is acquired under the coal-land laws. ${ }^{4}$ Land classed as coal land may be patented as non-mineral and the underlying coal be reserved to the government. ${ }^{5}$

2. Entry. Coal lands are subject to patent, by legal subdivisions, ${ }^{6}$ except in Alaska, ${ }^{7}$ to a limited extent, ${ }^{8}$ by a qualified person or association of persons or a corporation ${ }^{9}$ under the provisions of the coalland laws only. ${ }^{10}$

3. Preferentinl Right. Location is not a condition precedent to, but when coupled with actual possession and improvements gives a preferential, that is, exclusive ${ }^{11}$ right of entry.

4. Consolidation. There is no limitation as to the purchase or sale of coal lands after due entry thereof. ${ }^{12}$

1. Mullan v. U. S., 118 U. S. 271 ; Brown v. N. P. R. Co., 31 L. D. 29 ; T. P. Crowder, 30 L. D. 92 .

2. Leonard v. Lennox, 181 Fed. 760.

3. Barden v. N. P. R. Co., 154 U. S. 288. See this case for collection of land grant acts to railroad companies (p. 317).

4. Rev. Stats., § 2347; 35 Stats. $844 ; 36$ Stats. 583; 38 L. D. 183-576; 39 L. D. $156-179$.

5. 35 Stats, $844 ; 36$ Stats, 583; 39 L. D. 181-576; Instructions, 39 L. D. 179. Prospecting for coal may subsequently be prosecuted upon such lands. The prospector must give bond or undertaking, approved by the Secretary of the Interior, as security for the payment of all damages to the cróps and improvements on such lands by reason of such prospecting. 36 Stats. 583.

6. Rev. Stats., \& 2347.

7. 33 Stats, 525; Coal lands in Alaska, 39 L. D. 86, 322. 327; Instructions, ante.

8. Rev. Stats., § 2347 ; see Rev. Stats., \$2350; see Jessie E. Oviatt, 35 L. D. 235.

9. Id. U. S. v. Trinidad Co., 137 U. S. 160.

10. Rev. Stats., \$2347; see Instructions, 38 L. D. 271.

11. Chas. S. Morrison, 36 L. D. 126; see E. F. Filer, 36 L. D. 360. See $\$ 93$, ante.

12. Ireland v. Henkle, 179 Fed. 993; see U. S. v. Allen, 180 Fed. 855; U. S. v. Doughten, 186 Fed. 226; see Hiram M. Hamilton, 38 L. D. 597. 


\section{ERRATUM}

[The following matter, having been accidentally omitted in the transcription of the original notes upon the subject, it is here inserted.]

$\S 110$. 4a. Intra-limital Rights. Where there are two conflicting lode locations, within each of which there is a portion of the apex of the same lode or vein, the doctrine of extra-lateral rights has no application, as the rights of the junior locator cease at the point where the vein or lode passes a surface boundary line of the senior location. ${ }^{1}$ This, precisely as in cases of controversy where locations overlap each other lengthwise on the strike of the vein or lode. ${ }^{2}$

2. Proof of Priority. Where the patent for either of such claims does not give the date of the location such date may be proved de hors the patent. ${ }^{3}$

1. Tyler v. Sweeney, 79 Fed. 280; Jefferson Co. v. Anchoria Co., 32 Colo. 176; see also, Cosmopolitan Co. v. Foote, 101 Fed. 518. For Form of Instruction to Jury, see Tyler Co. v. Sweeney, 54 Fed. 284.

2. Tyler Co. v. Sweeney, 54 Fed. 284.

3. Last Chance Co. v. Tyler Co., 61 Fed. 557 ; s. c. 157 U. S. 683 . 



\section{CHAPTER XVI.}

\section{LODE CLAIMS.}

\$110. In general-top or apex-surface rights-subsurface rights-presumption-departure from surface lines.

$\S 111$. Limitation of subsurface rights-form of locationexceptions-priority of location-priority immaterial.

\$112. Dip right-basis of right-identity of vein-want of identity.

$\S 113$. Unlawful intrusion-exception.

$\S 110$. In General. A lode claim is that portion of a vein or lode, and of the adjoining surface, which has been acquired by a compliance with the law. ${ }^{1}$

2. TOP OR APEx. A lode claim must include the top or apex of a vein or lode, however small the latter may be. ${ }^{2}$

3. Surface Rights. The locator has the exclusive right of possession and enjoyment of all the surface within the lines of his location. ${ }^{3}$

Courts cannot enlarge a location nor make a new location by running either new end or side lines. ${ }^{4}$

4. Subsurface Rights. The locator has the exclusive right of possession and enjoyment of all veins, lodes and ledges throughout their entire depth, the top or apex of which lies inside of such surface lines extended downward vertically ${ }^{5}$ whether the vein or lode extends to the end lines or not, ${ }^{6}$ or departs from the side lines of the claim, ${ }^{7}$ provided, no right has attached in favor of other parties at the time the location was made. ${ }^{8}$

5. Presumption. Until the contrary is shown it is presumed that a lode location includes a vein or lode. ${ }^{9}$

6. Departure from Surface Lines. Where the vein or lode passes through one of the parallel end lines and one of the side lines of a location, the extralateral right is bounded by the vertical plane of such end line, and a parallel plane passing downward through the point where the top or apex crosses the side line. ${ }^{10}$ Where a vein or lode, upon its strike 
crosses an end line, departs from the claim through a side line and at some distance re-enters the claim and passes through the complemental end line of the claim so as to "belly" beyond the side line into adjacent territory, the extra-lateral right to such vein or lode is bounded by each end line and the several points at which the vein or lode intersects such side line. ${ }^{11}$

1. Mt. Diablo Co. v. Callison, 17 Fed. Cas. 9886.

The mining act of California provides that: "Any person, a citizen of the United States, or who has declared his intention to become such, who discovers a vein or lode of quartz, or other rock in place, bearing gold, silver, cinnabar, lead, tin, copper or other valuable deposit, may locate a claim upon such vein or lode by defining the boundaries of the claim, in the manner hereinafter described, and by posting a notice of such location, at the point of discovery, which notice must contain:

First. The name of the lode or claim.

Second. The name of the locator or locators.

Third. The number of linear feet claimed in length along the course of the vein, each way from the point of discovery, with the width on each side of the center of the claim, and the general course of the vein or lode, as near as may be.

Fourth. The date of the location.

Fifth. Such a description of the claim by reference to some natural object or permanent monument as will identify the claim located. C. C., $\$ 1426$.

The locator must define the boundaries of his claim so that they may be readily traced, and in no case shall the claim extend more than 1500 feet along the course of the vein or lode, nor more than 300 feet on either side thereof, measured from the center line of the vein at the surface. C. C., $\$ 1426$ a.

Within 30 days after the posting of his notice of location upon a lode-mining claim, the locator shall record a true copy thereof in the office of the County Recorder of the county in which such claim is situated, for which service the County Recorder shall receive a fee of $\$ 1$. C. C., $\$ 1426 \mathrm{~b}$.

2. Larkin v. Upton, 144 U. S. 19.

3. Mt. Diablo Co. v. Callison, ante; Crown Point Co. v. Buck, 97 Fed. 462. "Enjoyment" of the surface of an unpatented mining claim is limited to uses incident to mining operations. U. S. v. Rizzinelli, 182 Fed. 675 . See $\$ 208$, post. When the land is patented it is open to other uses. Schwab v. Beam, 86 Fed. 41.

4. King v. Amy Co., 152 U. S. 222; Cosmopolitan Co. v. Foote, 101 Fed. 518. Boundary planes are not subject to perpetual re-adjustment according to subterranean developments made by mine workings. Iron Co. v. Elgin Co., 118 U. S. 196. 
5. Flagstaff Co. v. Tarbet, 98 U. S. 463 ; Iron Co. v. Elgin Co., ante; Del Monte Co. v. Last Chance Co., 171 U. S. 55; Calhoun Co. v. Ajax Co., 182 U. S. 499; Iron Co. v. Cheesman, 8 Fed. 297; Last Chance Co. v. Bunker Hill Co., 131 Fed. 579; Daggett v. Yreka Co., 149 Cal. 357; Ajax Co. v. Hilkey, 31 Colo. 131; So. Nev. Co. v. Holmes Co., 27 Nev. 107.

6. Del Monte Co. v. Last Chance Co., ante. It will be presumed that the vein or lode extends to each end line. Armstrong v. Lower, 6 Colo. 393; see San Miguel Co. v. Bonner, 33 Colo. 207.

7. Flagstaff Co. v. Tarbet, ante; Iron Co. v. Cheesman, 116 U. S. 529.

8. See note 5, ante, Amador Median Co. v. So. Spring Hill Co., 36 Fed. 668 .

9. Patterson v. Hitchcock, 3 Colo. 533.

10. Del Monte Co. v. Last Chance Co., ante; see Belk v. Nickerson, 29 L. D. 662; Cosmopolitan Co. v. Foote, ante.

11. Waterloo Co. v. Doe, 82 Fed. 45.

$\S 111$. Limitation of Subsurface Rights. Subsurface rights are controlled by the form of the surface location, ${ }^{1}$ and sometimes by questions of priority. ${ }^{2}$

2. FORM OF LOcation. No extra-lateral right attaches to an irregularly shaped location as when in the shape of a horseshoe ${ }^{3}$ or of an isosceles triangle. ${ }^{4}$ The extra-lateral right is limited by the side lines when they cross the vein or lode. ${ }^{5}$

3. Exceptions. The extra-lateral right attaches to irregularly shaped locations which were made prior to the act of $1872 .^{6}$ It does not attach to a horizontal vein or lode, ${ }^{7}$ nor to a vein or lode not "in place," 8 nor to a " blind vein or lode" within the limits of a placer location. ${ }^{\circ}$

4. Priority of Lochtion. The extra-lateral right may be lost for want of priority of location, ${ }^{10}$ as where two or more veins unite, ${ }^{11}$ intersect or cross each other. ${ }^{12}$

5. Priority Immaterial. The dates of the respective locations or patents are immaterial in the pursuit of a vein or lode, the top or apex of which is in a claim adversely held, ${ }^{13}$ except where the vein or lode upon its dip enters ground which has been previously patented as agricultural in character. ${ }^{14}$ 
1. Flagstaff Co. v. Tarbet, 98 U. S. 463 ; Iron Co. v. Elgin Co., 118 U. S. 196; Argentine Co. v. Terrible Co., 122 U. S. 478; Del Monte Co. v, Last Chance Co., 171 U. S. 55; Mont. Co. v. Clark, 42 Fed. 626 . The mining act limits the dimensions of a lode claim but does not prescribe its shape. Breece Co., 3 L. D. 11.

2. Rev. Stats., $\$ 2336$.

3. Iron Co. v. Elgin Co., ante.

4. Mont. Co. v. Clark, ante.

5. Flagstaff Co. v. Tarbet, ante; Argentine Co. v. Terrible Co., ante; King v. Amy Co., 152 U. S. 222; Last Chance Co. v. Tyler Co., 157 U. S. 683 .

6. Argonaut Co. v. Kennedy Co., 131 Cal. 15; aff'd in 189 U. S. 1.

7. Leadville Co. v. Fitzgerald, 15 Fed. Cas. 8158.

8. Tabor v. Drexler, 23 Fed. Cas. 13723.

9. Rev. Stats., \& 2333 .

10. Rev. Stats., $\$ 2336$.

11. Little Josephine Co. v. Fullerton, 58 Fed. 521.

12. Rev. Stats., $\$ 2336$.

13. Colo. Cent. Co. v. Turck, 50 Fed. 888; s. c. 70 Fed. 294 ; Golden v. Murphy, 27 Nev. 379 ; Blake v. Butte Co., 2 Utah 54.

14. Amador Median Co. v. So. Spring Hill Co., 36 Fed. 468.

$\S 112$. Dip Right. The right to follow a vein or lode upon its dip or downward course outside the side lines of a lode claim ${ }^{1}$ to any depth below the surface, although laterally its inclination shall carry it far from the perpendicular, ${ }^{2}$ is usually called the extralateral right. ${ }^{3}$

2. BASIS of RIGHT. The dip right is based upon the supposition that the end lines of the location correspond substantially with the strike of the vein or lode at its apex. ${ }^{4}$

3. Identity of Vein. It is essential that the identity of the vein or lode pursued into adjoining ground be preserved. It must be continuous. Its identity is not destroyed by interruptions or closure of the fissure if the extent thereof does not prevent the tracing of the vein or lode through the fissure to be identical in its parts as a geological fact. ${ }^{5}$

4. WANT OF IDENTITY. The want of identity and continuity of a vein or lode may be established by assays of samples taken from a "fault" therein, consisting of country rock. ${ }^{6}$

See $\S 50,55,56,57,58$, ante. 
1. Flagstaff Co. v. Tarbet, 98 U. S. 463 ; Iron Co. v. Cheesman, 116 U. S. 529 ; see Cheesman v. Shreve, 40 Fed. 787.

2. Del Monte Co. v. Last Chance Co., 171 U. S. 55.

3. Grand Cent. Co. v. Mammoth Co., 29 Utah 490 .

4. Flagstaff Co. v. Tarbet, ante; see Cheesman v. Hart, 42 Fed: 98; Gibson v. Hjul, (Nev.) 108 Pac. 759.

5. Butte \& Boston Co. v. Societè, 23 Mont. 177; Grand Cent. Co. v. Mammoth Co., ante.

6. Anaconda Co. v. Heinze, 27 Mont. 161.

§ 113. Unlawful Intrusion. The owner of the top or apex may not, without the consent of the owner, legally invade the surface of ground adversely held, nor subterraneously explore such ground for the purpose of ascertaining the probable continuance of his vein or lode therein. ${ }^{1}$

2. Exception. It is not unlawful to place the location monuments upon adjacent lands, the property of others, without their consent, for the purpose of securing the extra-lateral right for an irregularly shaped piece of ground having the top or apex of a vein or lode therein. ${ }^{2}$

1. St. Louis Co. v. Mont. Co., 194 U. S. 235 ; Patten v, Conglomerate Co., 35 L. D. 617.

2. Del Monte Co. v. Last Chance Co., 171 U. S. 55; see \$17714-15, ante.

\section{CHAP'TER XVII.}

\section{MILL-SITES.}

\$116. In general-limitations-character of land-mining and milling purposes-who may locate-location-annual expenditure-patent.

$\S 116$. In General. Non-mineral land not adjacent to a vein or lode, ${ }^{1}$ but which may be in contact with the side line of a lode claim, ${ }^{2}$ not within the limits of a Congressional land grant ${ }^{3}$ nor within reserved or appropriated territory, ${ }^{4}$ may, to the extent of 5 acres, be located for "mining and milling purposes." 5

2. Limitations. A mill-site cannot be appropriated merely for water ${ }^{6}$ nor for the purpose of securing timber growing upon the land; ${ }^{7}$ but both a mill-site and a water right may be located upon the 
same tract of land. ${ }^{8}$ Satisfactory and sufficient reason should exist for the inclusion of more than one millsite in an application for patent for a group of claims. ${ }^{9}$ If there be several mill-sites applied for they should not, perhaps, aggregate more than 5 acres. ${ }^{10}$

The law makes no provision for acquiring land as a mill-site additional to or in connection with an existing mill-site. ${ }^{11}$

3. Character OF LAND. The character of the land must be determined of the date the right attached to the mill-site, as changed conditions in the character of the ground cannot affect the right of the mill-site elaimant. ${ }^{12}$

4. Mining and Milling Purposes. The term "mining and milling purposes" means more than a colorable use. ${ }^{13}$ The land must be used in good faith in connection with the ostensible purpose for which it was located. ${ }^{14}$ Whether the land is so "used and occupied" 15 is a question of both law and fact. ${ }^{16}$

5. Who May Locate. The right to locate a millsite is limited to the proprietor of a non-contiguous vein or lode or the owner of a quartz mill or reduction works, not owning a mine in connection therewith. ${ }^{17}$

6. Location. In the ordinary sense a mill-site is not a mining claim ${ }^{18}$ although in the case of a townsite patent it was held to be within the term "any" mining claim or possession held under existing laws." 19 Other than in the matter of discovery it should be located in the same manner as a placer claim. ${ }^{20}$

7. AnNuAL Expenditure. There is no specific time within which a mill-site shall commence to be used as such ${ }^{21}$ nor is annual expenditure required thereon. ${ }^{22}$

8. Patent. A mill-site is subject to patent independently or in conjunction with one or more mining claims ${ }^{23}$ upon proof of its non-mineral character ${ }^{24}$ 
and its reasonable use for mining, milling or smelting purposes. ${ }^{25}$

1. Rev. Stats., § 2337.

2. Yankee Mill-site, 37 L. D. 674.

3. Keystone Co. v. Nev., 15 L. D. 259 ; Mongrain v. N. P. R. Co., 18 L. D. 105.

4. Hamburg Co. v. Stephensin, $17 \mathrm{Nev} .450$.

5. Rev. Stats., §2337.

The mining act of California provides that: The proprietor of a vein or lode claim or mine, or the owner of a quartz mill or reduction works, or any person qualified by the laws of the United States, may locate not more than five acres of non-mineral land as a mill site. Such location shall be made in the same manner as hereinbefore required for locating placer claims. C. C. S., $1426 \mathrm{j}$. The locator of a mill-site claim or location shall, within thirty days from the date of his location, record a true copy of his location notice with the county recorder of the county in which such location is situated, for which service the recorder shall receive a fee of one dollar. C. C., $\$ 1426 \mathrm{k}$.

6. Cyprus Mill-site, 6 L. D. 706 .

7. Two Sisters Lode, 7 L. D. 557; see U. S. v. Iron Co., 128 U. S. 673, E. M. Palmer, 38 L. D. 294.

8. Chas. Lennig, 5 L. D. 190.

9. Alaska, C. Co., 32 L. D. 128; Brick Pomeroy, 34 L. D. 320 ; Hard Cash, 34 L. D. 325.

10. J. B. Hoggin, 2 L. D. 755 ; see Heckla Co., 12 L. D. 75; Alaska C. Co., ante.

11. Heckla Co., ante.

12. Cleary v. Skiffich, 28 Colo. 362.

13. Hard Cash, ante.

14. Hartman v. Smith, 7 Mont. 19.

15. Rev. Stats., § 2337 .

16. S. P. Mines v. Vaicalda, 79 Fed. 886.

17. Rev. Stats., § 2337 .

18. Helena Co. v. Dailey, 36 L. D. 144; Cleary v. Skiffich, ante.

19. Hartman v. Smith, ante; see Cleary v. Skiffich, ante.

20. See C. C. \$1426j; Burns v. Clark, 133 Cal. 634.

21. Valcalda v. S. P. Mines, 86 Fed. 91.

22. Alaska C. Co., ante.

23. Rev. Stats., \$2337; see Cleary v. Skiffich, ante.

24. Hard Cash, ante.

25. Valcalda v. S. P. Mines, ante; Cyprus mill-site, ante; Two Sisters Lode, ante; Le Neve Mill-site, 9 L. D. 460 ; Mint Lode, 12 L. D. 624 ; Alaska C. Co., ante.

\section{CHAP'TER XVIII.}

\section{placer Claims.}

\$119. In general-location rights-known vein-subsequent discovery-conflicting locations-area of placer locations-discovery, marking and annual expenditurepatent-joint entry-effect of excluding known vein--limitation. 
$\S 120$. Petroleum oil claims-rights preserved-withdrawalswithdrawals in California-the power of the President -act of June 25, 1910-construction of statute-protection under saving clause-opinion of the writerpeculiar conditions-questions arising from conditions - conflict of authority-established law-forcible entry and detainer-possessio pedis-conveyance before discovery-departmental ruling-confusion in land titles - rule of property-remedial legislation-ambiguity in statute-construction of statute-validity of withdrawals-discovery-insufficient discovery-possession while making discovery-good faith-single discovery -scripping.

$\S 120$ a. Natural gas-definition.

\$121. Mining for oil-no limit-unlawful drainage-possession of land not possession of oil-nuisance-Californian provision-commencing operations-diligence -test well-partnership-limitation-partition-damages.

\$ 121a. Recent Californian legislation.

$\$ 122$. Oil-land leases-implied covenants-forfeiture-vested right-paying quantity-taxation.

$\S 123$. Hydraulic claims-restriction-constitutionality of act - mining without restriction.

$\$ 124$. Dredge claims-in general-location.

$\$ 124$ a. Recent Californian legislation-uplands.

$\$ 125$. Stone claims - in general - character of locationtimber and stone act-agricultural entry-sale by entryman-return of fees.

$\S 126$. Salt claims-character of deposit-limitation-nitrate and borate lands.

$\S 127$. Tailings-deposition of tailings.

\section{§119. In General. The term "placer claim"} means ground that includes valuable deposits not in place, that is not fixed in rock. ${ }^{1}$ It is a location of a tract of land for the sake of loose deposits of mineral upon or near the surface. ${ }^{2}$

2. Location Rights. A valid placer location confers a qualified right to the surface, ${ }^{3}$ although no person can legally enter thereon and prospect for any vein or lode therein without the consent of the placer claimant. ${ }^{4}$ It also confers the right to all placer deposits and to all veins or lodes not known to exist at the time of the location $;^{5}$ except where the claim was located prior to the act of 1872 "known veins" within its area are included therein. ${ }^{6}$

3. Known Vein. A vein or lode is not known to exist within the location by the mere existence of out- 
croppings ${ }^{7}$ but by ascertainment of its mineral value ${ }^{8}$ or by exploration and common repute. ${ }^{9}$

4. Subsequent Discovery. The subsequent discovery of veins or lodes within a placer location and their successful working does not affect the good faith of the placer claimant. That must be determined by what was known at the time of the location. ${ }^{10}$

4a. Conflicting Locations. No reason can be suggested for permitting a junior locator of a placer claim to lay his lines across a claim already located. ${ }^{11}$

A known vein or lode may be located by another party either before or after the issuance of the placer patent, if not included therein ${ }^{12}$ or if not held by the placer claimant under a separate lode location. ${ }^{13}$

5. Area of Placer Lochtion. A placer location must not exceed 20 acres for an individual ${ }^{14}$ or a corporation ${ }^{15}$ nor exceed 160 acres for an association of not less than eight bona fide locators. ${ }^{16}$

6. Discovery, Marking and Annual ExpendiTURE. Discovery, marking of the location and the annual expenditure thereon are the same for each separate location, irrespective of its size. ${ }^{17}$

7. Patent. Placer claims are subject to patent under like circumstances and conditions and upon similar proceedings as are provided for lode claims. ${ }^{18}$

8. JoINT ENTrY. Two or more persons or associations of persons having contiguous placer claims of any size although such claims may be less than 10 acres each may make joint entry thereof. ${ }^{19}$

9. Effect of Excluding Known Vein. A placer claimant when in possession of a known vein within the limits of his location must include it within his placer application for patent, otherwise it is conclusively assumed he has no right thereto. ${ }^{20}$

10. Limitation. A vein or lode claim within a placer location is limited, for patent, to 25 feet on each side of the vein or lode claim. ${ }^{21}$ 
See $\$ 99-8$, ante.

1. U. S. v. Iron Co., 128 U. S. 673.

2. Clipper Co. v. Eli Co., 194 U. S. 220 ; see Webb v. American Co., 157 Fed. 203; Henderson v. Fulton, 35 L. D. 652; E. M. Palmer, 38 L. D. 294.

3, Rev. Stats., \$2333; Mt. Rosa Co. v. Palmer, 26 Colo. 56; see Clipper Co. v. Eli Co., ante; Mutchmor v. McCarty, 149 Cal. 603. See also U. S. v. Rizzinelli. 182 Fed. 675.

4. Clipper Co. v. Eli Co., ante.

5. See note 3 , ante.

6. Cranes Gulch Co. v. Scherrer, 134 Cal. 350.

7. U. S. v. Iron Co., ante; Brownfield v. Bier, 15 Mont. 403.

8. Migeon v. Mont. Cent. Co., 77 Fed. 249; see \$50-34, ante.

9. Iron Co. v. Mike \& Starr Co., 143 U. S. 431; see $\$ 50-34$, ante; see note 20 , post.

10. U. S. v. Iron Co., ante; Clipper Co. v. Eli Co., ante.

11. Stenfjeld v. Espe, 171 Fed. 825 .

12. Reynolds v. Iron Co., 116 U. S. 687; Mt. Rosa Co. v. Palmer, ante.

13. Noyes v. Clifford, 37 Mont. 138.

14. Rev. Stats., $\$ 2331$; see $\S 170$, post.

15. Igo Bridge Ex. Placer, 38 L. D. 281; see Gird v. Cal. Oil Co., 60 Fed. 531 .

16. Rev. Stats., $\S 2330$; see $\S 170$, post.

17. Miller v. Chrisman, 140 Cal. 440 ; McDonald v. Mont. Wood Co., 14 Mont. 88; Whiting v. Straup, 17 Wyo. 1; Moffat v. Blue River Co., 33 Colo. 142. Discovery work does not mean the doing of assessment work. It does not mean the pursuit of capital to prosecute the work. It does not mean any attempted holding by cabin, lumber pile or unused derrick. It means the diligent, continuous prosecution of the work with the expenditure of whatever money may be necessary to the end in view. McLemore v. Express Co., 158 Cal. 559; see Bishop v. Baisley, 28 Or. 119.

The Californian Mining Act provides that "The location of a placer claim shall be made in the following manner: By posting thereon, upon a tree, rock in place, stone, post or monument, a notice of location, containing the name of the claim, name of locator or locators, date of location, number of feet or acreage claimed, such a description of the claim by reference to some natural object or permanent monument as will identify the claim located, and by marking the boundaries so that they may be readily traced; provided, that where the United States survey has been extended over the land embraced in the location, the claim may be taken by legal subdivisions and no other reference than those of said survey need be required and the boundaries of a claim so located and described need not be staked or monumented. The description by legal subdivisions shall be deemed the equivalent of marking. C. C., $\$ 1426 \mathrm{c}$.

A true copy of the notice posted must be recorded in the office of the proper County Recorder within 30 days after posting such notice. C. C. $\$ 1426$ d.

18. Rev. Stats., $\$ 2329$; see $\$ 211-2$, post.

19. Rev. Stats., $\$ 2330$.

20. Reynolds v. Iron Co., ante; Noyes v. Clifford, ante. A quartz claim upon a patented placer depends for its 
ultimate validity and value upon its claimant's ability to prove that at the time application for patent was made the placer claim contained a known vein. Kift v. Mason, 42 Mont. 232; see Iron Co. v. Campbell, 135 U. S. 286 .

21. Rev. Stats., $\S 2333$; Noyes v. Clifford, ante.

$\S 120$. Petroleum Oil Claims. Lands chiefly valuable for petroleum or other mineral oils are subject to location and patent under the provisions of the law relating to placer claims, ${ }^{1}$ unless within area temporarily withdrawn by executive order previous to or under the provisions of the Act of Congress, approved June 25, 1910.2

2. Rights Preserved. The rights of any person who, at the date of any order of withdrawal is a bona fide occupant or claimant of oil or gas-bearing land, and who, at such date, is in diligent.prosecution of work leading to discovery of oil or gas, is not affected or impaired by such order, so long as he shall continue in the diligent prosecution of such work. ${ }^{3}$

3. WithdRAWALS. Withdrawals are either a law made or a joint resolution passed by Congress, or they are a proclamation by the President, or an order issued by officers of the land department or other proper officer. Thereby public lands are withdrawn from location, sale and entry under the laws affecting the public domain. They are sometimes made in recognition of what is about to occur and sometimes in recognition of what has occurred. ${ }^{4} \mathrm{~A}$ withdrawal by proclamation of the President takes effect from its date. An executive withdrawal operates from the time it is made or when received at the local land office, as its terms may dictate. ${ }^{5}$

4. Withidrawals in California. On September 27, 1909, by order of the President, the withdrawal affecting the bulk of the Californian oil fields was made. Whether this withdrawal is valid or not is a much mooted question. In the opinion of the writer, 
the President had no authority to withdraw such lands. ${ }^{6}$

5. The Power of the President. The laws of the United States provide that land chiefly valuable for mineral shall be disposed of in a certain way. A withdrawal of lands from entry is a repeal or suspension of this statute as far as the withdrawn lands are concerned, and it is, of course, obvious that it is beyond the power of the President to repeal, or to suspend any statute unless expressly or impliedly given that authority in the statute itself. 7

6. ACt of June 25, 1910. In order to cure such want of authority the act of June 25, 1910, was passed, expressly enabling the President to make withdrawals of lands containing oil, gas, phosphates and coal. ${ }^{8}$

7. Construction of Statute. Numerous questions may arise over the construction of this statute. It has not yet been passed upon by the courts, and the opinions here expressed are solely those of the writer.

8. Protection Under Saving Cluatse. (a) The first question is, Who are protected under the saving clause of said statute? The statute requires continuous and actual operation on the land; hence the performance of the annual assessment work, the erection of houses, the building of roads or derricks unless followed by the commencement and prosecution of work would not be sufficient. ${ }^{9}$ If, however, a road or a. water line were necessary for operation, and was being constructed at the time of the withdrawal, and, after withdrawal, was diligently carried to completion and the actual work of drilling diligently begun and carried on thereafter, it would be sufficient.

(b) If the withdrawals prior to this statute were invalid, of course, the diligent prosecution of work is only to be considered at the time of the subsequent withdrawal, and if work were being diligently prose- 
cuted when the subsequent withdrawals were made, the situation at the time of the earlier and invalid withdrawals is immaterial.

(c) If the withdrawals prior to the statute were valid, and the locator was not at work at that time, but was at work when the withdrawal was made of the same land after the passage of the statute, what is the situation?

9. OPINION OF THE Writer. In the opinion of the writer, the locator is protected if his location was made prior to the first withdrawal. The statute is disjunctive, it protects everyone at work at the time of any withdrawal "heretofore or hereafter made." If the President made a withdrawal before the passage of the Act, and again after the passage of the Act, and the locator is at work at the time of the second withdrawal, he is certainly at work at withdrawal "hereafter" made.

The reason we confine it to locations prior to the first withdrawal is again based on the peculiar phraseology of the statute which ex industria recites, "This -Act shall not be construed as a recognition, abridgment or enlargement of any asserted rights or claims initiated upon any oil or gas-bearing lands after any withdrawal of such lands made prior to the passage of this Act," thereby clearly taking locations after the first withdrawal, provided, of course, it was valid, out of the protection of the statute.

10. Peculiar Conditions. Although "oil lands" may be located as placer claims a complication has arisen in applying the law relating to such locations which is not of very much importance in mining for solid minerals. To constitute a valid location of either class there must be a discovery of mineral. In mining for solid minerals the discovery ordinarily follows closely after or may even precede the location. On supposed oil lands it is often a matter of years from 
the date of the location to the date of actual discovery. During all this time no vested rights have accrued to the locator as against the government, and two very vital and complicated questions have arisen.

11. Questions ARISING from Conditions. The first of these questions is to what extent is the location protected against third parties pending discovery? The second question is can the eight locators of an association claim convey their interests to one person prior to discovery, without destroying the validity of the location?

12. Conflict of Authority. On both the above points there was such a hopeless conflict of authority that remedial legislation was absolutely essential.

13. Established Law. There is, of course, the general and well established proposition of mining law that while a locator is in possession, at work in good faith, no person can make a valid location against him by a forcible, surreptitious or clandestine entry.

14. Forcible Entry and Detainer. The above proposition can not only be established by well founded authorities in mining law, but in default of such decisions could be maintained under the forcible entry and detainer statutes. Up to the decision in Hanson v. Craig (170 Fed. 62), diligent work at any part of the location protected the whole claim.

15. Possessio Pedis. In the case just cited, however, the court confined the locator to his actual possession which effectually destroys the force of the former decisions by confining the oil land operator to such a small portion of land as to render his claim practically valueless.

16. Conveyance Before Discovery. The question of the effect of conveyance before discovery within an association oil placer claim did not arise until the year 1909. The courts have repeatedly and consistently recognized the rights of the eight locators 
to vest all their interests in one person prior to discovery ${ }^{10}$ and the land department has issued patents for thousands of acres of land when this condition existed. ${ }^{10 a}$

17. Departmental Ruling. In 1909, the Secretary of the Interior abandoned the prior course of conduct of the land department and held that if the eight locators conveyed before discovery to one person the location no longer carried 160 acres upon subsequent discovery, but only 20 acres. ${ }^{11}$

18. Confusion in Land Titues. The question of reversing the above decision has been very vigorously urged upon the Secretary, owing to the tremendous confusion in land titles resulting therefrom; but without effect.

19. Rule of Property. The expression of the Secretary's opinion in that case was not only unnecessary to the decision but was contrary to prior court decisions and reversed the practice of the land department. The contrary has long been established as a rule of property and should be allowed to stand for that reason even if it were conceded that the strict literal construction of the statute as laid down in the case last cited were correct.

19a. Remedial Legislation. The doctrine of the H. H. Yard case (38 L. D. 59) and the Bakersfield Fuel \& Oil Company's ease. (39 L. D. 460) has been definitely reversed by the Act of March 2, 1911,12 in so far as the lands claimed contain petroleum, mineral oil or natural gas. In all such cases, therefore, a conveyance by the eight locators of an association claim to a lesser number, even though prior to discovery, does not defeat the right to patent 160 acres on a single discovery therein. All other placer locations still remain subject to the limitation announced in the Yard case. 
19b. Ambiguity in Statute. The recent statute, just referred to, is somewhat ambiguous. It only applies where "lands were not at the time of the inception of development on or under such claim withdrawn from mineral entry." The words "inception of development" will necessarily be construed in connection with the said enabling act of June 25, 1910, so as to mean the beginning of diligent prosecution of work leading to discovery of oil.

19c. Construction of Statute. The phrase "withdrawn from mineral entry" will be the basis of vigorous controversy with the land department, as to whether it refers to withdrawals made prior to said enabling act, or only to withdrawals made thereafter and in accordance therewith.

19d. Validity of Withdrawals. On final analysis the decision depends upon the validity of the earlier withdrawal. If the withdrawal was beyond the power of the President, it cannot be regarded for any purpose.

20. Discovery. In making the location the locator necessarily takes into consideration surface indications, geological formations, proximity to known mines or wells produçing oil. ${ }^{13}$

21. Insufficient Discovery. The fact that surface indications of petroleum oil or the geological formation of the country may be such as scientific research and practical experience has shown to be likely to lead to petroleum oil, in paying quantities, does not constitute a sufficient "discovery" within the meaning of the law. In order to support the location oil must be actually discovered within the limits of the location. Neither surface indications of the existence of oil therein, however strong, nor the existence of oil upon adjoining lands is sufficient discovery. ${ }^{14}$ 
22. Possession While Making Discovery. While the locator, who has made his location in good faith is prospecting it for minerals, complies with the law as to expenditures and is in actual possession, the land covered by his location is not open to location by others. ${ }^{15}$

23. Good FaIth. The location must be made in good faith and the locator must use proper diligence to make discovery of oil. If he does not do so he will lose his rights under his location to parties who may afterwards, in good faith, acquire rights. ${ }^{16}$

24. Single Discovery. A single discovery of oil is sufficient when made in a well common to contiguous oil claims, provided the well does not deflect in its downward course. ${ }^{17}$

25. ScripPING. Adverse rights can be acquired by "scripping" only after the selector or "scripper" has shown by affidavit, filed in the proper land office, that the land located or selected by him is not in any manner occupied adversely to him. That opportunity has been given to prove the mineral character of the land by notice of the application published in a newspaper nearest to the claim, posted upon the land included in the selection and upon each and every non-contiguous tract thereof. 18

1. 29 Stats. 526. All lands containing petroleum are not subject to location, but only such as are "chiefly valuable therefor." This is a subject of proof. If the oil is in such limited quantities that it cannot be worked at a profit, it is not "chiefly valuable" for its oil. Bay v. Oklahoma Co., 13 Okla. 425. Petroleum is a mineral substance obtained from the earth by the process of mining, and the land from which it is obtained may with propriety be called mining land. People v. Bell, 237 Ill. 332 . That gilsonite should be located as a "lode claim," see Webb v. American Co., 157 Fed. 203. For boring of oil and salt wells in Washington, see Pierce's Wash. Code, § 6454 .

2. Enabling Act. The President may, at any time in his discretion temporarily withdraw from settlement, location, sale, or entry any of the public lands of the United States including the District of Alaska and reserve the same for water-power sites, irrigation, classification of lands, or other public purposes to be speci- 
fied in the orders of withdrawals, and such withdrawals or reservations shall remain in force until revoked by him or by an Act of Congress.

§2. That all lands withdrawn under the provisions of this Act shall at all times be open to exploration, discovery, occupation, and purchase, under the mining laws of the United States, so far as the same apply to minerals other than coal, oil, gas, and phosphates: Provided, That the rights of any person who, at the date of any order of withdrawal heretofore or hereafter made, is a bona fide occupant or claimant of oil or gas-bearing lands, and who, at such date, is in diligent prosecution of work leading to discovery of oil or gas, shall not be affected or impaired by such order, so long as such occupant or claimant shall continue in diligent prosecution of said work: And provided further, That this Act shall not be construed as a recognition, abridgment, or enlargement of any asserted rights or claims initiated upon any oil or gas-bearing lands after any withdrawal of such lands made prior to the passage of this Act: And provided further, That there shall be excepted from the force and effect of any withdrawal made under the provisions of this Act all lands which are, on the date of sich withdrawal, embraced in any lawful homestead or desert-land entry theretofore made, or upon which any valid settlement has been made and is at said date being maintained and perfected pursuant to law; but the terms of this proviso shall not continue to apply to any particular tract of land unless the entryman or settler shall continue to comply with the law under which the entry or settlement was made; And provided further, That hereafter no forest reserve shall be created, nor shall any additions be made to one heretofore created within the limits of the States of Oregon, Washington, Idaho, Montana, Colorado, or Wyoming, except by Act of Congress.

§ 3 . That the Secretary of the Interior shall report all such withdrawals to Congress at the beginning of its next regular session after the date of the withdrawals, 36 Stats. 847. As to the effect of this act upon coal land selections, see Milton S. Gunn, 39 L. D. 561.

3. See note 2, ante; St. Paul Ry. Co. v. Keslik, 19 L. D. 275.

4. Hans Oleson, 28 L. D. 25.

5. Hiram C. Smith, 33 L. D. 677; see N. P. R. Co. v. Pettit, 14 L. D. 591; U. P. R. Co. v. Peterson, 28 L. D. 32.

6. See Lockhart v. Johnson, 181 U. S. 516; Gibson v. Anderson, 131 Fed. 39; U. S. v. Blendauer, 122 Fed. $703 ;$ O. \& C. R. R. Co. v. Willamette Co., 26 L. D. 546.

7. Gibson v. Anderson, ante; see notes 2 and 6 , ante.

8. See note 2 , ante. See Instructions, 39 L. D. 544.

9. McLemore v. Express Co., 158 Cal. 559. No hard or fast rule can be established fixing the amount of work which must be done by the occupant prosecuting the work leading to the discovery of oil or gas. Each case must rest upon its own showing of diligence when application for patent is filed. The chief of field division should be advised of all such applications and should be prepared to submit showing, if possible, be- 
fore the issuance of final certificate of entry. Instructions, 39 L. D. 544.

10. Miller v. Chrisman, 140 Cal 440 ; s. c. 197 U. S. 313 ; Week v. Snook, 144 Cal. 139; Whiting v. Straup, 17 Wyo. 1; but see H. H. Yard, 38 L. D. 59 .

10a. See Bakersfield Fueí Oil Co., 39 L. D. 460.

11. H. H. Yard, ante; see, also, Bakersfield Fuel \& Oil Co., ante.

12. Remedial Act. An act to protect the locators in good faith of oil and gas lands who shall have effected an actual discovery of oil or gas on the public lands of the United States, or their successors in interest.

That in no case shall patent be denied to or for any lands heretofore located or claimed under the mining laws of the United States containing petroleum, mineral oil, or gas solely because of any transfer or assignment thereof or of any interest or interests therein by the original locator or locators, or any of them, to any qualified persons or person, or corporation, prior to discovery of oil or gas therein, but if such claim is in all other respects valid and regular, patent therefor, not exceeding 160 acres in any one claim shall issue to the holder or holders thereof, as in other cases: Provided, however, That such lands were not at the time of inception of development on or under such claim withdrawn from mineral entry. 36 stats., p. 1015.

13. Weed v. Snook, ante; Olive Land Co. v. Olmstead, 103 Fed. 568; see Biglow v. Conradt, 159 Fed. 868; see note 2 , ante.

14. Nev. Sierra Co. v. Home Oil Co., 98 Fed. 673; Olive Land Co. v. Olmstead, ante; Miller v. Chrisman, ante. It is the common experience of persons of ordinary intelligence that petroleum in valuable quantities is not found on the surface of the ground nor is it found in paying quantities seeping from the earth. Valuable oil is found by drilling or boring into the interior of the earth, and either flows or is pumped to the surface, and until some body or vein has been discovered from which the oil can be brought to the surface, it cannot be considered of sufficient importance to warrant a location under the mineral laws. Bay v. Oklahoma Co., ante. The disclosure of a stratum of bituminous sand stone or shale from which a small quantity of oil seeps, not sufficient to impress the land with any value for mining purposes, does not constitute a sufficient discovery to support a valid mining location. So. Western Co. v. A. \& P. R. Co., 39 L. D. 335 . To constitute a discovery there must be some thing more than conjecture, hope or indications. New England Co. v. Congdon, 152 Cal. 211.

15. Weed v. Snook, ante. One who in good faith makes his location, remains in possession, and with due diligence prosecutes his work toward a discovery, is fully protected against all form of forcible, fraudulent, surreptitious or clandestine entries or intrusions upon his possession. Such entry must always be peaceable, open and above board, and made in good faith. or no right can be founded upon it. McLemore v. Express Co., ante. 
16. Phillips v. Brill, 17 Wyo. 26; see McLemore v. Express Co., ante.

17. Phillips v. Brill, ante. That a single discovery in a shaft common to two lode claims is insufficient; see Reynolds v. Pascoe, 24 Utah 219 ; but see Upton v. Larkin, 7 Mont. 449; Tiggeman v. Mrzlak, 40 Mont. 19.

18. I socation, 36 L. D. 278 ; John M. Rankin, 36 L. D. 522.

$\S 120$ a. Natural Gas. Natural gas is a fluid mineral substance, subterraneous in its origin and location, possessing in a restricted degree the properties of underground waters, and resembling water in some of its habits. Unlike water it is not generally distributed. Its physical occurrence is in limited quantities only, within circumscribed areas of greater or less extent. But the difference between natural gas and underground waters, whether flowing in channels or percolating the earth, is so marked that the principles which the courts apply to questions relating to the latter are not adapted to the adjustment of the difficulties arising from conflicting interests in the former. $^{1}$

1. Manf. Co. v. Indiana Co., 155 Ind. 461; see $\S 121$, post.

$\S 121$. Mining for Oil. The mining for mineral oils or natural gas cannot safely be conducted by awaiting developments of nearby land of similar character, as those substances, because of their wandering nature, belong to the owner of the land only so long as they remain therein. ${ }^{1}$

2. No Limit. There is no limit to the particular territorial area beneath the surface from which oils or gas may be drawn through any opening. ${ }^{2}$

3. Unlawful Drainage. The owner of superincumbent land cannot, lawfully, drain the property of another of its oils or gas simply for the purpose of depreciating its mineral value. ${ }^{3}$

4. Possession of Land Not Possession of OIL. Possession of the land is not necessarily the possession of the oils or gases that may be thereunder. ${ }^{4}$ The loss of the right to control the surface is not necessarily a 
loss of the right to mine. These may still be extracted through working thereunder, or upon adjacent territory. 5

5. Nuisance. Drilling or operating oil wells within navigable waters or upon the sea shore may constitute a nuisance, ${ }^{6}$ or upon un-navigable waters may be a trespass. ${ }^{7}$

6. Californian Provision. An oil well which is not drilled or which may be abandoned in violation of the provisions of an act entitled "An Act to prevent injury to oil, gas or petroleum-bearing strata or formations by the penetration or infiltration of water therein," will be declared to be a public nuisance. ${ }^{8}$

7. Commencing Operations To commence operations is the performance of some act which has a tendency to produce an intended result. ${ }^{9}$

8. Diligence. To prosecute drilling with due diligence to success or abandonment means, that there must be a product capable of division between the parties in the proportions mentioned in the lease. Unless this is done, drilling is not prosecuted to success. ${ }^{10}$

9. Test Well. A test well is one that determines not only the presence of petroleum oil but its commercial value considering its abundance and accessibility. The information resulting should be such as a prudent and experienced investor would desire to know before expending his capital in labor or improvements for the profitable working of the property. ${ }^{11}$

10. Partnership. Where co-locators or other tenants in common of oil lands or leases thereof actually engage in working the property and share according to the interest of each, the profit and loss, the partnership relation exists between them, though there is no express agreement between them to be partners or to share profits or loss. 
The presumption in such a case would be that of a mining partnership rather than an ordinary one, in the absence of an express agreement forming an ordinary partnership. ${ }^{12}$

11. Limitation. The authority of one member of a mining partnership to bind the other partners is limited; and without authority a partner cannot borrow money, execute notes, or accept bills of exchange, nor can a general superintendent or manager do so. The latter can bind the partners only in things that are necessary in the transaction of the particular business and which are usual and customary in such business. ${ }^{13}$

12. Partition. Partition of oil and gas owned by co-owners separate from the surface cannot be decreed except by sale and division of the proceeds. A judicial partition thereof by assignment of the oil and gas under sections of the surface is void. ${ }^{14}$

13. Damages. Although the title to oil in place is not in the lessee he may recover damages from one, who without his consent enters upon the demised premises during the time of the lease, drills wells and removes and sells oil therefrom. ${ }^{15}$

1. Brown v. Spilman, 155 U. S. 665 ; Acme Oil Co. v. Williams, 140 Cal. 681; S. P. R. Co. v. S. F. Sav. Union, 146 Cal. 290 ; Westmoreland Co. v. DeWitt, $130 \mathrm{~Pa}$. St. 235. As to distinction between things ferae naturae and oil and gas see Ohio Oil Co. v. Indiana, 177 U. S. 190; Atty. Gen. v. Hudson Co., 70 N. J. Eq. 695; Kansas Nat. Gas Co. v. Haskell, 172 Fed. 545.

2. S. P. R. Co. V. S. F. Sav. Union, ante; Brookshire Co. v. Casmalia Co., 156 Cal. 211; see $\$ 121 \mathrm{a}$.

3. Ohio Oil Co. v. Indiana, ante; Chesley v. King, 74 Me. 164; Westmoreland Co. v. DeWitt, ante.

The obvious difficulty in establishing the amount of oil or the amount diverted therefrom by the wells on adjacent lands would be a serious obstacle to the recovery of adequate damages at law. Brewster v. Lanyon Co., 140 Fed. 801 ; see $\$ 85$, note 19 , ante.

4. Ohio Oil Co. v. Indiana, ante; Acme Co. v. Williams, ante; S. P. R. Co. v. S. F. Sav. Union, ante; Westmoreland Co. v. DeWitt, ante; Kiser v. McLean, 67 W. Va. 294; see Katz v. Walkinshaw, 141 Cal. 116.

5. S. P. R. Co. v. S. F. Sav. Union, ante. 
6. S. F. Sav. Union v. Petroleum Co., 144 Cal. 134; see Yates v. Milwaukee, 77 U. S. 497; Shively v. Bowlby, 152 U. S. 1; Jas. W. Logan, 29 L. D. 395; Argillite Co.. 29 L. D. 585; Alaska Co. v. Barbridge, 1 Alaska 311; Long Beach Co. v. Richardson, 70 Cal. 206; Dana v. Jackson St. Wharf Co., 31 Cal. 118.

7. See Kirby v. Potter, 138 Cai. 686.

8. The Californian legislative provisions as to drilling and abandonment of oil wells are as follows:-

$\S 1$. It shall be the duty of the owner of any well now drilled or that may be drilled in the state of California on lands producing or containing oil, gas or petroleum, to properly case such well or wells, with metal casing in accordance with most approved methods, and to effectually shut off all water overlying or underlying the oil-bearing strata and to effectually prevent any water from penetrating such oil-bearing strata.

$\S 2$. It shali be the duty of the owner of any well referred to in section 1 of this act, before abandoning the same to withdraw the casing therefrom, and to securely fill such well with clay, earth or cement mortar, or other good and sufficient materials, used alone or in suitable combination, and thoroughly pack and tamp the same into such well to a point as far above the upper oil-bearing strata as the commissioner hereinafter provided for may decide shall be necessary, and while withdrawing the casing therefrom to effectually and permanently shut off and exclude all water underlying and overlying said oil-bearing strata, and to the satisfaction of the commissioner, whether any oil-bearing strata has been encountered or not.

$\S 3$. It shall be the duty of the owner of any well referred to in section 1 of this act, to keep a careful and accurate $\log$ of the drilling of such well, such log to show the character and depth of the formations passed through or encountered in the drilling of such well, and particularly to show the location and depth of the water-bearing strata together with the character of the water encountered from time to time, and to show at what point such water was shut off, if at all, and if not so state in such log, and show the depth at which oil-bearing strata is encountered, the depth and character of the same, and whether all water overlying and underlying such oil-bearing strata was successfully and permanently shut oft so as to prevent the percolation or penetration into such oil-bearing strata: said record of well to be kept on file and subject to the inspection of hereinafter mentioned commissioner at any time during business hours.

\& 4. The term "owner" as herein used shall mean and include each and every person, persons, partnership, co-partnership, association or corporation owning, leasing, managing, operating, drilling or possessing any well mentioned in sections 1 and 2 of this act: either as principal or principals, lessee or lessees of such principal or principals, contractor or contractors, and their and each of their employees. The term "oil-bearing strata" as herein used shall mean and include any bed, seam or stratum of rock or sand 
or other material which contains, includes, or yields earth oil, rock oil, or petroleum oil or natural gas or either of them.

In order to carry out the provisions of sections 1 and 2 of this act, upon petition of three or more operating oil companies, within the county, it shall be the duty of the board of supervisors of said county to appoint a commissioner who shall be a practical oil man, whose term of office shall be until December 31st of the year following time of appointment or until his successor is appointed.

The duties of said commissioner shall be to see that the provisions of this act shall be enforced.

The compensation of said commissioner shall be fixed by the board of supervisors and shall be paid out of the general county fund.

Upon the filing of a complaint with said commissioner alleging the violation of any of the provisions of sections 1 or 2 of this act, it shall be the duty of the hereinbefore mentioned commissioner of the county, if so requested by the complainants, to make or cause to be made, a thorough investigation of the well in question, to determine whether or not any of the provisions of this act have been violated and for such purpose he is hereby empowered to appoint all necessary agents and assistants to conduct such examination and such agents and assistants may enter upon the premises where such well is situated and may take charge of such well for the purpose of making such investigations. If the defendant in the action shall be convicted of a violation of any of the provisions of sections 1 or 2 of this act, he shall, in addition to the penalties hereafter set forth pay all reasonable and proper costs incident to the making of such investigations.

Any well drilled and abandoned, in violation of sections 1 or 2 of this act is hereby declared a public nuisance.

If any well, under the provisions of sections 1 or 2 of this act be declared a public nuisance, it shall be the duty of the commissioner of the county in which such well is situated to enter upon the premises, take possession of such well and to abate said nuisance and to take all necessary steps to prevent the percolation or penetration of water into the oil-bearing strata. He shall keep an accurate account of the expense of such work and all expenses so incurred shall be a charge against the owner of such well and a lien upon the same.

Any person violating the provisions of this act shall be guilty of a misdemeanor.

Any owner of any well referred to in sections 1 or 2 of this act, who refuses to permit the commissioner to inspect the same or who wilfully hinders or delays the commissioner in the performance of his duty is guilty of a misdemeanor.

An act to prevent injury to oil, or petroleum-bearing strata, or formations by infiltration or intrusion of water therein approved March 24, 1903, is hereby repealed. Cal. Stats. 1909 , p. 586. 
9. Fleming Co. v. So. Penn. Co., 37 W. Va. 645; Duffield v. Russell, 19 Ohio C. C. 266; see Henderson v. Ferrell, $183 \mathrm{~Pa}$. St. 547.

10. Kennedy v. Crawford, $138 \mathrm{~Pa}$. St. 561.

11. Petroleum Co. v. Coal Co., 89 Tenn. 381.

12. Childers v. Neely, 47 W. Va. 70 ; see $\S 58$, ante.

13. Id.; see Randall v. Meridith, 76 Tex. 669 .

14. Hall v. Vernon, 47 W. Va. 297.

15. Backer v. Penn Lub. Co., 162 Fed. 627 ; see $\$ 122$, note 7 , post.

\section{§121a. Recent Californian Legislation. Under a} recent Californian legislative enactment the wilful waste of natural gas into the atmosphere is deemed a misdemeanor, punishable by both fine and imprisonment. ${ }^{1}$

See $\S 120$ a, ante.

1. § 1. All persons, firms, corporations, and associations are hereby prohibited from wilfully permitting any natural gas wastefully to escape into the atmosphere. $\S 2$. All persons, firms, corporations and associations digging, drilling, excavating, constructing or owning or controlling any well from which natural gas flows shall upon abandonment of such well, cap or otherwise close the mouth of or entrance to the same in such a manner as to prevent the unnecessary or wasteful escape into the atmosphere of such natural gas. And no person, firm, corporation or association owning or controlling land in which such well or wells are situated shall wilfully permit natural gas flowing from such well or wells wastefully or unnecessarily to escape into the atmosphere.

§ 3. Any person, firm, corporation or association who shall violate any of the provisions of this act shall be deemed guilty of a misdemeanor, and upon conviction thereof shall be punished by a fine of not more than $\$ 1,000$, or by imprisonment in the county jail for not more than one year, or by both such fine and imprisonment.

$\S 4$. For the purposes of this act each day during which natural gas shall be wilfully allowed wastefully or unnecessarily to escape into the atmosphere shall be deemed a separate and distinct violation of this act.

$\S 5$. All acts or parts of acts in conflict herewith are hereby repealed.

$\S 6$. This act shall take effect immediately. proved March 25, 1911.) Cal: Stats. 1911, p. 499.

(Ap-

$\S 122$. Oil Land Leases. Because of the peculiar nature of petroleum oil, leases for lands of that character are governed by different principles from leases of other classes of real property. ${ }^{1}$ 
2. Construction. This class of leases is construed most strongly against the lessee and favorably to the lessor ${ }^{2}$ and the law.will imply conditions to attain the end sought by its execution. ${ }^{3}$

3. Implied Covenants. Where a lease of oil lands, with royalty to the lessor on the product is the sole and only consideration therefor it is necessarily implied, as of the essence of the contract, that the lessee shall work the wells with reasonable dispatch, for their mutual advantage ${ }^{4}$ and to prevent drainage by adverse operations in the vicinity of the demised land. ${ }^{5}$

4. Forfeiture. If these conditions are not performed the lessor is warranted in re-entering and taking possession of the premises and terminating the lease. If the right of forfeiture could not be exercised under such circumstances, a lessor would be at the mercy of the lessee. ${ }^{6}$

5. Vested Right. When oil is found the right to produce it becomes a vested right and the lessee will be protected in extracting it, agreeably to the terms of the lease. ${ }^{7}$

6. Paying Quantity. The phrase "paying quantity" is to be construed with reference to the operator, and by his judgment when exercised in good faith: ${ }^{8}$ There must also be taken into consideration the distance to market and the expense of marketing in determining whether oil can be marketed at a reasonable profit. ${ }^{9}$

7. Taxation. Mining rights and privileges under an oil lease are subject to taxation separately from and in addition to the interest or estate of the lessor, whether the fee is in the United States or in the State within which the claim may lie. ${ }^{10}$

See $\S 61$, ante.

1. Acme Oil Co. v. Williams, 140 Cal. 681.

2. Huggins v. Daley, 99 Fed. 606; Superior Oil Co. v. Mehlin, (Okla.) 108 Pac. 545.

3. Acme Oil Co. v. Williams, ante; see $\$ 61-4$, ante. 
4. Id. Daughetee v. Ohio Oil Co., 151 Ill. A. 102; Bettman v. Harness, 42 W. Va. 433; Parish Fork Co. v. Bridgewater Co., 51 W. Va. 583.

5. Aye v. Philadelphia Co., 193 Pa. St. 451; Kleppner v. Lemon, 198 Pa. St. 581; Parish Fork Co. v. Bridgewater Co., ante.

6. Acme Oil Co. v. Williams, ante.

7. Brookshire Co. v. Casmalia Co., 156 Cal. 211; Dickey v. Coffeyville Co., 69 Kan. 106; Colgan v. Forest Co., 194 Pa. St. 234; see Huggins v. Daley, ante; Backer v. Penn. Lub. Co., 162 Fed. 627; Florence Co. v. Orman, 19 Colo. A. 79; Rawlings v. Armel, 70 Kan. 778; Wagner v. Mallory, 169 N. Y. 501. Oil and gas, while in the earth, unlike solid minerals, are not the subject of ownership distinct from the soil, and the grant of the oil and gas, therefore, is a grant, not of the oil that is in the ground, but such a part as the grantee may find, and passing nothing that can be the subject of an ejectment or other real action. Kolachny v. Galbreath (Okla.), 110 Pac. 902; see Payne v. Neuval, 155 Cal. 46. The term "grant" may be synonymous with the term "lease." Raynolds v. Hanna, 55 Fed. 783.

8. Young v. Forest Co., $194 \mathrm{~Pa}$. St. 243; Summerville v. Apollo Co., $207 \mathrm{~Pa}$. St. 334; Manhattan Co. v. Carrell, 164 Ind. 526 ; see Tucker v. Watts, 25 Ohio C. C. 320.

9. Iams v. Carnegie Co., 194 Pa. St. 72 .

10. Graciosa Oil Co. v. Sta. Barbara Co., 155 Cal. 140; see Barnes v. Bee, 138 Fed. 476; Con. Coal Co. v. Baker, 135 IIl. 545; Md. City Co. v. Goodspeed Co. (Kan.), 109 Pac. 1002. See $\S 67-12$, ante.

$\S 123$. Hydraulic Claims. In California hydraulic mining is defined by legislative enactment as "mining by means of the application of water under pressure through a nozzle against a natural bank." 1

2. Restriction. Hydraulic mining is not of itself unlawful but is restricted within certain areas because detrimental to other interests. ${ }^{2}$ Lands within the San Joaquin and Sacramento River Systems within the State of California may be mined only under the provisions of the Congressional act of March 1, 1892. ${ }^{3}$

3. Constitutionality of Act. The above act has been declared to be constitutional. ${ }^{4}$

4. Mining Without Restriction. Mining on lands within the State of California, outside of the above mentioned areas may be carried on wherever and whenever the same will not result in material injury to navigable streams, or to land adjacent thereto. ${ }^{5}$ 
1. C. C., $\$ 1425$; see also Woodruff v. N. Bloomfield Co., 18 Fed. 753 , in which hydraulic mining is judicially defined as "the process by which a bank of gold bearing earth and rock is excavated by a jet of water, discharged through the converging nozzle of a pipe, under a great pressure, the earth or debris being carried away by the same water, through sluices, and discharged on lower levels into the natural streams and water courses below, where the gravel or other material of the bank is cemented, or where the bank is composed of masses of pipe-clay, it is shattered by blasting with powder"; see, also, U. S. v. N. Bloomfield Co., 53 Fed. 625 ; U. S. v. Lawrence, 53 Fed. 633.

2. N. Bloomfield Co. v. U. S., 88 Fed. 664; Yuba Co. v. Cloke, 79 Cal. 239.

3. 27 Stats. 507; Amended, 34 Stats. 1001; see N. Bloomfield Co. v. U. S., ante.

4. N. Bloomfield Co. v. U. S., ante.

5. C. C., § 1424 .

\section{§ 124. Dredge Claims - In General. Mining} rights cannot be acquired under the mining act in the bed or within or upon the banks of a navigable river. ${ }^{1}$

The bed of an un-navigable river is open to location and patent, as public land, when the opposite banks thereof have not passed into private ownership. Proprietors bordering on such streams, unless restricted by the terms of their grant from the government, hold to the center of the stream, notwithstanding the running of meander lines on the banks thereof, as the true boundary of the land is the thread of the stream. ${ }^{2}$

2. Location. When the bed of an un-navigable river is subject to location ${ }^{3}$ it is sufficient, under the mining act, to mark the location by the posting of a notice of location on some natural object in the stream, ${ }^{4}$ or on the bank, ${ }^{5}$ giving the measurements of the claim, identifying the stream and showing a definite relation between the stream and the object on which the notice is posted. ${ }^{6}$

1. Lockhart v. Johnson, 181 U. S. 516; Jas. W. Logan, 29 L. D. 395 ; Argillite Co., 29 L. D. 585.

2. St. Paul Co. v. Schurmeier, 74 U. S. 272 ; Hardin v. Jordan, 140 U. S. 371; Horne v. Smith, 159 U. S. 40; John P. Hoel, 13 L. D. 588; J. H. Lessard, 13 L. D. 724 ; Max Loibl, 21 L. D. 429; Wm. Rablin, 2 L. D. 764 ; Lux v. 
Haggin, 69 Cal. 255; Kirby v. Potter, 138 Cal. 686. The rules and laws controlling government surveys are not involved in the case of a private grant deed of a portion of a larger tract owned by the grantor. Freeman v. Bellegarde, 108 Cal. 179 ; see $\S 35-6$, ante.

3. Wm. Rablin, ante.

4. McKinley Creek Co. v. Alaska United Co., 183 U. S. 563.

5. Haws v. Victoria Copper Co., 160 U. S. 303.

6. McKinley Creek Co. v. Alaska United Co., ante.

§124a. Recent Californian Legislation. Under a legislative enactment in California, in effect April 14, 1911, the right to mine minerals contained in the waters of any stream or lake in that state may not be gained, in any manner, except by lease or express permission of the state. Such lease or permission cannot be granted for a longer period than 25 years. $^{1}$

2. UPLANDS. A leasehold interest, not exceeding 25 years, is the only lawful way of extracting minerals from land uncovered by the recession or drainage of the waters of inland lakes when the covering waters are so impregnated with minerals as to be valuable for the purpose of extracting such minerals. ${ }^{2}$

1. Cal. Stats. 1911, p. 904.

2. Cal. Stats. 1911, p. 903 .

\section{$\S 125$. Stone Claims-In General. Land chiefly} valuable for building stone and not reserved for the benefit of the public schools or donated to any state may be acquired by location and patent under the provisions of the law in relation to placer mining claims. ${ }^{1}$

2. Character of Location. Non-mineralized stone lying in vein formation must be located as a placer claim, ${ }^{2}$ but if it be mineralized and constitute "rock in place" it must be located as a lode claim. ${ }^{3}$

3. Timber and Stone Act. Surveyed public land that does not contain a valuable mineral deposit and is uninhabited, unfitted for cultivation and valuable chiefly for timber or stone may be entered under the provisions of the "Timber and Stone act." 4 
4. Agricultural Entry. Where land is entered under the provisions of that act it is immaterial whether it can be marketed at a profit or not. In that event it is in the nature of an "agricultural entry." 5

5. Sale by Entriman. An entryman may legally sell his claim after entry and before the final certificate is issued by the Land Department, although the entry was made in behalf of another. ${ }^{6}$

6. RetUrn of Fees. The fee required to be paid at the time of the presentation of a timber and stone sworn statement should be returned to the applicant in all cases where for any reason other than fraud, the local officers reject such sworn statement at the time of the presentation or at any time prior to the submission of proof in pursuance of the published notice. ${ }^{7}$

1. 27 Stats. 348 ; Forsythe v. Weingart, 27 L. D. 680 ; Henderson v. Fulton, 35 L. D. 652 .

2. Henderson v. Fulton, ante.

3. E. M. Palmer, 38 L. D. 294.

4. 20 Stats. 89; Amended, 27 Stats. 348; Regulations, 37.L. D. 289; Duncan v. Archambault, 35 L. D. 498; see Hammel v. Salzman, 17 L. D. 496 ; Forsythe v. Weingart, ante; Gallagher v. Gray. 35 L. D. 90 . The land is appraised by smallest legal subdivisions at their reasonable value, but at not less than $\$ 2.50$ an acre. Each of such subdivisions must be of the character subject to disposition under the law. This may be determined at any time before the actual issuance of the patent. Albert R. Pfau, Jr., 39 L. D. 359 . Land upon which there is a growth of timber useful for mining purposes and so located with reference to mines as to give it a value for such purposes greater than its value for agricultural purposes is timber land within the meaning of the Act of June 3,1878, and subject to entry under that Act. Grenon v. Miller, 39 L. D. 577. Mere errors of judgment by the applicant as to the character of the land, or as to its unoccupancy will not prevent repayment of the purchase money if the application be rejected. Frank G. Bell, 39 L. D. 191.

5. Narver v. Eastman, 34 L. D. 123 ; see Forsythe v. Weingart, ante.

6. U. S. v. Biggs, 211 U. S. 507 . See U. S. v. Doughten, 186 Fed. 226. That a transfer by the patentee to a corporation consisting of himself and family will not constitute the corporation a bona fide purchaser, see U. S. v. Smith, 181 Fed. 545.

7. Instructions, 39 L. D. 573. 
$\S 126$. Salt Claims-In General. Under a special act all unoccupied public lands of the United States containing salt springs or deposits of salt, ${ }^{1}$ that is common salt, or chloride of sodium, in its various forms of existence or deposit ${ }^{2}$ may be located and patented under the provisions of the law in relation to placer claims. ${ }^{3}$

2. Character of Deposit. It is the actual production of salt, by the usual processes that brings a saline spring or deposit within the purview of the law. 4

3. Limitation. The same person may not locate nor patent more than one claim. ${ }^{5}$

4. Nitrate aND Borate Lands. Lands chiefly valuable for nitrate or borate deposits are not within the provisions of the special act. ${ }^{6}$

1. 31 Stats. 745 ; as to saline lands in New Mexico see Terr. of N. M., 35 L. D. 1; in the Philippine Islands see 33

Stats. 695; in Utah see 28 Stats. 109 ; as excepted from

the grant to S. P. R. Co. see Elliott v. S. P. R. Co., 35 L. D. 149 .

2. Terr. of N. M., ante; Lovely Placer Claims, 35 L. D. 426.

3. 31 Stats. 745 .

4. Lovely Placer Claims, ante; Jeremy Co. v. Thompson, 20 L. D. 229 .

5. 31 Stats. 745 .

6. Min. Lands, 1 L. D. 561 .

\$127. Tailings-In General. Tailings deposited on public land initiate no right to dump thereon, ${ }^{1}$ and such land so covered may be located as a placer claim. ${ }^{2}$

2. Deposition of Tallings. Mining debris, sand, gravel, sediment or other material may not be deposited so as to injure the land of another, without his consent. ${ }^{3}$

1. Miser v. O'Shea, 37 Or. 231; see Jones v. Jackson, 9 Cal. 237; O'Keiffe v. Cunningham, 9 Cal. 589.

2. Jones v. Jackson, ante; Rogers v. Cooney, 7 Nev. 213; see Ritter v. Lynch, 123 Fed. 930; Miser v. O'Shea, ante.

3. Woodruff v. N. Bloomfield Co., 18 Fed. 753; Travis Placer Co. v. Mills, 94 Fed. 909; Otaheite Co. v. Dean 102 Fed. 929; Hobbs v. Amador Co., 66 Cal. 161; Yuba Co. v. Cloke, 79 Cal. 239; Fitzpatrick v. Montgomery, 20 Mont. 181; Carson v. Hayes, 39 Or. 97. 


\section{CHAPTER XIX.}

\section{TIMBER LANDS.}

\$129. In general-mineral land-mineral location-subsisting location-subsequent discovery.

$\S 130$. Timber cutting on mineral land-purposes-restriction -exceptional right.

$\S 131$. Timber cutting in forest reserves.

$\$ 132$. Timber cutting on Indian lands-criminal offense.

$\$ 133$. Timber cutting on abandoned military reservations.

\$134. Damages-bona fide purchaser.

$\S 129$. In General. Surveyed land within the public domain chiefly valuable for timber but unfit for cultivation at the time of sale, ${ }^{1}$ non-mineral in character, unoffered, unreserved, unappropriated, uninhabited and without improvements (except for ditch or canal purposes), save such as' were made by or belong to the claimant ${ }^{2}$ may be acquired under the provisions of the "Timber and Stone Act." 3

2. Mineral Land. If the land be mineral in character the title thereto together with the timber thereon may be acquired under the mining laws. ${ }^{4}$

3. Mineral Location. Until the final entry of the land as "timber land" it is subject to mineral location. ${ }^{5}$

4. Subsisting Location. Where, at the time of the issuance of a "timber patent" there was a valid subsisting mining claim upon the land covered thereby the patentee will be held as the trustee for the mineral claimant. ${ }^{6}$

5. Subsequent Discovery. Discovery of mineral subsequent to the issuance of such a patent will inure to the benefit of the patentee. ${ }^{7}$

1. U. S. V. Budd, 144 U. S. 154; Thayer v. Spratt, 189 U. S. 346; Gibson v. Smith, 18 L. D. 249; Johnson v. MacMillan, 22 L. D. 647; see. Instructions, 21 L. D. 67; see Bunker Hill Co. v. U. S. 178 Fed. 914.

2. Circular, 6 L. D. 114.

Improvements will not exclude land from disposal unless made and maintained under a bona fide occupation of the land, see Kingston v. Eckman, 22 L. D. 234. Abandoned mineral workings are no bar, see Chormicle v. Hiller, 26 L. D. 9-413. Burden of proof rests upon timber claimant. Peasely v. Whiting, 20 L. D. 24. 
3. 27 Stats. 88. As to timber lands in California, see U. S. v. Benjamin, 21 Fed. 285.

As to "all the public land states," see Circular, $15 \mathrm{~L}$. D. 360 .

4. Gallagher v. Gray, 35 L. D. 90.

5. See Mery v. Brodt, 121 Cal. 332.

6. Id.

7. See Shaw v. Kellogg, 170 U. S. 312; Cowell v. Lammers, 21 Fed. 200.

\section{$\S 130$. Timber Cutting on Mineral Land. Timber} on land belonging to the United States and known to be so valuable for its minerals as to justify expenditure for their extraction may be felled and removed by eitizens and bona fide residents (not railroad corporations) of the "mining states" and other mineral distriets of the United States. ${ }^{1}$

2. Purposes. The timber may be used for building, agricultural, mining, smelting, roasting of ores, or "other domestic purposes." 2

3. Restriction. The "cutting" is subject to such rules and regulations as the Secretary of the Interior may preseribe. ${ }^{3}$

4. Exceptional Right. The right to eut is exceptional and quite narrow. The party claiming it must prove it. 4 .

1, U. S. v. Plowman, 216 U. S. 372 , reversing s. c. 151 Fed. 1022 , based upon U. S. v. Basic Co., 121 Fed. 504 and U. S, v. Rossi, 133 Fed. 380.

2. 20 . Stats. 88 ; U. S. v. Price T. Co., 109 Fed. 239; Teller v. U. S., 113 Fed. 273 ; U. S. v. Edgar, 140 Fed. 655 ; U. S. v. United Verde Co., 196 U. S. 207; Gallagher v. Gray, 35 L. D. 90 ; Centerville. Co., 39 L. D. 80.

As to sale and use of timber on unreserved public land in Alaska, see Regulations, 36 L. D. 536; Instructions, 36 L. D. 73 .

3. 20 Stats., ante.

4. Instructions, 21 L. D. 67; Johnson v. MacMillan, 22 L. D. 647 ; U. S. v. Plowman, ante.

That a miner may cut timber in the ordinary working of his mining claim, see Gallagher v. Gray, ante; as to cutting timber necessary for the reduction of ores, see U. S. v. United Verde Co., ante.

$\S 131$. Timber Cutting in Forest Reserves. The timber (and stone) found upon forest reservations may be used free of charge, by bona fide settlers, min- 
ers, residents and prospectors for minerals, for fire wood, fencing, buildings, mining, prospecting and "other domestic purposes" as may be needed by such persons within the state or territory wherein such reservations may be located; as permitted by the Secretary of Agriculture under regulations prescribed by him. ${ }^{1}$

1. 30 Stats. 34 ; see 33 Stats. 628 ; U. S. v. United Verde Co., 196 U. S. 207; see Rules and Regulations, 24 L. D. 589;

U. S. v. Rizzinelli, 182 Fed. 675.

§ 132. Timber Cutting on Indian Lands. Where the fee remains in the United States, Indians residing on reservations or allotments may, from year to year, under such regulations as the President may prescribe fell, eut, remove, sell or otherwise dispose of the dead timber standing or fallen on such reservation or allotments for the sole benefit of such Indian or Indians. ${ }^{1}$

2. Criminal OfFense. Unlawful cutting of standing timber on such lands is a criminal offense. ${ }^{2}$

1. 25 Stats. 673 ; see 30 Stats. 501; Pine River Co. v. U. S., 186 U. S. 279 .

2. 25 stats. 166 .

\section{§133. Timber Cutting on Abandoned Military} Reservations. Timber cutting on an abandoned military reservation not restored to the public domain is unlawful. ${ }^{1}$

1. Fort Cameron Reserve, 2 L. D. 822.

§134. Damages. In an action to recover damages for cutting and carrying away timber from the public or Indian lands, the rules for assessing them are as follows. (1) When the defendant is a wilful trespasser, the full value of the property at the time of bringing the action, with no deduction for his labor and expense. (2) When the defendant is an unintentional or mistaken trespasser, the value at the time 
of the commission less the amount which such trespasser has added to its value. ${ }^{1}$

2. Bona fide Purchaser. A purchaser from a wilful trespasser, without notice of the wrong or the true ownership of the property, is only liable for the value thereof at the time of such purchase, and not for any labor or expense he may bestow upon it thereafter. $^{2}$

1. Woodenware Co. v. U. S., 106 U. S. 432 ; U. S. v. Williams, 18 Fed. 475.

2. U. S. v. Heilner, 26 Fed. 80 ; but see U. S. v. Bagnell Co., 178 Fed. 795; see, generally, U. S. v. Detroit Co., 200 U. S. 321.

\section{CHAPTER XX.}

\section{TOWNSITES.}

§ 135. In general-corporate authorities-county judge-trust $\S 136$. Adverse suits.

$\S 135$. In General. When public land, not subject to entry under the agricultural pre-emption laws, is settled upon and occupied as a townsite, it may be entered as such. ${ }^{1}$

2. Corporate Authorities. If the town or city be incorporated the entry may be made by the corporate authorities thereof. ${ }^{2}$

3. County Judge. If not incorporated the entry may be made by the judge of the county court for the county in which such town is situated. ${ }^{3}$

4. TRust. The latter entry is made in trust for the several use and benefit of the occupants thereof, according to their respective interests. ${ }^{4}$

5. Mineral Reservation. No title can be acquired under a townsite entry to any vein of gold, silver, cinnabar, copper, or lead, nor to any valid mining claim or possession held under existing law. ${ }^{5}$ Deposits not known to be of such extent and value as to justify expenditures for the purpose of extracting 
them at the time of the townsite entry will pass thereunder. ${ }^{6}$

6. Insufficient Mineral Right. A location will not be held to be a "valid mining claim and possession" where its claimant has had ample time and opportunity to show the mineral value of the land and has failed to do so. ${ }^{7}$ While a "mine" must be known to be such at the time of the townsite entry, although not in the possession of any person ${ }^{8}$ yet the possession of a mining claim upon which exploitation has been abandoned as unprofitable ${ }^{9}$ or mere indications of mineral before the entry ${ }^{10}$ will not defeat the townsite patent.

1. Rev. Stats., §2387. Townsites in Alaska, see Circular 33 L. D. 163 .

For a collection of statutes relating to townsites, see 38 L. D. 92 ; Townsite Reg., 38 L. D. 107; see Repinsky v. Hinchman, 181 Fed. 786 .

2. Rev. Stats., § 2387 .

3. Id.

4. Id. See Amador Co. v. Gilbert, 133 Cal. 51.

5. 26 Stats. 1101; see Steel v. St. Louis Co., 106 U. S. 447; Bonner v. Meikle, 82 Fed. 697; 38 L. D. 114; Poire v. Wells, 6 Colo. 406 , Traphagen v. Kirk, 30 Mont. 562.

That a placer claim may be used as a townsite; see Steel v. St. Louis Co., ante.

A "valid mining claim or possession" is any valid mining claim or possession held under existing law. Callahan v. James, 141 Cal. 291; see Blackmore v. Reilly, 2 Ariz. 442; Tombstone cases, 2 Ariz. 272. In controversies between mineral and townsite claimants the terms "lands known to be valuable for mineral," "mineral deposits," "known mines," "land containing known mines," are equivalent in meaning. If lands are known to be of that character at the time of the townsite entry no title thereto will pass thereunder. Brady's Mortgagee v. Harris, 29 L. D. 426.

6. Davis v. Weibbold, 139 U. S. 507; Dower v. Richards, 151 U. S. 658; Mill Side Lode, 39 L. D. 356.

7. Brophy v. O'Hare, 34 L. D. 596

8. Callahan v. James, ante.

9. Richards v. Dower, 81 Cal. 44; see Callahan v. James, ante.

10. Harkrader v. Goldstein, 31 L. D. 87.

$\S 136$. Adverse Suits. Adverse suits are not necessary between townsite and mineral claimants. ${ }^{1}$

1. Lalande v. Saltese, 32 L. D. 211; Nome \& Sinook Co. v. Townsite, 34 L. D. 276 ; Wright v. Town, 13 Wyo. 497; see Young v. Goldsteen, 97 Fed. 303. 


\section{CHAPTER XXI.}

\section{TUNNEI SITES.}

\$138. In general - beyond boundaries - assessment work location of tunnel-location of blind veins-priór location-adverse location-line of tunnel-no annual ex§ 139. Dump. penditure-abandonment-patent.

$\S 138$. In General. A tunnel site, sometimes termed a "mining claim," 1 may be located in unappropriated territory for the discovery of blind veins or lodes, not previously known to exist therein, but without inherent right in prosecuting such work to enter through property adversely held. ${ }^{2}$

2. Beyond Boundaries. A tunnel, outside of the boundaries of a lode claim may be run by the owner of the latter for the development of a vein or lode therein. ${ }^{3}$

3. Assessment Work. Work done in such a tunnel may be counted as assessment work upon a lode claim or a group of contiguous locations. ${ }^{4}$

4. Location of Tunnel. The mining act does not provide how a tunnel site shall be located. It leaves the matter to local statute or district rule. ${ }^{5}$

5. Location of Buind Veins. When discovered in the tunnel, blind veins or lodes may be located to the same extent and subject to the same proceedings as if discovered upon the surface, without further discovery. ${ }^{6}$ The tunnel claimants' rights thereto relate back to the date of the location of the tunnel-site. ${ }^{7}$

6. Prior Location. Blind veins within a prior lode location are not subject to any right in the tunnel claimant. ${ }^{\mathrm{s}}$

7. Adverse Locatron. A location of blind veins or lodes on the "line" of the tunnel, made by other parties, subsequent to the commencement of, and while work is being prosecuted on the tunnel is invalid. ${ }^{9}$ 
8. Line of Tunnel. The "line" of the tunnel is its width as designated by boundary marks. ${ }^{10}$

9. No Annual Expenditure. No "assessment work" is required on a tunnel-site.

10. Abandonments. Failure to prosecute work with reasonable diligence for 6 months is an abandonment of the right to all blind veins or lodes on the line thereof, not previously discovered by the tunnel claimant. ${ }^{11}$

11 Patent. A tunnel site cannot be patented. It may be made the subject of an "adverse" claim. ${ }^{12}$ Money expended in running the tunnel is counted in an application for patent for veins or lodes discovered therein at the rate of $\$ 500$ for each lode or vein applied for. ${ }^{13}$

1. Creede Co. v. Uinta Co., 196 U. S. 337; see Back v. Sierra Nev. Co., 2 Ida. (Hasb.) 420.

2. Calhoun Co. v. Ajax Co., 182 U. S. 499; St. Louis Co. v. Mont. Co., 194 U. S. 235; Fissure Co. v. Old Susan Co., 22 Utah 438.

3. Calhoun Co. v. Ajax Co., ante; Fissure Co. v. Old Susan Co., ante.

4. 18 Stats. 315 ; Hain v. Mattes, 34 Colo. 345.

5. Creede Co. v. Uinta Co., ante.

The Californian mining act provides that "The locator of a tunnel right or location, shall locate his tunnel right or location by posting a notice of location at the place or point of commencement of the tunnel, which must contain: First. The name of the locator or locators. Second. The date of the location. Third. The proposed course or direction of the tunnel. Fourth. A description of the tunnel, with reference to some natural object or permanent monument as shall identify the claim or tunnel right. C. C., $\$ 1426 \mathrm{e}$.

The boundary lines of the tunnel shall be established by stakes or monuments placed along the lines at an interval of not more than 600 feet from the face or point of commencement of the tunnel to the terminus of 3000 feet therefrom." C. C., $\$ 1426 \mathrm{f}$.

A true copy of the location notice must be filed with the proper county recorder within 30 days after posting the notice. C. C., \$1426g.

6. Calhoun Co. v. Ajax Co., ante.

7. Glacier Co. v. Willis, 127 U. S. 471; Enterprise Co. v. Rico-Aspen Co., 167 U. S. 108; Calhoun Co. v. Ajax Co., ante.

8. Calhoun Co. v. Ajax Co., ante.

9. Hope v. Brown, 11 Mont. 370.

10. Enterprise Co. v. Rico-Aspen Co., ante; Corning Co. v. Pell, 4 Colo. 507; Back v. Sierra Nev. Co., ante. 
11. Rev. Stats., $\$ 2323$; Enterprise Co. v. Rico-Aspen Co., ante; Hope v. Brown, ante.

12. Iron Co. v. Mike \& Starr Co., 143 U. S. 394; Creede Co. v Uinta Co., ante.

13. Zephyr Claims, 30 L. D. 510.

$\S 139$. Dump. There is no provision in the law whereby a tunnel-site claimant, as such, may acquire ground for dumping purposes prior to the discovery of a vein or lode within the tunnel area.

\section{CHAPTER XXII.}

\section{WATER RIGH'TS.}

$\$ 141$. Real property - what may be appropriated - volume and extent-public grants-private grants.

$\$ 142$. Rights of way.

$\$ 143$. Appropriation - different systems-compliance with local statute-no constructive appropriations-measure of right-non-user-adverse user-interruption of right-prescriptive right.

\$144. Diversion of water-adjacent water-pollution of water.

$\S 145$. Nuisance.

\$146. Tide lands-not subject to location-temporary possession.

$\S 141$. Real Property. Water rights are real property. ${ }^{1}$

2. What May Be Appropriated. All surplus waters over and above that necessarily used for the purpose of irrigation and reclamation of desert land; part of the public domain, together with the waters of all lakes, rivers and other sources of water supply upon the public land and not navigable, ${ }^{2}$ or elsewhere, when not appropriated, or in which no other person has or claims superior rights and interests, and by the latter only as far as there is a conflict, may be appropriated for mining purposes. ${ }^{3}$

3. Volume and Extent. The volume or extent of the water is immaterial. It may run upon or beneath the surface of the land ${ }^{4}$ but it must be separate and distinct from the soil, whether produced by percolation, filtration or otherwise. ${ }^{5}$ 
4. Public Grants. Grants of the public lands by the government are made subject to all water rights that may have previously accrued to any person other than the patentee. ${ }^{6}$

5. Private Grants. Conveyances of water rights or agreements in relation thereto must be in writing. ${ }^{\top}$

1. Bree v. Wheeler, 4 Cal. A. 109 ; see Parks Co. v. Hoyt, 57 Cal. 44; Ball v. Kehl, 95 Cal. 606; Wyatt v. Larimer Co., 18 Colo. 298; see, generally, Jennison v. Kirk, 98 U. S. 453; Howell v. Johnson, 89 Fed. 556; Mohl v. Lamar Co., 128 Fed. 776 . As to water rights in the Philippine Islands, see 33 Stats. 692.

2. 19 Stats. 377; Gutierres v. Albuquerque Co., 188 U. S. 545; Krall v. U. S., 79 Fed. 241.

3. U. S. v. Conrad Co., 156 Fed. 123; Duckworth v. Watsonville Co., 150 Cal. 520 ; see, generally, Schwab v. Beam, 86 Fed. 41; Rodgers v. Pitt, 129 Fed. 932; Davis v. Gale, 32 Cal. 26; Fair Play Co. v. Weston, 29 Colo. 125; Ripley v. Park, 40 Colo. 129; Cardelli v. Comstock Co., 26 Nev. 284; Crescent Co. v. Silver King Co., 17 Utah 444. In California it is unlawful for any person, firm, association, of corporation to transport or carry through pipes, conduits, ditches, tunnels, or canals the water of any fresh water lake, pond, brook, creek, river, or stream of that state into any other state, for use therein. Action may be brought through the attorney-general of the state to prevent such proceeding. Cal. Stats. 1911 , p. 271.

4. Cross v. Kitts, 69 Cal. 217; see Harrington v. Demaris, 46 Or. 111.

5. Wolfskill v. Smith, 5 Cal. A. 175 ; see S. P. R. Co. v. Dufour, 95 Cal. 615; see, generally, Cross v. Kitts, ante; Ely v. Ferguson, 91 Cal. 187; Sullivan v. N. Spy Co., 11 Utah 438; Dickey v. Maddux, 48 Wash. 411; see also Bear Lake Co. v. Garland, 164 U. S. 1.

6. Gutierres v. Albuquerque Co., ante; Smith v. Hawkins, 110 Cal. 122; Duckworth v. Watsonville Co., ante; see Shenandoah Co. v. Morgan, 106 Cal. 409; Sturr v. Beck, 6 Dak. 71; Nippel v. Forker, 26 Colo. 74.

The waters in a non-navigable stream flowing over the public lands is a part thereof and the national government can sell or grant the same or the use thereof separate from the rest of the estate under such conditions as may seem to it proper. Howell v. Johnson, ante; see Snyder v. Colo. Co., 181 Fed. 62.

7. See note 1 , ante.

$\S 142$. Rights of Way. Rights of way may be obtained through the public lands, forest and other reservations of the United States, and the national parks of California, for electrical plants, poles and lines for the generation and distribution of electrical power, 
etc., and for canals, ditches, pipes, pipe lines, flumes, tunnels or other water conduits, and for water plants, dams and reservoirs used to promote mining and for the reduction and milling of ores. ${ }^{1}$

1. 3 Stats. $790 ; 33$ Stats. 628 . See Instructions, 39 L. D. 334 .

§143. Appropriation. The appropriation and use of water are regulated by local statutes which vary in effect and detail. ${ }^{1}$

2. Different Systems. The different systems in effect in different states are termed the "California doctrine" and the "Colorado doctrine." 2

3. Compliance with Local Statute. The rights of the appropriator do not wholly depend upon his compliance with the provisions of the local statute $;^{3}$ a valid right may be acquired to water upon the public domain without strict observance thereof. ${ }^{4}$

4. No Constructive Appropriation. There can be no constructive appropriation of water. ${ }^{5}$

5. Measure of Right. It is the extent of the water and not the amount claimed in the notice of appropriation which is the measure of the appropriator's right. ${ }^{6}$ Actual user for a beneficial purpose is the true and only test touching the question whether or not the claim has ripened into a valid appropriation. ${ }^{7}$

6. NoN-USER. Non-user will not bar the right to water unless continued for the time which will bar an action to recover real property. ${ }^{8}$

7. Adverse User. An adverse use of water for the statutory period of limitation must be open, notorious, peaceable, continuous, and under a claim or color of right. The gradual and imperceptible encroachment by a subsequent appropriator will not raise the bar of the statute. ${ }^{9}$

8. Interruption of Right. If any act is done by other parties claiming the water that operates as an 
interruption, however slight, it prevents the acquisition of any adverse right. ${ }^{10}$

9. Prescriptive Right. The right acquired by prescription is only commensurate with the right enjoyed. The extent of the enjoyment measures the right. ${ }^{11}$

1. Snyder v. Colo. Co., 181 Fed. 62. (Californian law of Appropriation. C. C. $\S 1410-1422$.

$\$ 1410$. All water or the use of water within the State of California is the property of the people of the State of California, but the right to the use of running water flowing in a ravine or stream or down a canyon or ravine may be acquired by appropriation in the manner provided by law, provided that no water for the generation of electricity or electrical or other power may be appropriated for a longer period than 25 years, except by a municipal corporation, other than an irrigation district or a lighting district, or by an irrigation district when such electricity, electrical or other power is for use and distribution only within its own limits, and as subject to and mainly for the purpose of serving and carrying out irrigation or by a lighting district when such electricity, electrical or other power is for use and distribution only within its own limits. (Amended April 8, 1911.)

$\$ 1411$. The appropriation must be for some useful or beneficial purpose, and when the appropriator or his successor in interest ceases to use it for such a purpose, the right ceases.

$\S 1412$. The person entitled to the use may change the place of diversion, if others are not injured by such change, and may extend the ditch, flume, pipe or aqueduct by which the diversion is made to places beyond that where the first use was made.

$\S 1413$. The water appropriated may be turned into the channels of another stream and mingled with its water, and then reclaimed; but in reclaiming it the water already appropriated by another must not be diminished.

\$1414. As between appropriators, the one first in time is the first in right.

\$1415. A person desiring to appropriate water must post a notice in writing, in a conspicuous place at the point of intended diversion, stating therein:

1. That he claims the water there flowing to the extent of (giving the number) inches, measured under a four inch pressure;

2. The purposes for which he claims it, and the place of intended use;

3. The means by which he intends to divert it, and the size of the flume, ditch, pipe, or aqueduct in which he intends to divert it. A copy of the notice must, within ten days after it is posted, be recorded in the office of the recorder of the county in which it is posted. After filing such copy for record, the place 
of intended diversion or the place of intended use or the means by which it is intended to divert the water, may be changed by the person posting said notice or his assigns, if others are not injured by such change. This provision applies to notices already filed as well as to notices hereafter filed.

\$1416. Within sixty days after the notice is posted, the claimant must commence the excavation or construction of the works in which he intends to divert the water, or the survey, road or trail building necessarily incident thereto, and must prosecute the work diligently and uninterruptedly to completion, unless temporarily interrupted by snows or rain; provided, that if the erection of a dam has been recommended by the California debris commission at or near the place where it is intended to divert the water, the claimant shall have sixty days after the completion of such dam in which to commence the excavation or construction of the works in which he intends to divert the water; and provided further, that if it shall be necessary, by proceedings in eminent domain, to acquire water rights held by adverse riparian owners or to acquire sites for dams or power plants at the point of intended diversion or the point of intended use, as described in the notice of appropriation of said water, or if there shall be conflicting claims to the waters so appropriated, then the party so appropriating, or his assigns, shall have sixty days after the determination of legal proceedings by final judgment in which to commence to excavate or construct the works in which he intends to divert the water as provided in this section; and provided further, that if suits for such purpose are not already pending at the date of the passage of this act, they shall be commenced within sixty days after this act takes effect, and as to future appropriations of water, within sixty days after notice of such appropriation is posted as required by law; and such proceedings shall be prosecuted diligently to final judgment; but nothing in this act shall be construed to revive or renew appropriations of water heretofore made which have been abandoned and lost, as against subsequent claimants who have complied with this act. Amender (May 1, 1911) as to time for commencement of work by municipalities.

\$1417. By "completion" is meant conducting the waters to the place of intended use.

$\S 1418$. By a compliance with the above rules the claimant's right to the use of the water relates back to the time the notice was posted.

$\$ 1419$. A failure to comply with such rules deprives the claimants of the right to the use of the water as against a subsequent claimant who complies therewith.

$\S 1420$. Persons who have heretofore claimed the right to water and who have not constructed works in which to divert it, and who have not diverted nor applied it to some useful purpose, must, after this title takes effect and within twenty days thereafter, proceed as in this title provided, or their right ceases. 
$\S 1421$. The recorder of each county must keep a book, in which he must record the notices provided for in this title.

$\$ 1422$. If the place of intended diversion or any part of the raute of intended conveyance of water so claimed, be within, and a part of, any national park, forest reservation, or other public reservation, and be so shown in the notice of appropriation of said water, then the claimant shall have sixty days, after the grant of authority to occupy and use such park or reservation for such intended purpose, within which to commence the excavation or construction of said works; provided that within sixty days after the posting of said notice of appropriation, as provided in section 1415 of the Civil Code, the claimant shall in good faith commence (and thereafter diligently and continuously, except when temporarily interrupted by snow or rain, prosecute to completion) such surveys and other work as under the regulations governing such park or reservations, may be required as preliminary to, or for use with, an application for such authority; and provided also that the claimant shall in good faith on completion of said survey and preliminary work, apply to the officer, board or body, having charge of such park or reservation, for such authority, and shall thereafter, prosecute said application with reasonable diligence. See $\$ 141$, notes 3 and 6, ante.

The appropriation of water within the State of California for generating electricity or electrical or other power is subject to the provisions of an act of the legislature of that state, that went into effect on April 8, 1911. This act, among other things, regulates, limits, fixes the terms and conditions and provides the manner of procedure of its appropriation and use for such purposes. Cal. Stats. 1911, p. 813.

2. Willey v. Decker, 11 Wyo. 496; see Snyder v. Colo. Co., ante.

3. Wells v. Mantes, 99 Cal. 583.

4. S. P. Mines vo Valcalda, 79 Fed. 886.

5. Nev. Ditch Co. v. Bennett, 30 Or. 59.

6. Duckworth v. Watsonville Co., 150 Cal. 520.

7. Snyder v. Colo. Co., ante; Nev. Ditch Co. v. Bennett, ante.

8. Oviatt v. Big 4 Co.. 39 Or. 118 ; see Featherman v. Hennessy, (Mont.) 113 Pac. 751.

9. Union Co. v. Dangberg, 81 Fed. 73 ; Morris v. Beam, 146 Fed. 423.

10. Union Co. v. Dangberg, ante.

11. Id.

$\S 144$. Diversion of Water. Water appropriated under the provisions of a local statute may be diverted to the place of intended use although within the public lands or upon a subsequent homestead entry or claim. ${ }^{1}$ The point of diversion or the place or character of 
use $^{2}$ may be changed if without prejudice to preexisting or intervening rights. ${ }^{3}$

2. Adjacent Water. The right to water adiacent to a placer location does not necessarily attach thereto although it may be necessary for the successful working of the claim. ${ }^{4}$

3. Pollution of Water. Water may not be unreasonably polluted ${ }^{5}$ nor be used in a way detrimental to others. ${ }^{6}$

1. Wolfskill v. Smith. 5 Cal. A. 175.

2. Kidd v. Laird, 15 Cal. 162; Hargrave v. Cook, 108 Cal. 72; New Cache Co. v. Water Co., (Colo.) 111 Pac. 610; Meagher v. Hardenbrook, 11 Mont. 385.

3. Last Chance Co. v. Bunker Hill Co., 49 Fed. 430: Snyder v. Colo. Co., 181 Fed. 62. See Porters Bar Dredging Co.v. Beaudry, (Cal. A.) 115 Pac. 951.

4. Legatt v. Carroll, 30 Mont. 384: see Snyder v. Colo. Co., ante; see Schwab v. Beam, 86 Fed. 41; Davis v. Gale, 32 Cal. 26.

5. Crane v. Winsor, 2 Utah 248.

6. Woodruff v. N. Bloomfield Co., 18 Fed. 753 ; Williams v. Haile Co., (S. C.) 71 S. E. 26 .

§145. Nuisance. All unlawful intrusions upon a waterway for purposes unconnected with the rights of navigation or passage are nuisances. ${ }^{1}$

1. People v. Gold Run Co., 66 Cal. 138; see, generally, Travis Co. v. Mills, 94 Fed. 909; Alaska Co. v. Barbridge, 1 Alaska. 311; Jones v. Robertson, 116 Ill. 543; Lord v. Carbon Co., 38 N. J. Eq. 452.

§146. Tide Lands. Lands "under tide water" or "below high water mark," "lands flowed by the tide," and other expressions of similar import are usually employed in defining tide lands." The term "shore line" means mean high water line. ${ }^{2}$

2. Not Subject to Location. Lands under tide water are vested in the United States ${ }^{3}$ and are not subject to location under the mining laws. ${ }^{4}$

3. Temporary Possession. In the District of Alaska temporary possession of tide lands may be had for mining purposes. Such occupation is subject to such general limitations as may be necessary to ex- 
empt navigation from artificial obstruction. ${ }^{5}$ Mill-site locations may not be made in said district within 60 feet of the shore line of navigable waters. ${ }^{6}$

1. Shively v. Bowlby, 152 U. S. 1. In California the words "tide lands" do not apply to or include the shore, or any part thereof, or the bed, or any part thereof, of the ocean or of any navigable canal or stream or bay or inlet within that state, between ordinary high and low water mark. All such land over which the ordinary tide ebbs and flows is withheld from sale. Pol. C., §3443a; see Pearl Oyster Co. v. Heuston, 57 Wash. 533.

2. Nome T. Co., 29 L. D. 447. The "shore" is that ground that is between ordinary high and low water mark. Columbia Co. v. Hampton, 161 Fed. 60.

3. Shively v. Bowlby, ante.

4. Jas. W. Logan, 29 L. D. 395; Argillite Co., 29 L. D. 585.

5. 31 Stats. 325 .

6. Alaska C. Co., 32 L. D. 128.

\section{CHAPTER XXIII.}

\section{NATURAL OBJECT-PERMANEN'T MONUMENT.}

$\$ 149$. Natural objects-reference.

$\$ 150$. Permanent monuments.

$\$ 151$. Purpose-record-presumptions-burden of pyoof.

§149. Natural Objects. A natural object is any fixed natural object, as, an arm of the sea, bay, ${ }^{1}$. blazed tree, ${ }^{2}$ boulder ${ }^{3}$ buttes, cañon, ${ }^{4}$ mouth of a cañon, ${ }^{5}$ creek, ${ }^{6}$ croppings, ${ }^{7}$ gulch, ${ }^{8}$ the point of intersection of well known gulches, hill, inlet, lake or river, ${ }^{9}$ mounatains, ${ }^{10}$ mountain peaks, ${ }^{11}$ pillar of rock, ${ }^{12}$ ravine, ${ }^{13}$ ridge or hogsback, ${ }^{14}$ stream, ${ }^{15}$ the confluence of streams, ${ }^{16}$ tree, when marked, ${ }^{17}$ forked tree, ${ }^{18}$ stump of tree, ${ }^{19}$ waterfall or cascade. ${ }^{2 \theta}$

2. REFERENCE. It is not always possible to connect a location with a natural object. In such a case reference may be made to a permanent monument. ${ }^{21}$

1. Meydenbauer v. Stevens, 78 Fed. 787.

2. Drummond v. Long, 9 Colo. 538.

3. Gamer v. Glenn, 8 Mont. 371.

4. Meydenbauer v. Stevens, ante.

5. C. L. S. R. Co. v. San Garde, 7 Ida. 106.

6. McKinley Creek Co. v. Alaska United Co., 183-18. S. 563 ; Smith v. Cascaden, 148 Fed. 792. 
7. Daggett v. Yrekia Co., 149 Cal. 357.

8. Flavin v. Mattingly, 8 Mont. 242.

9. Meydenbauer v. Stevens, ante; Credo v. Highland Co., 95 Fed. 911; Johnson v. Dines, 13 Colo. 90.

10. Vougel v. Warsing, 146 Fed. 949.

11. Craig v. Thompson, 10 Colo. 517.

12. Daggett v. Yreka Co., ante.

13. Meydenbauer v. Stevens, ante.

14. Id.

15. Id.

16. Drummond v. Long, ante.

17. Allen v. Dunlap, 24 Or. 229.

18. Daggett v. Yreka Co., ante.

19. McKinley Creek Co. v. Alaska United Co., ante; Daggett v. Yreka Co., ante; Allen v. Dunlap, ante.

20. Meydenbauer v. Stevens, ante.

21. McIntosh v. Price, 121 Fed. 716. But a party in search of locatable ground has the right to rely upon finding the object or monument as named in the location notice. Duncan v. Eagle Rock Co., 48 Colo. 569; see $\S 185-3$, post.

\section{$\S 150$. Permanent Monuments. A permanent} monument may be any artificial distinctive mark or object of a lasting nature affixed to or carved from the soil or rock, as, for example, a city or town, ${ }^{1}$ depot, ${ }^{2}$ a race track inclosure, ${ }^{3}$ a named mining claim, ${ }^{4}$ permanent monuments of a mining claim,,$^{5}$ a cut or other excavation, as, a drift, ${ }^{6}$ prospect hole, ${ }^{7}$ shaft, $^{8}$ or tunnel; ${ }^{9}$ a government monument, ${ }^{10}$ monuments of stone, ${ }^{11}$ posts, ${ }^{12}$ stakes firmly planted in the ground, ${ }^{13}$ a pile of rocks, ${ }^{14}$ a road, ${ }^{15}$ the point of intersection of roads. ${ }^{16}$

1. McCann v. McMillan, 129 Cal. 350 .

2. Farmington Co. v. Rhymney Co., 20 Utah 363.

3. Tiggeman v. Mrzlak, 40 Mont. 19 .

4. Hammer v. Garfield Co., 130 U. S. 291; see Riste v. Morton, 20 Mont. 139; Baxter v. Pattrison, 3 N. M. 269.

5. Credo Co. v. Highland Co., 95 Fed. 911 ; So. Cross Co. v. Europa Co., 15 Nev. 383.

6. Meydenbauer v. Stevens, 78 Fed. 787.

7. Hansen v. Fletcher, 10 Utah 266.

8. Jupiter Co. v. Bodie Co., 11 Fed. 666.

9. Meydenbauer v. Stevens, ante.

10. Gird v. Cal. Oil Co., 60 Fed. 531; Green v. Garvin, $10 \mathrm{Cal}$. A. .330 .

11. Talmadge v. St. John, 129 Cal. 430.

12. Credo Co. v. Highland Co., ante.

13. Hammer v. Garfield Co., ante.

14. Temescal Co. v. Salcido, 137 Cal. 211.

15. McCann v. McMillan, ante.

16. Drummond v. Long, 9 Colo. 538. 
$\S 151$. Purpose. The purpose of requiring the record of a mining claim to contain a reference to a natural object or permanent monument ${ }^{1}$ is to furnish an initial or starting point for the identification of the location. ${ }^{2}$

2. RECORD. A record which contains no reference to a natural object or permanent monument is invalid ${ }^{3}$ and inadmissible in evidence for any purpose. ${ }^{4}$ The record, or possibly, the location, may be held to be void because of the vague character of the reference in the record to the natural object or permanent monument. ${ }^{5}$ But mere imperfections therein should not render either void. ${ }^{6}$ The reference should be intelligible, not delusive, meaningless, or misleading; ‘ it should identify the location with reasonable certainty. ${ }^{8}$ Whether the reference is sufficient is a question of fact $^{9}$ which may be aided by oral testimony. ${ }^{10}$

3. Presumptions. Generally speaking, any object, or monument that will serve to identify the location will be regarded as sufficient; but it is not conclusively presumed that the same exists or that the reference thereto sufficiently describes the location. ${ }^{11}$

In the absence of proof to the contrary it will be presumed that the object or monument referred to in the record exists, ${ }^{12}$ that it is well known ${ }^{13}$ and best serves to identify the location, ${ }^{14}$ whether it is on or off. the location, ${ }^{15}$ or was erected for the purpose of tying the location thereto. ${ }^{16}$

4. Burden of Proof. The burden of proof is upon the party claiming the insufficiency of the reference. ${ }^{\mathbf{1 7}}$

1. Rev. Stats., § 2324 .

2. Drummond v. Long, 9 Colo. 538; see Vogel v. Warsing, 146 Fed. 949 ; see, generaily, $\$ 190$, post.

3. Faxon v. Barnard, 4 Fed. 702 ; Fuller v. Harris, 29 Fed. 814; Mutchmor v. McCarty, 149 Cal. 603; see M'Intosh v. Price. 121 Fed. 716.

4. Golden Fleece Co. v. Cable Con. Co., 12 Nev. 312.

5. Faxon v. Barnard, ante; Gilpin Co. v. Drake, 8 Colo. 586 ; Drummond v. Long, ante; Brown v. Levan. 4 Ida. 794: 
Russell v. Chumasero, 4 Mont. 309; Deeney v. Minera! Creek Co., 11 N. M. 179.

6. Bennett v. Harkrader, 158 U. S. 441; Farmington Co. v. Rhymney Co., 20 Utah 363.

7. Dillon v. Bayliss, 11 Mont. 171.

8. Hammer v. Garfield Co., 130 U. S. 291; N. Noonday Co. v. Orient Co., 1 Fed. 522; Jupiter Co. v. Bodie Con Co., 11 Fed. 666; Brady v. Husby, 21 Nev. 453; Kahn v. Old Tel. Co., 2 Utah 174.

It is well recognized that the ties of mining claims to some natural object or permanent monument are not, and were not intended to be as accurate and correct as they would be if tied by a competent surveyor. If that were true very few, if any, of many hundreds of mining claims located in good faith by prospectors and miners would be valid. Bismark Co. v. No. Sunbeam Co., 14 Ida. 516.

9. Eilers v. Boatman, 111 U. S. 356 ; Bennett v. Harkrader, ante; Metcalf v. Prescott, 10 Mont. 283; Brady v. Husby, ante.

10. Drummond v. Long, ante.

11. Londonderry Co. v. United Gold Co., 38 Colo. 480; Duncan v. Eagle Rock Co., 48 Colo. 539.

12. Hammer v. Garfield Co., ante; Smith v. Cascaden, 148 Fed. 792.

13. Hammer v. Garfield Co., ante.

14. McCann v. McMillan, 129 Cal. 350.

15. N. Noonday Co. v. Orient Co., ante.

16. Brown $\dot{v}$. Levan, ante.

17. Kinney v. Fleming, 6 Ariz. 263. Monuments control courses and distances only where the monuments are clearly ascertained. Duncan v. Eagle Rock Co., ante; see Meydenbauer v. Stevens, 78 Fed. 787.

\section{CHAPTER XXIV.}

\section{DISCOVERY.}

$\$ 154$. In general-location not complete without discoveryrequisites of discovery-discovery may be insufficient -bisected discovery - single discovery in placer claim-place of discovery-absence of discovery.

\$ 155. Character of lođe discovery.

$\$ 156$. Development of discovery-local provisions-essential act of location-discovery shaft.

$\$ 157$. Proof of discovery - rule between rival claimants reason for rule-test-contests between mineral claimants - mineralogical and geological conditionssupplementary evidence-testimony-discovery point -expert testimony-conclusive testimony-negative testimony.

$\$ 158$. Loss of áiscovery-sale before discovery-sale after discovery.

$\S 154$. In General. Discovery is one of the sources of title to both lode and placer claims. ${ }^{1}$ It may be original or adopted ${ }^{2}$ but it must be actual. ${ }^{3}$ It can- 
not rest upon a mere guess, ${ }^{4}$ nor be based upon conjecture or the imaginary existence of mineral. ${ }^{5}$

2. Location Not Complete Without Discovery. No location is complete without discovery therein ${ }^{6}$ but it is not necessarily the first act of location. ${ }^{7}$ In the absence of an intervening right discovery subsequent to the other acts of location will validate the claim. ${ }^{8}$

3. Requisites of Discovery. There must be reasonable evidence of a vein or lode carrying mineral in a lode location or that it is valuable for placer mining if located as a placer claim. ${ }^{9}$

4. Discovery May Be Insufficientr. A discovery may be sufficient to sustain a location ${ }^{10}$ but may not be sufficient to sustain a claim of extra-lateral right, ${ }^{11}$ nor, in either a lode or placer location to defeat the claim of an "agricultural" claimant.12

5. Bisected Discovery. A single discovery bisected by an end line common to two lode claims may be sufficient. ${ }^{13}$

6. Single Discovery in Placer Claim. A single discovery is sufficient in each placer location, irrespective of the character of deposit or size of the location except that before patent each 10-acre tract therein found to be non-mineral may be excluded therefrom. ${ }^{14}$

7. Place of Discovery. Discovery may be made upon the surface, ${ }^{15}$ or in a tunnel, ${ }^{16}$ or in a shaft, ${ }^{17}$ or be deep in the ground. ${ }^{18}$ A secret underground discovery will not prevail against a previously located surface discovery. ${ }^{19}$

8. Absence OF Discovery. In the absence of discovery the locator's rights depend upon actual possession and diligent prosecution of the work of discovery. $^{20}$ Otherwise the claim is subject to location peaceably and openly made by another. ${ }^{21}$ 'The one first making the discovery has the full right to the claim. ${ }^{22}$ 
1. O'Reilly v. Campbell, 116 U. S. 418; Lawson v. U. S. Co., 207 U. S. 1; Chrisman v. Miller, 197 U. S. 313; Nev. Sierra Oil Co. v. Miller, 97 Fed. 681; Nev. Sierra Oil Co. v. Home Oil Co., 98 Fed. 673; Steele v. Tanana Co., 148 Fed. 678; Lange v. Robinson, 148 Fed. 799; New England Co. v. Congdon, 152 Cal. 211.

The term "discovery" has a technical meaning in mining. Upton v. Larkin, 7 Mont. 449; see McLemore v. Express Co., 158 Cal. 559. A mineral discovery subsequent to the grant of the title by the United States does not affect the title nor give the discoverer any right. Shaw v. Kellogg, 170 U. S. 312; Janette W. Riley, 33 L. D. 68.

2. Book v. Justice Co., 58 Fed. 106; Nev. Sierra Oil Co. v. Home Oil Co., ante; Willeford v. Bell, (Cal.) 49 Pac. 6; McMillen v. Ferrum Co., 32 Colo. 38; Hayes v. Lavagnino, 17 Utah 185.

3. King v. Amy Co., 152 U. S. 222; Chrisman v. Miller, ante; Smith v. Newell, 86 Fed. 56; Tuolumne Co. v. Maier, 134 Cal. 583; Copper Globe Co. v. Allman, 23 Utah, 410 .

4. Erhardt v. Boaro, 113 U. S. 527; Larkin v. Upton, 144 U. S. 19 ; Waterloo Co. v. Doe, 56 Fed. 685; Copper Globe Co. v. Allman, ante.

5. King v. Amy Co., ante; Ambergris Co. v. Day, 12 Ida. 108.

6. Creede Co. v. Uinta Co., 196 U. S. 337; McLemore v. Fxpress Co., ante; see also Nev. Sierra Oil Co. v. Home Oil Co., ante; Walton v. Wild Goose Co., 123 Fed. 209; Miller v. Chrisman, 140 Cal. 440; Dwinnell v. Dyer, 145 Cal. 12; Harper v. Hill, (Cal.) 113 Pac. 162; Healey v. Rupp, 37 Colo. 25; Cedar Canyon Co. v. Yarwood, 27 Wash. 271.

That discovery and assessment work are not equivalent, see McLemore v. Express Co., ante.

7. Creede Co. v. Uinta Co., ante; Nev. Sierra Oil Co. v. Home Oil Co., ante; Uinta Co. v. Creede Co., 119 Fed. 164; Waskey v. Hammer, 170 Fed. 31; Heman v. Griffith, 1 Alaska 264; Brockbank v. Albion Co., 29 Utah 367; New England Co. v. Congdon, ante; Cedar Canyon Co. v. Yarwood, ante.

8. Jupiter Co. v. Bodie Con. Co., 11 Fed. 666; Nev. Sierra Oil Co. v. Home Oil Co., ante; Beals v. Cone, 27 Colo. 473; Healey v. Rupp, ante.

9. Chrisman v. Miller, ante; Cascaden v. Bartolis, 146 Fed. 739; Lange v. Robinson, ante; Steele v. Tanana Co., ante; Harper v. Hill, ante.

10. O'Donnell v. Glenn, 8 Mont. 248; see also Cascaden v. Bartolis, ante; Muldrick v. Brown, 37 Or. 185.

11. Grand Cent. Co. v. Mammoth Co., 29 Utah 490.

12. Brophy v. O'Hare, 34 L. D. 596.

13. Larkin v. Upton, ante; Tiggeman v. Mrzlak, 40 Mont. 19; see Poplar Creek, 16 L. D. 1; Reynolds v. Pascoe, 24 Utah 219.

14. Ferrell v. Hoge, 27 L. D. 129 ; Reins v. Raunheim, 28 L. D. 526; American Co., 39 L. D. 299; McDonald v. Mont. Wood Placer Co., 14 Mont. 88.

15. Score v. Griffin, 9 Ariz. 295; Davidson v. Bordeaux, 15 Mont. 245; Fox v. Myers, 29 Nev. 169; Harrington v. Chambers, 3 Utah 94; Columbia Co. v. Duchess Co., 13 Wyo. 244 . 
16. Pelican Co. v. Snodgrass, 9 Colo. 339; Brewster v. Shoemaker, 28 Colo. 176.

17. Enterprise Co. v. Rico-Aspen Co., 167 U. S. 108.

18. Hayes v, Lavagnino, ante.

19. McMillen v. Ferrum Co., ante.

20. Johanson v. White, 160 Fed. 901; Phillips v. Brill, 17 Wyo. 26; see Hanson v. Craig, 170 Fed. 62.

21. Miller v. Chrisman, ante; New England Co. v. Congdon, ante; Whiting v. Straup, 17 Wyo. 1.

22. Johanson v. White, ante; see Hanson v. Craig, ante.

$\S 155$. Character of Lode Discovery. The discovery must be upon unappropriated territory. ${ }^{1}$ It must be rock in place, ${ }^{2}$ not necessarily in fissure,${ }^{3}$ nor with well defined walls ${ }^{4}$ but must include the top or apex. $^{5}$ It must occupy defined space and be capable of identification. ${ }^{6}$ It may be wide or narrow, ${ }^{7}$ be a seam or stringer, ${ }^{8}$ slightly interrupted, partially closed, ${ }^{9}$ pinched out in places or expand or swell out and as suddenly contract, forming "kidneys." 10

It must bear mineral, ${ }^{11}$ which may be rich or poor. ${ }^{12}$ While uniformity is not required ${ }^{\mathbf{1 3}}$ the mineral must not be fragmentary, ${ }^{14}$ although it may be unevenly distributed. ${ }^{15}$ It must not consist of pieces or bunches of quartz, not in place, ${ }^{16}$ nor of float rock, ${ }^{17}$ nor of boulders detached from the earth's crust. ${ }^{18}$

1. Brown v. Gurney, 201 U. S. 184; Little Pittsburg Co. v. Amie Co., 17 Fed. 57; Mont. Cent. Co. v. Migeon, 68 Fed. 811; Porter v. Tonopah Co., 133 Fed. 756; Winter Lode, 22 L. D. 362; Upton v. Larkin, 5 Mont. 600; Baker v. Butte City, 28 Mont. 222; Lockhart v. Farrell, 31 Utah 155.

Part or, all the location monuments may be upon property adversely held, Del Monte Co. v. Last Chance Co., 171 U. S. 55, but the discovery must be within the area not included in such territory. Gwillim v. Donnellan, 115 U. S. 45; Jupiter v. Bodie Con. Co., 11 Fed. 666; Bunker Hill Co. v. Shoshone Co., 33 L. D. 142; Sullivan v. Sharp, 33 Colo. 346; O'Donnell v. Glenn, 8 Mont. 248; Watson v. Mayberry, 15 Utah 265. That a part of a shaft is in ground belonging to an adjacent patented claim is immaterial. Nichols v. Williams, 38 Mont. 552 .

2. Book v. Justice Co., 58 Fed. 106; Meydenbauer v. Stevens, 78 Fed. 787; Fox v. Myers, 29 Nev. 169; Hayes v. Lavagnino, 17 Utah 185.

3. Mt. Diablo Co. v. Callison, 17 Fed. Cas. 9886. As to horizontal vein, irregular in form, not in fissure, and incapable of being traced by its outcrop, see Breece Co., 3 L. D. 11. 
4. Burke v. McDonald, 2 Ida. (Hasb.) 679; see O'Donnell v. Glenn, ante.

5. Larkin v. Upton, 144 U. S. 19; Bunker Hill Co. v. Shoshone Co., ante; see Iron Co. v. Murphy, 3 Fed. 368; Van Zandt v. Argentine Co., 8 Fed. 725.

6. Foote v. National Co., 2 Mont. 402 ; Fox v. Myers, ante.

7. N. Noonday Co. v. Orient Co., 1 Fed. 522; Meydenbauer v. Stevens, ante.

8. McShane v. Kenkle, 18 Mont. 208; see N. Noonday Co. v. Orient Co., ante; Jupiter Co. v. Bodie Con. Co., ante; Book v. Justice Co., ante; Shoshone Co. v. Rutter, 87 Fed. 801.

9. Jupiter Co. v. Bodie Con. Co., ante.

10. Meydenbauer v. Stevens, ante.

11. Book v. Justice Co., ante; Meydenbauer v. Stevens, ante; Fox v. Myers, ante; Hayes v. Lavagnino, ante.

12. Book v. Justice Co., ante; Meydenbauer v. Stevens, ante; see Ledoux v. Forester, 94 Fed. 600; So. Cross Co. v. Europa Co., 15 Nev. 383.

13. Meydenbauer v. Stevens, ante.

14. Terrible Co. v. Argentine Co., 89 Fed. 583; see Jones v. Prospect Co., 21 Nev. 339.

15. Jupiter Co. v. Bodie Con. Co., ante; Meydenbauer v. Stevens, ante; Murray v. White, (Mont.) 113 Pac. 754. 16. Jupiter Co. v. Bodie Con. Co., ante; Waterloo Co. v. Doe, 56 Fed. 685.

17. Book v. Justice Co., ante.

18. Meydenbauer v. Stevens, ante; see Ambergris Co. v. Day, 12 Ida. 108.

$\S 156$. Development of Discovery. The mining act does not require any particular manner of work, such as a shaft or its equivalent, ${ }^{1}$ to determine discovery.

2. Local Provisions. Local statutes or district rules usually provide for the character, extent and the time within which such work shall be performed.

3. Essential Act of Location. When such work is required it is an essential act of location. ${ }^{2}$ The claim is protected from adverse location during the period prescribed for sueh preliminary work. ${ }^{3}$

4. Discovery Shaft. The discovery shaft, or its equivalent, must be sunk or made upon otherwise unappropriated ground within the location. ${ }^{4}$ It should disclose mineral therein, but discovery may be shown elsewhere within the location. ${ }^{5}$

1. See Butte City Co. v. Baker, 196 U. S. 119; Gray v. Truby, 6 Colo. 278; Electro Mag. Co. v. VanAuken, 9 Colo. 204;

Butte City Co. v. Baker, 196 U. S. 119. 
2. Northmore v. Simmons, 97 Fed. 386 ; Eaton v. Norris, 131 Cal. 561; Becker v. Pugh, 9 Colo. 589; Lockhart v. Wills, 9 N. M. 344 .

The mere performance of the statutory acts of location, as the marking of the boundaries of the claim and the sinking of a shaft to a required depth without discovery of mineral will not validate the claim. McLaughlin v. Thompson, 2 Colo. A. 135.

3. Erhardt v. Boaro, 113 U. S. 527.

4. Zollars v. Evans, 5 Fed. 172; Little Pittsburg Co. v. Amie Co., 17 Fed. 57; Treasury Co. v. Boss, 32 Colo. 27; Butte City Co. v. Baker, ante; see Tonopah Co. v. Tonopah Co., 125 Fed. 408; Mitchell v. Broso, 27 L. D. 40 ; Nichols v. Williams, 38 Mont. 552 ; see $\$ 155$, ante.

5. Cheesman v. Shreve, 40 Fed. 787; Terrible Co. v. Argentine Co., 89 Fed. 583; McMillen v. Ferrum Co., 32 Colo. 38; Gibson v. Hjul, (Nev.) 108 Pac. 759.

$\S 157$. Proof of Discovery. The question of discovery is one of fact. ${ }^{1}$ It may be raised between mineral claimants, ${ }^{2}$ but not by a co-owner ${ }^{3}$ nor by $\dot{a}$ grantor of the property. ${ }^{4}$ It may be raised by one claiming the land to be more valuable for agricultural than for mining purposes. ${ }^{5}$

2. Rule Between Rival Claimants. When there is a controversy between two mineral claimants, the rule respecting the sufficiency of discovery of mineral is more liberal than when it is between a mineral claimant and one seeking to make an agricultural entry under the land laws. ${ }^{6}$

3. REASON FOR RULE. The reason for the above distinction is that when land is sought to be taken out of the category of agricultural lands the evidence of its mineral character should be reasonably clear, while in a controversy between rival claimants to mineral land, the question is simply which is entitled to priority; but even then the existence of mineral should be shown ${ }^{7}$ without, however, the weighing of scales to determine the value of the mineral found. 8

4. TEST. When the contest is between a mineral claimant and one claiming under the general land laws or a railroad company claiming under its land grant 9 the test is, not the mere existence of a mineral deposit, 
or the prospect of its existence, but, whether, as a present fact, it will pay to mine by the ordinary methods of mining. ${ }^{10}$

5. Contests Between Mineral Claimants. The courts are not in accord whether it is sufficient if the discovery be such as to justify an ordinarily prudent person, not necessarily a miner, in spending his time, labor and money in its development ${ }^{11}$ or to be such as to cause him to be willing to make such expenditures. ${ }^{12}$

6. Mineralogical and Geological Conditions. It has been held that the mineralogical and geological conditions that may exist in the ground and not whether a practical miner would feel justified in its exploitation, should control. ${ }^{13}$

7. Supplementary Evidence. A locator may supplement evidence of discovery by showing the situation, character, value and mineralogical conditions of adjacent claims and proving, by the opinions of experienced miners, based upon the facts, that the discovery was sufficient to justify the locator in developing the claim. ${ }^{14}$

8. Testimony. It may be shown that the outcroppings were mineralized, ${ }^{15}$ or probably carried mineral value. ${ }^{16}$ That a vein or lode was found or that indications existed which other miners followed on other ground in the same district; and on contiguous ground, in attempting to find mineral, and which, if followed, would lead to ore. ${ }^{17}$

9. Discovery Point. Discovery may be shown by proof of mineral at some point other than the discovery point. ${ }^{18}$

10. Expert Testimony. Discovery may be shown by opinion evidence ${ }^{\mathbf{1 9}}$ or by the testimony of an assayer. ${ }^{20}$

11. Conclusive Testimony. The patent may be conclusive evidence of discovery. ${ }^{21}$ 
12. Negative Testimony. Negative testimony may disprove the claim of discovery. ${ }^{22}$

1. Book v. Justice Co., 58 Fed. 106; Meydenbauer v. Stevens, 78 Fed. 787; Charlton v. Kelly, 2 Alaska 532.

2. Waterloo Co. v. Doe, 56 Fed. 685 ; see Book v. Justice Co., ante; Bevis v. Markland, 130 Fed. 226.

3. McCarthy v. Speed, 11 S. Dak. 362.

4. Blake v. Thorne, 2 Ariz. 347.

5. Steele v. Tanana Co., 148 Fed. 678; Bay v. Oklahoma Co., 13 Okla. 425; see Standard Co. v. Habishaw, 132 Cal. 115.

6. Chrisman v. Miller, 197 U. S. 313; Lange v. Robinson, 148

7. Id. Fed. 803; Steele v. Tanana Co., ante.

8. Bonner v. Meikle, 82 Fed. 697.

9. Steele v. Tanana Co., ante.

10. Davis v. Weibbold, 139 U. S. 507 ; U. S. v. Reed, 28 U. S. 482; Cutting v. Reininhausen. 7 L. D. 265; Harnish v. Wallace, 13 L. D. 108; Royal K Placer, 13 L. D. 86; Ferrell v. Hoge, 27 L. D. 129; Brophy v. O'Hare, 34 L. D. 596; Hunt v. Steese, 75 Cal. 629. The burden of proof is upon the mineral claimant. Dughi v. Harkins, 2 L. D. 721; Aspen Co. v. Williams, 23 L. D. 34.

11. Chrisman v. Miller, ante; Cascaden v. Bartolis, 146 Fed. 739; Burke v. McDonald, 2 Ida. (Hasb.) 296; Hayes v. Lavagnino, 17 Utah 185.

12. Shoshone Co. v. Rutter, 87 Fed. 801; Tuolumne Co. v. Maier, 134 Cal. 583.

13. McShane v. Kenkle, 18 Mont. 208.

14. While mere possibility that ground claimed as valuable for mineral, or that there are mere indications of the existence of mineral in the ground is not enough to justify a prudent person in expending money and work in exploration of it, yet where the evidence shows the actual existence of mineral in the claim, and such evidence is of sufficient weight to submit to the jury upon the issue of discovery, the locator has a right to strengthen his proof upon any of the elements which enter into what is comprehended by discovery. In doing so, he may supplement the showing that mineral actually did exist by introducing evidence of the fact that as a ground of justification for the expenditure of time and money. the adjacent ground in the immediate vicinity is rich in the same mineral, or that adjacent claims were developed into paying mines after development upon similar showings of mineral, or that geological conditions are so similar to that from the character of the mineral discovered, it is reasonable to expect to find mineral in valuable quantities in the exploitation of the ground staked. Cascaden v. Bartolis. 162 Fed. 267; see. Ambergris Co. v. Day. 12 Tra. 108.

15. Columbia Co. v. Duchess Co., 13 Wyo. 244.

16. Fox v. Myers, 29 Nev. 169

17. Cheesman v. Shreve, 40 Fed. 787 : but see Iron Co. v. Mike \& Starr Co.. 143 U. S. 394: Chrisman v. Miller. ante: Nev. Sierra Oil Co. v. Home Oil Co., 98 Fed. 671; and see Steele v. Tanana Co., ante; Lange v. Robinson, ante. 
18. Calhoun Co. v. Ajax Co., 182 U. S. 499; O'Donnell v. Glenn, 8 Mont. 248; Harrington v. Chambers, 3 Utah 94; Hayes v. Lavagnino, ante; see McMillen v. Ferrum, 32 Colo. 38. 19. Davidson v. Bordeaux 15 Mont. 245.

20. So. Cross Co. v. Europa Co. 15 Nev. 384; see Davidson v. Bordeaux ante.

21. Calhoun Co. v. Ajax Co., ante; see Creede Co. v. Uinta Co., 196 U. S. 337 ; see $\$ 68-12$, ante.

22. Ambergris Co. v. Day, ante.

$\S 158$. Loss of Discovery. All rights in a valid location will be lost if the place of discovery be patented to another, ${ }^{1}$ unless a re-conveyance has been agreed upon, ${ }^{2}$ or a new discovery is made elsewhere in the claim. ${ }^{3}$

2. Sale Before Discovery. A sale by a joint locator to the other locators, after marking the claim and before discovery, ${ }^{4}$ or a transfer of part of a claim after discovery and before fully marking the location carries no loss in the claim to the purchasers. ${ }^{5}$

3. Sale Afrer Discovery. A.sale of that portion of an unpatented location which contains the discovery does not invalidate the location. ${ }^{6}$

1. Gwillim v. Donnellan. 115 U. S. 56. See Lone Dane Lode, 10 L. D. 53. But the loss of the titular discovery is not necessarily loss of the claim. Bingham Co. v. Ute Co., 181 Fed. 748; Miller v. Girard, 3 Colo. A. 278.

2. Duxie Lode. 27 L. D. 88.

3. Perigo v. Erwin, 85 Fed. 904; Tonopah Co. v. Tonopah Co.. 125 Fed. 408; Bingham Co. v. Ute Co., ante; Miller v. Girard, ante; Girard v. Carson, 22 Colo. 345: Treasury Co. v. Boss, 32 Colo. 27: Silver City Co. v. Lowry, 19 Utah 334: see Richards v. Wolfing, 98 Cal. 195.

4. Miller v. Chrisman. 140 Cal. 440; Merced Co. v. Patterson, 153 Cal. 624: Whiting v. Straup, 17 Wvo. 1: but see H. H. Yard, 38 L. D. 59; Bakersfield Fuel \& Oil Co.. 39 L. D. 460: see $\$ 120-16$, ante; see Bay v. Oklahoma Co., 13 Okl. 425.

5. Doe v. Waterloo Co., 70 Fed. 455.

6. Little Pittsburg Co. v. Amie Co., 17 Fed. 57. See \& 67-4, also Zeckendorf v. Hutchinson, 1 N. M. 476. 


\section{CHAPTER XXV.}

\section{LOCATORS.}

$\S 162$. Rights of locators-basis of possession-forfeitureabandonment.

$\$ 163$. Citizens and aliens-location by alien-rights of alien - patent proceedings-presumption.

$\$ 164$. Agents-no divestiture of title.

$\S 165$. Who cannot be locators.

$\S 162$. Rights of Locators. The character of the right which is granted by the United States to a locator is that no written instrument is necessary to create it. ${ }^{1}$

2. Basis of Possession. Valid location and annual expenditure give and continue the right of possession. ${ }^{2}$

3. Forfeiture. The right to the location may be lost by a failure to do the necessary amount of work thereon or to contribute due proportion thereof. ${ }^{3}$

4. Abandonment. The right of possession may be renounced and the claim or an interest therein be abandoned. ${ }^{4}$

1. Black v. Elkhorn Co., 163 U. S. 445; Daggett v. Yreka Co., 149 Cal. 357.

The right to a mining claim rests (1) on the laws of the United States, (2) on the laws of the State, and (3) on the local rules, regulations of the mining district wherein the same is situated. Johnson v. McLaughlin, 1 Ariz. 493. See U. S. v. Rizzinelli, 182 Fed. 675 .

By the mining laws of the United States three classes of title are created, (1) title in fee simple, (2) title by possession, (3) the complete equitable title. The first vests in the grantee of the government an indefeasible title in the nature of an easement only. The first being an absolute grant by purchase and patent without condition, is not defeasible, while the second being a mere right of possession and enjoyment of profits without purchase and upon conditions, may be defeated at any time by the failure of the party in possession to comply with the conditions. The equitable title accrues immediately upon purchase, for the entry entitles the purchaser to a patent. So. End Co. v. Tinney, 22 Nev. 221.

2. Black v. Elkhorn Co., ante; Street v. Delta Co., 42 Mont. 371.

3. Black v. Elkhorn Co., ante; see $\$ 73$, ante.

4. Id.; see $\S 72$, ante. 
$\S 163$. Citizens and Aliens. Mining claims within the United States ${ }^{1}$ and the Philippine Islands ${ }^{2}$ may be located by citizens of the United States and those who have declared their intention to become such $;^{3}$ and within the Philippine Islands by citizens thereof. ${ }^{4}$ Native born citizens of the Dominion of Canada are accorded certain reciprocal rights within the District of Alaska. ${ }^{5}$

2. Location by Alien. A location by an alien of a mining claim within the United States or the Philippine Islands is not void but is voidable. ${ }^{6}$

3. Rights of Alien. A location made by an alien is not subject to attack except by the government in direct proceedings termed "inquest of office found" 7 or by the land department in the course of patent proceedings ${ }^{8}$ or by a party to a suit or action brought in opposition to a claim for patent. ${ }^{9}$ In no other way may persons legally raise the question of citizenship and the courts may be invoked to restrain any unlawful interferences. ${ }^{10}$

Naturalization before adverse rights attach or a judgment is rendered acts retroactively in patent proceedings, upon the rights of an alien. ${ }^{11}$

4. Patent Proceedings. In patent proceedings it is the citizenship of the applicant for patent or of the adverse claimant, not necessarily that of the locator which is involved. ${ }^{12}$

The patent is conclusive evidence of citizenship. ${ }^{13}$

5. Presumption. Sometimes citizenship is presumed from location. ${ }^{14}$

1. Rev. Stats., $\$ 2319$.

2. 32 Stats. $697 ; 33$ Stats. 692 .

3. Rev. Stats., $\$ 2319$.

A corporation may locate a mining claim. McKinley v. Wheeler, 130 U. S. 630 ; Book v. Justice Co., 58 Fed. 106; Gird v. Cal. Oil Co., 60 Fed. 531; Thomas v. Chisholm, 13 Colo. 105. That it may obtain a patent, see Rev. Stats., \$2332; Doe v. Waterloo Co., 70 Fed. 455. A patent for a mining claim to a corporation proves that the patentee was a corporation. Galbraith v. Shasta Co., 143 Cal. 94. 
4. 32 Stats. $697 ; 33$ Stats. 692 .

5. 30 Stats. 415 ; Instructions, 32 L. D. 424 . See $\S 3$, ante.

6. Manuel v. Wulff, 152 U. S. 505; McKinley Creek Co. v. Alaska United Co., 183 U. S. 563; Lone Jack Co. v. Megginson, 82 Fed. 89; Thornases v. Melsing, 109 Fed. 710; Shea v. Nilima, 133 Fed. 209; McEvoy v. Megginson, 29 L. D. 164; Ferguson v. Neville, 61 Cal. 356; Duncan v. Eagle Rock Co., 48 Colo. 569; Stewart v. G. \& C. Co., 29 Utah, 443 ; Davis v. Dennis, 43 Wash. 54. As to rights of aliens in the territories, see 24 Stats. $476 ; 29$ Stats. 618 . Alien heirs may inherit. Billings v. Aspen Co., 51 Fed. 338; Lohmann v. Helmer, 104 Fed. 178; Ferguson v. Neville, ante.

7. Manuel v. Wulff, ante; McKinley Creek Co. v. Alaska United Co., ante; Allyn v. Schultz, 5 Ariz. 152; Harris v. Kellogg, 117 Cal. 484; Keeler v. Trueman, 15 Colo. 143; Wilson v. Triumph Co., 19 Utah 66.

8. Wilson v. Triumph Co.. ante See Regulations. 39 L. D. 320 .

9. O'Reilly v. Campbell, 116 U. S. 418 ; Matlock v. Stone, 77 Ark. 195; Allyn v. Schuitz, ante; Harris v. Kellogg, ante.

An "adverse suit" is equivalent to "inquest of office" as the government is interested in the outcome of the proceeding or suit and either party to an adverse suit may question the citizenship of the other. An objection on the ground of alienage in a judicial proceeding, if sustained, will only defeat the claim of the alien and will not in any sense sustain the title of the objector. Sherlock v. Leighton, 9 Wyo. 297; see Holdt v. Hazard, 10 Cal. A. 440; Duncan v. Eagle Rock Co., ante.

10. McKinley Creek Co. v. Alaska United Co., ante; Thornases v. Melsing, ante; Davis v. Dennis, ante; Duncan v. Eagle Rock Co, ante; see Racoullat v. Sansevain, 32 Cal. 376.

11. O'Reilly v. Campbell, ante; Lone Jack Co. v. Megginson, ante; Adams v. Crawford, 116 Cal. 495.

12. Cash Lode, 1 C. L. O. 98; but see Duncan v. Eagle Rock Co., ante.

13. Steel v. St. Louis Co., 106 U. S. 447; Dahl v. Raunheim, 132 U. S. 260 ; Justice Co. v. Lee, 21 Colo. 260.

14. Jantzon v. Arizona Co., 3 Ariz. 6; Garfield Co. v. Hammer, 6 Mont. 53 ; see Strickley v. Hill, 22 Utah 257.

§164. Agents. The right to or in a location will vest in the principal when made by an agent, attorney in fact, ${ }^{1}$ partner, ${ }^{2}$ or employee ${ }^{3}$ who acts with ${ }^{4}$ or without 5 express authority, as the principal's authorization is presumed ${ }^{6}$ although he may have no previous knowledge of the location $;^{7}$ or he may subsequently acquiesce thereto. ${ }^{8}$ 
2. No Divestiture of Title. Subsequent destruction of a location notice once posted will not divest the title of the principal. ${ }^{9}$

1. Book v. Justice Co., 58 Fed. 106; Doe v. W.aterloo Co., 70 Fed. 455; Ledoux v. Forester, 94 Fed. 600; Walton v. Wild Goose Co., 123 Fed. 209; McCullough v. Murphy, 125 Fed. 147; Morton v. Solambo Co., 26 Cal. 527; Moore v. Hamerstag, 109 Cal. 122; Dunlap v. Pattison, 4 Ida. 473 ; Whiting v. Straup, 17 Wyo. 1.

2. Johnstone v. Robinson, 16 Fed. 903; M'Mahon v. Meehan, 2 Alaska, 278.

3. Fuller v. Harris, 29 Fed. 814; Book v. Justice, ante; Durant v. Corbin, 94 Fed. 382 .

4. Doe v. Waterloo Co., ante.

5. Rush v. French, 1 Áriz. 99; Thompson v. Spray, 72 Cal. 528; Van Valkenburg v. Huff, 1 Ney. 142.

6. Gore v. McBrayer, 18 Cal. 582; Kramer v. Settle; 1 Ida. (Hasb.) 485 ; Van Valkenburg v. Huff, ante; see Thompson v. Spray, ante.

7. Gore v. McBrayer, ante; Morton v. Solambo Co., ante; see also Walton v. Wild Goose Co., ante.

8. Thompson v. Spray, ante; see Rush v. French, ante.

9. Rush v. French, ante; Morton v. Solambo Co., ante.

$\S 165$. Who Cannot be Locators. All persons employed in the Department of the Interior as officers of the General Land Office, clerks, employees, and as Deputy United States Mineral Surveyors cannot legally locate, hold, nor patent a mining claim. ${ }^{1}$

1. Rev. Stats., § 452; Prosser v. Finn, 208 U. S. 67; Waskey v. Hammer, 170 Fed. 31 (now pending in U. S. Supreme Court on certiorari); Frank A. Maxwell, 29 L. D. 76; Alfred Baltzeli, 29 L. D. 333 ; Robt. J. Watson, 33 L. D. 435 ; Seymour K. Bradford, 36 L. D. 61; Philip Contzen, 38 L. D. 346 ; Ricard L. Powell, 39 L. D. 177; Lavagnino v. Uhlig, 26 Utah 1; s. c. 198 U. S. 443 ; Lockhart v. Farrell, 31 Utah 155; see Hand v. Cook, 29 Nev. 518; but see Gibson v. Hjul (Nev.), 108 Pac. 759.

\section{CHAPTER XXVI.}

\section{ORIGINAL LOCATIONS.}

$\S 168$. In general-possessory title-priority of title-independent locations-invalid locations-form of lode location-form of placer location-must conform to law-time of location-qualification of locator.

\$169. Equivalent of location-right to patent.

$\$ 170$. Fraudulent placer location-innocent participants.

$\S 171$. Voidable locations. 
$\S 172$. Void locations - absence of discovery - boundariesillustrations-timber-trespass.

$\S 173$. Size of lode claims-measurement-presumption-excessive size-segregation-reasonable time to cast off.

$\S 174$. Size of placer claims-cxcessive size.

$\$ 175$. Size of tunnel sites-excessive location.

$\S 176$. Size of mill-sites-form.

$\$ 177$. Acts of location-acts incumbent on locator-order of performance-original discoverer-re-locator not discoverer-limitation-boundaries-time and manner of marking boundaries-essential acts of locationpossible insufficiency of acts-question of fact-what controls-monuments as boundaries-position of lode claim monuments - consent of owner - limitation position of placer claim monuments - possible discrepancy-changing position of marks-obliteration of marks-no presumption-by whom the marks may be placed-end lines-effect of establishing end lines -question of fact-constructive end lines-side lines -irregularity of side lines-agreed lines.

$\S 168$. In General. At the date of the location the ground appropriated must be a part of the public domain ${ }^{1}$ available and valuable for mining purposes. ${ }^{2}$

2. Possessory Titue. Possessory title does not vest until both discovery and a proper marking of the claim. ${ }^{3}$ The marking may be prior to discovery ${ }^{4}$ or within a reasonable time thereafter 5 in the absence of an intervening right. ${ }^{6}$

3. Priority of Titue. Priority of title gives the better right as between adverse mineral claimants, ${ }^{7}$ but if the value of the land as mineral land is questioned the character of the land and not priority of the claim of title thereto controls. ${ }^{8}$

4. IndePendent Locations. Any number of independent locations contiguous or otherwise, ${ }^{9}$ except of saline lands, ${ }^{10}$ and possibly mill-sites ${ }^{11}$ may be made by the same party.

5. Invalid Locations. An invalid or incomplete location is subject to adverse location or entry. ${ }^{12}$ The validity of either of such proceedings is not affected by any knowledge of the previous attempt at appropriation. ${ }^{13}$ 
6. Form of Lode Location. Theoretically a lode location should be in the form of a parallelogram. ${ }^{14} \mathrm{~A}$ departure therefrom merely affects the claimant's right to follow the dip. ${ }^{15}$

7. Form of Placer Location. If upon surveyed lands a placer location should conform as nearly as is reasonably practicable to the rectangular subdivisions of the public surveys. ${ }^{16}$ But whether upon surveyed or unsurveyed lands the location should be rectangular in form, compact, and with north and south and east and west boundary lines. It should not encroach upon appropriated territory. ${ }^{17}$

8. Must Conform to Law. No placer location will be passed to patent unless the land department be satisfied that it sufficiently conforms to the law. 18

9. Trme of Location. A location may legally be made upon a Sunday ${ }^{19}$ or other legal holiday.

10. Qualification of Locator. A location may be made without regard to age, ${ }^{20}$ sex, ${ }^{21}$ residence ${ }^{22}$ or citizenship of the locator. ${ }^{23}$

1. Brown v. Gurney, 201 U. S. 184; Street v. Delta Co., 42 Mont. 371. There are three kinds of mineral locations, viz: "lode locations," "tunnel locations," and "placer locations." A proper location in either class fully maintained by use, enjoyment or patent is not subject to adverse location by a claimant of the same class or any other class, because it has become private property and no longer open to a new appropriation. Calhoun Co. v. Ajax Co., 27 Colo. 1.

2. U. S. v. C. P. R. Co., 93 Fed. 871; Steele v. Tanana Co., 148 Fed. 678; Alford v. Barnum, 45 Cal. 482; Mutchmor v. McCarty, 149 Cal. 603; Merrill v. Dixon, $15 \mathrm{Nev} .401$.

3. Ledoux v. Forester, 94 Fed. 600 ;, Charlton v. Kelly, 156 Fed. 433 ; Eaton v. Norris, 131 Cal. 561; Miller v. Chrisman, 140 Cal. 440; Wright v. Lyons, 45 Or. 167.

4. Sharkey v. Candiani, 48 Or. 112.

5. Brockbank v. Albion Co., 29 Utah 367; Union Co. v. Leitch, 24 Wash. 585.

6. Brewster v. Shoemaker, 28 Colo. 176.

7. Van Zandt v. Argentine Co., 8 Fed. 725.

8. Bay v. Oklahoma Co., 13 Okla. 425.

9. Last Chance Co. v. Bunker Hill Co., 131 Fed. 579; Tomera Placer Claim, 33 L. D. 560 ; see Prosser v. Parks, 18 Cal. 47. In Oregon the right is limited by local statute to one location upon a lode except it be the first thereon. In the latter case an additional location may be made. B. \& C. Codes, $\$ 3974$. 
10. 31 Stats. 745 .

11. Alaska C. Co., 32 L. D. 128; see J. B. Hoggin, 2 L. D. 755.

12. Erwin v. Perego, 93 Fed. 609; see J. B. Hoggin, ante; Funk v. Sterrett, 59 Cal. 613; Adams v. Crawford, 116 Cal. 495; Miller v. Chrisman, ante; Lockhart v. Wills, 9 N. M. 344.

13. Brown v. Or. King Co., 110 Fed. 728; Galbraith v. Shasta Iron Co., 143 Cal. 94 .

14. Rev. Stats., $\$ 2320$; see Carson City Co. v. N. Star Co., 83 Fed. 579 ; Last Chance Co. v. Bunker Hill Co., 131 Fed. 527. That the form of the location is not absolutely essential to either a lode or a placer location, see Walrath v. Champion Co., 171 U. S. 293; Breece. Co. 3 L. D. 11; Miller Placer Claim, 30 L. D. 225; Doe v. Sanger, 83 Cal. 203; Mitchell v. Hutchinson, 142 Cal. 404 ; S. C. R. Co. v. O'Donnell, 3 Cal. A. 382 . As to placer claims in Alaska, see McKinley Creek Co. v. Alaska United Co., 183 U. S. 563; Loeser v. Gardiner, 1 Alaska 641.

15. Iron Co. v. Elgin Co., 118 U. S. 196; Walrath v. Champion Co., ante. See Del Monte v. Last Chance Co., 171 U. S. 55.

16. Rev. Stats., $\$ 2329$. A placer location in the form of a lode location has been upheld in California. McCann v. McMillan, 129 Cal. 350; also in Alaska, McKinley Creek Co. v. Alaska Unjted Co., ante.

17. Min. Reg., par. 30; Snow Flake Fraction, 37 L. D. 250, appd. in Hanson v. Craig, 170 Fed. 62 ; see Mitchell v. Hutchinson. ante; see Stenfjeld v. Espe, 171 Fed. 825.

18. Min. Reg., par. 30 .

19. Dolly Varden Min. Law Dig. 98.

20. Thompson v. Spray, 72 Cal. 528; Davis v. Dennis, 43 Wash. 54.

21. Eureka Office, 4 C. L. O. 179.

22. Book v. Justice Co., 58 Fed. 106; see Rush v. French, 1 Ariz. 99.

23. Davis v. Dennis, ante; Holdt v. Hazard, 10 Cal. A. 440.

§ 169. Equivalent to Location. In the absence of an adverse claim the possession and working of a mining claim for a period equal to the time prescribed by the local statute of limitations is equivalent to a valid location. ${ }^{1}$

2. Right to Patent. The statutory expenditure being made thereon ${ }^{2}$ the claimant is entitled to a patent from the government therefor. ${ }^{3}$

1. 420 Co. v. Bullion Co., 9 Nev. 240; Buffalo Zinc Co. v. Crump, 70 Ark. 525; Altoona Co. v. Integral Co., 114 Cal. 100; Upton v. Sta. Rita Co., 14 N. M. 96; see Risch v. Wiseman, 36 Or. 484 ; see $\$ 84$, ante.

2. See Stewart v. Rees. 21 L. D. 446.

3. Cleary v. Skiffich, 28 Colo. 362; McCowan v. Maclay, 16 Mont. 234 . 
$\S 170$. Fraudulent Placer Location. Where an association of persons locates a placer claim in the interest of a single individual ${ }^{1}$ or of a corporation ${ }^{2}$ the location is valid only to the extent of 20 acres.

2. InNocent Participants. Locators not implicated in such fraud may select and hold their proportionate share of the location, that is, 20 acres each. ${ }^{3}$

1. Durant v. Corbin, 94 Fed. 382; Cook v. Klonas, 164 Fed. 529; Mitchell v. Cline, 84 Cal. 409 ; see U. S. v. Portland

Co., 173 Fed. 566; Nome \& Sinook Co. v. 'Snyder, 187 Fed. 385 ; see $\$ 174$, post.

2. Gird v. Cal. Oil Co., 60 Fed. 531; see also U. S. v. Trinidad Co., 137 U. S. 160 .

3. Cook v. Klonas, 168 Fed. 700 .

$\S 171$. Voidable Locations. A location otherwise valid but made by an alien is voidable and not void. ${ }^{1}$

1. Manuel v. Wulff, 152 U. S. 505; McKinley Creek Co. v. Alaska United Co., 183 U. S. 563 ; see $\$ .163$, ante.

$\S 172$. Void Locations. A location may be marked upon the ground and still be neither valid nor subsisting. ${ }^{1}$ Each locator must stand on his own location. He can take only what it will give him under the law. ${ }^{2}$

2. Absence of Discovery. In the absence of discovery no act of the claimant can confer validity upon the claim. ${ }^{3}$

3. Boundaries. Where discovery is made, but the location is not so marked that its boundaries can be readily traced, the claimant assumes the risk of intervening rights. ${ }^{4}$

4. Illustrations. A location based upon a discovery which is within the limits of a prior location, ${ }^{5}$ when, possibly, of excessive size ${ }^{6}$ upon the dip of a vein or lode, ${ }^{7}$ or a lode location of a placer deposit, ${ }^{8}$ or vice versa, or a placer location intended to secure a known vein therein, ${ }^{9}$ or merely to secure a water right, ${ }^{10}$ or a mill-site location intended merely to secure a water right ${ }^{11}$ is void.

5. Timber. A valuable growth of timber upon a claim may properly be an incentive to its location. ${ }^{12}$ 
6. Trespass. Trespass initiates no right in land which is in the actual possession of another. ${ }^{13}$ The performance of acts necessary to constitute a location upon land held by another is only a trespass and cannot form the basis for the acquisition of title ${ }^{14}$ save when by acquiescence or neglect the right to object to it is waived. ${ }^{15}$

1. Del Monte Co. v. Last Chance Co., 171 U. S. 55.

2. Lockhart v. Farrell, 31 Utah 155.

3. Wright v. Killian, 132 Cal. 251; Lockhart v. Farrell, ante.

4. O'Reilly v. Campbell, 116 U. S. 418; Del Monte Co. v. Last Chance Co., ante.

5. Gwillim v. Donnellan, 115 U. S. 45; Tuolumne Co. v. Maier, 134 Cal. 583; Sullivan v. Sharp, 33 Colo. 346 ; McPherson v. Julius, 17 S. Dak. 98; see Tonopah Co. v. Tonopah Co., 123 Fed. 408; Reiner v. Schroeder, 146 Cal. 411.

6. See Nicholls v. Lewis \& Clark Co. (Ida.) 109 Pac. 846; Flynn Group Co. v. Murphy, 18 Ida. 266; but see Jones v. Wild Goose Co., 177 Fed. 95.

7. Larkin v. Upton, 144 U. S. 19; Iron Co. v. Murphy, 3 Fed. 368; Van Zandt v. Argentine Co., 8 Fed. 725 ; Bunker Hill Co. v. Shoshone Co., 33 L. D. 142.

8. Henderson v. Fulton, 35 L. D. 652 .

9. Grosfield v. Nigger Hill Co., 14 L. D. 685.

10. Wm. A. Cheesman, 2 L. D. 774.

11. Chas. Lennig, 5 L. D. 190.

12. U. S. v. Iron Co., 128 U. S. 673 ; see E. M. Palmer, 38 L. D. 294 .

13. Cowell v. Lammers, 21 Fed. 200; Neuebaumer v. Woodman, 89 Cal. 310 ; see $\S 113$, ante, and $\S 180$, post.

14. Weese v. Barker, 7 Colo. 178; see O'Reilly v. Campbell, ante; see note 13 , ante.

15. Snyder v. Colo , Co., 181 Fed. 62 ; see $\S 180-6-7$, post.

$\S 173$. Size of Lode Claims. A lode claim should not exceed 1500 feet along the vein or lode, nor extend more than 300 feet, nor be limited by local statute or district rule, to less than 25 feet on each side of the middle of the vein or lode at the surface. ${ }^{1}$

2. Measurement. The length and width (that is the distance between the side lines) ${ }^{2}$ may be measured from the point of discovery. ${ }^{3}$ Neither the end lines ${ }^{4}$ nor the side lines ${ }^{5}$ need, necessarily, be equi-distant from the "discovery."

3. Presumption. In the absence of a contrary statement in the location notice, ${ }^{6}$ knowledge of the 
locus of the vein or lode, ${ }^{7}$ or proof to the contrary, it will be presumed that the point of discovery was in the middle of the vein or lode. ${ }^{8}$

4. Excessive Size. A location that exceeds the maximum size is void only as to the excess ${ }^{9}$ unless fraudulent ${ }^{10}$ or misleading. ${ }^{11}$

5. Segregation. When innocently done the claimant may selèct the ground to be retained and draw in his lines accordingly. ${ }^{12}$

6. Reasonable Time to Cast OfF. This should be done within a reasonable time, pending which an adverse location of any part thereof is perhaps a nullity. ${ }^{13}$

1. Rev. Stats., $\$ 2320$; see King v. Amy Co., 152 U. S. 222; Con. Wyo. Co. v. Champion Co., 63 Fed. 540.

2. Flagstaff Co. v. Tarbet, 98 U. S. 463; Davis v. Shepherd, 31 Colo. 141.

3. Hope Co., 5 C. L. O. 116; Johnson, 7 C. L. O. 35.

4. See Zerres v. Vanina, 134 Fed. 610.

5. Taylor v. Parenteau, 23 Colo. 368.

6. Stemwinder Co. v. Emma Co., 2 Ida. (Hasb.) 456.

7. Farmington Co. v. Rhymney Co., 20 Utah 363.

8. See note 3, ante; see Harper v. Hill, (Cal.) 113 Pac. 162.

9. Howeth v. Sullenger, 113 Cal. 547: McElligott v. Krogh, 151 Cal. 126; Burke v. McDonald, 2 Ida. (Hasb.) 679; McPherson v. Julius, 17 S. Dak. 98; Hansen v. Fletcher, 10 Utah 266.

10. Gohres v. Illinois Co., 40 Or. 516. If a claim is so excessive in size as to preclude presumption of innocent error, fraud will be presumed. Flynn Group Co. v. Murphy, 18 Ida. 266.

11. Ledoux v. Forester, 94 Fed. 600; Hauswirth v. Butcher, 4 Mont. 299.

12. Hansen v. Fletcher, ante; see U. S. v. Keitel, 211 U. S. 370; M'Intosh v. Price, 121 Fed. 716; Zimmerman v. Funchion, 161. Fed. 859; Nicholls v. Lewis \& Clark Co., 18 Ida. 224.

13. Jones v. Wild Goose Co., 177 Fed. 95; see Flynn Group Co. v. Murphy, ante.

\$174. Size of Placer Claims. The maximum size is 20 acres for an individual and 160 acres for an association of not less than 8 persons, ${ }^{1}$ or, correspondingly, if the association is composed of a less number. ${ }^{2}$

2. Excessive Size. Mere excess over the maximum amount may not invalidate the location ${ }^{3}$ unless the excess be great. ${ }^{4}$ 
1. Rev. Stats., \$\$ 2330-2331; Gird v. Cal. Oil Co., 60 Fed. 531; Kirk v. Meldrum, 28 Colo. 453 ; see $\$ 170$, ante.

2. Kirk v. Meldrum, ante.

3. Walton v. Wild Goose Co., 123 Fed. 209; Waskey v. Hammer, 170 Fed. 31 ; see M'Intosh v. Price, 121 Fed. 716; Zimmerman v. Funchion, 161 Fed. 859; Waskey v. Hammer, ante; Jones v. Wild Goose Co., 177 Fed. 95.

4. Pratt v. United Alaska Co., 1 Alaska 95; see $\$ 173,4-6$, ante.

$\S 175$. Size of Tunnel-sites. The maximum length of a tunnel is 3000 feet from its face, ${ }^{1}$ that is, the point at which it actually enters under cover. ${ }^{2}$ It is not limited to any particular width. ${ }^{3}$

2. Excessive Location. It is void only as to any excess in length. ${ }^{4}$

1. Glacier Co. v. Willis, 127 U. S. 471.

2. Min. Reg., par. 16.

3. Rev. Stats., \& 2323 .

4. Glacier Co. v. Willis, ante; see Jones v. Wild Goose Co., 177 Fed. 95.

$\S 176$. Size of Mill-sites. A mill-site cannot exceed 5 acres in extent. ${ }^{1}$

2. Form. There is no provision in the law as to the form of the location.

1. Rev. Stats., § 2337.

$\S 177$. Acts of Location. A locator must take measures to inform the world that he has appropriated a certain portion of the public mineral lands and state the extent and boundaries thereof.*

2. Acts Incumbent on Locator. This involves the marking of the claim so that its boundaries can be readily traced, making discovery, and doing whatever else may be required by the local statute or district rule. $^{1}$

3. Order of Performance. The order in which the acts of location are performed is, generally, immaterial, provided that no adverse right intervenes. ${ }^{2}$ 
4. Original Discoverer. The original locator is the discoverer of the mineral contained in the location. ${ }^{3}$

5. Re-Locator Not Discoverer. A re-locator is not the discoverer of the mineral in the location. He is the appropriator thereof. 4

6. Limitation. If questioned a re-locator cannot hold the ground except upon proof that the preceding locator had abandoned or forfeited the location. ${ }^{5}$

7. Boundaries. The mining act requires that the boundaries shall be so marked that they can be readily traced. ${ }^{6}$ It does not define the manner nor time of demarcation. ${ }^{7}$

8. Time and Manner of Marking Boundaries. The time and manner of marking a location are usually prescribed by local statute or district rule.

9. Essential acts of Location: The provisions of a local statute or district rule in relation to the time and mannier of marking of a location or the doing of preliminary work on the discovery, should be complied with as essential acts of location. ${ }^{8}$

10. Possible Insufficiency of Acts. It does not necessarily follow that a compliance with a local statute or district rule in the above respects constitutes a sufficient compliance with the provisions of the mining act. ${ }^{9}$

11. Question of Fact. The sufficiency of the marking of the claim ${ }^{10}$ or of the "discovery" work ${ }^{11}$ is a question of fact.

12. What Controls. The conformation and condition of the ground located with the character and extent of the markings ultimately control as to the sufficiency of the demarcation. ${ }^{12}$

13. Monuments as Boundaries. Monuments at the corners of a claim do not mark the boundaries. They are only means by which the boundaries may be traced. ${ }^{13}$ A written notice posted on ${ }^{14}$ or off ${ }^{15}$ the 
location would be sufficient if, therefrom, the boundaries of the claim could be readily traced with absolute certainty and without any practical difficulty. ${ }^{16}$

14. Position of Lode Claim Monuments. Part or all of the monuments of a lode location may, by accident or design, be placed upon adjoining ground, although adversely held, if openly and peaceably done. It is immaterial whether the territory so encroached upon be patented or unpatented. ${ }^{17}$

15. CONSENT OF OwNER. The consent of the owner of such other ground is not essential. Subsequent objection by him is unavailing. ${ }^{18}$

16. Limitation. The right of such overlapping locator is limited to the ground within such boundaries as was then open to location. ${ }^{19}$

17. Position of Placer Clatim Monuments. The foregoing rule as to the position of monuments of lode claims does not apply to placer claims. ${ }^{20}$

In the states of California ${ }^{21}$ and Nevada, ${ }^{22}$ a placer location is sufficiently marked by posting a notice of location thereon and by a reference to legal subdivisions, if upon surveyed lands, ${ }^{23}$ otherwise, in the same manner that a lode claim is ordinarily located. In the state of Washington a placer location may be made and described by legal subdivisions, but it must still be marked the same as other locations. ${ }^{24}$

18. Possible Discrepancy. A danger in pursuing the former course is the loss of corners or the possible discrepancy between the official field notes of the public survey and the locus of the ground. In which case the survey must control. ${ }^{25}$

19. Changing Position of Marks. The position of the monuments, or any of them, may be changed so as to include land open to location and not originally embraced in the claim $;^{26}$ or to draw in the lines to 
avoid an excess, ${ }^{27}$ or for the purpose of paralleling the end lines. 28

20. Obitteration of Marks. The subsequent obliteration or removal of the marks, if without the act or fault of the claimant will not divest him of title to a claim otherwise valid. ${ }^{29}$

21. No Presumption. There is no presumption as to boundary marks on old claims. ${ }^{30}$ If questioned their former existence must be established. ${ }^{31}$

22. By Whom the Marks May Be Placed. The boundary marks may be those placed by the original locator or those placed, adopted or repaired by a subsequent claimant. ${ }^{32}$

23. END Lines. The end lines of a lode claim are those which cross the vein or lode at the surface, ${ }^{33}$ at any angle ${ }^{34}$ or variation from the true dip. ${ }^{35}$ They extend downward continued in their own direction, either way, horizontally. ${ }^{36}$ If laid along the vein or lode they are side lines. ${ }^{37}$ If the end lines are not parallel with each other the claimant has no extralateral rights. ${ }^{38}$ They may be made parallel and the right to follow the dip be thus obtained. ${ }^{39}$

If the end lines converge the extra-lateral right is confined to the area embraced by such lines. ${ }^{40}$

24. EfFect of Establishing End Lines. The existence of end lines is essential to the extra-lateral right. ${ }^{41}$ When once established they are the end lines of all veins or lodes having their apexes within the location. ${ }^{42}$ End lines cannot be drawn at right angles to the strike of all veins or lodes within the claim if they do not run parallel with each other ${ }^{43}$ although there may be different veins or lodes with different dips therein. ${ }^{44}$

25. Question of FAct. Whether the end lines are substantially parallel or not is a question of fact ${ }^{45}$ of which the patent is conclusive evidence. ${ }^{46}$ 
26. Constructive End Lines. End lines may be judicially constructed within the surface lines of a lode location. ${ }^{47}$

27. Side Lines. The side lines of a lode location are those which are laid along the course or strike of a vein or lode. ${ }^{48}$ If laid across the vein or lode they become end lines ${ }^{49}$ whether so intended by the locator or not. ${ }^{50}$

28. Irregularity of Side Lines. While side lines should be equidistant 51 they may be irregular 52 and of unequal width, not exceeding 300 feet on either side of the center of the vein or lode at the surface. ${ }^{53}$

29. AGReed Lines. Boundary lines may be agreed upon between, ${ }^{54}$ or acquiesced in by, ${ }^{55}$ the owners of the adjoining claims or be fixed by conveyance. ${ }^{56}$

* Duncan v. Eagle Rock Co., 48 Colo. 569; see Zeiger v. Dowdy, (Ariz.) 114 Pac. 765.

1. Belk v. Meagher, 104 U. S. 279; Dwinnell v. Dyer, 145 Cal. 12; see Charlton v. Kelly, 156 Fed. 433; Eaton v. Norris, 131 Cal. 561: McKay v. McDougall, 25 Mont. 258; Street v. Delta Co., 42 Mont. 371; Gleeson v. Martin White Co., 13 Nev. 442.

2. Chrisman v. Miller, 197 U. S. 313; Erwin v. Perego, 93 Fed. 608; Uinta Co. v. Creede Co., 119 Fed. 164; Dwinnell v. Dyer, ante; Green v. Garvin, 11 Cal. A. 506; Beals v. Cone, 27 Colo. 473.

3. Zerres v. Vanina, 134 Fed. 610 .

4. Id.

5. Id.; Bingham Co. v. Ute Co., 181 Fed. 748; St. John v. Kidd, 26 Cal. 263; Oreamuno v. Uncle Sam Co., 1 Nev. 215.

6. Doe v. Waterloo Co., 70 Fed. 455; Eaton v. Norris, ante.

7. Del Monte Co. v. Last Chance Co., 171 U. S. 55. Under the mining act any natural or artificial physical marks or objects or writings alone or in connection therewith that serve to define the boundaries of the claim upon the surface are sufficient. Haws v. Victoria Copper Co., 160 U. S. 303; Book v. Justice Ċo., 58 Fed. 106; Oregon King Co. v. Brown, 119 Fed. 48; Charlton v. Kelly, ante; Worthen v. Sidway, 72 Ark. 215; Miller v. Chrisman, 140 Cal. 440. In California any marking on the ground, whether by stakes, monuments or written notices whereby the boundaries of the location can be readily traced is sufficient. See C. C. \$1426 et seq.

8. Butte City Co. v. Baker, 196 U. S. 119; Ledoux v. Forester, 94 Fed. 600; Dutch Flat co. v. Mooney, 12 Cal. 534; Myers v. Spooner, 55 Cal. 257.

9. Charlton v. Keliy, ante.

As a general rule it is sufficient if the center line of a lode claim be marked by three stakes or monuments 
-one at the center, and one at each end-upon the center one of which is placed the location notice stating the direction of the lode with reference to the points of the compass, and declaring the stake or monument to be the limit stake or monument of the lode in the direction mentioned in the notice upon it, as, to illustrate, the east and west end line of the lode (naming it). In addition to the foregoing a stake or monument may be placed at each corner of the surface of the claim, designating which corner it is with reference to the points of the compass, and also containing the name of the claim.

It may be further necessary to blaze trees along the line of the location, or cut away brush, or set more stakes at such distarices that they may be seen from one to another, or dig up the ground in a way to indicate the lines so that the boundaries of the claim may be readily traced. Ledoux v. Forester, ante; see Book v. Justice Co., ante. The fact that the ground sought to be located is extremely rough and mountainous does not relieve the locator of obligation to properly mark the boundaries of his location. Gird v. Cal. Oil Co., 60 Fed. 531. See Brockbank v. Albion Co., 29 Utah, 367; but see Howeth v. Sullenger, 113 Cal. 547.

10. Eilers v. Boatman, 111 U. S. 356 ; Book v. Justice Co., ante; Meydenbauer v. Stevens, 78 Fed. 787; Yreka Co. v. Knight, 133 Cal. 544.

11. Nichols v. Williams, 38 Mont. 552.

12. Book v. Justice Co., ante; Charlton v. Kelly, ante; see note 9 , ante.

13. Gleeson v. Martin White Co., ante.

14. McKinley Creek Co. v. United Alaska Co., 183 U. S. 563; see Worthen v. Sidway, ante.

15. Haws v. Victoria Copper Co., ante; Kern Oil Co. v. Crawford, 134 Cal. 298; see Worthen v. Sidway, ante.

16. See Gleason v. Martin White Co., ante; see also McKinley Creek Co. v. Alaska United Co., ante. All objects or monuments placed upon the ground, either at the time of the location or subsequently, whether intended as monuments or not, may be considered if, in fact, they help to mark it. Eaton v. Norris, ante.

17. Del Monte Co. v. Last Chance Co., ante; Bunker Hill Co. v. Empire State Co., 134 Fed. 268; Grassy Gulch Claim, 30 L. D. 191; Hidee Co., 30 L. D. 420 ; W. Granite Co. v. Granite Co., 7 Mont. 356; see Mont. Co. v. Clark, 42 Fed. 626 ; see $\$ 180-3$, post.

18. Bunker Hill Co. v. Empire State Co., ante.

19. See Del Monte Co. v. Last Chance Co., ante.

20. Stenfjeld v. Espe, 171 Fed. 825 .

21. C. C. $1426 \mathrm{c}$.

22. Nev. Comp. Laws. \& 220.

23. See Reins v. Murray. 22 L. D. 409; Kern Oil Co. v. Crawford, ante; Saxton v. Parry, 47 Colo. 263.

24. Rem. \& Ball. C. \& S.. $\$ 7367$.

25. Goss v. Golinsky, 12 Cal. A. 71; Brown v. Yarraham Co., 3 Cal. A. 474 ; see Kern Co. v. Crawford, ante.

26. Sanders v. Noble, 22 Mont. 110 ; see Lindley on Mines ( 2 d ed.), \& 396 .

27. McPherson v. Julius, 17 S. Dak. 98.

28. Doe v. Sanger, 83 Cal. 203. 
29. Del Monte Co. v. Last Chance Co., ante; Book v. Justice Co., ante; Smith v. Newell, 86 Fed. 56; Tonopah Co. v. Tonopah Co., 125 Fed. 408.

30. Temescal Co. v. Salcido, 137 Cal. 211.

31. Daggett v. Yreka Co., 149 Cal. 357.

32. Conway v. Hart, 129 Cal. 480 ; Brockbank v. Albion Co., ante.

33. Flagstaff Co. v. Tarbet, 98 U. S. 463; Daggett v. Yreka Co., ante; S. C. R. Co. v. O'Donnell, 3 Cal. A. 382.

34. Last Chance Co. v. Bunker Hill Co., 131 Fed. 579.

35. Bunker Hill Co. v. Empire State Co., ante; s. c. 134 Fed. 268.

36. Flagstaff Co. v. Tarbet, ante.

37. Id.

38. Iron Co. v. Elgin Co., 118 U. S. 196.

39. Doe v. Waterloo Co., 54 Fed. 935; Tyler v. Sweeny, 54 Fed. 284.

40. Carson City Co. v. N. Star Co., 73 Fed. 597.

41. Iron Co. v. Elgin Co., ante.

42. Cosmopolitan Co. v. Foote, 101 Fed. 518; St. Louis Co. v. Mont. Co., 104 Fed. 664; see Flagstaff Co. v. Tarbet, ante; Argentine Co. v. Terrible Co., 122 U. S. 478; Del Monte Co. V. Last Chance Co., ante; Walrath v. Champion Co., 63 Fed. 552; Jefferson Co. v. Anchoria Co., 32 Colo. 176.

43. Cosmopolitan Co. v. Foote, ante; Last Chance Co. v. Bunker Hill Co., ante.

44. Iron Co. v. Elgin Co., ante.

45. Cheesman v. Hart, 42 Fed. 98.

46. Doe v. Waterloo Co., ante.

47. Argonaut Co. v. Kennedy Co., 131 Cal. 15; affd. in 189 U. S. 1; King v. Amy Co., 152 U. S. 222; Doe v. Sanger, ante.

48. Flagstaff Co. v. Tarbet, ante; Argentine Co. v. Terrible Co.. ante; King v. Amy Co., ante; Last Chance Co. v. Tyler, 157 U. S. 683; Del Monte Co. v. Last Chance Co., ante; Last Chance Co. v. Bunker Hill Co., ante.

49. Bunker Hill Co. v. Empire State Co., ante; S. C. R. Co. v: O'Donnell, ante.

50. King v. Amy Co., ante; Bunker Hill Co. v. Empire State Co., ante.

51. Meydenbauer v. Stevens, ante; Belligerent Claims, 35 L. D. 22; McElligott v. Krogh, 151 Cal. 126; see Harper v. Hill, (Cal.) 113 Pac. 162.

52. Del Monte Co. v. Last Chance Co., ante.

53. Rev. Stats., $\$ 2320$; Meydenbauer v. Stevens, ante.

54. Eureka Co. v. Richmond Co., 8 Fed. Cas. 4548; Tonopah Co. v. Tonopah Co., ante; Empire State Co. v. Bunker Hill Co., 131 Fed. 591; Argonaut Co. v. Kennedy Co., ante.

55. Mont. Co. v. St. Louis Co., 183 Fed. 51.

56. Mont. Co. v. Boston Co., 22 Mont. 159. 


\section{CHAP'IER XXVII.}

\section{SUBSEQUEN'T LOCATIONS.}

$\S 178$. Amended or additional location-basis-office of amendment-contents of notice-one instrument.

$\S 179$. Re-location-when void-assumption of risk-statutory bar to re-location-fraudulent re-location-exception-improvements.

$\S 180$. Overlapping locations-basis-boundary marks-consent of owner-re-location-application for patentlaches and limitation.

$\S 181$. Lode location within placer claim-presumption-trespass - not trespass-limitation of area,

$\S 182$. Location of cross lodes.

$\S 178$. Amended or Additional Location. The mining act makes no provision for an amended or additional location. ${ }^{1}$ It may be made as of course. ${ }^{2}$ It relates back to the original location and completes the same. $^{3}$ It is not, strictly speaking, a re-location. ${ }^{4}$

2. Basis. It must be based upon a pre-existing but not necessarily perfect location. ${ }^{5}$ It works no forfeiture of previously acquired rights not inconsistent with the amendment. ${ }^{6}$ It must not interfere with the rights of others acquired between the time of making the original location and the amendment. ${ }^{7}$ It does not require additional discovery in the added ground, physical possession ${ }^{8}$ nor additional annual expenditure thereon. ${ }^{9}$

3. OfFice of Amendment. It may be designed to include additional territory, ${ }^{10}$ but not to effect a consolidation of independent mining claims. ${ }^{11}$

It may cure defects ${ }^{12}$ or supply omissions ${ }^{13}$ in the original location ${ }^{14}$ or in the posted notice or record, ${ }^{15}$ It may serve to change the name of the claim. ${ }^{16}$

4. Contents of Notice. Unless required by local statute or district rule an amended location notice need not state the purpose for which it is made. ${ }^{17}$

5. ONE Instrument. The original notice and the amendment are deemed to be one instrument though perhaps neither as a whole is absolutely correct and 
in conformity to the law, if in substantial compliance therewith. ${ }^{18}$

1. John C. Teller, 26 L. D. 484.

2. Thompson v. Spray, 72 Cal. 528.

3. Tonopah Co. v. Tonopah Co., 125 Fed. 389; Bunker Hill Co. v. Empire State Co., 134 Fed. 268; McGinnis v. Egbert, 8 Colo. 41; see Brown v. Or. King Co., 110 Fed. 728 .

4. Belk v. Meagher, 104 U. S. 279; Cheesman v. Shreve, 40 Fed. 787; Zerres v. Vanina, 150 Fed. 564; John C. Teller, ante; Quigley v. Gillett, 101 Cal. 462.

5. John C. Teller, ante; Sullivan v. Sharp, 33 Colo. 346 ; Milwaukee Co. v. Gordan, 37 Mont. 209; see Washington Co. v. O'Laughlin, 46 Cblo. 503.

6. Id.; Street v. Delta Co., 42 Mont. 371; see Kirk v. Meldrum, 28 Colo. 453.

7. Id.; Street v. Delta Co., ante; see Kirk v. Meldrum, ante.

8. Tonopah Co. V. Tonopah Co., ante; Hallack v. Traber. 23 Colo. 14; but see Biglow v. Conradt, 159 Fed. 868; Weed v. Snook, 144 Cal. 439.

9. Tonopah Co. v. Tonopah Co., ante; Hallack v. Traber, ante.

10. Seymour v. Fisher, 16 Colo. 188; Sullivan v. Sharp, ante; see Garden Gulch Bar Placer, 38 L. D. 28.

11. Garden Gulch Bar Placer, ante.

12. Porter v. Tonopah Co., 133 Fed. 756; Strepey v. Stark. 7 Colo. 614; Frisholm v. Fitzgerald, 25 Colo. 290; Morrison v. Regan, 8 Ida. 291; see Jordan v. Duke, 6 Ariz. 55.

13. Sullivan v. Sharp, ante.

14. Thompson v. Spray, ante; Wilson v. Freeman, 29 Mont. 470.

15. Bunker Hill Co. v. Empire State Co., ante; Tonopah Co. v. Tonopah Co., ante; Sam H. Auerbach, 29 L. D. 208; Wiltsee v. King Co., 7 Ariz. 95; Thompson v. Spray, ante.

16. Shoshone Co. v. Rutter, 87 Fed. 801; Seymour v. Fisher, ante; Butte Con. Co. v, Barker, 35 Mont. 327.

17. Tonopah Co. v. Tonopah Co., ante; Johnson v. Young, 18 Colo. 625 .

18. Duncan v. Fulton. 15 Colo. A. 140; see Giberson v. Tuolumne Co., 41 Mont. 396.

$\S 179$. Re-location. A subsequent location of a forfeited or abandoned claim is a re-location and not an original location. ${ }^{1}$ It is made in the same manner and is subject to the same conditions as an original location. ${ }^{2}$

2. WHEN VOID. It is void if entirely upon land actually covered by a valid and subsisting location ${ }^{3}$ or made under a fraudulent abandonment. ${ }^{3 a}$

3. Assumption of Risk. A re-location may be made without awaiting a judicial determination as to 
whether or not the claim was open to re-location, but the re-locator assumes the risk of possible future litigation over his action. ${ }^{4}$

4. Statutory Bar to Re-location. A valid relocation may be made by a claimant who has failed to make the requisite annual expenditure upon his location, either in his own name, ${ }^{5}$ or in that of a third party, ${ }^{6}$ except by statutory enactment, within the states of California ${ }^{7}$ and Montana. ${ }^{8}$

5. Fraudulent Re-locations. A vendor of property, not acting in good faith, ${ }^{9}$ a lessee in violation of the terms of his lease, ${ }^{10}$ a mortgagor for the purpose of defeating a mortgage, ${ }^{11}$ or a co-tenant for his own exclusive benefit ${ }^{12}$ may not make an adverse relocation.

An agent cannot re-locate, nor connive at a re-location in hostility to his principal. ${ }^{13}$ A watchman may not adversely re-locate the property formerly in his care. ${ }^{14}$

6. Exception. The existence of a partnership or the fact of previous employment may not perhaps create a trust in a location or re-location which is inimical to co-partners or the former employer. ${ }^{15}$

7. IMPROVEMENTS All improvements which are attached to or become a part of the realty pass to the re-locator. ${ }^{16}$ But they cannot be counted as part of the expenditure necessary in patent proceedings. ${ }^{17}$

1. Zerres v. Vanina, 150 Fed. 564.

2. Armstrong v. Lower, 6 Colo. 393; see Belk v. Meagher, 104 U. S. 279; Porter v. Tonopah Co., 133 Fed. 756.

3. Brown v. Gurney, 201 U. S. 184; Farrell v. Lockhart, 210 U. S. 142; Porter v. Tonopah Co., ante; Malone v. Jackson, 137 Fed. 787; Swanson v. Kettler, 17 Ida. 321; Berquist v. W. Va. Co., (Wyo.) 106 Pac. 673; see Lavagnino v. Uhilg, 198 U. S. 443. The rule is well established that the rights which a valid location of a claim secures to the locator and his grantors and successors are clearly defined by law and are wholly unaffected by any subsequent conflicting location. Del Monte Co. v. Last Chance Co., 171 U. S. 55; Street v. Delta Co., 42 Mont. 371. 
Re-location cannot be effected by interference with the performance of annual labor. Garvey v. Elder, 21 S. Dak. 77 ; see $\S 180$, note 11 , post.

3a. McCann v. McMillan, 129 Cal. 350 .

4. Del Monte Co. v. Last Chance Co., ante.

5. Hunt v. Patchin, 35 Fed. 816; Warnock v. DeWitt, 11 Utah 324; but see McCann v. McMillan, ante; Miles v. Kennan, 27 Colo. 502; see Malone v. Jackson, ante; but see Lindley on Mines, ( 2 d ed.) \& 405 .

It is the entry of a new claimant, with intent to relocate the property, and not lapse of time that determines the right of the original claimant. Little Gunnell Co. v. Kimber, 15 Fed. Cas. 8402 .

6. N. Noonday Co. v. Orient Co., 1 Fed. 522; see Alexander v. Sherman, 2 Ariz. 326 ; but see Lindley on Mines, ante.

7. The Californian mining act provides that "The failure or neglect of any locator of a mining claim to perform development work of the character, in the manner and within the time required by the laws of the United States, shall disqualify such locators from relocating the ground embraced in the original location or mining claim or any part thereof under the mining laws, within 3 years after the date of his original location and any attempted re-location thereof by any of the original locators shall render such location void." C. C., $\$ 1426$ s; see also McCann v. McMillan, ante.

8. Mont. Stats. 1907, p. 22.

9. Minah Co. v. Briscoe, 89 Fed. 891.

10. Stewart v. Westlake, 148 Fed. 349 ; Silver City Co. v. Lowry, 19 Utah 334 ; s. c. 179 U. S. 196.

11. Alexander v. Sherman, ante.

12. Stevens v. Grand Cent. Co., 133 Fed. 28; Speed v. McCarthy, 181 U. S. 269 . One of several co-tenants after default by all may re-locate for his own benefit. Strang v. Ryan, 46 Cal. 33; Doherty v. Morris, 11 Colo. 12; Saunders v. Mackèy, 5 Mont. 527.

13. Haws v. Victoria Copper Co., 160 U. S. 303 ; Page v. Summers, 70 Cal. 121; Lockhart v. Rollins, 2 Ida. (Hasb.) 540; Largey v. Bartlett, 18 Mont. 265.

14. Lockhart v. Rollins, ante; see Lockhart v. Leeds, 195 U. S. 427.

15. Lockhart v. Johnson, 181 U. S. 516; Doherty v. Morris, ante; Thallman v. Thomas, 111 Fed. 277.

16. Yankee Lode, 30 L. D. 289; Merritt v. Judd, 14 Cal. 59; Roseville Co. v. Iowa Co.. 15 Colo. 29.

17. Yankee Lode, ante; Russell v. Wilson Creek Co., 30 L. D. State Co., 109 Fed. 538; Mono Fraction, 31 L. D. 121, 34.

$\S 180$. Overlapping Locations. Mining claims often overlap one another ${ }^{1}$ through accident, innocent mistake ${ }^{2}$ or from design. ${ }^{3}$

It does not necessarily follow that either must fail nor that the conflicting area shall be awarded to the senior locator. ${ }^{4}$ Acts or circumstances entirely consistent with the true order of location may intervene 
which require that the overlap be awarded to the junior locator. ${ }^{5}$

2. BAsis. At the date of the location the ground located must be partly laid upon the public domain. ${ }^{6}$

3. Boundary Marks. The boundary marks of lode locations may be placed upon or across the surface of a prior location, or intervening ground, ${ }^{7}$ whether patented or unpatented, mining or agricultural ground, 8 and the extra-lateral right be thus secured. ${ }^{9}$

4. Consent of OWNer. The consent of the claimant or owner is not essential to the making of the overlap. In the absence thereof it must be peaceably made. ${ }^{10}$

5. RE-LOCATION. Upon forfeiture or abandonment by the former locator the overlapping unpatented area should be re-located by the junior locator. ${ }^{11}$

6. Application For PAtent. A failure of the senior locator to adverse an application for patent by the junior locator and which includes the overlap will vest the title thereto in such applicant. ${ }^{12}$

7. LaChes AND Limitation. The overlapping locator may, possibly, acquire the conflicting area by laches or limitation. ${ }^{13}$

1. Del Monte Co. v. Last Chance Co., 171 U. S. 55; Doe v Tyler, 73 Cal. 21.

2. Doe v. Tyler, ante.

3. Del Monte Co. v. Last Chance Co., ante; see Biglow v. Conradt, 159 Fed. 868; Weed v. Snook, 144 Cal. 439.

4. Id. U. S. Co. v. Lawson, 134 Fed. 769; Johanson v. White, 160 Fed. 901; Doe v. Tyler, ante; Street v. Delta Co., 42 Mont. 371 .

5. U. S. Co. v. Lawson, ante; Johanson v. White, ante; Garthe v. Hart, 73 Cal. 541; Gemmell v. Swain, 28 Mont. 331.

6. Belk v. Meagher, 104 U. S. 279 ; Brown v. Gurney, 201 U. S. 184; Farrell v. Lockhart, 210 U. S. 142; Crown Point Co. v. Buck, 97 Fed. 462; Bunker Hill Co. v. Empire State Co., 134 Fed. 268; Swanson v. Kettler, 17 Ida. 321; Bergquist, v. W. Va. Co., (Wyo.) 106 Pac. 673 ; see Lavagnino v. Uhlig, 198 U. S. 443.

7. Del Monte Co. v. Last Chance Co., ante; Alice Lode, 30 L. D. 481.

8. Hidee Co., 30 L. D. 420 ; cited in Bunker Hill Co. v. Empire State Co., 109 Fed. 538; Mono Fraction, 31 L. D. 121, 34 
L. D. 44; MePherson v. Julius, 17 S. Dak. 98; see $\$ 177-14,17$, ante.

9. Del Monte Co. v. Last Chance Co., ante; Empire State Co. v. Bunker Hill Co., 131 Fed. 591; Bunker Hill Co. v. Empire State Co., ante; Alice Lode, ante. But see A. C. M. Co. v. Court, 25 Mont. 504.

10. Del Monte Co. v. Last Chance Co., ante; Bunker Hill Co. v. Last Chance Co., ante; Hidee Co., ante; Cleary v. Skiffich, 28 Colo. 362; McElligott v. Krogh, 151 Cal. 126 ; see Mont. Co. v. Clark, 42 Fed. 626.

11. Oscamp v. Crystal River Co., 58 Fed. 293; Bingham Co. v. Ute Co., 181 Fed. 748; Johnson v. Young, 18 Colo. 625; Moorhead v. Erie Co., 43 Colo. 408; Farrell v. Lockhart, ante; Slavonian Co. v. Perasich, 7 Fed. 331; Biglow v. Conradt, ante; McCann v. McMillan, 129 Cal. 350. A location made within the limits of ground already appropriated is void ab initio. Street v. Delta Co., ante.

12. Lavagnino v. Uhlig, ante; Bingham Co. v. Ute Co., ante.

13. Oscamp v. Crystal River Co., ante; see Farrell v. Lockhart, ante; Brown v. Gurney, ante; Wilson v. Freeman, 29 Mont. 470; Moorhead v. Erie Co., ante; Nash v. McNamara, 30 Nev. 114; Bingham Co. v. Ute Co., ante; see $\$ 172-6$, ante.

§ 181. Lode Location within Placer Claim. A vein or lode which is of such a character as to exclude it from a placer location and which is not included in a patent therefor may be adversely located. ${ }^{1}$

2. Presumption. The presumption is in favor of the placer claimant. ${ }^{2}$

3. Trespass. The vein or lode must be known to exist as prospecting within the limits of a placer location without the will or consent of the placer claimant is prohibited. ${ }^{3}$

4. Not Trespass. It is held that a subsequent location of a vein or lode which is exempt from the placer claim is not a trespass. ${ }^{4}$

5. Limitation of Area. A valid subsequent lode location within the limits of a placer claim limits the placer claimant to the remainder of the placer location, although the entire area be included in a patent previously issued for the placer claim. ${ }^{5}$

1. Conaghy v. Doyle, 32 Colo. 92.

2. Iron Co. v. Campbell, 135 U. S. 286 ; see Grand Cent. Co. v. Mammoth Co., 29 Utah 490.

3. Clipper Co. v. Eli Co., 194 U. S. 220. 
4. Mt. Rosa Co. v. Palmer, 26 Colo. 56.

5. Reynolds v. Iron Co., 116 U. S. 687; Mt. Rosa Co. v. Palmer, ante; see-Washoe Co. v. Junila, (Mont.) 115 Pac. 917.

§182. Location of Cross Lodes. A subsequent locator of a vein or lode which erosses a prior location obtains only a right of way in such location. ${ }^{1}$

1. Wilhelm v. Silvester, 101 Cal. 358; Calhoun Co. v. Ajax Co., 27 Colo. 1 affd. in 182 U. S. 499; see Del Monte Co. v. Last Chance Co., 171 U. S. 55.

\section{CHAP'TER XXVIII.}

\section{NOTICE OF LOCATION.}

$\S 185$. In general - supplementary legislation - contents of record-additional recitals-not necessarily part of location-substantial compliance-oral testimonyimportance of boundaries - construction of notice sufficiency of notice-purpose fulfilled.

$\$ 186$. The posted notice-evidence of discovery and appropriation - recitals - question of fact - descriptionname of lode - errors in description - surplusage where posted-miners' devices-presumption.

\$187. The amended notice-intervening rights-evidence.

$\S 188$. The re-location notice-void notice-effect of statement -proof.

\$189. Ante-dated notice-felony.

$\$ 190$. Where recorded-county recorder-district recorderfailure to make record - description - what record need not show-question of fact-record as noticerecord not notice-record as title-effect of recordrecord as evidence-does not preclude parol evidence -when prima facie evidence-color of title.

$\S 185$. In General. The mining act does not require either the posting ${ }^{1}$ or recording ${ }^{2}$ of a notice of location.

2. Supplementary Legislation. The above matters are left to local statute or district rule. ${ }^{2 a}$

3. Contents of Record. When a record is made it must contain the name of the locator, the name of the lode or placer, the date of the location and such a description together with a reference to a natural object or permanent monument sufficient to identify the claim with reasonable certainty when such reference can be made to either. ${ }^{3}$ 
4. Additional Recitals. Additional recitals are usually prescribed by local statute or district rule $;^{4}$ the absence or insufficiency of such statements or other statutory requirements, as, to illustrate, the verification of the notice, may be fatal. ${ }^{5}$

5. Not Necessarily Part of Location. In the absence of a local statute or district rule requiring posting or recording neither act is any part of a legal location. ${ }^{6}$

6. Substantial Compliance. The question whether the requirements of a local statute or district rule have been complied with arises only upon the assertion of an adverse claim. ${ }^{7}$ It is then sufficient to show a substantial compliance therewith. ${ }^{8}$

7. Oral Testimony. The location may be aided, or wholly shown by oral testimony. ${ }^{9}$

8. IMPORTANCE OF Boundaries. A location will be sustained without either posting or recording, although both acts may be required by local law or district rule as acts of location, provided, the boundaries of the claim are defined and work is diligently prosecuted thereon. ${ }^{10}$

9. Construction of Notice. The notice of location should be liberally, not technically construed. ${ }^{11}$ A location is not absolutely void because the record may be indefinite, ${ }^{12}$ nor by reason of mistakes or imperfections therein. ${ }^{13}$

10. Sufficiency of Notice. The notice is sufficient when it contains directions which will enable a person of ordinary intelligence to find the claim and trace the boundaries therenf ${ }^{14}$ although it may not state the state or county or mining district within which it is situated ${ }^{15}$ or the proper legal subdivision within which it may. be located, if the remaining description sufficiently identifies the land. ${ }^{16}$ It may mis-describe the character of the monuments, ${ }^{17}$ or mistake the courses or distances of the boundaries, ${ }^{18}$ or the 
points of the compass. ${ }^{19}$ Such defects do not vitiate the notice. ${ }^{20}$

11. Purpose Fulfilled. The purpose of the notice is fulfilled when it informs others of the appropriation of the ground $;^{21}$ whether it does so or not is a question of fact. ${ }^{22}$

1. Book v. Justice Co., 58 Fed. 106; Walton v. Wild Goose Co., 123 Fed. 209; Daggett v. Yreka Co., 149 Cal. 357.

2. Haws v. Victoria Co., 160 U. S. 303: Peters v. Tonopah Co., 120 Fed. 587; Anthony v. Jillson, 83 Cal. 296; So. Cross Co. v. Europa Co., 15 Nev. 383; Deeny v. Min. Creek Co., 11 N. M. 279; Payton v. Burns, 41 Or. 430.

2a. Sturtevant v. Togel, 167 Fed. 448.

3. Rev. Stats., $\$ 2324$; Hoyt v. Russell, 117 U. S. 401; M'Intosh v. Price, 121. Fed. 716.

4. Hammer v. Garfield Co., 130 U. S. 291; Butte City v. Baker, 196 U. S. 119; M'Intosh v. Price, ante; Purdum v. Laddin, 23 Mont. 387; see Hickey v. Anaconda Co., 33 Mont. 46; Wright v. Lyons, 45 Or. 167; Van Buren v. McKinley, 8 Ida. 93 .

Under the provisions of the Californian mining act a notice of a lode location must be posted at the point of discovery (C. C., $\$ 1426$ ) of a placer claim within the boundaries thereof (C. C., $\$ 1426 \mathrm{c}$ ), of a tunnel site at the face or point of commencement of the tunnel (C. C., $\$ 1426 \mathrm{e})$, of a mill-site within the boundaries thereof. (C. C., \& 1426 j.)

5. Davidson v. Bordeaux, 15 Mont. 245.

6. Sturtevant v. Vogel, ante; see Dwinnell v. Dyer, $145 \mathrm{Cal}$. 12. The rule is not applicable in Alaska. 31 Stats. 327.

7. Hughes v. Ochsner, 27 L. D. 396 ; Sharkey v. Candiani, 48 Or. 112.

8. Zerres v. Vanina, 134 Fed. 610; Wells v. Davis, 22 Utah 322 .

9. Londonderry v. United Gold Co., 38 Colo. 480; Metcalf v. Prescott, 10 Mont. 283; Seidler v. LaFave, 5 N. M. 44.

10. Wailes v. Davies, 158 Fed. 667 ; see also Zerres v. Vanina, ante; Ford v. Campbell, 29 Nev. 578; Sharkey v. Candiani, ante.

11. Dwinnell v. Dyer, ante; Green v. Garvin, 10 Cal. A. 330.

12. Walton v. Wild Goose Co., ante; Zerres v. Vanina, ante; Wailes v. Davies, ante; Wiltsee v. King Co., 7 Ariz. 95; Talmadge v. St. John, 129 Cal. 430; Morrison v. Regan, 8 Ida. 291; Bismarck Co. v. No. Sunbeam Co., 14 Ida. 516; Wilson v. Triumph Co., 19 Utah 66; Farmington Co. v. Rhymney Co., 20 Utah 363 ; Wells v. Davies, ante.

13. Bennett v. Harkrader, 158 U. S. 441; see Darger v. LeSieur, 8 Utah 160.

14. Walton v. Wild Goose Co., ante; Sturtevant v. Vogel, ante; Providence Co. v. Burke, 6 Ariz. 323: Wiltsee v. King Co., ante; Sanders v. Noble, 22 Mont. 110; Gleeson v. Martin White Co., 13 Nev. 442; Bonanza Co. v. Golden Head Co., 29 Utah 159. 
15. Bramlett v. Flick, 23 Mont. 95; Bonanza Co. v. Golden Head Co., ante.

16. Carter v. Bacigalupi, 83 Cal. 187; Talmadge v. St. John, ante. Upon the subject of description see Metcalf v. Prescott, ante.

17. Duryea v. Boucher, $67 \mathrm{Cal}$. 141; see $\$ 149$, note 21 , ante.

18. Upton v. Larkin, 7 Mont. 449; Hansen v. Fletcher, 10 Utah 266.

19. Walton v. Wild Goose Co., ante; Providence Co. v. Burke, ante; Gamer v. Glenn, 8 Mont. 371.

20. Green v. Garvin, ante; Book v. Justice Co., ante; Wiltsee v. King Co., ante.

21. Gird v. Cal. Oil Co., 60 Fed. 531; Rush v. French, 1 Ariz. 99 ; Seidler v. LaFave, ante.

22. Eilers v. Boatman, 111 U. S. 356; Reilly v. Berry, 2 Ariz. 272 ; Blackmore v. Reilly, 2 Ariz. 442 .

$\S 186$. The Posted Notice. The posted notice required by the local statute or district rule serves as a protection to the locator while engaged in marking and developing his claim. ${ }^{1}$

2. Evidence OF Discovery and ApPropriation. The posted notice is also some evidence of discovery ${ }^{2}$ and a declaration of the locator's intention to possess it. ${ }^{3}$

3. Recitals. No particular recitals are necessary in the posted notice, except such as may be required by local statute or district rule; in which case, it should conform thereto $;^{4}$ otherwise it is sufficient if it imparts notice of the ground claimed. ${ }^{5}$

4. Question OF FACT. The sufficiency of the notice is a question of fact. ${ }^{6}$ If it is uncertain it may be aided by evidence of possession and the erection of monuments. ${ }^{7}$

5. DESCRIPTION. A notice claiming a location on "this vein" has only one meaning. 8 It raises an inference that the notice was posted on or in close proximity to a vein or lode ${ }^{9}$ although, as a fact, no vein or lode was then exposed. ${ }^{10}$

6. NAME OF Lode. The name of the lode is that by which it is designated in the notice ${ }^{11}$ and subsequent addition thereto is immaterial, ${ }^{12}$ The same 
vein or lode may have different names in different mining locations. ${ }^{13}$

7. ERRors in Description. Errors in description will not invalidate the location, if it can be sufficiently identified. ${ }^{14}$ Stating an erroneous date ${ }^{15}$ or erasing a locator's name from the location notice is immaterial, unless fraudulently done. ${ }^{16}$ Mis-naming some of the boundary marks is not fatal. ${ }^{17}$

8. SurPlusage. Unless required by local statute or district rule the posted notice need not contain a reference to a natural object or permanent monument, ${ }^{18}$ nor the words "dated on the ground", 19 nor be a literal copy of the record. ${ }^{20}$

9. Where Posted. The notice is usually posted at the place of discovery ${ }^{21}$ but unless its position is prescribed by local statute or district rule the notice may be placed upon or off the location. ${ }^{22}$

10. Miners' Devices. Miners use various devices to protect the posted notice from destruction by the elements, such as covering it with glass, or folding it in a box and placing the box in a conspicuous place, or putting the notice upon a mound of rocks, folding it and partially covering it with rock, ${ }^{23}$ or putting the notice in a tin can. ${ }^{24}$ A substantial compliance with the law is sufficient. ${ }^{25}$

11. Presumption. It may be presumed from a recital to that effect in the record that the notice of location was in fact posted. ${ }^{26}$

1. Erhardt v. Boaro, 113 U. S. 527; Green v. Garvin, 10 Cal. A. 330; Sanders v. Noble, 22 Mont. 110; Street v. Delta Co., 42 Mont. 371 .

2. Fox v. Myers, 29 Nev. 169.

3. Thompson v. Lee, 8 Cal. 276.

4. Baker v. Butte City Co., 28 Mont. 222.

Under the federal mining act it is not necessary to designate in the location notice the particular use or character of a placer claim. It is sufficient to designate it as a placer claim without any description as to kind or quality. Such words in no way abridge the right of the owner, but should be treated as surplus- 
age. Freezer v. Sweeny, 8 Mont. 508; see McCann v. McMillan, 129 Cal. 350.

In California the record must be a true copy of the posted notice. C. C., $\$ 1426 \mathrm{~b}-\mathrm{d}-\mathrm{g}-\mathrm{k}$.

5. Farmington Co. v. Rhymney Co., 20 Utah 363 ; see Gird v. Cal. Oil Co., 60 Fed. 531; Rush v. French, 1 Ariz. 99.

6. Eilers v. Boatman, 111 U. S. 356 .

7. Reilly v. Berry, 2 Ariz. 272.

8. Phillpotts v. Blasdell, 8 Nev. 61; Daggett v. Yreka Co., 149 Cal. 357.

9. Daggett v. Yreka Co., ante.

10. Book v. Justice Co., 58 Fed. 106; see Willeford v. Bell, (Cal.) 49 Pac. 6; Daggett v. Yreka Co., ante.

11. Phillpotts v. Blasdell, ante. See Rose v. Richmond Co., $17 \mathrm{Nev} .25$.

12. Doe v Waterloo Co., 55 Fed. 11.

13. Phillpotts v. Blasdell, ante.

14. Walton v. Wild Goose Co., 123 Fed. 209; Providence Co. v. Burke, 6 Ariz. 523; Green v. Garvin, ante; Butte N. Co. v. Radmilovich, 39 Mont. 157.

15. Webb v. Carlon, 148 Cal. 555 .

16. Muldoon v. Brown, 21 Utah 121; see Morton v. Solambo Co., 26 Cal. 527.

17. Upton v. Larkin, 7 Mont. 449; Hansen v. Fletcher, 10 Utah 266 ; see $\$ 185-10$, ante.

18. Gleeson v. Martin White Co., 13 Nev. 442.

19. Preston v. Hunter, 67 Fed. 998.

20. Gird v. Cal. Oil Co., ante; see note 4, ante.

21. Sanders v. Noble, ante.

22. Haws v. Victoria Co., 160 U. S. 303 ; Upton v. Sta. Rita Co., 14 N. M. 96; see Green v. Garvin, ante.

23. Donahue v. Meister, 88 Cal. 121.

24. Gird v. Cal. Oil Co., ante.

25. Donahue v. Meister, ante.

26. Jantzon v. Arizona Co., 3 Ariz. 6.

$\S 187$. The Amended Notice. An amended notice of location is made for the purpose of correcting errors and defects in the original notice or as evidence of the changing of the boundaries of the original location. ${ }^{1}$

2. InTERVENING Rights. In the absence of intervening rights ${ }^{2}$ it relates back to the original location ${ }^{3}$ without loss of rights not inconsistent with the amendment. 4

3. Evidence. Except as against intervening rights an amended notice serves the same purpose, in its admission in evidence, as that of the original notice of location. ${ }^{5}$ 
1. Porter v. Tonopah Co., 133 Fed. 756; Sullivan v. Sharp, 33 Colo. 346; Bismarck Co. v. No. Sunbeam Co., 14 Ida. 516; Wilson v. Freeman, 29 Mont. 470.

The mining act of California provides that "If at any time the locator of any mining claim heretofore or hereafter located, or his assigns, shall apprehend that his original location notice was defective, erroneous, or that the requirements of the law had not been complled with before filing; or in case the original notice was made prior to the passage of this act, and he shall be desirous of securing the benefit of this act, such locator, or his assigns, may file an additional notice, subject to the provisions of this act; provided, that such amended location notice does not interfere with the existing rights of others at the time of posting and filing such amended location notice, and no such amended location notice or the record thereof, shall preclude the claimant, or claimants from proving any such title as he or they may have held under previous locations." C. C., $\$ 1426 \mathrm{~h}$.

2. Bunker Hill Co. v. Empire State Co., 134 Fed. 268; John C. Teller, 26 L. D. 484; Morrison v. Regan, 8 Ida. 291.

3. McGinnis v. Egbert, 8 Colo. 41; see Bismark Co. v. No. Sunbeam Co., ante.

4. Bunker Hill Co. v. Empire State Co., ante.

5. Milwaukee Co. v. Gordan, 37 Mont. 209; see Moyle v. Bullene, 7 Colo. A. 308 .

$\S 188$. The Re-location Notice. Unless required by local statute or district rule it is not necessary to state in the notice the fact of re-location.

2. Void Notice. When so required the absence of such a recital renders the re-location void. ${ }^{1}$

3. EFfect of Statement. A statement in a notice that it is a re-location of a named claim is the equivalent of an admission of its validity, that the re-locator claims a forfeiture or abandonment on the part of the prior claimant ${ }^{2}$ and precludes the former from asserting the contrary. ${ }^{3}$

4. Proof. It is not necessary to prove either forfeiture or abandonment on the part of the prior claimant in the absence of an adverse claim by him. ${ }^{4}$

1. Omar v. Soper, 11 Colo. 380; Cunningham v, Pirrung, 9 Ariz. 288.

2. Manhattan Co., 2 L. D. 698; Cunningham v. Pirrung, ante; Murray v. Osborne, (Nev.) 111 Pac. 31; Wills v. Blain, 5 N. M. 238; Zeiger v. Dowdy, (Ariz.) 114 Pac. 765.

3. Zerres v. Vanina, 150 Fed. 564 .

4. Manhattan Co., ante. 
$\S 189$. Ante-dated Notice. A location notice which is ante-dated, with fraudulent intent, is void. ${ }^{1}$ In Nevada false dating of a location notice is a felony. ${ }^{2}$

1. Bramlett v. Flick, 23 Mont. 95; Muldoon v. Brown, 21 Utah 121. A posted location notice is not invalidated by the fact that it is posted after midnight of the date it bears, no fraud appearing and the notice being posted before the initiation of a conflicting claim. Bergquist v. W. Va. Wyo, Co. (Wyo.), 106 Pac. 673.

2. Nev. Stats. 1907 , p. 373 .

$\S 190$. Where Recorded. The recording of a notice of location is necessary only when required by local statute or district rule $;^{1}$ which usually fixes the time and place therefor. ${ }^{2}$

2. County Recorder. The office of the County Recorder of the county within which the claim is situated is usually fixed by local statute as the place of record and also sometimes, in addition thereto, the office of the proper Mining Recorder.

3. District Recorder. The district rules, generally, require the notice to be recorded in the office of the mining district as well as in the office of the County Recorder. If it be required that the notice be filed with the Mining Recorder and his place of business is publicly known it is essential that such be done. ${ }^{3}$

4. Failure to Make Record. Failure to make the record within the prescribed time does not work a forfeiture of the claim unless so expressly provided ${ }^{4}$ or no intervening rights have accrued. ${ }^{5}$

5. Description. The description given in the record must be sufficient to apprise others of the precise location of the claim, as, for example, a prospector ${ }^{6}$ or an officer seeking to execute process, ${ }^{7}$ or to sustain a judgment. ${ }^{8}$

6. What Record Need Not Show. The mining act does not require that the record shall show that the location is so marked that the boundaries of the claim can be readily traced, ${ }^{9}$ 
7. Question of FACT. It is a question of fact whether or not it is so marked. ${ }^{10}$

8. RECORD as Notice. A recorded notice of location gives no information of a claim not actually located; nor does even a notice posted on the ground, unless it appears that the party posting it is proceeding with reasonable diligence to indicate, or is about to indicate the boundaries by marking them. ${ }^{11}$

9. Record Not Notice. Record evidence of a location is not made in the United States Land Office but in the local place of record. The first official information that office has of the location is, when the application for patent is filed therein. In agricultural entries all the record is made in such office. ${ }^{12}$

10. Record as Titse. The record of the location of a mining claim is not a title nor proof of a title, nor does it constitute nor of itself establish the possessory right to which it relates, ${ }^{13}$ although in part the basis of the right to the location, ${ }^{14}$ and one of the steps to perfect the same. ${ }^{15}$

11. EFFECT OF RECORD. It has no greater effect than that given by the registration laws of the State, ${ }^{16}$ and conclusively proves no more than its own recordation as all the other necessary steps of location, when contested, must be established by proof outside of such record. ${ }^{17}$

12. ReCord as Evidence. When required under a local statute or district rule the failure to record may be supplied by oral proof of the location ${ }^{18}$ as such law is directory ${ }^{19}$ and designed as a rule of evidence only, to determine the rights of an adverse claimant of the premises under a subsequent location. ${ }^{20}$ When not so required it is not admissible in evidence, ${ }^{21}$ nor is it a link in the chain of title. ${ }^{22}$

13. Does Not Preclude Parol Evidence. The record does not exclude parol proof of actual posses- 
sion and the extent of that possession as prima facie evidence of title. ${ }^{23}$

14. When Prima Facie Evidence. When made so by local statute 23 a or when not objected to in the course of judicial proceedings the record is prima facie evidence of citizenship of the locator ${ }^{24}$ and of all the law requires such record to contain and which are therein sufficiently set forth 25 as, for instance, discovery, that the reference therein to a natural object or permanent monument is sufficient to identify the claim ${ }^{26}$ and that the locator has fully complied with the law in making the location. ${ }^{27}$

15. ColOR of Titue. When coupled with possession it may be sufficient color of title. ${ }^{2 s}$

1. Haws v. Victoria Co., 160 U. S. 303: Peters v. Tonopah Co., 120 Fed. 587; Moore v. Steelsmith, 1 Alaska 121; Anthony v. Jillson, 83 Cal. 296; Deeny v. Min. Creek Co., 11 N. M. 279; So. Cross Co. v. Europa Co., $15 \mathrm{Nev}$. 383 ; Payton v. Burns, 41 Or. 430.

2. Meydenbauer v. Stevens, 78 Fed. 787; Butler v. Good Enough Co., 1 Alaska 246.

3. Fox v. Myers, 29 Nev. 169.

4. Last Chance Co. v. Bunker Hill Co., 131 Fed. 579; Sturtevant v. Vogei, 167 Fed. 448.

5. Preston v. Hunter, 67 Fed. 996 ; Zerres v. Vanina, 134 Fed. 610; Buffalo Zine Co. v. Crump, 70 Ark. 525; Columbia Co. v. Duchess Co., 13 Wyo. 244; Slothower v. Hunter, 15 Wyo. 189; see Kendall v. San Juan Co., 144 U. S. 658 .

6. Eilers v. Boatman, 111 U. S. 356.

7. Darger v. Le Siêr, 8 Utah 160.

8. Tracy v. Harmon, 17 Mont. 465.

9. McCann v. McMillan, 129 Cal. 350. The description of the location as appears from the record is binding on the locator except that if it varies from the markings actually on the ground the latter prevail, although they may include less ground than called for by the record. Meydenbauer v. Stevens, ante.

10. Taylor v. Middleton, 67 Cal. 656 ; Farmington Co. v. Rhymney Co., 20 Utah 363.

11. Gregory v. Pershbaker, 73 Cal. 109.

12. Caribou Lode, 24 L. D. 488.

13. Zerres v. Vanina, ante; Strepey v. Stark, 7 Colo. 614.

14. Pollard v. Shively, 5 Colo. 309.

15. Strepey $\ddot{v}$. Stark, ante.

16. Campbell v. Rankin, 99 U. S. 261 ; see Jordan v. Duke, 6 Ariz. 55.

The mining act of California provides that: "Copies of the records of all instruments required to be recorded by the provisions of this act, duly certified by the recorder, in whose custody such records are, 
may be read in evidence, under the same circumstances and rules as are now, or may be hereafter provided by law, for using copies of instruments relating to real estate, duly executed or acknowledged or proved and recorded." C. C., \$1426q.

17. Mutchmor v. McCarty, 149 Cal. 603; see also Uinta Co. v. Creede Co., 119 Fed. 164; Campbell v. Rankin, ante; Strepey v. Stark, ante; see note $23 \mathrm{a}$, post.

18. Wailes v. Davies, 158 Fed. 667; see Zerres v. Vanina, ante; Ford v. Campbell, 29 Nev. 578; Slothower v. Hunter, ante.

19. Wailes v. Davies, ante.

20. Sharkey v. Candiani, 48 Ore. 112. Where the relative priority of conflicting locations depends, upon the exact hour of the day or filing, fractions of a day are taken into account. Washington Co. v. O'Laughlin, 46 Colo. 503 .

21. Golden Fleece Co. v. Cable Con. Co., 12 Nev. 312.

22. Daggett v. Yreka Co., 149 Cal. 357.

23. Campbell v. Rankin, ante.

23a. Mont. Stats. 1907, p. 20; Nevada Stats. 1907, p. 419.

24. Jantzon v. Arizona Co., 3 Ariz. 6.

25. O'Reilly v. Campbell, 116 U. S. 418; Jantzon v. Arizona Co., ante; Strepey v. Stark, ante; see Uinta Co. v. Creede Co., ante.

26. Brady v. Husby, 21 Nev. 453; but see Smith v. Newell, 86 Fed. 56.

27. Cheesman v. Shreve, 40 Fed. 787; Cheesman v. Hart, 42 Fed. 98.

28. Protective Mg. Co. v. Forest City Co., 51 Wash. 643 .

\section{CHAPTER XXIX.}

\section{ANNUAL EXPENDITURE.}

\$193. Provisions of the mining act-district rule.

\$194. Place of performance-character of labor and improvements-personal services-group of locations-labor upon group-burden of proof.

§195. Sufficiency of performance-compliance with local statute or district rule-payment not conclusivepayment bears upon value-payment not essential.

$\S$ 196. Proof of performance-not mandatory laws-effect of filing-neglect to file not fatal.

\$ 197. Non-performance-when claim forfeited-claim of forfeiture-adverse possession-what is not excuse for non-performance.

\$198. Resumption of labor-time for resumption-effect of resumption-what is not resumption-trespass.

\$199. Who may make expenditure-presumption.

$\$ 200$. Failure to contribute-effect of demand-character of title-basis of notice-right to give notice-contents of notice-personal service-publication.

$\S 193$. Provisions of the Mining Act. The mining act prescribes the minimum amount of the annual ex- 
penditure and the maximum limit of the time within which it may be made. ${ }^{1}$ It provides that at least $\$ 100$ worth of labor, that is, prospecting and excavating for the purpose of development ${ }^{2}$ shall be done; or improvements, that is, tangible, and reasonably permanent additions for purpose of development ${ }^{3}$ shall be made upon or for each lode and placer location ${ }^{4}$ at some time during each calendar year ${ }^{5}$ succeeding the calendar year in which the location ${ }^{6}$ was made, ${ }^{\top}$ until patent, ${ }^{8}$ or its equivalent is issued. ${ }^{9}$

2. District Rule. A district rule may properly increase the amount of the expenditure and require labor to be done upon a claim within the first calendar year of location under penalty of forfeiture. ${ }^{10}$

1. Northmore v. Simmons, 97 Fed. 386 .

The mining act of California provides that: The amount of work done or improvements made during each year to hold possession of a mining claim shall be that prescribed by the laws of the United States, to wit: one hundred dollars annually. C. C., $\$ 14261$.

Where the location is incomplete no question of assessment work is involved. McLemore v. Express Co., 158 Cal. 559.

2. Power v. Sla, 24 Mont. 243.

3. Id. Fredericks v. Klauser, 52 Or. 110; Bishop v. Baisley, 28 Or. 119.

4. Rev. Stats., $\$ 2324$; Carney v. Arizona Co., 65 Cal. 40.

5. Mills v. Fletcher, 100 Cal. 142.

6. Anderson v. Caughey, 3 Cal. A. 22; McGinnis v. Egbert, 8 Colo. 41; see Hickey v. Anaconda Co., 33 Mont. 46.

7. Rev. Stats., § 2324; Malone v. Jackson, 137 Fed. 787.

8. Rev. Stats., § 2324 .

9. Benson v. Alta Co., 145 U. S. 428; Brown v. Gurney, 201 U. S. 184; but see Swigart v. Walker, 49 Kan. 100; Murray v. Polglase, 23 Mont. 401.

10. Northmore v. Simmons, ante; but see Original Co. v. Winthrop, 60 Cal. 631 .

$\S 194$. Place of Performance. The labor may be done upon or underneath the surface of the location, or be away therefrom. ${ }^{1}$ It must have a direct relation to the present or future development or working of the property. ${ }^{2}$

2. Character of Labor and Improvements. The labor may be upon the vein or lode ${ }^{3}$ but it must be something more than taking rock therefrom, from 
time to time, and testing it for the purpose of finding pay ore. ${ }^{4}$ It may consist of un-watering the claim ${ }^{5}$ or in the erection of a flume to carry away water or waste, or in the introduction of water or the turning of a stream. ${ }^{6}$ The erection of machinery and other works $^{7}$ or of a building; if of benefit to the claim ${ }^{8}$ and not too distant therefrom, ${ }^{9}$ or the building of a road $^{10}$ may be sufficient. Reasonable compensation may be allowed for the use of 11 or for the sharpening of tools used, ${ }^{12}$ but not the purchase price thereof. ${ }^{13}$ The value of powder, fuse, candles, rails and timber actually used, 14 but not the cost of transporting them, ${ }^{15}$ may be counted. Reasonable compensation for the daily use of horses employed in drawing cars or in raising ore, etc., but not their cost, livery hire, feed or shoeing, may be treated as labor performed. ${ }^{16}$ Reasonable value of meals furnished to men while employed in "assessment work," but not the cost of table ware, house furnishings, provisions, or tobacco, may be counted. ${ }^{17}$

3. Personal Services. The services of a watchman are sufficient, if necessary to preserve the excavations, the structures erected to work the claim ${ }^{18}$ or to preserve personal property $;^{19}$ but they are not sufficient where he merely lives upon the claim ${ }^{20}$ or warns others from locating it. ${ }^{21}$. The services of a person employed in planning and superintending the development of a claim and the erection of a mill and machinery may be deemed part of the assessment work, ${ }^{22}$ but the services of an agent or accountant ${ }^{23}$ or of a person whose time is spent in endeavoring to obtain means for the development of property, ${ }^{24}$ will be insufficient.

4. Group of Locations. Any number of contiguous locations held in common may form a group except in case of oil placer locations. These, by law, are limited to groups of five. ${ }^{25}$ 
5. Labor Upon Group. Labor may be done or improvements made upon or at a distance from any one of the locations comprising the group when of benefit and value to the entire group. ${ }^{26}$

The expenditure must equal, in the aggregate, the amount required on all the locations. ${ }^{27}$ It must be a part of a general plan having in view the development of the group ${ }^{28}$ as labor upon or for a location therein which has no reference to the development of all the locations will not be sufficient. ${ }^{29}$ While a court should not substitute its judgment for that of the locator as to the wisdom and expediency of the "plan" 30 yet it remains a question of fact whether the requirement of the law has been fulfilled. ${ }^{31}$ By adopting a general scheme for the group instead of making the expenditure upon each separate location there is the risk of an adverse legal determination of the question, ${ }^{32}$ a hazard which a mortgagee may insist shall not be taken. ${ }^{33}$

6. Burden of Proof. The burden of proof as to the sufficiency of the expenditure under the general plan to hold all the locations within the group rests with the claimant thereunder. ${ }^{34}$ The natural and reasonable presumption is that all the work is done as part of the system, and as such applicable to all the locations. ${ }^{35}$ But it must tend either to enhance the value of the claim in dollars and cents, or that which is of use in prospecting, developing or operating the property. ${ }^{36}$

1. Mt. Diablo Co. v. Callison, 17 Fed. Cas. 9886.

2. Jackson v. Roby, 109 U. S. 440 ; Yreka Co. v. Knight, 133 Cal. 544; Fissure Co. v. Old S'usan Co., 22 Utah 438.

3. Lockhart v. Rollins, 2 Ida. (Hasb.) 540.

4. Bishop v. Baisley, 28 Or. 119.

5. Honaker v. Martin, 11 Mont. 91; but see Evalina Co. v. Yosemite Co., (Cal. A.) 115 Pac. 947.

6. Jackson Co. v. Roby, ante. See Anvil Co. v. Code, 182 Fed. 205.

7. Lockhart v. Rollins, ante; but see Big 3 Co. v. Hamilton, 157 Cal. 130.

8. Bryan v. McCraig, 10 Colo. 309. 
9. Remington v. Baudit, 6 Mont. 138.

10. Doherty v. Morris, 17 Colo. 105. See Pierce's Wash. Code $\S 6453$.

11. Fredericks v. Klauser, 52 Or. 110.

12. Hirschler v. McKendricks, 16 Mont. 211.

13. Fredericks v. Klauser, ante.

14. Id.

15. Id.; but see Whalen Co. v. Whalen, 127 Fed. 611.

16. Fredericks v. Klauser, ante.

17. Id.

18. Altoona Co. v. Integral Co., 114 Cal. 100; Danaldson v. Orchard Co., 6 Cal. A. 641; Lockhart v. Rollins, ante; see Hough v. Hunt, 138 Cal. 142; Fredericks v. Klauser, ante.

19. Kinsley v. New Vulture Co., 11 Ariz. 66; Ingersol v. Scott (Ariz.), 108 Pac. 460.

20. Hough v. Hunt, ante.

21. Altoona Co. v. Integral Co., ante; Whiting v. Straup, 17 Wyo. 1.

22. Rara Avis Co. v. Bouscher, 9 Colo. 385.

23. Id.; but see Whalen Co. v. Whalen, ante.

24. Du Prat v. James, 65 Cal. 555; McLemore v. Express Co., 158 Cal. 559.

25. 32 Stats. 825 ; see Gird v. Cal. Oil Co., 60 Fed. 531.

26. Chambers v. Harrington, 111 U. S. 350; Book v. Justice Co., 58 Fed. 106; Anvil Co. v. Code, ante; Mt. Diablo Co. v. Callison, ante: Elmer F. Cassel, 32 L. D. 85; Wood Placer Co., 32 L. D. 401; Fredericks v. Klauser, ante; Hawgood v. Emery, 22 S. Dak. 573; see Aldebaran Co., 36 L. D. 551.

It .would be absurd to require a shaft to be sunk on each location in a consolidated claim when one shaft would suffice for all the locations. St. Louis Co. v. Kemp, 104 U. S. 636; Copper Mt. Co. v. Butte \& Corbin Co., 39 Mont. 487: Sexton v. Wash. Co., 55 Wash. 380. See Big 3 Co. v. Hamilton, ante. But if the claims are not contiguous the work is insufficient. Anvil Co. v. Code, 182 Fed. 205; see Morgan v. Myers, post.

27. St. Louis Co. v. Kemp, ante; Chambers v. Harrington, ante; Mt. Diablo Co. v. Callison, ante; Book v. Justice Co., ante; Gird v. Cal. Oil Co., ante; Justice Co. v. Barclay, 82 Fed. 554; Elmer F. Cassel, ante; Wood Placer Co., ante: James Caretto, 35 L. D. 361; Power v. Sla, 24 Mont. 243.

28. Jackson v. Roby, ante; Hìghland Marie Claims, 31 L. D. 37; Elmer F. Cassel, ante; Wood Co., ante; Copper Mt. Co. v. Butte \& Corbin Co., ante.

29. Jackson v. Roby, ante.

Where several contiguous mining claims constitute a group and expenditures are made upon an improvement which is intended to aid in the development of all so held, the improvement constitutes a distinct entity, not subject to physical subdivision or apportionment, in its application to the claims intended to be benefited by it. The work performed attaches to the claims collectively and not severally. Duncan v. Eagle Rock Co., 48 Colo. 569; see Jas. Carretto, ante.

30. Mann v. Budlong, 129 Cal. 577; Wright v. Killian, 132 Cal. 56; Gear v. Ford, 4 Cal. A. 556; see Copper Mt. Co. v. Butte \& Corbin Co., ante. 
31. Copper Co. v. Butte \& Corbin Co., ante; see Wailes v. Davies, 158 Fed. 667.

32. Anvil Co. v. Code, ante; Big 3 Co. v. Hamilton, ante; Copper Co. v. Butte \& Corbin Co., ante.

33. Copper Belle Co. v. Costello, 11 Ariz. 334.

34. Whalen Co. v. Whalen, ante; see Wailes v. Davies, ante; Yreka Co. v. Knight, ante.

35. Mt. Diablo Co. v. Callison, ante. In contested cases concerning assessment work upon a group of locations the best evidence of the existence of the group is the situs of the properties and the kind, quality and place of the work performed. The fact that the location notice recites that the locations are "together and touching" is not conclusive. Evidence of the claimant's intention to hold them as a group is inadmissible. Testimony as to the topography of the region, that unclaimed and unoccupied ground lies between some of the locations or that they are separated by a ravine is germane to the issue. Morgan v. Myers, (Cal.) 113 Pac. 153.

36. Anvil Co. v. Code, ante.

$\S 195$. Sufficiency of Performance. The test of the sufficiency of the expenditure is the reasonable value; not what is paid nor the contract price, but whether the expenditure tends to facilitate the development or actually promotes or directly tends to promote the extraction of mineral from or improve the property or be necessary for its care or the protection of the mining works thereon or pertaining thereto. ${ }^{1}$

2. Compliance with Local Statute or District RULE. A compliance with the provision of a local statute or district rule to the effect that a certain number of days' work at a certain sum a day, or that work of a certain character or extent shall constitute the requisite expenditure may be insufficient to meet the requirements of the mining act. ${ }^{2}$

3. Payment Not Conclusive. Payment is not conclusive proof of performance. ${ }^{3}$ It may be an evidence of good faith ${ }^{4}$ but not that the labor done or improvements made were worth the amount paid. ${ }^{5}$.

4. Payment Benrs upon Value. Payment bears upon the value ${ }^{6}$ which may be insufficient although equal to the amount required by law. ${ }^{7}$ 
5. Payment Not Essential. Labor actually done or improvements made may be sufficient to hold the claim although not in fact paid for; but payment made for work not done will not suffice. ${ }^{8}$

See $\& 199$, post.

1. Jackson v. Roby, 109 U. S. 440; McCulloch v. Murphy, 125 Fed. 147; McKay v. Neussler, 148 Fed. 86; Highland Marie, 31 L. D. 37 ; Elmer F. Cassel, 32 L. D. 85.

Work done for the purpose of discovering mineral, whatever the particular form or character of the deposit which is the subject of search, is within the spirit of the statute. U. S. v. Iron Co., 24 Fed. 568; see Bishop v. Baisley, 28 Or. 119. Work done upon the surface may be insufficient. Mills v. Fletcher, 100 Cal. 142.

2. Woody v. Bernard, 69 Ark. 579; Wright v. Killian, 132 Cal. 56 .

The test is not as to the number of days' work done, but what is the worth or reasonable value of the labor done or improvements made. These are to be measured in dollars, not in days. If, when completed, the labor or improvements are reasonably worth the required sum, the requirement of the law has been fulfilled. Penn v. Oldhauber, 24 Mont. 287.

3. McCulloch v. Murphy, ante.

4. McCulloch v. Murphy, ante; Whalen Co. v. Whalen, 127 Fed. 611; Anderson v. Caughey, 3 Cal. A. 22; Penn v.

5. Id. Oldhauber, ante; Wagner v. Dorris, 43 Or. 392.

6. McCormick v. Parriott, 33 Colo. 382.

7. Mills v. Fletcher, ante.

8. Big 3 Co. v. Hamilton, 157 Cal. 130; Coleman v. Curtis, 12 Mont. 301; Protective Co. v. Forest City Co., 51 Wash. 643.

$\S 196$. Proof of Performance. The various local statutes provide for the making, recording and legal effect of affidavits of annual expenditure. ${ }^{1}$

2. Not Mandatory Laws. Such laws are not mandatory. ${ }^{2}$

3. Effect of Filing. If the affidavit be filed within the statutory period ${ }^{3}$ it presents prima facie evidence of the facts properly therein stated ${ }^{4}$ but it does not prevent other proof by the claimant nor attack by his adversary. ${ }^{5}$ Its due filing may prevent re-location. ${ }^{6}$

4. Neglect to File Not Fatal. Neither the failure to record the affidavit nor a mistake therein will work a forfeiture of the claim. ${ }^{7}$ 
1. See Book v. Justice Co., 58 Fed. 106; McGinnis v. Egbert, 8 Colo. 41; Coleman v. Curtis, 12 Mont. 301; Davidson v. Bordeaux, 15 Mont. 245.

The Californian mining act provides that "Whenever mine owner, company or corporation shall have performed the labor and made the improvements required by law upon any mining claim, the person in whose behalf such labor was performed or improvements made, or some one in his behalf, shall within 30 days after the time limited for performing such labor or making such improvements make and have recorded by the county recorder, in books kept for that purpose in the county in which such mining claim is situated, an affidavit setting forth the value of labor or improvements made, the name of the claim, and the name of the owner or claimant of said claim at whose expense the same was made or performed. Such affidavit, or a copy thereof, duly certified by the county recorder, shall be prima facie evidence of the performance of such labor or the making of such improvements, or both." C. C., $\$ 1426 \mathrm{~m}$.

2. Davidson v. Bordeaux, ante; see Harris v. Kellogg, 117 Cal. 484 .

3. McGinnis v. Egbert, ante.

4. Book v. Justice Co., ante; Big 3 Co. v. Hamilton, $157 \mathrm{Cal}$. 130. In Idaho the failure to file such affidavit is considered prima facie evidence of abandonment. Ida. C. C. $\S 3211$.

5. Book v. Justice Co., ante; Whalen Co. v. Whalen, 127 Fed. 611. In contested cases there is often a wide divergence in the testimony of the opposing parties as to the actual or reasonable value of the work done or improvements made. MeCulloch v. Murphy, 125 Fed. 147.

6. MoCulloch v. Murphy, ante.

7. Id.; Bismarck Co. v. No. Sunbeam Co., 14 Ida. 561; Murray Hill Co. v. Havenor, 24 Utah, 73 ; but see Harris v. Kellogg, ante.

$\S 197$. Non-performance. Failure to make the required annual expenditure does not of itself operate as a forfeiture of the claim. It only permits a relocation. ${ }^{1}$ The law does not provide for a forfeiture merely because of such default. ${ }^{2}$

2. When Claim Forfeited. The location is forfeited only when the adverse rights of third parties attach thereto. ${ }^{3}$

3. Clajm of Forfeiture. He who asserts the forfeiture must prove it ${ }^{4}$ by clear and convincing testimony. ${ }^{5}$

4. Adverse Possession. Forcible or clandestine adverse possession ${ }^{6}$ or threats in the face of a bona 
fide attempt to do the work ${ }^{7}$ are not sufficient to defeat the right of the locator. But his claim to the property will be lost if not sustained by an action in ejectment brought within the period allowed by the statute of limitations. ${ }^{8}$

5. What Is Not Excuse for Non-Performance. The mere pendency of patent proceedings before payment for the land, ${ }^{9}$ the obtaining of the receiver's receipt therein through fraud, ${ }^{10}$ the pendency of court proceedings, ${ }^{11}$ or the rendition of a judgment therein ${ }^{12}$ are not sufficient grounds for non-performance.

1. Bingham Co. v. Ute Co., 181 Fed. 748; Madison v. Octave Oil Co., 154 Cal. 768; Beals v. Cone, 27 Colo. 473.

2. Knutson v. Fredlund, 56 Wash. 634 .

The word "lapsed" is unknown to mining usage or laws and is not equivalent to the term "forfeited," nor does it mean a technical forfeiture. Contreras v. Merck, 131 Cal. 211.

3. Lockhart v. Johnson, 181 U. S. 516; Field v. Tanner, 32 Colo. 278 ; see $\$ 73$, ante.

4. Hammer v. Garfield Co., 130 U. S. 291; McCulloch v. Murphy, 125 Fed. 147; Harris v. Kellogg, 117 Cal. 484; Callaghan v. James, 141 Cal. 291; Little Dorrit Co. v. Arapahoe Co., 30 Colo. 431 ; Sherlock v. Leighton, 9 Wyo. 297. An agricultural claimant can not raise the point. Coleman v. McKenzie, 29 L. D. 359.

5. Hammer v. Garfield Co., ante; Walton v. Wild Goose Co., 123 Fed. 209; Whalen Co. v. Whalen, 127 Fed. 611; Zerres v. Vanina, 134 Fed. 610; Wailes v. Davies, 158 Fed. 667; Goldberg v. Bruschi, 146 Cal. 708; Power v. Sla, 24 Mont. 243; Crown Point Co. v. Crismon, 39 Or. 346.

6. Mills v. Fletcher, 100 Cal. 142; Trevaskis v. Peard, 111 Cal. 599; Utah Co. v. Dickert, 6 Utah, 183.

An adverse locator cannot complain that the assessment work was not done by the original locator while he was in adverse possession. Madison v. Octave Oil Co., ante.

7. Slavonian Co. v. Perasich, 7 Fed. 331; Garvey v. Elder, 21 S. Dak. 77.

8. Trevaskis v. Peard, ante.

9. Gillis v. Downey, 85 Fed. 483; Ferguson v. Belvoir Co., 14 L. D. 43 ; Cain v. Addenda, 29 L. D. 62.

10. Murray v. Polglase, 23 Mont. 401.

11. Clark v. American Co., 7 C. L. O. 708.

12. Leadville office, Min. Law Dig. 96.

§ 198. Resumption of Labor. To "resume work" is to begin work in good faith and diligently prosecute 
the same to completion before re-location, ${ }^{1}$ or afterwards, if it can be done peaceably. ${ }^{2}$

2. TIME FOR RESUMPTION. Work may be resumed at any time before all the acts requisite to a valid adverse re-location have been performed. ${ }^{3}$

3. Effect of Resumption. After a valid resumption the rights of the claimant are precisely what they were before default. ${ }^{4}$

4. What is NOT a Resumption. Work is not "resumed" by the mere purchase of material nor the mere bringing of the same upon the claim. ${ }^{5}$

5. Trespass. An attempted adverse re-location of a mining claim during a temporary suspension of such work over Sunday is a trespass and no rights are initiated thereby. ${ }^{6}$

See $\$ 195$, ante.

1. McCormick v. Baldwin, 104 Cal. 227; Hirschler v. McKendricks, 16 Mont. 211.

2. Oscamp v. Crystal River Co., 58 Fed. 295; Preston v. Hunter, 67 Fed. 996.

3. Justice Co. v. Barclay, 82 Fed. 554; Du Prat v. James, 65 Cal. 555; McKay v. McDougall, 25 Mont. 258; Thornton v. Kaufman, 40 Mont. 282; Klopenstine v. Hays, 20 Utah, 45; see Ingersol v. Scott (Ariz.), 108 Pac. 460.

4. Belk v. Meagher, 104 U. S. 279.

5. Honaker v. Martin, 11 Mont. 91; Fredericks v. Klauser, 52 Or. 110.

6. Fee v. Durham, 121 Fed. 468.

$\S 199$. Who May Make Expenditure. The annual expenditure may be made by the locator, his heirs, assigns or legal representatives ${ }^{1}$ or by some one in privity therewith ${ }^{2}$ or by one who has an equitable or beneficial interest. ${ }^{3}$ A stockholder in a corporation claiming the property, ${ }^{4}$ or a receiver appointed by a court ${ }^{5}$ are within the rule.

It is sufficient if the labor is gratuitously contributed, ${ }^{6}$ but labor done or improvements made by a trespasser or a stranger to the title will not inure to the benefit of the claimant. ${ }^{7}$

2. Presumption. In the absence of proof to the contrary it will be presumed that the labor or im- 
provements made upon the claim were at the expense of its claimant. 8

1. Rev. Stats., $\$ 2324$.

2. Jupiter Co. v. Bodie Con. Co., 11 Fed. 666; Book v. Justice Co., 58 Fed. 106; see Nesbitt v. Delamar Co., 24 Nev. 283.

3. Jupiter Co. v. Bodie Con. Co., ante; Book v. Justice Co., ante; Anderson v. Caughey, 3 Cal. A. 22; Dye v. Crary, 13 N. M. 439. As to one holding under color of title, see Dolles v. Hamberg Co., 23 L. D. 267.

4. Wailes v. Davies, 158 Fed. 667 ; Repeater Claims, 35 L. D. 54. For work done by a superintendent see Godfrey v. Faust, 18 S. Dak. 567.

5. Whalen Co. v. Whalen, 127 Fed. 611.

6. Anderson v. Caughey, ante.

7. Nesbitt v. Delamar Co., ante.

8. Yarwood v. Johnson, 29 Wash. 643.

$\S 200$. Failure to Contribute. At the expiration of the calendar year the co-owners who have performed the work may demand contribution in writing or by publication from the co-owner who may have failed to pay or perform his share thereof. ${ }^{1}$

2. EFFect of Demand. Upon the failure of the defaulting co-owner to meet the demand thus made upon him, within the time fixed by statute, his interest in the claim becomes the property of the co-owners who have given such notice. ${ }^{2}$

3. Character of Title. The title accruing under these proceedings is much like that conveyed by a sheriff's deed after judgment and execution sale. Each results from a default in obligation followed by proceedings authorized by law. ${ }^{3}$ When rightfully given the notice is effective in cutting off all parties and the title thus kept free and clear from uncertainty and doubt. ${ }^{4}$

4. BASIS OF Notice. The question of the performance of assessment work is one of fact. ${ }^{5}$ If the work was not actually done or the improvements were not actually made the proceedings have no more effect or force than a forged deed. ${ }^{6}$ Hence, if the alleged default does not exist in fact the notice is ineffective. ${ }^{7}$ 
5. Right to Give Notice. 'The right to give the notice is limited to a co-owner who has performed the labor ${ }^{8}$ and does not extend to a person having an inchoate title ${ }^{9}$ nor to a stockholder of a corporation, as such. ${ }^{10}$

6. Contents of Notice. The notice should be addressed to the co-owner by name. If he be dead then to his heirs, not necessarily naming them, and to his administrator, although the latter may not have then been appointed. It should be addressed "to all whom it may concern." 11 It should state the descriptive name of the claim; the place of record; the amount expended upon each claim and each year for which the expenditure is claimed. ${ }^{12}$

7. Personai, Service. Personal service cannot be had by sending through the mail a copy of the newspaper in which the notice is published and proving that the person to whom the notice is directed received such newspaper. ${ }^{13}$

8. Publication. The publication must be made in the newspaper published nearest the claim. ${ }^{14}$ If not, the reason therefor must be stated. ${ }^{15}$

1. Elder v. Horseshoe Co., 194 U. S. 248. This provision of the law is constitutional. Van Sice v. Ibex Co., 173 Fed. 609. As a general rule the remedy so provided is exclusive. McDaniel v. Moore, (Ida.) 112 Pac. 317.

2. Rev. Stats., \$ 2324; see Faubel v. McFarland, 144 Cai. 717. The mining act of California provides that: "Whenever a co-owner or co-owners of a mining claim shall give to a delinquent co-owner or co-owners the notice in writing or notice by publication provided for in section 2324, Revised Statutes of the United States, an affidavit of the person giving such notice, stating the time, place, manner of service, and by whom and upon whom such service was made shall be attached to a true copy of such notice, and such notice and affidavit must be recorded in the office of the county recorder, in books kept for that purpose, in the county in which the claim is situated, within ninety days, after the giving of such notice; for the recording of which said recorder shall receive the same fees as are now allowed by law for recording deeds; or if such notice is given by publication in a newspaper, there shall be attached to a printed copy of such notice an affidavit of the printer or his foreman, or principal clerk of such paper, stating the date of the first, last and each 
insertion of such notice therein, and where the newspaper was published during that time, and the name of such newspaper. Such affidavit and notice shall be recorded as aforesaid, within one hundred and eighty days after the first publication thereof. The original of such notice and affidavit, or a duly certified copy of the record thereof, shall be prima facie evidence that the delinquent mentioned in section 2324 has failed or refused to contribute his proportion of the expenditure required by that section, and of the service of (by) publication of said notice; provided, the writing or affidavit hereinafter provided for is not of record. If such delinguent shall, within the ninety days required by section 2324 , aforesaid, contribute to his co-owner or co-owners, his proportion of such expenditures, and also all costs of service of the notice required by this section, whether incurred for publication charges or otherwise, such co-owner or co-owners shall sign and deliver to the delinquent or delinquents a writing, stating that the delinquent or delinquents by name has within the time required by section 2324 aforesaid, contributed his share for the year — upon the un mine, and further stating therein the district, county and state wherein the same is situated, and the book and page where the location notice is recorded, if said mine was located under the provisions of this act; such writing shall be recorded in the office of the county recorder of said county, for which he shall receive the same fees as are now allowed by law for recording deeds. If such co-owner or co-owners shall fail to sign and deliver such writing to the delinquent or delinquents within twenty days after such contribution, the co-owner or co-owners so failing as aforesaid, shall be liable to the penalty of $\$ 100$, to be recovered by any person for the use of the delinquent or delinquents in any court of competent jurisdiction. If such co-owner or co-owners fail to deliver such writing within said twenty days, the delinquent, with two disinterested persons having personal knowledge of such contribution, may make affidavit setting forth in what manner, the amount of, to whom, and upon what mine, such contribution was made. Such affidavit, or a record thereof, in the office of the county recorder, of the county in which such mine is situated, shall be prima facie evidence of such contribution." C. C., $\S 1426$ o.

3. Van Sice v. Ibex Co., ante.

4. Id. Elder v. Horseshoe Co., ante.

5. Knickerbocker v. Halla, 16\% Fed. 318.

6. Delmoe v. Long, 35 Mont. 139.

7. Crary v. Dye, 208 U. S. 515; Golden and Cord Claims, 31 L. D. 178; Delmoe v. Long, ante.

A co-owner cannot make the annual expenditure upon claims adjacent to the common property and in the absence of an agreement with the remaining coowners hold them liable for contribution. Ilawgood v. Emery, 22 S. Dak. 573.

8. Turner v. Sawyer, 150 U. S. 578; Van Sice v. Ibex Co., ante. 
9. Id. Repeater Claims, 35 L. D. 54.

10. Id.

11. Elder v. Horseshoe Co., ante; Badger v. Stockton Co., 139

Fed. 838; Ballard v. Gollob, 34 Colo. 417; see Eivalina

Co. v. Yosemite Co., (Cal. A.) 115 Pac. 947.

12. Elder v. Horseshoe Co., ante; Haynes v. Briscoe, 29 Colo. 137.

13. Haynes v. Briscoe, ante.

14. Rev. Stats., \& 2324 . The phrase "in the newspaper published nearest to the claim" means the nearest in a direct line. Haynes v. Briscoe, ante.

15. Elder v. Horseshoe Co., ante; Van Sice v. Ibex Co., ante.

\section{CHAP'TER XXX.}

\section{PATENTS.}

§ 206. In general-mining rights-agricultural patent-lode patent-placer patent-equivalent to patent-void patents-voidable patents.

\$207. Legal title-equitable title-superiority of titlepriority of title-evidence-facts settled by patentpresumptions.

$\S 208$. State legislation.

§206. In General. A patent is the deed of the government. ${ }^{1}$ It is not a distinct grant, but is the consummation of a grant which had its inception in the location of the claim patented. ${ }^{2}$ It carries with it the rights conferred by law. These cannot be enlarged nor diminished by reservation of the land department depending upon their fitness on its judgment. ${ }^{3}$ It affects no lien subsisting upon the property at the time of its issuance. ${ }^{4}$ There is no restriction as to the time when it shall be applied for ${ }^{5}$ nor as to the use ${ }^{6}$ or sale ${ }^{7}$ of the patented property.

2. Mining Rights. It is not essential to the enjoyment of a mining claim. ${ }^{8}$ It confers no greater mining rights than those obtained by a valid location. ${ }^{9}$ It adds but little to the security of a party in continuous possession. ${ }^{10}$

3. Agricultural Patent. An "agricultural" patent conveys the surface of the ground embraced therein and all that lies beneath it. ${ }^{11} \mathrm{~A}$ mineral patent does not necessarily do so. ${ }^{11 a}$ 
4. Lode Patent. A lode patent conveys the exclusive right to the surface within the patented ground; all veins, lodes and ledges having their top or apex therein together with the right to follow the same upon their dip into adjoining territory. ${ }^{12}$ It does not convey the veins, lodes and ledges which may apex outside the boundaries of the patented area and which extend thereunder. ${ }^{13}$

5. Placer Patent. A placer patent conveys a qualified right to the surface described therein. It confers no extra-lateral rights. ${ }^{14}$ A patent for a lode claim may be carved out of land previously patented as placer ground. ${ }^{15}$

6. Equivalent to Patent. An uncancelled certificate of purchase is equivalent to a patent as far as the rights of third parties are concerned. ${ }^{16}$

7. Void Patents. Patents are void upon their face when issued without authority of law, prohibited by statute or for land reserved from sale or which has been dedicated to special purposes or the title to which had previously passed from the government. ${ }^{17}$

8. VoIdable Patents. A patent obtained by fraud of the rights of the government is subject to cancellation. ${ }^{18}$

See $\S 82$, ante.

1. St. Louis Co. v. Mont. Co., 113 Fed. 900; Talbott v. King, 6 Mont. 76. The patent to a mining claim or a townsite is a quitclaim deed from the United States. It is recorded upon its public records and is notice to the world of what it contains. Eugene McCarthy, $14 \mathrm{~L}$. D. 105. The recording of the patent is in law delivery to the patentee. U. S. v. Schurz. 102 U. S. 378 . If the government possesses at the time no title, none passes by its execution. Patterson v. Tatum, 18 Fed. Cas. 1083.

2. Reed v. Munn, 148 Fed. 737; Butte City S. H. L. cases, 6 Mont. 397. The patent passes whatever title the government had to the surface and to any vein or lode thereunder not otherwise granted or reserved. Kahn v. Old Tel. Co., 2 Utah, 174; see Iron Co. v. Elgin Co., 118 U. S. 196; 'St. Louis Co. v. Mont. Co., 194 U. S. 235; Amador Median Co. v. S. Spring Hill Co., 36 Fed. 668, Colo. Cent. Co. v. Turck, 50 Fed. 888 ; Woods v. Holden, 26 L. D. 198,27 L. D. 375 ; Parrot Co. v. Heinze, 25 
Mont. 139; Grand Cent. Co. v. Mammoth Co., 29 Utah, 490 ; see A. C. M. Co. v. Court, 25 Mont. 504.

3. Davis v. Weibbold, 139 U. S. 507 .

4. Rev. Stats., $\$ \S 2332-2340 ; 29$ Stats. $120 ; 30$ Stats. 404 . As to highways, see Rockwell v. Graham, 9 Colo. 36. As to a judgment creditor, see Butte H. Co., v. Frank, 25 Mont. 344. It may create a dower right. Black v. Elkhorn Co. 163 U. S. 445.

5. Coleman v. McKenzie, 28 L. D. 348.

6. St. Louis Co. v. Kemp, 104 U. S. 636 ; Schwab v. Beam, 86 Fed. 41; U. S. v. Rizzinelli, 182 Fed. 675.

7. Rev. Stats., $\$ 2326$.

8. Coleman v. McKenzie, ante. It is sufficient to comply with all the requirements necessary to maintain the possessory right. Chapman v. Toy Long, 5 Fed. Cas. 2610; Gillis v. Downey, 85 Fed. 483; Daggett v. Yreka Co., 149 Cal. 357. Possession alone is sufficient to establish a right to a patent. Rev. Stats., §2332; Barklage v. Russell, 29 L. D. 401; Altoona Co. v. Integral Co., 114 Cal. 100; Cleary v. Skiffich, 28 Colo. 362; McCowan v. Maclay, 16 Mont. 234 . It is wholly a matter of self interest when a patent shall be applied for. Chapman v. Toy Long, ante.

9. Chapman v. Toy Long, ante.

10. Haws v. Victoria Copper Co., 160 U. S. 303.

11. Amador Median Co. v. S. Spring Hill Co., ante; see Woods v. Holden, ante; see East Or. Co. v. Willow R. Co., 187 Fed. 466.

11a. Last Chance Co. v. Tyler Co., 61 Fed. 557.

12. Iron Co. v. Cheesman, 116 U. S. 529 ; Doe v. Waterloo Co., 54 Fed. 935 ; see $\S 110-4$, ante.

13. Jones v. Prospect Co., 21 Nev. 339; see \$50-49, ante.

14. Noyes v. Mantle, 127 U. S. 348; Sullivan v. Iron Co., 143 U. S. 431; Clipper Co. v. Eli Co., 194 U. S. 220; Mt. Rosa Co. v. Palmer, 26 Colo. 56.

15. Iron Co. v. Campbell, 135 U. S. 286.

16. Deffeback v. Hawke, 115 U. S. 392 ; Aurora Hill Co. v. 85 Mg. Co., 34 Fed. 515; see $\S 28-11$, ante; $\$ \$ 214-15$, post. A valid location may be equivalent to a patent. Talbott v. King, ante.

17. See Doolan v. Carr, 125 U. S. 618; Iron Co. v. Campbell, ante; Garrard v. S. P. Mines, 82 Fed. 578; King v. McAndrews, 111 Fed. 860 ; Standard Co. v. Habishaw, 132 Cal. 115; Poire v. Wells, 6 Colo. 406; Rose v. Richmond Co., 17 Nev. 25. When a patent is not assailable see St. Louis Co. v. Kemp, ante; see Cowell v. Lammers, 21 Fed. 200; New Dunderberg Co. v. Old, 79 Fed. 598 ; Justice Co. v. Lee, 21 Colo. 260. The test of jurisdiction is the right to enter upon the inquiry and to make some decision. King v. McAndrews, ante.

18. Colo. Coal Co. v. U. S., 123 U. S. 307; U. S. v. Iron Co., 128 U. S. 673 ; U. S. v. Trinidad Co., 137 U. S 160 ; see U. S. v. Chandler-Dunbar Co., 209 U. S. 447; Illinois Co. v. Budzisz, 82 Fed. 160; see U. S. v. Smith, 181 Fed. 545.

$\S 207$. Legal title. The patent is the superior and exclusive evidence of the legal title. ${ }^{1}$

2. EQUitable Title. The person named as the patentee is not, necessarily, the exclusive owner of 
the premises described in the patent. ${ }^{2} \mathrm{He}$ may be judicially declared to be a trustee $^{3}$ unless suit be barred by limitation or laches. ${ }^{4}$ An adjudication against the government in a suit brought by it to annul a patent will not prevent the assertion of equitable rights in the land by a person not a party thereto. ${ }^{5}$

3. Superiority of Titue. In a controversy between a placer patentee and a lode patentee or between mineral patentees and townsite patentees the question of the superiority of title under different patents for the same land may arise. If the decision depends upon extrinsic facts, not shown by the patent, they may be established by proof thereof. ${ }^{6}$

4. PRIORITY OF TitLe. In controversies arising over the extra-lateral right priority of location and not of patent will prevail. ${ }^{7}$

5. Evidence. When material to the issues raised and when not shown by the patent the date of the location may be established by evidence in the same manner as any other question of fact not settled by the patent itself. ${ }^{8}$

6. Facts Setrled by Patent. In its potency a patent is iron-clad against all mere speculative inferences. ${ }^{9}$ Unless set aside and annulled by direct proceedings by the government ${ }^{10}$ a patent, regular on its face, establishes the regularity of its issuance, ${ }^{11}$ the fact that no adverse claim exists, ${ }^{12}$ the nature of the land, ${ }^{13}$ and the exterior boundaries of the claim; ${ }^{14}$ if a lode patent, that the apex of a vein or lode exists within the claim but not that such vein or lode dips beyond the side lines nor that it is the apex of a vein or lode in dispute between adverse dip elaimants. ${ }^{15}$

7. Presumptions. The presumption is that a patent is valid, ${ }^{\mathbf{1 6}}$ that the owner of a patented claim is in the possession thereof, ${ }^{17}$ that following a vein or 
lode upon its dip into territory adversely held (whether patented or not), is a trespass. ${ }^{18}$

See $\$ 68$, ante, $\S 82$, ante, $\S 206$, ante.

1. Bagnell v. Broderick, 38 U. S. 436 ; Steel v. St. Louis Co., 106 U. S. 447; Iron Co. v. Campbell, 135 U. S. 286; Frellsen \& Co. v. Crandell, 217 U. S. 71; Aurora Hill Co. v. 85 Mg. Co., 34 Fed. 515; Lonabaugh v. U. S., 179 Fed. 476 ; see Hickey v. Anaconda, 33 Mont. 46.

2. See $\S 82$, note 5 . A suit to declare a trust may be brought after entry and before patent. Malaby v. Rice, 15 Colo. A. 364. A protest may not furnish a basis for such a suit. Neilson v. Champagne Co., 119 Fed. 123.

3. Hunt v. Patchin, 35 Fed. 816; Suessenbach v. Bank, 5 Dak. 477. In Van Sice v. Ibex Co., 173 Fed. 609, the interest of one of the named patentees had previously passed, by forfeiture, to the others. See also Turner v. Sawyer, 150 U. S. 578; see also Mery v. Brodt, 121 Cal. 332.

4. Alsop v. Riker, 155 U. S. 448; see Hanchett v. Blair, 100 Fed. 817; Potts v. Alexander, 118 Fed. 885.

5. Brandon v. Ard, 211 U. S. 11.

6. Iron Co. v. Campbell, ante; Davis v. Weibbold, 139 U. S. 507.

7. Last Chance Co. v. Tyler, 61 Fed. 557.

8. Id.

9. Standard Co. v. Habishaw, 132 Cal. 115.

10. Barden v. N. P. R. Co., 154 U. S. 288; Burfenning v. Chicago Co., 163 U. S. 321 ; see also Corrine Co. v. Johnson, 156 U. S. 574 ; Bishop v. Gibbons, 158 U. S. 155; Shaw v. Kellogg, 170 U. S. 312; Carter v. Thompson, 65 Fed. 329; U. S. v. Winona R. R., 67 Fed. 948; Bealy v. Napthaly, 73 Fed. 120; Dreyfus v. Badger, 108 Cal. 58; Galbraith v. Shasta Iron Co., 143 Cal. 94.

11. Hooper v. Young, 140 Cal. 274.

12. Rev. Stats., \$ 2325 ; see Rose v. Richmond Co., 17 Nev. 25; Deno v. Griffin, 20 Nev. 249; see Saunders v. La Purisima Co., 125 Cal. 159.

13. Barden v. N. P. R. Co., ante; Standard Co. v. Habishaw, ante.

14. Waterloo Co. v. Doe, 82 Fed.. 45; Doe v. Sanger, 83 Cal. 203.

15. Grand Cent. Co. v. Mammoth Co., 29 Utah, 490; see Lawson v. U. S. Co., 207 U. S. 1.

16. Eureka Co. v. Richmond Co., 8 Fed. Cas. 4548; Leviston v. Ryan, 75 Cal. 293.

17. Original Co. v. Abbott, 167 Fed. 681.

18. Con. Wyo. Co. v. Champion Co., 63 Fed. 540 ; Waterloo Co. v. Doe, ante; Duggan v. Davey, 4 Dak. 110.

§208. State Legislation. After the issuance of the patent the land described therein is subject to state legislation so far as the same may be consistent with the admission that the title passed and vested according to the laws of the United States. ${ }^{1}$

1. Wilcox v. McConnell, 13 Pet. 498; see Black v. Elkhorn, 163 U. S. 445. 


\section{CHAPTER XXXI.}

\section{PATENT PROCEEDINGS.}

\$211. In general-manner of obtaining patent-limitationssurvey of claims-all placer-mixed lode and placer -waiver-adverse claimant-time to apply for a patent-place of filing-time to complete applicationcompletion-payment-divers patents-erroneous description.

\$ 212. The survey-accompanying papers-deputy surveyorduties of deputy-errors of deputy-expenditure upon the claim-conclusiveness of certificate-equivalent of certificate-basis of deputy's report-sufficient expenditure - insufficient expenditure - plat and field notes.

§213. Posting plat and notice - proof of posting - time for filing.

\$214. Proceedings in the local land office - application for patent-citizenship-appointment of attorney-abstract of title-subsequent transfers-the noticecontents of notice-insufficient notice-publication of notice-charges for publication-proof of publication-proof of continuous posting - statement of fees and charges-application to purchase-receiver's receipt-transmission of record-protest-grounds of protest-waiver of protest-delayed patent-cancellation of entry.

§ 215. Adverse claim-distinction-contents of adverse claim -time for filing adverse-computation of time-no extension of time-effect of filing adverse-evidence of waiver-appeal.

\$216. The adverse suit-subsequent proceedings-duty of register-proceedings in general land office.

§ 211. In General. A patent for land claimed and located for valuable mineral deposit may be obtained only by a person, association or corporation authorized to locate a mining claim, and which may have complied with the terms of the mining act in respect to such location, or by the grantee of the locator. ${ }^{1}$ That act provides what steps are necessary, and the land department regulates the proceedings for, and finally determines the right to the patent. ${ }^{2}$

2. Manner of Obtaining Patent. The manner of obtaining a patent for either a lode or a placer claim, whether for a single or for a consolidated claim of contiguous lode or lode and placer locations, ${ }^{3}$ that is, those which touch sides, lie alongside of, adjacent 
or adjoin, ${ }^{4}$ with or without a mill-site, or for a millsite alone, is substantially similar. ${ }^{5}$

3. Limitations. Only a reasonable number of mill-sites can be patented in connection with a group of contiguous locations held under one ownership. ${ }^{6}$ An application for saline lands is limited to a single location of 20 acres. $^{7}$

4. Survey of Claims. All lode claims, mill-sites 8 and placer locations which have not been located according to the rectangular subdivisions of the public survevs must be officially surveyed. ${ }^{9}$

5. Alu Placer. If the claim be all placer ground that fact must be stated in the application and be corroborated by the affidavit of two other persons. ${ }^{10}$

6. Mixed Lode and Placer. If the ground contains both a lode and placer deposit such fact should be stated, together with a specific description of all known lodes situated within the boundaries of the placer location. ${ }^{11}$

7. WAIVER. A known vein or lode situated within a placer claim must be specifically applied for by the placer claimant or his right thereto is waived. ${ }^{12}$

8. Adverse Claimant. If claimed adversely the lode claimant should "adverse," not "protest" against the placer application. ${ }^{13}$

9. Time to Apply for a Patent. There is no limit to the time that a mining claim must be located before application for patent may be made. It may be located on one day and official survey applied for the next. ${ }^{14}$ But the record must precede the making of such survey, ${ }^{15}$ and the location be otherwise valid. ${ }^{16}$

10. Place of Filing. The application for patent must be filed in the United States land office in the district in which the claim is wholly situated. ${ }^{17}$

11. Time to Complete Application. The application must be completed within a reasonable time after the expiration of the period of publication or after 
the termination of adverse proceedings in the courts. ${ }^{18}$

12. CoMpletion. An application for patent is "completed" by filing the necessary proofs and making payment for the land. ${ }^{19}$

13. Payment. Payment for the land embraced within the claim is at the rate of $\$ 5$ an acre and each fractional part of an acre in a lode claim, whether within or without a placer claim, and $\$ 2.50$ an acre and fractional part thereof for a placer location. ${ }^{20}$

14. Divers Patents. Where several parties are found to be entitled to separate and different portions of the same claim each may pay for his part ${ }^{21}$ and receive a patent therefor in his own name, or if dead the patent will issue to his heirs. ${ }^{22}$

15. Erroneous Description. An erroneous description or calls in a patent must give way to the monuments of the claim as placed upon the ground. ${ }^{23}$

1. Rev. Stats., § 2325; see Golden Crown Lode, 32 L. D. 217; Bunker Hill Co. v. Shoshone Co., 33 L. D. 142; Lackawanna Placer Claim, 46 L. D. 36; see So. Car. Claims, 29 L. D. 602 ; Extra Lode Claim, 34 L. D. 590.

2. Knight v. U. S. Land Assn., 142 U.S. 161; Bunker Hill Co. v. Shoshone, ante.

3. Mayflower Co., 29 L. D. 7 ; Hidden Treasure, 35 L. D. 485 ; see Mt. Chief Claims, 36 L. D. 100; Aldebaran Co., 36 L. D. 551.

4. Hidden Treasure, ante.

5. Min. Reg., pars. 58-59.

6. Alaska C. Co., 32 L. D. 128; Hard Cash, 34 L. D. 325.

7. 31 Stats. 745 .

8. Min. Reg., par. 34 ; see par. 58.

9. Min. Reg., par. 58. Ten-acre lots are considered as legal subdivisions. Min. Reg., pars. $22-24$; G. A. Khern, 6 L. D. 580; Mary Darling, 31 L. D. 64.

10. Min. Reg., pars. 26-60.

11. Min. Reg., par. 60.

12. Rev. Stats., \$2333; Min. Reg., par. 26; Reynolds v. Iron Co., 116 U. S. 687; Cape May Co. v. Wallace, 27 L. D. 676; see Aurora Lode v. Bulger Hill Co., 23 L. D. 95; Alice Placer, 27 L. D. 661.

13. Elda Co. v. Mayflower Co., 26 L. D. 573.

14. Gowdy v. Kismet Co., 22 L. D. 624 ; Nome \& Sinook Co. v. Townsite, 34 L. D. 276.

15. Min. Reg., par. 35 .

16. Bunker Hill Co. v. Shoshone Co., ante.

17. Fred. A. Williams, 17 L. D. 282 ; Alaska Placer, 34 L. D. 40 ; Foolkiller Lode, 35 L. D. 595.

18. Min. Reg., pars. 56-57; Copper Bullion Claims, 35 L. D. 27.

19. Rev. Stats., \$ 2325 ; Min. Reg., par. 56. 
20. Rev. Stats., § $2325-2333$.

21. Iron Co. v. Campbell, 135 U. S. 286.

22. Min. Reg., par. 71; Liddia Claim, 33 L. D. 127; see. ilothower v. Hunter, 15 Wyo. 189; Tripp v. Dunphy, 28 L. D. 14.

23. Rev. Stats., § 2327.

$\S 212$. The Survey. An application for an official survey is a written unverified request, subscribed by the claimant, his agent or attorney. It is addressed to the surveyor-general for the district in which the claim may be situated. ${ }^{1}$

2. Accompanying Papers. The request for a survey should be accompanied by a duly certified copy of the record of location ${ }^{2}$ or a verified statement showing sufficient reason for its absence; ${ }^{3}$ also by a certificate of deposit sufficient to cover the cost of preliminary work in the office of said surveyor-general. This certificate should be issued by a United States subtreasurer or United States depositary. ${ }^{4}$

3. Deputy Surveyor. The request usually contains the name of the United States deputy mineral surveyor chosen by the applicant for making the survey. ${ }^{\mathbf{5}}$ The deputy selected must have no interest in the claim. ${ }^{6}$ His charges must be met by the applicant. ${ }^{7}$

4. Duties of Deputy. The deputy must make an actual survey of the claim. ${ }^{8}$ A delegation of his power may cause a rejection of the survey. ${ }^{9}$ He must not act as surveyor, notary public nor as attorney in the same case. ${ }^{10}$ He must transmit to the surveyorgeneral his field notes, a plat of the survey, affidavits of expenditure, and in placer applications a descriptive report. ${ }^{11}$

5. ERrors of Deputy. Where errors occur in the survey through the carelessness or negligence of the deputy the claimant should apply for an amended survey. ${ }^{12}$ The failure of the deputy to amend the survey. within the time prescribed by the General 
Land Office is ground for his suspension or removal from office. ${ }^{13}$

6. Expenditure upon the Claim. It is usual but not essential for the surveyor-general to certify upon the plat of survey that the statutory expenditure precedent to patent has been made. ${ }^{14}$ This certificate is based upon the report of the deputy making the survey, but other or further evidence may be required. ${ }^{15}$

7. Conclusiveness of Certificate. Unless attacked in the land department such certificate is conclusive of the facts therein stated.16

8. Equivalent of Certificate. Where a placer claim is located according to legal subdivisions an affidavit made by two or more persons having no interest in the property takes the place of such certificate. The affidavit must show that not less than $\$ 500$ has been expended by the applicant or his grantors upon the claim. The work or improvements must be described in detail. ${ }^{17}$

9. Basis of Deputy's Report. In other cases the deputy must report upon the value of the improvements and include in his estimate all actual expenditures and mining improvements made by the applicant or his grantors having a direct relation to the development of the claim. ${ }^{18}$

10. Sufficient Expenditure. The expenditure may be upon or underneath the surface. ${ }^{19}$ It may consist of "assessment work." 20

11. Insufficient Expenditure. A quartz mill erected upon a lode claim ${ }^{21}$ or a lime-kiln erected upon a placer claim containing a deposit of limestone 22 or buildings, machinery or roadways not associated with actual mining excavations not essential to the practical development of and not actually facilitating the extraction of. mineral from the claim ${ }^{23}$ will not be sufficient as a condition precedent to ob- 
taining a patent. ${ }^{24}$ Yet a mining dredge placed upon a dredge placer claim has been held to be sufficient. ${ }^{25}$ 12. Plat and Field Notes. Two copies of the plat of survey and one copy of the field notes are furnished by the surveyor-general to the applicant. One plat, together with a notice of intention to apply for a patent, are to be posted upon the claim. ${ }^{26}$ One plat, together with the field notes, are to be filed as a part of the application for patent. ${ }^{27}$

1. Min. Reg., par. 34; Cir. to Applicants, sub. 1.

2. Cir. to Applicants, sub. 2; see Golden Rule Co., 37 L. D. 95.

3. Min. Reg., par. 43.

4. Min. Reg., par. 91; Cir. to Applicants, sub. 6; Geo. B. Foote, 2 L. D. 773. Unused deposits or any excess in the amount thereof in the actual cost of work in the surveyor-general's office will be refunded by the government. 36 Stats. 257; Peter N. Hanson, 38 L. D. 169-469. For repayment of moneys on entry cancelled see 30 L. D. 430 . See Instructions, 39 L. D. 141-146; Margaret E. Scully, 38 L. D. 564; see also \& 93-9, ante.

5. Cir. to Applicants, sub. 2-14.

6. Geo. B. Foote, ante; Tipton Co., 29 L. D. 718.

7. Min. Reg., pars. 120-127; Golden Rule Co., ante; see Wolfley v. Lebanon Co., 4 Colo. 112.

8. Min. Reg., par. 129. In making the survey the deputy is controlled by the location notice and the markings on the ground. Duncan v. Eagle Rock Co., 48 Colo. 569.

9. Homer Santee, 36 L. D. 286.

10. Min. Reg., pars. 93-128. In cases where great delay, expense or inconvenience can be avoided thereby, a deputy surveyor may administer oaths to his assistants. Min. Reg., par. 128.

11. Min. Reg., pars. 161-166.

12. Golden Rule Co., anté; see Basin Co. v. White, 22 Mont. 147.

13. Id.

14. Rev. Stats., §2325; Min. Reg., par. 50; see Nielson v. Champagne Co., 29 L. D. 491 .

15. Min. Reg., par. 49 ; U. S. v. King, 83 Fed. 188.

16. Deffeback v. Hawke, 115 U. S. 392 ; Olive Land Co. v. Olmstead, 103 Fed. 568; Bash v, Cascade Co., 29 Wash. 50; see Russell v. Maxwell Land Grant Co., 158 U. S. 253; Horne v. Smith, 159 U. S. 40; Miller v. Grunsky, 141 Cal. 451.

17. Min. Reg., pars. 25-60; Draper v. Wells, 25 L. D. 550.

18. Min. Reg., par. 156; Yankee Lode, 30 L. D. 289.

19. Min. Reg., par. 157.

20. See U. S. v. Iron Co., 24 Fed. 568.

21. Monster Lode No. 2, 35 L. D. 493.

22. Fargo Group No. 2, 37 L. D. 404 .

23. Min. Reg., par. 157; Fargo Group No. 2, ante; see Elmer F. Cassel, 32 L. D. 85 .

24. Schirm v. Carey, 37 L. D. 371. 
25. Garden Gulch Bar Placer, 38 L. D. 28.

26. Min. Reg., pars. 34-39.

27. Min. Reg., par. 38 , sub. 4.

\section{$\S 213$. Posting Plat and Notice. Prior to filing} the application papers the plat of survey, accompanied by a notice of intention to apply for patent, must be posted in a conspicuous place upon the claim sought to be patented. ${ }^{1}$ This notice must give the date of its posting, the name of the claimant, the name of the claim, the number of the survey, the mining district, county and state, and the names of the adjoining and conflicting claims as shown by the plat of survey. This notice, as well as that published, and also the application for patent, must state in express terms the portions to be excluded, if any, as, land previously certified or patented to a state or a railroad company, although such conflict may not be shown upon said plat. The posting must be done in the presence of two credible witnesses ${ }^{2}$ and the matter must be so placed as to be readily seen and examined. ${ }^{3}$ It must so remain during the 60 days' period of newspaper publication of the application. ${ }^{4}$

2. Proof of Posting. The said witnesses must sign the said notice as such witnesses. They must also make affidavit of the fact of posting. ${ }^{5}$ This affidavit must contain a copy of said notice and state the date and particular place of posting. ${ }^{6}$ It must be made within the land district in which the property is sitnated. ${ }^{7}$

3. Time for Filing. The affidavit of posting must be filed prior to or at the time of filing the application for patent. ${ }^{8}$

1. Rev. Stats., § 2325 ; Min. Reg., pars. 39-44; DeLong v. Hine, 9 C. L. O. 114 ; see $\$ 90$, ante.

2. Rev. Stats., \$2325; Min. Reg., par. 40.

3. Tom Moore Co. v. Nesmith, 36 L. D. 199; see $\$ 90$, ante.

4. Rev. Stats., § 2325; Min. Reg., par. 51.

5. Rev. Stats., § 2325 ; Min. Reg., par. 40 .

6. Min. Reg., par. 40 . 
7. El Paso Brick Co., 37 L. D. 155. All affidavits made outside of the proper land district are insufficient; Rev. Stats., \$2335; proceedings based thereon are void. Mattes v. Treasury Co., 34 L. D. 314; N. Clyde Claims, 35 L. D. 455 ; except that an applicant for patent may make affidavit of citizenship and an adverse claimant may verify his adverse claim when either reside or the latter at the time is beyond the limits of such district. 22 Stats. 49 ; see Rico Lode, 8 L. D. 223; Louisville Co. v. Hayman Co., 33 L. D. 680; Milford Co., 35 L. D. 174; Crosby Claims, 35 L. D. 434 . The affidavit is void if made over a telephone. Mattes v. Treasury Co., 33 L. D. 553.

8. Mojave Co. v. Kärma, 34 L. D. 583.

§ 214. Proceedings in the Local Land Office. Contemporaneously with the filing in the local land office of proof of the posting of the plat and notice upon the claim there should be filed the following documents : ${ }^{1}$

1. Application for Patent. The application for patent must be under the oath of the claimant ${ }^{2}$ or his agent or attorney thereunto duly authorized. ${ }^{3}$ It must show the applicant's compliance with the law, his possessory right to the premises, the origin thereof and the basis of his claim for a patent. ${ }^{4}$

If a lode claim is the subject for patent, the vein or lode must be fully described. ${ }^{5}$

If the application be for a gold placer claim it must be shown that the claim is valuable for its deposits of placer gold. ${ }^{6}$ If for a placer deposit, other than gold, there must be a full description of the kind, nature, and extent of the deposit and why it is regarded as a valuable mineral claim. ${ }^{7}$

If the application covers saline (not borate nor nitrate) lands there must be a statement to the effect that the applicant has never, either as an individual or as a member of an association, applied for nor held other saline lands. ${ }^{8}$

If the application is made by a trustee he must fully disclose the nature of the trust; and furnish proof of the citizenship of himself and trustors. ${ }^{9}$ 
2. Citrzenship. All applications for patent must show the citizenship of the applicant. This may be by affidavit, if the applicant be a natural person. ${ }^{10}$ The citizenship of a corporation is proved by the filing of a certified copy of its charter or articles of incorporation. ${ }^{11}$

3. Appointment of Attorney. Application for patent may be made by an agent or attorney resident of the land district in which the application is made. ${ }^{12}$ In the case of an individual applicant his agent's authority should be evidenced by letter of attorney. In the case of a corporation a copy of the resolution of the board of directors so appointing him should be certified to by its secretary under the seal of the corporation.

4. Abstract of Titue. The abstract of title should contain a copy of the notice of location, certified by the legal custodian thereof. The abstract must be completed to the filing of the application. ${ }^{13}$

It may be certified either by the legal custodian of the records, or by a duly authorized abstracter of titles. The certificate of either must state that no conveyances affecting the title to the claim or claims appear of record other than those set forth. ${ }^{14}$

An abstracter of titles must further show that he is authorized to compile abstracts of title by the law of the state in which he resides. ${ }^{15}$

In the event that the mining records have been destroyed or lost, affidavit of such loss should be made. In such case secondary evidence of possessory title is received. ${ }^{16}$

5. Subsequent Transfers. Transfers made subsequent to the filing of the application are not considered by the land department. ${ }^{17}$ In the event of the death of the applicant certificate and patent will nevertheless issue in his name. ${ }^{17 a}$ 
6. The Notice. The applicant must furnish to the officers of the land office three copies of a notice; one for publication in the newspaper, one for posting in the land office during the period of such publication, ${ }^{18}$ and one for the use of the special agent who may be sent by the government to examine into the good faith of the application. ${ }^{19}$

7. Contents of Notice. This notice must embrace all the data given in the notice posted upon the claim. It should also state the connecting line as shown by the plat and field notes, and thence the boundaries of the claim by courses and distances. ${ }^{20}$ It is sufficient if, taken as a whole, it designates the situation of the claim on the ground with substantial accuracy, ${ }^{21}$ although it may lack a required element in such a notice. ${ }^{22}$ The notice should not be so abbreviated as to curtail the description essential to a perfect notice. ${ }^{23}$

8. Insufficient Notice. If the notice be insufficient the application for patent is defective. Thereupon, from that point, the proceedings must commence anew. ${ }^{24}$

9. Publication of Notice. The notice must be published in a newspaper designated by the register as the one nearest to the claim. ${ }^{25}$ The newspaper must be one of established character and of general circulation. ${ }^{26}$ The publication is made at the expense of the applicant. ${ }^{27}$ The latter must file the agreement of the publisher of such newspaper holding the applicant alone responsible for the expense thereof. ${ }^{28}$

10. Charges for Publication. The advertisement should be in the usual body type used for advertisements. $^{29}$ It must be inserted for sixty consecutive times in a daily newspaper or nine consecutive times in a weekly newspaper. ${ }^{30} \mathrm{~A}$ daily newspaper may charge not more than $\$ 7$ and a weekly newspaper not more than $\$ 5$ for each ten lines of 
space occupied in each issue for the entire period required by law. ${ }^{31}$

11. Proof of Publication. After the statutory period for publication of the notice has expired the applicant must furnish from the office of publication an affidavit showing such publication. ${ }^{32}$ This must specifically state the first and last day thereof ${ }^{33}$ and should have attached thereto a copy of the notice as published.

12. Proof of Continuous Posting. The fact that the plat and notice remained posted upon the claim during the period of publication of the notice must be shown by the affidavit of the applicant or his duly authorized agent or attorney in fact, stating the dates. ${ }^{34}$

13. Statement of Fees and Charges. In the absence of an adverse claim the applicant may immediately after or at the time of filing proof of posting and of publication file a verified statement showing the charges and fees paid by him for the official survey, for publication, land office fees, and for the land embraced in the claim. ${ }^{35}$

14. Application to Purchase. A written application to purchase is then also filed with the local land officers. Thereupon, no objection appearing, the land may be paid for and the receiver's receipt issue. ${ }^{36}$

15. RECEIVER'S RECEIPT. A subsisting receiver's receipt, if in the form of a certificate of purchase, is equivalent to a patent, as far as the rights of third parties are concerned, ${ }^{\mathbf{3 7}}$ but if it is merely in the form of a receipt for money paid by the applicant, it does not form a link in the chain of title. ${ }^{37 a}$

It may be cancelled by the land department on the ground of fraud or mistake, ${ }^{38}$ due notice and opportunity to be heard having first been given to the applicant. ${ }^{39}$ 
It is void if issued during the pendency of an adverse suit. ${ }^{40}$

After its issuance annual expenditure upon the claim affected thereby is unnecessary ${ }^{41}$ unless the receipt was obtained by fraud. ${ }^{42}$

16. Transmission of Record. After the issuance of the receiver's receipt the local land officers forward the entire record to the General Land Office at Washington and a patent is issued thereon if the proceedings are found to be regular. ${ }^{43}$

17. Protest. At any time prior to the actual issuance of the patent a protest may be filed by any person against the patenting of the claim as applied for. ${ }^{44}$

18. Grounds of Protest. A protest may be based upon any ground tending to show that the applicant has failed to comply with the law in any manner essential to a valid entry under the patent proceedings, 45 as, for instance, that the annual assessment work has not been performed, that the necessary $\$ 500$ has not been expended in labor and improvements upon the claim, that the application was not made by the proper party, that the claimant was guilty of laches in making entry, that the second publication and posting of notice was' not preceded by the filing of a new application for patent. ${ }^{45 a}$ A protest may also be based upon the fact that the protestant is a claimant of a present joint interest in the premises sought to be patented; that he is excluded from the application to the prejudice of his rights therein. ${ }^{46}$

19. WaIver of Protest. Unless the protest is based upon the latter ground a contract based upon a promise not to protest is illegal and void as against public policy. ${ }^{47}$

20. Delayed Patent. Where suit is brought in protection of an equitable interest in the property and the land department is properly advised thereof 
the issuance of the patent will be delayed until the respective rights of the parties have been settled by the court. ${ }^{48}$ In other cases proceedings under the protest are confined to the land department, ${ }^{49}$ generally without right of appeal.50

21. CANCEllation of Entry. The cancellation of an entry is not necessarily fatal to the rights of the applicant. ${ }^{\mathbf{5 1}}$

1. Rev. Stats., $\$ 2325$; Min. Reg., pars. 40 et seq. If the land is not open to entry or the application is subject to other objections, filing will be refused. The reasons for the refusal must be given and thirty days allowed for appeal. Min. Reg., par. 44. Stemmons v. Hess, 32 L. D. 220; see Cleveland v. Eureka No. 1; 31 L. D. 69; E. J. Ritter, 37 L. D. 715 ; see $\$ 29-5$, ante.

2. Rev. Stats., § 2325 ; Min. Reg., par. 41.

3. 21 Stats. 61; Cir. 8 L. D. 505; see Crosby Claims, 35 L. D. 434 ; see note 12 , post.

4. Min. Reg., par. 41.

5. Id. See Instructions, 38 L. D. 40 . If the application includes a mill-site or the latter is applied for separately it must appear by the affidavit of at least two witnesses that the land is non-mineral in character. Min. Reg., par. 65; see Min. Reg., pars. 61-65.

6. Min. Reg., par. 60. A placer applicant is required to describe fully the natural features of the claim; streams, if any, must be fully described as to their course, amount of water carried, fall within the claim, the kind and amount of timber and other vegetation thereon and adaptability to mining and other uses.

7. Id. Id.

8. 31 Stats. 745; Min. Reg., par. 31; see Ter. N. M., 35 L. D. 1; Elliott v. S. P. R. Co., 35 L. D. 149; Lovely Placer Claims, 35 L. D. 426 . A person holding saline lands as an assignee may patent the same provided he has not previously exhausted his right. Min. Reg., par. 31.

9. Min. Reg., par. 54; see Capricorn Placer, 10 L. D. 641; Mary McM. Latham, 20 L. D. 379.

The names of the trustors as well as that of the trustee are inserted in the receiver's receipt. Min. Reg., ante.

10. Rev. Stats., \$ 2321; see Min. Reg., par. 66 et seq.

11. Id. See Alta Mill-site, 8 L. D. 195 ; Louisville Co. v. Hayman Co., 33 L. D. 680 ; see Clarks Mine, 27 L. D. 351.

12. The letter of attorney is not effective unless the applicant is a non-resident of the land district. Crosby Claims, ante, or is temporarily absent therefrom. W. B. Frue, 7 C. L. O. 20 ; see El Paso Brick Co., 37 L. D. 155.

13. Min. Reg., par. 42. When the abstract is not brought down to the date of filing the application or as close thereto as is reasonably practicable, a supplemental abstract must be filed. Dan. Cameron, 4 L. D. 515 The applicant must have the full possessory right or 
title to the claim at the date of filing the application Lackawanna Claim, 36 L. D. 36 ; but where a defect exists and is seasonably cured without detriment to others the application is entitled to equitable consideration. E. J. Ritter, ante; see Carrie S. Co., 29 L. D. 287 .

14. Min. Reg., par. 42.

15. Id.

16. Min. Reg., par. 43 ; Capital No. 5 Claim, 34 L. D. 462 ; see Little Emily Co., 34 L. D. 182.

17. Min. Reg., par. 71. It is common practice to obtain patents from the government without regard to intervening changes in the right of ownership. Van Sice v. Ibex Co., 173 Fed. 895; see Sold Again Fraction, 20 L. D. 58; see Lackawanna Co., ante.

17a. Woodman v. MeGilvary, 39 L. D. 574.

18. Min. Reg., par. 45; Condon "v. Mammoth Co., 14 L. D. 138; see, generally, Chas. W. Steele, 3 L. D. 115; Bretell v. Swift, 17 L. D. 558; Tough Nut Claims, 32 L. D. 359.

19. See Min. Reg. (Placer Claims), par. 60.

20. Min. Feg., pars. 39-46. In view of the different nature of lode and placer claims, it may be necessary to make slight modifications in the notice. Min. Reg., par. 59.

21. Lonergan v. Shockley, 33 L. D. 238; see Juno Lode Claim, 37 L. D. 365.

22. Nielson v. Champagne Co., 29 L. D. 491.

23. Min. Reg., par. 89 , sub. 1. The notice is equivalent to a summons in a judicial proceeding, and he who fails to heed it has no right to complain that his rights are concluded by his default and the issuance of the patent in pursuance of the application. Wight v. Dubois, 21 Fed. 693; Bunker Hill Co. v. Empire State Co., 109 Fed. 538; see, generally, Jefferson Co. v. Anchoria Co., 32 Colo. 176; Nesbitt v. Delamar Co., 24 Nev. 273; Lily Co. v. Kellogg, 27 Utah, 111; see, also, Golden Reward Co. v. Buxton, 79 Fed. 868; New Dunderberg Co. v. Old, 79 Fed. 598; Empire State Co. v. Bunker Hill Co., 114 Fed. 417; German Co. v. Hayden, 21 Colo. 127; Healey v. Rupp, 37 Colo. 25; So. End Co. v. Tinney, 22 Nev. 19.

24. Gross v. Hughes, 29 L. D. 467; S. Cross Co. v. Sexton, 31 L. D. 415 ; see Reed v. Bowron, 32 L. D. 383 .

25. Min. Reg., par. 47; Condon v. Mammoth Co., ante; see Haynes v. Briscoe, 29 Colo. 137. The action of the register is subject to review. Tough Nut Claims, ante; N. P. R. Co., 32 L. D. 611; see Rev. Stats., § 2334.

26. Min. Reg., par. 47; see Instructions, 38 L. D. 131.

27. Min. Reg., par. 45 .

28. Id.

29. Min. Reg., par. 89 , sub. 1.

30. Min. Reg., par. 45. In both cases the first day of issue must be excluded in estimating the period of 60 days. Id.; see Davidson v. Eliza Co., 28 L. D. 224.

31. Min. Reg., par. 89, sub. 1; see Rev. Stats., \$2334. Excessive or exorbitant charges will receive the prompt attention of the land department (Min. Reg., par. 94) and possibly lead to the designation of some other newspaper published in the land district. Rev. Stats., $\$ 2334$. 
32. Min. Reg., par. 51.

33. Id.

34. Id.

35. Min. Reg., par. 52 .

36. Id.

37. Maguire v. Tyler, 75 U. S. 650 ; Deffeback v. Hawke, 115 U. S. 392 ; Brown v. Gurney, 201 U. S. 184; Aurora Hill Co. v. 85 Co., 34 Fed. 515; Bingham Co. v. Ute Co., 181 Fed. 748; Bash v. Cascade Co., 29 Wash. 50.

37a. Con. G. \& S. Co. v. Struthers, 41 Mont. 565; see Murray v. Polglase, 17 Mont. 455.

38. Orchard v. Alexander, 157 U. S. 372; Parsons v. Venzke, 164 U. S. 89 ; Hosmer v. Walace, 47 Cal. 461,30 L. D. 298.

39. U. S. v. Detroit Co., 200 U. S. 321 ; Rebecca Co. v. Bryant, 31 Colo. 119; Romance Lode Claim, 31 L. D. 51.

40. Deeney v. Min. Creek Co., 11 N. M. 279.

41. Benson Co. v. Alta Co., 145 U. S. 428; Deno v. Griffin, 20 Nev. 330 ; see S. End Co. v. Tinney, ante.

42. Murray v. Polglase, 23 Mont. 401.

43. Min. Reg., par. 52 .

44. Rev. Stats., §§ 2325-2326; Min. Reg., par. 53; Wight v. Dubois, ante; see Crown Point Co. v. Buck, 97 Fed. 462; see Contests and Protests, 39 L. D. 150 ; see $\$ 24$, ante.

45. Min. Reg., par. 53; Grand Canyon Co. v. Cameron, 36 L. D. 66; German Co. v. Hayden, ante; LeFevre v. Amonsan, 11 Ida. 45. For form of protest by chiefs of field div. see Contests and Protests, ante. A court cannot determine the sufficiency of a protest. Cosmos Co. v. Gray Eagle Co., 104 Fed. 20.

45a. Woodman v. McGilvary, ante.

46. Id. See Golden and Cord Claims, 31 L. D. 178.

47. Roy v. Harney Peak Co., 21 S. Dak. 140.

48. Wight v. Dubois, ante; Northwestern Co., 8 L. D. 437 ; Thomas v. Elling, 25 L. D. 495.

49. Wight v. Dubois, ante.

50. Bright v. Elkhorn Co., 8 L. D. 122 ; Dotson v. Arnold, 8 L. D. 439. Appeal attaches to a protest only where the protestant has a substantial interest in the property. Min. Reg., par. 53; Grand Canyon Co. v. Cameron, ante; see Wight v. Dubois, ante; Beals v. Cone, 27 Colo. 473 ; but see Benjamin v. S. \& C. P. R. Cos., 21 L. D. 387. A writ of certiorari may be obtained by one denied the right of appeal. Rules of Practice, 4 L. D. 37; see Rules of Practice, 39 L. D. 395.

51. Clipper Co. v. Eli Co., 194 U. S. 220 ; McGowan v. Alps Co., 23 L. D. 113; Beals v. Cone, ante; So. Cross v. Sexton, ante; Peoria Co. v. Turner, 20 Colo. A. 474; see Lucky Find Placer Claim, 32 L. D. 200.

\section{$\S 215$. Adverse Claim. An adverse claim is limited} to the determination of surface conflicts arising from independent conflicting locations of the same ground by adverse mineral claimants, ${ }^{1}$ or between a mineral claimant and the owner of a mill-site, ${ }^{2}$ or, possibly, 
where the same land is claimed by different parties under different laws. ${ }^{3}$

2. Distinction. An adverse claim affects only private rights ${ }^{4}$ and must be filed within the statutory time and be followed by suit. ${ }^{5}$

A protest may be filed at any time before patent issues ${ }^{6}$ by any person with or without interest in the property. ${ }^{7}$ Neither can, properly, be made the subject of the other, ${ }^{8}$ but a protest may, sometimes, have the effect of an "adverse." 9 One who has lost his right to file an adverse claim may still file a protest. ${ }^{10}$ No equitable right is lost by failure to file an "adverse." 11

3. Contents of Adverse Clarm. The adverse claim consists of a written statement verified by the person or persons making the same. ${ }^{12}$ It must fully show the nature, boundaries and extent of the interference or conflict ${ }^{13}$ and be accompanied by a plat, ${ }^{14}$. not necessarily made by a deputy mineral surveyor. ${ }^{15}$ This plat must show the claimant's entire claim and its relative situation or position with the one against which he claims and the extent of the conflict unless both are described by legal subdivisions. ${ }^{16}$ There must also be filed therewith an abstract of title or other evidence of his right of possession. ${ }^{\mathbf{1 7}}$

4. Time for Filing Adverse. The adverse claim must be filed in the local land office in which the application is pending within the 60-days period of newspaper publication, ${ }^{18}$ or it is assumed that none exists. ${ }^{19}$

5. Computation of Time. Time is computed by excluding the first and including the last day of publication. ${ }^{20}$ Whenever the latter day falls upon a Sunday, or other legal holiday, the filing should be not later than on the preceding day. ${ }^{21}$

6. No Extension of Trme. The time for filing is not enlarged by the fact of excessive newspaper pub- 
lication ${ }^{22}$ nor by a mis-statement therein as to the termination of such period. ${ }^{23}$ A temporary suspension of business in the local land office may, however, operate as an extension of the time. ${ }^{24}$

7. Effect of Filing Adverse. When filed within the statutory period it suspends all proceedings in the land office except the newspaper publication, the posting upon the claim and the filing of proof thereof in such office. ${ }^{25}$ This suspension continues until the controversy is finally determined by the courts, is adjusted between the parties thereto or the adverse is waived. ${ }^{26}$

8. Evidence of WaIver. The waiver of the adverse claim may be by failure to commence suit within the thirty-day period required by law, or documentary evidence of waiver or settlement may be filed. 27

9. APPEAL. An appeal lies from the rejection of an adverse claim in the local land office. ${ }^{28}$ The pendency of such an appeal does not enlarge the time for filing the adverse suit. ${ }^{29}$

1. Rev. Stats., \$2325-2326; Turner v. Sawyer, 150 U. S. 578; Creede Co. v. Uinta Co., 196 U. S. 337; Lawson v. U. S. Co., 207 U. S. 1; N. Y. Hill Co. v. Rocky Bar Co., 6 L. D. 318; Smuggler Co. v. Trueworthy, 19 L. D. 356 ; Snyder v. Waller, 25 L. D. 7; Thomas v. Elling, 25 L. D. 495; Grand Canyon Co. v. Cameron, 35 L. D. 495 ; Lee v. Stahl, 13 Colo. 174; Allen v. Blanche Co., 46 Colo. 199; Wright v. Town, 13 Wyo. 497. See U. S. Co. v. Wall, 39 L. D. 546.

2. Durgan v. Redding, 103 Fëd. 914; Cleary v. Skiffich, 2S Colo. 362.

3. Bonner v. Meikle, 82 Fed. 697; see Wright v. Town, ante.

4. Wight v. Dubois, 21 Fed. 693.

5. Rev. Stats., $\$ 2325$; Wight v. Dubois, ante.

6. Id.; see § $24 ; \S 214-17$.

7. Wight v. Dubois, ante.

8. Id.

9. No. Star Lode. 28 L. D. 41; Cain v. Addenda Co., 29 L. D. 62; Grand Canyon Co. v. Cameron, ante; Behrends v. Goldstein, 1 Alaska 518.

10. Golden Reward Co. v. Buxton, 79 Fed. 868; Whitman v. Haltenhoff, 19 L. D. 245 . See preceding note. A protest cannot be made the means of preserving a surface conflict lost by failure to adverse or lost by the judgment of a court in an adverse suit. Min. Reg., par. 53. 
11. See Turner v. Sawyer, ante; Mery v. Brodt, 121 Cal. 332; Rockwell v. Graham, 9 Colo. 36; Butte H. Co. v. Frank, 25 Mont. 344; see Grand Canyon Co. v. Cameron, ante; E. J. Ritter, 37 L. D. 715 . An adverse claim is not necessary to protect the interests of a mining claimant as against an application for a townsite patent; Silver Bow Co. v. Clark, 5 Mont. 378; the owner of a known lode against an application for a placer patent; Elda Co. v. Mayflower Co., 26 L. D. 573; Cape May Co. v. Wallace, 27 L. D. 676 ; see Cripple Creek Co. v. Mt. Rosa Co., 26 L. D. 622; see Clipper Co. v. Eli Co., 194 U. S. 220 ; a senior patentee; Iron Co. v. Campbell, 135 U. S. 286; Discovery Placer Claim v. Murry, 25 L. D. 460 ; No. Star Lode,-ante; and in some cases a tunnel site claimant. Creede Co. v. Uinta Co., ante; see Back v. Sierra Nev. Co., 2 Ida. (Hasb.) 420; Hope Co. v. Brown, 11 Mont. 370 ; nor a mill-site claimant against an application for a mining claim. Helena Co. v. Dailey, 36 L. D. 144 .

12. Rev. Stats., $\$ 3226$; Min. Reg., pars. 78-79. The adverse claim may be verified by the oath of any duly authorized agent or attorney in fact of the adverse claim cognizant of the facts stated. It is only by the rules of the land department that he is required to make affidavit that he is agent or attorney, and to accompany his affidavit with proof thereof. A failure to comply with the above rule will not defeat the suit brought in support of such claim. Brown v. Bond, 17 L. D. 150 .

13. Min. Reg., par. 81. For sufficiency of adverse, see Kinney V. Van Bokern, 29 L. D. 460 . For its insufficiency see McFadden v. Mt. View Co., 26 L. D. 530.

14. Min. Reg., par. 82 .

15. Anchor v. Howe, 50 Fed. 366; Hoffman v. Beecher, 12 Mont. 489 ; see Min. Reg., par. 82 .

16. Min. Reg., par. 82 .

17. Min. Reg., par. 81 .

18. Rev. Stats., $\$ 2325$; Steves v. Carson, 42 Fed. 821; Gillis v. Downey, 85 Fed. 483; Sam McMaster, 2 L. D. 706; Scott v. Maloney, 22 L. D. 274; see Holman v. Cent. Mines Co., 34 L. D. 568; Nettie Lode v. Texas Lode, 14 L. D. 180; Selma Oil Claim, 33 L. D. 187; Hunt v. Eureka Co., 14 Colo. 451; Kannaugh v. Quartette Co., 16 Colo. 341 .

19. Rev. Stats., $\S 2325$; Healey v. Rupp, 37 Colo. 25.

20. Bonesell v. McNider, 13 L. D. 286 ; Waterhouse v. Scott, 13 L. D. 718 .

21. Holman v. Cent. Mines Co., ante.

22. Golden Reward Co. v. Buxton Co., ante.

23. Bonesell v. McNider, ante; Draper v. Wells, 25 L. D., 550.

24. Tilden v. Intervenor Co., 1 L. D. 572.

25. Rev. Stats., § 2325 ; see Morgan v. Antlers Co., 29 L. D. 114.

26. Gwillim v. Donnellan, 115 U. S. 45; Last Chance Co. v. Tyler Co., 157 U. S. 683.

27. Rev. Stats., \$ 2326; Min. Reg., pars. 85-86-87-88; Richmond v. Rose, 114 U. S. 576; Woods v. Holden, 26 L. D. 198; see Kannaugh v. Quartette Co., ante. An amicable adjustment of conflicting claims between adverse claimants is not against public policy. Specific per- 
formance of such an agreement will be enforced by the courts. St. Louis Co. v. Mont. Co., 171 U: S. 650; Murray v. White, 42 Mont. 423.

28. Waterhouse v. Scott, ante.

29. Scott v. Maloney, ante; see Sam. McMaster, ante; Holman v. Cent. Mines Co., ante.

§216. The Adverse Suit. The adverse suit is a continuation of the proceedings commenced in the land office by the filing of the adverse claim therein. ${ }^{1}$ The court determines the right of possession, ${ }^{2}$ but not the right to the patent. ${ }^{3}$

2. Subsequent Proceedings. 'There may be as many different judgments as there are successful parties to the suit. ${ }^{4}$ If several parties are found to be entitled to separate and different portions of the claim, each party may pay for his part thereof together with the proper fees, ${ }^{5}$ file a certified copy of the judgment roll ${ }^{6}$ and the certificate and description by the surveyor-general as in uncontested cases. ${ }^{7}$ Thereupon the final or receiver's receipt issues. ${ }^{8}$

3. Dutry of Register. The register being satisfied that proper proofs have been filed, $9^{\circ}$ certifies the proceedings and judgment roll to the Commissioner of the General Land Office. ${ }^{10}$

4. Proceedings in General Land Office. Thereafter patent issues in conformity to the judgment of the court, ${ }^{11}$ provided the officers of the General Land Office are satisfied that patent should issue at all. ${ }^{12}$

See $\$ 20$, ante.

1. Wolverton v. Nichols, 119 U. S. 485.

2. Alice Placer, 4 L. D. 314 ; Clipper Co. v. Ell Co., 33 L. D. 660 ; s. c., 194 U. S. 220 ; see Min. Reg., par. 55. A court may not determine whether the land is mineral or not. Wright v. Town, 13 Wyo. 497. Nor whether or not the expenditure necessary for patent has been made. Wilson v. Freeman, 29 Mont. 470. Nor may it determine which of the parties is entitled to the patent. Gruwell v. Rocea, 141 Cal. 417. But it may determine the meaning and effect of certain local rules and customs or the effect of state statutes, or entertain a question of fact as to the time of discovery of mineral or the location of the claim on the ground. Shoshone Co. v. Rutter, 177 U. S. 505. The judgment of the court is conclusive only between the parties as to the right 
of possession and not as between them, or any of them, and the government in the matter of the passage of the fee simple title. Alice Placer, ante, Nome \& Sinook Co. v. Townsite, 34 L. D. 276.

3. Deffebach v. Hawke, 115 U. S. 392; Orchard v. Alexander, 157 U. S. 372 ; Perego v. Dodge, 163 U. S. 160; Alice Placer, ante. The rejection by the land department of an application for patent for a mining claim because of failure to establish the presence in the land involved of mineral deposits of such extent and value as to justify the issuance of patent does not amount to a determination that the location upon which it is based is invalid. Clipper Co. v. Eli Co., ante; see $\$ 214$, note 51; see Min. Reg., par. 108; Parsons v. Venzke, $164 \mathrm{U}$. S. 89 ; Hosmer v. Wallace, 47 Cal. 461 .

4. Perego v. Dodge, ante; Wilson v. Freeman, ante.

5. Rev. Stats., $\$ 2326$.

6. Min. Reg., par. 85. As to evidence necessary to establish proof of dismissal, relinquishment or abandonment or that no suit was commenced within the statutory period, see Id., pars. 86-87-88. See St. Louis Co. v. Mont. Co., 171 U. S. 650; see, also, Roy v. Harney Peak Co., 21 S. Dak. 140 .

7. Rev. Stats., \$2326; Min. Reg., par. 85; see pars. 56-57. Lawrence Donlan, 39 L. D. 353 .

8. See Min. Reg., par. 52.

9. Min. Reg., par. 71.

10. Rev. Stats., § 2326.

11. Id.

12. Perego v. Dodge, ante; see note 3 , ante.

\section{CHAPTER XXXII.}

\section{TAXATION OF MINING CORPORATIONS.}

\$220. Federal taxation - returns - filing return - principal place of business-penalty.

§ 221. Commissioners' decisions-oil wells-dry wells-timber cutting-depreciation of minerals-exhaustion of deposits-unearned. increment-market value of minerals-determination of value-unit value-record of estimates-compilation of values-immaterial question-excess in development-memorandum of exclusion-deduction for depreciation-royalties-leasehold investment-limited deduction-no deduction.

\$ 222. Undetermined questions.

\$223. State taxation - graduated tax - time of payment forfeiture-revival-penalty-trustees-settlement of affairs-popular fallacy-consent not necessary.

$\S 224$. Recent legislation.

$\S 220$. Federal Taxation. Under the Act of August $5,1909,{ }^{1}$ which has been declared to be constitutional by the United States Supreme Court, 2 a special excisetax of one per centum upon the entire net income from all sources is imposed on mining (and other) corporations, etc., when the net income of a corporation or 
quasi corporation may have exceeded $\$ 5,000$ during the preceding calendar year.

2. Returns. Every corporation, not specifically enumerated in the law as exempt, must make written return, signed and verified or affirmed by its president, vice-president, or other principal officer, and its treasurer, or assistant treasurer, although its net income during such year may not have exceeded said sum.

3. Filing Return. The return must be filed with the collector of internal revenue, or deputy collector, for the district in which such corporation has its principal place of business, within the United States, before the first day of March succeeding such calendar year.

4. Principal Place of Business. "Principal place of business" is held to mean the principal office where the corporation keeps its books from which the required return is to be prepared and not the place where the operating plant is located. ${ }^{3}$

5. Penalty. A failure to file such retuirn within the statutory time with the proper officer subjects the defaulting corporation to a penalty of not less than $\$ 1,000$ and not exceeding $\$ 10,000$. A false or fraudulent return or statement is a misdemeanor. ${ }^{4}$

1. U. S. Comp. Stats. Supp. 1909 , pp. 659-844-849, § 38 .

2. Flint v. Stone Co., 31 Sup. Ct. Rep. 342.

3. Synopsis of Dec. T. D. 1675, issued February 14, 1911.

4. U. S. Comp. Stats. Supp., pp. 659-844-849, §38.

$\S 221$. Commissioner's Decisions. Mining corporations may possibly be assisted in the labor of making due return under said law by the following excerpts from the decisions of the Commissioner of Internal Revenue thereunder. ${ }^{1}$

2. Oil Wells. Cost of drilling new wells by oil corporations is considered betterments and additions to the capital assets of the corporation. ${ }^{2}$

3. DRY WeLLs. The expense of drilling dry wells may, however, be charged to profit and loss. ${ }^{3}$ 
4. Timber Cutring. The mere removal of timber by cutting from timber lands, unless the timber is otherwise disposed of through sales or plant operations, is considered simply a change in form of assets. If said timber is disposed of through sales or otherwise, it is to be accounted for in accordance with regulations governing disposition of capital and other assets. $^{4}$

5. Depreciation of Minerals. In case of corporations whose business consists in part or wholly of mining, producing, and disposing of deposits of nature (ores, coals, gas, petroleum and sundry minerals), the conduct of such business will be understood to comprehend two classes of gains or losses, viz.:

(a) The gain or loss resulting from the sale of capital assets, i. e. either the increment or the loss arising through possessing over a period of time the investment in the same.

(b) The trading or commercial gain attached to the conduct of the industry, the employment of working capital, the effort and risk involved. ${ }^{5}$

6. Exhaustion of Deposits. In the ascertainment of net income deduction will be allowed for depreciation arising from exhaustion of deposits of ore, mineral, etc., and for depreciation and obsolescence of improvements, in accordance with general regulations respecting depreciation allowances, on the basis of the original capital investment cost of the properties concerned to the company reporting: ${ }^{6}$

7. UNEARNED INCREMENT. A further deduction will also be allowed through not including the same at all in the item of gross income (item 3, Form 637), for the unearned increment represented in such properties as at January 1, 1909, which will be determined in general as follows: ${ }^{7}$ 
8. Market Value of Minerals. An estimate should be made as of January 1, 1909, of the fair market value at that date of the minerals, etc., in deposit. This estimate should be formed on the basis of the disposal value of the minerals in total and exclusive of value of improvements and development work. This valuation should also be reduced to a unit value-per ton, barrel, etc. ${ }^{8}$

9. Determination of Value. Values as aforesaid should not be estimated on the basis of the assumed salable value of the output under current operative conditions, less the actual cost of production, because, as hereinbefore stated, the selling price under such conditions comprehends a profit both for carrying the investment in minerals, improvements, and working capital, and for conducting operations in respect of production and disposal of product. The value to be determined as stated must be on the basis of the salable value of the entire deposit of the aggregate units of minerals considered en bloc if disposed of in that form. Nor must such valuation comprehend any speculative value which might attach to a sale of the minerals en bloc, i. e. a value which might be obtained on the ground that the future would develop a much greater reserve of mineral deposits than were believed to exist at the time estimate as of January 1 , 1909, was formed. Any value of this latter character would attach obviously to such additional reserves when developed in future. ${ }^{9}$

10. UNIT VALUE. The unit value as of January 1, 1909, ascertained as above outlined, would indicate the value to be attached at that date to the capital assets disposed of during any calendar year succeeding, and should be used in determining the unearned increment at January 1, 1909, which may be excluded entirely from the item of gross income, as before explained, in following manner, viz.: 
Value at January 1,1909 , determined in manner outlined, of minerals, etc., which may be removed and disposed of in any year subsequent thereto, $\$$........

Less the following:

(a) Proportion of depreciation charge applying to exhaustion of minerals disposed of, ascertained as first explained herein on basis of original cost, $\$ \ldots \ldots \ldots \ldots$

(b) Royalty paid, if any, on minerals disposed of,

Balance, being unearned increment at January 1 , 1909 , to be excluded from gross-income item ${ }^{10}$.......

11. Record of Estimates. The precise detailed manner in which the estimate of value of minerals, etc., as at January 1, 1909, shall be formed, must naturally be determined upon by each corporation interested, but formal record of such estimates, together with all sustaining information, should be carefully filed so as to be readily accessible for reference. ${ }^{11}$

12. Compilation of Values. Values as stated, as determined at January 1, 1909, should be used in compilation in all subsequent years' excise-tax returns. ${ }^{12}$

13. Immaterial Question. The question as to whether it subsequently develops the property possessed a greater quantity of mineral, etc., reserve than was in the aggregate estimated as of January 1, 1909, is immaterial. ${ }^{13}$

14. Excess in Development. Any excess which may be developed will be considered as possessing the same value at January 1, 1909, as that which then may have been known to be in the property. ${ }^{14}$

15. Memorandum of Exclusion. Each excise-tax return (Form 637, which is furnished by the government), should be accompanied with memoranda setting forth the extent in amount of the exclusion made from the item gross income for unearned increment realized during the year, as above outlined. ${ }^{15}$

16. Deduction for Depreciation. As to the amount to be deducted for depreciation (paragraph 2 
preceding) is to be formed on basis of the estimated reserve of minerals, etc., it follows that if it develops such estimate is understated, the cost investment in the capital asset may be wholly extinguished before all mineral reserves are removed. When this is reached, further deductions for exhaustion of minerals should be discontinued, but in such event, it will be noted, the allowance for unearned increment which is to be excluded entirely from gross income will be correspondingly increased. ${ }^{16}$

17. Royalties. In case of corporations leasing mines and paying royalties on minerals, etc., removed, the royalties paid are to be treated as expenses and deducted in ascertaining net income, as provided in general regulations. ${ }^{17}$

18. Leasehold Investment. Any leasehold investment which the operating corporation may have in such properties, either through a payment originally made for acquirement thereof or for improvements made upon the property, are to be accounted for in accordance with regulations governing depreciation allowances and disposition of capital assets. ${ }^{18}$

19. Limited Deduction. In respect to properties of the character in question which may be acquired by a corporation after January 1, 1909, a deduction will be allowed only as to depreciation arising from exhaustion based on original cost. ${ }^{19}$

20. No Deduction: No exclusion from gross income can be made for unearned increment, as profit arising in sale of such capital assets applies wholly to the period subsequent to January 1, 1909.20

1. Synopsis of Dec. T. D. 1675, issued February 14, 1911.

2. Id., par. 72 .

3. Id.

4. Id., par. 75 .

5. Id., par. 80 .

6. Id., par. 81 .

7. Id., par. 82 .

8. Id., par. 83 .

9. Id.

10. Id., par. 84 . 
11. Id., par. 85 .

12. Id.

13. Id.

14. Id.

15. Id., par. 86 .

16. Id., par. 87 .

17. Id., par. 88 .

18. Id.

19. Id., par. 89 .

20. Id.

§222. Undetermined Questions. The foregoing rulings of the Commissioner of Internal Revenue seem to be based upon conditions applicable only to mercantile corporations. Consequently the method outlined by him for the purpose of determining the gross income of mining corporations, particularly in the case of oil mining corporations, is exceedingly difficult if not impossible of achievement.

It is safe to say that under the conditions existing in oil mining no person can conscientiously make the full, and in some instances even partial return, as demanded by him.

This, particularly in relation to the oil "in deposit," the "fair market value" of the oil in situ, or when, or what portion of the expense of drilling a well shall be charged to profit and loss or not.

$\S 223$. State Taxation. In California a constitutional ${ }^{1}$ annual license tax, ${ }^{2}$ commencing on the first day of July and including the thirtieth day of June thereafter, is imposed on all corporations, not specially exempt by law, ${ }^{3}$ which are doing business within the state, whether incorporated under the laws of the state or not. ${ }^{4}$

2. Graduated Tax. The tax is based upon the amount of the authorized capital stock of the corporation.

3. Time of Payment. The payment may be full or fractional, depending upon the time when the articles of incorporation are filed with the Secretary 
of State or the subsequent existence of the corporation. The tax becomes delinquent on the first day of September of each year.

4. Forfeiture. If the tax and a penalty of $\$ 10$ are not paid on or before the hour of 4 o'clock of the thirtieth day of November of each year the charter of a delinquent domestic corporation or the right to do business within the state of a delinquent foreign corporation is forfeited. 5

5. Revival. A corporation may be rehabilitated within the time allowed by law upon paying the license taxes and penalties that would have accrued if such corporation had not forfeited its charter or right to business within the state. ${ }^{5 a}$

6. Penalty. It is unlawful for either a domestic or foreign corporation, which may not have paid the tax and penalty for such delinquency to thereafter transact any business within the state. Each and every person who exercises any of the powers of either class of corporations, so delinquent, is guilty of a misdemeanor and upon conviction thereof shall be punished by a fine of not less than $\$ 100$ and not exceeding $\$ 1,000$, or by imprisonment in the county jail not less than 50 days nor more than 500 days, or by both such fine and imprisonment.

7. TRustees. The directors or managers in office of the affairs of a domestic corporation whose charter has been forfeited, or of a foreign corporation whose right to do business within the state has been forfeited are deemed to be the trustees of the corporation and stockholders or members thereof. ${ }^{6}$

8. Setruement of AfFairs. Such trustees have full power to settle the affairs of the corporation and to maintain or defend any action or proceeding then pending, or to sue or be sued in any subsequent actions. 
9. Popular Fallacy. It is popularly supposed that upon the forfeiture of the charter of a domestic corporation, owning real estate, the legal title to the latter immediately vests, by operation of law, in the stockholders of such corporation, as tenants in common. On the contrary, by operation of the provisions of the license tax law, the legal title then vests in the trustees, in office, with full power of disposition thereof; subject to the rights of the stockholders and creditors of such corporation. ${ }^{7}$

10. Consent not Necessary. Although it is sometimes demanded by the grantee, the consent of the stockholders, holding of record two thirds of the issued capital stock of a corporation, as required, generally, by the Civil Code ${ }^{8}$ is not essential in a deed from the trustees of the whole of the property. By reason of the forfeiture of its charter the corporation has ceased to exist, as such. ${ }^{9}$

1. See Ukiah Co. v. Curry, 148 Cal. 256; Kaiser Co. v. Curry, 155 Cal. 638; Lewis v. Miller \& Lux, 156 Cal. 93.

2. Cal. Stats. 1909 , p. 454 .

3. See Lewis v. Curry, 156 Cal. 101.

4. Cal. Stats. 1909 , p. 454 .

5. See American Co. v. Colorado, 204 U. S. 103.

5a. Cal. Stats. 1911, p. 1094.

6. Cal. Stats. 1909 , p. 454 ; see C. C. $\$ 400$; Lewis v. Miller \& Lux, ante.

7. See Lewis v. Miller \& Lux, ante.

8. §361a.

9. See Lewis v. Miller \& Lux, ante.

§224. Recent Legislation. A late Californian statute provides for a tax upon the franchise of a corporation, domestic or foreign, when the latter is doing business within the state. The amount of the tax is a lien upon the corporate property. This tax is additional to the "License Tax" 1 but carries with it the same penalties as well as additional penalties in case of delinquency or the making of a false report. ${ }^{2}$

1. $\S 223$, ante.

2. Cal. Stats. 1911, p. 530 . 
APPENDIX

FORMS 


\section{APPENDIX}

\section{FORMS}

\section{AFFIDAVITS.}

(See Patent Proceedings.)

\section{AFFIDAVIT OF ANNUAL EXPENDITURE.}

Form No. 1.

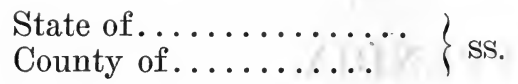

County of ...........

being first duly sworn, deposes and says, that at least..........dollars' worth of labor was performed (or improvements made) between the ......... day of .......... 19..., and the..........day of .........., 19.., upon the ......... Mining Claim, situate in the Mining District, County of..........., State of.......... Such expenditure was made by or at the expense of .........., the owner of said claim, for the purpose of complying with the laws of the United States and of the State of .......... pertaining to annual assessment work.

Said labor, 'so performed, (or improvements so made) being as follows :

(Describe the labor or improvements.)

Subscribed and sworn to before me this......... day of........., 19.... 
NON-MINERAL AFFIDAVIT.

Form No. 2.

Department of the Interior.

United States Land Office.

19

being duly sworn according to law, deposes and says that he is the identical........ who is an applicant for government title to the that he is well acquainted with the character of said described land, and with each and every legal subdivision thereof, having frequently passed over the same; that his personal knowledge of said land is such as to enable him to testify understandingly with regard thereto; that there is not, to his knowledge, within the limits thereof, any vein, or lode or quartz or other rock in place, bearing gold, silver, cinnabar, lead, tin, or copper, or any deposit of coal; that there is not within the limits of said land, to his knowledge, any placer, cement, gravel, or other valuable mineral deposit; that the land contains no salt spring, or deposits of salt in any form sufficient to render it chiefly valuable therefor; that no portion of said land is claimed for mining purposes under the local customs or rules of miners or otherwise; that no portion of said land is worked for mineral during any part of the year by any person or persons; that said land is essentially non-mineral land, and that his application therefor is not made for the purpose of fraudulently obtaining title to the mineral land, but with the object of securing said land for agricultural purposes; that the said land is not occupied and improved by any Indian, and that his post office address is

Note.-See Revised Statutes of the United States, Title LXX, Crimes, Chap. 4. 
I hereby certify that the foregoing affidavit was read to affiant in my presence before he signed his name thereto; that said affiant is to me personally known (or has been satisfactorily identified before me by..$\ldots \ldots \ldots \ldots)$, and that I verily believe him to be a credible person and the person he represents himself to be, and that this affidavit was subseribed and sworn to before me at my office in............ within the..........land district, on this....... day of...............

\section{ARTICLES OF INCORPORATION.}

Form No. 3.

(As Articles of Incorporation must conform to the laws of the State or Territory in which the corporation is organized, only the "purposes" of a mining corporation are subjoined.)

The business, objects and purposes to be transacted, promoted and carried on by this corporation, and the purposes for which it is formed are locating, working, developing, leasing, buying, selling, and otherwise dealing in mines, mining locations, mining claims, mining rights, mineral deposits, mill-sites, tunnelclaims, or rights, water rights, mining plants, mining dredges, machinery, or works used in connection therewith. Also, to engage in and carry on the business of dredging for gold and other mineral substances or deposits, in water or upon land. Also, to engage in and carry on the business of boring for, producing, owning, holding, buying and selling petroleum oils, natural gas, asphaltum, bitumen, and other hydrocarbon substances. Also, to produce, generate, or otherwise obtain electric light, power and heat. Also, to engage in and carry on the business of crushing, smelting, milling, calcining, refining, dressing, concentrating, cyaniding, generating, manipulating, and preparing for market gold, silver, quicksilver, lead, tin, 
copper, zinc, iron, or other ore, coal, slag, petroleum oil, metals, and mineral substances of all kinds; and to carry on any other reducing, smelting, or metallurgical operations which may seem conducive to any of this corporation's objects, purposes or business. Also, to engage in and carry on the business of buying, selling, manufacturing, and dealing in ores, tailings, slag, metals, mining plants, machinery, implements, conveniences, provisions and things used in connection with the business of this corporation, or required by the workmen and others employed by this corporation.

Also, the entering into partnerships, or into any arrangement for sharing profits, union of interests, cooperation, joint adventure, reciprocal concession, or otherwise, with any person, firm or corporation carrying on or engaged in, or about to carry on and engage in any business or transaction which this corporation is authorized to carry on, or engage in any business or transaction capable of being conducted so as to directly or indirectly benefit this corporation. Also, to take and acquire, by purchase or exchange, or other lawful modes, and to hold, own, deal in, sell, and otherwise dispose of the capital stock or bonds of other corporations.

And, in general to do and perform any and every other act or acts, or things, of whatsoever name or nature, incident to, growing out of, or connected with the purposes, objects and buisiness for which this corporation is formed.

\section{CONTRACTS.}

AGREEMENT TO PURCHASE.

Form No. 4.

(Precedent in Eisleben v. Brooks, 179 Fed. 86.)

Memorandum of agreement made and entered into in duplicate at .......... this ....... day of 
, 191.., by and between

and.......... both of............ parties of the first part, and all of

parties of the second part. witnesseth: That the parties of the first part are the owners and holders of options on mineral rights and are in process of acquiring under purchase, options, and leases, other mineral rights in all, or as much thereof as can be had of what is

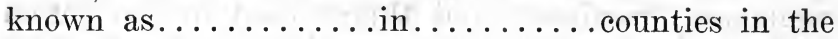
state of...........

Money is needed for the immediate prospecting of and the purchasing of said mineral rights from said first parties, and the parties of the second part agree to furnish such funds.

The parties of the first part agree to convey by proper deeds and transfers to.............. of as trustee, or his successor in person or corporation, all of said mineral rights now owned by them or whether they acquire an option thereon, or whether they acquire them by purchase, options or leases at any time in the future. The said parties of the second part agree to furnish for immediate use a drilling fund enough to sufficiently drill said......... otherwise to accept same without drilling, and as said property is drilled to accept for said trustee, or his successor, the mineral rights under any and all lands in said............ which are now and in the future may be owned, purchased, optioned, or leased by said first parties, which are shown by ordinary methods of drilling to contain............paying to said first parties......... dollars, cash per acre for the same, upon conveyance to said trustee or successor as above.

Upon completion of said drilling and purchasing, or before if deemed advisable, the parties hereto agree to organize a corporation for the division of and further development of said properties, and to which corporation the parties of the second part hereby subscribe 


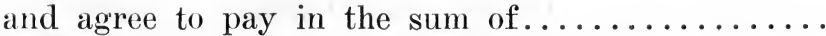
dollars cash, and which organization shall be duly incorporated under the laws of the state of..........., and its capital stock shall be issued fully paid and non-assessable.

The capital stock of said corporation shall be issued and divided as follows: The said parties of the first part are to receive........ of said stock and the parties of the second part are to receive.......... of said stock.

It is understood that the corporation thus formed shall refund to said second parties the amount of money paid out by them to the first parties in the purchasing of said mineral rights. In the perfecting of the arrangements under this contract, it is considered and understood that the development of said properties on an extensive scale shall be carried into effect, and that no less than........ fully equipped modern .......... plants shall be put into operation just as soon as the market by proper advertising, soliciting, etc., will justify.

The situation being, however, that the parties of the first part are unable to furnish capital to assist in the carrying of said operation into effect, it is hereby understood and agreed, and is the chief consideration to first parties in this contract, that said second parties shall furnish or aequire for said corporation the necessary capital for said development, and to protect first parties' interests in said corporation until such time as said corporation shall have accumulated sufficient working capital to justly protect first parties therein.

In witness whereof the parties hereto, and to its duplicate, set their hands and seals, the day and year first above written. 


\section{AGREEMEN'T TO SELL.}

Form No. 5.

(Precedent in Fulkerson v. Chisna M. \& I. Co., 122 Fed. 783.)

This instrument made and entered into by and between......... party of the first part, and......... Company, a corporation, party of the second part, witnesseth as follows: Whereas, the said party of the first part by a certain contract heretofore executed and delivered, has agreed to sell, assign, transfer and convey to.......... and ......... the.......mining claim hereinafter described, for value received, and for certain considerations expressed in said contract, which contract has been duly assigned to the said party of the second part, said........... Company, now, therefore, in consideration of the said contract and for a valuable consideration in hand paid to the said party of the first part by the said party of the second part, the said party of the first part hereby sells to the said party of the second part that certain ........mining claim described as follows:

\section{(Description)}

and hereby agrees to execute a lawful deed conveying said property to the said party of the second part and to place said deed in the hands of......... to be held by him in escrow and to be by him delivered to the said party of the second part, said............ Company, at any time on or after the........... day of ........, 19..., provided, on said......... day of.........., 19..., the said party of the second part has, on its part, performed the terms and conditions of the above mentioned contract and required therein to be performed by said............. and their heirs and assigns, in so far as said 
terms and conditions are subject to be performed prior to the said.......... day of........., 19....

In witness whereof the parties hereto, and to its duplicate, have set their hands and seals this, the $\ldots \ldots \ldots$ day of . ............. 19.

\section{COMPROMISE OF ADVERSE CLAIM.}

Form No. $5^{\mathrm{a}}$.

(Precedent in St. Louis Co. v. Montana Co., 171 U. S. 650.)

The terms of the agreement made this........ day of........, 19..., by and between........., the party of the first part, and.........., the party of the second part, are as follows:

That in consideration of the compromise and settlement of the adverse suit brought by said party of the ........part in the ........ Court of the......... to determine the right of possession to the......... mining claim, as mentioned and described in the complaint in said suit, and also of the withdrawal of the adverse claim upon which said suit is based, and also of settling and agreeing upon the boundary line between said........mining claim and the........mining claim of said party of the......... part, the said party of the......... part hereby agrees and binds .................. days after the issuance of the patent as applied for to make, execute and deliver to said party of the......... part, or ........ assigns a good and sufficient deed of conveyance for

(Description)

That thereupon the said party of the........ part shall, immediately dismiss said suit and withdraw said adverse claim.

That during the pendency of said patent proceedings, or during any of the times herein provided for the said party of the.......... part shall not make, nor cause to be made, any motion in said court for the dismissal of said suit, for want of prosecution, nor at all. 


\section{GIRUB S'TAIKE CON'TRAC'T.}

Form No. 6.

(Precedent in Morrow v. Matthew, 10 Idaho 423.)

The terms of the agreement made this....... day of ........., 19.., between........., of State of .........., the party of the first part, and.......... of the same place, the party of the second part, are as follows:

That the party of the first part shall forthwith proceed to.........., in the State of.........., and for......months from the date hereof devote his time, labor and skill in prospecting for mineral deposits therein, and when found he shall locate mining claims thereon subject to location under the laws of the United States, the State of.........., and the local rules, regulations and customs of miners in force in the mining district in which such deposits may be situated for the joint use and benefit of the said parties hereto.

That the said parties hereto shall be equally interested in each and every mining claim so discovered, located, or which may be acquired in any manner by said party of the first part within said territory during the time aforesaid.

That the said party of the second part shall, from time to time and upon his demand, furnish the said party of the first part with such supplies, tools and instruments and other things of necessity incident to such prospecting, locating and acquiring mining claims as said party of the first part shall properly require in the keeping of this agreement on his part.

In witness whereof, the said parties hereto have hereunto and to its duplicate, set their hands the day and year first above written. 


\section{CONTRAC'T WITH MINING ENGINEER.}

Form No. 7.

(Precedent in Wishon v. Great Western Co., 29 Wash. 355.)

This agreement, made and entered into this...... day of........, 19.., between........, of in the County of.......... in the State of........., the party of the first part, and of......... in the County of......... and State of........., the party of the second part, Witnesseth: That whereas, the said party of the first part is a mining engineer and expert, whose opinions and statements concerning mines and mining properties are of value and are highly regarded by those who are purchasing mines and mining property; and

Whereas, the said party of the second part is desirous of selling and disposing of those certain mines and mining property, of which the said party of the second part is the owner, hereinafter described; and is desirous of employing the said party of the first part in reporting on the said property, so as to have his professional recommendation, or other report, upon the same, as the property may warrant. Now, therefore, this Agreement witnesseth :

That for and in consideration of the services rendered and to be rendered by the said party of the first part in the sale of the said mines and mining property, which is now pending or on any sale or sales which may be made by and through the report upon said property, by the said party of the first part, at any time, or to any person whomsoever of the...... group or property, consisting of the.......... and ......... lode mining claims, situate at........ Mining District, County of...... and State of..... ; 
and in consideration of the report of the said party of the first part, or any part of the said report, or any map, writing, printed matter, or other recommendation, or statement, made by said party of the first part, for and on account of the sale, which is now pending, for the price of.......... dollars, or any sale or sales hereafter to be made by and through the said report, or any part thereof, of the said property, the said party of the second part covenants and agrees, to, and with the said party of the first part that he will pay him, said party of the first part, or his heirs or assigns, the full sum of......... dollars, to be paid immediately upon the payment of the purchase money. And it is further agreed and understood that the expenses incurred in making the trip from ....... to the said property and return, and during the examination, assays, maps, etc., by the party of the first part shall be repaid to him by the said party of the second part at the time and times said expense is incurred. And the said party of the first part promises and agrees to and with the said party of the second part that he will use all his professional skill and will make a full and complete report of the said mines and mining property and will expert the same, and will do all in his power to bring about a fair and honest sale of the said property upon the terms and conditions hereinbefore set forth.

In witness whereof, the said parties hereto have hereunto and to its duplicate, set their hands the day and year first above written. 


\section{OIL WELL DRILLING CONTRAC'T.}

Form No. 8.

(Precedent in Cook v. Columbian Co., 144 Cal. 670.)

This agreement, made and entered into this...... . day of ........., 19..., between........., of the party of the first part, and....... $\ldots \ldots \ldots$ of..................... the party of the second part, Witnesseth:

That the party of the second part will furnish at his own cost and expense all the machinery, tools, paraphernalia and materials of all kinds, including labor, fuel, water, and any and all things of whatsoever kind and nature that may be necessary and needful (except casing, pipe and shoes) to properly perform the work of drilling or boring not less than.......... feet of hole or wells, and to drill or bore the same at any one or more places on the following described land situate, lying and being in the County of......., State of.........., and more particularly described as follows, to wit:

\section{(Description)}

as may be desired and designated by the party of the first part, for the agreed price per foot sunk, as shown and set forth in the following scale of prices, at different depths up to........... feet, and in accordance with the further terms and conditions herein

Note.-Under the provisions of an Act to prevent injury to oil, gas or petroleum-bearing strata or formations by the penetration or infiltration of water therein, it is provided in California that any well drilled and abandoned in violation of the terms of the statute is a public nuisance and may be abated by appropriate action of the board of supervisors of the county. The expenses so incurred are a charge against the owner of the well and a lien upon the well. Interference with official action is a misdemeanor. Cal. Stats., 1909, p. 586 .

For capping of wells to prevent wasteful escape of natural gas into the atmosphere see $\$ 121 \mathrm{a}$, ante. 
contained. Provided, however, that in case the drilling of any well shall be stopped by the party of the first part for any cause after it has been begun, that the party of the first part will pay the net cost of moving the drilling outfit to any other place on the said property where another well is to be started, in addition to the amount earned for the number of feet sunk in accordance with the said scale of prices per foot and that should work be stopped on any well, for any cause, after a depth of........ feet has been sunk, then the said party of the second part shall move the rig at his own cost and expense to the place designated by the party of the first part. That in case of abandonment of any well or wells for any cause the party of the second part will pull and remove, in a careful manner, all casing, pipe and fittings used in said well or wells that can be got out by a reasonable and faithful effort by the use of all appliances and tools ordinarily used in performing such work.

That all casing, pipe and shoes of the proper sizes necessary to be used in the well or wells will be furnished and delivered on the ground by the party of the first part and shall be of such sizes as such party may select, and the same shall be properly inserted and used in the wells by the party of the second part and carried to the bottom, if possible without diminishing the size except in cases where it is found absolutely unavailable after the use of under-reamers and other appliances, as may be necessary and proper for keeping the whole in proper shape.

That in case a body of asphaltum be encountered at any considerable depth and it is found impossible after a faithful and reasonable effort so to do that it cannot be drilled through nor penetrated by the use of any of the known tools and appliances, then the said well will be considered as completed and a settlement made in full for the depth drilled accord- 
ing to the said scale of prices; provided, however, that the party of the first part shall have full and free right and privilege to use and operate the machinery and outfit of the party of the second part at his own cost and expense for a period not to exceed .......... or until satisfied that the hole cannot be sunk any deeper.

That in case oil, gas or asphaltum shall be found at any depth in any well and the party of the first part shall elect to stop drilling in such well, the party of the second part shall properly test the well and leave the same in condition ready for the pump or other working appliance before moving the rig and outfit away.

It is understood by and between both parties hereto that this contract is for a total of.......... feet of hole or wells, and that the party of the second part agrees to put down any one hole to a total depth of ...........feet, if the ground is such that it can possibly be done, by reasonable effort, or that he will stop the drilling of any well at any depth, as directed by the party of the first part and in accordance with the said scale of prices per foot sunk, and the terms and conditions herein contained.

That the party of the first part will pay, or cause to be paid to the party of the second part the amount earned for each foot of hole sunk in accordance with the said scale of prices at times and as follows, to wit:

An advance sum of......... dollars, when the rig and outfit are on the ground and ready to commence the work of drilling; ........ per cent of the amount earned as per scale when the well has been sunk to a depth of........... feet and a like.........per cent of the amount earned at the completion of each ......... feet until the well is either completed or abandoned, or the work stopped by the party of the first part, when the balance in full shall be paid, after 
deducting the said advance payment of.......... dollars.

Done in duplicate, the day and year first above written.

\section{option.}

Form No. 9.

This agreement, made the......day of.........., $19 .$. , between.........., a corporation organized and existing under and by virtue of the laws of the State of.........., the party of the first part, and .......... of the County of........., State of.........., the party of the second part, Witnesseth: That the party of the first part, in consideration of..........., will sell to the party of the second part all those certain mining claims and water rights situate, lying and being within the......... Mining District, County of............. State of ............ more particularly bounded and described as follows, to wit:

\section{(Description.)}

upon the following terms and conditions, to wit:

The party of the first part will cause to be deposited in escrow in the Bank of......... in the County of .........., State of ........., at the time of the execution of this instrument, its deed in writing, good and sufficient in the law, to the party of the second part, or his assigns, of each and all of the properties hereinbefore mentioned and described.

The party of the second part is hereby granted an option to purchase all of said mining claims and water rights for the sum of.......... dollars, subject to the terms and special exceptions and conditions hereof, in the following manner: That the said party of the second part shall pay in to the credit of the said party of first part at said Bank of........., on or before 
12 o'clock noon of each day specified, to wit: on or before the..... day of......., 19..,.....per cent of the said purchase price of said properties and the balance of said purchase money in..........equal payments of...... per cent of the whole every....... months thereafter.

It is hereby agreed that all of the foregoing payments shall be made in United States gold coin of the present standard of value.

It is hereby agreed that the party of the second part.shall have the right to anticipate the payments of the entire unpaid purchase price of said properties at said Bank of..........., but in the event that he exercises such right he shall pay all of the unpaid installments in full; provided, that he be allowed an amount equal to............ per cent per annum on each unpaid installment for the length of time for which such installment is thus anticipated; and provided further, that such payment or payments, or any part thereof, is not derived from the proceeds of said properties, or any part thereof; and provided further, that if the party of the second part shall exercise the option conferred hereby to anticipate deferred payments, he shall give notice in writing to the party of the first part of his intention to exercise such option ......... days prior to the time he shall be allowed to exercise the same.

It is further agreed that during the period from the date hereof until the final payment of the said entire purchase price of said properties is made, said party of the first part shall remain in the entire possession and control of the property hereinbefore particularly mentioned and described, except that upon the making of said first payment of said.......per cent. of said purchase price of said properties the said party of the second part may, and shall have the right to enter into and take possession of all and 
singular said premises and property, and commence work and make improvements thereon, and operate, mine and extract the mineral from said premises and property. That in order that said party of the first part may be fully protected hereunder, it is hereby agreed that all work done and improvements made by said party of the second part upon said premises and property under the terms hereof shall be done in a miner-like and proper manner to enable said premises to be carefully operated, and so that the mineral therein contained may be extracted in an economical and miner-like manner, and all of said work done and improvements made shall be done or made under the supervision of said party of the first part and with its consent, and to that end it is hereby agreed that Mr. .......... its superintendent, or his successor in office, shall have the right to finally pass upon and approve of, or reject, any plan or portion of a plan of the party of the second part for the working and improvement of said premises and property; or any part thereof, or of any work or ditches or pipe lines which may be connected therewith. That said party of the second part hereby agrees to dispose of the proceeds of the working of said premises as obtained or received by him from time to time as follows: All of such proceeds, less the actual cost of extraction, reduction or refining, hauling and freight charges, shall be applied as a payment upon the unpaid portion of the next payment falling due hereunder upon the purchase price of said mining claims and water rights.

It is understood and agreed that in consideration of the premises, that said party of the second part shall within......... days from the date hereof enter upon said premises by his duly accredited agent or agents, mining engineer or mining engineers, mining expert or mining experts, together with proper assist- 
ants and paraphernalia constituting a proper and sufficient outfit therefor, and in a proper and minerlike manner, and at his own cost and expense, make a proper examination and test of the mineral value of said premises and properties, holding and keeping the same, and all thereof, free and clear of all costs, charges and liens for such examination and working.

It being further understood and agreed that the said party of the second part shall keep the party of the first part fully informed of said work, and permit the said party of the first part at all times, and at any time, to inspect such work, and any and all thereof; and it is further agreed that in furtherance of such examination and test said party of the second part may use and enjoy the improvements now placed upon said premises and properties together with such personal property now thereon as may be necessary or proper in the making of such examination and test; but in the event that said work is not being done to the satisfaction of the said party of the first part, it shall have the right and it is hereby given the right to cause all work being done by said party of the second part to immediately cease.

It being further distinctly understood and agreed that upon the failure on the part of the party of the second part to enter upon said premises and properties within the time and in the manner lastly hereinbefore aforesaid this option and all rights and privileges thereunder shall, upon and at the expiration of said..........days be instantly forfeited, cancelled and annulled.

In the event that such examination is made within the time hereinbefore specified, and that thereafter the said party of the second part shall elect not to purchase said premises and properties under the terms hereof, he, the said party of the second part shall deliver to the said party of the first part, free from 
all cost, charges and expense to it whatsoever, copies of all data, plans, field notes, analyses, samples, photographs and other determinations and reports that he, the said party of the second part, shall have made or caused to be made, or otherwise obtained, in and about and by reason of said examination and test, the same to be so delivered within....... days after this option may have been concluded under the terms hereof.

In the event that the said party of the second part does not purchase said premises and properties, in accordance with the terms hereof, or shall default in any payment herein provided for, or this option be revoked for legal cause by the said party of the first part, any and all improvements placed upon said hereinabove described premises and properties by the said party of the second part shall thereupon immediately become and be the property of said party of the first part, without any cost, charge or expense to it whatsoever therefor.

It is hereby further agreed that if at any time the party of the second part shall fail to make any payments herein provided for upon the said purchase price of said premises and properties at the time and place herein specified for the same to be made, the rights of the party of the second part under this option shall immediately cease and determine, and the payments which shall have been made by him therefor shall be applied as follows:

Whereas, the damage to the present or future value of the several properties affected by this agreement by a failure to purchase the same as herein provided, and the damage which may be occasioned to the same during the existence of this option prior to any breach thereof by the party of the second part, cannot be estimated or established in a court of justice by reason of the difficulty of establishing hereafter the present appearance, prospects and apparent value of said 
hereinabove described mining claims and the changes in the appearance, prospects and value of the same at the time of such breach, and other difficulties and the consequent damage resulting thereby to the party of the first part;

It is hereby agreed that all payments and expenditures which shall have been made under this option by the party of the second part upon said premises and properties, or upon any part thereof, shall be deemed to be liquidated and assessed damages caused by the said party of the second part to the party of the first part by virtue of his failure to comply with and perform the conditions of this option and shall remain the property of the party of the first part; and the party of the second part hereby releases all claim thereto.

The party of the first part hereby agrees that it will not act nor consent to the doing of any act by it tending to alienate or encumber said premises and properties, or any part thereof, hereinabove described or which will prevent the party of the second part (upon the completion by him of all the conditions herein provided to be performed by him) from acquiring the same rights therein as are now possessed by the party of the first part.

The said party of the second part hereby covenants and agrees to hold harmless the party of the first part hereto as against all liens and claims of mechanies for labor done and materials furnished under this option, and hereby grants to said party of the first part through its duly accredited agent, to be present at the payment and ascertain that all wages of employees of the party of the second part, and all sums of money due to contractors or subcontractors under the said party of the second part, if any, and all sums of money due for materials furnished, are paid.

The party of the second part agrees to have each 
and every man employed by him and working upon said premises and properties and each and every person, company or corporation from whom he buys material, sign a contract, as follows :

"In consideration of my' being employed by....... ........ or of .......... purchasing materials of me, I hereby covenant and agree to look alone to said........... for my pay, and I hereby waive all rights or claims that I may have in law or in equity against the properties, or any one of them, upon which said labor is bestowed or to which said material is furnished."

(All blanks to be properly filled.)

That upon a failure in any instance to properly secure such waiver of lien this option, and all rights and privileges thereunder shall be instantly forfeited, cancelled, annulled and revoked.

Time is of the essence of this agreement, and upon the failure to perform any of the covenants and obligations' hereby imposed upon the party of the second part, the said Bank of........... is hereby authorized and directed to deliver said deed of conveyance, and all other papers, instruments or documents which may. be deposited in escrow in said bank by the parties hereto under the terms or by reason of this option, and upon the failure of the party of the second part to perform any of the conditions or obligations hereby imposed upon him, the party of the first part is hereby absolved from the performance of any conditions or covenants imposed upon it hereby.

The said Bank of........... is hereby made the sole arbiter between the parties hereto as to whether the said conditions or obligations have been performed, and the said bank's decision shall bind the respective parties; and if said bank decides that said party of the second part has not fully performed the same as herein provided, said bank shall not be restrained 
from the surrender of said deed of conveyance and other papers, instruments or documents as herein directed; and said Bank of.......... shall be absolved from all liability hereunder, except fraud in the performance of its duties.

Upon the performance by the party of the second part of all the conditions of this option and the payment of the said full purchase price of said premises and properties as herein provided said Bank of..... .......shall deliver said deed of conveyance, papers, instruments and documents as may be deposited in escrow with it hereunder to the said party of the second part.

This option shall be binding upon, and run in favor of the heirs, executors, administrators, successors and assigns of each of the parties hereto except as herein specially provided.

In witness whereof, the said party of the first part has caused its corporate name to be hereunto subscribed, and its corporate seal to be hereunto affixed, by its officers thereunto duly authorized, and the said party of the second part has hereunto set his hand, in duplicate, the day and year first above written.

\section{RATIFICATION OF OPTION BY STOCKHOLDERS.}

Form No. 10.

Know all men by these presents, That we, the undersigned, ........... stockholders of......... Mining Company, a corporation organized and existing under and by virtue of the laws of the State of .......... and having a capital stock of.

dollars, divided into........shares of the par value of.......... dollars each, and severally the owners and holders of record on the books of said corporation of the number of shares of the capital stock of said corporation set opposite our respective signatures, and 
together owning and holding more than two thirds of the entire issued and outstanding capital stock of said corporation, being fully advised in the premises, hereby agree, consent to, approve of, ratify and confirm the foregoing option.

In witness whereof, we have hereunto set our hands this.......... day of........., 19...

NAME OF STOCKHOLDER.

NO. OF SHARES.

\section{CERTIFICATE OF SECRETARY.}

Form No. 11.

I, ........... do hereby certify that I am the duly appointed and acting secretary of........................ Mining Company, a corporation organized and existing under and by virtue of the laws of the State of

That the capital stock of said corporation is...... dollars, divided into....... shares of the par value of......... dollars each.

That only..... shares of said capital stock of said corporation have been issued and are now outstanding. That the persons signing the above and foregoing ratification at the time their respective signatures were affixed thereto were stockholders of said corporation, holding of record at least two thirds of the entire issued and outstanding shares of the capital stock of said corporation, and were at such time the owners and holders of the number of shares set opposite their respective names.

Witness my hand and the corporate seal of said corporation by me hereto affixed this........ day of .........., 19 ...

Secretary, Mining Company. 


\section{INSTRUCTIONS TO ESCROW HOLDER.}

Form No. 12.

(Precedent in Pollard v. Sayre, 45 Colo. 195.)

To Bank ............. at

Herewith enclosed find deed from the undersigned

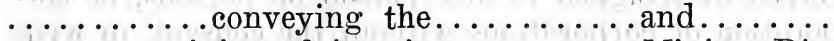
........mining claims in...........Mining District, County of.........., State of. This deed is to be held by you in escrow subject to delivery to .......... his heirs or assigns, upon their complying with the conditions of a.......... said property executed by us to said.........., on the ...... day of ........., 19., a copy of which is enclosed herewith. Upon the payment of any sum as therein provided, ............ thereof is to be placed to the credit of.

Dated........, 19...

\section{pooling agreement.}

Form No. 13.

To the Bank.

Gentlemen :

$\mathrm{We}, \ldots \ldots \ldots \ldots$ and............... severally deliver to you the following certificates, calling for the number of shares of capital stock of the............ Mining Company and issued to the persons respectively as herein named:

Certificate No......to......... for....... shares. Certificate No......to.......... for....... shares.

These certificates, numbers.........to......... inclusive, are to be held by you as a depositary, and pursuant to the agreement of said persons (herewith evidenced by their signatures to this paper), are not to be re-delivered by you to said persons, or any of 
them, except in the event you should receive instructions in writing signed by all of such persons, it having been, and being now agreed by them, that neither said certificate nor the shares of stock called for thereby, nor any portion thereof, shall be sold, transferred or assigned to any person or persons, or corporation or corporations without the consent, in writing, of all the said persons being obtained as aforesaid; but, provided, however, that said shares, or any of them, may be sold, transferred and assigned by any of said persons to any other of said persons without such consent.

The foregoing shall be construed both as a letter of instructions to the Bank of........... and as an agreement between the undersigned.

In witness whereof, the said parties have hereunto set their hands, in.......... this, the...... day of........., 19...

\section{ADDENDUM.}

(Precedent in Smith v. S. F. Ry. Co., 115 Cal. 584.)

It is mutually agreed between said persons that for the purpose of keeping control of said corporation in the interest of themselves (and of all persons who shall buy any portion of said stock from them) that they will during the period of..........., from the date hereof, retain the power to vote said shares in one body; and that the vote which shall be cast by said shares, whether for directors, or for any other purpose, shall be determined by ballot between them or their survivors. 


\section{DEEDS.}

GIRANT DEED.

Form No. 14.

(Precedent in Carter v. Bacigalupi, 83 Cal. 187.)

I, ........... grant to.......... all that certain mining claim situated in the............Mining District, County of.........., State of........., being the.........mining claim, more fully described in the notice of location thereof which is recorded in the office of the County Recorder of said County of......... on the..... day of........, 19.., in Book......, at page..... of the Record of of the records of said county; and which said record is hereby referred to and made a part hereof. $19 . .$.

Witness my hand this...... day of.........,

\section{ADDENDUM.}

(Precedent in Catron v. So. Butte Co., 181 Fed. 941.)

It being understood that the surface only is hereby conveyed and that all minerals and metals and ores below the surface with the right to mine, prospect for, and extract the same, is hereby reserved to the parties of the first part, their heirs, representatives and assigns, and excepted and excluded from and not passed by this conveyance. But the said parties of the first part, their heirs, representatives and assigns covenant and agree that they will not mine or excavate under the surface of that portion of the lot above described, and which is covered by the said .lode, nearer to the surface than...... feet from the present surface of the ground, but will in their mining operations, leave...... feet below the present surface of the ground for support. But they 
do not obligate themselves, or their heirs, representatives or assigns, to support or maintain the said...... feet by timbers or otherwise, but only not to mine or excavate within...... feet of the present surface.

And the said parties of the first part, for themselves, their heirs, personal representatives, and assigns, covenant and agree that they will not mine or excavate under the surface of that portion of the said lode claim which is hereinbefore described, and hereby conveyed nearer to the surface thereof than..........feet, but will so conduct their mining operations as not to injure the surface rights hereby conveyed and so as to at all times abundantly protect said surface with a depth of........... feet thereunder.

\section{DEED OF TRUSTEES FOR CORPORATION (Charter forfeited).}

Form No. 15.

This Indenture, made this..... day of........, A. D. 19. , between.......... and ........... as trustees for.......... Company and its stockholders, all of.......... the parties of the first part, and...................... in the State of .........., the part... of the second part.

Witnesseth :

Whereas, ............ Company, a corporation heretofore duly organized and existing under and by virtue of the laws of the State of..........., and having its principal place of business at.........., in the County of.......... and State of........, was, at the time of the forfeiture of its charter hereinafter particularly mentioned and prior thereto and at all such times had and now has the record title to 
all and singular those certain mining claims, ground and premises situate, lying and being in the......... Mining District, County of ........, State of....... known as.......... and hereinafter more particularly described; and

Whereas, at the time of such forfeiture, and prior thereto, and in accordance with and as required by its articles of incorporation the corporate powers, business and property of said corporation were conducted, exercised and controlled by a board of.......... directors and

Whereas, said corporation continued to be a valid corporation under and by virtue of the laws of the State of ..........., until, on or about the....... day of........., 19.., on which last named day the charter of said corporation became and was forfeited by reason of the failure and neglect of said corporation to pay to the Secretary of State of the State of........... the license tax for the year. as provided to be paid by corporations under the provisions of a certain act of the legislature of the said State of........., entitled "An Act, etc......... Approved.........., 19..." and

Whereas, said corporation has not been relieved from said forfeiture nor been rehabilitated under the provisions of said act and since the day lastly hereinbefore aforesaid the said corporation has had and now has no power nor right to do business; and

Whereas, prior to the time of said forfeiture and on, to wit; the...... day of .......... 19.., $\ldots \ldots \ldots \ldots$ and.............. duly elected as the directors of said corporation and thereafter acted as such. That while acting as such directors and prior to said forfeiture the said......... died on the...... day of ........., 19... That no person was ever elected to fill the vacancy caused 
thereby and at the time of said forfeiture of said charter the said parties of the first part. were the only directors of said corporation in office and since said time have been and now are the sole and only directors of said corporation and by reason of said forfeiture of the said charter of said corporation have become and now are the trustees for the said............ Company and its stockholders; which said corporation had a capital stock of....... ........dollars; divided into...........shares.

Now, therefore, the said parties of the first part, as truistees for said.......... Company and its stockholders, in consideration of the sum of........... dollars, to them in hand paid, hereby remise, release and quitclaim to the said part... of the second part, .......heirs and assigns forever, all of the rights, title and interest which the said parties of the first part, as such trustees for the said corporation, said Company and its stockholders, now hold or have a right to convey, to all and singular all of the said mining claims so owned, claimed or held by the said .............. Company . (Description.)

The said parties of the first part so make this conveyance upon the express terms and conditions that thereby the said parties of the first part personally assume no liability or responsibility to the said part... of the second part, or.......heirs or assigns, but in this instrument are acting solely as trustees for the said corporation, said.......... Company and its stockholders, under the provisions of said act hereinbefore particularly mentioned.

In witness whereof, we have hereunto set our hands and seals the day and year first above written.
(Seal) As Trustees for
(Seal)
. Company
(Seal) and its Stockholders. 


\section{IRA'TIFICATION OF DEED BY STOCKHOLDERS.*}

Form No. 16.

Know all men by these Presents :

That we, ............., stockholders of the Mining Company, a corporation heretofore duly organized and existing under the laws of the State of.........., the charter of which corporation was and it still is forfeited by reason of its failure to pay to the Secretary of State of the State of..........., the license tax provided to be paid by corporations and which said corporation had a capital stock of ............dollars, divided into .......... shares of the par value of.......... dollars each, (of which........ shares were unissued), and severally the owners and holders of record on the books of said corporation of the number of shares of the said capital stock of said corporation set opposite our respective signatures hereto, and together owning and holding more than two thirds of the entire issued and outstanding capital stock of said corporation at the time of said forfeiture, being fully advised in the premises, hereby agree, consent to, approve of, ratify and confirm the foregoing deed of conveyance.

In witness whereof, we have hereunto set our hands this, the...... day of........., 19 .

NAME OF STOCKHOLDER. NUMBER OF SHARES.

* See $\S 223-10$, ante.

\section{CERTIFICATE OF SECRETARY.}

Form No. 17.

I, .......... do hereby certify that I was the duly appointed and acting Secretary of the.......... Mining Company, the corporation in the foregoing deed of conveyance named, prior to and at the time of the forfeiture of its charter as aforesaid, under the laws of the State of.......... 
That the capital stock of said corporation was .dollars, divided into.........shares, of the par value of..........dollars each.

That no more than......... shares of said capital stock of said corporation had been issued at the time of the forfeiture of the charter of said corporation, as in the deed of conveyance hereto attached, specifically mentioned, and said........... shares were the entire capital stock of said corporation then outstanding.

That the persons signing the above and foregoing ratification were, at the time of said forfeiture and also at the time their respective signatures were affixed to such ratification, stockholders in said corporation holding of record at least two-thirds of the said entire issued and outstanding capital stock of said corporation, and, severally were, at such times, the owners and holders of record of the number of shares set opposite their respective names.

Witness my hand and the corporate seal of the said former corporation, by me hereto affixed, this, the $\ldots \ldots$. day of ........., 19...

\section{NOTICE OF FORFEITURE.}

\section{Form No. 18.}

(Precedent in Elder v. Horseshoe Co., 194 U. S. 248 ; s. c. 9 S. Dak. 636.)

To.......... his heirs, administrators, and to all whom it may concern:

Take notice that I have done...........dollars' worth of labor, each year in order to hold the........ .......mining claim, situated in........... Mining District, County of........., State of........, the notice of location whereof is recorded in the office of the Recorder of............ in Book........ at page...... of Locations of the records of said County of......... for the years ending December 31st, 
19..., and December 31st, 19.., and December 31st, $19 . .$, and unless within ninety days after this notice by publication you fail or refuse to contribute your proportion of such expenditure, viz. \$......., being $\$ \ldots . .$. for each of said years, your interests in said ..........mining claim will be forfeited to and become the property of the subseriber under Section 2324 of the Revised Statutes of the United States.

\section{AFFIDAVIT OF PERSONAL SERVICE.}

(In California in case of personal service of the above notice an affidavit in substantially the following form, attached to a true copy of such notice, must be filed with the proper County Recorder within ninety days after the giving of said notice. C. C., § 1426o.)

State of California, County of.......... ss.

.......... being duly sworn, deposes and says; That he is the person giving the notice, a true copy whereof is hereto attached, marked Exhibit "A," and made a part hereof.

That on the....... day of .........., 19.., ........... personally served the said notice upon ............ the person (co-owner) therein named, by delivering to and leaving said notice with said ........... personally, at.......... in the County of..........., State of California.

\section{AFFIDAVIT OF PUBLICATION.}

When, in California, the service is by publication a printed copy of the notice attached to an affidavit of the printer or the foreman or principal clerk of the newspaper publishing the same must be recorded as aforesaid within 180 days after the first publication thereof. 
This affidavit may be in the usual form furnished by newspapers publishing legal notices. It is essential, however, that the name of the newspaper, place, and first and last days of publication be stated therein. C. C., $\S 14260$.

\section{LEGAL PROCEEDINGS.}

\section{ANSWER-ADVERSE CLAIM.}

Form No. 19.

\section{(Title of court and cause.)}

Comes now the defendant in the above entitled action and answering the complaint of the plaintiff herein, says :

1. Defendant avers that he declared his intention to become a citizen of the United States of America on the .... day of ......., 19.., in the........ Court of the State of........., in and for the County of.............

2. (Deny the allegations of the complaint as the facts may warrant.)

\section{II.}

For a further and separate answer and defense herein defendant says

1. (Repeat paragraph 1, ante.)

2. Defendant avers that he and his predecessors in interest and grantors under and by virtue of a location made by .................. of the premises hereinafter and in the next succeeding paragraph hereof fully described, have claimed, and defendant does still claim adversely to plaintiff an estate and interest in said portion of said pretended........... mining claim said portion being the alleged overlap of the said.........mining claim upon the said alleged ........mining claim. 
3. Defendant denies that his said title, right and estate were acquired by him subsequent to said alleged acquisition of the plaintiff and avers that his right, title and estate and right of possession of, in and to all of the premises hereinafter in this paragraph described and set forth and every part thereof, is of right and that he has the exclusive right, title and interest and right of possession of the same, and every part thereof, as against the plaintiff and all others; and that such right and estate were acquired by the predecessors in interest and grantors of this defendant prior to the alleged acquisition of the said plaintiff's pretended right or estate in said alleged........ mining claim. And defendant avers that plaintiff has no right, title, interest in or right of possession therein or thereto, or any part thereof. That by virtue of a location made by .............. ............ each and both of them citizens of the United States on, to wit; the..... day of......... 19 .., as appears by reference to the notice of location thereof, which is in the words and figures following

(Here insert)

and by reason of mesne conveyances in writing from said..................... and their successors in interest and grantees, and by a compliance, by defendant, and his predecessors in interest and grantors with the mining acts of Congress, the laws of the State of.......... and the rules, regulations and customs of the miners of the said...........Mining District, wherein the said premises are situated, defendant is the owner of and entitled to the possession of said..........mining claim, and of the whole thereof.

\section{III.}

For a further and separate answer and defense herein defendant says 
1. (Repeat paragraph 1, ante.)

2. (Allege as in Complaint, Form No. 22, paragraphs 2 to 4 , inclusive.)

Wherefore, defendant demands judgment that he is entitled to the possession of the said mining ground in dispute and for his costs herein expended.

\section{ANSWER (Negligence).}

Form No. 20.

(Title of court and cause.)

(After making proper denials and admissions proceed as follows:)

And for affirmative answer defendant herein alleges :

1. The defendant herein here repeats and alleges all the matters and things set forth in the subdivisions of its answer and numbered........., and expressly makes said subdivisions, and each of them, a part of this its further and separate answer and affirmative defense the same as if incorporated herein, and prays that the said subdivisions, and each of them, be taken and deemed a part of this separate answer and defense the same as though herein set out at length.

2. That on the...... day of........., 19.., and at all times mentioned in the said complaint, the said mine and the............were in as safe and proper conditions as it is possible under the most skillful supervision of the most skillful miners to keep them and each of them. That the most approved method and manner of.......... has been adopted and was in use in said mine on said...... day of .......... 19... That the defendant has exercised and did exercise great care in supplying and did supply, its employees at said mine with suitable appliances and safe materials to.......... in a safe and proper conditions so as to avoid all possible 
danger to its employees, and all persons working in or about said...........

3. That the plaintiff was accustomed to working in mines of a similar character to that of defendant and was perfectly competent to judge of the safety of the said mine, and the safety of............ wherein he was working, and the manner and method of .......... That the risk of working therein was assumed by the plaintiff as a part of his employment in said mine with a full knowledge of the condition and safety thereof and of the manner and method of................ day of.........., 19...

4. That the persons whose immediate duty it was, and upon whom the responsibility rested to........ in a safe and proper condition at the time of the plaintiff's alleged injuries, were all fellow servants of the plaintiff at the time of the said alleged accident and injury to plaintiff, and at all times prior thereto, during which the plaintiff was employed in working in the said...........

5. That said alleged hurt or injuries were and are the result of the negligence of fellow servants of the plaintiff in............ and not the result of any fault, negligence, neglect, intent or act on the part of defendant.

\section{ANSWER-UNDERGROUND TRESPASS.}

Form No. 21.

\section{(Title of court and cause.)}

Comes now............, the defendant in the above entitled action and answering the complaint of the plaintiff herein, says :

1. That as to whether or not the plaintiff is now, or ever was at any time. the owner of, or entitled to the possession of that certain lode mining claim known 
as or called the...........lode, situated in the . Mining District, County of..........., State of........, described as in the.......paragraph in the plaintiff's complaint set forth, this defendant has not sufficient information upon which to base a belief and placing his denial upon that ground, defendant denies the same.

2. Defendant denies that any vein, lode or ledge of quartz rock in place, bearing............ or other precious metal, is found in the said.......... lode mining claim that in its longitudinal course or strike passes into the said pretended........... lode mining claim through the..........end line thereof and extends through the said mining claim in a..... direction and lengthwise of said mining claim and passes out of said mining claim through the..........end line thereof, or that the top or apex of said vein, or any vein, lode or ledge lies throughout the entire length of the said mining claim inside the surface thereof extended downward vertically; that said vein, lode or ledge in its downward course departs from the perpendicular at an angle of about...... degrees from the horizontal, or at an angle from the horizontal in a......... direction, or any direction, or that the general course or strike of said vein, lode or ledge, or any vein, lode or ledge lying within the said pretended..........lode mining claim is nearly or quite co-incident with the surface side lines of the said pretended lode mining claim, or that by reason thereof, or for any reason. the plaintiff is now, or at any time mentioned in the complaint, the owner of, or entitled to the exclusive possession of any vein, lode or ledge, or so much thereof as the top or apex thereof lies inside of the said surface boundaries of the said pretended....... ......lode mining claim throughout its entire depth, or that the plaintiff has at all times, or at any time, 
been in possession of said pretended.......... lode mining claim, or said vein, lode or ledge, as in the ........paragraph of said eomplaint mentioned, or at all.

3. Denies that the plaintiff has any lode or vein or ledge of mineral-bearing rock in place extending throughout the said pretended........... lode mining claim, or that any vein or lode or ledge or mineralbearing rock having its apex within the said........ lode mining claim has any dip in a......... direction outside the surface lines of the said pretended lode mining claim.

4. Denies that any vein, lode or ledge or mineralbearing rock in place having its top or apex within the surface lines of the plaintiff's pretended.

lode mining claim in its course downward between vertical planes drawn downward through the end lines of said pretended..........lode mining claim continued in their own direction in its departure from its perpendicular extends to a great depth, to wit: to a point far outside......... of or.......... or at all, or below, or beyond the workings of the defendant, or any workings of the defendant continued in its downward course between said planes to an unknown distance, or to any distance.

5. Defendant denies that on or about the....... day of ........, 19.., or at any other time he wrongfully or unlawfully entered into or upon that part or portion of any vein, lode or ledge having its top or apex within the lines of the said pretended ..........lode mining claim which in its course downward extends outside of and to the........ of the vertical............side lines of said pretended .lode mining claim so continued in their own direction that the same will intersect such exterior portions of said vein, lode or ledge having its top or apex within such surface lines of said pre- 
tended...........lode mining claim, or that he ousted or ejected the plaintiff therefrom or from any vein, lode or ledge, or that he wrongfully took, or carried away therefrom, or converted to his own use large or valuable quantities, or any quantity of ore in said vein, lode or ledge constituting the property of the plaintiff of the value of........ dollars, or of any value, or that he has, at all times since, or at any time or since, wrongfully withheld or that he does now wrongfully withhold from the plaintiff the possession of the said vein, lode or ledge so lying to the........ of the ........ side line of the said pretended....... lode mining claim between the planes drawn down through the end lines of said claim as aforesaid, or that he wrongfully withholds from the plaintiff the possession of any vein, lode or ledge, or bodies of ore, or any property of any kind or character to damage plaintiff in the sum of..........dollars, or to the damage of plaintiff in any sum whatever.

6. Defendant alleges the truth to be that all the ores, mineral and rock that have been extracted and carried away from the point in controversy by him are and were a part of a vein, lode or ledge having its top or apex within the surface lines of the....... lode mining claim, the property of this defendant, which said vein, lode or ledge and ores belonged to and were and are the property of this defendant by virtue of the same being a part of the......... lode mining claim, located on the..... day of........., 19.., by the grantors and predecessors in interest of this defendant, which said..........lode mining claim is now the property of this defendant, together with all ores, ledges, lodes and veins having their apex or top within the surface lines of the said........... lode mining claim.

7. Defendant denies that any of the ores, metals, minerals, rock, or earth which he has mined or re- 
moved from within the surface side lines of the said lode mining claim extended downward vertically were a part of or belonged to any vein, lode or ledge having its top or apex within the surface side lines of the said pretended...........lode mining claim, the property of the plaintiff.

8. Defendant denies that he has ever removed, extracted, mined or carried away any ores, metals, mineral rock, or earth from any vein, lode or ledge other than a vein, lode or ledge having its top or apex within the surface of the said...........lode mining claim, the property of this defendant.

Wherefore, defendant prays that this action may be dismissed and that defendant may go hence without day and that he have and recover his costs and disbursements herein.

\section{COMPLAINT-ADVERSE CLAIM.}

Form No. 22.

\section{(Title of court and cause.)}

Comes now the plaintiff in the above entitled action and complains of the defendant, and for cause of action, alleges :

1. That the plaintiff is a citizen of the United States of America.

2. That on or about the...... day of........... $19 . \ldots \ldots \ldots \ldots \ldots$, being citizens of the United States, entered upon and discovered that certain mining ground, and mining claim since then known and designated as the.............mining claim, situated in the...........Mining District, County of............, State of.........., and then and there took possession of and located the same, after discovering therein a vein, lode or ledge of mineral bearing ore in place bearing........ by building large stone monuments at each of the corners of 
said mining claim and similar monuments at or near the center of each end line thereof and by placing in one of said monuments, to wit: the.........monument, a notice of location of said mining claim and designating the same as the location monument; all of said monuments being built in conspicuous places, and so placed upon the ground that the boundaries of said claim were distinctly marked on the ground and that the boundaries thereof could be readily traced. That at the time of making the said location said ground was a part of the public domain, unoccupied, vacant, and unclaimed. That the said claim so located by the above named persons was described in said notice of location as follows.

\section{(Description.)}

That said notice contained the names of the locators, to wit.................the date of location, the name of the claim, and such a description of the claim located with reference to a natural object and permanent monument as to identify the said claim. That thereafter, on the.......... day of 19 .., the said locators caused a record of said location notice to be made in the office of the County Recorder of said County of..........., and that thereafter, the said locators caused a record of said location notice to be made in the office of the Mining Recorder of said........... Mining District.

3. That after the said location of said.......... mining claim all of the said locators of said......... mining claim did, by divers conveyances grant, bargain and sell, convey and confirm all right, title and interest they had in and to said claim to divers other person or persons who, thereafter, conveyed the said mining claim to the plaintiff, who, ever since has been and now is the owner of the said..........mining claim. 
4. That the plaintiff and his said grantors have performed more than one hundred (100) dollars worth of work on said claim each year since........ and performed work thereon of the value of......... dollars.

5. That subsequent to the said location of the said mining claim and prior to the bringing of this suit, the defendant entered upon and took possession of a portion of said.........mining claim, ealling the portion so taken possession of, with other ground, the .mining: claim, and ousted and ejected the plaintiff from said portion, and ever since then defendant has claimed, and does still claim adversely to this plaintiff an estate and interest in said portion of said mining claim, the said portion being the overlap of the said..........mining claim consisting of about.........acres, and particularly described as follows

\section{(Description.)}

as appears by reference to a diagram of said claims hereto annexed, marked Exhibit $\mathrm{A}$ and hereby made a part of this complaint.

6. That on or about the....... day of......... $19 .$. , the defendant made an application to the Government of the United States for a patent for the said...........mining claim, including the said portion of the said..........mining claim overlapped. That thereafter, and on or about the...... day of........., 19.., and within the sixty days period of newspaper publication of the notice of such application the plaintiff herein filed his adverse claim against the issuance of the patent to the said defendant with the Register of the United States Land Office at......., that being the I and Office District in which said.......mining claim is situated; said adverse showing the nature, boundaries and extent of 
such adverse claim; and the plaintiff brings this action for the purpose of determining such adverse claim and the right of possession to the said overlap hereinbefore and in paragraph 5 hereof particularly described.

Wherefore plaintiff demands judgment that he is entitled to the possession of the said mining ground in dispute and for his costs herein expended.

\section{COMPLAIN'T (B11)-ADVERSE CLAIM. (U. S. Court.)}

\section{Form No. 22a}

(Title of court and cause.)

Bill in suit to quiet title.

To the Honorable the Judges of the Circuit Court of the United States in and for the......... Circuit, . District of ........, sitting in equity.

.............. complainant, brings this, his bill, against the respondent........... Company, a corporation, and thereupon your orator complains and says :

I. Your orator showeth unto your Honors and avers that he is a citizen of the United States of America, and was at all of the.times herein mentioned, continuously, and now is a citizen, resident and inhabitant of the County of.......... in the State of

II. That said respondent is a corporation organized and existing under and by virtue of the laws of the State of......... having its principal place of business at......., County of......... State of........., and engaged in the business of mining. in the.........Mining District, County of........ State of........, and that said respondent is, and at all the times herein mentioned, and prior thereto, was a citizen of said State of......... 
III. That the amount in controversy herein exceeds the sum or value of two thousand $(2,000)$ dollars, exclusive of interest and costs.*

3. That on and prior to the....... day of..... $19 . .$, the property hereinafter described and known as Section......... in Township........ Range..............., in the.........Mining District, County of.........., State of........., was a part of the vacant and unappropriated public land of the United States, free and open to exploration and purchase by the citizens thereof, for the valuable mineral deposits therein contained.

4. That on said date, to-wit: the.......day of $19 \ldots, \ldots \ldots \ldots$.............. being citizens of the United States, entered upon said ground, hereinafter particularly described, and known as the...........Placer Mining Claim, and segregated the same from the public domain, by posting a notice of location thereon and by distinctly marking the boundaries thereof upon the ground, so that the same could be readily traced; and did immediately thereafter, to-wit: on or about the....... day of......, 19.., make a discovery of. and.......... and other valuable minerals and valuable mineral deposits within the exterior boundaries of said..........Placer Mining Claim, and did, thereafter, to-wit: on the....... day of......... 19. ., cause to be recorded in the office of the County Recorder of said County of........., which was and is the County within which said placer mining claim was and is situate, a true copy of said notice of location of said placer mining claim, giving the names of said locators, said.......... and his said associates, as the locators thereof, the date of said location, the name of the claim, and such a description of such placer mining claim hereinbefore re-

* See \$17, ante. 
ferred to, and hereinafter particularly described, with reference to natural objects and permanent monuments so that the same could be readily identified. Said property so located as aforesaid, being described as follows, to-wit: 'The......... quarter of Section.......... in Township......... of Range................., containing one hundred and sixty acres of land.

5. Your orator further showeth unto your Honors and avers that said locators, said......... and his said associates, ever since the said date of the location of said placer mining claim, and now are, the owners of said placer mining claim and location, premises and property, and the whole thereof, as to all persons, save and except the United States of America; in the possession and entitled to the possession of every part of the same. That said......... and his said associates have complied with every rule, regulation and custom, in force in said.........Mining District, and with the provisions of the mining laws of the State of........ and the Acts of Congress in that behalf enacted; and the respondent herein has no right, title or estate whatsoever in or to said placer mining claim or location, or in or to any part, portion or parcel thereof.

6. Your orator further showeth unto your Honors and avers that respondent herein asserts that it is, and pretends to be the owner of all of said Section in Township........ of Range........., M. hereinbefore described, under and by virtue of placer mining locations pretendedly made by it, or those under whom it claims, prior to the title of your orator, or his said co-tenants, but which said pretended placer mining locations, and each thereof, so claimed by the respondent herein, or those under whom it claims, were pretendedly made by respondent at the time when the said Section........ and the whole thereof, had passed into private owner- 
ship, and the same, and no part thereof, was vacant or unappropriated public land, or free or open to exploration, or location, or purchase, as a part of the public domain, under the mining law of the United States, or otherwise.

7. That said assertion of title and pretension of ownership upon the part of the respondent herein, is wrongful and without right, and the alleged title of said respondent is fraudulent and void; the said respondent or those under whom it claims, never, at any time, having made or adopted a discovery of any valuable mineral within the boundaries of said Section hereinbefore described, and known as and called by it, the.......... Consolidated Placer Mining Claim, or within the boundaries of any part or portion, or parcel of ground claimed by it, within said Section, by whatsoever name by it called.

8. That the respondent herein, or those under whom it claims, did not, prior to the said location of said.......... and his said associates, as hereinbefore aforesaid, or at any other time, mark the boundaries of said or any placer location, therein alleged to be embraced and included in and constituting a part of its said alleged, and pretended......... Consolidated Placer Mining Claim, upon the ground, so that the same could be readily traced, nor traced at all.

9. Your orator further showeth unto your Honors and avers that the respondent herein, and those under whom it claims, in fraud of the rights of the citizens of the United States, and particularty in frand of the rights of your orator, and his said co-tenants, have caused to be recorded in the office of the said County Recorder, pretended notices of location, describing said Section........ in Township........ of Range........ M. therein and thereby covering, including and overlapping the said placer mining claim and location of your orator, and his said co- 
tenants, in said Section......... calling the alleged placer mining locations therein, the......... placer mining claim, pretendedly located upon and pretendedly including all of the northeast quarter of said Section......... ; the........ placer mining claim pretendedly located upon and pretendedly including all of the southeast quarter of said Section.........; the.........placer mining claim pretendedly located upon and pretendedly including all of the northwest quarter of said Section..........; the......... placer mining claim pretendedly located upon and pretendedly including all of the southwest quarter of said Section; each of said pretended locations pretendedly containing 160 acres of land, and said four alleged locations of land pretendedly constituting the said alleged...........Consolidated Placer Mining Claim.

10. That said notice of location, and each of them, is an assertion of rights claimed under and by virtue of fraudulent, void and fictitious mining locations falsely and fraudulently claimed to have been made by the respondent herein, or those under whom it claims, and which cast a cloud upon the title of your orator and of his said co-tenants.

11. That the claims of the respondent herein are all, and each of them is, inferior and subordinate to the title of your orator and his said co-tenants, which title, last aforesaid, arises by virtue of the valid location so made by said............ and his said associates, as hereinbefore set forth, and respondent's claims and titles cast a cloud upon the possession and title of your orator, and his said co-tenants, and prevent them from enjoying fully and peaceably the fruits of their said ownership.

12. Your orator further showeth unto your Honors and avers that the said alleged several placer mining claims, and locations, particularly mentioned in para- 
graph 9 hereof, and each of them, is and at all times has been, a fraudulent and void location against the Government of the United States and your orator and his said co-tenants and all other persons interested in the ground sought to be embraced therein or covered thereby. That at the time of the alleged location of each thereof, and at all times subsequently, there were not eight, nor any bona fide individual claimants as locators thereof, among the eight alleged locators of each of said alleged placer locations, and that 160 acres of mineral land were so illegally and fraudulently included within each of said alleged placer mining claims or locations, to-wit : said........ placer mining claim, said........... placer mining claim, said.......... placer mining claim and said - placer mining claim, by the respondent herein, or those under whom it claims, for the purpose of thereby surreptitiously acquiring and appropriating to their own use more mineral land in one location than they were entitled to under the mining law of the United States. That the names of....... and........., named and used as locators of said alleged placer mining claims and locations mentioned in paragraph 9 hereof, by said............ and , were each and all dummies and sham locators and none of said six persons, whose names were so used ever had or was intended by said...... ...... and........ to have any estate, right, title or interest whatsoever in said alleged placer mining claims or locations, or of, in, or to any one of them, nor were they, nor any of them, ever informed, or had any knowledge of the existence of said, or of any one of said pretended placer locations at the time of the said pretended location thereof, and said and.......... did wrongfully and unlawfully conspire with each other at and prior to the date of the alleged location of each of said alleged 
and pretended placer claims and locations, to wrongfully and fraudulently make and claim the said several alleged and pretended placer mining claims or locations and each of them, in the manner and way aforesaid, and said................ by the use of said six sham and dummy locators and did attempt to make said pretended locations, and each of them, in pursuance of such conspiracy, and said respondent has, and now claims, the said 160 acres of mineral land in each of said several placer mining claims and locations in controversy herein and called by respondent herein the........... Consolidated Placer Mining Claim, under and by virtue of the said. false, fraudulent and illegal pretended several locations mentioned and described in paragraph 9 hereof.

13. Your orator further showeth unto your Honors and avers that the respondent herein in pursuance of such conspiracy and to fully consummate the same, and wrongfully claiming to be the owner of said alleged and pretended placer mining claims, did heretofore, to-wit: on or about the..... day of.......... $19 .$. , file or cause to be filed in the United States Land Office at......... in the State of........, its application for a patent from the Government of the United States of America, for said alleged and pretended........... Consolidated Placer Mining Claim, and for the whole thereof, and therein described as embracing all of said Section......... in Township........ of Range................., containing about 640 acres of land.

14. That in and by said application for patent, respondent herein wrongfully, falsely and fraudulently set up, alleged and claimed that it, said respondent, was and is the owner and in possession and entitled to the possession of the whole of the said alleged......... Consolidated Placer Mining Claim, embracing all of said Section......... and the said 
placer mining claim and location of your orator and his said co-tenants.

15. That the said respondent has at all times since maintained and prosecuted and now does maintain and prosecute its said false, fraudulent and wrongful application for said patent, and thereby the title of your orator, and his said co-tenants, in, and to said placer mining claim and location hereinbefore mentioned, as duly located by said........... and his said associates, is impeached, clouded and encumbered and the value of the estate and property of your orator and his co-tenants therein are greatly depreciated to the great and irreparable damage of your orator and his said co-tenants.

16. Your orator further showeth unto your Honors and avers that heretofore, to-wit: on the...... day of

19. , and within the 60 days' period of newspaper publication of the said respondent's notice of application for patent, your orator filed his adverse claim against the issuance of such patent to the said respondent for its said alleged and pretended....... Consolidated Placer Mining Claim, as so applied for, with the Register of the United States Land Office aforesaid, that being the Land Office District in which the said alleged and pretended...........Consolidated Placer Mining Claim is situated, said adverse claim showing the nature, boundaries and extent of said adverse claim; and your orator brings this his suit within 30 days after the filing thereof, for the purpose of determining said adverse claim and the right of possession to the said placer mining claim so located as aforesaid by said.......... and his said associates.

In Consideration Whereof, and for as much as your orator is remediless in the premises, at and by the strict rules of the common law, and is only reliev- 
able in a court of equity, where matters of this kind are properly recognizable and relievable;

To the end therefore, that the said respondent, be compelled to answer all and singular the premises in this bill, (but not under oath, answer under oath being hereby expressly waived) and that it may be decreed that said respondent, .......... has no estate, interest, possession or right of possession in or to said alleged........... Consolidated Placer Mining Claim in said.......... quarter of said Section........ in Township........ of Range M. and the said placer mining claim and location hereinbefore and in paragraph 4 hereof, particularly described, as the property and estate of your orator and his said co-tenants and the said mineral substances in said......... quarter of said section...........contained, or either, or any of them; and that your orator be deemed to be the owner, subordinate to the rights of his co-tenants, and subject to the paramount title of the United States of America and lawfully in and entitled to the possession of the placer mining claim and location in said paragraph 4 particularly mentioned and described, and of each and every the mineral deposits and mineral substances therein contained, and that your orator's title thereto and to each and all thereof and to the possession thereof be quieted and confirmed as against said respondent and all persons claiming by, through or under it; and that said respondent has not, and never has had, any estate, possession, right of possession, title or interest whatsoever of, in or to said ....... quarter of said Section........ in Township....... of Range............... or any part or portion thereof, and that said respondent be. forever barred from asserting or claiming any estate, right, interest or right of possession therein, or to any part or parcel thereof, or to any mining claim or loca- 
tion therein; and that your orator may have such other and further relief as the nature of his case may require and as to your Honors shall seem meet;

May it please your Honors to grant unto your orator the most gracious writ of subpœna of the United States of America, directed to the said respondent, said........., thereby commanding it to personally appear before this Honorable Court, and then and there upon a day to be named therein under a certain penalty to be limited to make answer to the premises, and to further abide by and perform such order, direction and decree therein, agreeably to equity and good conscience.

And your orator will ever pray, etc.

\section{COMPLAIN'T IN FJEC'TMENT. (U. S. Court.)}

Form No. 23.

(Precedent in Glacier v. Willis, 130 U. S. 471.)

\section{(Title of court and cause.)}

The plaintiff complains and alleges that it is a corporation organized and existing under the laws of the State of.........., and is a citizen of the State of .........., that the defendants are, and each of them is a citizen of the State of........, and a resident of........... in the County of......... and State last aforesaid and that the property in controversy exceeds the value of two thousand dollars.*

The plaintiff further alleges that on the......... day of ........., 19.., one......... and one ............., each being a citizen of the United States, went upon the public domain of the United States, theretofore wholly unoccupied and unclaimed, and located on said day a tunnel and tunnel-site at

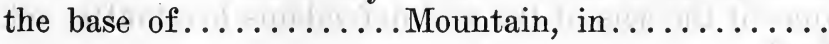


Mining District, County of..........., State of

That afterwards, and on the same day, they marked the boundaries of their said location and commenced to run a tunnel into said........ Mountain, and, after complying with the laws of the United States and the laws of the State of........., and the local rules and regulations of said...........Mining District, they caused to be made out and recorded in the Recorder's office of the County of........... aforesaid, a location certificate of said tunnel claim, which said certificate described the location and boundaries of said tunnel claim.

That from the day of said location until the ouster hereinafter set forth the said locators of said tunnel claim, and their grantees remained continuously in possession of the said tunnel claim, and have expended thereon more than the sum of.......... dollars.

That plaintiff is the owner of said tunnel claim above described by location and purchase, and is now entitled to the quiet and peaceable and exclusive possession thereof by virtue of a full compliance on its part, and on the part of its grantors, with the laws, rules and customs above set forth.

That the plaintiff, and its grantors have been in the peaceable and undisputed possession of said tunnel claim by virtue of said location, occupation, preemption and record for more than...........years prior to the ouster hereinafter complained of.

That plaintiff and its grantors, for more than .consecutive years prior to the acts of the defendants, hereinafter mentioned, paid all the taxes, legally or otherwise assessed upon said tunnel claim, and have worked and mined the same from said day of ........., 19., up to the time of the acts of the said defendants hereinafter set forth. 
That said tunnel claim, so located, embraces....... valuable lodes or veins which have been discovered, worked and mined by the plaintiff and its grantors.

That the said tunnel claim was, by its locators, named the..........tunnel claim, and is described more fully as follows,

\section{(Description.)}

Plaintiff further alleges that while it was in the quiet and peaceable possession of said tunnel claim, and every part thereof, the defendants wrongfully, and without right, and without consent of the plaintiff, to wit: on or about the..... day of.......... $19 .$. , entered upon the premises, and into said tunnel, so run by plaintiff, and its grantors on said claim, and wrongfully and unlawfully ousted the plaintiff therefrom; claiming said tunnel as the........ (claim).

That on or about said last mentioned date the defendants, without right, made a pretended location of a lode claim across said tunnel and within said tunnel claim, and therein wrongfully ousted the plaintiff therefrom, claiming that they had discovered a lode, which they called the........... lode.

That the defendants ever since hitherto unlawfully and wrongfully withheld the possession of the said premises and tunnel claim from the plaintiff to its damage in the sum of ..........dollars.

Wherefore, plaintiff demands judgment against the defendants

1. For the recovery of the possession of said .........tunnel, tunnel-site and claim.

2. For the sum of..........dollars, damages for the wrongful withholding thereof.

3. For costs of suit. 
COMPLAINT-UNDERGROUND TRESPASS.

(At Law.)

Form No. 24.

(Title of court and cause.)

The plaintiff in the above-entitled action complains of the defendant, and for a cause of action alleges:-

1. That the plaintiff is now and at all times since the year.........has been a corporation organized and existing under and by virtue of the laws of the State of .......... having its principal place of business at........., in the State of........, and engaged in the business of mining at.......... Mining District, in the County of.........., in the State last aforesaid.

2. That the plaintiff now is and during all the time for more than........years, last past, has been the owner of and entitled to the possession of that certain lode mining claim known as and called....... mining claim, situated in the...........Mining District, in the County of........, State of........., and more particularly described as follows,

(Description.)

3. Plaintiff further alleges that a vein, lode or ledge of quartz rock in place, bearing.......... and .......... is found in said.......... lode mining claim, so owned by the plaintiff. That the same, in its longitudinal course or strike passes into the said .......... lode mining elaim through the........ end line thereof and extends (through) the said mining claim in a.......... direction, and lengthwise of said mining claim (and passes out of said mining claim through the...........end line thereof) and that the top or apex of said vein, lode or ledge lies (throughout the entire length) of said mining claim inside the surface lines thereof, as aforesaid, extended downward vertically. That said vein, lode or ledge, in its downward course departs from a perpendicular 
at an angle of about......... degrees from the horizontal, said departure from a perpendicular being in a......... direction; and that the general strike or course of said vein, lode or ledge is nearly, or quite, coincident with the surface side lines of the said mining claim; and that by reason of the foregoing the plaintiff is now, and at all times hereinafter mentioned, has been the owner of, and entitled to the exclusive possession of the said vein, lode or ledge, and so much of the said vein, lode or ledge as the top or apex whereof lies inside of said surface boundaries as aforesaid, throughout its entire depth; and that the plaintiff has, at all times, been in possession of said mining claim and said vein, lode or ledge, as above described, save and except as it has been ousted and ejected by the defendant, as hereinafter alleged.

4. That the said vein, lode or ledge, so having its top or apex within the surface lines of plaintiff's said mining claim, as aforesaid, in its course downward between vertical planes drawn downward through the end lines of said mining claim continued in their own direction and in its departure from its perpendicular as aforesaid, extends to a great depth, to-wit: to a point far outside of and to the.......... of the said vertical side line of said mining claim and to a point far.......... of and below and beyond the workings of the defendant, hereinafter described, and continues, in its downward course and between said planes aforesaid to an unknown distance.

5. That heretofore, to-wit: on or about the....... day of..........., and while the plaintiff was the owner of, and lawfully possessed of, and entitled to the possession of said mining claim and of the said vein, lode or ledge therein and the ores therein contained, the defendant wrongfully and unlawfully entered into and upon that part and portion of said vein, lode or ledge, which in its downward course ex- 
tends outside of and to the.......... of the vertical side line of said mining claim and which lies between vertical planes drawn downward through the end lines of said mining claim, so continued in their own direction that the same will intersect said exterior portions of said vein, lode or ledge and being a part of the same vein, lode or ledge which has its top or apex within such surface lines of said mining claim, aforesaid, and ousted and ejected the plaintiff therefrom, and wrongfully took and carried away therefrom and converted to his own use large and valuable quantities of the ores in the said vein, lode or ledge contained, the property of the plaintiff, of the value of........... dollars, and has at all times since wrongfully withheld, and does now wrongfully withhold from the plaintiff the possession of the said vein, lode or ledge so lying to the......... of said........... side line of said..........mining claim and between the planes drawn through the end lines of said mining claim, as aforesaid, to the great damage of the plaintiff in the sum of...........dollars.

Wherefore, the plaintiff demands judgment against the defendant

1. For the recovery of the possession of said portion of said vein, lode or ledge so as aforesaid wrongfully withheld by the defendant.

2. For the sum of..........dollars, the value of the said ores taken from said vein, lode or ledge by the defendant, as aforesaid, and costs of suit.

COMPLAIN'T-UNDERGROUND TRESPASS.

(In equity.)

Form No. 25.

(Title of court and cause.)

Comes now the plaintiff in the above entitled action and complains of the defendant herein, and for a cause of action alleges: 
1. That the defendant, the said..........Mining Company, is, and was at all the times hereinafter mentioned, a corporation organized and existing under the laws of the State of.........., having its principal place of business at......... in said State and engaged in the business of mining at........... Mining District, in the County of.........., and State aforesaid.

2. That on the....... day of......., 19.., plaintiff was and ever since has been, and now is, the owner and possessed and entitled to the possession of that certain parcel of mining ground situate and being in the.........Mining District, in the County of........., and State of.........., consisting of those two certain contiguous and adjoining pieces of mining ground, the one known as.............. ing Claim and also known as............ Lode Claim and in the system of United States surveys for patents for mineral lands from the Government of the United States designated as Survey No......., and also so designated in a certificate of purchase therefor from the United States of America, which was issued on the $\ldots \ldots \ldots$. day of ........., 19.., to the plaintiff by the Receiver of the United States Land Office at .........., in the State of.........., and the other known as...........Mining Claim, and described as follows, to-wit:

\section{(Description.)}

together with all the veins, lodes, ledges, dips, deposits and bodies of ore, rock and earth bearing...... and....... and other precious metals.

3. That said mining claim and ground lastly hereinbefore mentioned adjoins said............Mining Claim or ground on the.......... and that said two lode claims have been worked by plaintiff since about 
.........., and form and constitute but one parcel of mining ground and one property.

4. That said mining ground contains valuable mineral deposits, lodes, ledges, dips, deposits and veins, rock and earth bearing................. and other precious metals; and the said mineral deposits, lodes, ledges, dips, deposits and veins constitute the sole value of said mining ground.

5. That plaintiff was at all the times hereinafter mentioned, and now is engaged in mining and developing the said mining ground, lands and premises, and extracting therefrom the said ores and minerals; and constructed at great expense, and has and had thereon mines, drifts, cuts, excavations and other works necessary for and adapted to the work of mining and developing the said mining ground.

6 . That heretofore, and on or about the........ day of .........., 19.., the said defendant, said .Mining Company, by itself and its agents, servants and employees, forcibly and wilfully, against the will and without the consent of the plaintiff entered into and upon the said mining ground hereinbefore described, and commenced to, and then and thereafter, for the purpose of mining the said ground and extracting the ores therefrom, cut, made and excavated certain drifts and openings into and under and upon the said mining ground, and invaded the drifts, excavations and mines made thereon by the plaintiff, and ever since last mentioned date has intruded and trespassed upon the said mining ground, drifts, excavations and mines of the plaintiff; and has dug up and extracted, taken out of and removed from said mining ground and converted to its own use large quantities of the mineral deposits, earth and ores bearing .............. and . other precious metals and the mineral deposits therein of the value of..........dollars, and upwards, and will thereby 
take from the said mining ground the entire value thereof, to the great and irreparable injury of the plaintiff.

8. That unless the said defendant, its agents, servants and employees are restrained and enjoined from intruding and trespassing upon the said mining ground, and making cuts, openings and excavations therein and digging up, extracting, removing and carrying away from said mining ground said mineral deposits, rock, ores and earth bearing.......... and ......... and other precious metals, the value and substance of said mining ground will be destroyed, and this plaintiff will suffer irreparable injury.

Wherefore, plaintiff prays that this Honorable Court grant to him a writ of injunction pendente lite issuing out of and in accordance with the rules and practice of this Honorable Court to be directed to the said defendant...........Mining Company, to restrain it, and its agents, servants, employees and confederates, from entering into or upon the mine, or mines, mining ground, lode, dips, drifts, cuts, excavations or works, or upon any part of the land, property and premises hereinbefore particularly described, and from working or mining thereon, or making or continuing any cut, opening or excavation on or in said mining ground, or upon or in any part thereof, or digging up, extracting, or removing from said mining ground, or any part thereof, any mineral, mineral deposit, ore, rock or earth, or any mineral substance whatever, whether the same be in place, or heretofore severed from the freehold, and from in any manner hindering or obstructing plaintiff, or his agents, servants or employees, or any, or either of them, in working or mining upon said premises, and from in any manner interfering with the said premises, or with anything thereon; as, also, a restraining order to the same effect until an application for such an injunction 
can be heard; and that at the final hearing such injunction may be made perpetual, and that an account be taken of the waste committed, and for such other and further relief as to this Court may seem just and meet.

\section{FINDINGS OF FAC'T AND CONCLUSIONS OF LAW.}

Form No. 26.

(Precedent in Harrington v. Chambers, 3 Utah, 94.) (Title of court and cause.) :

This cause came on regularly for trial on the..... day of........., 19.., before the above entitled court, sitting without a jury.

Esq., appeared as counsel for the plaintiff, and ............ Esqs., for the defendant.

And the court having heard proof of the facts alleged in the complaint and other pleadings on file herein, and the arguments of the respective counsel herein, and this action having been submitted to the court for its decision, the court now finds the following facts :

\section{Findings of fact.}

(1) That the locators of the..........mining claim, mentioned in the complaint, at the time of the location of said claim, viz., on the ......... day of $. . \ldots \ldots \ldots, 19 \ldots$, at the "discovery point" of said claim, discovered a mineral-bearing vein or lode and the claim was duly recorded on the......... day of $\ldots \ldots \ldots, 19 \ldots$

(2) That soon after said location, to wit, in the month of ............, 19.., the locators of said ......... mining claim marked on the ground the

Note.-For additional findings see Yarwood v. Johnson, 29 Wash. 643 ; also, Iron Co. v. Campbell, 135 U. S. 286. 
boundaries of said claim by setting stakes at the eorners thereof.

(3) That prior to the ........ day of......., $19 .$. , and within a year preceding that time, the owners of said claim performed labor and made improvements thereon of.......... dollars in value.

(4) That each year thereafter, up to.......... $19 .$. , work of the value of..........dollars, was done on said claim by the owners thereof.

(5) That during the year beginning on the..... day of ........, 19.., the owners of the....... claim were also the owners of two certain claims called respectively the...................., the adjoining the .......... and the adjoining the.........mining claim -and that with a view to the future working and development of all three of said claims, the owners thereof located what is called the "main shaft," in the surface ground; that such shaft is in such proximity to said..........mining claim that work in it has a tendency to develop said claim and said shaft was located. and intended for the purpose of developing all of said claims. That during said lastnamed year work was prosecuted in said shaft, and by improvements made thereat, exceeding in value...... dollars, and of not less than...........dollars in value.

No work was done in said year after......... in $19 .$. , and prior to the......... day of........ $19 .$. , in the surface ground, or within its limits, by the owners thereof.

The court also finds that the............mining claim, on application for patent, was entered and paid for at the United States Land Office at. City, ........., no protest having been made prior to ........., 19., but no patent for said claim has yet been issued. 
(6) That at the time this action was commenced the plaintiffs were in possession of said........... mining claim; that by the admission of the defendants, on the trial, the plaintiffs at the commencement of this action had the title to said mining claim by regular conveyances from the locators; that the.......... Mining Company was organized as a corporation on the ........ day of ........., 19.., and on or about the ....... day of ........., 19., received a conveyance from said plaintiffs of said mining claim, and possession thereof, and this action is prosecuted in the interests and for the benefit of said corporation.

(7) Before and at the commencement of this action the defendants claimed an interest in only a part of the premises embraced in said...........mining claim, and claimed said interest adverse to said plaintiffs; that said adverse consists of, and was based solely on, an alleged mineral location made in........, 19.., called the .......... mining claim, which embraced a part of said ........ mining claim, described in the complaint.

(8) On the $\ldots \ldots \ldots$ day of $\ldots \ldots \ldots \ldots, 19$. , and ............ entered upon the ground described in the pleadings as the........... mining claim, and marked the boundaries as set forth in the answer, and posted at the discovery point on a vein of mineral-bearing rock in place, by them opened and discovered, a notice of said claim, which notice described the said claim set forth in the answer, and afterwards, on the ........ day of .......... 19.., filed a copy of said notice as posted for record, in the office of the recorder of the..........mining district in the County of ............. State of which notice was recorded as follows:

(Here insert notice.) 
'That afterwards, and on or about the........ day of $\ldots \ldots \ldots \ldots, 19 \ldots$, the attention of the persoris who had recorded the said notice was called to the discrepancy between the record and the notice filed for record, said person having in the meantime ceased to be recorder of the district, and thereupon said person changed said record to correspond to the notice filed.

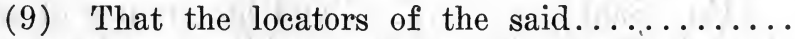
claim, and their grantees claiming under said location, have in each year since done work, and made improvements thereon of the value of more than ........... dollars, and have been in the continuous possession of said improvements.

(10) That the defendants, by conveyances from the locators and their immediate grantees, at the time of the commencement of this action, have acquired, and still have the record title to said claim, and own all the title and interest therein which could be acquired from said locators, and by subsequent compliance with mining laws and customs.

(11) The discovery point of the...........claim, and the point where the location point was posted is within the bounds of the..........mining claim.

(12) That on the ....... day of........., $19 . ., \ldots \ldots \ldots$. claiming the .......... mining claim was forfeited for want of work and improvements, located a mining claim called the........... embracing the premises in dispute in this action, and all that part of the ......... mining claim lying ............... of the end line of the ............ claim.

(13) Said .........., on said day, posted a written notice of location on a lode of rock bearing found within said claim, and at the discovery point. Said notice described the claim by reference to natural objects and permanent monu- 
ments, so it could be identified, and described it by metes and bounds, and said notice also contained the name of the locator and date of location.

(14) Said ......... on the ....... day of 19. , filed a copy of said notice of location in the office of the recorder of said.......... Mining District, for record, where the same was duly recorded.

(15) Said .........., and his grantee of said claim, have in each year since said location, done work and made improvements thereon of the value of more than .......... dollars.

(16) On the ......... day of $19 \ldots$, the said.$\ldots \ldots \ldots \ldots$ conveyed said .......... claim to the defendants, who have since owner the same.

As conclusions of law from the foregoing facts, the court now hereby finds and decides:

\section{Conclusions of law.}

(1) That the plaintiffs at the commencement of this action were the owners and in the possession of the mining claim called the ........... mining claim, which was then, and still is, a valid mining claim, embracing the premises described in the complaint; subject only to the paramount title of the United States; that the same is now owned and held by the .......... Mining Company by like valid title derived from the plaintiffs during the pendency of this action.

(2) That the defendants have no title or interest in said premises, and had none at the time this action was commenced.

(3) That said plaintiffs or their grantees are entitled to judgments or decree declaring and confirming their title to said .......... mining claim, and the premises embraced therein, and that the defend- 
ants have no right, title, or interest in said premises, or any part thereof, and also for costs of suit.

And judgment is hereby ordered to be entered accordingly.

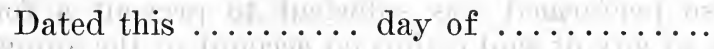

\section{INS'TRUC'TIONS. (Annual Expenditure.)}

Form No. 27.

(Precedent in Big 3 Co. v. Hamilton, 157 Cal. 130.)

You are instructed that the laws of the United States require one hundred dollars' worth of work or improvements annually to be performed or made on a mining claim. Such work or improvements so required by the laws of the United States may be done or made within the boundaries of such claim, or such work may be done outside the boundaries of such claim on one of a group of claims adjoining each other and owned by the same party, if done in pursuance of a system of development and if the same has a tendency to benefit or develop each claim in the group. Work done on one of a group of mining claims which has a tendency to develop or benefit all of the claims in the said group inures to the benefit of each and all of said claims, even though the system adopted may not be the best that could have been devised under the circumstances. Improvements made, such as the construction of roads, mills or mining machinery for the working and operation of an entire group owned by one party, and which said improvements tend to the benefit of all the claims in said group even though such improvements be made outside the lines of any of such claims. If you believe that in the year....... there was more than........ dollars worth of work done within the boundaries of $\ldots \ldots \ldots \ldots$ mining claim by the ......... in this case or any one acting under the.......... and with the.........consent, and that such work was 
done in pursuance of a system that tended to the development of all of the claims claimed by the....... herein in............complaint, and tended to the development and benefit of all such claims, then the work so performed was sufficient to prevent a forfeiture of any of said claims on account of the annual labor or improvement requirements of the year....... You are further instructed that even though the work done on said ................. claim in ...... was not of the value of ......... dollars, still if you believe from the evidence that improvements were made consisting of ................ and as great a value as ........ dollars, which taken in connection with such work as you find to have been done on the claim, under such conditions as those above stated, would equal or exceed the sum of dollars, and that such improvements were of such a character, and so constructed as to benefit and tend to the development of all of said claims and each of them, then the court instructs you that upon those facts existing there was no forfeiture of such claims or any of them, on account of the said annual labor or improvement requirements. It is not necessary that a party in doing the work on a claim or on a system for the benefit of all claims held by such party and contiguous to each other shall be the same specifically as annual labor or assessment work; but if such work is done in good faith, and is equal in amount to the work required to be done by the act of Congress then the same will be sufficient to prevent a forfeiture. 


\section{INS'TRUC'TIONS. (Marking Boundaries.)}

Form No. 28.

(Precedent in Willeford v. Bell (Cal.), 49 Pac. 6.)

The jury are instructed by the court that the mining claim of the .........., in order to be valid, must have been distinctly marked upon the ground, so that its boundaries could be readily traced, on or before the $\ldots \ldots \ldots$ day of $\ldots \ldots \ldots, 19 \ldots$ The law requires this marking of the claim upon the ground to be done in such manner that any person of reasonable intelligence may go upon the ground and readily trace the claim out, and readily find the boundaries and limits of the claim, without instructions, advice, or information from any one or thing other than the marking upon the ground; and it is not necessary nor required that such person shall have a copy of the notice of location or necessarily use it in the tracing the boundaries of the claim, but where such notice is posted upon the claim, and constitutes a part of the marking of the claim upon the ground, it may be used as a part of the means by which the boundaries of the claim can be traced.

And if you believe from the evidence that the $\ldots \ldots \ldots$. prior to the ....... day of........., 19 .., failed to so mark his claim upon the ground so that any person of reasonable intelligence could go upon the ground, either with or without a copy of the notice of location and readily trace the claim out, and find its boundaries and limits your verdict should be that the claim was not so marked on the ground that its boundaries could be readily traced.

(Precedent in Charlton v. Kelly, 156 Fed. 433.)

You are instructed that a claim may be marked upon the ground by stakes or other permanent mon- 
uments, but you are instructed that the law requires a claim to be so distinctly marked upon the ground that its boundaries can be readily traced. The requirements of the statute in this respect are not necessarily fulfilled by merely setting stakes at each of the corners of the claim, and at the center of the end lines, unless the topography of the ground and the surrounding conditions are such that a person accustomed to tracing lines of mining claims can, after reading a description of the claim in the posted or recorded notice of location or upon the stakes, by a reasonable and bona fide effort to do so, find all the stakes and thereby readily trace the boundaries; where the country is broken, or the view from one stake or monument to another is obstructed by intervening timber or brush, it may be necessary to blaze trees along the line, or cut away the brush, or set more stakes at such distances, that they may be seen from one to the other, in a way to indicate the lines so that the boundaries can be readily traced. But it is not for the court to say what is a sufficient marking of the boundaries. It is your duty to determine, from all the evidence in the case and from the topography of the ground in question, whether or not a sufficient marking of the boundaries of the claim by the............. mas made so that the same could be readily traced by a person making a reasonable effort to do so. If you find from the evidence in this case that this location was so definitely marked on the ground by the.................................. its boundaries could be readily traced, then, I instruct you that, the........................ requirement of the law. If not, then I instruct you that.............. failed in one of the essentials of a valid........mining location, and that your verdict must be for the.......... 


\section{INSTR UC'TIONS. (Discovery-Lode.)}

Form No. 29.

(Precedent in Larkin v. Upton, 144 U. S. 19.)

The apex of a vein or lode is the highest point thereof, and may be at the surface of the ground or at a point below the surface. When the vein or lode does not crop out, but is what is called a blind vein or lode, the apex thereof would necessarily be below the surface of the ground; and in this case you are instructed that if the locators of the ......... lode vein, at the time of the location thereof, found, or if from the work done by others prior thereto, they could see, at any point within the limits of said location, a lode or vein the top or apex of which was within the said lines of their location, then, in such case, they made a discovery of a lode or vein such as the law requires to be made to entitle them to locate the ground, and it is wholly immaterial as to the amount or quantity of such a vein or lode which may have been found within the limits of their said location; any amount of it would suffice, however small, either as to the amount of the vein or its apex within the limits of the said location.

Note.-The apex of a vein is not necessarily a point, but often a line of great length. Larkin v. Upton, ante.

\section{Form No. 30.}

\section{INGTRUC'TIONS. (Discovery-Placer.)}

(Precedent in Charlton v. Kelly, 156 Fed. 433.)

If you shall find and believe from the evidence in this case that ......... found the colors and particles of gold so testified to by ........... in the .......... on the surface of the ground in dispute then you should determine whether or not such finding was of sufficient character and found in such places, and under such conditions as to constitute a discovery of mineral as will satisfy the law. You are instructed that mere indications, however strong, are not sufficient to answer the requirement of the statute. 


\section{NSTIRUC'IONS. (End Lines.)}

\section{Form No. 31.}

(Precedent in Cheesman v. Hart, 42 Fed. 98.)

The court further charges the jury at the instance of the plaintiffs that end lines as described in the location certificate are not necessarily in law the end lines, unless they actually cross the actual outcrop of the vein.

The statute of the United States also requires that the end lines of the claim should be parallel with each other, and in asserting a right to follow the vein on its dip without the side lines of their location into plaintiff's location the defendants must show the outcrop or apex of such vein to be in their own location throughout the ground in controversy, being the extent of the locations of plaintiffs and defendants parallel to each other.

\section{INSTRUCTIONS. (Extra-lateral right.)}

Form No. 32.

(Precedent in Flagstaff' Co. v. Tarbet, 98 U. S. 463.)

If you find that .......... during the time mentioned in the complaint, to-wit: from ......... to (being a period of ........ years, $\ldots \ldots \ldots$ months, and $\ldots \ldots \ldots$ days $)$, was in possession of ........ mining claim, holding the same in accordance with the mining laws and the customs of the miners of the mining district and that the apex and course of the vein in dispute is within such surface-then, as against one subsequently entering, he is deemed to be possessed of the land within his boundaries to any depth, and also of the vein in the surface to any depth on its dip, though the vein in its dip downward passes the side line of the surface boundary and extends beneath other and adjoining 
lands, and a trespass upon such part of the vein on its dip, though beyond the side surface line, is unlawful to the same extent as a trespass on the vein inside of the surface boundary. This possession of the vein outside of the surface line, on its dip is limited in two ways - by the length of the course of the vein within the surface; and by an extension of the end lines of the surface claim vertically, and in their own direction, so as to intersect the vein on its dip, and the right of a possessor to recover for trespass on the vein is subject to only these restrictions.

\section{INSTRUCTIONS. (Forfeiture.)}

Form No. 33.

(Precedent in Big $3 \mathrm{Mg}$. Co. v. Hamilton, 157 Cal. 130.)

You are instructed that the law requires clear and convincing evidence to support the forfeiture of a claim duly located and worked in good faith and if the evidence does not satisfy you by a clear preponderance thereof that the plaintiff failed to perform the necessary work, then it follows that the plaintiff did not forfeit the said claim.

ORDER TO SHOW CAUSE AND RESTRAINING ORDER.

(Underground trespass.)

Form No. 34.

(Title of court and cause.)

Upon reading and filing the complaint herein (with the affidavit of .........., in support thereof), and on motion of...$\ldots \ldots \ldots \ldots$. Esq., ............ Attorney for the plaintiff............

It is ordered

that the defendant, ......... Mining Company, show cause, if any it has, before the above entitled court, at the court-house thereof, in the City of 
in the County of $\ldots \ldots \ldots \ldots$ and State of ........... on the ........ day of $19 \ldots$, at .... o'clock, in the forenoon of that day, or as soon thereafter as counsel can be heard, why an injunction pendente lite should not issue, restraining and enjoining said defendant, Mining Company, its agents, servants and employees and confederates from entering into or upon the mining ground situate and being in the Mining District, County of and State of .........., consisting of those two certain contiguous and adjoining premises or mining ground, the one known as the ......... mining claim and also known as ......... lode claim and in the system of United States Surveys for patents for mineral lands from the Government of the United States designated as Survey No.... and also so designated in a certificate of purchase from the United States of America, which was issued on the ......... day of .........., 19.., to the plaintiff by the Receiver of the United States Land Office at........., in the State of ........, and the other described as follows, to wit:

\section{(Description.)}

and from entering into or upon the mine or mines, lodes, drifts, cuts, excavations or works, or any thereof, on said mining ground or into or upon any part of said ground, and from working, or mining, or making, or continuing any cut, opening or excavation on, or in said mining ground, or on or in any part thereof, or digging up, extracting, taking, or removing from said mining ground, or any part thereof, any mineral, mineral deposit, ore, rock or earth, or any mineral substance whatever, whether the same be in place, or severed from the freehold; and from in any manner, hindering or obstructing plaintiff, or his agents, servants or employees, or any, or either of 
them, in working and mining upon said premises, and from in any manner interfering with said premises, or with anything thereon; such cause to be shown on said complaint (and on the affidavit of ........... thereto annexed) and to be herewith served.

And it is further hereby ordered that in the meantime, and until the hearing upon the foregoing order to show cause and the further order of this court, the said defendant, .......... Mining Company, its agents, servants and employees, and each and every of them, be, and they are hereby enjoined and restrained and ordered to refrain and desist from entering into or upon the said mining ground, or any part thereof, in the foregoing order to show cause mentioned and designated; and from entering into, or upon, the mine or mines, lodes, dips, cuts, excavations, or works, or any part thereof, on said mining ground; and from working or mining, or making, or continuing any cut, opening, or excavation on, or in said mining ground; or digging up, or extracting, taking or removing from said mining ground, or any part thereof, any mineral, mineral deposit, ore, rock or earth, or any mineral substance whatever, whether the same be in place or severed from the freehold; and from in any manner hindering or obstructing plaintiff, or his agents, servants or employees, or any, or either of them, in working and mining upon said premises, and from in any-manner interfering with said premises, or with anything thereon, upon the said plaintiff giving bond in the sum of ........ dollars.

And it is further hereby ordered that any and all affidavits, depositions and documents to be used by defendant on the hearing of said order to show cause shall be served, by copy, on the attorney for the plaintiff at least ....... days before the hearing of said order.

Dated ........., 19... 
ORDER FOR SURVEY, E'TC. (Underground trespass.) Form No. 35.

(Precedent in St. Louis Co. v. Montana Co., 9 Mont. 288; State v. Anaconda Co., 26 Mont. 396.)

(Title of court and cause.)

This matter coming on to be heard upon the petition for an order for survey, examination, and inspection of all of the shafts and underground workings in the ............. and ........ lode claims, or connected therewith, and an order to show cause having heretofore been issued and duly served upon said Mining Company; and said defendant appearing by counsel; and said petition having been duly heard and considered upon the return of said order to show cause upon evidence introduced by both parties, the court finds that it is necessary that the petitioner have a survey and inspection.

It is therefore ordered that you, the said......... Mining Company, give to ........... the petitioner herein, a survey, examination and inspection of all of the shafts and underground workings contained within the ............. and ...... claims, situate in...........Mining District, County of State of ........., and of all the underground workings connected therewith and extending into the........., and..........lode claims.

It is further ordered that ........., the petitioner herein make such survey, examination and inspection commencing on the ...... day of........, $19 .$. , and that you, the said ............ Mining Company, at all the times during the said period, upon the demand of said ........... lower and hoist him through said shafts and permit him to enter said underground workings; that you remove all bulkheads and obstructions which may be necessary to have re- 
moved to permit such survey, examination and inspection.

That said work of survey, examination and inspection shall be completed within ....... days from the date of this order unless, for good cause, the court shall order a longer time to be used.

Said..........., petitioner herein shall be responsible for all damage done in making said survey, examination and inspection.

The survey, examination and inspection by the said ............. shall be confined within the vertical

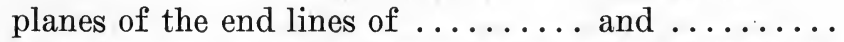
lode elaims, except so far as it may be necessary to run lines in underground workings outside of such planes in order to complete an accurate survey of said workings within the said end lines. Such survey to be conducted so far as possible without interference with the regular and orderly working and operation

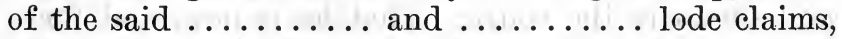
or the employees of said .......... Mining Company in the discharge of their various duties; and the engineers of the said .......... shall not dispose of, nor sell to any one any plan or section of said ................ lode claims; or any matter or data obtained or resulting from such survey, except to..........., its agents and attorneys. The surveyors of said .......... are not to enter said ................. and ...... lode claims unless accompanied by three representatives, appointed by said ........... Mining Company, to accompany them, unless, after reasonable notice, not to exceed .......... such persons shall fail to attend. The persons so hereinbefore authorized to make such survey shall not take nor remove from said .......... and...........lode claims any samples of ore or minerals at any point therein, but they shall be allowed to examine and trace the walls of the vein or fissure; 
and for this purpose they shall be allowed to use the pick and remove such material as shall enable them to make such survey, examination and inspection. A copy of this order shall be sufficient notice to said Mining Company, its agents, servants, officers and employees of the right of said.......... and the persons named in this order to make said survey, examination and inspection, and to enter the premises herein described for such purpose.

Done in open court this .......... day of $\ldots \ldots \ldots, 19 \ldots$

\section{PETITION FOR SURVEY, ETC. (Underground trespass.)}

Form No. 36.

(Precedent in State v. Anaconda Copper Co., 26 Mont. 396.) (Title of court and cause.)

Comes now .......... and respectfully alleges and shows to the court: That he is now, and for a long time prior hereto has been the lessee from the owners of an undivided ......... of the ........ lode mining claim, situated in the ............ Mining District, County of ........, State of ........, and lying adjacent to the $\ldots \ldots \ldots$ and $\ldots \ldots \ldots$. lode claims on the .......... and entitled to become the purchaser of said portion of said lode claim under and by virtue of an agreement from the owners thereof. That the............Mining Company is in the possession of the................... lode claims, and of all the shafts and underground workings therein.

That, as petitioner is informed and believes, certain underground workings have been made by said Mining Company into the said.......... lode claim. That there are certain veins or ore bodies which have their tops or apices in the said.......... lode claim but so far depart from a perpendicular in 
their downward course as to pass into the......... and $\ldots \ldots \ldots \ldots$ lode claims beneath the surface thereof, and that as petitioner is informed and believes said .......... Mining Company has been and is now engaged in extracting valuable ores from said .lode claims and the veins and ores belonging thereto, and that certain of the underground workings made in and extending from the.......... and .......... lode claims are upon the veins and ore bodies which belong to said .......... lode claim.

That the only means of access to said underground workings is through the shafts in said and ......... lode claims in the possession of said Mining Company and the underground workings in said claims and extending therefrom. That it is necessary for your petitioner to have a survey, examination and inspection of all of the shafts and underground workings in said .......... and lode claims and the underground workings extending therefrom or connected therewith, in order to ascertain, protect, and enforce his rights to the ......... lode claim, and to the veins and ore bodies belonging thereto.

That on the ........ day of .......... your petitioner served upon said.......... Mining Company a demand and request in writing of which Exhibit " $A$ " hereto attached and hereof made a part, is a copy, but that said .......... Mining Company has failed and refused for more than ......... days since the service of said demand and request upon it to grant the same or to permit your petitioner to have the survey, examination and inspection therein, as requested.

That as your petitioner is informed and believes it will be necessary for him to have access to said shafts and underground workings in said,.......... and 
........ lode claims by at least.......... persons, for a period of.......... days, in order to make a proper and thorough survey, examination and inspection of the same.

Wherefore, your petitioner prays an order of this court, or the judge thereof, requiring the said........ Mining Company to appear and show cause why an order for survey, examination and inspection of said ............. lode claims, and of all the shafts and underground workings therein contained, should not be granted to him in accordance with the allegations of this petition.

\section{VERDICT-ADVERSE CLAIM.}

Form No. 37.

(Precedent in Bennet v. Harkrader, 158 U. S. 441.)

(Title of court and cause.)

We, the jury find for the..........

Foreman.

\section{LEASES.}

\section{ASSIGNMENT OF LEASE AND OPTION.}

Form No. 38.

(Precedent in Pollard v. Sayre, 45 Colo. 195.)

For and in consideration of the sum of.......... dollars, to me in hand paid, by ........... the receipt whereof is hereby acknowledged, and the further sum of ......... dollars, to be paid to me, my executors, administrators, or assigns, within ......... months from the date hereof, I hereby sell, assign, transfer and convey to said .......... the within bond and lease and all my right, title, and interest. therein and all my right, title and interest in and to 
the real estate therein described. The deferred payment to be deposited in the.......... bank, to the credit of............

It is hereby agreed that no personal liability shall attach to said ......... for said deferred payment, and that it shall be optional with him whether he shall make the same; but if not paid then all rights acquired by said .......... by virtue hereof in and to the within bond and lease and in and to the real estate therein described, shall become forfeited and all payments theretofore made by said......... shall be likewise forfeited to me and the above assignment and conveyance become null and void.

In witness whereof, I have hereunto set my hand and seal this.... day of......., 19...

\section{LEASE WITH PRIVILEGE OF PURCHASE.}

Form No. 39.

(Precedent in Settle v. Winters, 2 Idaho (Hasb.) 215.)

This Indenture, with privilege of purchase, made and executed this day of ........, 19.., by and between ..........., the parties of the first part, and ............., the parties of the second part, Witnesseth:-That the said parties of the first part, for and in consideration of ......... dollars to them in hand paid, at and before the ensealing and delivery of these presents, the receipt whereof is hereby acknowledged, do hereby covenant and agree to and with the said parties of the second part, their heirs and assigns, as follows, to wit: The said parties of the first part hereby grant, demise, and lease to the said parties of the second part, the following described property, situate, lying and being in ........... Mining District, County of ........... State of ..........., and more particularly described as follows, to wit:

(Description.) 
Also that certain engine and boiler, known as the ........., now lying on said.......... from the $\ldots \ldots$ day of $\ldots \ldots \ldots \ldots, 19 \ldots$, on the expiration of a certain lease of the................. mines, executed and delivered by the parties of the first part to...............; or in the event of the assignment of said lease to the parties of the second part before the said ....... day of ....... 19. , then from the date of such assignment until the day of ........, 19.., upon the following terms and conditions:

That said parties of the second part, so long as they shall deem fit to hold said property, and to mine and extract ore therefrom and to pay the said parties of the first part........... of the gross proceeds in manner hereinafter specified; and when the sum of.......... dollars shall have been paid, either out of the proceeds of the said property hereby leased, or otherwise, by the said parties of the second part to the parties of the first part, the said parties of the first part hereby covenant and agree, for themselves, their executors, administrators and assigns, to and with said parties of the second part, their heirs and assigns, to convey to them by good and sufficient deed all of the above described property, free and clear of all incumbrance upon such payment, provided, the said sum of ......... dollars shall have been paid on or before the ....... day of ........ $19 . .$.

And the said parties of the second part hereby covenant and agree to enter upon said property, and to mine and extract ore from the same so long as they shall find it profitable; to do the work in a proper and workmanlike manner, and at their own cost and expense; and to hold and keep said property free and clear of all costs, charge or lien for the working of the same; and out of the gross proceeds of said mines to 
pay .......... thereof, as fast as taken out, to said parties of the first part in a manner hereinafter specified; and, upon the expiration of the term hereby granted, to surrender up the possession of said premises, with all the improvements, to the said parties of the first part, unless, on or before the said ......... day of ........, 19.., the said sum of ........ dollars, shall have been paid; and in the event of the said parties of the second part, or their assigns, failing to comply with either or any, of the foregoing covenants, or any covenant, promise, or thing herein contained, on their part to be done, kept, or performed, that then it shall be lawful for said parties of the first part to re-enter, possess, and enjoy the above described property and premises, and every part thereof; and the said parties of the second part hereby agree, in the event of such non-performance on their part, to surrender possession of the said premises upon demand by said parties of the first part claiming their right to re-enter.

It is hereby mutually covenanted and agreed by and between the parties to this instrument that the said parties of the first part shall have the right, at all times, of inspecting the said mines above described, and all mining operations and work thereon; that the said parties of the second part shall have the right, at any time to stop work on said mines when they shall find or deem the same unprofitable; that, in working said ores, at each clean-up the said parties of the second part shall and will furnish a true account of all ores extracted and milled, and all bullion received, to the said parties of the first part; that, in milling said ores so taken from said property, the said parties of the first part, if they so desire, shall have an equal right with said parties of the second part, in milling the ores, cleaning and retorting the same, weighing and storing the bullion, until the said parties of the 
second part receipt to them for.......... of the ........... proceeds; it being expressly understood that upon each clean-up the said parties of the second part are to receipt to the said parties of the first part that they own............... of the same, and that the said parties of the second part hold the same for them; and the said parties of the second part are then to dispose of the bullion to the best advantage, and to pay to the parties of the first part of the proceeds thereof in money; currency or coin; and upon such payment the parties of the first part will credit said purchase price of dollars, with the sum so received; and, lastly, that in no event shall the said properties above described, or any part thereof, be held for any claim, cost, charge, or lien for working the same by the said parties of the second part, under this instrument; but, that all such work shall be done at the expense of the said parties of the second part solely and alone; and the said parties of the first part, for themselves, their executors, administrators and assigns hereby covenant and agree to and with the said parties of the second part, their heirs and assigns, to convey, by good and sufficient deed, all the above described properties, free and clear of all incumbrances, to them, the said parties of the second part, or their assigns, at any time, upon the payment to them, the said parties of the first part, of the sum of ......... dollars, either out of the proceeds of the said mines, or otherwise, on or before ........., in the manner hereinbefore specified, by the said parties of the second part, or their assigns. And it is hereby expressly and mutually covenanted and agreed that this covenant shall be taken, held and deemed a covenant real, running with and binding the land.

In witness whereof, the said parties have hereunto, in duplicate set their hands and seals this ......... day of $\ldots \ldots \ldots, 19 \ldots$ 
OIL LAND LEASE.

Form No. 40.

This Indenture, made this ..... day of ........ 191.., by and between.........., a corporation, organized and existing under and by virtue of the laws of the State of ........., hereinafter called the lessor, and the .........., a corporation, hereinafter called the lessee, Witnesseth: That for and in consideration of the covenants and agreements hereinafter expressed and by the lessee to be fully kept and performed, the lessor has demised and leased, and does hereby demise and lease unto the said lessee, all that certain piece or parcel of land situate in the county of .................., State of and more particularly described as follows, to-wit: (Here insert description), containing ....... acres, more or less.

The lessor has furthermore granted, demised and leased, and by these presents does grant, demise and lease unto the said lessee, all the oil, gas, hydro-carbons, water and minerals of every kind and character whatsoever, in and under said lands, and the right to sever and remove the same; also the right to construct and maintain telegraph, telephone, pipe lines and roadways from adjoining lands on or across the demised premises; the right to construct and maintain buildings, derricks, tanks and other structures used or necessary for the boring for, excavating, preserving and handling oil, gas, hydro-carbons, water and other minerals produced on the demised premises.

To have and to hold the same unto the said lessee for the full term of ........ years from and after the date hereof, provided that all covenants and con-

Note.-For form of oil leases used in Indiana, Kansas, New York, Pennsylvania, Tennessee and Texas, see Donahue Pet. \& Gas., §\$ 28-34; Thornton's Oil and Gas, appendix. 
ditions hereof are fully kept and performed by the said lessee.

The said lessee agrees to commence the erection of a standard or rotary drilling rig on said lands within ........ days from the date hereof, and carry forward the work of completing the same with all reasonable despatch, working continuously with a proper force of men for at least ........ hours every day, except Sundays and holidays, and unless prevented by strikes, the elements, or other causes beyond the control of the lessee.

Within ....... days from the completion of said rig the said lessee agrees to commence the actual work of drilling for oil, and thereafter shall work continuously twenty-four hours each day, unless prevented by strikes, the elements, unavoidable accidents or other causes beyond the control of the lessee, until a depth of ........ feet is reached, or until oil is discovered in paying quantities at a lesser depth. Oil in paying quantities is hereby defined as the production of not less than ........ barrels during twenty-four hours continuous pumping.

In drilling said wells the lessee agrees to proceed in a workmanlike manner in accordance with the best practice of the Field, properly casing said well, and shutting off therefrom any water encountered; to comply with all statutes of the United States, the State of California and all local ordinances.

Upon the discovery of oil in paying quantities, as herein defined, the lessee shall during each ealendar year thereafter commence and complete...... wells to a depth of.......... feet, or until oil is discovered in paying quantities at a lesser depth, until a total of wells has been drilled. The number of wells herein specified shall not prevent the lessee from drilling as many more wells as it may desire. 
Upon the completion of a well the lessee shall use diligence and care to keep the same in good condition, and free from sand, and if the well does not flow freely, shall pump it so that the well shall produce at all times to its maximum capacity. No well producing less than ......... barrels a day, however, need be pumped. Whenever the market value of oil shall fall below ......... cents per barrel at the well, pumping and further drilling may be discontinued while such price prevails, provided, there shall be no. discontinuance of drilling until the first well has been completed.

The lessee agrees to deliver to the lessor........ of all oil, gas, water or other minerals produced from said land over and above what is necessary for actual operation of the property. The lessor shall have the option to take said royalty in kind or in money, but said election when exercised shall be changed not oftener than once every.......months. In the event of the lessor taking the royalty in kind the'same shall be delivered as produced into the lessor's tanks erected on the demised land by lessor for that purpose. In the event of the lessor electing to take such royalty in money, the lessee shall pay to the lessor on the ...... day of each and every month the market value of all royalty produced during the preceding calendar month.

The lessee agrees to protect said lands against all claims of labor and material men, and to see that the notices which may be posted by the lessor to protect said land from such liens are kept in place; to pay all taxes and assessments levied on said lands and improvements; provided, however, that should any royalty or tax on production be demanded by the United States, the lessor shall pay the royalty or tax on the royalty oil, and the lessee shall pay the tax on its oil. 
The lessee further agrees to keep careful and accurate logs of all wells drilled, showing the width, depth and character of the various strata encountered, and to give copies thereof and maps of the various strata to the lessor if required. To keep careful and accurate books of account showing production, and to keep all samples or run tags on file which shall at all reasonable times or time be open to the inspection of the lessor.

It is understood and agreed that lessor claims said land under mining locations, and does not warrant or guarantee the title against the claims of the United States or rulings of the land department. In the event that any title to said land shall be vested in the lessee by the United States, the lessee shall nevertheless hold the same, subject to all the terms and conditions hereof.

The lessor hereby extends to the lessee the privilege of purchasing said lands at any time within one year from the date hereof for...........dollars.

Time and each and every stipulation of this agreement is of the essence hereof, and in the event of the failure to perform any of the terms hereof, this lease shall at once become null and void at the option of the lessor.

Upon the expiration of the term hereof, or sooner termination of this lease, the lessee shall quietly and peaceably surrender possession there of to the lessor. Lessee shall have......... days to remove all property placed on the land by it, excepting derricks and casings in the wells, but the lessor shall have the. right to purchase the whole or any part of such property during such...... days by paying.....\% of the first cost thereof on the land.

In the event of any action at law being necessary to recover possession of said land, or any of the royalties hereunder, the lessee shall pay to lessor all 
costs and a reasonable attorney's fee to be fixed by the court in said action, which costs and fee shall be a lien on the property of the lessee.

This agreement shall run to and be binding upon. the successors and assigns of the parties hereto.

In witness whereof, the parties hereto have caused their respective corporate names and seals to be hereto affixed by their respective presidents and secretaries thereunto duly authorized by resolution of their respective boards of directors, the day and year first above written.

\section{ADDENDUM.}

Upon the expiration of the term of said lease, the lessee, if he shall have fully and faithfully kept and performed all the terms and conditions hereof, shall have the right to the production forever of all wells so long as they shall produce....... barrels per day, subject to all terms hereof as to royalty and operation, and he may clean out or deepen the said wells, and he shall have the right to go on and across said land, but all work shall be confined to an area of one acre around each well, provided this shall not apply to any well started....... years after the date hereof.

\section{NOTICE OF FORFEITURE OF LEASE.}

\section{Form No. 41.}

(Precedent in Mathews Slate Co. v. New Empire Slate Co., 122 Fed. 972.)

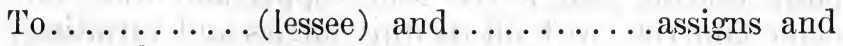
employees :

Take notice that under and by virtue of the provisions of the lease from the........... Company to .......... bearing date the.... day of .......... $19 . .$, that the said Company has exercised and does hereby exercise its option to terminate this lease and to re-enter upon and possess itself of the premises 
demised for the reasons that the said........... and his successors in interest have failed to keep and perform their promises, contracts, and agreements in said instrument set forth, as follows :

(Insert ground of forfeiture.)

And you are hereby notified that all rights and privileges conveyed and contracted under said instrument have become forfeit and are hereby terminated.

Dated.........., 19...

\section{LOCATION NOTICES.}

ADDITIONAL AND AMENDED CERTIFICATE OF LOCATION.

Form No. 42.

(Precedent in Porter v. North Star Co., 133 Fed. 756.)

Know all men by these presents that the undersigned .........., a citizen of the United States, has this .......day of........., 19.., amended, located and claimed, and by these presents does amend, locate and claim by the rights of original discovery, and the location heretofore made, such deeds, transfers, or conveyances as may have been made, and this amended certificate made, filed and recorded as provided by Federal law and by the laws of the State of........ now in force, and local customs and rules, ......... hundred linear feet, on this lode, vein, ledge or deposit, bearing gold, silver, lead, copper and other valuable minerals, with all its dips, angles and variations as allowed by law, together with........hundred feet on each side of the middle of said vein at the surface and all veins, lodes, ledges or deposits and surface ground within the lines of said claim. This said

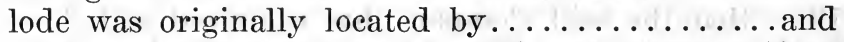
$\ldots \ldots \ldots \ldots$ on the..... day of.........., 19.., and named the.........., by which name it is 
found of record in Book...... of Mining Locations, pages......and............. County.......Records. It is also found in Book....., page......, Records of..........Mining District, said County and State. The name of this lode in future will be the The date this amended location is made is the..... day of ........, 19. The name of the amending locator is.......... From the discovery point at the discovery monument there is claimed by him..... feet in a........ direction and feet in a........ direction along the course of said lode or vein. The general course of this vein is......... The discovery shaft or its equivalent is situated upon the claim.......hundred feet....... from the....... and exposes the ledge at a depth of fully........ feet; its dimensions are ................. feet deep.

This further and additional and amended certificate of location is made and filed without waiver or any previously acquired and existing rights in and to said mining. claim, but for the purpose of correcting any errors or omissions in the original location or location certificate, description or record; and for the purpose of securing the benefit of the act of the legislature of the State of........., approved........, and the amendments thereto, and of conforming to the requirements of law. That said mining claim is situate in the..........Mining District, County of State of........, and more particularly described as follows, to wit:

(Description.)

Locator. 


\section{LODE LOCATION.}

Form No. 43.

(Precedent in Hammer v. Garfield Co., 130 U. S. 291; adapted to use in California, C. C., $\$ 1426$, in which state the record must be a true copy of the notice posted.)

\section{Notice of Location.}

Notice is hereby given that the undersigned, having complied with the requirements of Chapter VI of Title XXXII of the Revised Statutes of the United States and the laws of the State of California, and the local customs, laws and regulations has located...... hundred linear feet on the.... .lode running in a.... and...... direction as near as can be determined from present developments with....... feet on each side of the center of the claim situated in..........Mining District, County of........... and State of California and described as follows: Commencing at discovery stake, thence running.......feet.......to center stake; thence........ feet.......to stake "A," thence...... feet to stake "B," thence...... ffeet to stake "C," and...... feet.......to stake " $D$ " and ...... feet.......to place of commencement. This lode is located about..... feet..... of......... Dated.........., 19...

\section{Locator.}

\section{MILL-SITE LOCATION.}

Form No. 44.

(330 feet by 600 feet equals 5 acres.)

Notice of LOCATION.

Notice is hereby given that the undersigned, proprietor of that certain vein or lode claim known as

Note-All notices of location, or of forfeiture, or of annual expenditure must substantially conform to the law of the state or the local rules of the mining district in which the claim is situated. 
the.........mining claim (or the owner of that certain quartz mill or reduction works known as the ..........) has this day located five (5) acres of non-mineral land to be known as the...........Millsite, situate in the.........Mining District, County of......... and State of........, and described as follows:

Beginning at the northeast corner of said mill-site, a post marked N. E. cor. No. 1, which corner is about ...... feet in a...... direction from the corner of the........mining claim, U. S. survey No.., thence west...... feet to a post marked N. W. cor. No. 2; thence south..... feet to a post marked S. W. cor. No. 3, thence east...... feet to a post marked S. E. cor. No. 4; thence north...... feet to the place of beginning.

Dated........., $19 \ldots$

Locator.

PLACER LOCATION (on surveyed land).

Form No. 45.

(Precedent in Kern Oil Co. v. Crawford, 143 Cal, 298.)

Notice of Location.

Notice is hereby given that the undersigned has this ..... day of . ......, 19.., located a placer mining claim situated in.........Mining District, County of ......., State of......., described as follows: The..... of Section...... in Township...... Range .......M., containing.......acres.

This claim shall be known as the..... placer mining claim.

Locator. 


\section{PLACER hochtion (on unsurveyed lands). \\ Form No. 46.}

(Precedent in McKinley Creek Co. v. Alaska United Co., 183 U. S. 563.)

Notice of Location.

Notice is hereby given that $I$, the undersigned, have this......day of ........., 19.., located a placer mining claim 1500 feet running with the creek and 300 feet on each side from center of creek known as ........ Creek in.........Mining District, running into........River. This claim is the east extension of ..........claim on about..... feet from the first falls above the...... River in the..... of ......., and shall be known as the...... placer mining claim.

Witnesses :

\section{Locator.}

\section{TUNNEL-SITE LOCATION.}

Form No. 47.

(Precedent in Min. Reg., par. 17.)

Notice of Location.

Notice is hereby given that I, the undersigned, have this......day of ......., 19.., located a tunnelsite to be known as the........ Tunnel Claim, situate in the.........Mining District, County of........ State of......., and described as follows:

Commencing at this post and location notice distant ......feet from a (blazed tree..... inches in diam-

Note.-In California the location notice must be posted at the face or point of comencement of the tunnel. C. C., $\$ 1426 \mathrm{e}$. The boundary lines of the tunnel must be established by stakes or monuments placed along the lines at an interval of not more than 600 feet from the face or point of commencement of the tunnel to the terminus of 3000 feet therefrom. Id., \& $1426 \mathrm{f}$. 
eter, marked......, or other natural object or permanent monument); thence rumning $(3,000)$ feet ..... to a post marked...... ; the intermediate distance on the line of said tunnel being marked by posts placed thereon........feet apart and, respectively, marked as follows : ..............

The said tunnel shall be......feet in length and ...... feet in width in the clear.

\section{Locator.}

\section{WATER LOCATION.}

Form No. 48.

(California.)

Notice is hereby given that the undersigned hereby appropriates......inches of water, measured under a ...... inch pressure flowing in the...... County of ......., State of......., for the purpose of furnishing water and power to......... and at other places along the line of diversion.

That said water shall be diverted from said...... at a point about..... on the.....bank thereof, thence in.a..... direction for about...... to.....

That the means of the diversion of said water shall be by a ditch...... feet wide at the top, ...... feet wide at the bottom and..... . feet deep, and other necessary or convenient appliances therefrom.

Dated........, 19... 


\section{PA'TEN'T PROCEEDINGS.}

\section{ADVEIRSE CIAIM.}

Form No. 49.

In the United States Land Office at........, State of ........

In the matter of the application of.........Mining Company for a........ patent for the....... mining claim situate in........Mining District, County of........, State of......... Township No..., Range No..., .......Meridian.

To the Register and Receiver of the United States Land Office at........, State of.......

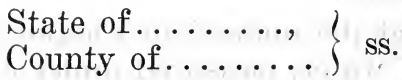

.......... being first duly sworn, according to law, deposes and says that he is a citizen of the United States, born in the State of........., and residing at ......., in the County of........ and State of

Deponent further says that in virtue of a compliance on his part and that of his grantors with the laws of the United States relating to taking up, locating and holding mining claims or mineral lands in the public domain and with the laws of the State of ........, and with the local laws, customs and usages of the.........Mining District, deponent has become, and now is, the owner, in possession of and entitled to own and possess...... linear feet on the...... vein, lode or ledge of quartz and other rock in place, bearing........and.......together with certain surface ground appurtenant thereto for the convenient use thereof in working said vein, lode or ledge; said claim embracing in all......acres in superficial area, sit- 
uate, lying and being in the........Mining District, County of........., State of........

Deponent further says that the facts relative to his claim, right and title of possession to said vein, lode or ledge and mining ground, claim and premises are substantially as follows: That on and before the day of the location thereof, hereinafter mentioned, the said........ vein, lode or ledge and mining premises were mineral land of the public domain and entirely vacant and unoccupied and were not owned, held or claimed by any person or party as mining ground, or otherwise, and that while the same were so vacant, unoccupied and unclaimed, to wit: on the..... day of ......., 19.., ........ and......., each of them being citizens of the United States, entered upon and explored the premises, discovered and located the said......... vein, lode or ledge and oceupied the same as a mining claim.

That the said premises so located and appropriated consist of....... feet in a........ direction on and along the said vein, lode or ledge from the location stake and....... feet in width, as will more fully appear by reference to the notice of location, a duly certified copy whereof is hereunto annexed, marked Exhibit "A," and made a part hereof. That the said locators upon the making of said location entered into and took possession of said vein, lode or ledge, mining ground, claim and premises, erected thereon such stakes and monuments as were necessary to point and designate the boundaries and extent thereof, did such work thereon and performed all such acts as were required by the mining laws of Congress, and of the State of......, and by the laws, customs, rules and regulations of the miners of the said......... Mining District, in which said claim is situated and filed their said notice of location in the office of the County Recorder of said County of........, by whom the 
same was recorded on the......day of........, at page..... of Book..... of..... of the Records of said county.

That said locators remained in the possession, occupation and enjoyment of the said vein, lode or ledge, mining claim, ground and premises and continued from the date of said location to work upon, prospect and develop the same until the.... day of......... 19 .., on which date the said locators, owners and possessors of said vein, lode or ledge, and said mining ground, claim and premises, by their deed in writing, good and sufficient in the law, conveyed all of said ...... vein, lode or ledge, mining ground, claim and premises, so as aforesaid located by them, to........ who thereupon entered into, took possession and control, and has since possessed, controlled; enjoyed and occupied all of said........ vein, lode or ledge, mining ground, claim and premises. That the said locators and said........, their said grantee and the adverse claimant herein did comply with every rule, regulation and custom in force in the said........ Mining District, and with the provisions of the mining laws of the State of........, and of the Acts of Congress in that behalf enacted.

That there is a........vein, lode or ledge with ......wall within said mining ground, claim and premises of an average width of......, running in a ............direction, containing........ vein matter carrying.....; and there is blocked out, or in sight, ......tons of ore therein.

That there has been a large amount of money expended on said...... vein, lode or ledge and said mining ground, claim and premises by said........, the adverse claimant herein, and his grantor and predecessors in interest aforesaid, to wit: ....... dollars, in .........., and there has been extracted from said vein, lode or ledge and said mining ground, 
claim and premises, more than.........tons of ore of the value of..........dollars. That by reason of the facts aforesaid deponent has become and now is the rightful owner (except as against the paramount title of the United States), and the lawful possessor of the said vein, lode or ledge and the said mining ground, claim and premises.

That the abstract of title, herewith presented and made a part hereof, shows the deed, conveyance and transfer, whereby deponent became, and is vested with all the right, title and interest of the said locators in and to the said vein, lode or ledge, and said mining ground and premises, so located as aforesaid.

Deponent further says that the pretended mining claim of said applicant for patent known as the..... mining claim, overlaps, embraces and includes a part and portion of deponent's said vein, lode or ledge, mining ground, claim and premises.

That the relative position of said several mining claims and the boundaries and extent of said overlap, at the surface, are more particularly set forth, mentioned and specifically described by courses and distances in the plat hereto attached, marked Exhibit "B," and made a part hereof.

Wherefore, deponent does dispute and contest the right of said applicant for a patent from the Government of the United States for said pretended........ mining claim, and respectfully asks that all further proceedings in the matter of said application be stayed in said land office until the controversy shall have been settled by a court of competent jurisdiction.

Subscribed and sworn to before me this..... day of .........., 19... 


\section{STATEMENT OF CHARGES AND FEES. \\ Form No. $50^{\circ}$.}

(Caption as in Form No. 49.)

State of.

County of............

being first duly sworn, according to law, deposes and says, that he is the attorney in fact for the........Mining Company, the applicant for patent for the........mining claim, designated as Mineral Entry No... That said claimant has paid the following charges and fees for publication, and surveys and fees and money to the Register and Receiver of the land office, viz. :

To the Surveyor-General . ............... To the Deputy U. S. Mineral Surveyor for making the survey................... To......... for publication of notice.....\$.... To Register and Receiver for filing application.\$.... To the Receiver of the local land office, for the land embraced in the claim...............

Subscribed and sworn to before me this...... day of . ......., 19...

\section{AFFIDAVIT THAT NO KNOWN VEIN EXISTS. Form No. 51.}

(Caption as in Form No. 49.)

State of.........., \},

County of ...........

..................... of the said County and State, being first duly sworn, each for himself and not one for the other, deposes and says:

That he is well acquainted with the........mining claim, embracing.......acres, situated in the 
.Mining District, County of.......... and State of.........., owned and worked by........, the applicant for a United States.patent therefor.

'That for many years he has resided near, and often been upon said mining premises, and that no known vein or veins of quartz or other rock in place, bearing gold, silver, cinnabar, lead, tin, or copper exist on said placer mine and claim, or on any part thereof, so far as he knows, and he verily believes that none exist thereon.

Subscribed and sworn to before me this......day of ......., 19...

FINAL AFFIDAVI'T OF POSTING.

Form No. 52.

(Caption as in Form No. 49.)

- State of ..........., s.

.......... being first duly sworn according to law, deposes and says, that he is the duly authorized attorney in fact and superintendent of the......... Mining Company, the claimant of the....... mining claim in ........Mining District, County of....... and State of......., the official plat of which premises designated by the Surveyor-General as United States Survey No..., together with the notice of its intention to apply for a patent therefor, was posted thereon on the...... day of......., 19.., as fully set.forth and described in the affidavit of......... and ........, dated the .... day of ......, 19.., which affidavit was filed in the land office at........ in the State of........ in this case, and that the plat and notice so mentioned and described remained conspicuously and continuously posted upon said mining claim from and including the said.... day of......., 
$19 . .$, until and including the.... day of ....., 19... including the sixty days' period during which notice of said application for patent was published in the newspaper.

Subscribed and sworn to before me this..... day of $19 . .$.

AFFIDAVIT OF EXPENDI'URES ON PLACER CLAIM.

Form No. 53.

(Caption as in Form No. 49.)

State of.........., ,

County of........... Ss.

We, ........ and........, being severally duly sworn, on oath depose and say, that we are citizens of the United States and of the State of........, that we are well acquainted with the situation and character of the........mining claim claimed by ........ Mining Company, located in.........Mining District, County of........, State of......., in Section........, Township No... of Range No..., Meridian.

That the same is a placer mining claim containing That we have no financial interest in said mining claim. That we are conversant with the working of said mining claim, and that to the best of our knowledge and belief the amount expended on said mining claim in labor and improvements by the said claimant and its grantors is not less than $\$ 500$.

That said labor and improvements consist of.......

Subscribed and sworn to before me this...... day of ........, 19... 


\section{PRELIMINAIR ARTIDAVIT ON POSTING.}

Form No. 54.

(Caption as in Form No. 49.)

State of.........., \}

County of ..............

................, each for himself and not one for the other, being first duly sworn according to law, deposes and says, that he is a citizen of the United States over the age of twenty-one years and was present on the..... day of......., 19.., when a plat representing the.......mining claim and premises and certified to as correct by the United States Surveyor-General of the District and State of......... and designated by him as Survey No..., together with a notice of intention of........ Mining Company to apply for a patent from the government of the United States for the mining claim and premises so platted, was posted in a conspicuous place upon said mining claim, to wit:

\section{(Describe place of posting.)}

where the same could be easily seen and examined. The notice so conspicuously posted upon said mining claim being in words and figures as follows, to wit:

\section{(Insert "Legal Notice," Form No. 63.)}

Subscribed and sworn to before me this...... day of ............ and I hereby certify that I consider the above deponents credible and reliable witnesses and that the foregoing affidavit and notice were read by each of them before their signatires were affixed thereto and the oath made by them. 
AFFIDA VIT OF: PUBLICATION.

Form No. 55.

(Caption as in Form No. 49.)

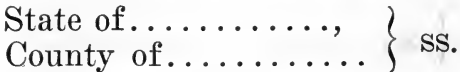

.......... being first duly sworn, according to law, deposes and says that he is the proprietor of the ........, a......newspaper, published at....... in the County of........, State of........ That the annexed notice of the intention of........ Mining Company to apply for a patent from the Government of the United States for the........ mining claim designated as Survey No... was published in said newspaper..........., commencing on the....... day of ........., 19.., and ending on the...... day of......., 19.., as follows, to wit:.

Subscribed and sworn to before me this.... day of ........, 19...

Note. Attach copy of printed notice hereto.

AGREEMENT OF PUBLISHER.

Form No. 56.

(Caption as in Form No. 49.)

I, ......, owner and publisher of the......, a ......newspaper of general circulation published at ...... in the County of....... and State of ......., hereby agree to publish in said newspaper the notice of the intention of........ Mining Company to apply for a patent from the Government of the United States for the.......mining claim designated as Survey No... and situated in the........ Mining District, County of........, State of........, as required by the mining laws of the United States, and to hold said applicant alone responsible for my charges for 
making such publication; and no claim nor charge whatever shall be made by me against the Government of the United States, or any of its officers or agents therefor.

In witness whereof, I have hereunto set my hand this..... day of......., 19...

\section{APPLICATION FOR PATENT.}

Form No. 57.

In the United States Land Office at........, in the State of........

Application of.........Mining Company for a patent for its claim of...... linear feet of the....... Lode, bearing....... and......, together with surface ground adjacent and appurtenant thereto, embracing an area of.......acres, lying and being in the......... Mining District, County of........., State of......., and officially designated by the Surveyor-General as Survey No...., in Township No...., Range No...., .......Meridian, as shown by the official plat thereof filed herewith and the official field notes of survey hereto attached.

To the Register and Receiver of the United States Land Office for the District of Lands subject to sale at........, in the State of.......

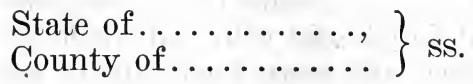

$\left.\begin{array}{l}\text { State of } \ldots \ldots \ldots \ldots, \\ \text { County of } \ldots \ldots \ldots \ldots\end{array}\right\}$ ss. law, on his oath, deposes and says that he is a citizen of the United States, over the age of twenty-one years, residing at........ in the County of........, State of........., and that he is the agent and superin. tendent of..........Mining Company, and is duly authorized and empowered to verify and file this appli- 
cation, as will appear by a resolntion of the board of directors of said company, a copy whereof is hereto attached, marked Exhibit “A," and made a part hereof.

That the said.........Mining Company is a corporation duly organized and existing under and by virtue of the laws of the State of......... having its principal place of business at....... in the State of......... as will appear by a certified copy of its articles of incorporation, hereto attached, marked Exhibit "B," and made a part hereof.

Deponent further says that the said........... ing Company, in virtue of a compliance on the part of itself and its grantors with the laws of the United States relating to taking up, locating and holding mining claims or mineral lands in the public domain and with the mining laws of the State of........, and with the local laws, customs and usages of the........ Mining District, has become and now is the owner of and in the actual possession of and entitled to so own and possess.....linear feet on the....... lode, being a mineral vein or lode or ledge of quartz and other rock in place, bearing...... and...... together with certain surface ground appurtenant thereto, for the convenient use thereof in working said lode, vein or ledge; said claim embracing in all..... acres in superficial area; situate, lying and being in the...... Mining District, County of......., State of......., the boundaries and extent of which said vein, lode or ledge and claim, at the surface, are more particularly set forth, mentioned and specifically described, by. course and distance, in the official field notes of survey thereof, hereto attached, marked Exhibit "C" and made a part hereof; and also in the official plat of said mining claim designated as Mineral Survey No....... Township No..., Range No...,.............Meridian, and which said plat is now posted eonspicuously upon said 
mining claim and premises; to which said plat and field notes of said Mineral Survey No..., reference is hereby particularly made as fully describing and setting forth by actual survey the boundary lines at the surface of the vein, lode, ledge and mining ground so owned by, in the possession of, and for which the said ......... Mining Company hereby makes application for a patent; this deponent making the said plat and field notes of survey of said Mineral Survey No...., a part of this statement as describing the mining premises hereby sought to be patented and wherein the same are described as follows, to wit:

\section{(Description.)}

(There is expressly excluded from this application for patent the following portion of said Survey No..., to wit: ........., as shown on said official plat.)

Deponent further says that the facts relative to the . Mining Company's claim, title and right of possession to said vein, lode, ledge and mining premises are substantially as follows:

That on and before the day of the location thereof, hereinafter mentioned, the premises hereinbefore described were mineral lands of the public domain and entirely vacant and unoceupied, and were not owned, held, or claimed, by any person, or party as mining ground, or otherwise; and that while the same were so vacant and unoccupied and unclaimed, to wit: on the...... day of ........, 19......... and .......... each and all of them being citizens of the United States, entered upon and explored the premises, discovered and located the said.......vein, lode or ledge and occupied the same as a mining claim.

That the said premises so located and appropriated consist of..... feet in a..... direction on and along the said vein, lode or ledge from the location stake and ...... feet in width, together with all the dips, spurs, 
angles, depths, widths, offshoots, sinuosities and variations, as will more fully appear by reference to the notice of location, a duly certified copy whereof is hereunto attached, marked Exhibit "D" and made a part hereof.

That the said locators, said.......... and his said associates, upon the making of said location entered into and took possession of said........ vein, lode or ledge and said mining ground, claim and premises, erected thereon such stakes and monuments as were necessary to point and designate the boundaries and extent thereof, did such work thereon and performed all such acts as were required by the mining laws of Congress, of the State of........, and by the laws, customs, rules and regulations of the miners of the district in which said claim is situated, and filed their said notice of location in the office of the County Recorder of the said County of......... by whom the same was recorded on the..... day of........ $19 .$. , in Book...... at page..... of ....... of the Records of said county.

That said locators remained in the possession, occupation and enjoyment of the said......... vein, lode or ledge and said mining claim, ground and premises and continued, from the date of said location, to work upon, prospect and develop the same until the....... day of........, 19.., on which date the owners and possessors of said......... vein, lode or ledge, mining ground, claim and premises by their deed in writing, good and sufficient in the law, conveyed all of said vein, lode or ledge and mining ground, claim and premises so as aforesaid located by said........, and his said associates, to......... and thereupon said.........entered into, took possession and control, and commenced to work upon anddevelop the same, and so continued in such possession and work until the..... day of......., 19.., on 
which date the said....... by his deed in writing, good and sufficient in the law, conveyed all of said ........ vein, lode or ledge and said mining ground, claim and premises, to........Mining Company, the applicant for patent herein, and thereupon the said corporation entered into, took possession and control, and has since possessed, controlled, enjoyed, and oceupied and is now in the actual and peaceable possession of all of said.........vein, lode or ledge and said mining claim, ground and premises.

That the said locators, said......... and his said associates and their said grantee and said corporation, did comply with every custom, rule, regulation and requirement in force in the......... Mining District, and with the provisions of the mining laws of the State of........, and of the acts of Congress in that behalf enacted.

That there is a true fissure vein, lode or ledge with well defined walls carrying gouge, within said claim, having an average width of........ feet, running in a...... and..... direction and containing quartzose vein matter carrying iron and copper pyrites, and there is blocked out or in sight......tons of ore therein of an average value of...... dollars per ton.

That there has been a large amount of money expended on said.........vein, lode or ledge, mining ground, claim and premises by said corporation, the applicant for patent herein, and by its grantors, to wit: ....... dollars in running a tunnel....... feet long with drifts, cross cuts, and stopes therefrom; and there has been extracted from said vein, lode or ledge more than, to wit.....tons of ore of the value of about......dollars per ton.

That by reason of the facts aforesaid the said..... Mining Company, the applicant for patent herein, has become and is the rightful owner (except as against the paramount title of the United States), and the 
lawful possessor of the aforesaid........vein, lode, or ledge and the said mining ground, claim and premises.

That the abstract of title, herewith presented, duly certified by the........., shows the various deeds, conveyances and transfers whereby the said........ Mining Company, the applicant for patent herein, became and is vested with all the rights, title and interest of the said locators, said........ and his'said associates and their said grantee in and to said........ vein, lode or ledge and said mining ground, claim and premises, so located as aforesaid.

In consideration of which facts, and in conformity with the provisions of Chapter VI of Title XXXII, of the Revised Statutes of the United States, application is hereby made for and in behalf of said......... Mining Company, for a patent from the Government of the United States for the said........ vein, lode or ledge, deposit, mining ground, claim and premises so officially surveyed and platted.

Subscribed and sworn to before me this..... day of $19 .$. , and I hereby certify that I consider the above deponent a credible and reliable person, and that the foregoing affidavit, to which was attached the field notes of survey of the........mining claim, was read and examined by him before his signature was affixed thereto.

\section{APPLICATION TO PURCHASE.}

Form No. 58.

\section{(Caption as in Form No. 49.)}

To the Register and Receiver, United States Land Office at.........

The undersigned, claimant under the provisions of the Revised Statutes, Chapter Six, Title Thirty-two, 


\section{Messrs..................}

\section{Absent: Messrs..........}

After due and legal proceedings the following preamble and resolution were adopted by the unanimous vote of the directors present:

Whereas, it is the intention of this corporation to apply for a patent from the Government of the United States for its certain mining claim, ledge, lode and premises situate, lying and being in the.........Mining District, County of......... State of....... and called the.........Mining Claim.

Now, therefore, be, and it is hereby

Resolved, That...........the superintendent and managing agent of this corporation be and he is hereby fully authorized and empowered for and on behalf of this corporation, and in its name to do all acts whatsoever necessary or proper for the purpose of making and completing said application for and procuring the patent for said mining claim and to make and file any and all affidavits or other papers of any kind necessary or required for the procuring of said patent for said mining claim and premises.

I hereby certify the foregoing to be a full, true and correct transcript from the minute book of the Board of Directors of......... Mining Company and a full, true and correct copy of the preamble and resolution adopted at a regularly called meeting of said Directors held at the office of said corporation in the city of ........, County of......... State of........

Witness my hand and the corporate seal of....... Mining Company, by me hereto affixed this...... day of ......., 19...

Secretary..........Mining Company. 


\section{CERTIFICATE' THAT' NO SUIT IS PENDING.}

Form No. 62.

\section{(Caption as in Form No. 49.)}

$\left.\begin{array}{l}\text { State of } \ldots \ldots \ldots \ldots, \\ \text { County of } \ldots \ldots \ldots \ldots\end{array}\right\}$ ss.

$I, \ldots \ldots \ldots \ldots$, do hereby certify that $I$ am the duly elected, qualified and acting clerk of the County of........, State of......., and ex-officio clerk of the........Court of the State of......., in and for the County of........

And I do hereby further certify that there is now no suit or action of any character pending in said court involving the right of possession to the........ mining claim, or any part thereof, and there has been no litigation before said court affecting the title to said mining claim, or any part thereof, for........ years last past, or within the period prescribed by the statute of limitations affecting real property, to wit:......years, other than what has been finally decided in favor of said...... Mining Company.

In witness whereof, I have hereunto set my hand and affixed the seal of said........ Court this..... day of......., 19...

County Clerk and ex-officio Clerk of the....... Court of the State of....... in and for the County of.......... 
NO'TICE FOL POS'TING OF APPIICATION FOR FA'TEN'T. Form No. 63.

Ijegal Notice of the Application of......... Mining Company for a United States Patent.

State of...

County of.............. ss.

Mining Company hereby gives notice that under and in pursuance of Chapter VI of Title XXXII of the Revised Statutes of the United States, Mining Company, a corporation organized and existing under the laws of the State of......... having its principal place of business and post-office address at................... the state of engaged in the business of mining at........ Mining District, in the County of......., State of........, and which is authorized to locate a mining claim under the provisions of said Chapter VI, and which has complied with its terms, does claim............ linear feet of the....... vein, lode, ledge or mineral deposit bearing. ...... and...... with surface ground...... feet in width, lying and being situate within the . Mining District, County of........., State of ........, and has made application to the United States for a patent for said mining claim, vein, lode, ledge and mineral deposit and intends to and will file in the United States. Land Office at........, in the State of........, that being the proper land office, its said application for patent, under oath, showing such compliance, together with the plat and field notes' of the survey of the claim, made by or under the direction of the United States Surveyor-General for the State and District of........, showing accurately the boundaries of the said claim, which are dis-

Note. Areas intended to be excluded from the application for patent must be expressly stated in both the posted and published notice as well as in the application for patent. Min. Reg., pars. 38-39. 
tinctly marked by monuments on the ground wherein and whereby the boundaries and extent of said claim, on the surface, are described as follows, to wit:

\section{(Description.)}

The names of the adjoining and conflicting claims, as shown by said plat and survey, are the........ officially designated as Survey No.... on the north, and by the........mining claim (unsurveyed) on the east and said claim of said..........Mining Company is designated as Survey No... in the said official plat posted herewith.

Any and all persons claiming adversely the mining ground, vein, ledge, premises, or any part of the same so designated, surveyed, platted and applied for, are hereby notified that unless their adverse claims are duly filed according to law and the regulations thereunder, within the sixty days' period of the publication of the notice of said application with the Register of the United States Land Office at........ in the State of......., they will be barred in virtue of the provisions of said statute.

Dated and posted on the ground this....... day of $19 .$.

$$
\text { by... }
$$

Its Superintendent and Attorney in Fact.

Witnesses : 


\section{NOTICE FOR PUBLICATION.}

Form No. 64.

Notice of Application for Patent.

Mineral Application No...

In the United States Land Office at.........,

$19 .$.

Notice is hereby given that.......... Mining Company, a corporation organized and existing under the laws of the State of.........., having its principal place of business and post-office address at......... by and through............., the duly authorized and empowered attorney in fact and superintendent of said..............Mining Company and by the resolution of the directors thereof herein specifically authorized and whose post-office address is at........, in the County of.......... and State of.........., has made and filed in the United States Land Office at........... and State of......... its duly verified application for patent from the Government of the United States for..........linear feet of the . Mining Claim, situate in..........Mining District, County of........, State of........, and being officially surveyed, platted and designated as United States Survey No.... in Township No...., Range No..., .......Meridian, and bounded and described according to the field notes and plat of said official survey as follows:

\section{(Description.)}

- Particular reference is hereby made to the plat and field notes of the survey of the said United States Survey No... in Township No..., Range No..., ........ Meridian and surface ground now on file in this office and to the plat and notice posted upon said lode claim, said Survey No.., , for any further description of the 
vein, lode, ledge, deposit, mining claim and premises hereby sought to be patented.

The names of the adjoining and conflicting claims as shown by said plat and survey are.

And notice is further given, that any and all persons having or claiming adversely or in opposition to the said.........Mining Company to the said vein, lode, ledge, deposit, mining ground and premises hereinbefore described, or any part thereof, are required to present and file their adverse and opposing claims during the sixty days' newspaper publication of this notice to and with the Register of the United IStates Land Office at........, or they will be barred by virtue of the statute.

\section{Register.}

It is hereby ordered that the foregoing notice of application for patent be published for a period of nine consecutive weeks (or sixty days) in the........., a.........newspaper published at.........

\section{Register.}

\section{PRO'TES'T.}

Form No. 65.

(Precedent in Grand Canyon Co. v. Cameron, 36 L. D. 66.)

In the United States Land Office at........ in the State of.........

In the matter of the application of........ for a United States patent for......... mining claim known as the........ and Lodes and mill-sites in Section......, Township......, Range...... of

Protest of ......... Company. 
To the Register and Receiver of the United States Land Office for the district of land subject to sale at........ in the State of.......

State of $\ldots \ldots \ldots \ldots$,
County of $\ldots \ldots \ldots$, ss.

.......... being duly sworn, according to law, on his oath deposes and says: that he is the........ of the........Company, the protestant herein, and is duly authorized and empowered to verify and file this protest as will appear by a resolution of the board of directors of said company, a copy whereof is hereto attached, marked Exhibit " $\mathrm{A}$ " and made a part hereof.

That the said......... Company, the protestant herein, is, and since the..... day of ......., 19.., has been a corporation maintaining and operating a railroad for the carriage of freight and passengers from the town of....... in the State of....... to a point on the rim of the........ in said State near what is known as the.........Trail, as will appear by a certified copy of its articles of incorporation hereto attached, marked Exhibit "B," and made a part hereof.

That on the.....day of ......, 19.., the said . filed his application to the Government of the United States for a patent for the mining claim known as the.......... and Lodes and Mill-sites in Section......., Township......, Range...... of ....... ; and which said application has ever since been and still is pending and undetermined.

That at the time of the location of said alleged lodes said applicant for patent had made no discovery of any valuable deposit of mineral within the limits of either, or any of said locations and has not since made any such discovery; and that the lands so lo- 
cated by him do not contain valuable deposits of any kind, so far as known.

That the plat of survey and the notice of the application for patent aforesaid were not posted in a conspicuous place upon said mining claim. That if said plat and notice were posted at all they, and each of them, were posted where they could not be seen.

That the notice of application for patent for said mining claim was published in a weekly newspaper in . called the........, a newspaper of small circulation and read by few persons. That said notice, as published, was defective in this: That it failed to give the connecting line of said mining claim with a corner of the public surveys or a United States mineral monument. That it failed to give the names of the adjoining and conflicting claims, or the number of the survey thereof.

That the expenditures in labor or improvements upon the said lodes are insufficient in amount and kind for patent purposes.

That said........, said applicant for patent, is seeking by means of fraud, deceit and misrepresentation to acquire a patent for the lands embraced in said mining claim in that such lands are not valuable for minerals and the said alleged mining claims were not located for mining purposes but for the purpose of controlling, so far as possible, the use of a portion of the.........Trail leading from the terminus of the line of railroad of this protestant down to the walls of the......... Cañon of the......... River to said river, and thereby placing himself in a position either to prevent the public from using said portion or to pay to said......... such sums of money as he shall see fit to exact for the privilege of using said trail.

That the boundaries of the said locations were so fixed upon the face of the earth as to include that por- 
tion of said trail known as the........, which, because of the topography of the ground traversed by it, is located upon the only practicable and feasible route for a trail from the terminus of the protestant's line of railroad to the........ River, and that as far as can be determined from an inspection of the surface of the ground and the small amount of excavation thereon, the course of the said alleged mining claims was determined by the course of the said portion of said trail rather than by the course of any lode or mineral-bearing vein.

That the lands embraced in the so-called........ and.......mill-sites are not now and never have been used or occupied for either mining or milling purposes, and that said........ is seeking to acquire patent to said mill-sites and each of them by means of fraud, misrepresentation and deceit and as part of a scheme devised by him for acquiring control of said Trail and the waters flowing in what is known as.......... Creek.

That in carrying out said fraudulent scheme and purpose said........made pretended locations of lodes and mill-sites along and across said trail from its head on the rim near the terminus of the line of railroad of this protestant, to the foot of said trail at the........River, all in the........ Cañon of the .........River, so located as to include the greatest possible portion of said trail.

That the.......Cañon of the.......River is one of the great natural wonders of the world, is visited by large numbers of people from all parts of the world, practically all of whom travel over the line of railroad of this protestant and the most of whom make the trip over said trail down to said river.

That said trail and said alleged mining claim and mill-sites are within the......... Forest Reserve.

That this protest is made for the purpose of pre- 
venting the consummation of what protestant verily believes to be a fraudulent scheme to obtain patents for lands within a forest reserve regardless of their value for mining uses and to secure control of the waters flowing in what are known as....... Creeks; and also for the purpose of securing to the public and particularly to all persons who travel upon the protestant's line of railroad with the intention of visiting the........ Cañon of the........River the right freely and unrestrictedly to travel upon and over said trail down into said cañon.

Wherefore; protestant respectfully prays that a hearing be ordered to allow it to prove the foregoing allegations, protect its legal rights, and also to show cause why said application for patent should be cancelled.

\section{TIMBER OR STONE ENTRY.}

Form No. 66.

U. S. Land Office, ................ No......

Receipt No.......

Application and Sworn Statement.

('To be made in duplicate.)

I, ......... (give full Christian name),$\ldots \ldots$. (male or female), hereby make application to purchase the........, Section....., Township......, Range................... acres, within the.........Land District, in the State of........, and the timber thereon, at such value as may be fixed by appraisement, made under authority of the Secretary of the Interior, under the act of June 3, 1878, commonly known as the "Timber and Stone Law," and acts amendatory thereof, and in support of this application I do solemnly swear that I

(Applicant must state whether native born, naturalized, or has filed declaration of intention to become a citizen. If not native born, certified copy of naturalization or declaration of intention, as case may be, must be filed with this affidavit.) 
. citizen of the United States, of the age of .....years, and by occupation a........; that I did, on......., 19.., examine said land, and from my personal knowledge state that said land is unfit for cultivation and is valuable chiefly for its timber; and that to my best knowledge and belief, based upon said examination, the land is worth........dollars, and the timber thereon, which I estimate to be....... feet, board measure, is worth........ dollars, making a total value for the land and timber of........ dollars, and no more; that the land is uninhabited; that it contains no mining or other improvements, nor, as I verily believe, any valuable deposit of gold, siler, cinnabar, copper, coal, or other minerals, salt springs, or deposits of salt; that I have made no other application under said acts; that I do not apply to purchase the land above described on speculation, but in good faith to appropriate it to my own exclusive use and benefit, and that I have not, directly or indirectly, made any agreement or contract, in any way or manner, with any person or persons whomsoever, by which the title I may acquire from the Government of the United States may inure in whole or in part to the benefit of any person except myself; that since August 30, 1890, I have not entered and acquired title to, nor am I now claiming, under an entry made under any of the non-mineral public-land laws, any amount of land which, together with the land now applied for, will exceed in the aggregate 320 acres; that I am not a member of any association, or a stockholder in any corporation which has filed an application and sworn statement under said act; and that my postoffice address is............ (if a city, street and number must be given), at which place any notice affecting my rights under this application may be sent.

I request that notice be furnished me for publication in the.......newspaper, published (the news- 
paper must be one of general circulation, published nearest the land) at........

(Sign here, with full Christian name.)

I hereby certify that the foregoing affidavit was read to or by affiant in my presence before affiant affixed signature thereto; that affiant is to me personally known (or has been satisfactorily identified before me by .......... (give full name and postoffice address); that I verily believe affiant to be a qualified applicant and the identical person hereinbefore described, and that said affidavit was duly subscribed and sworn to before me at my office in....... (town), ........... (county and state), within the........land district, this........ day of ........, $19 \ldots$

(Official designation of officer.)

Note.-Every person swearing falsely to the above statements may be punished as provided by law for such offense. (See Rev. Stats., \&5392.)

In addition thereto, the money that may be paid for the land is forfeited, and all conveyances of the land, or of any right, title, or claim thereto, are absolutely null and void as against the United States. 
- INIEX-FORMS 


\section{N D E X}

\section{FORMS}

AFFIDAVITS.

Form No.

(See Patent Proceedings.)

1. Annual Expenditure.

2. Non-mineral.

\section{ARTICLES OF INCORPORATION.}

3. Purposes of corporation.

\section{CONTRACTS.}

4. Agreement to purchase.

5. Agreement to sell.

5a. Compromise of adverse claim.

6. Grubstake contract.

7. Contract with mining engineer.

8. Oil-well drilling contract.

9. Option.

10. Ratification of option by stockholders.

11. Certificate of Secretary.

12. Instructions to escrow holder.

13. Pooling agreement.

\section{DEEDS.}

14. Deed.

15. Deed of Trustees for Corporation.

16. Ratification of deed by stockholders.

17. Certificate of secretary.

18. Notice of.

\section{FORFEITURE.}

\section{LEGAL PROCEEDINGS.}

19. Answer-adverse claim.

20. Answer-negligence. 
21. Answer-underground trespass.

22. Complaint-adverse claim.

22a. Complaint in equity-adverse claim.

23. Complaint in ejectment.

24. Complaint-underground trespass (at law).

25. Complaint-do. (in equity).

26. Findings of fact and conclusions of law.

27. Instruction-annual expenditure.

28. Instruction-boundaries.

29. Instruction-discovery-lode.

30. Instruction-discovery-placer.

31. Instruction-end lines.

32. Instruction-extra-lateral right.

33. Instruction-forfeiture.

34. Order to show cause and restraining order-Underground trespass.

35. Order for survey-Underground trespass.

36. Petition for survey-Underground trespass.

37. Verdict-Adverse claim.

\section{LEASES.}

38. Assignment of lease and option.

39. Lease with privilege of purchase.

40. Oil land lease.

41. Notice of forfeiture of lease.

\section{LOCATION NOTICES.}

42. Additional and amended certificate of location.

43. Lode location.

44. Mill-site location.

45. Placer location (on surveyed land)

46. - (on unsurveyed land).

47. Tunnel-site location.

48. Water location.

\section{PATENT PROCEEDINGS.}

49. Adverse claim.

50. Affidavit, charges and fees.

51. — no known vein exists.

52. - posting (final).

53. - expenditures on placer claim.

54. — posting (preliminary).

55. — publication. 
56. Agreement of publisher.

57. Application for patent.

58. — to purchase.

59. — for repayment-Letter of attorney.

60. — for survey.

61. Appointment, attorney in fact.

62. Certificate that no suit is pending.

63. Notice for posting.

64. - for publication.

65. Protest.

66. Timber or Stone entry. 
INDEX 
K.H1: 


\section{INDEX}

(The references are to the sections and their subdivisions.)

ABANDONMENT: See Forfeiture.

Definition of, $\S 72$.

Intent controls, $\S 72-2$.

How effected, § 72-3.

Californian provision, $\S 72$, note 8 .

By co-tenant, $\S 72-4$.

What is not an, $\S 72-5$; $\S 72$, note 11 .

Deed after passes no title, $\S 72-6$.

Proof of, § 72-7.

Test of, $\S 72-8$.

What will warrant assumption of, $\S 72$, note 8 .

Allegation of in pleading, § 72-9.

Re-location not evidence of, when, $\S 72$, note 11 .

Failure to file adverse claim may not be, $\S 72$, note 13 .

Of oil well, §121-6; § 121, note 8 .

ABSTRACTS OF TITLE, what to unpatented claim do not show, § 68-2-3-4-5-6-7-8-9-10-11.

Inconclusiveness of patent in, $\S 68-12$.

In patent proceedings, $\S 214: 4 ; \S 214$, note 13 .

ACCOUNTING: See Mining Partnerships; Co-tenants; Courts.

ACTIONS: See Possessory Actions; Adverse Suit; Cotenants; Rescission; Remedies.

\section{ACTS OF LOCATION.}

Acts incumbent on locator, $\$ 177$.

Order of performance may be immaterial, $\$ 177-3$.

ADVERSE CLAIM: See Possessory Actions; Adverse Suit; Patent Proceedings. 
(The references are to the sections and their subdivisions.)

ADVERSE CLAIM SURVEY: See Patent Proceedings.

Definition of, $\S 38$.

What must show, $\S 38-2$.

Not necessary when, $\S 38-3$.

Not made by Surveyor-General, § 38-4.

ADVERSE POSSESSION: See Co-tenants; Possession;

Water Rights; Annual Expenditure.

Of mining claims in Alaska, § 3-10.

When title in fee, $\S 71-9$.

General principle, § 71-10.

Continuity of, $\S 71-11$.

Insufficiency of, $\S 71-12$.

Effect of patent upon, $\S 71-13$.

As against homestead entryman, §104-8.

ADVERSE SUIT: See Patent Proceedings.

Definition of, $\S 20$.

Basis of, $\S 20$.

Basis of intervention in, $\S 20$.

Commencement and prosecution of, $\S 20$.

Jury trial not of right, $\S 20$, note 1 .

Jurisdiction of court limited, $\S 20-2$.

Burden upon plaintiff, $\S 20-2$.

Both parties actors, $\S 20-3$.

Pleading, generally, § 20-3.

Pleading citizenship, § 20-3.

Question of citizenship cannot be primarily raised in an appellate court, $\S 20-3$.

Each party must prove right, $\S 20-3-4$.

Questions involved in, $\$ 20-4$.

May be dismissed, § 20-5.

Non-suit may be granted, $\S 20-6$.

Diligence is question for court, $\S 20$, note 7 .

Judgment determines only right of possession, $\$ 20-7$.

Province of land department, $\S 20-7$.

Finality of judgment, $\S 20-8$.

Defendant may show prior subsisting location in third party, $\S 20$, note 16 .

What must be established in, $\S 20$, note 18 .

Dates of filing may be considered upon motion to dismiss, $\S 20$, note 19 .

Court cannot pass upon sufficiency of adverse claim in, $\S 20$, note 19 .

Complaint must support judgment in, $\S 20$, note 22 .

Equivalent to office found, $\S 163$, note 9 . 
(The references are to the sections and their subdivisions.)

When not necessary, $\$ 215$, note 11 .

Continuation of land office proceedings, $\S 216$.

May be different judgments in, $\$ 216-2$.

Effect of several judgments in, § 216-2.

What court may not determine in, $\$ 216$, note 2 .

Duty of register, $\$ 216-3$.

Proceedings in general land office after judgment, § 216-4.

AFFIDAVITS: See Patent Proceedings.

Where to be made, $\S 213$, note 7 .

When proceedings based upon void, § 213 , note 7 .

Over telephone are void, $\S 213$, note 7 .

AGENTS. May locate in behalf of principal, $\S 164$.

Subsequent destruction of location notice, $\$ 164-2$.

Cannot re-locate in hostility to principal, \& 179-5.

Personal services in annual expenditure, § 194-3.

AGREED LINES: See Acts of Location.

AGRICULTURAL PATENT. Mineral land covered by not

a mining claim, §102-7.

Precludes extra-lateral right, when, § 111-5.

Conveys what, § 206-3.

ALASKA: See Tide Lands.

Laws of the United States extended to, $\S 3$.

Records and mining recorders in, $\S 3-2$.

Explorations on Behring Sea, § 3-3.

Dredging in, § 3-4.

Beach claims in, § 3-5.

Roadway reservation in, § 3-6.

Aliens in, § 3-7.

Adverse claims, time to file in, § $3-8$.

Adverse suits, time to commence in, § 3-9.

Adverse possession, § 3-10.

Appeals, \& 14, note 1 .

Reciprocal rights in, $\$ 163$.

Posting and recording essential acts of location in, $\S 185$, note 6 .

ALIENS: See Citizens and Aliens.

AMENDED LOCATION NOTICE: See Amended Location; Re-location Notice.

Purpose of making, $\S 187$.

Californian provision, $\S 187$, and note 1 .

Effect of intervening rights, $\S 187-2-3$. 
(The references are to the sections and their subdivisions.)

AMENDED LOCATIONS: See Re-locations.

No provision for in mining act, § 178 .

Not a re-location, $\S 178$.

Relation to original, $\S 178$.

Basis of, § 178-2.

Additional discovery not necessary, $\$ 178-2$.

Additional annual expenditure not necessary in, § 178-2.

Office of, $\S 178-3$.

Contents of notice of, $\S 178-4$.

Effect of original and amended notice of, $\S 178-5$.

ANNUAL EXPENDITURE: See Contribution.

By option holder, § 66-4-5-6.

When question of immaterial, $\S 72$, note 5 .

Not required on mill-sites, $\S 116-7$.

In placer claims, § 119-6.

On tunnel sites, $\S 138-3$; $\$ 138-9$.

Re-location cannot be effected by interference with. $\S 179$, note 3 .

Penalty under state laws for failure to make, $\$ 179$, notes 7 and 8 .

Provisions of mining act in relation to, $\S 193$.

District rules in relation to, $\S 193-2$.

Place of performance, $\S 194$.

Character of, $\S 194-2$.

Personal services, § 194-3.

Exception as to oil claims, § 194-4.

On group, \& 194-4-5.

Burden of proof as to sufficiency of, $\S 194-6$.

Upon contiguous locations, § 194, note 26.

Attaches to claims in group collectively, § 194, note 28 .

When within spirit of statute, $\S 195$, note 1 .

Upon the surface may be insufficient, $\S 195$, note 1 .

Test of sufficiency, $\S 195$, note 2 .

Compliance with local statute or district rule, $\S 195-2$.

Payment for not conclusive, $\S 195-3$.

Payment for bears upon value, $\S 195-4$.

Payment for not essential, § 195-5.

Proof of performance of, $\S 196$.

Californian provision, $\S 196$, note 1 .

Effect of filing proof of, $\$ 196-3$.

Failure to file proof not fatal, $\S 196-4$.

Effect of non-performance of, $\S 197$.

Forfeiture for non-performance, $\S 197-2$.

Claim of forfeiture for non-performance, $\$ 197-4$. 
(The references are to the sections and their subdivisions.)

Agricultural claimant can not raise question of, $\$ 197$, note 4 .

What not sufficient excuse for non-performance, $\S 197-5$.

When adverse claimant cannot complain, § 197 , note 6 .

Resumption of, $\S 198$.

Time for resumption, $\S 198-2$.

Effect of resumption, $\S 198-3$.

What is not resumption, $\S 198-4$.

Effect of temporary suspension, § 198-5.

Who may make, § 199 .

Presumed to have been made by claimant, § 199-2.

Failure to contribute, § 200-2-3-4-5-6-7-8.

Californian provision, $\S 200$, note 2 .

ANTE-DATED NOTICE OF LOCATION. Fraudulent, § 189.

When not fraudulent, $\S 189$, note 1 .

Nevadan provision, $\S 189-2$.

APEX OR TOP. See Top or Apex.

APPEALS: See Courts.

Lie from rulings of Surveyor-General, $\$ 39$.

By protestant, $\$ 214$, note 50 .

Lie from rejection of adverse claim, $\S 215-9$.

Pendency of does not extend time to file adverse, $\S 215-9$.

APPLICATION TO SUE. When must be made, $\S 82-8$.

ASSAYS. Definition of, $\S 87$.

Different kinds of, $\S 87$.

Meaning of value, $\S 87-2$. •

Silver bullion, $\S 87$, note 2 .

Not necessarily conclusive of value, $\S 87-3$.

Car and mill samples, \& 87-4.

May establish want of identity of vein, $\S 112-4$.

ASSESSMENT WORK: See Annual Expenditure; Options.

ASSIGNMENT OF ERRORS: See Courts.

ASSOCIATION OF PERSONS: See Deeds.

BISECTED DISCOVERY, in lode claims, § 154-5.

BLANKET SLUICE. Definition of, $\S 88$.

BLANKET VEIN. Definition of, $\$ 50-25$.

Extra-lateral right does not attach to, § 111-3. 
(The references are to the sections and their subdivisions.)

BLIND VEIN. Definition of, $\S 50-24$.

Belongs to surface location, $\$ 50-24$.

Extra-lateral right does not attach to in placer location, $\S$ 111-3.

BOARD OF EQUITABLE ADJUDICATION: See Land Department.

BONA FIDE PURCHASER: See Patents; Scrip; Timber Cutting.

BORATE LANDS: See Salt Claims.

BOUNDARIES. When not subject to re-adjustment, $\S 110$, note 4 .

Should be found as named in the location notice, $\S 149$, note 21.

Upon property adversely held, $\S 155$, note 1 ; $\S 177-14-15$. May be fixed before discovery, $\S 168$-2.

May exist without existing location, $\S 172$.

Must be such as to be readily traced, $\S$ 177-2-7-13; $\S 185-10$.

What may be sufficient, $\S 177$, note 7 .

Character of prescribed by local statute or district rule, $\S 177-8-9$.

May be insufficient, $\S 177-10 ; \S 177$, note 9 .

Sufficiency of question of fact, $\S 177-11$.

What controls, § 177-12.

Monuments as, $\S 177-13$.

What may be considered as, $\S 177$, note 16 .

Danger in adopting survey, §177-18.

May be changed, $\S 177-19$.

Obliteration of, $\S 177-20$.

No presumption of as to old claims, $\S 177-21$.

Must be established, § 177-21.

By whom placed, $\S 177-22$.

End lines, § 177-23-24-25-26.

Side lines, § 177-27-28.

Agreed lines, § 177-29.

Of overlapping locations, $\S 180-3$.

Importance of, $\S 185-8$.

Misnaming some not fatal, § 186-7.

Correcting errors in, § 187.

When record need not show, § 190-6.

Binding upon locator, $\S 190$, note 9 . 
(The references are to the sections and their subdivisions.)

BROAD LODE. Lode containing more than one vein popularly called, § 50-7.

Separate veins within, §50-7-23.

Not comprehended in definition of vein, $\S 50-20$.

Use of term by courts, $\S 50-20$.

May be without distinct walls, § 50-21.

Indivisibility of, $\S 50-22$.

BURDEN OF PROOF: See Evidence.

BUSINESS OF MINING, definition of, $\S 101-4$.

Instrumentalities, $\S 101-5$.

CALIFORNIAN STATUTORY LAW. Míning districts, $\S 1$-5.

Local rules as evidence, $\S 19$, note 2 .

State lands, § 28-6-7, § 124a-2.

State patents, $\$ 28-12-13$.

Limitation of actions, § 28-12-13, § 84-4.

School lands, certain withdrawn from sale, § 28-14.

Conservation, $\$ 28 \mathrm{a}$.

Land bordering on waters, $\S 35-8, \S 35$, note 12 .

Survey of, unpatented locations, $\S 40$, note 1 .

Underground surveys, $\$ 40$, note 4 .

Mining partnerships, $\S 58$, note 2 .

Proceedings to obtain order to agree to sell mining claims, in probate, $\S 66$, note 1 .

Summary sale of mining claims, in probate, $\S 66$, note 1 .

Protection of abandoned mining shafts, $\S 72$, note 8 .

Eminent domain, § 76a.

Easements in mining claims, $\S 77$, note 1 .

Protection against liens, $\$ 79-8$.

Egress from certain quartz mines, $\S 80$, note 5 .

Coal mines, $\$ 80$, note 6 .

Bell signals, $\S 80$, note 7 .

Hours of labor, $\S 80$, note 8 .

Employers' liability act, $\$ 80$ a.

Exemptions, § 94-2.

Fixtures, § 95-3.

Miners' inch, $\$ 100-2$.

Wages, certificate of indebtedness, $\S 101$, note 6 .

Lode claims, location of, $\$ 110$, note 1 .

Millsites, location of, $\$ 116$, note 5 .

Placer claims, location of $\S 119$, note 17 .

Drilling and abandonment of oil wells, $\S 121$, note 8 .

Natural gas, §121a. 
(The references are to the sections and their subdivisions.)

Hydraulic mining, $\S 123$.

Mineral in waters of streams and lakes, $\S 124 \mathrm{a}$.

Minerals in waters of inland lakes, $\$ 124 \mathrm{a}$.

Tunnel claims, location of, $\S 138$, note 5 .

Water, preservation of from use in other states. $\S 141$, note 3.

Water rights, appropriation of, $\S 143$, note 1 .

Tide lands, $\$ 146$, note 1 .

Re-location upon failure to perform assessment work, $\S 179$, note 7 .

Amended notice of location, $\S 187$, note 1 .

Record, copies of as evidence, $\S 190$, note 16 .

Assessment work, amount required, §193, note 1 .

Record of assessment work, $\S 196$, note 1 .

Delinquent co-owners, $\$ 200$, note 2 .

Taxation of corporations, $\S \S 223-224$.

CERTIFICATE OF ENTRY: See Entry.

Equivalent to patent issued, $\S 93-3$.

Basis of, § 93-4.

Completes contract of purchase, $\S$ 93-5.

CERTIFICATE OF LOCATION: See Location Notice.

CERTIORARI lies when appeal denied, § 214, note 50.

CHARACTER OF LAND: See Contests; Hearings.

Land department determines, $\S 23-2$.

Same land may be claimed as mineral and agricultural, $\S 25$, note 2 .

No definite boundary as to, $\S 45-3$.

Who may question, § 45-4.

Trespasser may not question, $\S 45$, note 12 .

Point of time for determination, $\S 45$, note 13 .

When question as to open, $\S 45$, note 14 .

CHATTEL: See Conditional Sale.

CITIZENS AND ALIENS: See Possessory Actions; Adverse Suits.

Either may locate a mining claim, § 163.

Location by alien not void but voidable, $\S$ 163-2.

Government only can attack location by alien, $\S 163-3$.

Effect of naturalization before judgment, $\S 163-3$.

In patent proceedings citizenship of applicant only involved, § 163-4.

Patent conclusive evidence of citizenship, § 163-4. 
(The references are to the sections and their subdivisions.)

Presumption as to citizenship, § 163-5.

Adverse suit equivalent to inquest of office, $\S 163$, note 9.

Effect of objection of alienage upon title, $\S 163$, note 9 . Citizenship of trustor and trustee in patent proceedings, § 214.

How citizenship proved in patent proceedings, § 214-2.

CLAIM, definition of, $\S 89$.

Application of term, $\S 89-2$.

Perfected, § 89-3.

Contiguoùs, § 89-4.

CLASSIFICATION OF LAND: See Mineral Lands.

COAL LANDS are mineral lands, § 108.

Not subject to location within railroad grant, § 108.

Mineral and non-mineral rights in, $\$ 108$.

Fee simple title acquired under coal land laws, § 108-2.

Entry by legal subdivisions, § 108-2.

Preferential right, § 108-3.

Consolidation of interests, $\S 108-4$.

Prospecting in patented as non-mineral, $\S 108$, note 5 .

COAL MINE. Operating under Californian law, $\S 80$, note 6.

Land worked as, is a mining claim, $§ 102-8$.

COMPROMISE. Valid between mineral and agricultura] claimants, § 24-9.

Of protest illegal, when, § 214-19.

Not void between adverse mineral claimants, §215, note 27.

CONDEMNATION PROCEEDINGS. Against national and state governments, $\S 28$, note 23 .

Federal government, $\$ 76$.

Right of mineral claimant, $\S 76-2$.

Right of legislature, $\S 76-3$.

When mining a public use, § 76-4.

Californian provisions as to, $\$ 76 \mathrm{a}$.

CONDITIONAL SALE, chattel remains such when subject of, $\S 95$, note 1 .

CONFLICTING DECISIONS: See Courts.

CONFLICTING LOCATIONS: See Overlapping Locations. 
(The references are to the sections and their subdivisions.)

CONSERVATION. Californian school lands, § 28-14.

Committee on in California, § 28 a.

Coal lands, $\$ 108$.

Public domain, § 121a.

Natural gas, §121a.

Minerals in waters of streams or lakes, $\S 124 \mathrm{a}$.

Fresh water, $\$ 141$, note 3 .

Water used in generating power, § 143.

CONSOLIDATED LOCATIONS common to unite locations, § 96-3.

Annual expenditure upon, $\S 194-4-5-6 ; \S 194$, note 26.

CONSPICUOUS PLACE, definition of, $\S 90$.

Penalty for failure to post in, $\S 90-2$.

CONSPIRACY, in making placer locations, $\S 170$.

Innocent participants, §170-2.

CONTACT VEIN, definition of, $\S 50-33$.

CONTESTS: See Character of Land; Hearings.

Initiation of, $\S 24 ; \S 45$, note 2 .

What protest should state, $\S 24$, note 1 .

Grounds of, \$ 24-2.

Want of discovery, $\S 24$, note 2 .

Procedure, § 24-3.

Notice required, $\S 24-4$.

Purpose of notice, $\S 24-5$.

Effect of notice, $\$ 24-6$.

Effect of default, $\S 24-7$.

Notice after appearance, § 24-8.

Compromise of $\S 24-9 ; \S 214-19$.

Effect of appearance after notice, $\S 24$, note 12 .

CONTRIBUTION: See Co-tenants.

When may be demanded, § 200.

Effect of demand for, $\S 200-2$.

Character of title, $\S 200-3$.

Basis of notice for, $\S 200-4$.

Californian provision, $\S 200$, note 4 .

Right to give notice for, $\S 200-5$.

Contents of notice for, $\S 200-6$.

Personal service of notice for, $\S 200-7$.

Publication of notice for, $\S 200-8$. 
(The references are to the sections and their subdivisions.)

CORPORATION: See Deeds.

Not a co-tenant, $\S 59-5 ; \S 200-5$.

Definition of, $\S 91$.

Location rights of, $\S 91-2 ; \S 119-5 ; \S 163$, note 3 .

Not bona fide holder, when, $\S 125$, note 6 .

Right to patent, $\S 163$, note 3 .

Patent proof of existence, $\S 163$, note 3 .

Stockholder of may not give notice for contribution, $\S 200-5$.

Federal excise tax upon, $\S 220$.

Decisions of commissioner under federal excise tax upon, $\S 221$.

Questions undetermined by commissioner's decision, $\S 222$.

Californian tax upon, $\S \S 223-224$.

Directors or managers as trustees of, when, $\S 223-7$.

CO-TENANTS, how relation of created, $\S 59$.

When mining partners, $\S 59-2$.

When trustees, $\S 59-3$.

Termination of trust, $\S 59-4$.

Corporation not, $\S 59-5$.

Certain persons not, $\S 59-6$.

Divestiture of title, $\S 59-7$.

Exclusion from patent, $\S 59-8$.

When rights of are barred, $\S 59-9$.

May maintain action without joining other, $\S 59-10$.

Questioning title among, § 59-11.

Working claim of, $\S 59-12$.

Accounting between, $\S 59-13 ; \S 59$, note 28 .

Contribution by non-working, $\S 59-14$; $\S 59$, note 29 .

Liability for working, § 59-15.

Adverse possession between, $\S 59-16$.

Efflux of time bars accounting, §59-16.

Set off, $\S 59$, note 29 .

May abandon individual interest, $\S 72-4$.

Cannot re-locate, when, § 179-5.

May make re-Iocation, when, $\S 179$, note 12 .

Contribution for annual expenditure, $\S 200$.

Cannot claim contribution, when, $\$ 200$, note 7 .

COUNTRY ROCK, definition of, $\S 50-41$.

COURSE OR STRIKE: See Dip.

Definition of, $\S 50-52$.

Practical rule, $\S 50-53$. 
(The references are to the sections and their subdivisions.)

COURTS. Definition of competent jurisdiction, $\S 10$.

Jurisdiction of state, $\S 10-2$.

Jurisdiction of federal, $\S 10-3 ; \S 17$.

Removal from state to federal, $\S 10-4$.

Assignment of errors, $\S 10$, note 4 .

Remand, § 10-5.

Questions without jurisdiction of, § 10-6.

When should not interfere, \$ 10-7.

Necessity for interference, § 10-7.

Federal question, § 11.

Jurisdictional facts must be shown, $\S 11-2$.

Remedies may not be united in federal, $\S 12$.

Uniformity of equitable jurisdiction, $\S 12$, note 1 .

Action for accounting may be united with action for trespass in federal, $\S 12$, note 1 .

Recasting of pleadings, $\S 12-2$.

Recasting not necessary when, §12-3.

Dismissal of cause, $\S 13$.

Appeal, federal, § 14 .

Alaskan appeals, $\S 14$, note 1 .

Appeal, state, $\S 15$.

Writs of error, $\S 15-2$.

Conflicting decisions, $\S 16$.

Receivers, appointment of, by, § 19-6.

Cannot pass upon sufficiency of adverse claim, $\$ 20$, note 19.

Liberal in granting writ of injunction, $\S 85-4$.

CROSS VEINS, priority of title governs, $\S 50-31$.

Junior locator has right of way, $\S 50-31 ; \S 182$.

Ambiguity of term "space of intersection," $§ 50-32$.

DAMAGES: See Licenses; Options; Trespass; Mining for Oil; Timber Cutting.

DECLARATORY STATEMENT: See Location Notice.

DEEDS, must be in writing, $\S 67$.

What passes by, $\S 67-2$.

Unnecessary recitals, § 67-3.

Creation of independent estates by, $\S 67-4$.

Effect of quit claim, $\S 67-5$.

Subsurface support, $\$ 67$, note 6 .

To or from corporation, $\S 67-6 ; \S 223-10$.

To unincorporated association, $\S 67-7$.

Validity of location cannot be attacked by grantor, $\S 67-8$. 
(The references are to the sections and their subdivisions.)

Agreement for, § 67-9.

Applicant for patent, trustee under, $\S 67$, note 9 .

In escrow prior to entry passes no title, $\S 67$, note 9 .

Description in, \& $67-10$.

Statute of limitations, § 67-11.

Taxation, \& 67-12.

One of several names of claim sufficient in, $\S 67$, note 17.

Effect of tax deed, $\S 96$, note 23 .

Patent is quit claim deed, $\S 206$, note 1 .

Patent is of government, $\S 206$; $\S 206$, notes $1-2$.

DEFINITIONS: See Appropriate Titles.

DEPUTY MINERAL SURVEYORS: See Patent Proceedings.

DESERT LANDS, what are not, § 92.

DIP: See Course or Strike.

Miner's term, § 50-55.

Synonymous with "downward course," \& 50-55.

Definition of, § $50-55 ; \S 112$.

Variance of, \& 50-55.

Same vein or lode may have different, § 50-55.

How measured, \& 50-56.

Easement or servitude, $\S 50-57$.

Following, \& 50-58.

DIP RIGHT: See Extra-Lateral Right.

Definition of, $\S 50-55 ; \S 112$.

Basis of, \& 112-2.

Identity of vein or lode, $\S 112-3$.

Want of identity, § 112-4.

DISCOVERY: See Deeds.

In forest reserves, $\S 45$, note 2 .

Not necessary in mill-sites, § 116-6.

Subsequent of lode in placer, \& 119-4.

In placer claim, § 119-6.

Assessment work not equivalent to, $\S 119$, note 17 .

Single in lode claim, \& 120 , note 8 .

In oil placer claim, $\S 120-20-21-23$, notes 14 and 15 .

Single in oil placer claim, § 120-24.

Source of title, $\S 154$.

When not source of title, $\S 154$, note 1 .

May be original or adopted, § 154 . 
(The references are to the sections and their subdivisions.)

Must be actual, $\S 154$.

Location not complete without, $\S 154-2$.

Not necessarily first act of location, $\S 154-2$.

When subsequent validates location, § 154-2.

Requisites of, § 154-3.

When insufficient, § 154-4-7.

Bisected, § 154-5.

Single in placer, § 154-6.

Place of, § 154-7.

Absence of, $\S 154-8$.

Effect of first, $\S 154-8$.

Character of lode, $\S 155$.

Part of shaft may be in other ground, $\S 155$, note 1 .

Must be within location, $\S 155$, note 1 .

Of horizontal vein, $\$ 155$, note 3 .

Particular act of required only by local statute or district rule, $\S 156$.

Preliminary work of may be insufficient, $\S 156$, note 2 .

When work of an essential act, $\S 156-3$.

Preliminary work protects claim, $\S 156-3$.

Where preliminary work may be done, $\S 156-4$.

What preliminary work must disclose, $\S 156-4$.

Proof of, § 157.

Rule between rival claimants, $\S 157-2$.

Reason for rule, $\S 157-3$.

Test, § 157-4.

Contests between rival claimants, $\S 157-5$.

What should control, § 157-6.

Supplementary evidence, $\S$ 157-7.

What may be shown, $\S 157-8-9$.

Expert testimony, $\S 157-10$.

Conclusive testimony, $\S 157-11$.

Negative testimony, $\S 157-12$.

Loss of, § 158.

Sale before, $\S \cdot 158-2$.

Sale after, \& 158-3.

Neither end nor side lines necessarily equi-distant from, $\S 173-2$.

Original, $\$ 177-4$.

Adopted, § 177-5.

DISTRICT RULES: See Local Rules, Regulations and Customs.

May require additional expenditure, $\$$ 193-2.

DITCH may be mining ground, $\S 102-9$.

Rights of way for, $\S 142$. 
(The references are to the sections and their subdivisions.)

DITCHES AND RESERVOIRS: See Easements; Rights of Way.

DREDGE CLAIMS in general, \$ 124.

Location, § 124-2.

Californian provision, $\S 124 \mathrm{a}$.

DUMP, no provision for in mining act, $\S 139$.

DYKES, definition of, $\S 50-43$.

EASEMENTS left to local law, § 77.

Californian provision, $\$ 77$, note 1 .

Exception as to right of way, $\S 77$.

Exception as to water and ditch rights, $\$ 77-2$.

No legal proceedings necessary, when, $\S 77-3$.

Condemnation proceedings, § 77-3.

Damages to settler, $\S 77-4$.

ELECTRICAL POWER, rights of way for, $\S 142$. Appropriation of water for, $\S 143$, note 1 .

EMINENT DOMAIN: See Condemnation Proceedings.

ENABLING ACT: See Federal Statutes.

END LINES, courts cannot enlarge location by new, $\S 110-3$. Presumption as to relative position to strike of vein, $\S 112-2$.

Not necessarily equi-distant from discovery, $\S 173-2$.

Definition of, $\S 177-23$.

Effect of non-parallelism of, $\S 177-23$.

Effect of establishing, § 177-24.

Existence of essential to extra-lateral right, § 177-24.

Parallelism of question of fact, $\S 177-25$.

Constructive, § 177-26.

ENTRY: See Certificate of Entry.

An inceptive right, $\S 93$.

Term sometimes applied to re-location, $\S 93$.

Preferential right of, $\S$ 93-2.

Certificate of, $\S$ 93-3.

Cancellation of, $\S 93-6$.

Repayment upon cancellation of, § 93-7.

Requisites under Homestead law, $\S 93$, note 1 . Joint entry, § 119-8. 
(The references are to the sections and their subdivisions.)

EVIDENCE: Miner's rules, §1-10; $\$ 19$, note 2 .

Burden of proof may be cast by land department, $\S 26-5$.

Map as, $\S 36-6-7-8-9-10$.

In case of abandonment, $\S 72-7$.

In case of forfeiture, $\S 73-3$.

In case of attack upon patent, $\S 82-3 ; \S 82$, note 9 .

Effect of false or forged documents, $\$ 82-9$.

Model as, § 85-12.

In case of identity of vein, $\S 112-3-4$.

As to sufficiency of natural object or permanent monument, § 151-4.

As to discovery, $\S 157-2-3-4-5-6-7-8-9-10-11-12$.

Required of re-locator, $\S 177-6$.

End lines, § 177-25.

In case of re-location, $\S 179-7$.

In aid of location, $\S 185-6-7-11 ; \S 190-11$.

Of discovery and appropriation, $\S 186-2-4$.

Amended notice, $\S 187$.

Re-location notice, $\$ 188-3-4$.

Outside of record, $\S 190-11$.

Californian provision, $\S 190$, note 17 .

Record does not preclude parol, § 190-13.

When record prima facie, $\$ 190-14$.

Record color of title, $\S 190-15$.

In case of annual expenditure, $\S 194$, notes 26 and 35 ;

$\S 195$, note $1 ; \S 196$, note 5 .

Admissible and inadmissible evidence in annual expenditure, $\S 194$, note 35 , and $\S 196$, note 6 .

Proof of performance, $\$ 196-3$.

Californian provision, $\S 196$, note 1 .

Settled by patent, $\S 207-5-6-7$.

In application for patent, $\S 212-6, \S 213-2, \S 214-11-12$, $\S 216$, note 6 .

of dismissal, relinquishment or abandonment of adverse suit, $\S 216$, note 6 .

EXAMINATION OF TITLE: See Title; Abstracts of Title.

EXCESSIVE DEPOSITS: See Unused Deposits.

EXCESSIVE LOCATIONS: See Locations.

EXCISE TAX: See Corporation; Federal Statutes.

EXEMPTIONS, definition of, $\$ 94$.

Californian provision, $\S$ 94-2. 
(The references are to the sections and their subdivisions.)

EXPENDITURE IN PATENT PROCEEDINGS: See Patent Proceedings.

EXTRA-LATERAL RIGHT: See Lode Claims; Dip Right; End Lines.

Departure from side lines, $\S 110-4-6$.

Prior rights preclude, $\S 110-4, \S 111-4$.

Controlled by form of location, $\S 111$.

Sometimes controlled by priority, $\S 111$.

When do not attach to irregularly shaped locations, $\S 111-2$.

Attach to irregularly shaped locations, when, § 111-3.

When do not attach to vein or lode, § 111-3.

When priority immaterial, § 111-5.

Unlawful intrusion, § 113.

Securing for irregularly shaped ground, §§ 113-2; § 180-3.

FALSE TESTIMONY, will not defeat patent when, $\$ 82-9$.

FEDERAL COURTS: See Courts.

FEDERAL STATUTES:

Alaskan mining, $\S 3$.

Philippine mining, \&5.

Judiciary Act of 1911, § 17 .

Enabling Act, $\S 120$, note 2 .

Remedial Act, $\S 120$, note 12 .

Excise Tax upon corporations, $\$ 220$.

FINAL CERTIFICATE: See Receiver's Receipt.

FISSURE VEINS: See Vein, Lode or Ledge.

Definition of, § 50-19.

Characteristics of, $\S 50-19$.

May not form part of zone, \& 50-19.

FIXTURES: See Chattel.

Definition of, $\S 95$.

Examples, \& 95-2.

Californian provision, \& 95-3.

Character of title to soil immaterial, § $\mathbf{9 5 - 4}$.

FLOAT: Definition of, § 99-4.

Belongs to finder when, 899 , note 4 .

FOREST RESERVES, mineral land within subject to mineral location, § 45 .

Land department may inquire into sufficlency of discovery, $\S 45$, note 2 . 
(The references are to the sections and their subdivisions.)

Limitation as to creation of, $\S 120$, note 2 .

Timber and stone in, $\$ 131$.

Rights of way in, $\S 142$.

Appropriation of water in, $\$ 143$, note 1 .

FORFEITURE: See Abandonment.

Under district rules, §1-11.

Definition of, $\S 73$.

Distinction between and abandonment, $\S 73$.

Proof in case of, $\S 73-2 ; \S 73$, note $2 ; \S 197-3$.

Burden of proof, $\S 73-3$.

Courts reluctant to enforce, $\S 73-4$.

Pleading in case of, $\$ 73-5$.

Question of cannot be raised, when, § 73-6.

In oil land leases, $\S 122-4$.

Term "lapsed" not equivalent to, § 197, note 2 .

FORMS: See Index of Forms.

FRAUD: See Fraudulent Patentee; Patents.

FRAUDULENT PATENTEE a trustee, $\S 82-4$.

Not attack upon patent, $\S 82-5$.

Status of trustor, $\S 82-6$.

Charges of fraud must be specific, $\S 82-7$.

Application to sue, $\$ 82-8$.

FRAUDULENT PLACER LOCATION, extent of right in, $\S 170$.

Innocent participants in, $\S 170-2$.

GRUB-STAKE CONTRACT, definition of, $\S 57$.

Qualified partnership, § 57-2.

Not mining partnership, § 57-2.

Parties to are trustees, $\S 57-3$.

Right to property under, § 57-4.

Consideration for, $\S 57-5$.

Termination of, $\S 57-6$.

Accrued rights not disturbed, § 57-7.

Subsequent location, § 57-7.

Omission of name from notice immaterial, $\S 57$, note 8 .

Duty of outfitter, $\S 57-8$.

Duty of prospector, $\S 57-9$.

What is not a, $\$ 57-10$.

Prospector may pay for supplies, $\$ 67$, note 16 .

HAWAII, local statutes prevail in, $\S 4$.

Land department without jurisdiction, § 4-2. 
(The references are to the sections and their subdivisions.) HEARINGS governed by Rules of Practice, $\S 25$.

Are of two kinds, § 25-2.

Different parties may, in good faith, claim same land as of either class, $\S 25$, note 2 .

Presumption, § 25-3.

Presumption overcome by testimony, § 25-3.

Character of testimony, $\S 26$.

Use may tend to establish character of land, $\$ 26$, note 1 .

Testimony must be specific, $\$ 26-3$.

What land not reserved as mineral, $\S 26$, note 3 .

Mere discovery insufficient, $\S 26-4$.

Burden of proof, $\& 26-5$.

Exceptions, § 26-6.

Conclusiveness, $\S 27$.

Segregation survey, \& 27-2.

Judgment not equivalent to patent, § 27-3.

Subsequent legal proceedings, \& 27-4.

HOMESTEADS: What necessary to constitute entry of, $\S 93$, note 1 .

Divestiture of title to, $\S 104-7$.

Possession of between agricultural and mineral claimants, § 104-8.

HORIZONTAL VEIN: See Blanket Vein; Discovery.

HORSE, definition of, $\S 50-42$.

HYDRAULIC CLAIMS, definition of, §.123.

Restriction of mining, $\S 123-2$.

Constitutionality of act, $\S 123-3$.

Unrestricted mining, \& 123-4.

IMPREGNATIONS, sufficient when traceable as body of ore, $\S 50-62$.

When mining limited by, §124a-2.

IMPROVEMENTS: See Annual Expenditure.

Pass to re-locator, when, § 179-7.

Definition of, § 193.

INDEPENDENT ESTATES: See Deeds.

INDIAN LANDS not subject to location, § 46-2.

May be leased, § 46-2.

May be declared to be mineral land, $\$ 46-3$. 
(The references are to the sections and their subdivisions.)

Patents for, § 46-4.

Timber cutting in, § 132 .

INDICATIONS not sufficient discovery, $\S 50-61$.

INJUNCTIONS: See Licenses.

In cases of trespass, $\S 85$.

Courts liberal in granting writ, $\S 85-4$.

Denial of, $\S 85-5 ; \S 85$, note 10 .

What writ should contain, $\S 85$, note 7 .

INSPECTION: See Trespass.

INTERSECTING VEINS. Veins intersect upon strike or $\operatorname{dip}, \S 50-29$.

Rights below point of union, $\S 50-29$.

Apex of, § 50-30.

JOINT ENTRY: See Entry.

JUDGMENT: See Possessory Actions; Adverse Suits.

JURISDICTION: See Courts.

Test of, $\S 206$, note 17 .

KNOWN VEIN, definition of, $\S 50-34$

How existence established, §50-34, § 119-3.

Existence of, $\S 50$, note 43 .

Not synonymous with located vein, $\S 50$, note 43 .

Subsequent discovery of within placer, $\S 119-4$.

Good faith of placer claimant, $\S 119-4$.

When subject to location, §119-4a.

Effect of excluding, $\S 119-9$.

Limitation of surface, $\S 119-10$.

What validity of upon patented placer depends upon, $\S 119$, note 20 .

LABOR: See Annual Expenditure.

Definition of, $\S 193$.

LACHES: See Co-tenants.

Definition of, $\S 78$.

Unlike limitation, § 78-2.

Equitable defense, § 78-3.

Excuse for delay, \& 78-4.

Measure of diligence, $\S 78-5$.

In relation to mining claims, $\S 78-5$.

What defendant must show, § 78-6. 
(The references are to the sections and their subdivisions.)

Plaintiff's allegations, § 78-7.

Trespass validated by, $\S 172-6$.

Favorable to overlapping locator, § 180-7.

LAND DEPARTMENT: See Courts; Possessory Actions; Adverse Suit; Official Surveys; Contests; Hear. ings.

How constituted, $\S 23$.

Special tribunal, $\S 23$.

Powers of, $\S 23-2$.

Subordinate officers of, $\S 23$, note 1 .

Courts take judicial notice of regulations of, $\S 23$, note 2.

Action of courts upon regulations of, $\S 23$, note 2 .

Judgment of unassailable, § 23-3.

Courts not vested with supervisory power over, when, $\S 23-3$.

Judgment not conclusive, §23-4.

Board of Equitable Adjudication, § 23-5.

Character of entries submitted, § 23-6.

Procedure, \& 23-7.

Appeal, § 23-8.

Termination of jurisdiction, $\S 23-9$,

LAND DISTRICTS, definition of, $\$ 41$.

Additional, § 41-2.

LAPSED, not synonymous with forfeiture, $\S 197$, note 2.

LAW OF POSSESSION, definition of, $\S 19-2 ; \S 19$, note 1 .

LEASE: See Mining Leases, Oil Land Leases.

LEDGE MATTER, definition of; § 50-35.

How recognized, § 50-35.

How considered, $\S 50-35$.

May not warrant location, $\S 50-35$.

LESSEE cannot re-locate, when, § 179-5.

LICENSE TAX: See Californian Statutory Law.

LICENSES, test to determine whether lease or, \$61-2a.

Definition of, $\S 62$.

Intent, not form controls, § 62-2.

When revocable, § 62-3.

When irrevocable, § 62-4.

Injunction, § 62-5. 
(The references are to the sections and their subdivisions.)

LIENS: See Mechanics' Liens.

How created, § 79 .

Not impaired by patent, § 79-2.

Waiver or loss of, $\S 79-3$.

Protection against, $\$ 79-8$.

Illustrations, $\$ 79$, note 6 .

LIMITATION OF ACTIONS: See Co-tenants.

On cancellation of patent, $\S 82-2$.

Sale to bona fide purchaser, $\S 82-2$.

Junior locator may acquire by, $\S 180-7$.

LOCAL RULES, REGULATIONS AND CUSTOMS, basic principle of, $\S 1$.

Introduction and source, $\S 1$.

Cause of establishment, $\S 1$ 1-2.

Common law of mining, $\S 1-3$.

Statutory limitations, \& 1-4.

Californian provision, $\S 1$-5.

Effect of absence of, $\S 1-6$.

When void, § 1-7.

Presumptions, § 1-8.

No distinction between, $\S 1-9$.

How construed, § 1-9.

Judicial notice of not taken, $\S 1-10$.

Existence must be proved, \& 1-10.

When in force must be complied with, § 1-11.

Must provide for forfeiture, $\S 1-11$.

LOCATION: See Amended Location; Consolidated Location; Re-location.

Test of as lode or placer claim, $\S 47$, note 6 .

Of lode usually laid along outcrop, $\$ 50-46$.

Grantor cannot attack validity of, $\$ 67-8$.

Refers to what, § 96 .

Includes both lode and placer claim, $\S 96$.

Mining claim may consist of several, $\S 96-2$.

Consolidated, § 96-3.

Technical, § 96-4.

Illustrations, $\S$ 96-5.

As property, § 96-6.

Incidents of ownership, $§ 96-7$.

Not community property, $\S 96-8$.

Taxation of possessory right, $\S 96-9$.

Of land not held by superior right, $\S 104$, note 6 .

By intrusion, § 113. 
(The references are to the sections and their subdivisions.)

Of mill-sites, § 116-6.

Must be part of public domain, $\S 168$.

Three kinds of mineral, $\S 168$, note 1 .

When title to vests, $\S 168-2$.

Marking of before discovery, $\S 168-2$.

Priority of title to, $\$ 168-3$.

Questioning character of land in, $\S 168-3$.

Independent, § 168-4.

Oregonian provision, $\S 168$, note 9 .

Limitation of saline land, $\S 168$-4.

Limitation of mill-site, $\S 168-4$.

Invalid or incomplete, $\S 168-5$.

Form of lode, $\S 168-6$.

Form not absolutely essential, § 168, note 14 .

Form of placer in Alaska, $\S 168$, note 14 .

Effect of form of lode, $\S 168-6$.

Form of placer on surveyed land, $\S 168-7$.

Form of placer must conform to law, when, $\S 168-8$.

Form of placer in California, $\S 168$, note 16 .

May be made upon a holiday, $\S 168-9$.

Equivalent of, $\S 169$.

Fraudulent placer, $\S 170$.

Innocent participants in fraudulent placer, $\$ 170-2$.

Voidable, § 171.

Void, § 172 .

Timber may be an incentive to make, $\S 172-5$.

Trespass upon initiates no rights, § 172-6.

Trespass validated by laches, $\$ 172-6$.

Size of lode, $\S 173$.

Measurement of lode, $\S 173-2$.

Presumption as to measurement of lode, $\S 173-3$.

Excessive size of lode, $\S 173-4$.

Fraud presumed, $\S 173$, note 10 .

Segregation of, $\S 173-5$.

Reasonable time to segregate, § 173-6.

Size of placer, $§ 174$.

Excessive size of placer, $\S 174-2 ; \S 173$, note 10 .

Size of tunnel sites, $\S 175$.

Excessive size of tunnel site, $\S 175-2$.

Size of mill-site, $\$ 176$.

Form of mill-site, $\S 176-2$.

Acts of, $\S 177$.

Insufficiency of acts of, $\S 177-10$.

What valid secures to locator, $\$ 179$, note 3 .

When void, $a b$ initio, $\S 180$, note 11 .

When equivalent to patent, $\S 206$, note 16 . 
(The references are to the sections and their subdivisions.)

LOCATION MONUMENTS: See Boundaries.

LOCATION NOTICE: See Record of Location.

Of mill-site, $\S 116$, note 5 .

Of placer claims, $\S 119$, note 17 .

Not required by mining act, $\S 185$.

Supplementary legislation affecting, § 185-2.

Contents of, $\S 185-3, \S 186-3-11$.

Additional recitals, \& 185-4.

When omissions in fatal, §185-4.

Not part of location, when, $\S 185-5$.

When question of sufficiency arises, § 185-6.

Oral testimony may aid, § 185-7, §186-4.

Construction of, $\S 185-9$.

Sufficiency of, $\$ 185-10, \S 186-3$.

Under federal law not necessary to state character of mineral in placer, $\S 186$, note 4 .

Protection to locator, $\S 186$.

Description in, $\$ 186-5$.

Errors in description, $\S 186-7$.

Surplusage in, § 186-8.

Where posted, § 186-9.

Miners' devices, $\S 186-10$.

Presumption, \& 186-11.

Purpose fulfilled, when, § 186-11.

Amended, § 187.

Re-location, § 188.

Record, § 190 .

When description binding on locator, $\S 190$, note 9 .

LOCATORS: See Citizens and Aliens; Agents.

Right of competent to initiate claim, $\S 104$, note 6 .

Character of right granted to, $\S 162 ; \S 162$, note $1 ; \S 179$, note 3.

Basis of possession, $\S 162-2$.

How rights may be lost, $\S 162-3$.

Renunciation of rights, $\S 162-4$.

Who may not be, $\S 165$.

Age, sex, residence or citizenship of immaterial, § 168-10.

LODE: See Vein, Lode and Ledge.

LODE CLAIMS: See Extra-Lateral Right.

Definition of, § 110.

Californian provision, $\S 110$, note 1 .

Must include top or apex, $\S 110-2$. 
(The references are to the sections and their subdivisions.)

Exclusive right of surface, $\S 110$-3.

Courts cannot enlarge, $\$ 110-3, \S 110$, note 4 .

Exclusive right of all veins, $\S 110-4$.

It is presumed that include a vein or lode, $\S 110-5$.

Limitation is as to size, not shape, $\S 111$, note 1 .

LODE WITHIN PLACER CLAIM subject to location, when,

$\S 181$.

Presumption in favor of placer claimant, $\S 181-2$.

Trespass upon, $\S 181-3$.

Not a trespass upon, $\S 181-4$.

Limitation as to area, $\S 181-5$.

MAPS must be supported by competent evidence, $\S 36-5-6$.

Testimony of surveyor, $\S 36-8$.

Fabricated survey, § 36-9.

Does not put lode in claim, $\S 36-10$.

MARKETABLE TITLE: Want of insufficient grounds for rescission, \& 83-9.

MARKINGS, definition of, $\S 97$.

MARKS: See Markings; Boundaries; Monuments.

MASTER AND SERVANT. Safe place, $\S 80$.

Fellow servants, $\S 80-2$.

Assumption of risk, $\S 80-3$.

Legislative safeguards, $\$ 80-4$.

Limitation of hours of labor, $\S 80-5$.

Californian law in relation to Quartz Mines, Coal

Mines, Bell Signal Acts, and Hours of Labor.

$\S 80$, notes $5,6,7,8$.

Constitutionality of act, $\S 80-6$.

MEANDER LINES: See Public Land Surveys; Dredge Claims.

MECHANICS' LIENS: See Liens.

Creature of local statute, $\S 79-4$.

Purpose of, § 79-5.

Contract essential, § 79-6.

Option holder not vendee nor agent, $\S 79$, note 12 .

Protection of owner, § 79-7.

Statutory requirement, $\S 79-8$.

Indemnification, $\S 79-9$.

Subordinate to mortgage, § 79-10. 
(The references are to the sections and their subdivisions.) METAL: See Mineral.

MEXICAN GRANT, mineral locations may be made in unconfirmed, § 45 .

Mine within, not a mining claim, when, § 102-6.

MILITARY RESERVATIONS, mineral location may not be made in, $\S 46$.

Timber cutting in, $\S 133$.

MILL-SITES, what may be located as, § 116.

What may not be located as, $\S 116-2$.

Character of land, $\S 116-3 ; \S 214$, note 5 .

Mining and milling purposes, $\S 116-4$.

Who may locate, $\S 116-5$.

Not a mining claim, $\S 116-6$.

May be mining claim or possession, § 116-6.

Manner of location, $\S 116-6$.

No specific time for use, $\S 116-7$.

Annual expenditure not required upon, § 116-7.

Patenting of, $\S 116-8$.

Californian provision, $\S 119$, note 17 .

MINE, definition of, § 98 .

How existence of determined, $\S 98-2$.

Synonymous with vein or lode, § 98-3.

Includes mines valuable for minerals or valuable mineral deposits, § 98-3.

When used as descriptive name, § 98-4.

Want of identity, § 98-5.

MINER, definition of, $\S 101-8$.

MINERAL: See Mineral Deposits.

Definition of, $\S 99$.

Term should not be confined to metals or metallic ores, $\S 99$, note 1 .

All metals are, $\$ 99$, note 1 .

Substances, § 99-2.

When within purview of mining laws, $\S 99-3$.

MINERAL DEPOSITS: See Mineral; Mineral Lands.

What declared by Congress to be, $\$ 47$.

Test for location, $\S 47$, note 6 .

What the courts and the land department have declared to be, $\$ 47$. 
(The references are to the sections and their subdivisions.)

MINERAL DISTRICT: See Mining District.

Definition of, $\S 42$.

MINERAL LANDS: See Mineral; Mineral Deposits.

What subject to location as, § 45 .

Land valuable for its mineral deposits defined, $\S$ 45-2.

Classification of land, $\S 45-3$.

Character conclusively determined by land department, $\S 45-4 ; \S 154$, note 2 .

When question of character usually arises, $\S 45-4$.

What lands not subject to location as, § 46 .

Test as to form of locating, $\S 47$, note 6 .

Equivalent terms, $§ 135$, note 5 .

MINERAL RIGHT: See Mining Right.

Definition of, $\S 103$, note 1 .

MINERALS IN WATER: Right to mine limited in California, § 124a.

MINERS' DEVICES, for protection of posted notice, $\$ 186$ 10.

MINER'S INCH not definite when, $§ 100$.

Californian provision, $\S 100-2$.

MINERS' RULES: See Local Rules, Regulations and Customs.

MINING: See Prospecting and Mining; Process of Mining; Process of Milling; Business of Mining; Superintendent; Shift Boss; Miner; Mining for Oil.

MINING CLAIM: See Mining Ground.

Unpatented held by peculiar title, $\S 89$, note 3 .

And location used interchangeably, § 96-2.

May consist of several locations, $\$ 96-2$.

Definition of, $\S 102$.

Statutory meaning, § 102-2.

Distinction between and location, § 102-3.

Distinction between and mining ground, $\S 102-4$.

Navigable river not a, $\$ 102-5$.

Mexican grant not a, $\S 102-6$.

Agricultural patented land not a, § 102-7.

Oil claim is a, $\S 102-8$.

Coal mine is a, $\S 102-8$.

Unworked placer, in probate proceedings, §102-10. 
(The references are to the sections and their subdivisions.) MINING CLAIM OR POSSESSION: Definition of, §135, note 5 .

MINING DISTRICT: See Mineral District.

Definition of, $\S 43$.

Extent, § 43-2.

Changing boundaries, $\S 43-3$.

No certain number of persons necessary to create, § 43-4.

Corporation may help to form, § 43-5.

Mode of organization not subject of inquiry, § 43-6.

Effect of fraud, $\S 43-6$.

Officers of, § 43-7.

Duties of recorder of, $\S 43-8$.

Recorder's errors not necessarily fatal, § 43-8.

MINING FOR OIL, how safely conducted, § 121.

No limit to drainage, $\S 121-2$.

Unlawful drainage, $\S 121-3$, note 3 .

Possession of land not possession of oil, $\S 121-4$.

When a nuisance, $\S 121-5$.

Californian provision, $\S 121-6$.

Text of Californian act regulating, $\$ 121$, note 8 .

Diligence in drilling to success or abandonment, $\$ 121-8$.

Test well, § 121-9.

Partnership, \& 121-10.

Limitation as to power of partners in, $\S 121-11$.

Partition, § 121-12.

Damages, §121-13; § 121, note 3 .

MINING GROUND: See Mining Claim.

Distinction between, and mining claim, § 102-3.

Navigable river may be, $\S 102-5$.

Agricultural patented land may be, §102-7.

Ditch may be, § 102-9.

MINING LAND, definition of, $\S 102-4$; $\$ 120$, note 1 .

MINING LEASES: See Oil Land Leases.

Have peculiar details, $\S 61$.

Sometimes coupled with option, § 61 .

Time essence of, $\S 61$.

When contract of labor, $\$ 61$.

Meaning of continuously, $\S 61-2$.

Stoping, \& 61-3.

Royalty, implies diligent exploration, § 61-4.

Extension of rights under, $\$ 61-4$. 
(The references are to the sections and their subdivisions.)

MINING PARTNERSHIPS: See Grub-stake Contract; Cotenants; Mining for Oil.

Distinct from ordinary, $\S 58$.

Peculiar rules applicable to, § 58-2.

Essential difference between and ordinary, § 58-3.

How created, \& 58-4.

General partners, when, § 58-5.

Partners are trustees, $\S 58-6$.

Control of partnership property, § 58-7.

Debts, $\S 58-8$.

Liens, \& 58-9.

Accounting, \& 58-10.

Dissolution of, § $58-11$.

Sale by partner, \& 58-12.

MINING RECORDER: See Mining District.

MINING RIGHT: See Mineral Right.

Not capable of partition, $\S 81-4$.

Definition of, § 103.

Is a species of trade, $\S 103-2$.

Qualified partnership in, § 103-3.

MINING TITLE, definition of, § 103-4.

MODEL as evidence, § 85-12.

MONUMENTS: See Marks; Boundaries.

Control courses and distances, when, § 151, note 17 .

Do not mark boundaries, § 177-13.

Written notice sufficient, § $177-13 ; \S 177$, note 7 .

Position of, § 177-14.

May be upon patented or unpatented ground, § 177-14.

Consent to place, $\S 177-15$.

Limitation as to placer, $\S 177-17$.

Placer in California, Nevada, Washington, § 177-17.

Discrepancy as to government, § 177-18.

Changing position of, $\S 177-19$.

Obliteration of, \& 177-20.

When existence of must be established, § 177-21.

By whom placed, § 177-22.

MORTGAGE, may require assent of stockholders, $\S 67$, note 10.

When subordinate to lien, $\S 79-10$.

MORTGAGEE. Annual expenditure by, § 79-10.

MORTGAGOR cannot re-locate, when, § 179-5. 
(The references are to the sections and their subdivisions.) NAME OF LODE. Meaning of "this vein," $§ 186-5$.

Different in different locations, $\$ 186-6$.

NATURAL GAS, prevention of waste in California. Definition of, $\$ 120$ a.

NATURAL OBJECT: See Permanent Monument.

Definition of, $\S 149$.

Not always possible to refer to, $\S 149-2 ; \S 185-3$.

Is starting or initial point, $\S 151$.

Purpose of reference in record, $\$ 151-2$.

Failure to refer to in record is fatal, $\S 151-2$.

Imperfections in reference to should not vitiate, $\S 151-2$;

$\S 151$, note 8 .

Reference should identify claim, § 151-2.

Sufficiency a question of fact, $\S 151-2$.

When any sufficient, $\S 151-3$.

Presumptions as to sufficiency, $\S 151-3$.

May be on or off location, $\S 151-3$.

Burden of proof, $\S 151-4$.

Ties to, $\S 151$, note 8 .

NITRATE LANDS: See Salt Claims.

NOTICE, in land office proceedings, $\S 24-4-8 ; \S 24$, note 12 ; $\S 214$, note 23.

NOTICE OF LOCATION: See Location Notice.

NUISANCE: See Mining for Oil; Water-Rights.

OBLITERATION OF MARKS, when without fault or act of claimant, \& 177-20.

OFFICIAL SURVEY: See Patent Proceedings.

Is one made in course of patent proceedings, $\S 36$.

Lode claim survey, $\S 36-2$.

Placer claim survey, $\S 36-3$.

Connecting line, § $36-4$.

Effect of failure to refer to connecting line, $\S 36-5$.

When agricultural claimant must prove mineral character under, \$37-2.

May be made one day after location, § 211-9.

OIL-BEARING STRATA, definition of, $\S 47$, note 51 .

OIL CLAIMS: See Mining for Oil; Oil Land Leases.

Land worked as, is a mining claim, $\S 102-8$.

When subject to location, $§ 120$. 
(The references are to the sections and their subdivisions.)

Oil is a mineral substance, $\S 120$, note 1 .

Preservation of rights in, $\$ 120-2$.

Text of Enabling Act, $\S 120$, note 2 .

Withdrawal, definition of, $\$ 120-3$.

When withdrawal takes effect, $\S 120$-3.

Withdrawals in California, $\S 120-4$.

The power of the President, $\S 120-5$.

Act of June 25, 1910, purpose of, $\S 120-6$.

Construction of Enabling Act, $\S 120-7$.

Protection under saving clause, § 120-8.

Opinion of the writer, $\S 120-9$.

Peculiar conditions incident to, $\S 120-10$.

Questions arising from conditions, § 120-11.

Conflict of authority, $\S 120-12$.

Established law, § 120-13.

Forcible entry and detainer, $\S 120-14$.

Possessio pedis, $\$ 120-15$.

Effect of conveyance of before discovery, $\S 120-16$.

Departmental ruling upon conveyance before discovery, $\S 120-17$.

Confusion in land titles, $\S \mathbf{1 2 0 - 1 8}$.

Rule of property, $\S 120-19$.

Remedial legislation, $\$ 120-19$-a-b-c-d.

Text of Remedial Act, $\S 120$, note 12 .

Discovery, definition of, $\S 120-20$.

Insufficient discovery, \& 120-21.

Possession while making discovery, § 120-22.

Good faith in locator necessary, $\S 120-23$.

Single discovery may be sufficient, § 120-24.

Scripping, § 120-25.

Limitation of group of in annual expenditure, $\S 194-4$.

OIL LAND LEASES: See Leases.

Peculiar nature of, $\S 122$.

How construed, § 122-2.

Implied covenants, § 122-3.

When re-entry warranted, $\S 122-4$.

Vested right, $\S 122-5 ; \S 122$, note 7 .

Taxation, $\$ 122-7$.

Distinction between oil and solid minerals, $\S 122$, note 7 . "Grant" and "lease" interchangeable terms, § 122, note 7.

OIL MINING: See Mining for Oil.

OKLAHOMA, lands subject to mineral location in, $\S 46$, note 4. 
(The references are to the sections and their subdivisions.)

OPTIONS, definition of, $\S 66$.

May be a license or covenant, $\S 66$.

May be coupled with a lease, $\S 66$.

Time essence of, $\S 66$.

How secured in California from estate in probate, $\S 66$, note 1.

Distinction between and contract, § 66-2.

When merely offer of sale, $\S 66-3$, note 7 .

Sufficient consideration, § 66-4.

Duty of owner, $\S 66-5$.

Damages, § 66-6.

May be agreement to sell, $\S 66$, note 6 .

Default in payments, $\S 66-7$.

When parties to mutually bound, $\S 66$, note 7 .

Option holder is neither vendee nor agent, § 79, note 12.

ORE. Error in estimating ore in sight, § 99-4.

Definition of, $\S 99-5$.

Ore in sight, $\$ 99-6$.

Personal property, § 99-7.

Reliance upon statements of ore in sight, $\S 99$, note 7 .

OREGON, limitation upon lode locations, §168, note 9 .

OTHER ROCK IN PLACE, definition of, $\S 50-38$.

OUTCROPPINGS, definition of, §50-44.

Sometimes used synonymously with top or apex, §50-44.

Identity of vein and outcrop, § 50-45.

Are not essential, § 50-46.

Locations usually laid along, § 50-46.

Existence of does not establish mine, § 50, note 94 .

OVERLAPPING LOCATIONS cannot affect valid subsisting location, $\S 179$, note 3 .

Of common occurrence, $\S 180$.

How caused, § 180.

When awarded to junior locator, $\S 180$.

Basis, § 180-2.

Boundary marks of, $\S 180-3$.

Consent of owner, $\$ 180-4$.

When re-location necessary, $\S 180-5$.

Failure to adverse, $\S 180-6$.

Title to by efflux of time, $\S 180-7$.

PARTITION: See Co-tenants; Mining for Oil.

Mining claims subject to, $\S 81$.

Suit for usually results in sale, $\S 81$. 
(The references are to the sections and their subdivisions.)

Why suit for usually results in sale, $\S 81$, note 3 .

Agreed, § 81-2.

Arbitration, $\S 81-3$.

Mining right not capable of, $\S 81-4$.

PARTNERSHIP: See Mining Partners; Mining for Oil.

Re-location by member of, $\S 179-5$.

PATENT PROCEEDINGS (In General).

Refusal of application, $\S 29-5 ; \S 214$, note $1 ; \S 216$, note 3 .

Who may obtain patent, § 211 .

Manner of obtaining patent, $\S 211-2$.

Limitation as to mill-sites, $\S 211-3 ; \S 214$, note 5 .

Limitations as to saline lands, $\S 211-3 ; \S 214$, note 8 .

Survey of claims, $\S 211-4$.

When all placer ground, $\S 211-5 ; \S 214$, note 6 .

Mixed lode and placer, $\$ 211-6$.

Waiver of known vein, $\S 211-7$.

Adverse claimant, § 211-8.

Time to apply for patent, § 211-9.

Place for filing application, § 211-10.

Time to complete application, $\$ 211-11$.

Completion of application, $\S$ 211-12.

Payment for land, $\S 211-13$.

Divers patents, $\S 211-14$.

\section{(The Survey).}

Application for, § 212.

To whom application for addressed, § 212 .

Accompanying papers, § 212-2.

Deputy surveyor, § 212-3.

Duties of deputy, $\S 212-4$.

Errors of deputy, § 212-5.

Expenditure upon claim, § 212-6.

Conclusiveness of certificate, $\S 212-7$.

Equivalent of certificate, $\S 212-8$.

Basis of deputy's report, $\S 212-9$.

Sufficient expenditure, § 212-10.

Insufficient expenditure, $\$ 212-11$.

Plat and field notes, § 212-12.

Return of unused deposits, $\S 212$, note 4 .

Oaths of assistants, $\$ 212$, note 10 .

(Plat and Notice).

Nearest newspaper, $\S 200$, note 14 .

Contents of notice, $\S 213$. 
(The references are to the sections and their subdivisions.)

Where, how, and for how long posted, § 213.

Proof of posting, § 213-2.

Place for making affidavits, § 213 , note 7 .

Time for filing proof, $\S 213-3$.

Copies required, § 214-6.

Contents of, $\S 214-7$.

Sufficiency of, § 214-7.

Insufficient, $\S 214-8$.

Publication of, $\S$ 214-9.

Charges for publication of $\S 214-10$.

Proof of publication of, $\S 214-11$.

Proof of continuous posting, § 214-12.

When modification of necessary, $\S 214$, note 20 .

Equivalent to summons, § 214, note 23.

Designation of newspaper subject to review, §214, note 25 .

Computation of time, $\S 214$, note 30 .

(Application for Patent).

Made by whom, $\S 214$.

Contents of, $\S 214$.

Possessory title of applicant, §214, note 13.

(Citizenship).

How shown, § 214-2.

(Attorney).

Applications for patent may be made by attorney in fact, $\S 214-3$.

When appointment not effective, § 214, note 12 .

(Abstract of Title).

Subsequent transfers, § 67, § 214-5.

Contents of, § 214-4.

Supplemental, § 214, note 13 .

By whom certified, § 214-4.

What certificate abstracter must furnish, § 214-4.

(Fees and Charges).

Statement of paid, § 214-13.

(Application to Purchase).

In writing to be filed, § 214-14.

(Receiver's Receipt).

Equivalent to patent, $\S 93-3 ; \S 214-15$.

When not sufficient to prevent annual expenditure, $\S 214-15$.

Names of trustor and trustee to be inserted in, $\S 214$, note $\mathbf{y}$. 
(The references are to the sections and their subdivisions.)

Not equivalent to patent, $\S 214-15$.

May be cancelled, § 214-15.

When void, § 214-15.

No annual expenditure required after issuance, when, $\S 214-15$.

After issuance record forwarded, § 214-16.

Cancellation of not necessarily fatal, § 214-20.

(Protest).

By whom may be filed, $\S 24 ; \S 214-17 ; \S 215-2$.

Grounds of, § 214-18; § 215, note 10 .

Waiver of, § 214-19.

May delay patent, $\S 214-20$.

Confined to land department, when, § 214-20.

Cancellation of entry, $\S 214-21$.

Appeal by protestant, $\S 214$, note 50 .

Distinction between and adverse, § 215-2.

When may be filed, $\S 215-2$.

Sometimes has effect of adverse, $\S 215$-2.

Cannot take place of adverse, $\S 215$, note 10 .

(Adverse Claim): See Adverse Suit.

Effect of senior locator's failure to file, § 180-6.

Limited to surface conflicts, § 215.

Distinction between and protest, $\S 215-2$.

Filing protest after loss of right to file, $\S 215-2$.

No equitable right lost by failure to file, § 215-2.

Contents of, $\S 215-3$.

Time of filing, $\S 215-4$.

Computation of time, $\S 215-5$.

No extension of time, $\S 215-6$.

Effect of filing, § 215-7.

Evidence of waiver, $\S 215-8$.

Appeal lies for rejection of; $\S 215-9$.

Not necessary to file when, $\S 215$, note 11 .

By whom verified, $\S 215$, note 12 .

Effect of failure to comply with rules, $\S 215$, note 12 .

For sufficiency of, $\S 215$, note 13 .

For insufficiency of, $\S 215$, note 13 .

May be amicably adjusted, $\S 215$, note 27 .

PATENTS: See Co-tenants; Abstracts of Title; Adverse Possession; Liens; Fraudulent Patentee; Patent Proceedings.

When application for will be rejected, $\S 29-5 ; \S 214$, note 1.

May be cancelled, $\S 82$. 
(The references are to the sections and their subdivisions.)

Bona fide purchaser, $\S 82-2$; $\$ 134-2$.

Burden of proof, $\S 82-3$.

Concealment of facts not basis for attack upon, $\S 82$, note 12 .

Agricultural, § 102-7; §111-5; §116-8.

For mill-sites, $\S 116-8$.

For placer claims, § 119-7; § 168-8; § 181-5.

None for tumnel-sites, § 138-11.

Money expended on tunnel-sites counted in proceedings for, $\S 138-11$.

Conclusive evidence of citizenship, $\S 163-4$.

Evidence of corporate existence, $\S 163$, note 3 .

Under statute of limitations, $\S 169-2$.

Improvements in proceedings for, $\S 179-9$.

For lode subsequent to placer, $\S 181-5$.

Definition of, $\S 206$.

When to be applied for, $\S 206$.

Effect of recording, $\S 206$, note 1 .

Not essential, § 206-2; $\$ 206$, note 8 .

What passes by lode, $\S 206$, notes 2 and 4 .

Adds but little to security, $\$ 206-2$.

Distinction between agricultural and mineral, § 206-3.

Placer convey what, § 206-5.

Lode claim may exist within placer, § 206-5.

Receiver's receipt equivalent to, § 206-6.

When void, § 206-7.

Voidable subject to cancellation, § 206-8.

When not assailable, $\S 206$, note 17 .

Superior and exclusive evidence of legal title, § 207.

Equitable title, § 207-2.

Suit to declare trust before, $\S 207$, note 2 .

Superiority of title, $\S 207-3$.

Priority of title, $\S 207-4$.

Facts settled by, $\S 207-5$.

Presumptions attending, \$ 207-7.

State legislation concerning, § 208.

Different in same ground, § 211-14.

Effect of erroneous description in, § 211-15.

Obtained without regard to change in ownership, § 214, note 17.

When will issue, § 216-4.

PAYMENT for lode or placer, § 211-13; § 216-2.

PEDIS POSSESSIO, definition of, $\S 71$, note 6 .

PERJURY: See Patents. 
(The references are to the sections and their subdivisions.)

PERMANENT MONUMENT: See Natural Object.

Definition of, \& 150 .

PETROLEUM OIL CLAIMS: See Oil Claims.

PHILIPPINE ISLANDS, special mining act for, § 5 .

Dissimilar provisions, § 5-2.

Land department without jurisdiction, § 5-4.

PLACER CLAIMS: See Dredge Claims; Hydraulic Claims; Oil Claims; Mining for Oil; Oil Land Leases; Salt Claims; Stone Claims; Tailings; Location.

Definition of, § 119 .

Location rights in, § 119-2.

Known vein within, § 119-3.

Conflicting locations, § 119-4a.

Area of, § 119-5.

Discovery, marking and annual expenditure, § 119-6.

Patenting, § 119-7.

Joint entry of, $\S 119-8$.

Effect of excluding known vein, § 119-9.

Limitation, § 119-10.

Form of, § 168-7.

Size of, § 174 .

Excess may not invalidate, § 174-2.

PLACERS: Definition of, $\S 99-8$.

Include what, § 99-8.

Surface workings, § 99-9.

Unworked may not be a mine, § 102-10.

PLEADING, in federal courts, $\S 11-2 ; \S 12$.

In possessory actions, $\S 19-3$.

Citizenship, § 19-4; § 20-3.

In adverse suits, $\$ 20-3$.

Descriptive name, $\S 67$, note 17 .

In case of abandonment, $\S 72-9$.

In case of forfeiture, $\$ 73-5$.

In case of laches, $\S 78-6-7$.

In case of attack or annulment of patent, $\$ 82-6$, note 9 .

In cases of trespass or waste, $\$ 85-11$.

PORTO RICO. Control of public land, $\S 6$.

POSSESSION, valid location carries right of, $\S 71$.

Meaning of actual, $\S 71-2$.

Actual not required, § 71-3. 
(The references are to the sections and their subdivisions.)

Effect of actual without boundaries, § 71-4.

Constructive, $\S 71-5$.

Constructive without discovery, $\S 71-6$.

Pedis possessio, definition of, $\S 71$, note 6 .

Presumption as to ownership, § 71-7.

Evidence of, $\S 71-8$.

Of land not of oil, $\S 121-4$.

While making discovery, $\S 120-22$; $\$ 154-8$.

Alone is necessary for patent, $\S 206$, note 8 .

POSSESSORY ACTIONS: See Adverse Suit.

Adjudged by law of possession, $\S 19$.

Law of possession, definition of, $\S 19$, note 1 .

Pleading, § 19-3.

May include action to restrain trespass and waste, $\S 19$, note 3 .

Pleading citizenship, § 19-4.

Pending litigation ineffective, $\S 19-5$.

Prior judgment may be ineffective, $\S 19-5$.

Appointment of receiver, $\S 19-6$.

POSSESSORY RIGHT, definition of, $\S 19-2$; $\$ 96$, note 23.

Divestiture of, $\S 19$, note 2 .

POSTED NOTICE OF LOCATION: See Location Notice.

PRIORITY: See Extra-Lateral Rights; Cross Veins; Intersecting Veins; Subsurface.

When fraction of a day may determine, $\S 190$, note 20 .

PROCESS OF MILLING, definition of, $\S 101-3$; $\S 116-4$.

PROCESS OF MINING, definition of, $\S 101-2$; $\$ 116-4$.

PROOF: See Evidence.

PROSPECT, definition of, $\S 98$, note 1 .

PROSPECTING AND MINING, definition of, § 101 .

PROTEST: See Contests; Hearings; Patent Proceedings.

PUBLIC LAND, definition of, $\S 104$.

Distinction between and public use, $\S 104-2$.

Unoccupied and unappropriated, § 104-3.

Vacant, § 104-4.

Occupancy and improvements, § 104-5.

Mineral, § 104-6. 
(The references are to the sections and their subdivisions.)

PUBLIC LAND SURVEYS: See Official Survey.

Distinction between and official, $\S 35$.

Made under direction of Surveyor-General, $\S 35$.

Province of land department concerning, § 35-2-3.

What questions open to inquiry by court, $\$ 35-3$.

Duty of surveyor as to character of land, $\S 35-4$.

Basis of Surveyor-General's return, $\$ 35-4$.

Division and numbering of the public lands, $\S 35-5$.

Smallest subdivision, $\S 35$, note 6 .

Meander lines, $\$ 35-6$.

Californian provision, $\S 35-8$; $\S 35$, note 12 .

PUBLIC USE, when mining a, § 76-4.

RAILROAD LANDS. Congressional grants, § 29.

Classification of, $\S 29-2$.

Inconclusiveness of classification, $\S 29-3$.

Subsequent discovery of mineral, § 29-4.

Rejection of application for mineral patent of, $\S 29-5$.

Land department concerning, \& 29-6.

RECEIVER: See Courts; Possessory Actions.

RECEIVER'S RECEIPT: See Patent Proceedings.

RECLAMATION PROJECTS. Mineral lands within subject to location, $\S 46$, note 9 .

RECORD OF LOCATION, contents of, § 185-3.

Time and place for, $\S 190$.

County recorder, $\$ 190-2$.

District recorder, \& 190-3.

Failure to make, $\$ 190-4$.

Description in, $\$ 190-5$.

What need not show. $\$ 190-6$.

Question of fact, $\S 190-7$.

As notice, § 190-8.

Not notice, \& 190-9.

As title, § 190-10.

Californian provision, $\S 190$, note 16 .

Effect of record, § 190-11.

As evidence, \& 190-12.

When not admissible in evidence, \$ 190-12.

Does not preclude parol evidence, \& 190-13.

When prima facie evidence, \& 190-14.

Color of title, $\S 190-15$.

Must precede official survey, \& 211-9. 
(The references are to the sections and their subdivisions.)

RE-LOCATION: See Amended Locations.

Not an original location, § 179.

How made, § 179.

Void, when, § 179-2.

Assumption of risk in making, § 179-3.

Cannot be effected by interference with annual expenditure, $\$ 179$, note 3 .

Statutory bar to, $\S 179-4 ; \S 179$, note 7 .

Fraudulent, § 179-5.

Effect of entry, $\S 179$, note 5 .

When not fraudulent, § 179-6.

Effect of statement in re-location notice, $\S 179-7$.

Improvements in making, § 179-7.

Of overlap, § 180-5.

RE-LOCATION NOTICE: See Re-location; Amended Locations.

Unnecessary to state re-location in, § 188 .

Void, when, § 188-2.

Effect of statement of re-location in, $\S 188-3$.

Proof of forfeiture or abandonment unnecessary, when, $\S 188-4$.

RE-LOCATOR not discoverer, but appropriator of discovery, § 177-5.

Proof required of, $\S 177-6$.

Cannot complain, when, $\S 197$, note 6 .

REMAND: See Courts.

REMEDIAL ACT: See Federal Statutes.

REMEDIES: See Condemnation Proceedings; Easements; Laches; Liens; Mechanics' Liens; Master and Servant; Partition; Patents; Rescission; Statute of Limitations; Trespass.

REPAYMENT: See Unused Deposits.

How application for made, $\S 93-7$.

RESCISSION: See Salting.

Application of rule as to mining property, $\S 82-3$.

How effected, § 83 .

Condition precedent, $\S 83-2$.

Grounds for, § 83-4.

Insufficient grounds for, § 83-8. 
(The references are to the sections and their subdivisions.)

RESUMPTION OF LABOR, definition of, § 198.

May be before adverse re-location perfected, § 198-2.

Rights same as before, $\S 198-3$.

What is not, § 198-4.

Effect of temporary suspension of labor, § 198-5.

RIGHT OF WAY: See Easements; Water-Rights.

Of subsequent locator of cross lode, $\S 182$.

ROCK IN PLACE, definition of, § 50-36-37.

Term liberally construed, § 50-37.

Mineralized stone is, $\$ 125-2$.

ROYALTY: See Mining Leases.

SALE: See Discovery; Mining Partnerships; Partition.

SALINE LANDS: See Salt Claims; Patent Proceedings.

SALT CLAIMS, what may be located as, § 126.

Character of deposit, §126-2.

Limitation, \& 126-3.

Nitrate and borate lands not subject to "saline act," § 126-4.

SALT LICK, definition of, § 105.

SALTING, definition of, $\S 83-5$.

Unintentional, §83-6.

Remedies for, § 83-7.

SCRIP, definition of, § 106-2.

Selection of land, § 106-3.

Sale of, § 106-4.

Guarantee, \& 106-5.

Doctrine of bona fide purchaser not applicable, $\S 106-5$. Adverse rights may be acquired by, §120-25.

SECONDARY OR INCIDENTAL VEIN, definition of, § 50-26. Extra-lateral right to, § 50-27.

SEGREGATION SURVEY: See Hearings.

Definition of, $\S 37$.

Ordered at expense of party, $\S 37-2$.

Non-mineral claimant must establish mineral character of land in, \& 37-2.

Appears upon records, when, § 37-3. 
(The references are to the sections and their subdivisions.)

SHIFT BOSS: Definition of, $\S 101-7$.

SIDE LINES, court cannot enlarge location by new, § 110-3. Not necessarily equi-distant from discovery, $\$ 173-2$; $\S 177-27$.

Definition of, $\S 177-27$.

Irregularity of, $\S 177-28$.

SINGLE VEIN, definition of, § 50-28.

Value of, §50-28.

SMELTING. Reasonable use in mill-sites, $\S$ 116-8.

Cutting timber for, $\S 130$, note 4 .

SPECIAL AGENTS may protest, § 24.

Reports of are privileged communications, $\$ 24$, note 2 .

SPECIFIC PERFORMANCE. Enforcement of between mineral and agricultural claimants, § 24-10.

May be compelled under option, $\S 66$, note 7 .

Enforced between adverse mineral claimants, §215, note 27.

STATE COURTS: See Courts.

STATE LANDS. Congressional grants, § 28.

When title passes, § 28-2.

When closed to prospector, § 28-3.

Proof of mineral value, $\S 28-4$.

Discovery subsequent to patent, $\S 28-4$.

Land department concerning, § 28-5.

Californian provisions in relation to, § 28-6-7-8-9-10.

Effect of payment for, § 28-11.

STATE SURVEYS. Prior to official survey, $\S 40$.

Record of, § 40-2.

Record prima facie evidence, § 40-3.

STATE TAXATION: See Californian Statutory Law.

STATUTE OF LIMITATIONS: See Limitation of Actions; Deeds; Adverse Possession; Californian Statutory Law.

Object of Federal, $\S 82$, note 2 .

Foundation to assert right, when, $\S 84 ; \S 169-2$.

Establishes right to patent, $\S 84-2$.

Controlling factor, $\S 84-3$. 
(The references are to the sections and their subdivisions.)

STATUTES: See Californian Statutory Law, Federal Statutes.

STATUTORY LAW, constituent elements of, § 2.

Subsidiary invited, $\S 2$.

State must not be in conflict with paramount, $\S 2$.

Is not uniform, § 2-2.

Salutary provisions in subsidiary, \& 2-3.

When not mandatory, $\S 196-2$.

Effect of State upon patented land, § 208.

STAY OF PROCEEDINGS: See Courts.

STOCKHOLDERS, co-tenants not, $\$ 59-5 ; \S 223-9$.

When consent of to conveyance necessary, $\$ 67-6$.

May make annual expenditure, § 199.

May not "advertise out," $\$ 200-5$.

When consent of to conveyance not necessary, § 223-10.

STONE CLAIMS: See Timber and Stone.

In general, § 125 .

Character of location, § 125-2.

SUBSURFACE: See Surface.

SUMMONS, notice of intention to apply for a patent equivalent to, § 214, note 23 .

SUNDAY, location may be made on, $\S 168-9$.

Adverse claim must be filed before, $\S 215-5$.

SUPERINTENDENT, duties of, § 101-6.

Personal services in annual expenditure, § 194-3.

SURFACE, in adverse suit, $\S 20-2$.

Definition of, $\S 67-4$.

Obligation to protect, $\S 67$, note 6 .

Rights of surface and subsurface owners, $\S 67$, note 6 .

Exclusive right to, $\S 110-3$.

Distinction between of patented and unpatented claim, $\S 110$, note 3 .

Subsurface rights, $\S 110-4 ; \S 111$.

Right to follow vein below, $\$ 112$.

Basis of right below, $\$ 112-2$.

Qualified right to, § 119-2.

Loss of right to control, § 121-2.

SURVEYOR-GENERAL: See Public Land Surveys; Patent Proceedings. 
(The references are to the sections and their subdivisions.) SURVEYS: See Public Land Surveys; Official Surveys; Segregation Survey; Adverse Claim Survey; State Surveys; Underground Surveys.

TAILINGS. No right to dump on public land, § 127.

Public land covered by may be located as placer claim, $\S 127$.

Deposition must not injure another, § 127-2.

TAXATION: See Californian Statutes; Federal Statutes. Independent estates subject to, $\S 67-12 ; \S 122-7$.

Of possessory right, $\S 96-9$.

TELEPHONE: Affidavit over, is void, $\S 213$, note 7 .

TEST WELL, definition of, $\S 121-9$.

TESTIMONY: See Evidence.

TEXAS, independent mining law within, § 2 .

TIDE LANDS, definition of, $\S 146$.

Californian provision, $\S 146$, note 1 .

Not subject to location, $\S 146-2$.

Limited possession of in Alaska, § 146-3.

TIMBER may properly be an incentive to location, $\S 172-5$.

TIMBER AND STONE: See Stone Claims.

What may be entered as, §125-3; 129.

Agricultural entry, \& 125-4.

Terms of sale, $\S 125$, note 4 .

How land is appraised, $\S 125$, note 4 .

Errors of judgment will not prevent repayment, $\S 125$, note 4 .

Sale by entryman, $\S 125-5$.

Corporation not bona fide purchaser, when, §125, note 6 .

In. forest reserves, $\S 131$.

TIMBER CUTTING in mineral districts, § 130.

Purpose of, $\S 130-2$.

In Alaska, $\S 130$, note 2 .

Miner may engage in, when, $\S 130$, note 3 .

Right to exceptional, § $130-4$.

Party asserting must prove right to, $\$ 130-4$.

Forest reserves, $\S 131$.

Indian lands, § 132.

Criminal offense, $\S 132-2$. 
(The references are to the sections and their subdivisions.)

Abandoned military reservations, § 133.

Damages, measure of in, $\S 134$.

Bona fide purchaser, $\S 134-2$.

TIMBER LANDS, definition of, $\S 129 ; \S 129$, note 2 .

Mineral character of, $\S 129-2$.

Improvements and occupation, $§ 129$, note 2 .

Mineral location of, $\S 129-3$.

In California, $\$ 129$, note 3 .

Subsisting location on, § 129-4.

Patentee of may be trustee, $\S 129-4$.

Patentee of 'may be trustee for mineral claimant, § 129-4. Subsequent discovery of mineral in lands patented as, $\S 129-5$.

TIME CHECKS in California, $\$ 101$, note $b$.

TITLE: See Co-tenants; Deeds; Abstracts of Title; Marketable Title.

Unpatented mining claim held by peculiar, $\$ 89$, note 3 .

When character of immaterial, § 95-4.

Three classes of created by law, $\S 162$, note 1 .

When possessory vests, $\S 168-2$.

Priority gives better, when, $\$ 168-3$.

When claim of will not control, § 168-3.

Fraudulent placer, $\S 170$.

Trespass cannot form basis of, § 172-6.

Location notice as, § 190-10-11.

Prima facie evidence of, $\S 190-13$.

Color of, § 190-15.

Patent as, \& $207 ;$ \& 207-2-3-4.

When receiver's receipt not link in chain of, $\S 214-15$.

TOP OR APEX, definition of, § 50-47-48.

Legal top or apex, $\S 50-49^{\circ}$.

Discovery of, $\$ 50-50$.

Lode location must include, $\S 50-51 ; \S 110-2$.

Blanket formation, may have no, $\$ 50$, note 67 .

Swell in vein not, $\S 50$, note 72 .

What is a, question of fact, $\S 50$, note 74 .

TOWNSHIP RECORDS, when mining claim appear's on, $\S 37-3$.

TOWNSITES, what subject to entry as, § 135 .

Corporate authorities, $\S 135-2$.

County judge, § 135-3.

Trust, $\S 135-4$. 
(The references are to the sections and their subdivisions.)

Mineral reservation, $\S 135-5$.

Placer claim as, $\S 135$, note 5 .

Valid claim and possession, definition of, $\S 135$, note 5 . Insufficient mineral rights, $\S 135-6$.

Adverse suits not necessary, $\S 136 ; \S 215$, note 11 .

TRESPASS: See Bona Fide Purchaser; Injunctions.

Injunction granted in cases of, $\S 85$.

Ignorance of boundaries no excuse for, $\S 85-2$.

Right of inspection incident to, $\S 85-6$.

Grounds for order of inspection, \& 85-7.

Substance of order, $\S 85-8$.

Damages, § 85-9.

Good faith of trespasser, $\S 85-10$.

When insolvency of defendants need not be pleaded, $\S 85-11$.

Presumption as to value, $\S 85$, note 15 .

When irreparable, $\S 85$, note 19 .

Invasion of surface, $\S 113$.

Subterranean exploration, § 113 .

What is not, $\S 113-2 ; \S 181-4$.

Cannot form basis of title, $\S 172-6$.

Waiver of right to object to, $\S 172-6$.

Upon placer claim, § 181-4.

Attempted re-location is, when, § 198-5.

TRESPASSER: See Trespass.

TRUSTEES: See Deeds; Grub-stake Contract; Mining Partnerships; Co-tenants; Fraudulent Patentee; Timber Lands; Agents; Patents; Patent Proceedings; State Taxation.

Government as, § 93-5.

Directors or managers of corporations are, when, $\S 223-7$. Investment of legal title in, $\S 223-9$.

Consent of stockholders not necessary to deed of, $\S 223-10$.

TUNNEL RIGHT, definition of, $\S 107$.

Implied rights, $\S 107-2$.

TUNNEL-SITES, sometimes termed a mining claim, $\S 138$.

Double purpose of, $\S 138$; $\S 138$, note 2 .

Assessment work on counted for lode claim, $\$$ 138-3.

Manner of location matter of local law, $\S 138-4$.

Californian provision, $\S 138$, note 5 .

Location of blind veins, $\S 138-5$. 
(The references are to the sections and their subdivisions.)

Prior location, § 138-6.

Adverse location, § 138-7.

Line of tunnel defined, $\S 138-8$.

No annual expenditure required, § 138-9.

Abandonment, § 138-10.

Not subject of patent, $\S 138-11$.

May be subject of adverse claim, § 138-11.

Money expended on, how counted in patent proceedings, § 138-11.

Dump, no provision for, $\S 139$.

UNDERGROUND SURVEY, court may order when, § 40-4.

Californian provision, $\S 40$, note 4 .

Service of order for, $\S 40-5$.

UNION OF REMEDIES: See Courts.

UNNAVIGABLE RIVER: See Water-rights.

Bed of subject to mineral location, $\S 124$.

How location in may be made, $\S 124-2$.

Is part of public lands, $\S 141$, note 6 .

UNUSED DEPOSITS: See Re-payment.

Return of, $\S 212$, note 4 .

UPLANDS, rights of owner of, $\S 35$, note 12 .

Leasehold interest in, $\S 124 \mathrm{a}$.

VALID MINING CLAIM OR POSSESSION, definition of, $\S 135$, note 5 .

VEIN, LODE AND LEDGE: See Blanket Vein, Blind Vein, Broad Lode, Contact Vein, Cross Veins, Extralateral Right, Intersecting Veins, Known Vein, Ledge Matter, Rock in Place, Secondary Vein, Single Vein, Vein or Lode in Place, Walls of Vein, Lode and Ledge.

No definition of in mining act, $\S 50$.

Interchangeable terms, \$ 50-2.

Miners' use of terms, $\S 50-2-3$.

Common use, $\S 50-4$.

What is to miner, $\S 50-5$.

When question of arises, $\S 50$, note 5 .

Definitions given usually restricted to character and place, $\S 50$, note $5 ; \S 50-11$.

Miners' distinction between, $\S 50-6$.

Vein within lode, § 50-7.

Synonymous terms, § 50-8. 
(The references are to the sections and their subdivisions.)

Meaning of in mining act, $\S 50-9$.

Not an imaginary line, $\S 50$, note 9 .

Not always straight line of uniform dip, thickness nor richness, $§ 50$, note 9 .

Various definitions given, $\S 50-10$.

Characteristics in different districts, $\S 50$, note 10 .

No arbitrary definition possible, $\S$ 50-14.

Approved definition, § 50-15.

Crevice is a term sometimes applied to, $\S 50$, note 15 .

Gravel deposits, § 50-16.

Characteristics of, $\S 50-17$.

Elements of, § 50-18.

May not appear upon surface, $\S 50-24 ; \S 50$, note 67 .

Presumption as to existence of, $\S 110-5$.

Presumption as to extent of, $\S 110$, note 6 .

Departure from surface lines, $\$ 110-6$.

VEIN OR LODE IN PLACE. When in place, $\S 50-39$.

When not in place, $\S 50-40$.

Extra-lateral right does not attach when not in place, § 111-3.

VOID LOCATIONS, when no act can confer validity on, \& 172-2.

Effect of want of proper boundaries, $\S 172-3$.

Illustrations of, $\S$ 172-4-6.

VOIDABLE LOCATIONS: See Citizens and Aliens.

By. alien is, § $163-2 ; \S 171$.

WAIVER, of exemption for contribution between co-tenants, $\S 59-14$.

In annual expenditure, $\$ 200-2$.

Of protest, illegal, when, § 214-19.

Of adverse claim, $\S 215-8$.

Evidence of, $\S 215-8 ; \S 216$, note 6 .

WALLS OF VEIN, LODE AND LEDGE, definition of, $\S 50$ 59.

Barren or mineralized, $\S 50-59$.

Hanging and foot, $\S 50-59$.

May be of similar character, $\S 50-59$.

Importance of, $\S 50-60$.

Both not essential, § 50-60.

Existence may be determined by analysis and assay, $\S 50-60$.

What indications of permanency and continuity; $\S 50-60$. 
(The references are to the sections and their subdivisions.)

WASHINGTON, placer locations in, § 177-17.

WATCHMAN cannot re-locate, when, § 179-5.

Personal services of in annual expenditure, $\S 194-3$. •

WATER-RIGHTS: See Easements; Tide Lands.

Are real property, $\S 141$.

What may be appropriated, § 141-2.

Volume and extent, § 141-3.

Public grants, $\S 141-4$.

Conveyances or agreements in relation to must be in writing, § 141-5.

Rights of way, $\S 142$.

Appropriation of, $\S 143$.

Californian provision, $\S 143$, note 1 .

Different systems, § 143-2.

Compliance with local statutes, § 143-3.

No constructive appropriation of, $\S 143-4$.

Measure of right, § 143-5.

Actual user for beneficial purpose, § 143-5.

Non-user, § 143-6.

Adverse user, § 143-7.

Interruption of right, $\S 143-8$.

Prescriptive right, $\S 143-9$.

Diversion, § 144 .

Adjacent water, $\S 144-2$.

Pollution of water, $\S 144-3$.

Nuisance, § 145.

WITHDRAWAL.

Of state lands, $\S 36-8$.

Of oil lands, $\$ 120$.

WRIT OF REVIEW: See Certiorari.

WRITS OF ERROR: See Courts.

YARD DECISION, effect of, $\S 120-17$.

Effect of remedial act upon, $\S 120-19$ a.

ZONE: See Broad Lode.

Metal equivalent to mineral, $\$ 99-10$. 


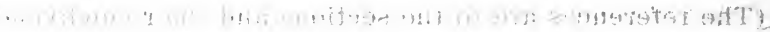

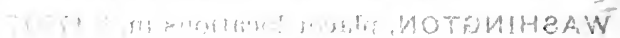

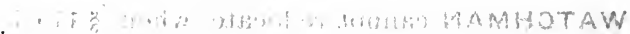

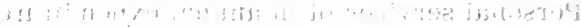

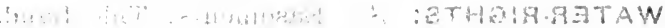

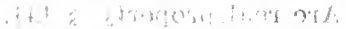

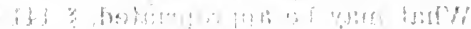

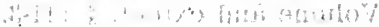

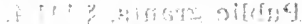

$+1,1, i, i+1 \mid \therefore 11$

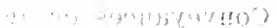

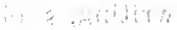

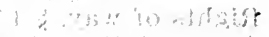

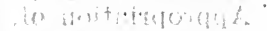

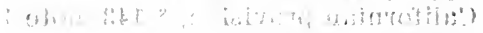

A

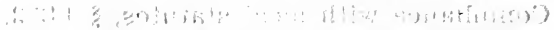

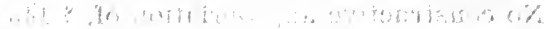

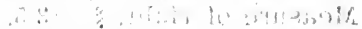
(4)

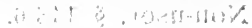

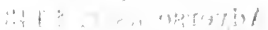

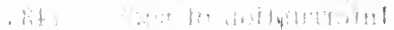

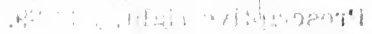

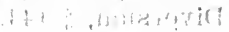

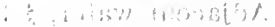

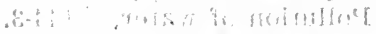

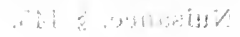

IFA WPOHTIW

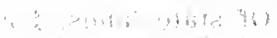

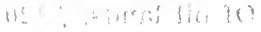

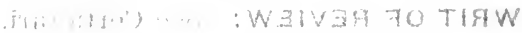

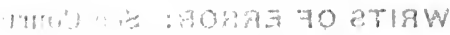

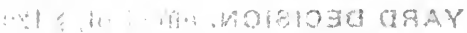

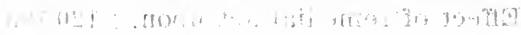

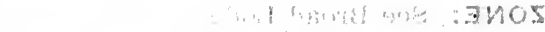

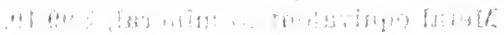




\section{TABLE OF CASES CITED}





\section{TABLE OF CASES CITED}

(The references are to the sections.)

A. C. M. Co. v. Court, 180, 206.

Acme Co., 46.

Acme Oil Co. v. Williams, 121 122.

Adams v. Crawford, 163, 168.

Ah Yew v. Choate, 45.

Ajax Co. v. Hilkey, 50, 110.

Alaska C. Co., 116, 146, 168, 211.

Alaska Co. v. Barbridge, 46, $116,121,145$.

Alaska Placer, 211.

Albert R. Pfau, Jr., 93, 125.

Aldebaran Co., 194, 211.

Alderson v. Crocker, 101.

Alexander v. Sherman, 179.

Alford v. Barnum, 26, 45, 104, 168.

Alfred Baltzell, 165.

Alice Lode, 36, 180.

Alice Placer, 211, 216.

Allen v. Blanche, 215.

v. Dunlap, 85, 149.

Allen H. Cox, 46.

Allyn v. Schultz, 20, 163.

Alsop v. Riker, 207.

Alta Mill Site, 214.

Altoona Co. v. Integral Co., 20, $84,169,194,206$.

Amador Co. v. Gilbert, 135.

Amador Median Co. v. So. Spring Hill Co., 93, 110, 111, 206.

Amador Queen Co. v. DeWitt, 77.

Amanda Hines, 35 .

Ambergris Co. v. Day, 50, 154, $155,157$.

American Co. 23, 24, 45, 154.

- v. Colo., 223.

Anaconda Co. v. Butte \& Boston Co., 57, 58.

Anchor Co. v. Howe, 23, 38, 215.

Anderson v. Caughey, 1, 2, 193, $195,199$.

- v. Phegley, 66.

Anthony v. Jillson, 20, 185.

Anvil Co. v. Code, 88, 194.

Apple Blossom Co. v. Cora Lee, 20.

Argentine Co. v. Terrible Co., $111,177$.
Argillite Co., 35, 46, 121, 124, 146.

Argonaut Co. v. Kennedy Co., $11,111,177$.

Armstrong v. Lower, 110, 179. - v. Maryland Co., 103.

Arnold, 47.

- v. Goldfield Co., 95.

Aspen Co. v. Rucker, 81.

- v. Williams, 26, 157.

Athens Co. v. Carnduff, 80 .

Atty.-Gen. v. Hudson Co., 121. v. Tomline, 47.

Attwood v. Fricot, 71.

Aurora Hill Co. v. 85 Mg. Co., $206,207,214$.

Aurora Lode v. Bulger Hill Co., 211.

Aye v. Philadelphia Co., 122.

Back v. Sierra Nev. Co., 138, 215.

Backer v. Penn Lub. Co., 85, 121, 122.

Bacon v. Federal Co., 85.

Badger Co. v. Stocktón Co., 71, 72,200 .

Bagnell v. Broderick, 207.

Baker v. Butte City Co., 155, 186.

-186 v. Clark, 62.

Bakersfield Co. v. Kern Co., 96.

Bakersfield Fuel \& Oil Co., 120, 158.

Baldwin Co. v. Quinn, 23.

Ball v. Kehi, 141.

$\frac{1}{\text { val }}$. Tolman, 46, 102.

Ballard v. Golob, 200.

Ballinger v. Frost, 46 .

Barden v. N. P. R. Co., 24, 35, $98,104,108,207$.

Barklage v. Russel, 206.

Barnard v. McKenzie, 79.

Barnes v. Bee, 122.

Bash v. Cascade Co., 212, 214.

Basin Co. v. White, 72, 212.

Baxter v. Patterson, 150.

Bay v. Oklahoma Co., 26, 46, $104,120,157,158,168$.

Bay State Co. v. Brown, 20, 89.

Beals v. Cone, 15, 20, 50, 154, $177,197,214$.

Bealy v. Napthaly, 207. 
(The references are to the sections.)

Bear Lake Co. v. Garland, 141. Beaudette v. N. P. R. Co., 29. Becker v. Pugl, 20, 156.

Behrends v. Goldstein, 46, 215. Belk v. Meagher, 19, 71, 96, $177,178,179,180,198$.

- v. Nickerson, 110.

Bell v. Bed Rock Co., 72.

Belligerent Claims, 177.

Benjamin v. S. \& C. P. R. Cos., $29,35,214$.

Bennett v. Harkrader, 20, 151, 185.

- v. Red Cloud Co., 67.

Benson Co. v. Alta Co., 85, 193, 214.

Bently v. Brossard, 58.

Berentz v. Belmont Oil Co., 102.

Bergquist v. W. Va. Co., 67, 72, $179,180,189$.

Bernard v. Parmelee, 10, 20.

Berry v. Woodburn, 57.

Bettman v. Harness, 85, 122.

Bevis v. Markland, 157.

Bewick v. Muir, 102.

Big Horn R. Co., 77.

Big 3 Co. v. Hamilton, 73, 194, $195,196$.

Big 6 Co. v. Mitchell, 85.

Biglow v. Conradt, 120, 178, 180.

Billings v. Aspen Co., 163.

Bingham Co. v. Ute Co., 72, $158,177,180,197,214$.

Bishop v. Baisley, 72, 73, 101, $119,190,193,194,195$.

- v. Gibbons, 207.

v. Thompson, 83 .

Bismark Co. v. No. Sunbeam Co., 151, 185, 187, 196.

Bissel v. Foss, 58.

Black v. Elkhorn Co., 72, 96, $162,206$.

Blackburn v. Portland Co., 10, 11.

Blackmore v. Reilly, 135, 185.

Blake Placer, 47.

$\longrightarrow$ v. Butte Co., 111.

- v. Doherty, 36.

- v. Thorne, 67, 157.

Blue Bird Co. v. Largey, 50.

Board v. Mansfield, 68.

Boeme v. Fitzgerald, 58.

Bonanza Co. v. Golden Head Co., 185.

Bond v. Cal., 28.

- v. U. S., 46.

Bonesell v. McNider, 215.

Bonner v. Meikle, 28, 50, 68, $104,135,157,215$.
Bonner v. Fio Grande Co., 46. Book v. Justice Co., 2, 45, 50 , $73,97,99,154,155,157,163$, $164,168,177,185,186,194$, $196,199$.

Boske v. Comingore, 23.

Boskowitz v. Davis, 59 .

Botsford v. Van Riper, 57, 66.

Bowen v. Aubrey, 79.

Boyle v. Mt. Key Co., 79.

Bradford v. Morrison, 79, 93, 96.

Brady v. Husby, 151, 190.

Brady's Mortgagee v. Harris, $67,135$.

Bramlett v. Frick, 185, 189.

Brandon v. Ard, 207.

Bree v. Wheeler, 141.

Breece Co., 111, 155, 168.

Bretell v. Swift, 214.

Brewster v. Lanyon Co., 121.

v. Shoemaker, 50, 154, 168. Brick Pomeroy, 116.

Brickell v. Atlas Co., 66.

Brien v. Moffitt, 20.

Bright v. Elkhorn Co., 214.

Brockbank v. Albion Co., 154, $168,177$.

Brookshire Co. v. Casmalia Co., $121,122$.

Brophy v. O'Hare, 26, 45, 68, $135,154,157$.

Brown v. Bond, 215.

- v. Bowman, 57.

v. Challis, 81 .

- v. Gurney, 20, 72, 155, 168 $179,180,193,214$.

- v. Levan, 151.

v. N. P. R. Co., 108.

178 .

v. Oregon King Co., 168 ,

v. S. F. Sav. Union, 66.

v. Spilman, 121.

v. Yarrahan Co., 35, 177.

Broughton v. Exchange Bank, 15.

Brownfield v. Bier, 119.

Brunswick v. Winters, 58.

Bryan v. McCaig, 194.

Buena Vista Co. v. Tulare Co. 28.

Buffalo Co., 47.

Buffalo Zinc Co. v. Crump, 47, $71,72,169,190$.

Bullion Beck Co. v. Eureka Hill Co., 50, 85, 98.

Bullion Co. v. Croesus Co., 50.

Bunker Hill Co. "v. Empire State Co., 20, 50, 177, 178, 180, $187,214$. 
(The references are to the sections.)

Bunker Hill Co. v. Kettleson, 80

- v. Last Chance Co., 180.

v. Shoshone Co., 68, 155,

$172,211$.

- v. U. S., 129.

Burfenning v. Chicago R. Co., $23,45,68,207$.

Burke v. McDonald, 50, 155, $157,173$.

Burley v. U. S., 76.

Burns v. Clark, 116.

\section{- v. Schoenfield, 99.}

v. White Swan Co., 79.

Butler v. Goodenough Co., 1, 190.

Butte \& Boston Co. v. Mont. Co., 59, 85.

v. Societe, 112.

Butte City Co. v. Baker, 1, 2, $156,177,185,186$.

Butte City Smoke House Lode Cases, 206.

Butte Con. Co. v. Barker, 20, 178.

Butte H. Co. v. Frank, 68, 79, $206,215$.

Butte N. C. Co. v. Radmilovich, 186.

Buttz v. N. P. R. Co., 46.

Byrne v. Knight, 57.

Byrnes v. Douglas, 76 .

Byrnes Estate, 98, 102.

Cadierque v. Duran, 28.

Cagle v. Dunham, 23, 24.

Cain v. Addenda Co., 197, 215.

Caley v. Portland Co., 61.

Calhoun Co. v. Ajax Co., 50, $68,77,110,138,157,168,182$.

Callahan v. James, $68,73,98$, $135,197$.

Cameron v. Hodges, 10.

Campbell v. Rankin, 1, 43, 190.

Cape May Co. v. Wallace, 211, 215.

Capital No. 5 Claim, 19, 84, 214.

Caples v. Stteel, 83.

Capricorn Placer, 214.

Capron v. Strout, 79 .

Cardelli v. Comstock, 141.

Caribou Lode. 190.

Carney v. Arizona Co., 193.

Carr v. U. S., 28.

Carrie S. Co., 20, 214.

Carson v. Hayes, 127.

Carson City Co. v. N. Star Co., $168,177$.

Carter v. Bacigalupi, 67, 185. v. Thompson, $82,207$.

Carterville Co. v. Abbott, 80 .
Cary Co. v. Mecarty, 62, 79.

Cascaden v. Bartolis, 50, 154 , 157.

- v. Dunbar, 57, 68.

v. Wimbish, 79.

Casey v. Vassor, 27.

Cash Lode, 163. Castegnetto v. Coppertown Co.,
$\mathbf{9 6 .}$

Catlin Coal Co. v. Lloyd, 67.

Catron v. So. Butte Co., 67.

Cedar Canyon Co. v. Yarwood, $59,154$.

Centerville Co., 130.

Cent. Coal Co. v. Penny, 85.

Cent. Eureka Co. v. E. Cent. Eureka Co., 67.

C. F. Conrad, 47.

Chambers v. Harrington, 194.

- v. Low ry, 61.

Champion Co. v. Con. Wyo. Co., $20,50$.

Chapin v. Fye, 10 .

Chapman v. Pollock, 35.

v. Toy Long, 206.

Charlton v. Kelly, 157, 168, 177.

Chas. Lennig, 116, 172.

Chas. A. Barnes, 47.

Chas. F. Whitehead, 24.

Chas. S. Morrison, 93, 108.

Chas. W. Steele, 214.

Chase v. Savage, 59.

Cheesman v. Hart, 177, 190.

- v. Shreve, 50, 87, 112, 156, $157,178,190$.

Chesley v. King, 121.

Chicago Placer, 36.

Childers v. Neely, 19, 121.

Chism v. Price, 104.

Chormicle v. Hiller, 129.

Chrisman v. Miller, 26, 45, 50, $71,104,154,157,158,177$.

Chung Kee v. Davidson, 58.

Church v. Smithea, 79 .

Cisna v. Mallory, 57.

Clark v. American Co., 66, 197.

Clark v. Barnard, 71.

$\longrightarrow$ v: Nash, 76 .

- v. Rosario Co., 12.

v. Wall, 62 .

Clark, Prentiss \& Clark, 24.

Clark's Mine, 214.

Clary v. Hazlett, 45.

Cleary v. Skiffich, $1,84,116$, $169,180,206,215$.

Clemmons v. Gillette, 28.

Cleveland v. Eureka No. 1, 214.

Clipper Co., 20.

v. Eli. Co., 68, 96, 99, 119,

$181,206,214,215,216$. 


\section{(The references are to the sections.)}

C. L. S. R. Co. v. San Garde, 149.

Clyde v. Cummings, 23.

Cochrian v. O'Keefe, 67.

Cole v. Markley, 35.

Coleman v. Curtis, 73, 195, 196.

- v. Homestake Co., 59.

- v. McKenzie, 24, 197, 206.

Colgan v. Forest Co., 122.

Collins v. MeKay, 67.

Colomokas Co., 46.

Colo. Cent. Co. v. Turck, 111, 206.

Colo. Coal Co. v. U. S., 50, 82, 206.

Columbia Co. v. Duchess Co., $154,157,190$.

- v. Hampton, 41, 146.

Com'r. to Sec'y. Noble, 47.

Conaghy v. Doyle, 181.

Conde v. Sweeney, 94, 95.

Condon v. Mammoth Co., 214.

Congdon v. Olds, 58.

Conn v. Oberto, 72, 104.

Con. Channel Co. v. C. P. R. Co., 76.

Con. Coal Co. v. Baker, 67, 122.

Con. Divide Co. v. Bliley, 58.

Con. G. \& S. Co. v. Struthers, 214.

Con. Wyo. Co. v. Champion Co., $12,36,50,173,207$.

Contreras v. Merck, 19, 20, 72, 197.

Conway v. Hart, 177.

Cook v. Klonas, 170.

Coolbaugh v. Lehigh Co., 62.

Copper Belle Co. v. Costello, 194.

Copper Bullion Claims, 211.

Copper Co. v. Butte \& Corbin Co., 73, 194.

Copper Globe Co. v. Allman, 2, 154.

Copper River Co. v. McClellan, 57.

Corning v. Pell, 138.

Corrine Co. v. Johnson, 207.

Coryell v. Cain, 71.

Cosmopolitan Co. v. Foote, 50, $110,177$.

Cosmos Co. v. Gray Eagle Co., $10,19,23,71,104,214$.

Costello v. Muheim, 71.

- v. Scott, 57.

Cowell v. Lammers, 45, 71, 72, 129. $172,206$.

C. P. R. Co. v. DeRego, 29.

Cragie v. Roberts, 23, 82 .

Cragin v. Powell, 23, 35.
Craig v, Leitendorfer, 82 .

- v. Thompson, 149 .

Crane v. Winsor, 144.

Cranes Gulch Co. v. Scherrer, $68,119$.

Crary v. Dye, 72, 200.

Credo Co. v. Highland Co., 149, 150.

Creede Co. v. Uinta Co., 20, 68, $138,154,157,215$.

Crehore v. O. \& M. R. Co., 10.

Crescent Co. v. Silver King Co., 141.

Cripple Creek Co. v. Mt. Rosa Co., 215.

Crocker v. Manley, 50, 83.

Cronin v. Bear Creek Co., 20.

Crosby Claims, 23, 213, 214.

Cross v. Kitts, 141.

Crossman v. Pendery, 71.

Crown Point Co. v. Buck, 110, $180,214$.

- v. Crismon, 197.

Cullins v. Flagstaff Co., 79.

Cunningham v. Pirrung, 73, 188.

Cutting v. Reininhaus, 157.

Cyprus Mill-site, 116.

Czarecki v. Seattle Co., 80.

Dag'gett v. Yreka Co., 36, 50, $110,149,162,177,185,186$, $190,206$.

Dahl v. Raunheim, 163.

Dall v. Confidence Co., 81.

Dana v. Jackson St. Wharf, 121.

Danaldson v. Orchard Co., 194.

Dan. Cameron, 214.

Danielwitz v. Temple, 28.

Darger v. LeSieur, 185, 190.

Daughetee v. Ohio Oil Co., 122.

Davidson v. Bordeaux, 154, 157, $185,196$.

- v. Eliza Co., 214.

v. Fraser, 20, 59 .

Davis v. Alford, 79.

v. Dennis, 72, 163, 168.

v. Gale, $141,144$.

v. McDonald, 20.

v. Shepherd, 71, 173.

v. Weibbold, 26, 28, 45, 98 , $135,157,206,207$.

Dayton v. Seawell, 76 .

Decker v. Howell, 58.

Deeney v. Min. Creek Co., 20, $151,185,190,214$.

Deffeback v. Hawke, 28, 45 , $68,104,206,212,214,216$.

De Lamars Co. v. Nesbitt, 10.

De Long v. Hine, 213. 
(The references are to the sections.)

Del Monte Co. v. Last Chance Co., 36, 96, 110, 111, 112, 113, $155,168,172,177,179,180$, 182 .

Dellapiazza v. Foley, 58.

Delmoe v. Long, $82,200$.

Delmonico v. Roudebush, 57.

Deniss v. Sinnott, 20.

Deno v. Griffin, 207, 214.

Derry v. Ross, 72.

Deserant v. Cerillos Co., 80.

Dickey v. Coffeyville Co., 122.

- v. Maddux, 141.

Dillon v. Bayliss, 151.

Discovery Placer Claim v. Murry, 215.

Doe v. Sanger, 168, 177, 207.

v. Tyler, 180.

v. Waterloo Co., 1, 10, 50 , $67,68,158,163,164,177,186$, 206.

Doherty v. Morris, 20, 59, 179, 194.

Dolles v. Hamberg Co., 199.

Dolly Varden, 168.

Donahue v. Meister, 186.

Donohoe v. Trinity Co., 79.

Donovan v. Hanauer, 67.

v. St. Louis Co., 85.

Doolan v. Carr, 82, 206.

Doon v. Tesh, 20.

Dorsey v. Newcomer, 57.

Dotson v. Arnold, 214.

Dougherty v. Cleary, 58.

- v. Haggin, 100.

Dower v. Richards, $68,72,98$, 135.

Downing v. More, 76.

v. Rademacher, 59, 85.

Doyle v. Austin, 96.

Drake v. Gilpin, 67.

Draper v. Wells, 212, 215.

Dreyfus v. Badger, 82, 207.

Drummond v. Long, 149, 150, 151.

Du Prat v. James, 73, 194, 198.

Duckworth v. Watsonville Co., $141,143$.

Duffield v. Russell, 121.

Duggan v. Davey, 19, 47, 50, 207.

Dughi v. Harkins, 26, 157.

Duncan v. Archambault, 125.

- v. Eagle.Rock Co., 20, 36, $149,151,163,177,194,212$.

v. Fulton, 16, 178 .

Dunlap v. Pattison, 164 .

Durant v. Corbin, 164, 170.

Durant Co. v. Percy Co., 85.

Durgan v. Redding, 12, 20, 215.
Duryea v. Boucher, 185.

v. Burt, 58.

Dutch Flat Co. v. Mooney, 177.

Duxie Lode. 158.

Dwinnell v. Dyer, 154, 177, 185.

Dye v. Crary, 199.

E. Jersey Co. v. Wright, 62 .

East. Or. Co. v. Willow R. Co., 206.

Eaton v. Norris, 156, 168, 177.

Edinger v. So. Oil Co., 58.

E. F. Filer, 108.

Eilers v. Boatman, 151, 177, $185,186,190$.

E. J. Ritter, 214, 215 .

Elda Co. v. Mayflower Co., 211, 215.

Elder v. Horseshoe Co., 59, 200.

- v. Wood, 96.

Electric Mg. Co. v. Van Auken, 156.

Elliott v. S. P. R. Co., 47, 126, 214.

Elmer F. Cassel, 194, 195, 212.

El Paso Brick Co., 213, 214.

Ely v. Ferguson, 141.

E. M. Palmer, 47, 68, 96, 99, $115,119,125,172$.

Emblen Co., 82 . 82.

v. Lincoln Land Co., 23,

Emerson v. Bergin, 62.

- v. McWhirter, 1, 73.

Emma Lode, 39.

Empire Co. v. Bonanza Co., 85.

- v. Tombstone Co., 50.

Empire State Co. v. Bunker Hill Co., 81, 177, 180, 214.

English v. Johnson, 1, 71.

Enterprise Co. v. Rico-Aspen Co., 138, 154.

Erhardt v. Boaro, 1, 85, 154, $156,186$.

Erwin v. Perego, 168, 177.

Escott v. Crescent City Co., 98,102 .

Etling v. Potter, 26.

Eubanks v. Petree, 57.

Eugene McCarthy, 206.

Eureka Co. v. Richmond Co., $50,177,207$.

Eureka Office, 168.

Evalina Co. v. Yosemite Co., $194,200$.

Ex parte Boyce, 80 .

Kair, 80.

Martin, 80 .

Extra Lode Claim, 211. 


\section{(The references are to the sections.)}

F. A. Hyde \& Co., 28.

Fairplay Co. v. Weston, 141.

Fargo Group No. 2, 212.

Farmington Co. v. Rhymney Co.; $150,151,173,185,186$, 190 .

Farrell v. Lockhart, 20, 72, 179, 180.

Faubel v. McFarland, 59, 200.

Faxon v. Barnard, 151.

Featherman v. Hennessy, 143.

Fee v. Durham, 198.

Feliz v. Feliz, 59.

Ferguson v. Belvoir, 197.

- v. Hanson, 90.

- v. McGuire, 66.

v. Neville, 163.

Ferrell v. Hoge, 26, 154, 157.

Ferris v. Baker, 58.

Ferry v. Street, 28.

Fidelity Co. v. Shenandoah Co., 79.

Field v. Tanner, 197.

Finch v. Ogden, 35.

Fissure Co. v. Old Susan Co., $138,194$.

Fitzpatrick v. Montgomery, 127.

Flagstaff Co. v. Collins, 79 .

v. Tarbet, $50,68,110,111$, $112,173,177$.

Flaherty v. Gwinn, 1.

Flavin v. Mattingly, 149.

Fleming Co. v. So. Penn. Co., 121.

Flint v. Stone Co., 220.

Florence Co. v. Orman, 122.

Florida Cent. Co. v. Bell, 10.

Flynn Group Co. v. Murphy, 173.

Foolkiller Lode, 211.

Foote v. Nat. Co., 50, 155.

Forbes v. Gracey, 19, 77, 79, 96, $99,102$.

Ford v. Campbell, 185, 190.

v. Milk Ass'n, 66 .

Forestier v. Johnson, 28 .

Forsythe v. Weingart, 47, 125.

Fort Cameron Reserve, 133.

Foss v. Johnstone, 16,35 .

420 Co. v. Bullion Co., 81, 84, 169.

Fox v. Hale \& Norcross Co., $87,88,101$.

186. 190 .

Francoeur v. Newhouse, 46, 68.

Frank v. Stratford-Hancock, 66.

Frank A. Maxwell, 165.

Frank G. Bell, 93, 125.
Franklin Co. v. O'Brien, 59.

Fred. A. Williams, 24, 211.

Fredericks v. Klauser, 193, 194, 198.

Freeman v. Bellegarde, 124.

Frees v. State, 50 .

Freezer v. Sweeney, 47, 186.

Frellsen \& Co. v. Crandell, 28, 207.

Frisholm v. Fitzgerald, 178.

F. T. Palmer, 47.

Fulkerson v. Chisna Co., 19.

Fuller v. Harris, 43, 151, 164.

Funk v. Sterrett, 168.

G. A. Khern, 211.

Gage v. Gunther, 23.

Gaines v. Chew, 66 .

Galbraith v. Shasta Co., 163, $168,207$.

Gallagher v. Gray, 125, 129, 130.

Galliher v. Cadwell, 78 .

Gamer v. Glenn, 149, 185.

Ganse v. Perkins, 85.

Garden Gulch Bar Placer, 178, 212.

Garfield v. Goldsby, 23.

Garfield Co. v. Hammer, 163.

Garrard v. S. P. Mines, 45,47 , 206.

Garthe v. Hart, 67, 180.

Garvey v. Elder, 179, 197.

Gary v. Todd, 47.

Gauthier v. Morrison, 35.

Gaylord v. Place, 96.

Gear v. Ford, 194.

Gemmell v. Swain, 180.

Geo. B. Foote, 212.

German Co. v. Hayden, 24, 214.

Germania Iron Co. v. U. S. 23.

Giberson v. Tuolumne Co.. 178.

Gibson v. Anderson. 46. 120.

$\longrightarrow$ v. Hjul, 111, 156, 165.

- v. Smith, 129.

- v. Tyean, 47.

Gillis v. Downey, 19, 103, 196, $197,206,215$.

Gilmer v. Lime Point, 76 .

Gilpin Co. v. Drake, 151.

Girard v. Carson. 158.

Gird v. Cal. Oil Co., 20, 36, 47, $91,119,150,163,170,174,177$, $185,186,194$.

Glacier Co. v. Willis, 67, 71, 84, 138. 175.

Gleeson v. Martin White, Co., $177,185,186$.

Godfrey v. Faust, 199.

Gohres v. Illinois Co., 173.

Gold Dirt Lode, 59 . 


\section{(The references are to the sections.)}

Goldberg v. Bruschi, 197.

Golden v. Murphy, $50,111$.

Golden \& Cord Claims, 59, 200, 214.

Golden Crown Lode, 211.

Golden Fleece Co. v. Cable Con. Co., 1, 2, 151, 190.

Golden Reward Co. v. Buxton, $24,87,214,215$.

Golden Rule Co., 212.

Goodenow v. Ewer, 59.

Gordan v. Darnell, 66.

Gore v. McBrayer, 43, 57, 58, 164.

Goss v. Golinsky, 177.

Gould v. Wise, 79 .

Gowdy v. Kismet Co., 90, 211.

Graciosa Oil Co. v. Sta. Barbara Co., 79, 96, 122 .

Grand Canyon Co. v. Cameron, $20,23,24,214,215$.

Grand Cent. Co. v. Mammoth Co.. 50, 112, 154, 181, 206, 207. Granite Co. v. Maginnes, 67.

Grassy Gulch Claim 177.

Gray v. N. M. Co., 79, 102.

v. Truby, 156.

Gray Lumber Co. v. Gaskin, 85. Green v. Garvin, 150, 177, 185, 186.

v. Turner, 99.

Greenameyer v. Coate, 82.

Gregory v. Gregory, 59. 190.

Grenon v. Miller, 125.

Grosfield v. Nigger Hill Co., 172.

Gross v. Fughes, 214.

Grubb v. Bayard, 62.

Gruwell v. Rocca, 216.

Gutierres v. Albuquerque Co., 141.

G. V. B. Co. v. Bank, 57.

- v. Hailey, 58.

Gwillim v. Donnellan, 155, 158, $172,215$.

Gypsum Placer Claim, 20.

Haggin v. Kelly, 85.

Hahn v. James, 20.

Hailey v. G. V. B. Co., 58.

Hain v. Mattes, 138.

Hall v. Abraham, 62.

v. Kearney, 73.

v. Vernon, 81,121 ,

Halla v. Rogers, 61, 85 .

Hallack v. Traber, 178.

Hamburg Co. v. Stephenson, 116.
Hamilton v. Delhi Co., 79, 95, 96.

v. So. Nevada Co., 71, 96.

Hammel v. Salzman, 125.

Hammer v. Garfield Co., 73, 150, 151, 185, 197.

Hanchett v. Blair, 207.

Hand v. Cook, 165 .

Ianley v. Watterson, 66 .

Hans Oleson, 120.

Hansen v. Fletcher, 150, 173 , $185,186$.

Hanson v. Craig, 71, 120, 154, 168.

Hard Cash, 116, 211,

Hardin v. Hardin, 57.

$\longrightarrow$ v. Jordan, 35, 124.

Hardy v. Johnson, 59.

Hare v. Birkenfield, 13.

Hargrave v. Cook, 144 .

Harkrader v. Carroll, 10, 19, 72 .

- v. Goldstein, 135

Harnish v. Wallace, 157.

Harper v. Hill, 50, 154, 173, 177.

Har v. Independence Co., 66, 79, Harrington v. Chambers, 50 , $154,157$.

- v. Demaris, 141.

V. Paterson, 83.

Harris v. Equator Co., 67, 71, 84.

197. Kellogg, 19, 163, 196,

v. Lloyd, 58.

v. Tyson, 83 .

Hartman v. Smith, 116.

- v. Warren, 82 .

Hartney v. Gosling, 57, 58, 59.

Hartwell v. Camman, 47.

Harvey v. Ryan, 1.

Harvey M. La Follette, 35 .

Hastings Co. v. Whitney, 10, 93.

Hausewirth v. Butcher, 173.

Hawes v. Contra Costa Co., 13.

Hawgood v. Emery, 194, 200 .

Hawkins v. Spokane Co., 59.

Hawley v Diller, 23, 82, 93.

Haws v. Victoria Copper Co. $1,124,177,179,185,186,190$, 206.

Hayes v. Lavagnino, 50, 96, $154,155,157$.

Haynes v. Briscoe, 59, 200, 214.

Hays v. U. S., 104 .

Headley v. Colonial Oil Co., 96. Healey v. Rupp, 20, 87, 154, $214,215$.

Hecla Co., 116. 


\section{(The references are to the sections.)}

Helena Co. v. Baggaley, 20.

- v. Dailey, $116,215$.

Heman v. Griffith, 154.

Henderson v. Ferrell, 121.

-v. Fulton, 47, 50,68, 96, 99,

$119,125,172$.

Hendricks v. Morgan, 57.

Hendy v. Compton, 28.

Henry Wax, 36.

Hess v. Winder, 71.

Heydenfeldt v. Daney Co., 28, 45.

Hickey v. Anaconda Co., 68, $185,193,207$.

Hidden Treasure, 89, 211.

Hidee Co. 177, 180.

Higgins v. Armstrong, 58.

- v. Carlotta Co., 79.

Highland Boy Co. v. Strickley, 76.

Highland Marie, 194, 195.

H. H. Yard, 24, 45, 67, 120, 158. Hines v. Miller, 79, 101 .

Hiram M. Hamilton, 82, 93, 108.

Hiram C. Smith, 120.

Hirschler v. MeKendricks, 194, 1.98.

Hisbour v. Reeding, 57.

Hoban v. Boyer, 20.

Hobart v. Ford, 77.

Hobbs v. Amador Co., 127.

Hoffman v. Beecher, 215.

Holden v. Hardy, 80.

Holdt v. Hazard, 163, 168.

Holman v. Central Mines Co., 215.

Holmes v. Salamanca Co., 20, 73.

Holmes Placer, 36.

Holt v. Murphy, 23, 59, 68.

Homer Santee, 212.

Honaker v. Martin, 194, 198.

Hoogendorn v. Daniel, 66 .

Hooper v. Young, 207.

Hope v. Brown, 138, 215.

Hope Co., 173.

Hopkins v. Butte Co., 20.

Horne v. Smith, 35, 124, 212.

Hosford v. Metcalf, 62 .

Hosmer v. Wallace, 214, 216.

Hough v. Hunt, 194.

Howard v. Luce, 58 .

v. Throckmorton, 59.

Howell v. Johnson, 141.

Howeth v. Sullinger, 173, 177.

Hoyt v. Russell, 185.

$\frac{}{} v$. Weyerhaueser, 23.

Hudephol v. Liberty Hill Co., 61.

Huff v. McCauley, 62

Huggins v. Daley, 122.
Hughes v. Devlin, 81 .

- v. Lansing, 79.

v. Ochsner, 1, 185.

Hulda Rosling, 93 .

Humbird v. Avery, 10.

Hunt v. Eureka Co., 215.

- v. Patchin, 59, 82, 179 ,

207.

$\longrightarrow v$. Steese, 26, 85, 157.

Hutchinson v. Kline, 67.

Hyman v. Wheeler, 50.

Iams v. Carnegie Co., 122.

Iba Co. v. Central Ass'n., 20.

Idaho Co. v. Davis, 79, 96.

v. Winchell, 79.

Ide Co. v. Leiser, 66.

Igo Bridge Ex. Placer, 91; 119 .

Illinois Co. v. Budzisz, 206.

- v. Raff, 50,85 .

In re Morgan, 80 .

Indiana v. Miller, 105.

Ingersol v. Scott, 194, 198.

Ireland v. Henkle, 108.

Iron Co. v. Campbell, 89, 96,

$119,181,206,207,211,215$.

206 .

- v. Elgin Co., 50, 110, 111,

$168,177,206$.

- vike \& Starr Co., 50, $119,138,157$.

- v. Murphy, 50, 155, 172.

Ivanhoe Co. v. Keystone Co., 28,45 .

Jackscn v. MeFall, 20.

- v. Roby, 194, 195.

James v. Germania Co., 23, 82, 106.

James Carretto, 194.

Jas. W. Logan, 121, 124, 146.

Jameson V. James, 82.

Janette W. Riley, 46, 154.

Jantzon v. Arizona Co., 168, $186,190$.

J. B. Hoggin, 116, 168.

Jefferson v. Anchoria Co., 20, $24,177,214$.

Jefford v. Hines, 23.

Jenkins v. Johnson, 99.

Jennings v. Rickard, 57.

Jennison v. Kirk, 1, 77, 141.

Jeremy Co. v. Thompson, 3, 92, 126.

Jessie E. Oviatt, 108.

J. H. Lessard, 124.

Johanson v. Washington, 28.

- v. White, 154, 180 .

John C. Miller, 24. 
(The references are to the sections.)

John C. Teller, 178, 187.

John M. Rankin, 120.

John P. Hoel, 124.

John R. Gentle \& Co. v. Britton, 79 .

John W. Gabathuler, 46.

Johnson, 173.

101 .

v. Cal. Lustral Co., 47, 98, 101, 102.

v. Dines, 149.

v. Johnson, 35.

v. McLaughlin, 1, 162.

v. MacMillan, $129,130$.

v. Skillman, 62 .

v. Towsley, 82 .

v. Withers, 47, 83, 99.

v. Young, 178, 180 .

Johnston v. Standard Co., 78, 83.

Johnstone v. Robinson, 164.

Jones v. Clark, 58.

$\longrightarrow$ v. Jackson, 127.

v. Pac. Co., 19.

v. Prospect Co., 50, 155,

206 .

v. Robertson, 145.

v. U. S., 76 .

v. Wild Goose Co., 172 ,

$173,174,175$.

Jordan v. Duke, 178, 190.

Joseph Black Bear, 46 .

Juno Lode Claim, 214.

Jupiter Co. v. Bodie Con. Co.

$1,50,150,151,154,155,199$.

Jurgenson v. Diller, 79.

Justice Co. v. Barclay, 50, 71, $194,198$.

v. Lee, 163, 206.

v. Plank Co., 85 .

Kahn v. Cent. Smelt. Co., 58.

v. Old Tel. Co., 151, 206.

Kaiser Co. v. Curry, 223.

Kannaugh v. Quartette Co., 20, 215.

Kan. City Co. v. Quigley, 11.

Kan. Nat. Co. v. Haskell. 121.

Katz v. Walkinshaw, 121.

Kean v. Calumet Co.. 35 .

Keeler v. Trueman, 163.

Kelley v. Owens, 83.

Kellogg v. King, 85.

Kenrall v. San Juan Co., 46 , 190.

Kennedy v. Crawford, 121.

- v. Dickey, 23.

v. Pekin Co., 67.

Kerlin v, West, 85.
Kern Oil Co. v. Crawford, 177.

Kerns v. Lee, 24, 82.

Keystone Co. v. Gallagher, 79.

$\longrightarrow$ v. Nev., 45, 116.

Kidd v. Laird, 144.

Kift v. Mason, 61, 119.

Kimberly v, Árms, 58.

King v. Amy Co., 2, 50, 110,

$111,154,173,177$.

- v. Bradford, $4 \dot{7}$.

- v. Edwards, 1, 43

v. McAndrews, 82, 206.

Kingston v. Eckman, 129.

Kinkade v. Cal. 25, 28, 35.

Kinney v. Fleming, 72, 151.

v. VanBokern, 215.

Kinsley v. New Vulture Co., 194.

Kirby v. Potter, 35, 46, 121, 124.

Kirchner v. Smith, 58 .

Kirk v. Meldrum, 20, 174, 178.

Kirwan v, Murphy, 27, 35 .

Kiser v. McLean, 121.

Kjellman v. Rogers, 19.

Kleppner v. Lemon, 122.

Klopenstine v. Hays, 198.

Knickerbocker Co. v. Halla, 200.

Knight v. U. S. Land Ass'n, ₹3, $46,211$.

Knutson v. Fredlund, 73, 197.

Kohl v. U. S., 20, 76.

Kolachny v. Galbreath, 122.

Koons v. Bryson, 71.

Krall v. U. S., 141.

Kramer v. Settle, 164.

Lackawanna Placer Claim, 211, 214.

Lake Superior Co. v. Patterson, 24.

Lakin v. Sierra Buttes Co., 72, 73,82 .

Lalande v. Saltese, 45, 68, 136.

Landsdale v. Smith, 78 .

Lange v. Robinson, 71, 154, 157.

Largey v. Bartlett, 179.

Larkin v. Upton, 50, 6s, 110, $154,155,172$.

Larned v. Jenkins, 68.

Larsh v. Boyle, 58.

Last Chance Co. v. Bunker Hill Co., $50,68,71,72,103,110$, $144,168,177,190$.

$206,207,215$

Lauman v. Hoofer, 20.

Lavagnino v. Uhlig, 20, 165 , $179,180$. 


\section{(The references are to the sections.)}

Lawrence v. Potter, 23.

- v. Robinson, 57, 58 .

Lawrence Donlan, 216.

Lawson v. U. S. Co., 50, 154, $207,215$.

Leadville Co. v. Fitzgerald, 50, $71,111$.

Leadville Office, 197.

Leavenworth Co. v. U. S., 46.

Lebanon Co. v. Con. Republican Co., 67.

Ledoux v. Forester, 155, 164, $168,173,177$.

Le Fevre v. Amonsan, 214.

Le Marchal v. Tegarden, 23.

Le Neve Mill-site, 116.

Lee v. Johnson, 10, 82 .

v. Stahl, 50, 215.

Lee Doon v. Tesh, 20.

Legatt v. Carroll, 144.

Leonard v. Lennox, 23, 47, 108.

Leviston v. Ryan, 207.

Lewis v. Beeman, 79.

v. Curry, 223.

- v. Miller \& Lux, 223.

Liddia Claim, 67, 211.

Lightner Co. v. Court. 10.

Lily Co. v. Kellogg, 20. 214.

Lindemann v. Belden Con. Co., 79.

Litchfield v. Register \& Receiver, 27.

Little Dorrit Co. v. Arapahoe Co., 73, 197.

Little Emily Co., 214.

Little Gunnell Co. v. Kimber, 179.

Little Josephine Co. v. Fullerton, $50,111$.

Little Pittsburg Co. v. Amie Co., 155, 156, 158.

Loaiza v. Court, 19.

Lockhart v. Farrell, 20, 155, $165,172$.

v. Johnson, $46,73,120,124$, $179,197$.

— v. Leeds, 45, 59, 179.

- v. Rollins, $179,194$.

- v. Wills, $45,156,168$.

Loeser v. Gardiner, 72, 168.

Lohman v. Helmer, 67, 163.

Lonabaugh v. U. S., 207.

Londonderry Co. v. United Gold Co., 151, 185.

Lone Dane Lode, 158.

Lone Jack Co. v. Megginson, 163.

Lonergan v. Shockley, 214.

Loney v. Scott, 19, 29, 46, 47, 82.
Long Beach Co. v. Rishardson, 121.

Longmire v. Smith, 100.

Lord v. Carbon Co., $14 \bar{j}$.

Lorenz v. Jacob, 76.

- v. Waldron, 45.

Louisville Co. v. Hayman Co., $213,214$.

Louisville Lode Case, 90.

Iovely Placer Claims, 126, 214.

Loy v. Alston, 58.

Lozar v. Neill, 20.

Lucky Find Co., 214.

Lux v. Haggin, 35, 124.

Lynch v. U. S., 26, 29.

Mabel v. Pearson, 85.

McCann v. McMillan, 43, 72, 96, $150,151,168,179,180,186$, 190.

McCarthy v. Speed, 67, 72, 73, 157.

McCleary v. Broaddus, 1.

McCord v. Oakland Co., 59, 85.

MeCormick v. Baldwin, 198.

— v. Hayes, 23.

— v. Los Angeles Co., 79.

v. Parriott, 195.

v. Sutton, 28.

McCowan v. Maclay, 169, 206.

McCreery v. Haskell, 28.

McCullough v. Murphy, 164, $195,196,197$.

McDaniel v. Moore, 59, 200.

McDonald v. Mont. Wood Co., $119,154$.

MeDonnell v. Eaton, 12.

MeElligott v. Krogh, 173, 177, 180.

McEvoy v. Megginson, 163.

McFadden v. Mt. View Co., 3, 4, $6,14,46,104,215$.

McGahey v. Oregon Co., 57.

McGinnis v. Egbert, 178, 187, $193,196$.

McGowan v. Alps Co., 20, 214.

McGraw v. Lakin, 67, 103.

M'Intosh v. Price, 149, 151, 173, $174,185$.

MeIntosh v. Robb, 61.

McKay v. McDougall, 1, 2, 72, $73,96,177,198$.

v. Neussler, 73, 195.

McKenzie, Petitioner, 14, 19.

v. Coslet, 57.

McKinley v. Wheeler, 43, 163.

McKinley Creek Co. v. Alaska United Co., 124, 149, 163, 168, 171, 177. 
(The references are to the sections.)

MeLaughlin v. Thompson, 57, 156.

McLemore v. Express Co., 71, $93,104,106,119,120,154,193$, 194.

M'Mahon v. Meehan, 164.

M'Millen v. Ferrum Co., 50, $154,156,157$.

McPherson v. Julius, 172, 173, $177,180$.

McQuiddy v. Cal., 45, 47.

McShane v. Carter, 67, 102.

- venkle, 155, 157.

McWilliams v. Winslow, 20.

Madar v. Norman, 59.

Madison v. Octave Oil Co., 47, $50,197$.

Madison Placer Claim Co., 20.

Magruder v. O. \& C. R. Co., 26.

Maguire v. Tyler, 214.

Malaby v. Rice, 59, 207.

Mallett v. Uncle Sam Co.. 1.

Malone v. Big Flat Co., 79, 95.

193.

Mammoth Co. v. Juab Co., 95.

Manhattan Co., 188.

- v. Carrell, 122.

Manley v. Boone, 81.

Mann v. Budlong, 194.

Manning v. App Con. Co., 80. v. Fraser, 62.

- v. Strehlow, 20.

Manuel v. Wulff, $163,171$.

Manufacturing Co. v. Indiana Co., 47, 120a.

Manville v. Parks, 57.

Mares v. Dillon, 20.

Margaret E. Scully, 212.

Marks v. Gates, 57.

Marquez v. Frisbie, 10, 27.

Marthinson v, King, 66 .

Marvel v. Merritt, 98, 99.

Mary Darling, 211.

Mary McM. Latham, 214.

Mary Ward, 93.

Mathews Slate Co. v. New Empire Slate Co., 61, 66 .

Matlock v. Stone, 163.

Mattes v. Treasury Co., 213.

Mattingly v. Lewisohn, 59.

Max Loibl, 124.

Maxwell v. Brierly, 47.

Maye v. Yappen, $8 \dot{5}$.

Mayflower Co., 211.

Meagher v. Hardenbrook, 144. v. Reed, 57.

Medley v. Robertson, 28.

Megarrigle, 47.

Menotti v. Dillon, 10.
Merced Co. v. Fremont, 85.

Merced Oil Co. v. Patterson, 67, 158.

Merk v. Bowery Co., 61, 66 .

Merrill v. Dixon, 26, 45, 168.

Merritt v. Judd, 95, 179.

Mery v. Brodt, 68. 129, 207, 215.

Metcalf v. Prescott, 151, 185.

- v. Watertown, 11.

Meydenbauer v. Stevens, 19, 50. $97,99,149,150,151,155,157$, $177,190$.

Meyers v. Farquaharson, 67.

Meylette v. Brennan, 57.

Michael Pszyk, 4.

Midland Oil Co. v. Turner, 19.

Migeon v. Mont. Cent. Co., 50, 119.

Miles v. Kennan, 179.

Milford Co., 213.

Mill Side Lode, 135.

Miller v. Butterfield, 57.

v. Chrisman, 46, 67, 72, $119,120,154,158,168,177$.

- v. Girard, 158.

- v. Grunsky, 212.

v. Hamley, 72.

Miller Placer Claim, 168.

Mills v. Fletcher, 193, 195, 197.

Milton S. Gunn, 120.

Milwaukee Co. v. Gordan, 178, 187.

- v. Shea, 66.

Minah Co. v. Briscoe, 179.

Mint Lode, 116.

Miocene Co. v. Jacobsen, 77.

Miser v. O'Shea, 127.

Mitchell v. Broso, 156.

- v. Cline, 81, 170.

- v. Hutchinson. 168.

Moffat v. Blue River Co., 72, 119.

Mohl v. Lamar Co., 141.

Mojave Co. v. Karma Co., 213.

Mongrain v. N. P. R. Co., 116.

Mono Fraction, $179,180$.

Monroe Cattle Co. v. Becker, 82.

Monster Lode No. 2, 212.

Montague v. Dobbs, 47.

Mont. Cent. Co. v. Migeon, 155.

Mont. Co. v. Boston Co., $17 \%$.

— v. Clark, 111, 177, 180.

- v. Mont. \& Boston Co., 67.

$\longrightarrow v$. St. Louis Co., 67, 85, 177.

Montrozona Co. v. Thatcher, 61.

Moon v. Rollins, 72.

Moore v. Hammerstag, 57, 67, 164. 
(The references are to the sections.)

Moore v. Pooley, 83.

v. Robbins, 23 .

v. Steelsmith, 190.

Moorhead v. Erie Co., 180.

Moran v. Bonynge, 28 .

Morenhaut v. Wilson, 59, 72.

Morgan v. Antlers Co., 215.

- v. Myers, 194.

Moritz v. Lavelle, 57.

Morrill v. N. P. R. Co., 47.

Morris v. Beam, 143.

- v. Gilmer, 13.

Morrison v. Regan, 178, 185, 187.

Morrow v. Matthews, 57, 78.

Morse v. DeArdo, 102.

Morton v. Solambo Co., 1, 59, $72,164,186$.

Md. City Co. v. Goodspeed Co., 122.

Mt. Blanc Co. v. Debour, 20.

Mt. Chief Claims, 211.

Mt. Copper Co. v. VanBuren, 80.

Mt. Diablo Co. v. Callison, 50, $99,102,110,155,194$.

Mt. Rosa Co. v. Palmer, 45, 68, $119,181,206$.

Moxon v. Wilkinson, 99.

Moyle v. Bullene, 187.

Mudsill Co. v. Watrous, 83, 87, 99.

Muldoon v. Brown, 186, 189.

Muldrick v. Brown, 154.

Mullan v. U. S., 47, 108.

Mullins v. Butte Co., 81 .

Murley v. Ennis, 57.

Murphy v. Tanner, 35 .

Murray v. Allred, 47, 67, 98, 99.

- v. Osborne, 73, 188 .

214 .

v. Polglase, 20, 193, 197,

v. Tulare Co.. 67.

v. White, 24, 25, 155, 215.

Murray Hill Co. v. Havenor, 196.

Mutchmor v. McCarty, 45, 50, 119, 151, 168, 190.

Myers v. Spooner, 43, 72, 177.

Narver v. Eastman, 125.

Nash v. MeNamara, 16, 180.

National Co. v. Piccolo, 19.

Neill v. Shamburg, 83.

Neilson v. Champagne Co., 82, 207.

Nesbitt v. Delamar Co., 20, 199, 214.

Nettie Lode v. Texas Lode, 215.

Neuebaumer v. Woodman, 172.
Neuman v. Driefurst, 59.

Nev. Ditch Co. v. Bennett, 143.

Nev. Sierra Oil Co. v. Home Oil Co., 19, 46, 71, 104, 120, $154,157$.

New Cache Co. v. Water Co., 144

New Dunderberg Co. v. Old, $206,214$.

New England Co. v. Congdon, $120,154$.

N. J. Co. v. Gardner, 71.

N. Y. Hill Co. v. Rocky Bar Co., 215.

Newcomb v. Burbank, 10, 13.

Newhall v. Sanger, 104.

Newman v. Barnes, 20.

Nicholls v. Lewis \& Clark Co., $172,173$.

Nichols v. Williams, 155, 156, 177.

Nielson v. Champagne Co., 212. 214

Niles v. Cedar Point Club, 35.

Nippel v. Forker, 141.

Noland v. Coon, 67 :

Nome and Sinook Co. v. Simpson, 10.

- v. Snyder, 91, 170.

- v. Townsite, 136, 211, 216.

Nome T. Co., 146.

N. Bloomfield Co. v. U. S., 123.

N. Clyde Claims, 213.

N. Noonday Co. v. Orient Co.. 151, 155. 179.

N. P. R. Co., 214.

- v. Cannon, 24.

- v. Pettit, 120.

- v. Sanders, 89.

v. Soderberg, 45, 47, 99.

No. Star Lode, 215.

Northmore v. Simmons, 1, 2, $156,193$.

Northwestern Co., 214.

Nowell v. McBride, 82.

Noyes v. Clifford. 119.

- v. Mantle, 206.

Oberto v. Smith, 72.

O'Connell v. Pinnacle Co., 67.

O'Donnell v. Glenn, 154, 155, 157.

Ohio Oil Co. v. Indiana, 121.

O'Keiffe v. Cunningham, 127.

Olive Land Co. v. Olmstead, 45, $46,120,212$.

Omar v. Soper, 50, 188.

Orchard v. Alexander, 214, 216.

Oreamuno v. Uncle Sam Co., 177. 


\section{(The references are to the sections.)}

Oregon Co. v. Hertzberg, 82.

Oregon King Co. v. Brown, 177.

p. \& C. R. R. Co. v. Puckett, 29.

v. Willamette Co., 120.

O'Relliy v. Campbell, 20, 154, $163,172,190$.

Original Co. v. Abbott, 207.

v. Winthrop, 1, 2, 193.

Ormund v. Granite Mt. Co., 87.

Orr v. Haskell, 1.

Oscamp v. Crystal River Co., $180,198$.

Otaheite Co. v. Dean, 127.

Overman Co. v. Corcoran, 76 .

Oviatt v. Big 4 Co., 143.

Pac. Coast Co. v. N. P. R. Co., $45,46,47,99,104$.

v. Spargo, 46.

Packer v. Bird, 35.

Page v. Summers, 57, 179.

Pagosa Springs, 46.

Palmer v. Uncas Co., 79.

Parish Fork Co. v. Bridgewater Co., 122 .

Parks Co. v. Hoyt, 141.

Parrot Co. v. Heinze, 206.

Parsons v. Venzke, 214, 216.

Patrick v. Weston, 58.

Patten v. Conglomerate Co., 113.

Patterson v. Hewitt, 59, 68, 78, 83.

- v. Hitchcock, 68, 110.

- v. Tatum, 206.

Paul v. Cragnaz, 59.

Pawnee Co. v. Royce, 80.

Payne v. Neuval, 122.

Payton v. Burns, 185, 190.

Peabody Co. v. Gold Hill Co., 82.

Pearl Oyster Co. v. Heuston, 146.

Peasely v. Whiting, 129.

Pelican Co. v. Snodgrass, 154.

Penn v. Oldhauber, 1, 195.

Penn Co. v. Bales, 20. v. Smith, 66 .

Penny v. Cent. Coal Co., 85.

People v. Bell, 98, 102, 103, 120. v. Blake, 67.

v. District Court, 76.

v. Gold Run Co., 145 .

Peoria Co. v. Turner, 214.

Perego v. Dodge, 20, 216.

Perigo v. Erwin, 158.

Peter N. Hanson, 212.

Peters v. Tonopah Co., 185, 190.
Petroleum Co. v. Coal Co., 121.

Pettus v. Roberts, 83.

Phifer v. Heaton, 47.

Philes v. Hickey, 67.

Philip Contzen, 165.

Phillips v. Brill, 120, 154.

v. Salmon R. Co., 96. v. Smith, 20, 46.

Philpotts v. Blasdeli, 67, 186.

Phipps v. Hully, 87.

Phoenix Co. v. Pechner, 10.

v. Scott, 96 .

Pierce v. Sparks, 82.

Pine R. Co. v. U. S., 132.

Pittsburg Co. v. Bailey, 66 .

v. Glick, 87.

Pittsburg-Nevada Co., 67.

Plummer v. Brown, 82.

P. M. Gill, 47.

Poire v. Wells, 82, 96, 135, 206.

Polk v. Sayre, 66.

- v. Sleeper, 28.

Pollard v. Shively, 190.

Poplar Creek, 154.

Porter v. Tonopah Co., 20, 155, $178,179,187$.

Porters Bar Dredging Co. v. Beaudry, 144.

Postal Tel. Co. v. O. S. L. Ry. Co., 76.

Potts v. Alexander, 207.

Power v. Sla, 73, 193, 194, 197.

Powers v. C. \& O. R. Co., 10.

Pralus v. Pacific Co., 1.

Pratt v. United Alaska Co., 174.

Preston v. Hunter, 186, 190, 198.

Price v. M'Intosh, 1.

Prince v. Lamb, 57.

Prosser v. Finn, 165.

v. Parks, 1, 168.

Protective Mg. Co. v. Forest

City Co., 190, 195.

Providence Co. v. Burke, 20, $185,186$.

- v. Marks; 20.

- v. Nicholson, 101.

Puget Co., 87.

Purdum v. Laddin, 185.

Purtle v. Steffee, 26.

Quigley v. Gillett, 16, 73, 178.

Quinby v. Conlan, 23.

Quinlan v. Noble, 77.

Racoullat v. Sansevain, 163.

Randall v. Meredith, 121.

Rara Avis Co. v. Bouscher, 79. 


\section{(The references are to the sections.)}

Rawlings v. Armel, 122. v. Casey, 20.

Ray v. Hodge, 57.

Raynolds v. Hanna, 122.

Reavis v. Fianza, 5.

Rebecca Co. v. Bryant, 214.

Redfield v. Parks, 71.

Reed v. Bowron, 214.

- v. Hickey, 66.

v. Munn, 59, 67, 206.

Reedy v. Wesson, 68.

Reese v. Bald Mt. Co., 79.

- v. Thorburn, 28.

Reilly v. Berry, 185, 186.

Reiner v. Schroeder, 172.

Reins v. Murray, 177.

v. Raunheim, 154.

R. F. Pettigrew, 106.

Remington v. Baudit, 194.

- v. C. P. R. Co., 10.

Renshaw v. Switzer, 72.

Repeater Claims, 59, 199, 200.

Repinsky v. Hinchman, 135.

Resurrection Co. v. Fortune Co., 85.

Reynolds v. Iron Co., 45, 68, $119,181,211$.

v. Pascoe, 120, 154.

Riborado v. Quang Pang Co., 1.

Ricard L. Powell, 165.

Rice v. Rigley, 57.

v. State, 28.

Richards v. Dower, 134.

v. Woifing, 24, 158.

Richardson v. Hardwick, 66.

Richmond Co. v. Rose, 20, 215.

Richter v. Utah, 47.

Rico Lode, 213.

Rico-Aspen Co. V. Enterprise Co., 19.

Ridgeway Co. v. Elk Co., 47.

Riley v. N. Star Co., 67.

Ripinsky v. Hinchman, 10.

Ripley v. Park, 141.

Risch v. Wiseman, 169.

Riste v. Morton, 2. 150.

Ritter v. Lynch, 127.

Robert J. Watson, 165.

Roberts v. Date, 57.

v. Wilson, 1 .

Robertson v. Smith, 1, 96.

Rockwell v. Graham, 206, 215.

Rodgers v. Pitt, 141.

Rogers v. Cooney, 47, 127.

Rollins Co., 101.

Romance Lode, 214.

Rose v. Richmond Co., 20, 68, $82,186,206,207$.

Roseville Co. v. Iowa Co., 179.
Roseville Alta Co. v. Iowa Gulch Co., 95.

Rough v. Simmons, 20.

Roughton v. Knight, 45 .

Roxana Co. v. Cone, 50.

Roy v. Harney Peak Co., 214, 216.

Royal Con. Co. v. Royal Con. Mines, 67.

Royal K Placer, 26, 157.

Royston v. Miller, 81 .

Rupp v. Healey, 24.

Rush v. French, 1, 164, 168, $185,186$.

Russell v. Bank, 59.

- v. Chumasero, 151.

v. Maxwell Land Grant Co., 35, 212.

- v. Wilson Creek Co., 179.

Ryan v. Egan, 81.

v. Granite Hill Co., 45.

Safford v. Fleming, 85 .

St. Anthony Co. v. Shaffra, 50.

St. John v. Kidd, 177.

St. Josephs R. Co. v. Baldwin, 46.

St. Louis Co. v. Kemp, 96, 98, $102,194,206$.

- v. Mont. Co., 24, 50, 85, 113, 138, 177, 206, 215, 216.

St. Paul Co. v. Keslik, 120.

- y. Schurmeier, 35, 124.

Sam. H. Auerback, 178.

Sam McMaster, 215.

San Miguel Co. v. Bonner, 110.

Sanders v. Noble, $177,185,186$.

Sanford v. Sanford, 10, 82.

S. F. Sav. Union v. Petroleum Co., 121.

Sans Bois Co. v. Janeway, 80.

Saunders v. La Purisima Co.. $46,207$.

v. Mackey, 59, 179.

Saxton v. Perry, 2, 177.

Scadden Flat Co. v. Scadden, 71.

Scheel v. Alhambra Co., 107.

Schirm v. Carey, 212.

Schrimpf v. N. P. R. Co., 47.

Schultz v. McLean, 82.

Schwab v. Beam, 47, 110, 141, $144,206$.

Score v. Griffin, 154.

Scott v. Maloney, 215.

S. C. R. Co. v. O'Donnell, 46, $168,177$.

Scruggs v. Decatur Co., 78 .

Sears v. Taylor, 1.

Seidler v. La Fave, 185.

Selma Oil Claim, 19, 20, 215. 


\section{(The references are to the sections.)}

Semple v. Hagar, 82.

Settembre v. Putnam, 57, 58.

Settle v. Winters, 61, 66, 79 .

Sexton v. Wash. Co., 194.

Seymour v. Fisher, 178.

Seymour K. Bradford, 165.

Sharkey v. Candiani, 2, 72, 168, $185,190$.

Shaw v. Caldwell, 62 .

- v. Kellogg, 129, 154, 207.

Shea v. Nilima, 57, 163.

Shenandoah Co. v. Morgan, 141.

Shepherd v. Bird, 47.

Shepley v. Cowan, 23.

Sherlock v. Leighton, 20, 163, 197.

Shields v. Mongollon Co., 14.

Shively v. Bowlby, 121, 146.

Shoshone Co. v. Rutter, 10, 11, $20,50,155,157,178,216$.

Shreve v. Copper Bell Co. 67.

Shreveport v. Cole, 13.

Sierra Nev. Co. v. Sears, 85 .

Silver v. Ladd, 82.

Silver Bow Co. v. Clark, 215.

Silver City Co. v. Lowry, 158, 179.

S. P. Mines v. Court, 66 .

v. Valcalda, 116, 143.

Sisson v. Somers, 1.

Skidmore v. Eikenberry, 5.7.

Skillman v. Lachman, 57, 58.

Slavonian Co. v. Perascich, 180, 197.

Slothower v. Hunter, 67, 190, 211.

Smali v. Lutz, 16.

Smallhouse v. Kentucky Co., 79.

Smith v. Cascaden, 149, 151.

- v. Cooley, 81, 103.

v. Hawkins, 141.

v. Imperial Co., 20.

v. Jones, $66,67,81$.

v. Newell, $154,177,190$.

v. Sherman, 98.

Smuggler Co. v. Kent, 85.

v. Trueworthy, 215.

Snider v. Yarborough, 61, 66 .

Snow v. Nelson, 66.

Snow Flake Fraction, 168.

Snowy Peak Co. v. Tamarack Co., 73.

Snyder v. Colo. Co., 47, 141, 143, $144,172$.

v. Waller, 215.

Sold Again Fraction, 67, 214.

So. Car. Claims, 211.

So. Cross Co. v. Europa Co., $150,155,157,185,190$.
So. Cross Co. v. Sexton, 23, 214.

So. End Co. v. Tinney, 24, 71, $82,162,214$.

So. Nev. Co. v. Holmes, 110.

So. Nev. Dev. Co. v. Silva, 83, 99.

So. Penn Co. v. Miller, 12.

S. P. R. Co. v. Dufour, 141.

- v. Purcell, 104.

- v. S. F. Sav. Union, 121.

Southwestern Co., 47.

v. A. \& P. R. Co., 120.

Sparks v. Pierce, 104.

Speed v. McCarthy, 179.

Spencer V. Winselman, 81.

Spitley v. Frost, 94.

Spokane Co. v. Zeigler, 46.

Stacey v. Glen Ellyn Co., 62.

Stamey v. Hemple, 66 .

Standard Co. v. Habishaw, 10, $24,45,71,157,206,207$.

Stanley v. Min. Union, $4 \dot{5}$.

Stark v. Starrs, 93.

Starkweather v. Jenner, 78.

State v. District Court, 85 .

State v. N. P. R. Co., 29.

- v. Parker, 47.

v. Wright, 28.

Steel v. St. Louis Co., 10, 23, $45,134,163,207$.

Steele v. Tanana Co., 26, 45, 50, $154,157,168$.

Stemmons v. Hess, 214.

Stemwinder Co. v. Emma Co., 173.

Stenfjeld v. Espe, 119, 168, 177.

Stevens v. Gill, 50.

68 v. Grand Cent. Co, 20, 59, $68,78,179$.

v. Williams, 50 .

Steves v. Carson, 20, 215.

Stewart, 47.

$\longrightarrow$ v. Douglass, 47, 57.

- v. G. \& C. Co., 163.

- v. Rees, 71, 169.

v. Westlake, 179.

Stickley v. Mulrooney, 59.

Stinchfield v. Gillis, 50, 67.

Stinson v. Hardy, 79.

Stolp v. Treasury Co., 20.

Stone v. Arkwright, 47.

v. Geyser.Co., 72.

Stoner v. Zucker, 62, 77.

Stoneroad v. Stoneroad, 35.

Strang v. Ryan, 1, 59, 73, 179.

Street v. Delta Co., 16, 72, 7is.

$162,168,177,178,179,180$,

186 .

Strepey v. Stark, 178, 190.

Strickland v. Cóm. Co., 72 
(The references are to the sections.)

Strickley v. Highland Boy Co., 76.

- v. Hill, 20, 163.

Stuart v. Adams, 58, 59.

Sturr v. Beck, 93, 141.

Sturtevant v. Vogel, 1, 185, 190. Suessenback v. Bank, 59, 68, $82,207$.

Sullivan v. Dooley, 85 .

- v. Hense, 1.

- v. Iron Co., 96, 206.

v. No. Spy Co., 141.

v. Schultz, 99.

v. Sharp, 155, 172, 178, 187.

Summerville v. Apollo Co., 122.

Superior Oil Co. v. Mehlin, 122 .

Sutter Co. v. Nichols, 76, 101.

Swanson v. Kettler, 179, 180.

Sweeney v. N. P. R. Co., 26.

Sweet v. Webber, $89,96$.

Swigart v. Walker, 193 .

Sylvester v. Coe, 79.

Synott v. Shaugnessy, 50.

Table Mt. Co. v. Stranahan, 1.

Tabor v. Drexler, 50, 111.

Talbott v. King, 206.

Talmadge v. St. John, 150, 185.

Tanner v. Treasury Co., 76 .

Taylor v. Middleton, 190.

- v. Paranteau, 173.

T. D. $1675,220,221$.

Teller v. U. S., 130.

Temescal Co. v. Salcido, 150, 177.

Terrible Co. v. Argentine Co., $155,156$.

Territory v. Mackey, 50.

Territory of N. M., 126, 214.

Thallman v. Thomas, 23, 104, 179.

Thayer v. Spratt, 129.

Thomas V. Chisholm, 20, 163.

v. Elling, 20, 59, 214, 215.

Thomas B. Walker, 24, 28.

Thompson v. Lee, 186.

v: Spray, 164, 168, 178.

-v. Wise Boy Co., 79.

Thornases v. Melsing, 163.

Thornton v. Kaufman, 20, 73, 198.

Tiggeman v. Mrzlak, 120, 150, 154.

Tilden v. Intervenor Co.. 215.

Tillotson v. Prichard, $\mathbf{3 6}$.

Tinkham v. McCaffrey, 26 .

Tipton Co., 212.

Titcomb v. Kirk, 77.

Tom Moore Co. v. Nesmith, 90, 213.

Tombstone Cases. 134.
Tombstone Co. v. Way Up Co., 50.

Tomera Placer Claim. 168.

Tonopah Co. v. Douglass, 20.

— v. Fellanbaum, 68 .

v. Tonopah Co., 20,81, 156 ,

$158,172,177,178$.

Tough Nut Claims, 214.

T. P. Crowder, 108 .

Tracey v. Harmon, 190.

Traphagen v. Kirk, 29, 134.

Travis Co. v. Mills, 127, 145.

Traylor v. Barry, 79.

Treasury Co. v. Boss, 156, 158 .

Tredinnick v. Red Cloud Co., $79,96$.

Trevaskis v. Peard, 197.

Tripp v. Dunphy, 211.

$\longrightarrow$ v. Overocker, 76 .

Tucker v. Watts, 122.

Tuolumne Co. v. Maier, 154, $157,172$.

Turner v. Sawyer, 20, 59, 200 , $207,215$.

Twin Lick Co. v. Marbury, 78 . 83.

Two Sisters Lode, 116.

Tyee Con. Co. v. Jennings, 3.

$\longrightarrow$ v. Langstedt, 67, 71.

Tyler v. Sweeny, 72, 177.

Tynon v. Despain, 77.

Uinta Co. v. Ajax Co., 96, 154. v. Creede Co., 154, 177, 190. Ukiah Co. v. Curry, 223.

Union Co. v. Dangberg, 59, 143.

- v. Leitch, 168.

v. Taylor, 59.

U. P. R. Co. v. Flynn, 12

- v. Harris, 104.

v. Myers, 10.

v. Peterson, 120.

U. S. v. Allen, 108 .

- v. Atherton, 23, 82.

v. Bagnell Co., 134.

v. Basic Co., 130 .

v. Benjamin, 42, 129 .

v. Biggs, 125.

v. Blendauer, 104, 120.

v. Budd, 129.

v. C. P. R. Co., 26, 168 .

v. Chandler-Dunbar, 68,82 ,

206.

v. Clark, 82 .

v. Conrad Co., 141.

v. Copper Queen Co., 42.

v. Detroit Co., $82,134,214$.

v. Doughten, 108. 125.

v. Duncan Co., 47.

v. Edgar, 42, 130.

v. Forrester, 93. 
(The references are to the sections.)

U. S. v. Guglard, 85.

v. Heilner, 134.

v. Homestake Co., 85.

- v. Iron Co., 23, 26, 50, 68,

$82,99,116,119,172,195,206$,

212.

v. Keitel, 173.

v. King, 212.

v. Laam, 23.

v. Lawrence, 123.

v. McGraw, 82 .

v. Minor, 23, 82.

v. Missouri R. Co., 46.

v. Mont. Co., 36.

v. N. Bloomfield Co., 123.

v. Plowman, 130.

v. Portland Co., 170.

v. Price T. Co., 130.

v. Reed, 26, 82, 157.

v. Rizzinelli, 45, 110, 119,

$131,162,206$.

-v. Rossi, 68, 130.

v. Rumsey, 23.

v. Scholl, 82.

v. Schurz, 23, 206.

v. Smith, 24, 41, 42, 43, 68, $82,125,206$.

v. Trinidad Co., 91, 108,

$170,206$.

v. Tygh Valley Co., 104.

131 .

v. United Verde Co., 130,

v. White, 23, 82 .

- v. Williams, 134.

82,207 .

U. S. Co. v. Lawson, 50, 180.

v. Wall, 215.

Upton v. Larkin, 120, 154, 155, $185,186$.

186 .

Utah, 45.

Utah Co. v. Dickert, 197.

Utah Con. Co. v. Bateman, 80.

Utah Onyx Dev. Co., 47.

Utt v. Frey, 72.

Valcalda v. S. P. Mines, 116.

Van Buren v. McKinley, 185.

Van Doren v. Plested, 47.

Van Sice v. Ibex Co., 68, 200, 207, 214.

Van Valkenburg v. Huff, 164.

Van Zandt v. Argentine Co., $68,155,168,172$.

Vance v. Burbank, 82.

Veronda v. Dowdy, 67.

Victor A. Johnson, 35.

Vietti v. Nesbitt, 58, $61,87$.
Vogel v. Warsing, 71, 149, 151.

Wagner v. Baird, 78 .

- v. Dorris, 195.

v. Mallory, 122.

Wailes v. Davies, 185, 190, 194, $197,199$.

Walker v. Bruce, 58.

Walrath v. Champion Co., 168, 177.

Walton v. Wild Goose Co., 154, $164,174,185,186,197$.

Ward v. Eastwood, 99.

$\longrightarrow$ v. Sherman, 78.

Warnekros v. Cowan, 10.

Warnock v. DeWitt, 179.

Washburn v. Inter Mt. Co., 95.

Washington Co. v. O'Laughlin, $178,190$.

v. Osborn, 46.

Washoe Co. v. Junila, 181.

Waskey v. Hammer, 154, 165, 174.

v. M'Naught; 19, 85, 99.

Waterhouse v. Scott, 20, 215.

Waterloo Co. v. Doe, 50, 68, 110, $154,155,157,207$.

Waterman v. Banks, 66 .

Watervale Co. v. Leach, 50.

Watson v. Lederer, 101.

v. Mayberry 155.

W. B. Frue, 214.

Webb v. American Co., 47, 96, $99,119,120$.

v. Carlon, 186.

Webber v. Clarke, 71.

Weed v. Snook, 20, 96, 120, 178, 180.

Weill v. Lucerne Co., 67.

Welland v. Williams, 59.

Wells v. Davis, 185.

- v. Mantes, 143.

Wemple v. Yosemite Co., 96.

Wesse v. Barker, 43, 172.

Wessels v. Colebank, 62 .

W. Granite Co. v. Granite Mt. Co., 177.

West Pratt Co. v. Dorman, 67.

Westerman v. Dinsmore, 61, 78 .

Western Coal Co. v. Ingraham, 80.

Westmoreland Co. v. DeWitt. $47,121$.

Wetzstein v. Largey, 59, 68.

Weyerhaeuser v. Hoyt, 29.

Whalen Co. v. Whalen, 73,194 , $195,196,197,199$.

Wheeler v. Dunn, 83.

v. Smith, 20, 45 .

- v. West, 62 . 


\section{(Tine references are to the sections.)}

Whipple v. Hutchinson, \$5.

Whitcomb v. White, 23.

Whitehead v. Shattuck, 12.

Whiting v. Straup, 119, 120, $154,158,164,194$.

Whitman v. Haltenhoff, 215.

Wholey v. Cavanaugh, 67.

Wight v. Dubois, 24, 214, 215.

Wiley v. Helen, 83.

Wilhelm v. Silvester, 50, 182.

Wilkinson v. N. P. R. Co., 46.

Willeford v. Bell, 154, 186.

ivilley v. Decker, 143.

Wm. Rablin, 124 .

Wm. A. Cheesman, 172.

Wm. F. Roedde, 35, 37.

Williams v. Eldora Co., 79.

- v. Gaylord, 67.

— v. Haile Co., 144.

- v. Long, $66,85$.

- v. Mountaineer Co., 79.

— v. Sta. Clara Ass'n, 102.

- v. So. Penn. Co., 67, 99.

- v. Toledo Co., 101.

Willett v. Baker, 20.

Wills v. Blain, 188 .

Willson v. Cleaveland, 72 .

Wilson v. Freeman, 20, 178, $180,187,216$.

$-\mathrm{v}$. Triumph Co., 163, 185.

Wiltsee v. King Co., 178, 185.

Winscott v. N. P. R. Co., 35 .

Winter v. Bostwick, 83 .

Winter Lode, 155.

Winters v. Bliss, 26.

v. Stock, 67 .

Witcher v. Conklin, 67.

Witherspoon v. Duncan, 93.

Wolfe v. Childs, 59.

Wolfley v. Lebanon, 212.

Wolfskill v. Smith, 72, 141, 144.
Wolverton v. Nichols, 20, 71, 216.

Wood Placer Co., 154, 194.

Woodenware Co. v. U. S., 134.

Woodman v. McGilvary, 214.

Woodruff v. N. Bloomfield Co.. $1,19,77,123,127,144$.

Woods v. Holden, 50, 206, 215.

Woodside v. Ciceroni, 67.

Woody v. Bernard, 1, 195.

v. Hines, 20.

Worthen v. Sidway, 72, 177.

Wright v. Killian, 172, 194, 195.

$\longrightarrow$ v. Lyons, 168, 185.

- v. Town, 136, 215, 216.

Wyatt v. Larimer Co., 141.

Wynn v. Garland, 62.

Yankee Lode, 179, 212.

Yankee Mill-site, 116.

Yard v. Cook, 24.

Yarwood v. Johnson, 59, 199.

Yates v. Milwaukee, 121.

Yellow Poplar Co. v. Thompson, 67.

Young v. Forest Co., 122.

v. Goldsteen, 136.

Yreka Co. v. Knight, 177, 194.

Yuba Co. v. Cloke, 123, 127.

Yunker v. Nichols, 77.

Zechendorf v. Hutchinson, 67, 158.

Zeiger v. Dowdy, 45, 177, 188.

Zelleken v. Lynch, 61 .

Zephyr Claims, 138.

Zerres v. Vanina, 73, 173, 177, $178,179,185,188,190,197$.

Zimmerman v. Brunson, 47, 99.

$\longrightarrow$ v. Funchion, 173, 174 .

Zollars v. Evans, 156. 


\section{-}




\section{ADdendum \\ (RECENT CASES AFFEC'TING DATA OF CER'TAIN SECTIONS.)}


$$
4
$$ 


\section{ADDENDUM}

(Recent cases affecting data of certain sections.)

\$. Alaska. Section 2324 of the Revised Statutes in relation to the resumption of annual labor upon a mining claim is not applicable to Alaska. Such work, in that district, must be done within the year; otherwise the claim is forfeited and subject to adverse location, notwithstanding resumption is attempted immediately after the expiration of such year. ${ }^{1}$

1. Thatcher v. Brown, C. C. A. 9th Cir. Opinion filed Oct. 2, 1911, (not set published).

§19. Possessory Actions. The plaintiff may elect whether an action for trespass and appropriation of mineral shall be of a local or transitory nature. ${ }^{1}$

1. Pioneer Mining Co. v. Mitchell, C. C. A. 9 th Cir. Opinion filed Oct. 2, 1911, (not yet published).

§23. Disposal of the Public Lands. One who would attack a patent or decision of the land department for a mistake of fact must plead and prove the evidence before the department from which the mistake resulted, the particular mistake that was made, the way in which it occurred, and the fact that, if it had not been made, the decision would have been otherwise and the patent would not have issued to the patentee, before any court can enter upon the consideration of the original issue of fact determined by the department. ${ }^{1}$

A. Mistake of Law. While decisions of the land department on matters of law are not binding on the 
courts, they should not be annulled unless they are clearly erroneous.2

1. Ross v. Wright, (Okle.) 116 Pac. 949; see $\$ 82$, ante.

‥ Id.

$\$ 25$. Hearings. The mere fact that a tract of land adjoins the end of a patented lode claim will not prevent its appropriation under the non-mineral public land laws. ${ }^{1}$

A. Character of Proof. In such a case a higher degree of proof is necessary to establish its nonmineral character than is ordinarily required. ${ }^{2}$

1. Anna Dillon, 40 L. D. 84 .

2. Id.; see $\$ 26$, ante.

29. Railroad Lands. Mineral lands situated within the limits of railroad grants are subject to mineral location up to the time of the issuance of the patent to the railroad company. ${ }^{1}$

a. Validity of Location. The moment a locator has discovered a valuable mineral deposit on the land and perfected his location in accordance with law, the power of the United States government to deprive him of the exclusive right to the possession and enjoyment of the located claim is gone; the land has become known mineral land and is exempt from grant to another. ${ }^{2}$

B. Effect of Patent. A patent of the United States cannot, any more than a deed of an individual, transfer what the grantor does not possess. ${ }^{3}$

c. Exclusion of Location. To exclude a prior duly located mining claim, which is subject to identification, from the operation of the patent, it is not necessary that the existence of the mining claim be then known to the land department. ${ }^{4}$

D. Character of Relief. Proceedings to determine what lands, if any, covered by the patent, are in- 
cluded in the reserving clause of a railroad patent is not an action to annul or avoid a patent issued by the government of the United States. The effect of granting such relief does not in any way invalidate the patent in question. ${ }^{5}$

E. Proof. Where a patent to a railroad company is issued subsequent to the location of a mining claim that is within the area described in the patent, the mineral claimant may prove that the demanded premises were mineral lands. Such a patent grants only lands which are non-mineral in character and the exception of mineral lands in the patent is part of the description and equivalent to an exception therefrom of all lands that were mineral. ${ }^{6}$

F. Statute of Limitations. Such an action is not within the statute of limitations provided for under the act of 1896 . (29 Stats. 42. $)^{7}$

G. Junior Lochtor. Land patented as agricultural is conclusive as against a junior locator. ${ }^{8}$

H. Senior Locator. But a prior locator may maintain suit to quiet title against a railroad patentee. ${ }^{9}$

1. Van Ness v. Rooney, (Cal.) 116 Pac. 394; see §46, ante.

2. Van Ness v. Rooney, ante; see $\$ \S 46,162-168$, ante..

3 . Van Ness v. Rooney, ante; see $\$ 206$, ante.

4. Van Ness v. Rooney, ante; see $\$ 37-3$, ante.

5. Van Ness v. Rooney, ante; see $\$ 82-5$, ante.

6. Van Ness v. Rooney, ante; see $\$ 84-26$, ante.

7. Van Ness v. Rooney, ante; see $\$ \$ 46-82$, ante.

8. Van Ness v. Rooney, ante; see $\$ 23-2-3-4$, ante (pp. 37-38).

9. Id.; see $\S 19$, ante.

$\S 40$. Surveys. There have been but few cases considered by the courts involving the question of the power of the court to make an order for a survey of a mine prior to the institution of suit. It is conceded that, in the absence of statutory authority, such an order may be made. But where a statute providing for such survey does not authorize an order of survey 
except in a pending suit, it follows that such an order would be an excess of jurisdiction and void. ${ }^{1}$

1. National Mines Co. v. Court, (Nev.) 116 Pac. 996.

§ 47. Mineral Deposits. Deposits of slate which do not carry deposits of any other valuable mineral, and are found in quantity and quality sufficient to render the land more valuable on that account than for agricultural purposes, are subject to appropriation under the placer mining laws. ${ }^{1}$

1. Roy McDonald, 40 I. D. 7 ; see $\$ 45-3$, ante; $\$ 96-4$, ante.

§57. Grubstake. Where a prospector enters into a fraudulent conspiracy with third parties, refrains from doing those acts required by law to perfect the location, which he would otherwise have performed, and permits the claim to pass to his co-conspirators, the latter will be held to be trustees for the outfitter. ${ }^{1}$

1. Lockhart v. Washington Co., (N. M.) 117 Pac. 833. See this case for form of complaint, findings of fact and conclusions of law, and of decree.

\$58. Mining Partnerships. By cessation of work without agreement for resumption, a mining partnership is thereupon dissolved, and thereafter the partners are merely tenants in eommon and as such have no power to bind each other by contract. ${ }^{1}$

A. Abandonment Essential. But there must be an abandonment of work before it ean be said that the partnership is at an end. ${ }^{2}$

B. No Dissolution. If there be an understanding, express or implied, to resume work at a later date, the mere cessation of labor would not result as a dissolution. ${ }^{3}$

1. Nielson v. Gross, 13 Cal. A. Dec. 279.

2. Id.

3. Id. 
§59. Co-tenants. A conveyance of a mining claim to partners in designated undivided proportions is not a conveyance to the partnership, but to the partners as tenants in common. ${ }^{1}$

a. Not Necessarily Partnership Property. Property may be used for partnership purposes and not belong to the partnership. It may belong to a third person, to one of the partners, or to the partners as tenants in common. ${ }^{2}$

B. Accounting. Where a tenant in common receives rent or royalty under a lease of the common property, made by him to a third party, he is subject to an accounting for only the amount thereof which has been received by him beyond his proportionate share. ${ }^{3}$

1. Grant v. Bannister, 42 Cal. Dec. 387

2. Id.

3. Cascaden v. Dunbar, C. C. A. 9th Cir. Opinion filed Oct. 2, 1911, (not yet published).

§61. Mining Leases and Licenses. Where the lessees of a mining claim are enjoined by the lessors from doing the agreed assessment work upon the claim and from working a valuable portion thereof until final hearing, the lessors cannot enforce forfeiture. ${ }^{1}$

1. Rogers v. Halla, 187 Fed. 778.

$\S 67$. Deeds. Contracts excepting ores and minerals from grants of land, with a reservation of the right to enter upon the portion thereof granted, are in accordance with long-established usage and have been invariably held by the courts to be valid; hence they are not contrary to, but in harmony with, public policy. ${ }^{1}$

A. Severance of Rights. A possession of the surface of land, exercised for agricultural purposes only, although taken and held under an ordinary deed pur- 
porting to transfer the complete ownership, is not adverse as to mining rights previously severed by a reservation in a conveyance in the same chain of title. ${ }^{2}$ 1. Buck v. Walker, (Minn.) 132 N. W. 205.

2. Crowe Co. v. Atkinson, (Kan.) 115 Pac. 499.

$\S 68$. Examination of Title. See $\$ 82$, post.

$\S 72$. Abandonment. In a contest between adverse mineral claimants proof of a subsisting adverse location prior to that of either contestant rests upon the one alleging its existence. ${ }^{1}$

1. Presumption. Upon proof of a valid prior location a prima facie presumption arises that the claim still subsists and had not been abandoned, although the testimony produced tends to show that there were no posts nor marks upon the ground to indicate that a prior location had been made. ${ }^{2}$

1. Willison v. Ringwood, C. C. A. 9th Cir. Opinion filed Oct. 2, 1911, (not yet published).

2. Id. See Temescal v. Salcido, 137 Cal. 211; Daggett v. Yreka Co., 149 Cai. 357.

\$82. Patent. Where, through the mistake of the land department, land is patented to a subsequent applicant, suit may be brought either by the United States to set aside the patent, or by the prior claimant, to cause the title to such land to be held in trust for him, by such patentee. ${ }^{1}$

A. Laches. Laches does not apply to the United States. ${ }^{2}$

B. EFFeCT of RECond. Mere reliance upon the record of the patent, under a state recordation law, ${ }^{3}$ will not protect a purchaser thereunder, as inquiry at the local land office would disclose the fact that such patentee was not entitled to the land as against the first applicant. ${ }^{4}$

1. U. S. v. Wesely, 189 Fed. 276.

2. Id.

3. See C. C. $\$ \$ 1160,1213$.

4. U. S. v. Wesely, ante. 
\$93. Entry. The right to a return of the fee paid under the Stone and Timber Act may be forfeited through the fault of the applicant. ${ }^{1}$

1. Instructions, 40 L. D. 131; see Flossie Freeman, 40 L. D. 106 ; see $\$ 125-6$, ante.

$\$ 108$. Coal Lands. The method of acquiring land under the Coal Land Acts is analogous to that of the Timber and Stone Acts, and not that of Homestead and Pre-emption Acts. Each of the spouses, exclusive of the other, can, during the marital relation, make an entry and aequire title either under the Coal Land Act or Timber and Stone Act. ${ }^{1}$

1. Guye v. Guye, (Wash.) 115 Pac. 73.

$\S 120$. Placer Claims. Mere paper locations, under the placer laws, of lands upon which no discovery of oil has been made and upon which the mineral claimants are not prosecuting with diligence the work of making a discovery of oil, do not prevent appropriation of the land by location of "soldiers' additional rights." 1

A. Equitable Title. Equitable title under "soldiers' additional applications" covered by such paper locations vests when the applicants thereunder have done all that they are required to do, unless the lands are at the time known to be oil lands. ${ }^{2}$

B. Character of LaNd. In determining the oil or non-oil character of the lands covered by the "soldiers" additional applications," evidence as to the discovery and development of oil in adjacent lands, and as to their geological formation, and the relation of the land in question to known oil fields, will be admissible. ${ }^{3}$

1. Skinner v. Fisher, 40 L. D. 112; citing with approval and following McLemore v. Express Oil Company, 158 Cal. 559.

2. Skinner v. Fisher, ante; see $\$ 106$, ante.

3. Id. 
$\$ 125$. Stone Claims. Land acquired under the Timber and Stone Act from the United States by either spouse during the marital relation is separate property. ${ }^{1}$

a. Personal Inspection. The regulation of the land department that the preliminary affidavit of an applicant to purchase under the Timber and Stone Act must be based upon personal inspection of the land is a proper and reasonable requirement under the Act, and a failure to comply therewith is sufficient ground for cancellation of the entry. ${ }^{2}$

B. Bona fide Purchaser. A purchaser after final entry and before patent from an entryman who failed to make such personal examination, takes, subject to such defect, and is not entitled to special consideration as an innocent purchaser. ${ }^{3}$

1. Guye v. Guye, (Wash.) 115 Pac. 73.

2. Frank L. Chambers, 40 L. D. 85.

3. Id.

\$141. Water Rights (note 3). An Act substantially similar to the Act of 1911, (Cal. Stats. 1911, p. 271), which prohibits the transportation or carrying of certain waters from California into any other state for use therein, was previously enacted in New Jersey, (Laws 1905 , c. 238, p. 461), and formed the subject for decision in the case of Hudson Water Co. v. McCarter, 209 U. S. 349. See s. c., 70 N. J. Eq. 695. The constitutionality of the latter act was upheld and the claim of its violation of the Interstate Commerce Act was therein denied.

\$142. Rights of Way. No company will be recognized by the land department as a beneficiary under the provisions of the Act of March 3, 1891, granting rights of way over the public lands and reservations to Canal and Ditch Companies organized for the pur- 
pose of irrigation, until the formal presentation of an application for a specific right of way. ${ }^{1}$

a. What Showing Must be Made. An application for right of way by a company claiming to own existing rights of way must be accompanied by a showing of the uses made of such rights of way, and those intended to be made of the additional right of way applied for, sufficient to enable the land department to determine whether the purposes of the company are properly within the intendment of the Act of March 3, 1891. as amended by the Act of May 11, 1898. (30 Stats. 404.) 2

1. Pacific Gas and Electric Co., 40 L. D. 125; see $\S 77-3$.

2. Id.

$\$ 165$. Who Cannot be Locators. A deputy mineral surveyor cannot own shares in the capital stock of a corporation, nor act as its agent in the sale of town lots included within the area of an unpatented location and claimed by such corporation. He must either divest himself of such interest in or connection therewith or become liable to the revocation of his appointment as such official. ${ }^{1}$

1. Chas. F. Saunders, 40 L. D. 217.

§178. Subsequent Locations. A placer location for 20 acres cannot by means of an amended or supplemental location be enlarged to cover 40 acres, as such amendment would constitute in effect a new location. ${ }^{1}$

1. Charles H. Head, 40 L. D. 135.

§181. Lode Location within Placer Claim. In order to exclude a lode from a placer claim, the lode must have been known at the time the application for placer patent was made; but actual knowledge on 
the part of the placer applicant is not absolutely essential. ${ }^{1}$

A. Union of Rights. The same person may properly claim the same land under both a placer patent and a lode location. ${ }^{2}$

1. Washoe Co. v. Junila, (Mont.) 115 Pac. 917.

2. Id.

$\$$ 194. Annual Expenditure. Expenditures on a tunnel under $\$ 2323$, Revised Statutes, may be credited toward meeting the requirements of the statute with respect to expenditures as to all existing claims in fact benefited thereby, if the prerequisite conditions of eontiguity and community of interest are present. ${ }^{1}$

1. William Dawson. 40 L. D. 17; see $\S 138$, ante.

\$211. Patent Proceedings. As a general rule, final certificate and patent for a mining claim now issues to the applicant in whose name the patent proceedings were initiated and prosecuted. In the event of his death, certificate and patent now issues in his name, and not to his heirs or devisees. ${ }^{1}$

1. F. M. Graham, 40 L. D. 128 , overruling Tripp v. Dunphy, 28 L. D. 14.

\$212. The Survey. Under a recent regulation ${ }^{1}$ the original plat of survey is forwarded by the surveyor-general to the General Land Office. The Commissioner causes three photolithographic copies to be made and sent to the former officer. He signs such copies and the four plats are filed and disposed of in the manner provided for by paragraph 34 of the Mining Regulations. Additional copies may be obtained from the surveyor-general for 30 cents each, or blue prints may be obtained from him at cost.

A. An expenditure of $\$ 500$ in labor or improvements, to be available as a basis for patent for a 
mining claim, must have been made upon, or for the benefit of the location for which patent is sought.?

B. Consolidated Placer Claim. Work performed upon and for the benefit of a 20 -acre placer location is not available as a patent expenditure for the benefit of a maximum location of 160 acres by eight persons, embracing the 20-acre location and 140 acres of additional ground. ${ }^{3}$

c. Contiguous Lode Locations. Where a number of valid lode locations, forming upon the ground a contiguous group, are embraced in a single application for patent, upon which due publication and posting of notice has been had, and the application is rejected as to one of the locations because of insufficient patent improvements, the remainder of the locations within the group, although not in themselves contiguous, may be patented in such single entry. ${ }^{4}$

D. Patenting Part of Group. The owner of a group of contiguous mining claims and of an improvement constructed for their common development and effective to that end, and of sufficient value for patent purposes as to the entire group, may, instead of embracing all the claims in one application for patent, apply for and obtain patent for a portion of such locations based upon their due share or interest in the common improvement. 5

e. Subsequent Transfer. A subsequent break in the common ownership by a sale or other disposition of one or more of the patented locations, or of any interest therein, will constitute no bar to later patent proceedings for the remaining locations of the group, based upon their due share or interest in the same common improvement. ${ }^{6}$

1. 40 L. D. 216 .

2. Charles H. Head, 40 L. D. 135: see $\$ 194-4-5-6$, ante.

3 . Charles H. Head, ante; see $\$ 96-3$, ante; see $\S 119-6$, ante.

4. William Dawson, 40 L. D. 17.

5. Id.

6. Id. 
§214. Proceedings in the Local Land Office. In the procedure under the mining laws the "application for patent" bears a close analogy to the initial pleading in a judicial proceeding. ${ }^{1}$

a. Notice of Application. The published and posted notice of the application is "process." 2

B. Affidavits of Posting and Publication. The affidavit of the posting of the notice and plat upon the claim, and proof of publication in the newspaper and of the continuous posting of the notice, correspond in legal effect to the sheriff's or marshal's return where personal service has been had, or to the preliminary affidavits and the proofs of publication, etc., where in appropriate cases substituted service has been resorted to. ${ }^{3}$

c. Practice. A greater degree of strictness than obtains in judicial proceedings is not required by the land department in entertaining and proceeding with an application for mineral patent. ${ }^{4}$

D. Amended Affidavits. Proof of posting upon the claim and the verification of the application for patent when made before an inhibited official may be amended and filed as of the proper date if there is no question as to the fact of notice. ${ }^{5}$

E. Newspaper. Where two newspapers are published practically the same distance from a tract for which patent is sought, both having a general circulation in the vicinity of the land, the register may designate either of them for the publication of the notice of application for patent, regardless of the fact that the rates of the paper so designated are less reasonable than those charged by the other newspaper. ${ }^{6}$

1. Stock Oil Co., 40 L. D. 198. As the land department is a special tribunal charged with the administration of the public land laws, exercising not only executive but 
judicial powers, an application to obtain a patent addressed to that tribunal should recite all facts necessary to show jurisdiction in the Department to convey the particular tract applied for to the particular individual applying for it. . . A petition or application thus framed presents a foundation for such corroborative evidence as required by the rules.... The proceedings by which this jurisdiction is invoked should be conducted fairly on the line of proceedings in rem in courts of common law or equity jurisdiction. Lindley on Mines (2nd ed.), $\$ 680$.

2. Stock Oil Co., ante. The proceedings by which the patent for a mining claim is obtained are essentially in rem, and are binding upon all the world so far as any unpresented adverse claim is concerned. They are judicial. The publication and posting of notice for patent is a process which brings all adverse claimants into court-a summons to all persons whose interests may be affected by the issuance of a patent to the tract applied for, to appear and file their adverse claims. Lindley on Mines (2nd ed.), \&713.

3. Stock Oil Co., ante.

4. Id.

5. Id. El Paso Brick Co., 37 L. D. 155, overruled, in so far as in conflict.

6. Thomas M. Trippe, 40 L. D. 190.

\section{\$214. Proceedings in the Local Land Office, (note} 1). Paragraph 44 of the Mining Regulations has been amended so as to read as follows: "Before approving for publication any notice of an application for mineral patent, local officers will be particular to see that it includes no land which is embraced in a prior or pending application for patent or entry, or for any land embraced in a railroad selection, or for which publication is pending or has been made by any other claimants, and if, in their opinion, after investigation, it should appear that notice of a mineral application should not, for this or other reasons, be approved for publication, they should formally reject the same, giving the reasons therefor and allow the applicant 30 days for appeal to this office under the rules of practice." 1

1. 40 L. D. 222 . 
$\$ 214$. Re-hearing (note 50). Rule 83 of the new Rules of Practice, (39 L. D. 395), providing for motions for re-hearing in lieu of motions for review under the old rules, (4 L. D. 37), are administered as nearly as possible in accordance with the rules governing rehearings in courts of justice, and observance of its provisions are insisted upon by the land department. ${ }^{1}$

1. William T. Schreiner, 40 L. D. 87.

$\$ 224$. State Taxation. A proper method for ascertaining the value of a franchise of a corporation is by deducting from the aggregate market value of its shares the value of its tangible property, and taking the difference as the value of the franchise. ${ }^{1}$

A. Market Value. Market value is synonymous with "value" and "full cash value" as defined by $\$ 3716$ of the Political Code. ${ }^{2}$

1. Los Angeles v. Western Oil Co., 42 Cal. Dec. 538.

2. Id. 
- 


$$
-
$$



